\begin{abstract}
UNIVERSIDADE DE SÃO PAULO
FACULDADE DE FILOSOFIA, LETRAS E CIÊNCIAS HUMANAS DEPARTAMENTO DE LETRAS MODERNAS

PROGRAMA DE PÓS-GRADUAÇÃO EM ESTUDOS LINGUÍSTICOS E LITERÁRIOS EM INGLÊS
\end{abstract}

NELAGLEY MARQUES

QUEM QUER SER PROFESSOR? MOBILIZANDO SABERES E CONSTRUINDO SENTIDOS SOBRE A CARREIRA DOCENTE NO ESTADO DE MATO GROSSO DO SUL 


\author{
UNIVERSIDADE DE SÃO PAULO \\ FACULDADE DE FILOSOFIA, LETRAS E CIÊNCIAS HUMANAS \\ DEPARTAMENTO DE LETRAS MODERNAS \\ PROGRAMA DE PÓS-GRADUAÇÃO EM ESTUDOS LINGUÍSTICOS E \\ LITERÁRIOS EM INGLÊS
}

NELAGLEY MARQUES

\title{
QUEM QUER SER PROFESSOR? MOBILIZANDO SABERES E CONSTRUINDO SENTIDOS SOBRE A CARREIRA DOCENTE NO ESTADO DE MATO GROSSO DO SUL
}

Tese de Doutorado apresentada ao Programa de Pós-Graduação em Estudos Linguísticos e Literários em Inglês do Departamento de Letras Modernas da Faculdade de Filosofia, Letras e Ciências Humanas da Universidade de São Paulo sob a orientação da Profa. Dra. Walkyria Monte Mór. 
Autorizo a reprodução e divulgação total ou parcial deste trabalho, por qualquer meio convencional ou eletrônico, para fins de estudo e pesquisa, desde que citada a fonte.

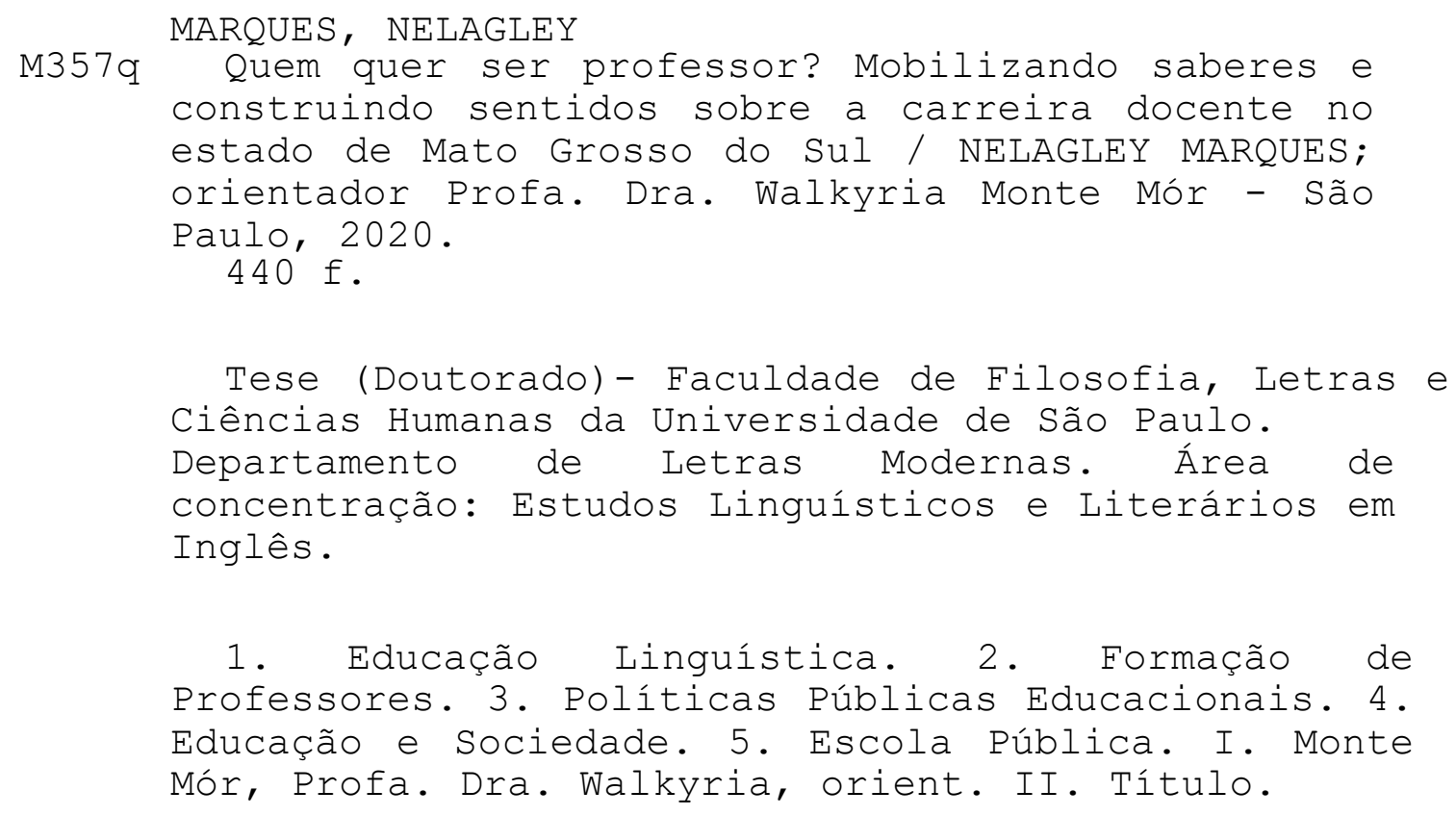




\section{ENTREGA DO EXEMPLAR CORRIGIDO DA DISSERTACÃO/TESE}

\section{Termo de Ciência e Concordância do (a) orientador (a)}

\section{Nome do (a) aluno (a): Nelagley Marques}

Data da defesa: 26/01/2021

Nome do Prof. (a) orientador (a): Profa. Dra. Walkyria Monte Mór

Nos termos da legislação vigente, declaro ESTAR CIENTE do conteúdo deste EXEMPLAR CORRIGIDO elaborado em atenção às sugestões dos membros da comissão Julgadora na sessão de defesa do trabalho, manifestando-me plenamente favorável ao seu encaminhamento e publicação no Portal Digital de Teses da USP.

São Paulo, 29/01/2021

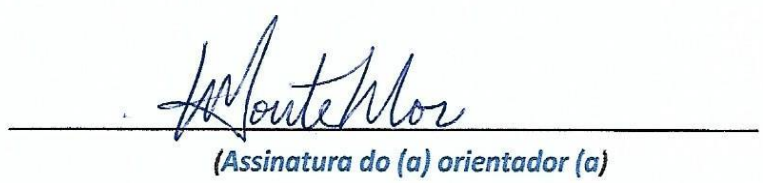




\section{BANCA EXAMINADORA}

Profa. Dra. Walkyria Monte Mór/USP

Prof. Dr. Lynn Mario Trindade Menezes de Souza/USP

Profa. Dra Maria Leda Pinto/UEMS

Prof. Dr. Ruberval Franco Maciel/UEMS 
Para os meus ancestrais e para Ana Laura, minha filha amada. 


\section{AGRADECIMENTOS}

A Deus, por seus planos para minha vida serem sempre maiores do que os meus sonhos.

A Profa. Dra. Walkyria Monte Mór, pela calorosa acolhida no Programa de PósGraduação, por sua orientação primorosa, e pelo respeito e confiança em meu trabalho.

A minha filha Ana Laura, fonte inesgotável de amor e aprendizagem.

Ao meu marido Fabio Angelo Paulista, meu inestimável companheiro de vida, pelo apoio incondicional aos meus estudos.

Aos meus pais Neraldo e Laura Miti, meus maiores exemplos de respeito ao próximo, de caridade, de solidariedade, de resistência e de amor pela vida, pela família e pelo trabalho. Gratidão por todos os ensinamentos de ética e caráter.

Ao Ruberval Franco Maciel, pelo incentivo pleno aos meus estudos, e pela convivência alegre e fraterna.

Aos amigos Carolina Monteiro Santee e Daniel Santee, pelas incontáveis ajudas, e pela amizade sincera e verdadeira que construímos juntos.

Aos professores Lynn Mario Trindade Menezes de Souza e Cintya Regina Ribeiro, pelas várias provocações durante as aulas, e por me mostrarem como se joga "o jogo".

Aos professores da banca examinadora, gratidão pela oportunidade de diálo partilha de conhecimentos.

A Secretaria de Estado de Educação de Mato Grosso do Sul, por viabilizar parte dessa pesquisa. 
Aos alunos participantes da pesquisa, pela valorosa contribuição para que esta pesquisa pudesse se realizar.

Aos professores Carolina Santee, Maria Leda Pinto, Aracy Mendes, Edinéia Leite dos Santos Oliveira, Heraldo Sousa Purcena, Antônio Geraldo Teixeira Júnior, Everton Paulino, Cláudia Rodrigues e Cristiane Marcheti dos Santos, todo o meu respeito e gratidão a vocês que fazem a diferença na luta por uma educação de qualidade.

Aos amigos Michel Constantino, Vanessa Weber, Maria das Dores Dias Acosta, Alessandra Rebelato Marques, Lorene Ferrari, Sérgio Ifa, Gisleine Rodrigues, Marcelo Salomão, Marcos Brandão, Waldir Leonel e Adilson Crepalde, por não medirem esforços em me ajudar sempre que precisei.

Aos amigos Andréia Rosendo, Kézia Nunes, Ana Paula Guimarães, Elaine Reis, Cristiane Eluf, Ricardo Saito, Alessandra Coutinho Fernandes e Denise Landin, pela oportunidade de conhecê-los na USP, e por desfrutarmos bons momentos juntos.

Aos meus afilhados Lucas, Mariana e Vítor, e as sobrinhas Maria Clara e Maria Júlia, por todo amor e cumplicidade que temos uns pelos outros.

Aos meus tios Marina e Kouji, pelo apoio e acolhida em sua casa na cidade de São Paulo.

A todos os meus familiares, irmãos, sogra, cunhados, tios, sobrinhos e primos, por compartilharem comigo momentos de afeto.

As minhas madrinhas Angélica Serrano Machado e Marisa Serrano, por $t$ incentivo ao longo da minha vida pessoal e profissional.

Aos meus compadres Karla, Pedro Henrique, Roberto, Robson, Noélia, Marisa, Nerilma e Robert, pelos laços familiares que construímos juntos ao longo da vida. 
Não sou nem otimista, nem pessimista. Os otimistas são ingênuos, e os pessimistas amargos. Sou um realista esperançoso. Sou um homem da esperança. Sei que é para um futuro muito longínquo. Sonho com o dia em que o sol de Deus vai espalhar justiça pelo mundo todo. 


\section{SUMÁRIO}

O MARCO ZERO

1. Abrangência da pesquisa ............................................................ 23

2. Algumas características dos participantes da pesquisa ........................24

3. Mapeamento dos aspectos sobre formação e renda familiar dos participantes da pesquisa .................................................................2

4. Dados sobre o processo de escolarização dos alunos participantes da pesquisa ....................................................................................... 31

5. Mapeamento sobre a intenção profissional pretendida dos alunos participantes da pesquisa .........................................................................3

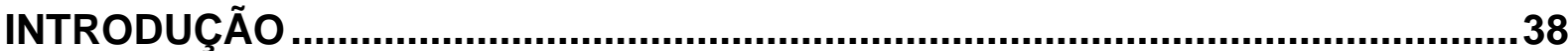

1. A relevância da pesquisa................................................................... 41

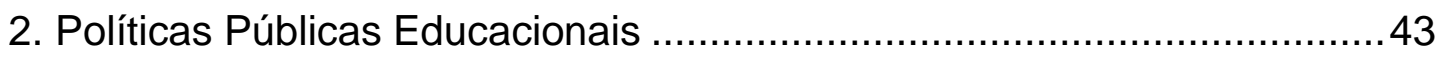

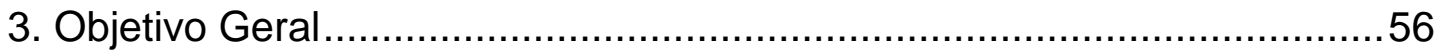

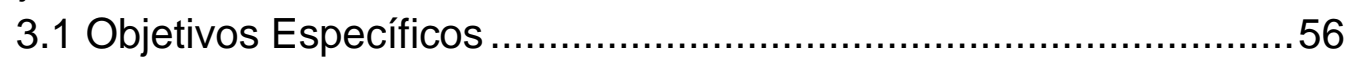

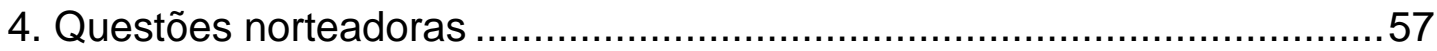

5. Modus Operandi: sobre a construção da pesquisa..................................57

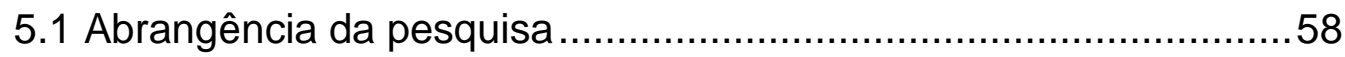

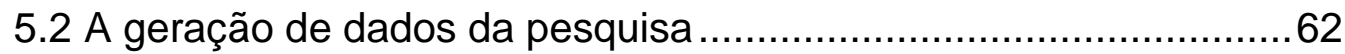

5.2.1 A geração de dados da primeira fase da pesquisa .....................62

5.2.2 Tabulação, Análise e Disseminação dos dados gerados .............63

5.2.3 Algumas características dos alunos participantes da pesquisa ..64

5.2.4 A geração de dados da segunda fase da pesquisa.....................67

5.2.5 Algumas características dos participantes do Grupo de Discussão

6. Organização da Tese ................................................................... 73

7. O caminho que se conhece e se faz no caminhar: aspectos filosóficos, epistemológicos e metodológicos .............................................................75

7.1. Pesquisa quanti-qualitativa para além do pensamento positivista ....

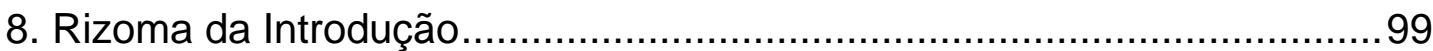

\section{CAPÍTULO I - CONHECENDO O CAMPO INVESTIGATIVO: A GARRAFA}

LANÇADA AO MAR .

1. A constituição familiar dos participantes da pesquisa e o problema da segurança alimentar

2. A formação dos pais ou responsáveis e a renda familiar podem influe nas escolhas profissionais dos alunos participantes da pesquisa? ............108

3. O processo de escolarização dos alunos participantes da pesquisa e os desafios que alguns têm de conciliarem os estudos e o trabalho.

4. O mapeamento sobre a intenção profissional pretendida dos alunos participantes da pesquisa 


\section{CAPÍTULO II - A CONSTRUÇÃO DE SENTIDOS SOBRE A CARREIRA DOCENTE}

PELOS PARTICIPANTES DA PESQUISA ...................................................140

1. Os estudos Decoloniais como um caminho possível para uma educação emancipadora

2. Os grupos minoritários e os desafios dos processos de escolarização na visão deles mesmos ...................................................................... 153

3. A decisão por ser professor na área de Línguas e os estudos dos Letramentos.

4. A construção de sentidos sobre a carreira docente pelos participantes da pesquisa que em algum momento pensam em ser professor 166

CAPÍTULO III - O INTERESSE OU NÃO PELA CARREIRA DOCENTE: DESAFIOS E PERSPECTIVAS

1. Como a eficácia das ideologias neoliberais reinantes pode afetar as

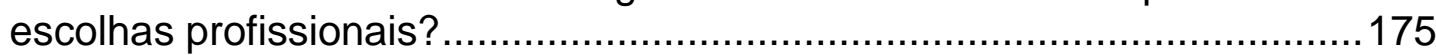
2. As principais justificativas dos alunos participantes da pesquisa para serem professores

3. As principais justificativas dos alunos participantes da pesquisa para não serem professores

4. A construção de sentidos sobre a carreira docente: uma análise colaborativa .................................................................................. 194

5. A compreensão Nietzschiana sobre a educação de seu tempo e os desafios de pensarmos em nosso tempo sobre a importância da educação para a vida

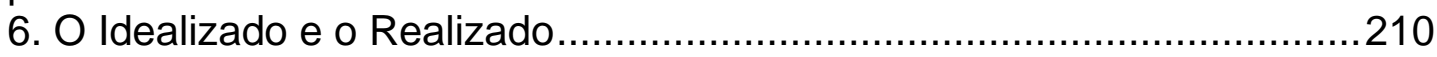




\section{LISTA DE SIGLAS E ABREVIATRAS}

ABMES. Associação Brasileira de Mantenedoras de Ensino

Superior

AEMS Faculdades Integradas de Três Lagoas

ANPED SUL Associação Nacional de Pós-Graduação e Pesquisa em Educação

BBC British Broadcasting Corporation

Censo Escolar Censo Escolar da Educação Básica

CIES Curso Estadual Preparatório para Ingresso na

Educação Superior

CNTE Confederação Nacional dos Trabalhadores em

Educação

CONEP Comissão Nacional de Ética em Pesquisa

$\mathrm{EACH}$ Escola de Artes, Ciências e Humanidades

EE Escola Estadual

EERP Escola de Enfermagem de Ribeirão Preto

EESC Escola de Engenharia de São Carlos

EJA Educação de Jovens e Adultos

EMBRAPA Empresa Brasileira de Pesquisa Agropecuária

ENEM Exame Nacional do Ensino Médio

FATEC/SENAI Faculdade de Tecnologia

FE Faculdade de Educação

FETEMS Federação dos Trabalhadores em Educação de Mato

Grosso do Sul

FGV Fundação Getúlio Vargas

FIES Financiamento ao Estudante do Ensino Superior

FLACSO Faculdade Latino-Americana de Ciências Sociais FORP Faculdade de Odontologia de Ribeirão Preto

FUNEC Faculdades Integradas de Santa Fé do Sul

IBGE Instituto Brasileiro de Geografia e Estatística

IEDE Interdisciplinaridade e Evidências no

Debate

Educacional 
IFMS Instituto Federal de Mato Grosso do Sul

IME Instituto de Matemática e Estatística da USP

INEP Instituto Nacional de Estudos e Pesquisas

Educacionais Anísio Teixeira InSAN. Insegurança Alimentar e Nutricional

IQSC Instituto de Química de São Carlos

MAGSUL Faculdades Integradas de Ponta Porã

MEC Ministério da Educação

MS Mato Grosso do Sul

OCDE Organização para a Cooperação e Desenvolvimento

Econômico

ONG Organização Não Governamental

ONGS Organizações Não Governamentais

Oxfam Oxford e Famine - Oxford Committee for Famine Reliefe/Comitê de Oxford para o Alívio da Fome PISA Programa Internacional de Avaliação dos Estudantes

PME Pesquisa Mensal de Emprego

Pnad Contínua Pesquisa Nacional por Amostra de Domicílios Contínua

PNAD Pesquisa Nacional por Amostra de Domicílios

PRG-USP Pró-Reitoria de Graduação da USP

PROGRAD Pró-Reitoria de Graduação (da UFG)

PRONATEC Programa Nacional de Acesso ao Ensino Técnico e Emprego

PROUNI Programa Universidade para Todos

$\mathrm{RH}$ Recurso Humano

SED/MS Secretaria de Estado de Educação Mato Grosso do Sul

SEMED/MS Secretaria Municipal de Campo Grande-MS

SGB Sistema Geodésico Brasileiro

SISU Sistema de Seleção Unificada

SUPED Superintendência de Políticas Públicas

UCDB Universidade Católica Dom Bosco

UEMS Universidade Estadual de Mato Grosso do Sul

UFG Universidade Federal de Goiás 
UFGD ............................... Universidade Federal da Grande Dourados

UFMS ................................. Universidade Federal de Mato Grosso do Sul

UNB .................................... Universidade de Brasília

UNESP ................................ Universidade Estadual Paulista

UNICAMP ............................ Universidade Estadual de Campinas

Uniderp/Anhanguera ............ Universidade para o Desenvolvimento do Estado e da

Região do Pantanal

UNIESP

União das Instituições Educacionais do Estado de São

Paulo

Unigran

Centro Universitário da Grande Dourados

UNIPAR

Universidade Paranaense

UNOESTE Universidade do Oeste Paulista

UNOPAR Universidade Norte do Paraná

USP Universidade de São Paulo 


\section{LISTA DE SÍMBOLOS UTILIZADOS NAS TRANSCRIÇÕES}

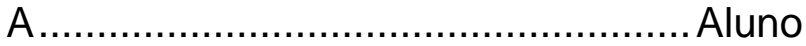
P ................................................. Pesquisadora
Prof.do EM 1 - P1 ..............................Professor do Ensino Médio
Prof.do EM 2 - P2 ........................... Professor do Ensino Médio
Profá . do EM 3 - P3 ........................... Professora do Ensino Médio
Prof ${ }^{a}$ do ES 1 - P4 ............................Professora do Ensino Superior
Prof $^{a}$ do ES 2 - P5 …......................Professora do Ensino Superior
Prof $^{a}$ do ES 3 - P6 .............................Professora do Ensino Superior
Técnica da SED/MS 1 - P7 ............... Técnica da Secretaria de Estado de Educação
Técnica da SED/MS 2 - P8............... Técnica da Secretaria de Estado de Educação
Técnico da SED/MS 3 - P9................ Técnico da Secretaria de Estado de Educação 


\section{LISTA DE TABELAS}

Tabela 1: Comparação entre o grau de escolaridade dos pais ou responsáveis dos

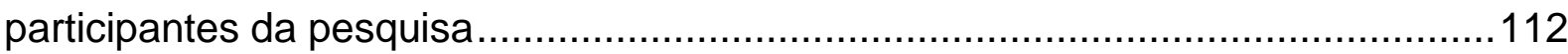
Tabela 2: Comparativo da quantidade de pessoas que residem na mesma casa e a

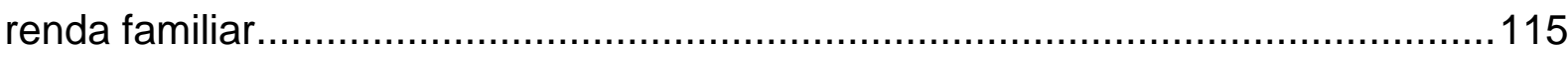

Tabela 3: Quantitativo de Cursos de Graduação ofertados pela UFMS..................136 Tabela 4: Razões pelas quais os alunos querem ser professor de disciplina

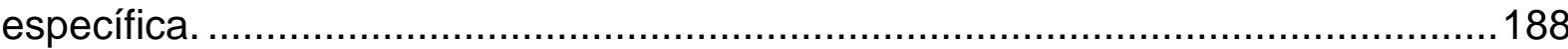




\section{LISTA DE ILUSTRAÇÕES}

Imagem 1: Marco Zero da Cidade de Campo Grande - MS .................................21

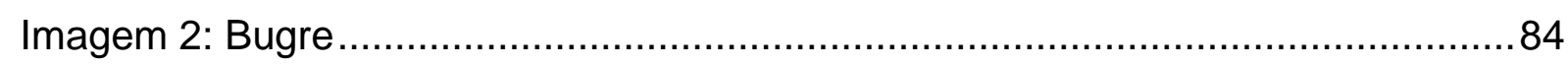

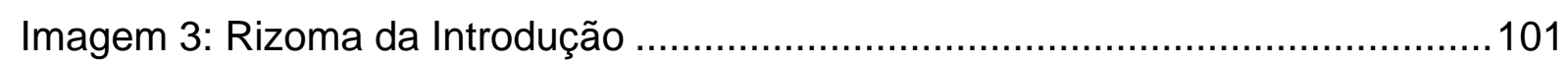

Infográfico 1: Mapa de MS com os municípios participantes e não participantes da

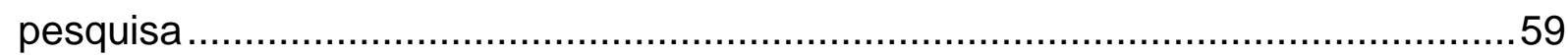

Infográfico 2: Quantitativo de alunos matriculados no $3^{\circ}$ ano do Ensino Médio que participaram da pesquisa, distribuídos por modalidade de ensino ...........................61

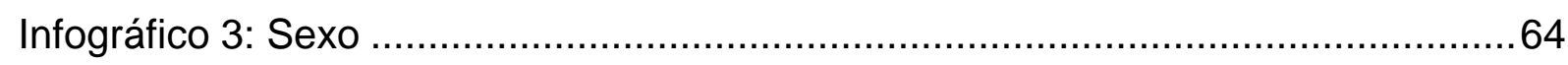

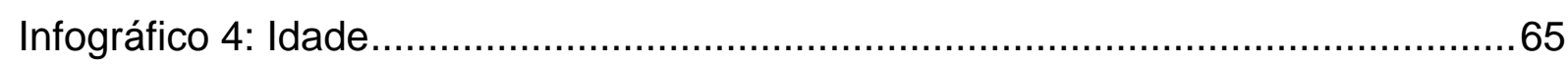

Infográfico 5: Autodeclaração de raça .............................................................66

Infográfico 6: Características gerais dos professores do Ensino Médio .....................70

Infográfico 7: Características gerais dos professores do Ensino Superior .................71

Infográfico 8: Características gerais dos técnicos da SED/MS...............................72

Infográfico 9: Grau de escolaridade do pai ou responsável ...................................108

Infográfico 10: Grau de escolaridade da mãe ou responsável ..............................111

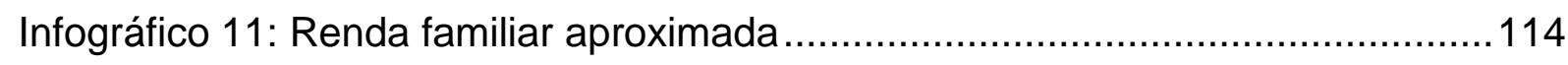

Infográfico 12: Desde qual idade trabalha com remuneração ................................123

Infográfico 13: A intenção de ingresso no Ensino Superior e as escolhas

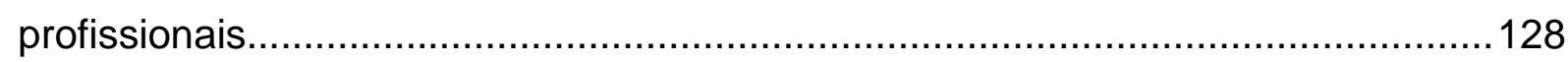

Infográfico 14: Pretensão de ingresso em quais Instituições de Ensino Superior ...134 


\section{RESUMO}

Este estudo é uma ação de pesquisa colaborativa entre a Secretaria Estadual de Mato Grosso do Sul - SED/MS, professores do Ensino Superior e Médio, técnicos da SED/MS, alunos concluintes do Ensino Médio de escolas públicas estaduais de MS, e a pesquisadora. Busquei investigar a construção de sentidos sobre a carreira docente, bem como o interesse ou não em ser professor com suas justificativas. Além disso, o Modus Operandi que orientou o processo de discussão e análise dos dados teve como propósito tornar visível as forças que direcionam as escolhas profissionais dos participantes envolvidos, em contextos histórico e situado, focando em como o neoliberalismo e o Estado operam no sentido de afetar essa escolha. A pesquisa de natureza quanti-qualitativa abrangeu 75 municípios de MS, 211 unidades escolares públicas estaduais de MS, e 7.894 alunos. As discussões e análises dos dados gerados tiveram as contribuições das teorizações Pósestruturalistas, Decoloniais, dos Letramentos e Neoliberais. De modo geral, os participantes da pesquisa manifestaram grande respeito pela profissão de professor, assim como a consideraram de muita responsabilidade, compreendendo a relevância do professor na sociedade e na formação holística dos sujeitos. Apesar de afirmarem o valor do professor na sociedade, uma parcela significativa $(63,38 \%)$ alegou que em nenhum momento pensou em ser professor. Todavia, a pesquisa constatou que o fato da maioria dos alunos participantes que nunca pensou em se formar professor quando responderam ao questionário de pesquisa, pode não implicar que esses mesmos participantes mudem de interesse, e venham a se formar professores ao longo de sua trajetória profissional, pois novas oportunidades podem se abrir, ao considerar que estamos em constante processo de formação, construção e aprendizagem.

Palavras-chave: Carreira docente; Políticas Públicas Educacionais; Pósestruturalismo; Decolonialidade; Letramentos. 


\begin{abstract}
This study is a collaborative research action involving the State Board of Education of the State of Mato Grosso do Sul, Brasil - SED/MS, High School teachers, College professors, technicians from SED/MS, High School graduates from state public schools, and the researcher. I sought to investigate the construction of what the teaching career means, as well as the interest or not in becoming a teacher and the reasons as to why/why not. In addition, the Modus Operandi that guided the process of discussion and analysis of the data aimed at disclosing the causes that influenced the professional choices of the participants involved, in historical and situational contexts, focusing on how Neoliberalismo and the State operate to affect choices. The quanti-qualitative research covered 75 municipalities in the State of Mato Grosso do Sul, Brazil, 211 state public school units in MS, and 7.894 students. The discussions and analyzes of the data which was generated received contributions of Post-structuralist, Decolonial, Literacy and Neoliberal theorizations. In general, the research participants expressed great respect for the teaching profession and considered it to be of great responsability. They understood the relevance of the teacher to society and in the holistic formation of the subjects. Despite acknowledging the value of the teacher in society, a significant portion of the subjects $(63.38 \%)$ claimed that they never thought about becoming a teacher. The research found that most of the participating students never considered becoming a teacher up to the time of the research. However, this does not imply that they will never train to become teachers as part of their careers as opportunities arise. After all, each one of us is subjected to a constant process of formation, construction and learning.
\end{abstract}

Keywords: Teaching career; Public Education Policies; Post-structuralism; Decoloniality; Literacies. 


\section{RESUMEN}

Este estudio es una acción de investigación colaborativa entre la Secretaría Estadual de Educación de Mato Grosso do Sul - SED/MS, profesores de Enseñanza Superior y Secundaria, técnicos de la SED/MS, egresados de Secundaria de escuelas públicas estatales de MS, y la investigadora. Busqué investigar la construcción de sentidos sobre la carrera docente, así como el interés o no en ser profesor con sus justificaciones. Además, el Modus Operandi que orientó el proceso de discusión y análisis de los datos tuvo como objetivo tornar visible las fuerzas que orientan las escojas profesionales de los participantes involucrados, en contextos histórico y situado, enfocándose en cómo operan el neoliberalismo y el Estado en el sentido de afectar esa elección. La investigación de naturaleza cuanti-cualitativa abarcó 75 municipios de MS, 211 unidades de escuelas públicas estatales de MS y 7.894 estudiantes. Las discusiones y análisis de los datos generados contaron con los aportes de las teorizaciones Postestructuralistas, Decoloniales, de las Literacidades y Neoliberales. En general, los participantes de la investigación manifestaron un gran respeto por la profesión del profesor, además de considerarla de mucha responsabilidad, entendiendo la relevancia del profesor en la sociedad y en la formación holística de los sujetos. A pesar de afirmar el valor del profesor en la sociedad, una parte significativa $(63,38 \%)$ afirmó que en ningún momento pensó en ser profesor. Sin embargo, la investigación verificó que este hecho no implica que estos participantes cambien su interés, y que vengan a graduarse como profesores a lo largo de su trayectoria profesional, ya que se pueden abrir nuevas oportunidades, considerando que estamos en un proceso constante de formación, construcción y aprendizaje.

Palabras Clave: Carrera docente; Políticas Públicas Educacionales; Postestructuralismo; Decolonialidad; Literacidades. 


\section{ÑEMOMBYKY}

Koa arandueka ñesambyhy ñeporandua rupiveguare ha ñepytyvõ ambytépe Secretaria Estadual de Educação de Mato Grosso do Sul- SED/MS, mboehara kuera araguymbyte hárupy iñaranduva há avei ka'arapy apyte harupi iñaranduava, upei ave aporeko kuaa kera da SED/MS, mbo'epy oimeva mbo'éroga pavẽ pypegua oguãhetamava ijapype há oikoava ko tetã de MS, há avei imba'e poranduva kuera ave. Aheka tesarekorupi ajapo haguã upe mba'e ñeñandupyva tekombo'e pype oimeva, teerã oikoseva mbo'ehary há ndoikoseva ave mbo'ehary ramo upe ijeko omombe'u. Upeagui rire, tekokuaa ombohesabysó koa tembiapo ñe'ẽ mbojovái pype há ave ñembojoja rupive koa ñe'ẽ ojaposégui ojehechauka mbarete mbo'epy jehoha rehe umi oikosevape, ojehesaityva mba'ereta mombe'u pyrehe oimehapy, upearente teko pyahu ambue tetã guasu pygua ombomguata ha ohekovereka ambue haguã mboe'py ñesambyhy. Ñeporandu jepapapy reko kuaa rehe mbovy háguipa há ombopysó 75 município tetã hérava MS, 211 oimeva mbo'eroga pavẽ tetã MS, há 7.894 mbo'epy. Ñe'ẽ ñembohovái upei ñembojoja pype ojecha ha ome'ẽ arandupytyvõ mba'e kuaa ojehu pyahu jerokyta va'ea rehe, decoloniais, jehaípy há avei mba'e ogueruva mba'e pyahu. Upea tekorupi, upe onhemoĩva ñeporãdupypeva ochuka mba'e tee tekombo'epy rehe, há avei oñeñandu tekombo'epype mba'epohyi ñangareko hekovepe, há oikuaa mbo'ehára mba'eguasuha opa ambue tentãguasu apytepe ijyvateve upei ave imbo'e pyre rekovépe ombohesajera umĩ mba'e retarehe. Upeagui joty, je'é mbo'ehara ndoguerokoiha itembiapope mba'e iporã teeva, upeicha ojehesa mondova hetavê oime $(63,38 \%)$ ndoikoséiva mbo'ehára rekorami. Upeicha ojekuaa, ñeporandu hárupi ojohu ndoguerekoiha mba'e puaka teeeva ha oikomava mbo'ehára oime hatã joty upe tembiapo rehe, hou joty omboguapy ojehe aranduete reta ara rire hekovepy, oikuaake ojepe'ata peteĩ mba'eporã, há avei oñemoĩ upe teko puku ohasata opamba'e tenonde kuarã, tembiapo há tekokuaa mbo'epy.

Ñẽ’ẽ poravó pyre: Mbo'epy rekomoña, Arandu pavẽ rehe ojokuáikuaava, Pósestruturalismo; Decolonialidade; Jehaipy. 


\section{O MARCO ZERO}

O Marco Zero

De Buda, Gautama,

o Nada.

do ocidente o todo pensado se coloca em muitas faces, um dilema é o polígono da vigília, panóptico, ciclópico, olhos que tudo veem cegos sem ver sempre o nada.

Gustavo Bastos

O Marco Zero de uma cidade estabelece as medições de distâncias relativas ao município, e uma das ferramentas utilizadas para mensurar com precisão essas distâncias são os chamados marcos geodésicos que formam o Sistema Geodésico Brasileiro - SGB, sendo, por exemplo, uma chapa de ferro fixada em uma superfície de concreto onde são gravadas informações relativas a latitude, longitude e altitude de determinado local, conforme definiu a Câmara de Vereados de Campo Grande MS (2018), em sessão realizada no mês de maio de 2018.

O Marco Zero da capital Campo Grande tem como medições: "Latitude (S): 20²8'13,40737, Longitude (W): 54 37'25,87099, UTM (N) 7734665,656 m e UTM (E) 747864, 760 m", e está localizado no gramado em frente ao monumento "Carro de Boi". A definição do local foi estabelecida por meio da Lei ํㅜ 6.004, publicada em Diário Oficial no dia 18 de maio de 2018. Anteriormente, o Obelisco era usado como ponto de medida de distâncias entre as cidades, mas, agora, coordenadas geográficas definiram o local correto. 
Imagem 1: Marco Zero da cidade de Campo Grande - MS

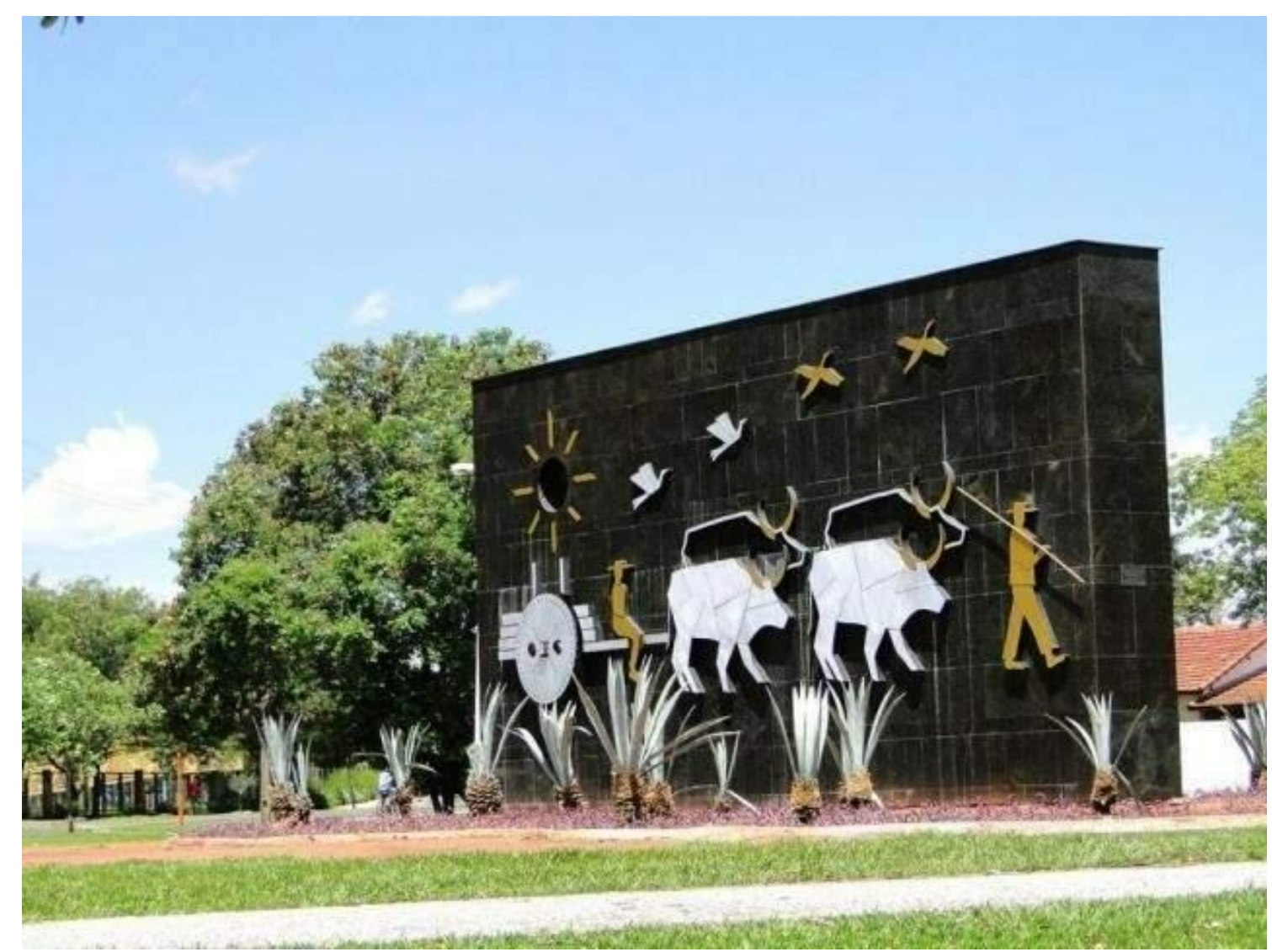

Fonte: "Marco Zero" da Cidade de Campo Grande - MS. Campo Grande News (2018).

Mais que um centro geográfico, entendo que o Marco Zero evidencia também o crescimento da cidade que começou a partir daquele local, além disso, expressa um valor afetivo, ao marcar na história como aconteceu e continua acontecendo o desenvolvimento do estado de MS e da capital Campo Grande. Ao trazer a ideia do Marco Zero para tese, da mesma maneira, intencionei marcar o centro geográfico que delimita o ponto de origem deste trabalho, um horizonte ou o sinal de alguma coisa, quem sabe? Talvez um ponto para entender o início de uma história.

Nesse "Marco Zero" apresento apenas os infográficos, agrupados de acordo com os focos específicos observados na geração de dados: (1) Abrangência da pesquisa; (2) Características dos participantes da pesquisa, ou seja, alunos do $3^{\circ}$ ano do Ensino Médio e professores que compuseram um grupo observador; (3) Aspectos sobre a formação e a renda familiar dos integrantes da pesquisa; (4) Dados sobre o processo de escolarização dos alunos participantes da pesquisa; (5) 
Mapeamento sobre a intenção profissional pretendida dos alunos participantes da pesquisa.

A opção em utilizar infográficos se justifica pela importância de apresentar informações preponderantes por meio de elementos gráfico-visuais, integrados com texto sintético e dados numéricos. Todos os infográficos da tese são originais, foram criados pela pesquisadora, fotografados e formatados por um designer gráfico.

Saliento, no entanto, que nesta parte da tese, a ideia é apresentar a visualização dos dados e respectivos agrupamentos. A análise e a construção de sentidos desses infográficos serão apresentadas ao longo dos capítulos da tese. A opção pela organização deste "Marco Zero" se deve à minha percepção de dois fatores: (1) a valorização do levantamento de dados no modo quantitativo, reconhecendo a força deles para a compreensão do quadro social, cultural, educacional e político do foco desta pesquisa, ou seja, o interesse/desinteresse pela profissão docente no Mato Grosso do Sul; (2) a priorização à uma análise qualitativa desse quadro social, cultural, educacional e político. Essa análise pretende contar com dados estatísticos, trabalhando os eventuais conflitos entre o quantitativo e o qualitativo, sem deixar que a força do primeiro se sobreponha sobre o segundo, ou que interfira numa construção de sentidos voltada para a qualidade dos dados. 


\section{Abrangência da Pesquisa}

Infográfico 1: Mapa de MS com os municípios participantes e não participantes da pesquisa

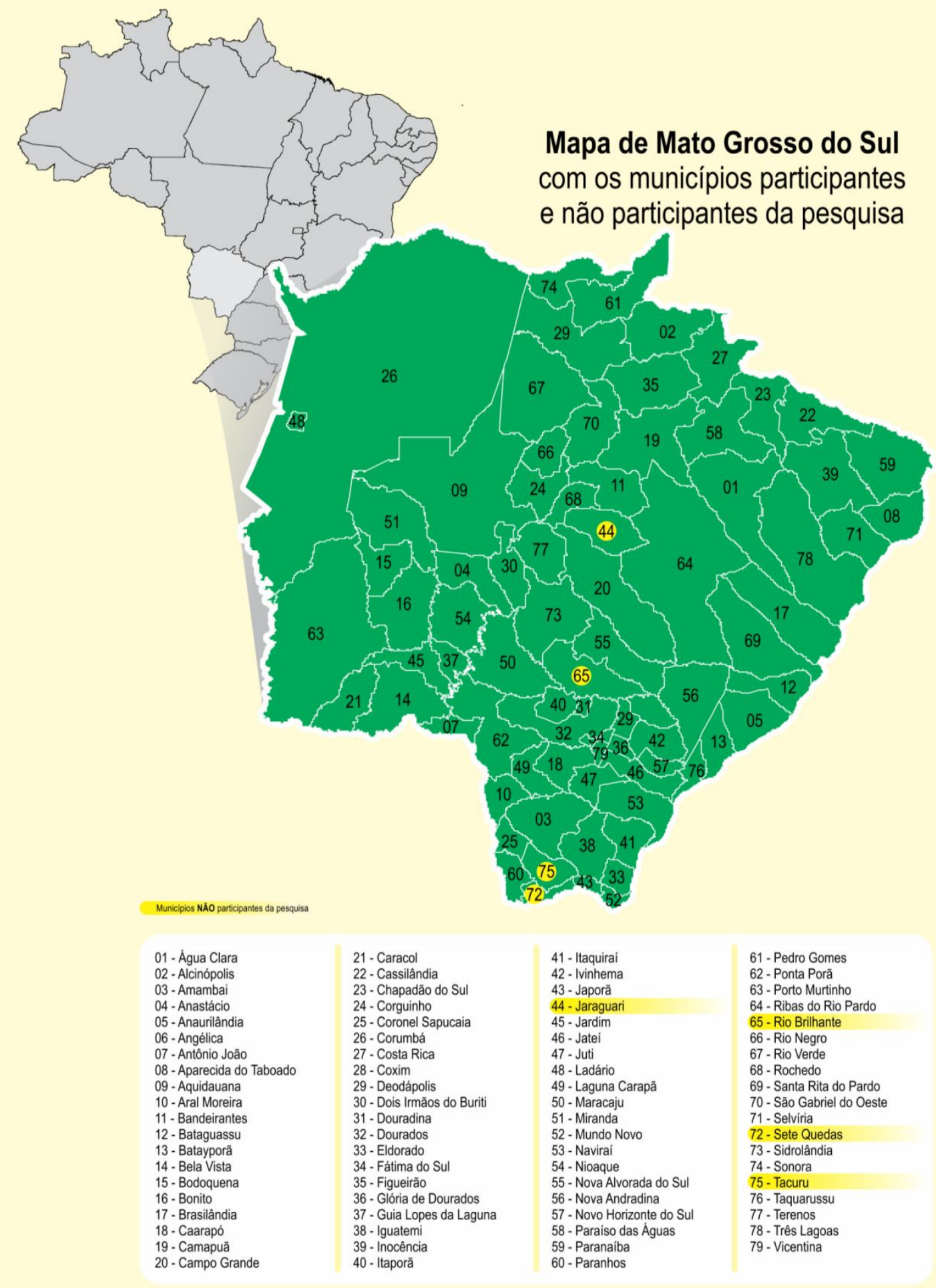

Fonte: Própria (2018) 
Infográfico 2: Quantitativo de alunos matriculados no $3^{\circ}$ ano do Ensino Médio que participaram da pesquisa, distribuídos por modalidade de ensino

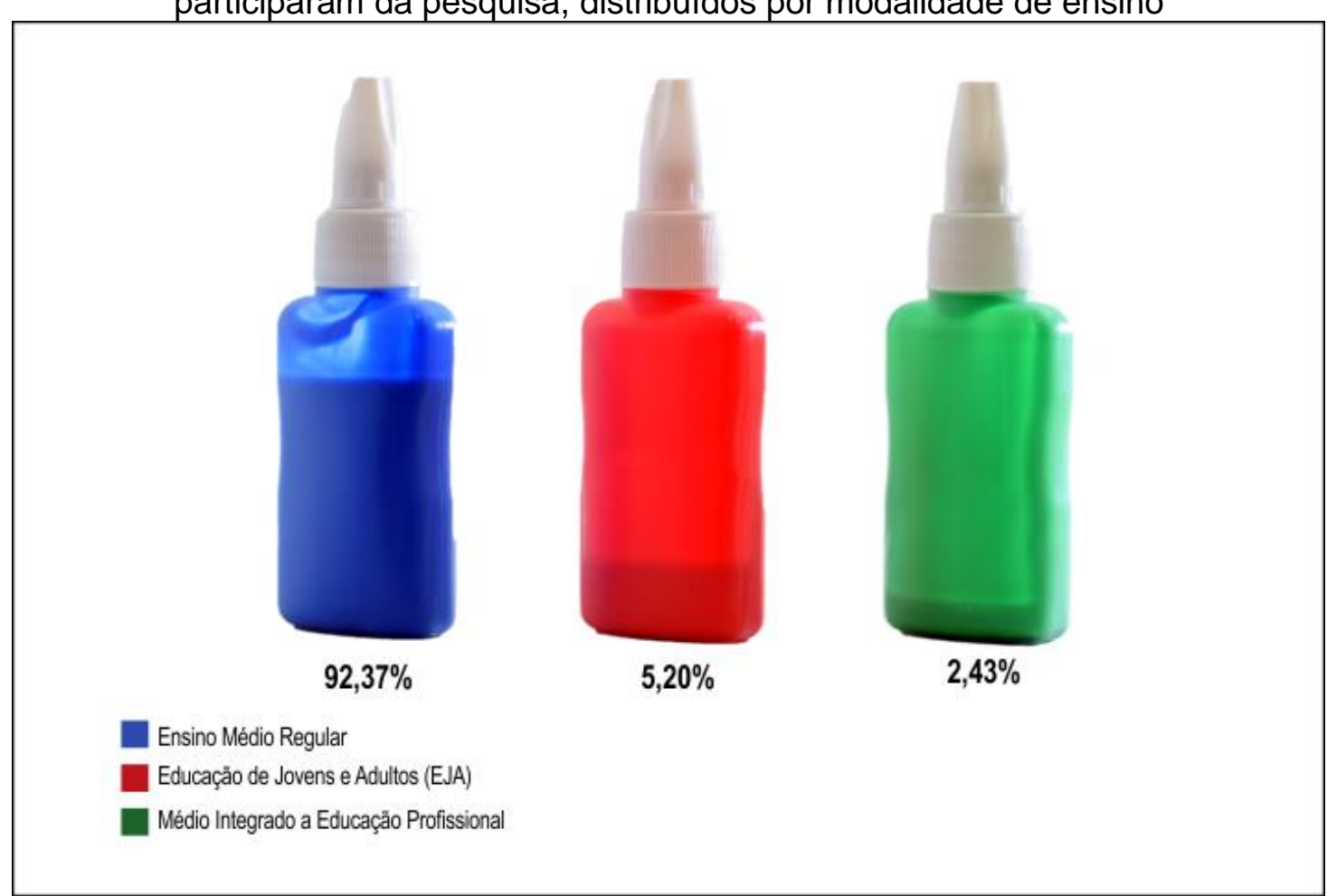

Fonte: Própria (2018)

\section{Algumas características dos participantes da pesquisa}

Infográfico 3: Sexo

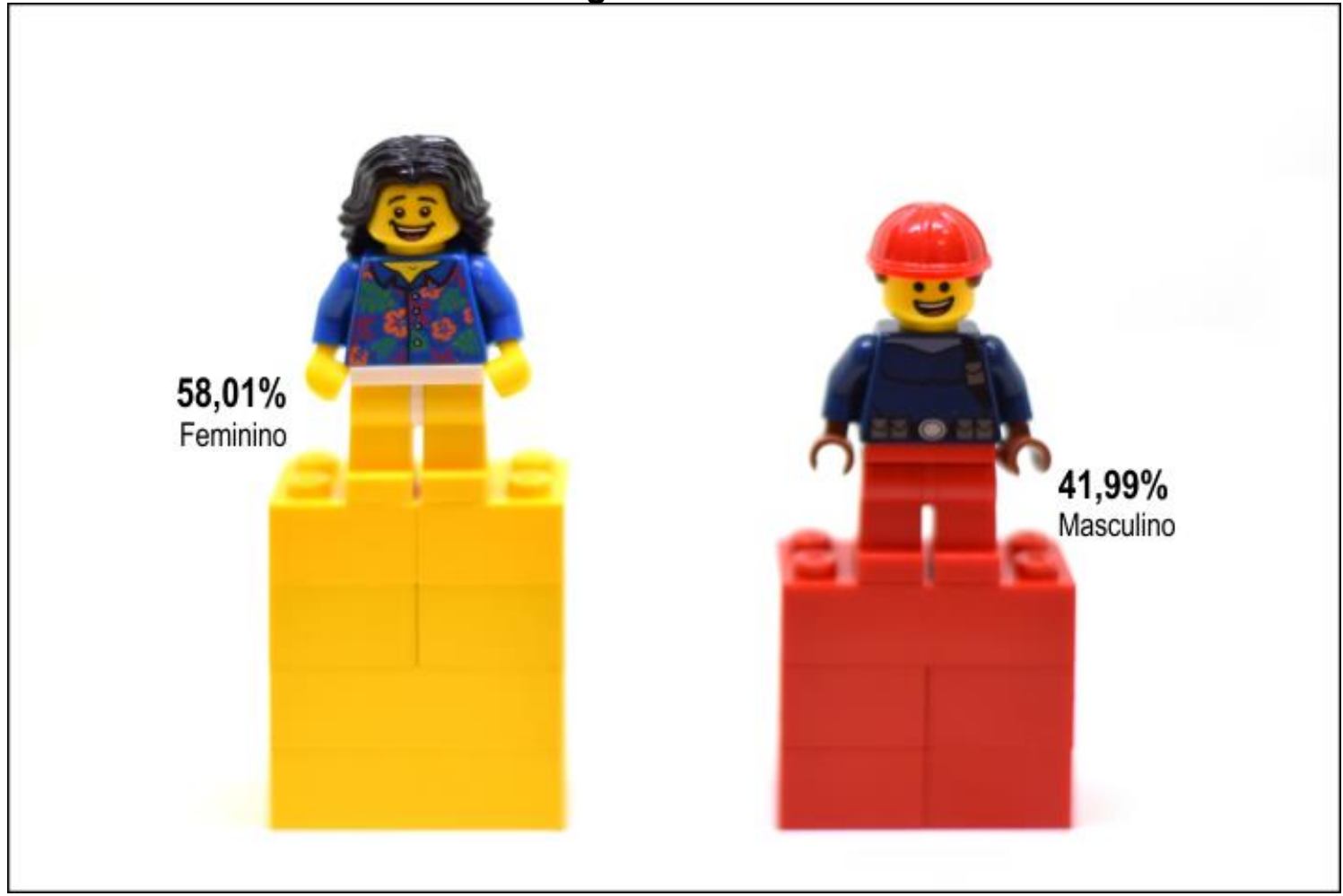

Fonte: Própria (2018) 
Infográfico 4: Idade

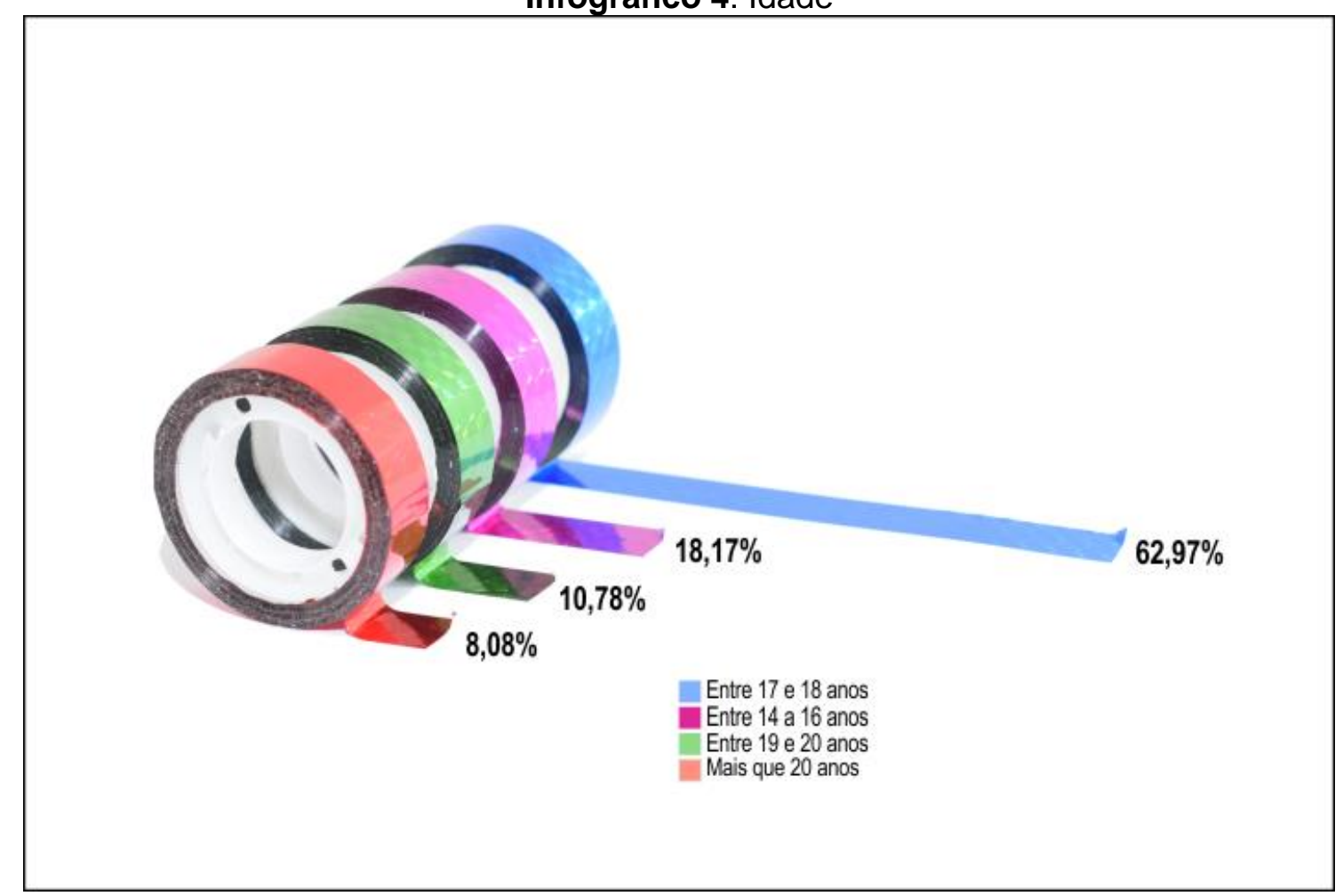

Fonte: Própria (2018)

Infográfico 5: Autodeclaração de raça

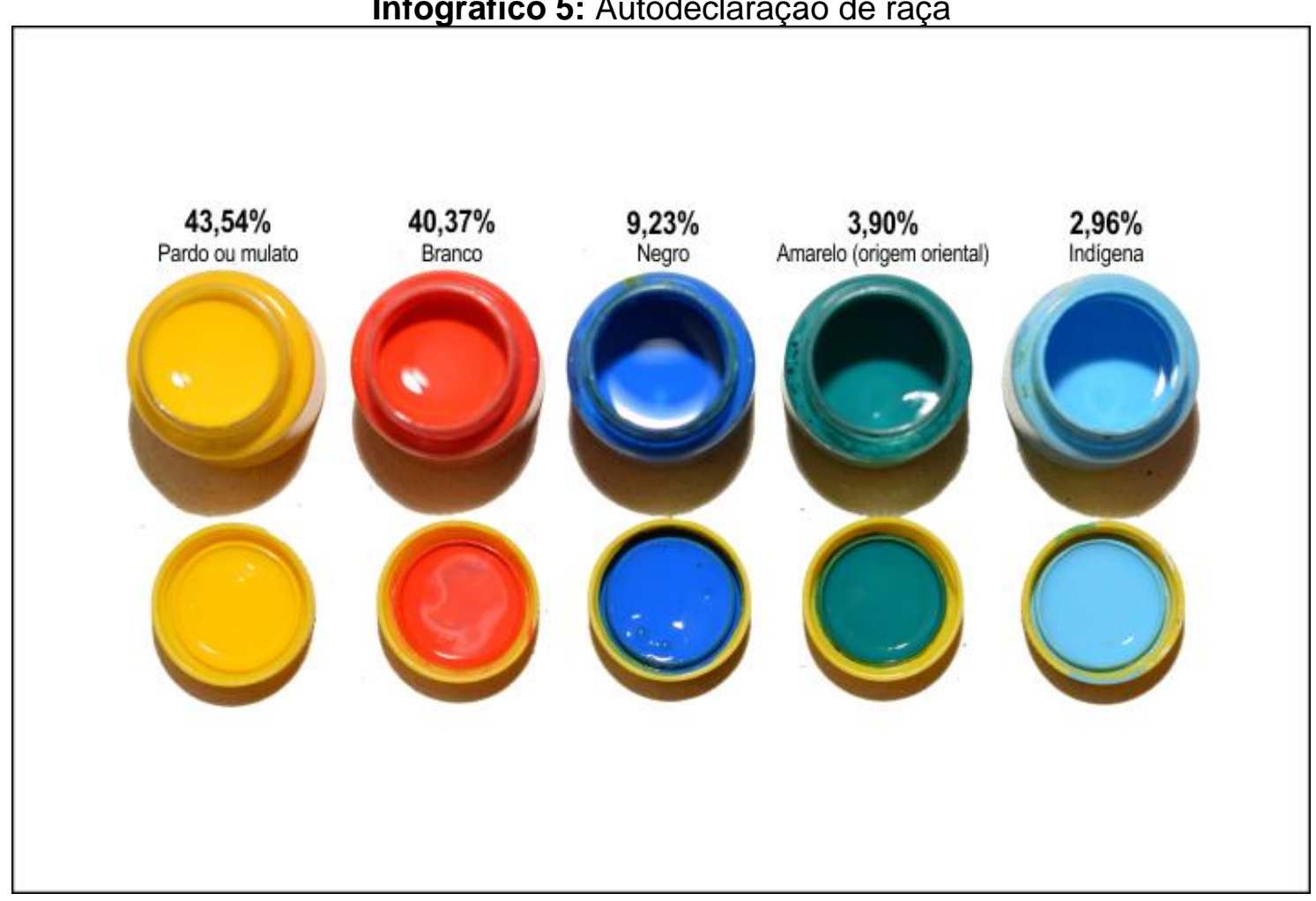

Fonte: Própria (2018) 
Infográfico 6: Características gerais dos professores do Ensino Médio

\section{PROFESSORES}

\section{ENSINO MÉDIO}

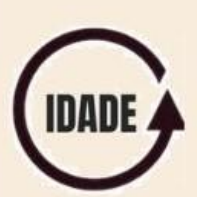

IDADE

Professor 1: 36 anos

Professor 2: 42 anos

Professor 3: 43 anos

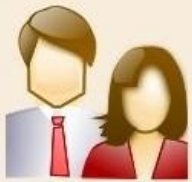

SEXO

Professor 1: masculino

Professor 2: masculino

Professor 3: feminino

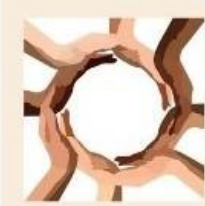

AUTODECLARAĢ̃̃o dE RAÇA

Professor 1: pardo

Professor 2: branco

Professor 3: pardo

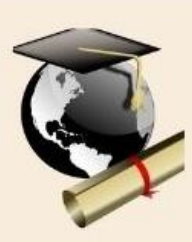

\section{FORMAÇÃOO}

Professor 1: Graduação em Letras, Especialização em Língua

Inglesa e mestrando em Letras

Professor 2: Graduação em Letras, Especialização em

Multiletramentos

Professor 3: Graduação em Letras, duas especializações em Língua Inglesa e mestranda em Letras

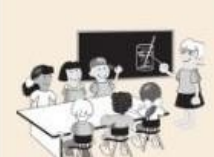

\section{REDE DE ENSINO}

Professor 1: Estadual e Municipal

Professor 2: Estadual e Particular

Professor 3: Estadual e Municipal

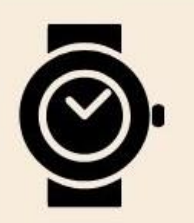

\section{TEMPO DE DOCÊNCIA}

Professor 1: 19 anos

Professor 2: 20 anos

Professor 3: 20 anos

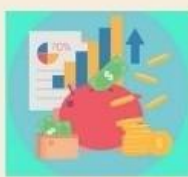

\section{RENDA FAMILIAR}

Professor 1: $\mathrm{R} \$ 12 \mathrm{mil}$

Professor 2: $\mathrm{R} \$ 15 \mathrm{mil}$

Professor 3: $\mathrm{R} \$ 14 \mathrm{mil}$

Fonte: Própria (2019 
Infográfico 7: Características gerais dos professores do Ensino Superior

\section{PROFESSORES}

ENSINO SUPERIOR

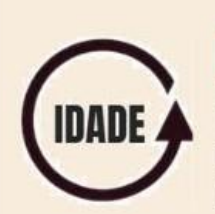

IDADE

Professor 1: 61 anos

Professor 2: 60 anos

Professor 3: 68 anos

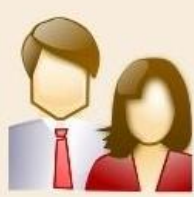

\section{SEXO}

Professor 1: feminino

Professor 2: feminino

Professor 3: feminino

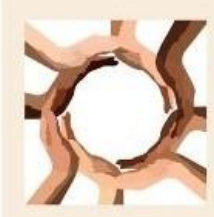

\section{AUTODEGLARAÇÃo DE RAÇA}

Professor 1: negra ou parda

Professor 2: parda

Professor 3: parda

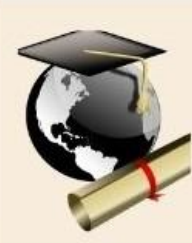

FORMAĢ̃̃̃O

Professor 1: Graduação em Letras, Mestrado e Doutorado em Educação

Professor 2: Graduação em Psicologia, Especialização em Psicologia, Mestrado e Doutorado em Educação Professor 3: Graduação em Letras, Especialização, Mestrado e Doutorado em Educação
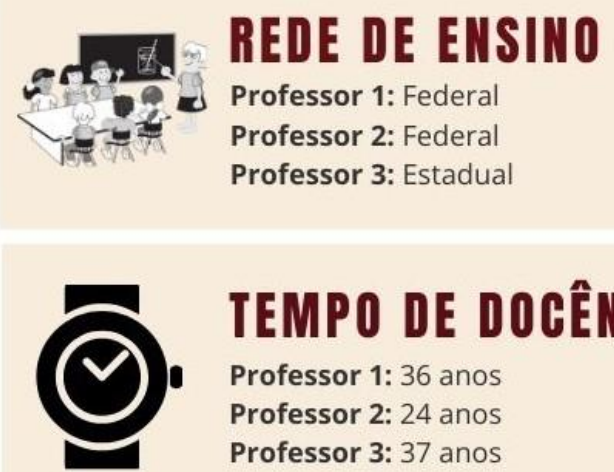

\section{TEMPO DE DOCÊNCIA}

Professor 1: 36 anos

Professor 2: 24 anos

Professor 3: 37 anos

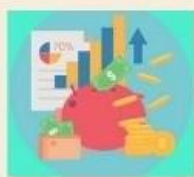

RENDA FAMILIAR

Professor 1: $\mathrm{R} \$ 16.000,00$

Professor 2: $\mathrm{R} \$ 16.900,00$

Professor 3: $\mathrm{R} \$ 12.500,00$

Fonte: Própria (2019) 
Infográfico 8: Características gerais dos técnicos da SED/MS

\section{TÉGNICOS}

\section{SED/MS}

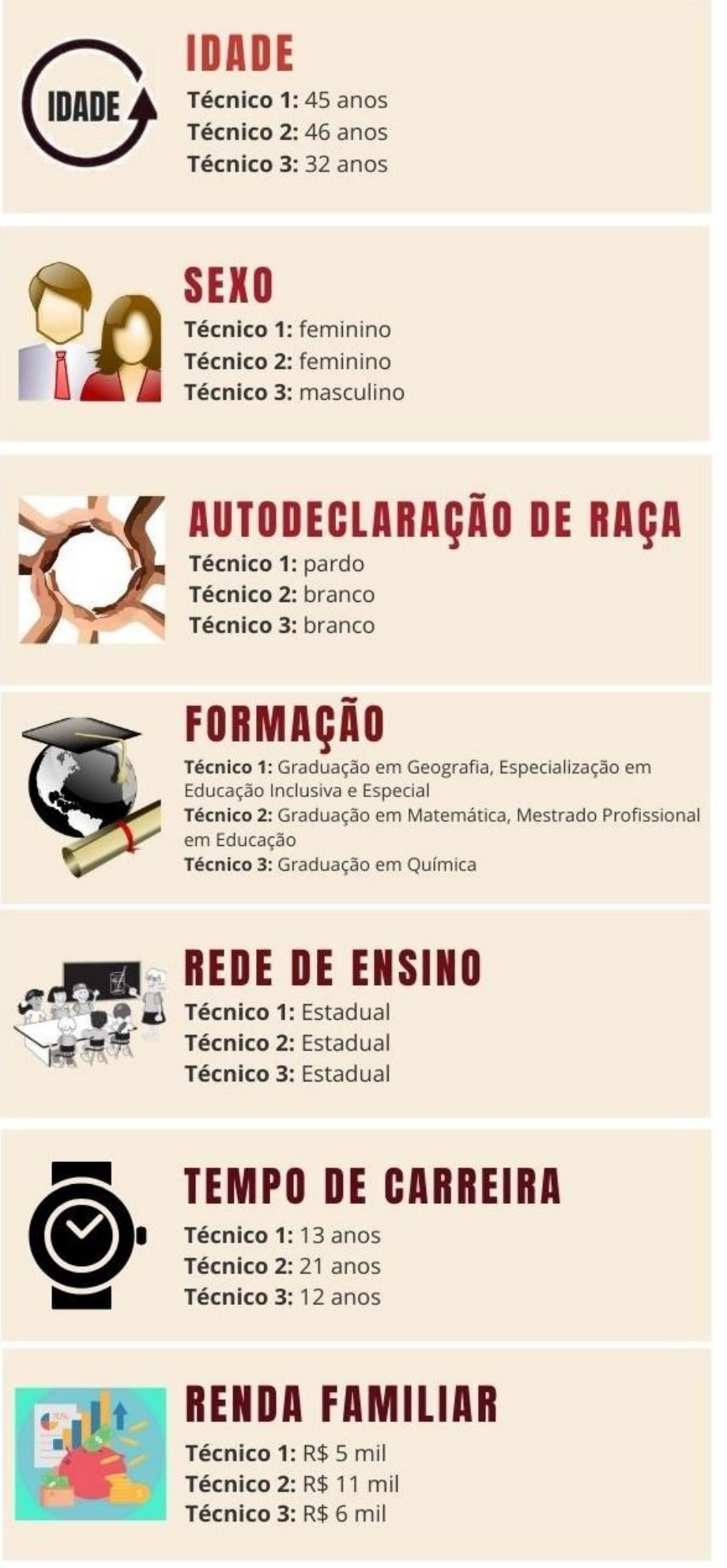

Fonte: Própria (2019) 
3. Mapeamento dos aspectos sobre formação e renda familiar dos participantes da pesquisa

Infográfico 9: Quantitativo de pessoas que residem na mesma casa

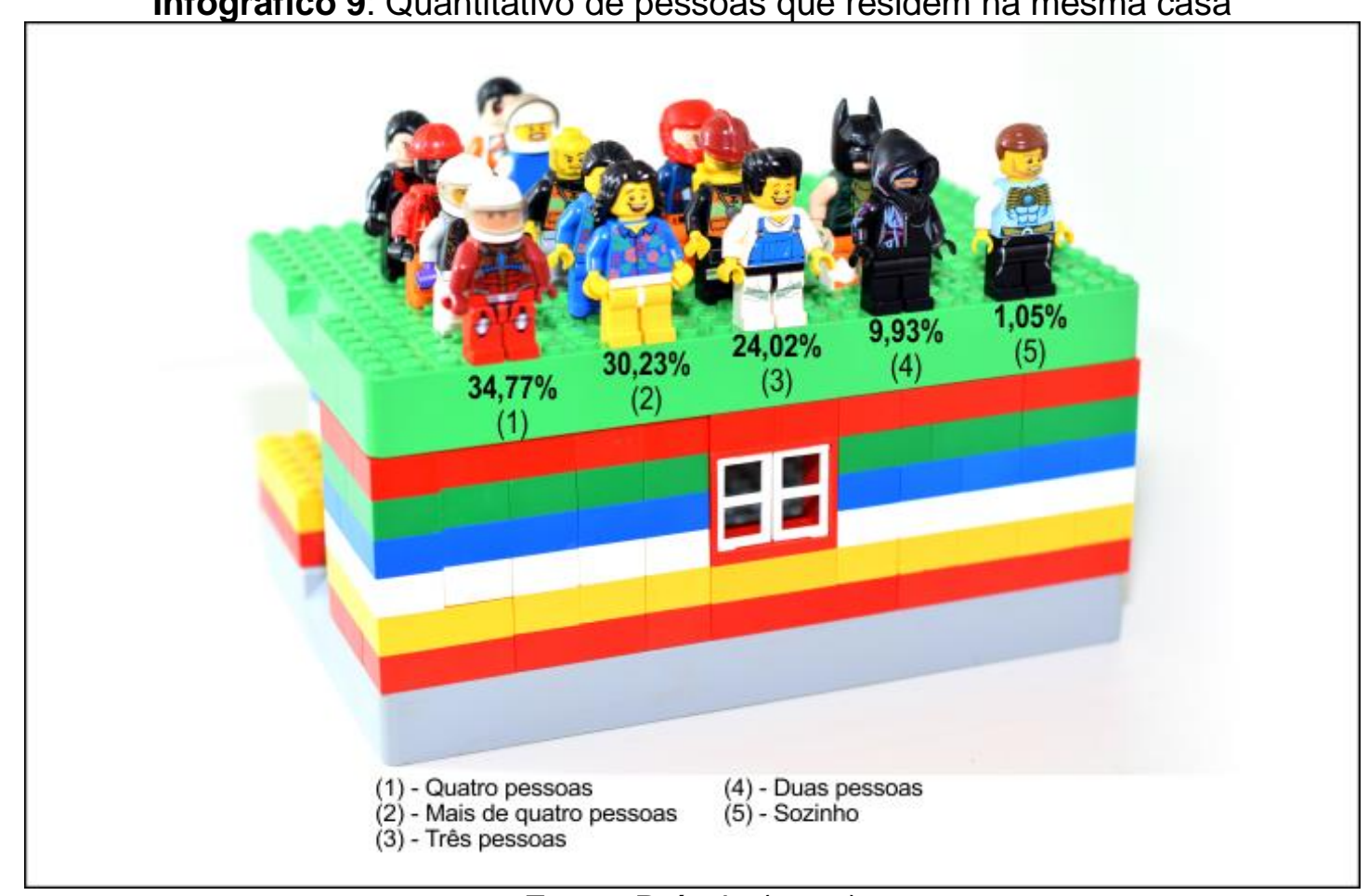

Fonte: Própria (2018)

Infográfico 10: Renda familiar aproximada

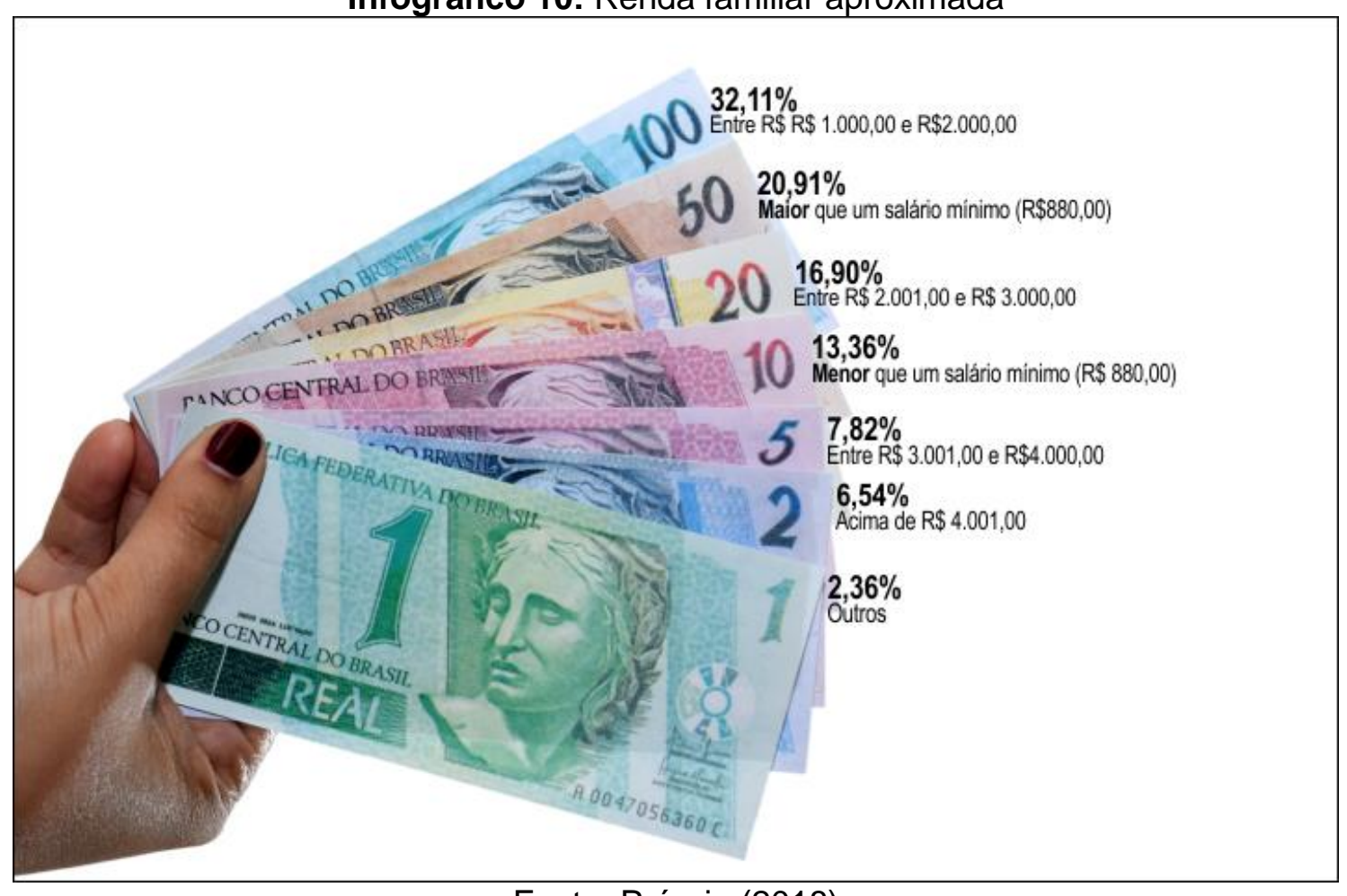

Fonte: Própria (2018) 
Infográfico 11: Grau de escolaridade do pai ou responsável

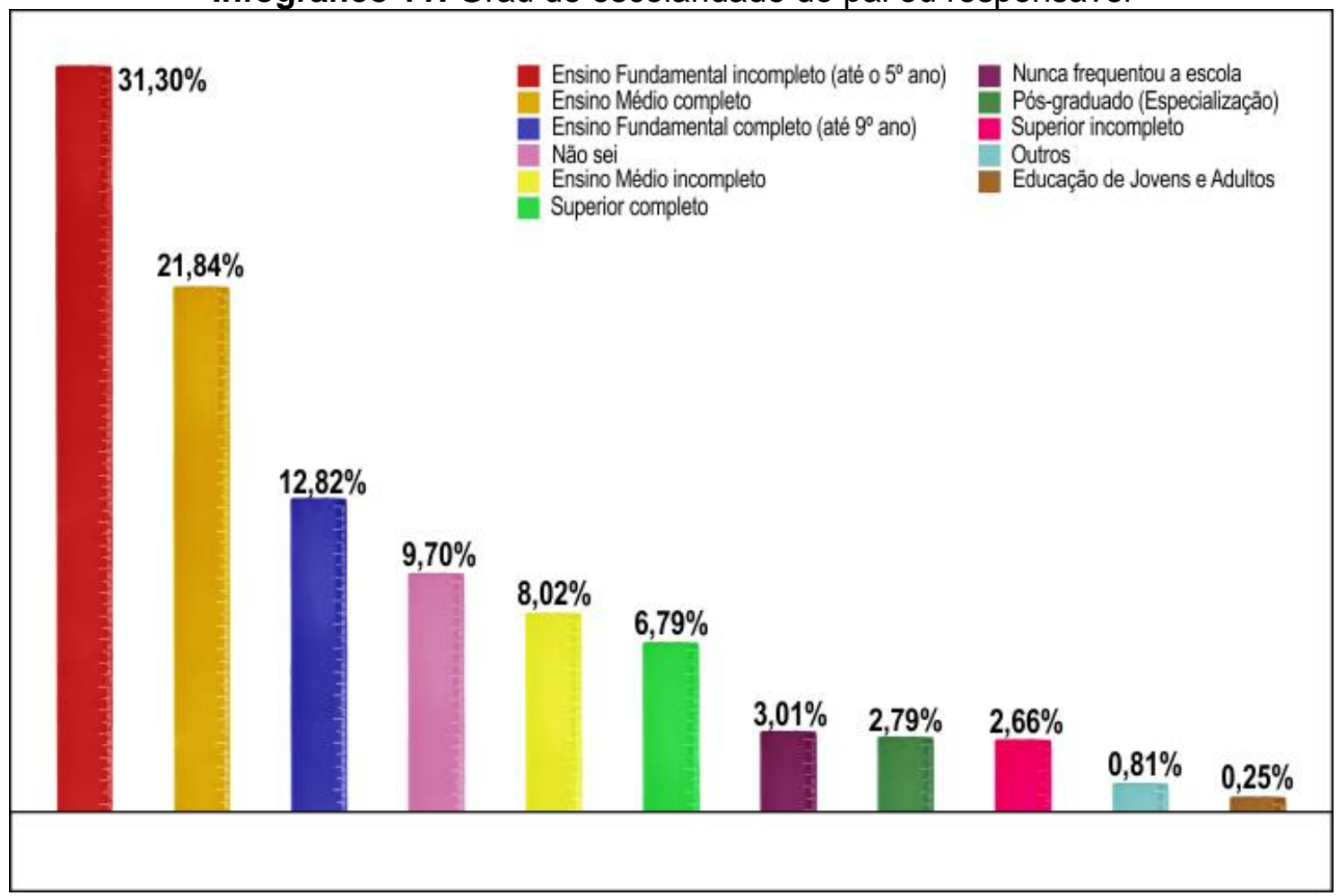

Fonte: Própria (2018)

Infográfico 12: Grau de escolaridade da mãe ou responsável

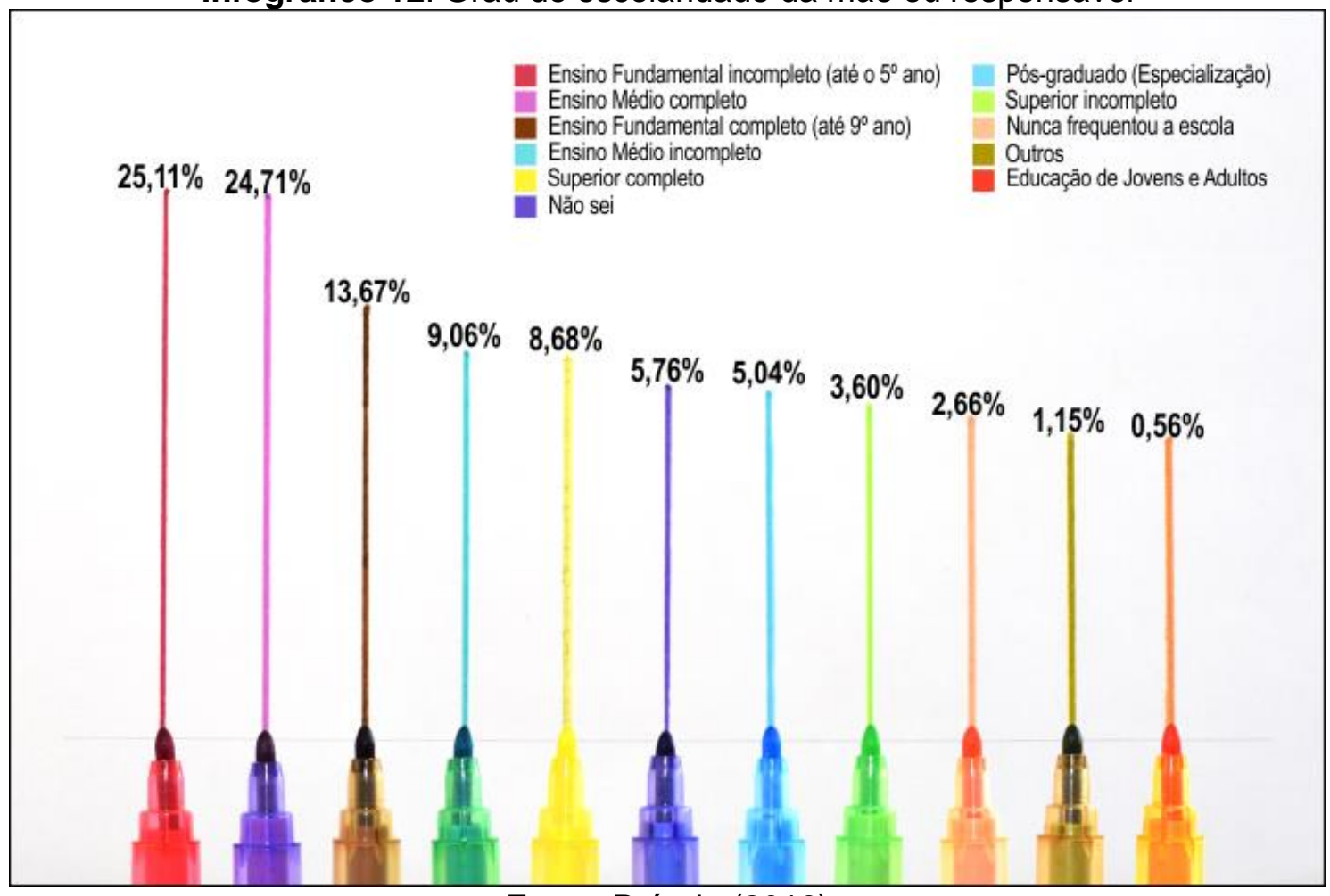

Fonte: Própria (2018) 
4. Dados sobre o processo de escolarização dos alunos participantes da pesquisa

Infográfico 13: Período que estuda na escola

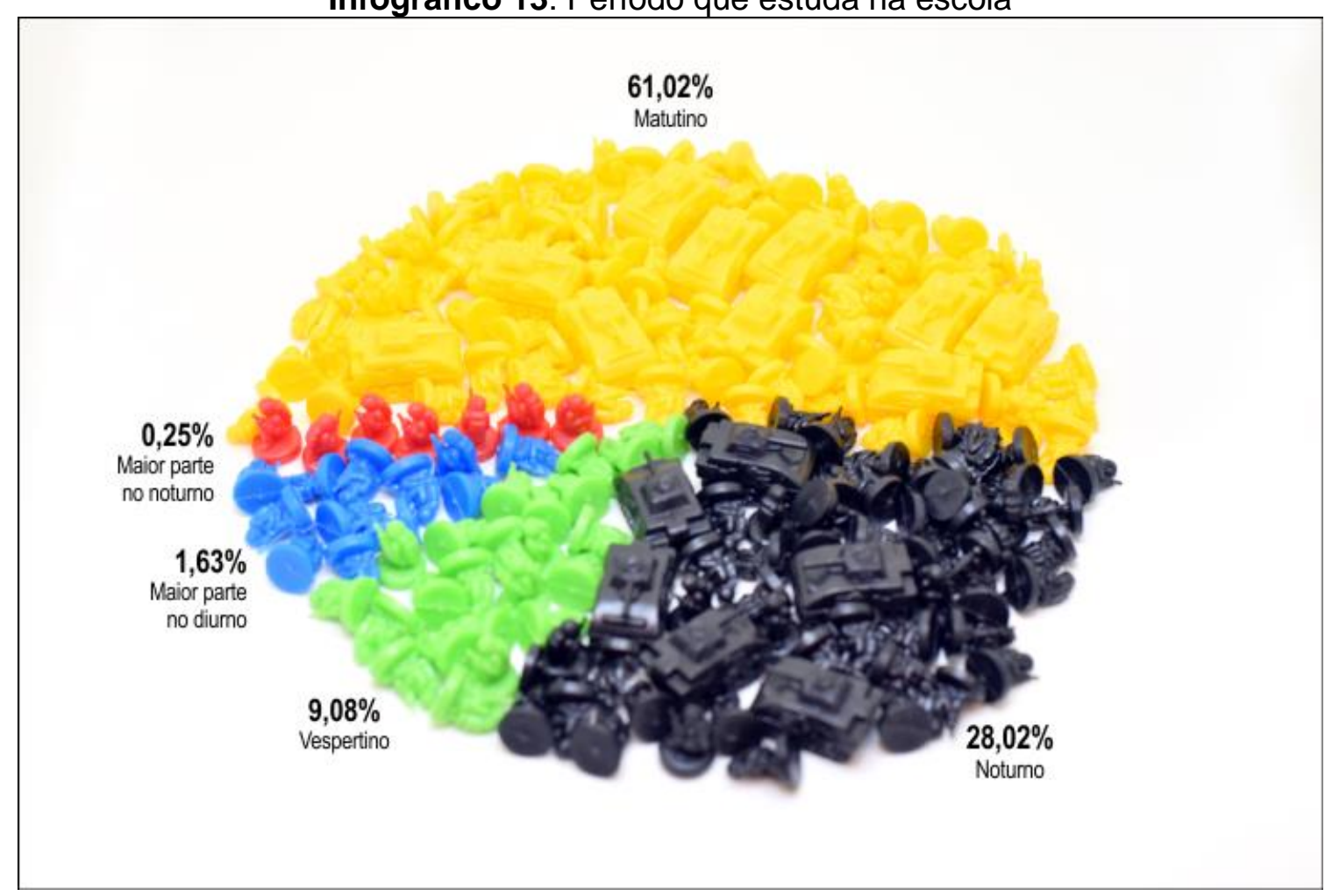

Fonte: Própria (2018)

Infográfico 14: Processo de escolarização em rede pública ou privada

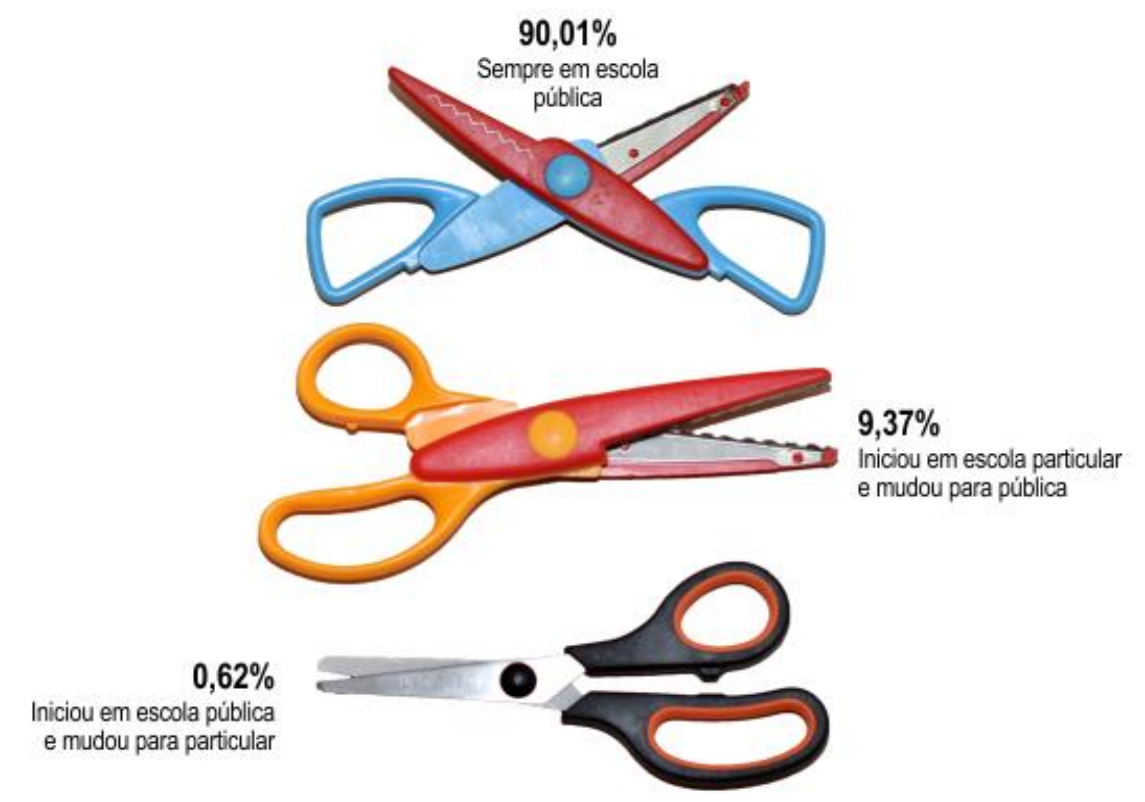

Fonte: Própria (2018) 
Infográfico 15: Exerce algum tipo de trabalho remunerado

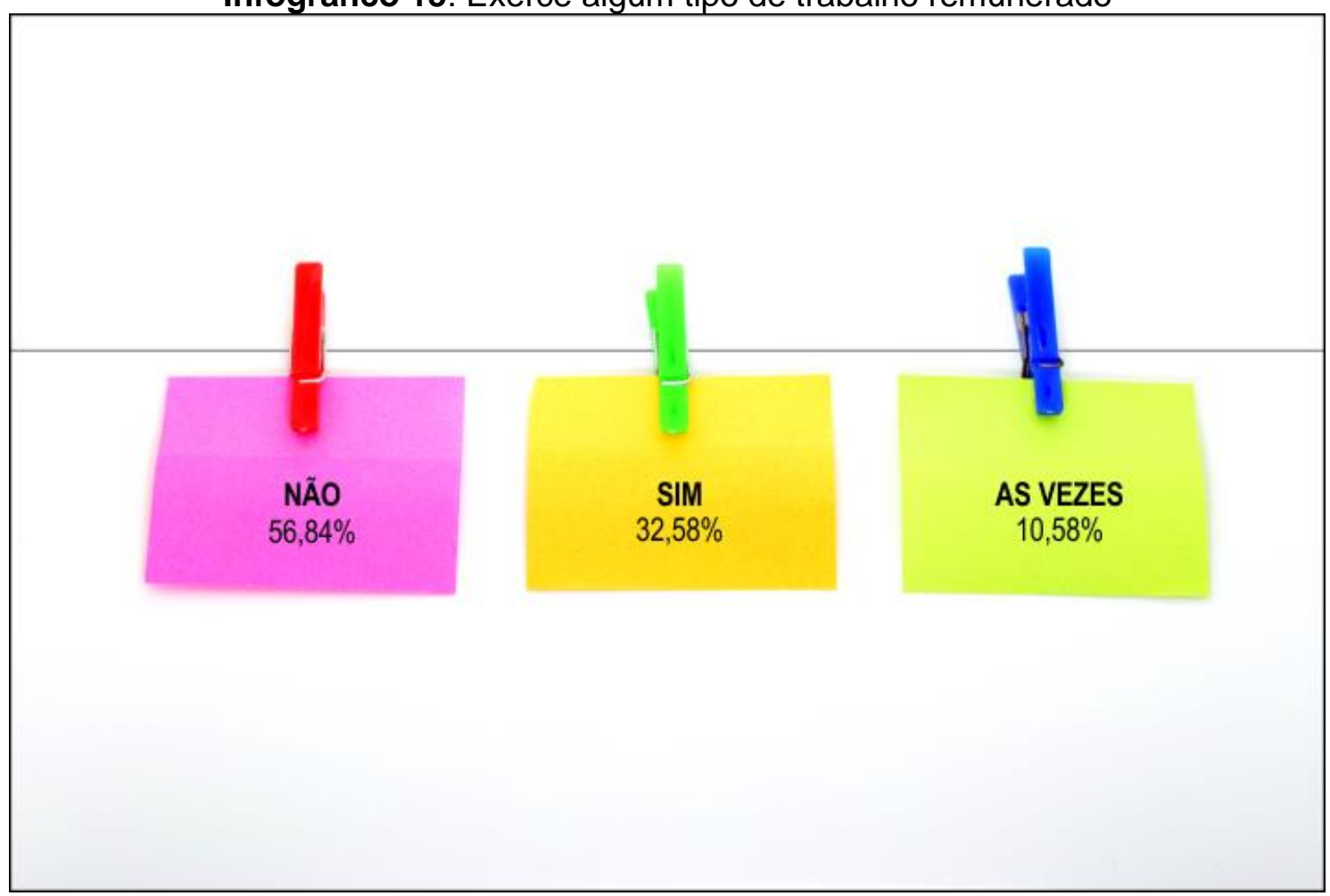

Fonte: Própria (2018)

Infográfico 16: A principal finalidade de trabalhar com remuneração

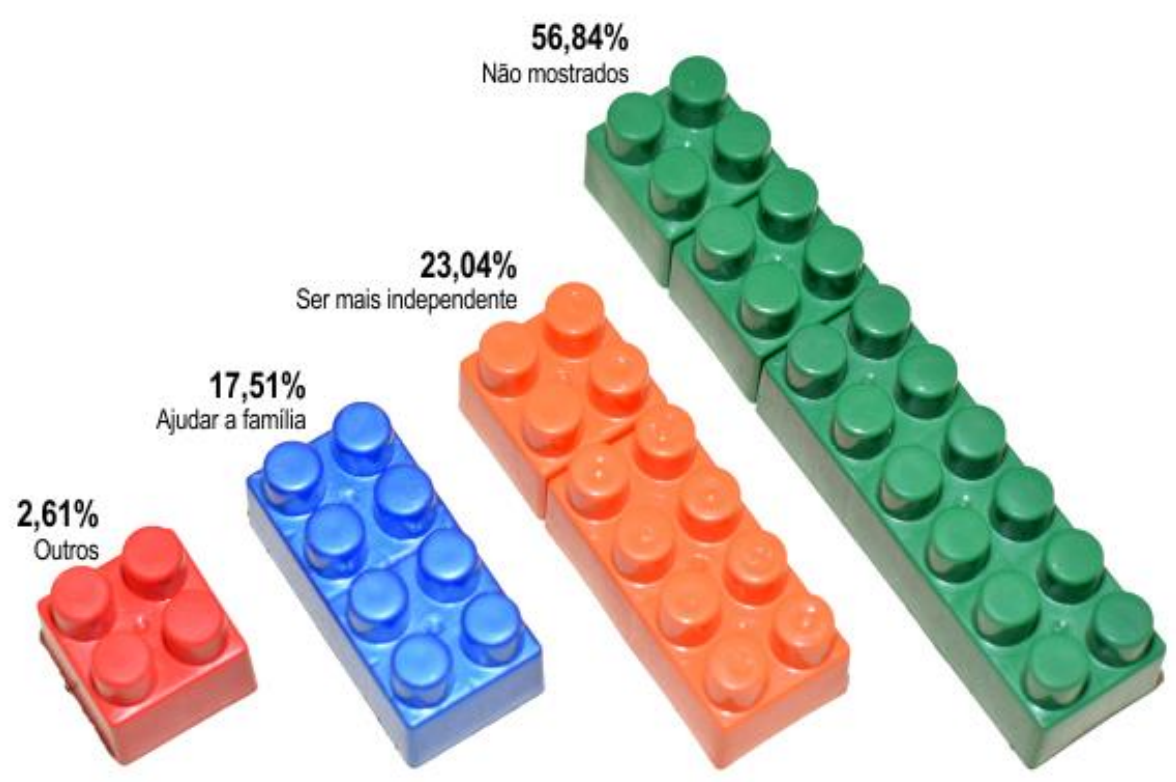

Fonte: Própria (2018) 
Infográfico 17: Desde qual idade trabalha com remuneração

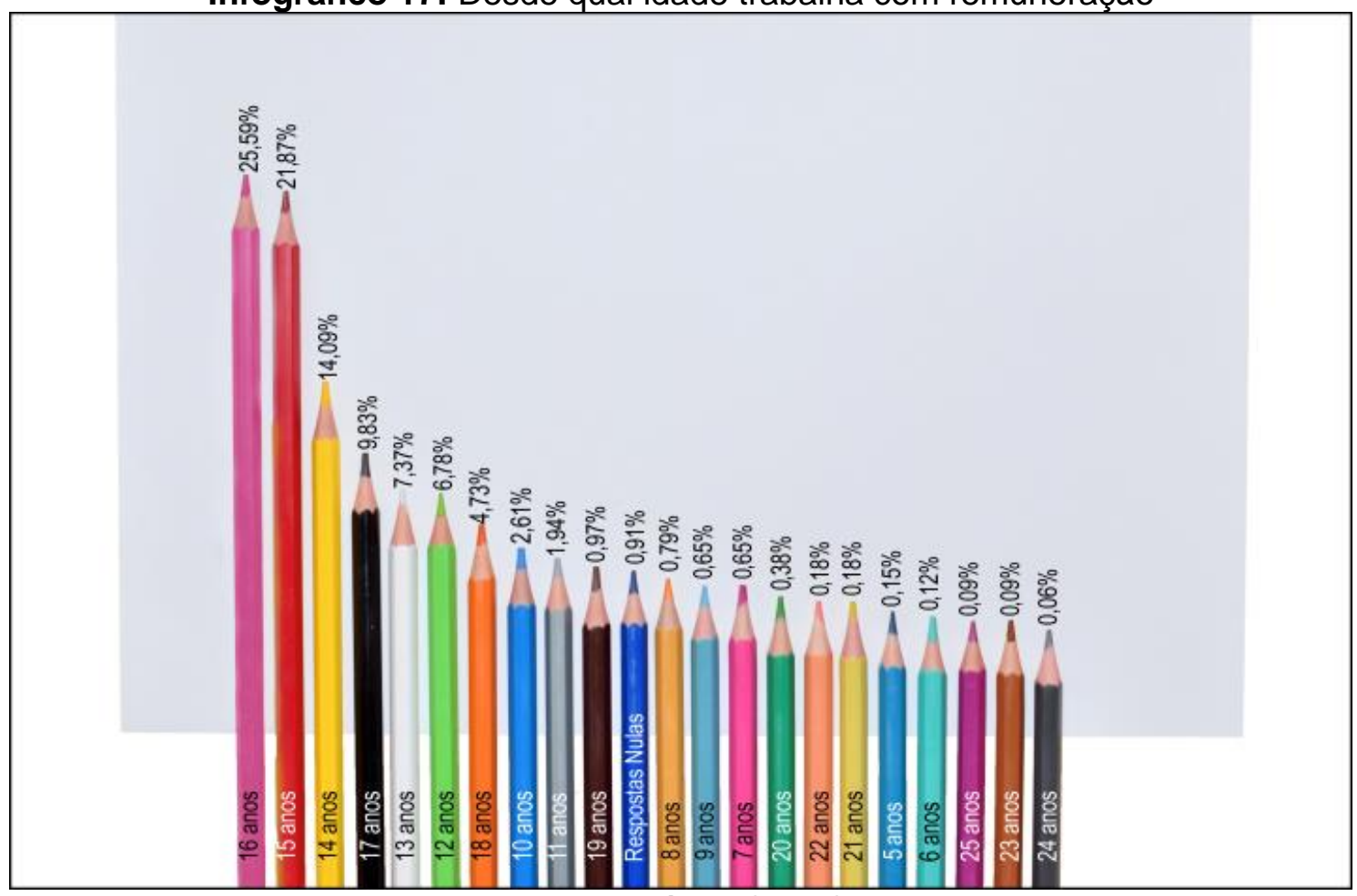

Fonte: Própria (2018)

5. Mapeamento sobre a intenção profissional pretendida dos alunos participantes da pesquisa

Infográfico 18: Pretensão de atividade para quando terminar o Ensino Médio

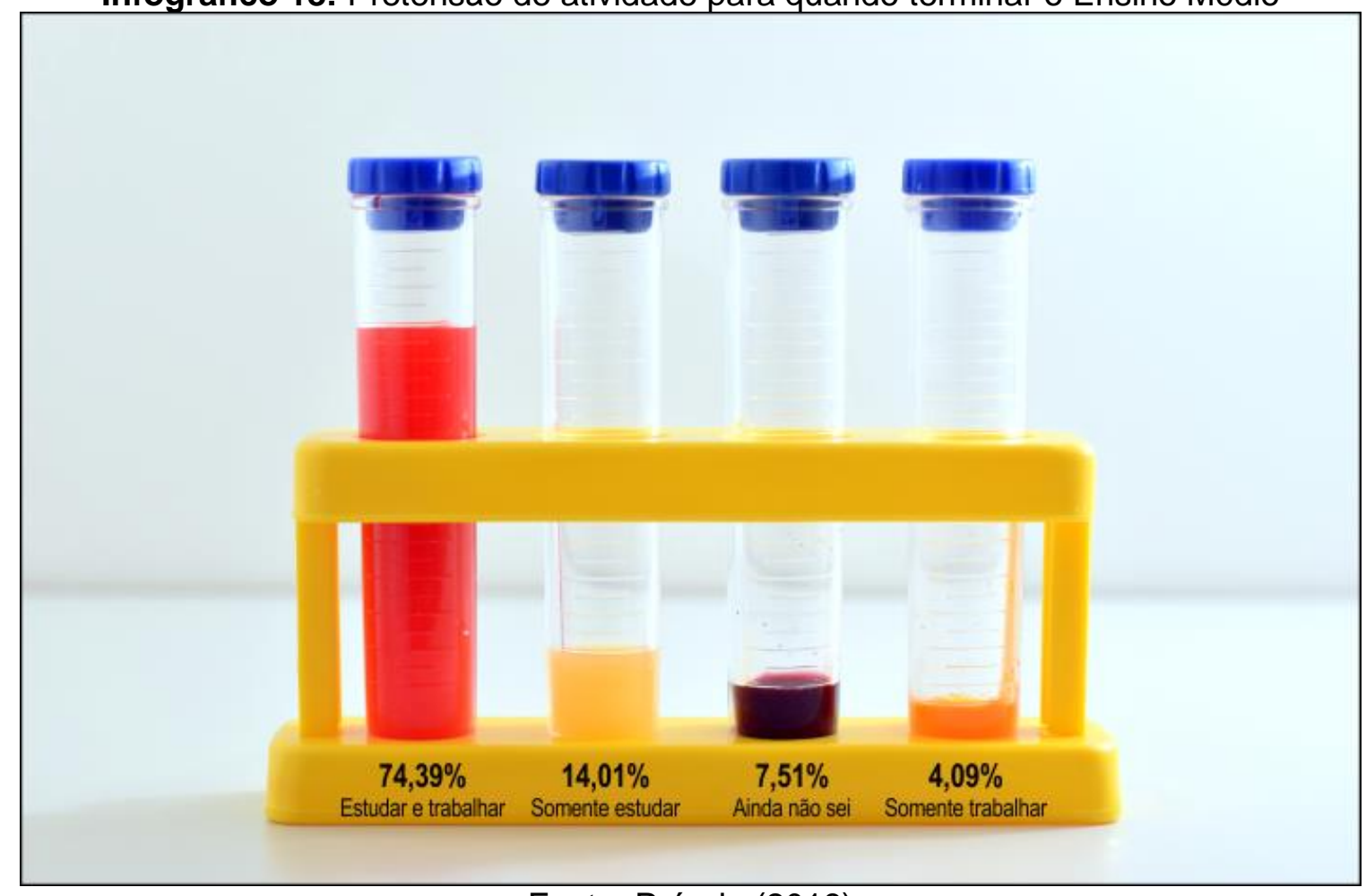

Fonte: Própria (2018) 
Infográfico 19: Quantitativo de alunos que fazem cursinho para prestar o Exame Nacional do Ensino Médio - ENEM

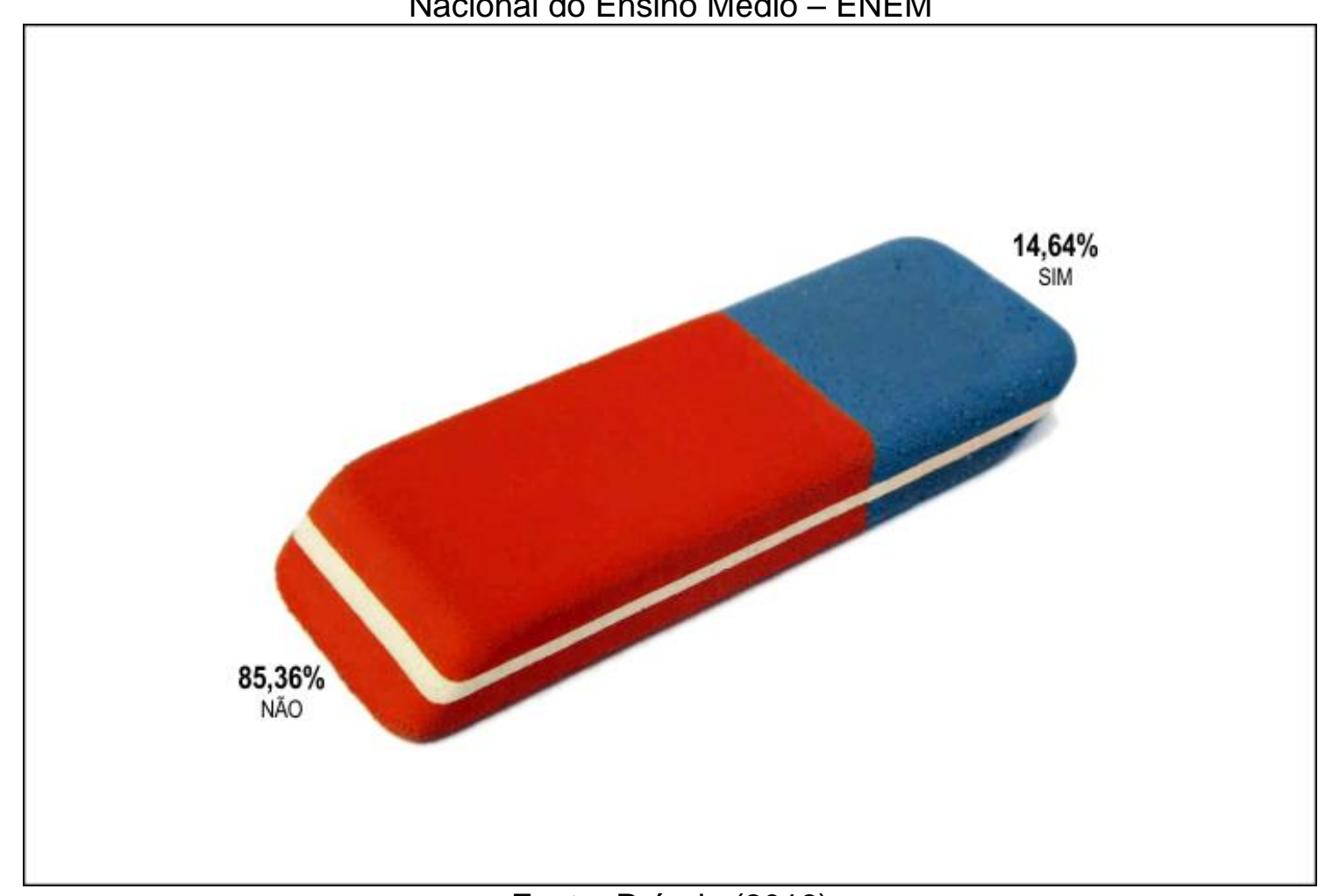

Fonte: Própria (2018)

Infográfico 20: Intenção de ingresso em Instituição de Ensino Superior

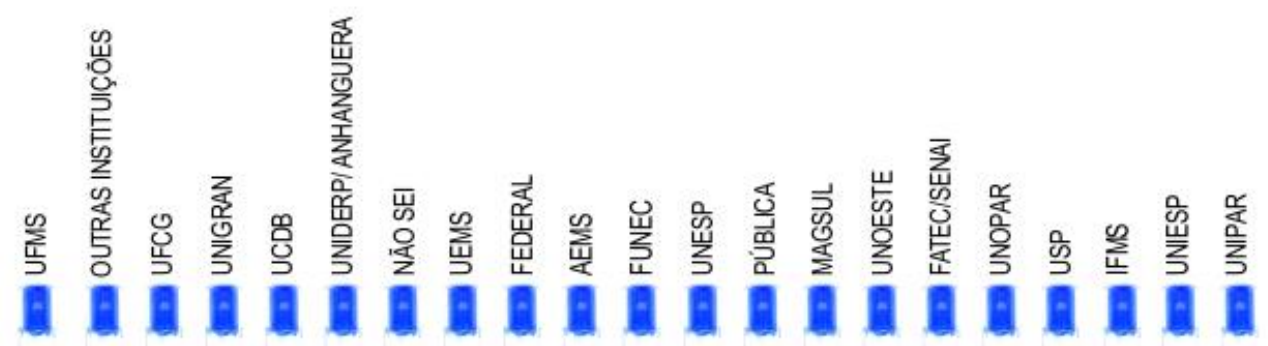

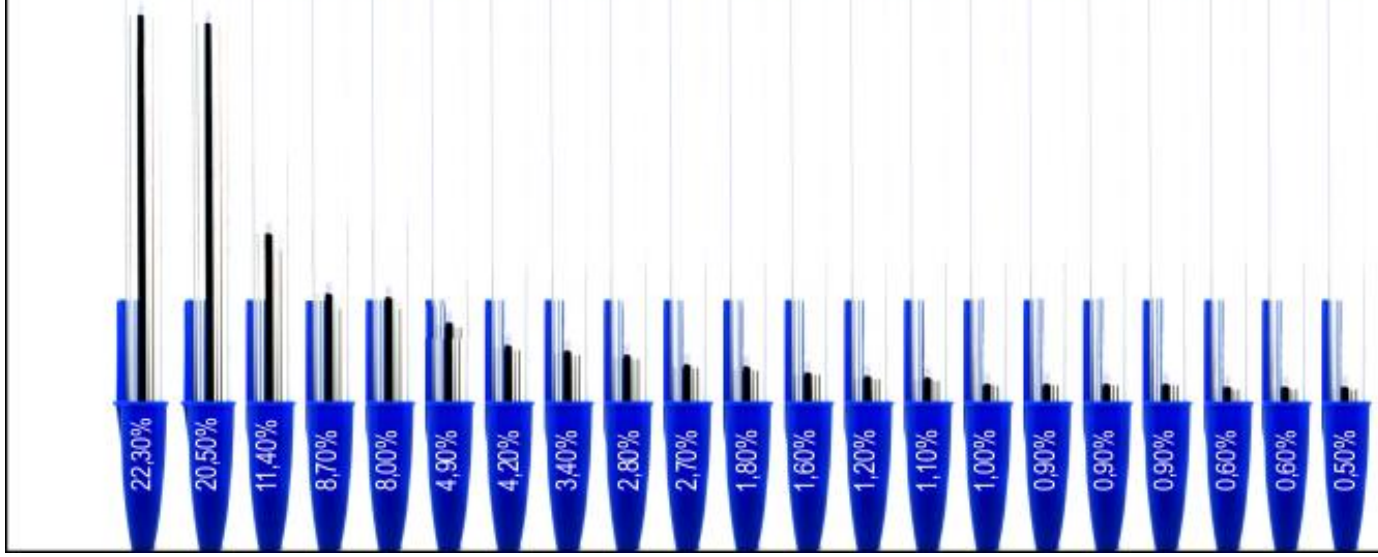

Fonte: Própria (2018) 
Infográfico 21: Pretensão de curso para ingressar na Instituição de Ensino Superior

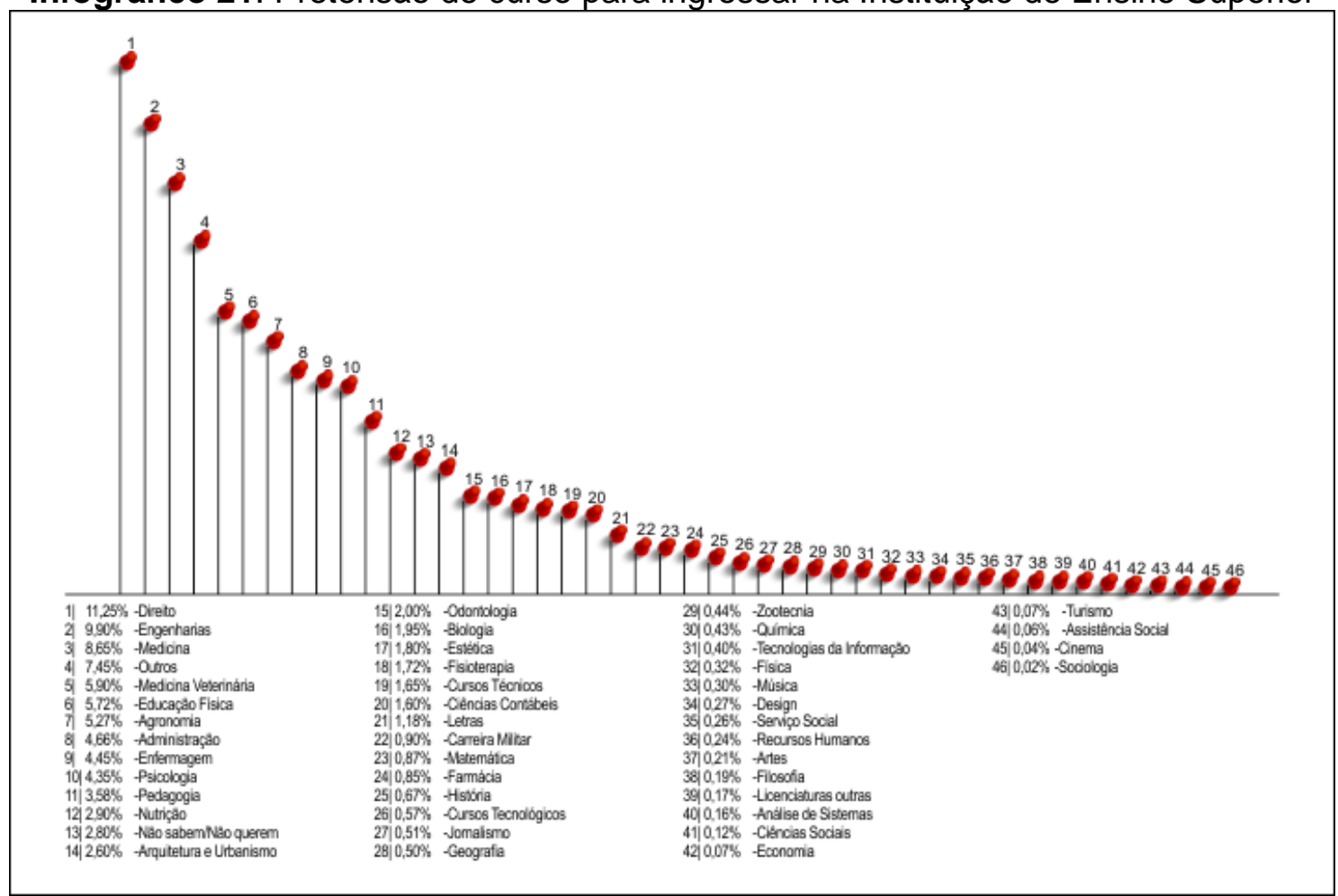

Fonte: Própria (2018)

Infográfico 22: Quantitativo de alunos que em algum momento pensam em ser professor

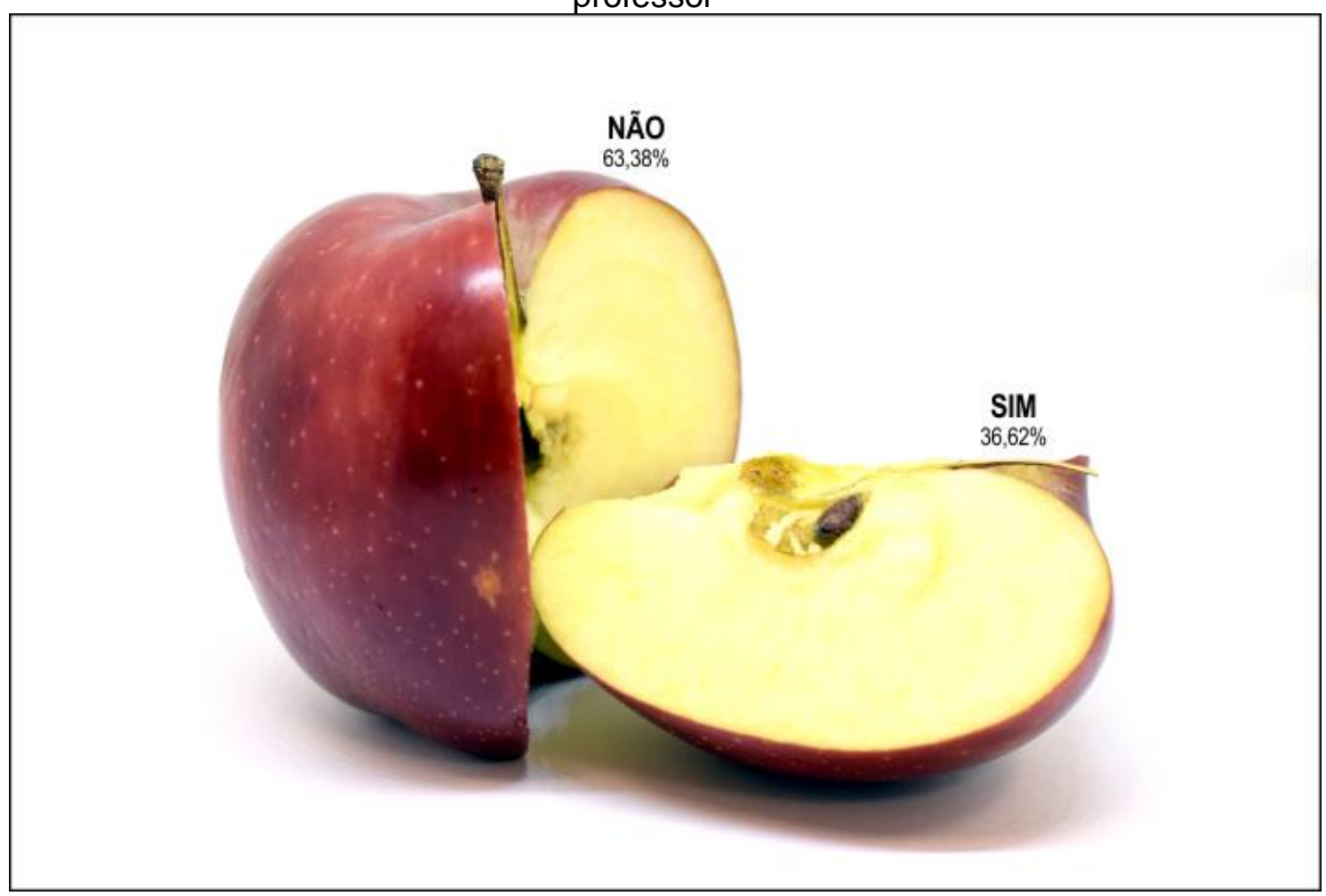

Fonte: Própria (2018) 
Infográfico 23: Se pensa em ser professor, seria da Educação Básica, do Ensino Superior ou de uma disciplina específica - 6 ao 9ำ anos e/ ou Ensino Médio

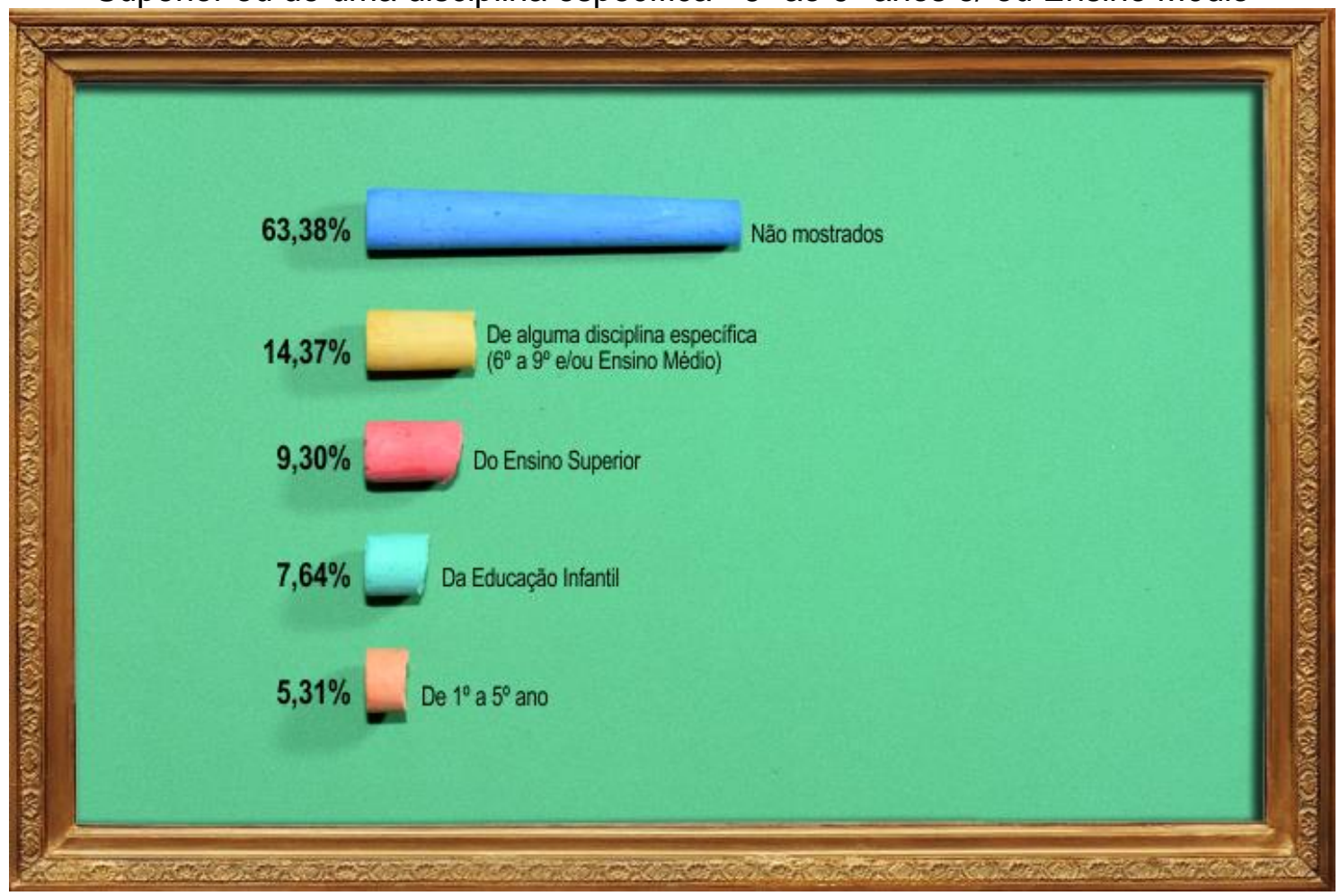

Fonte: Própria (2018)

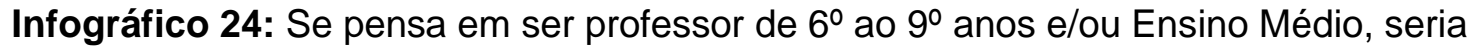
em qual disciplina

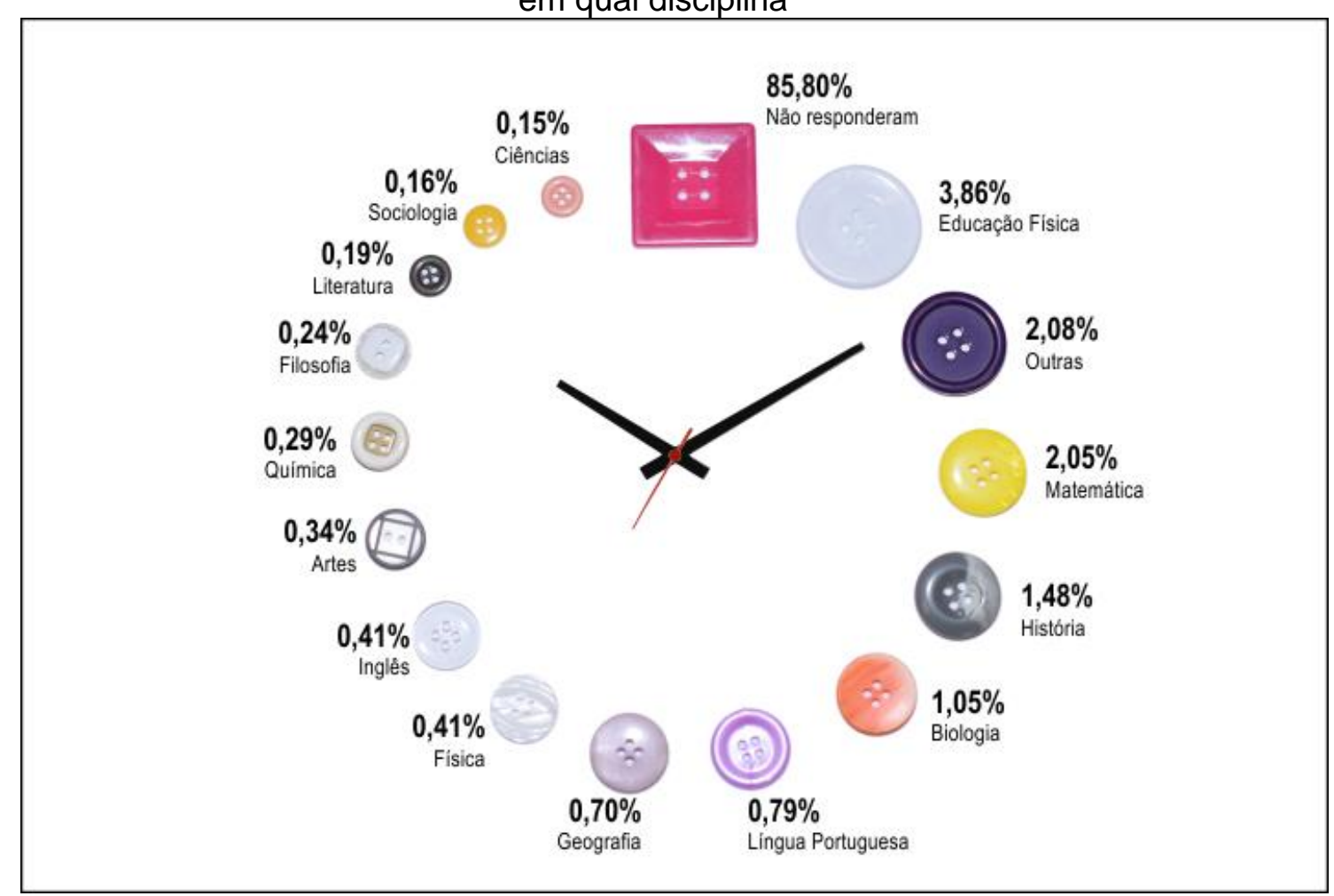

Fonte: Própria (2018) 
Infográfico 25: A principal razão para escolher ser professor

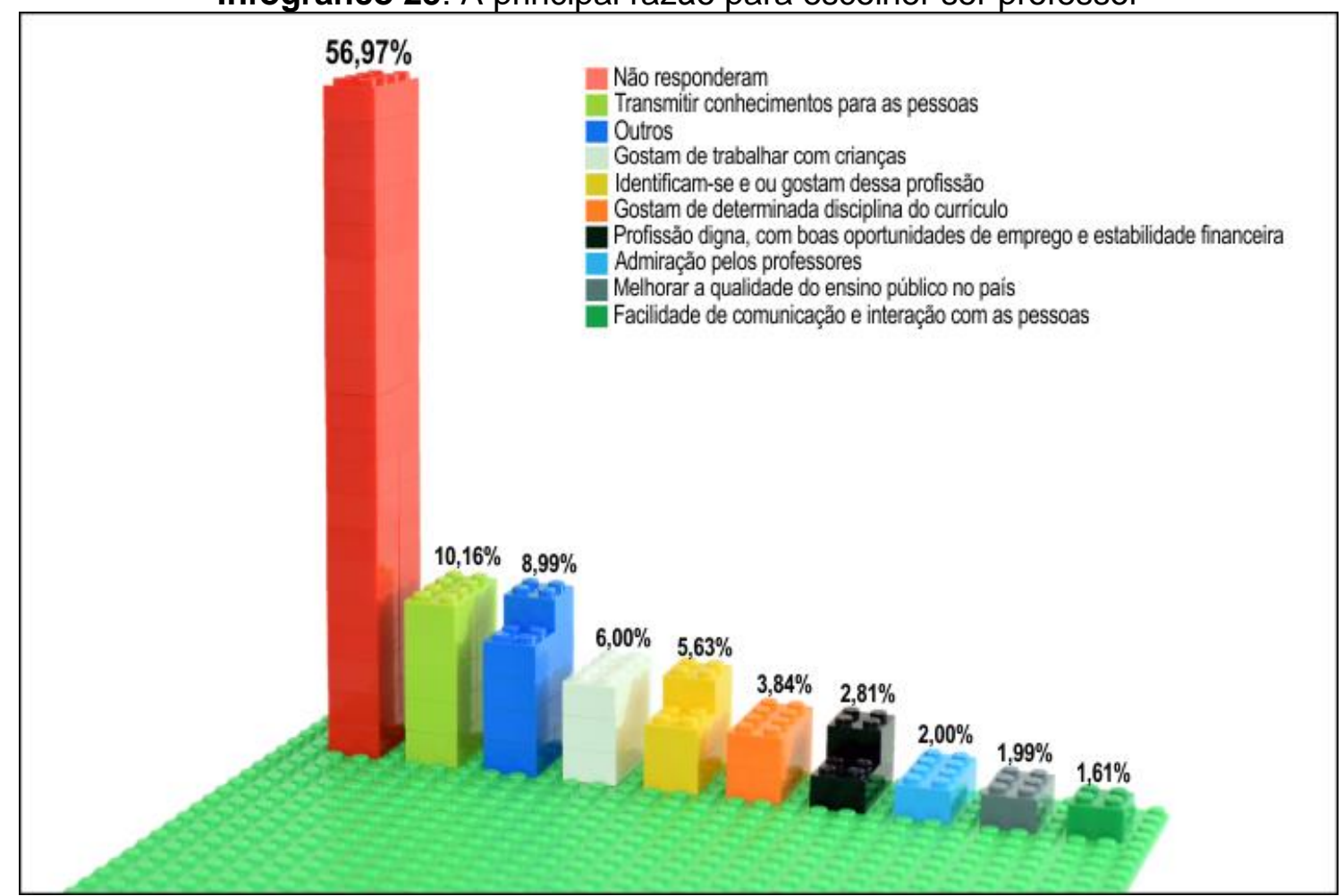

Fonte: Própria (2018)

Infográfico 26: A principal razão para não escolher ser professor

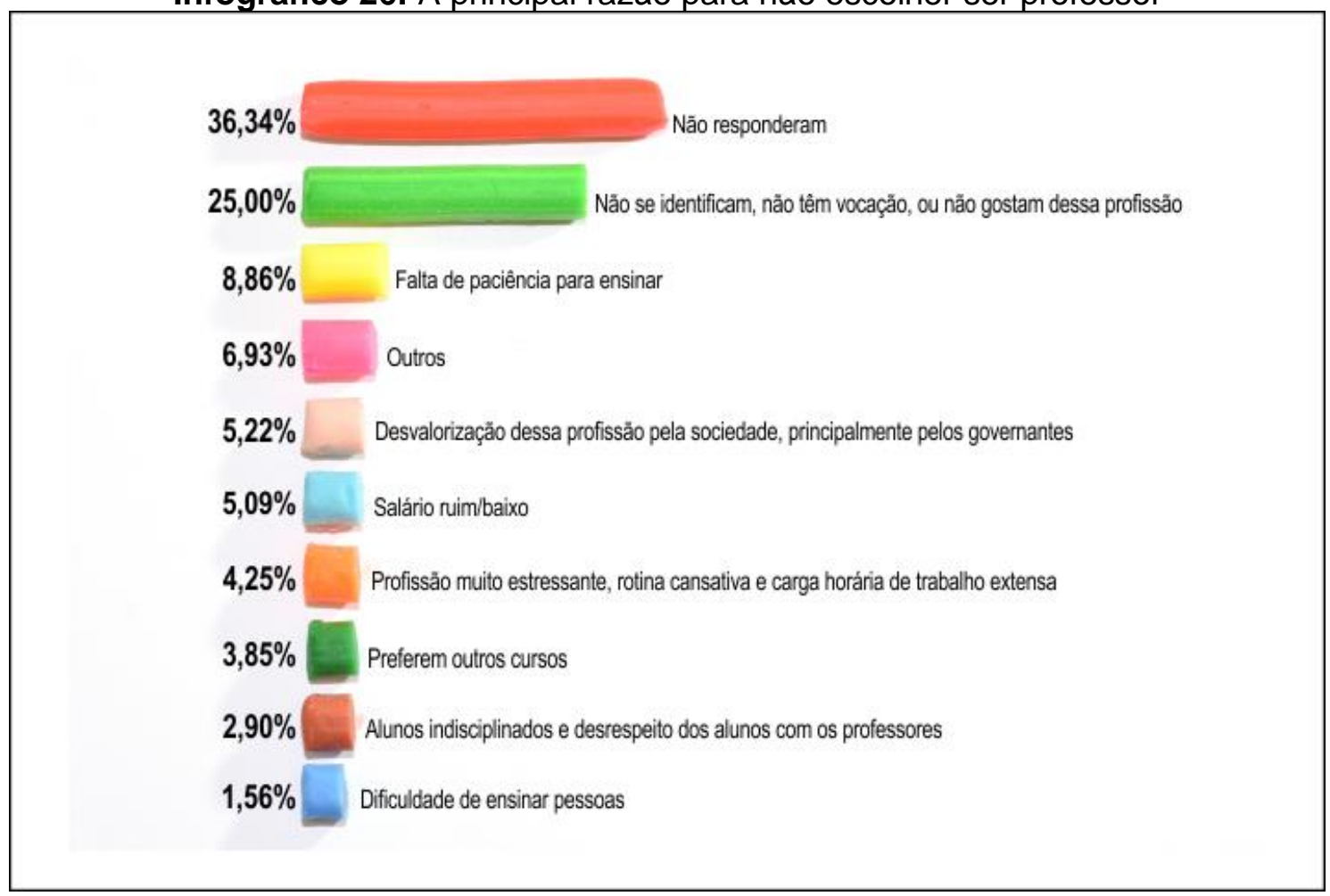

Fonte: Própria (2018) 


\title{
INTRODUÇÃO
}

Ando devagar, porque já tive pressa Levo esse sorriso, porque já chorei demais Hoje me sinto mais forte, mais feliz, quem sabe?

Só levo a certeza de que muito pouco eu sei, Ou nada sei.

Conhecer as manhas e as manhãs, O sabor das massas e das maçãs, É preciso amor pra poder pulsar, É preciso paz pra poder sorrir, É preciso a chuva para florir.

Penso que cumprir a vida seja simplesmente Compreender a marcha e ir tocando em frente,

Como um velho boiadeiro levando a boiada Eu vou tocando os dias pela longa estrada eu vou, Estrada eu sou.

\footnotetext{
Conhecer as manhas e as manhãs, O sabor das massas e das maçãs, É preciso amor pra poder pulsar, É preciso paz pra poder sorrir, É preciso a chuva para florir.
}

Todo mundo ama um dia todo mundo chora, Um dia a gente chega, no outro vai embora Cada um de nós compõe a sua história, Cada ser em si carrega o dom de ser capaz, De ser feliz.

\begin{abstract}
Conhecer as manhas e as manhãs O sabor das massas e das maçãs É preciso amor pra poder pulsar, É preciso paz pra poder sorrir, É preciso a chuva para florir.
\end{abstract}

Ando devagar, porque já tive pressa E levo esse sorriso, porque já chorei demais, Cada um de nós compõe a sua história, Cada ser em si carrega o dom de ser capaz, de ser feliz. 
O processo de escrita de uma tese assemelha-se ao da produção de uma obra de arte, assim como uma bela composição musical, que encanta pela leveza da poesia, pelas paisagens descritas de forma simbólica que ganham sentidos múltiplos, que descreve a dinâmica da vida e nos mostra a impermanência do que somos, sinalizando que a felicidade está dentro de nós e não fora, que somos todos aprendizes e pouco sabemos nessa longa estrada da vida, que certamente, cada um de nós, tem uma "sina", um caminhar.

Somos marcados pelo tempo, pelas idades, por cronometrias visíveis e invisíveis. "A palavra, na sua composição poética, vai além, não tem fronteiras: Palavra é deslimite" (Barros, 2003, p.39), por isso, uma obra é, antes de tudo, atemporal e um ato criativo do pensamento. Igualmente, a produção de uma pesquisa é como uma espécie de peregrinação, cujo caminho se faz e se conhece ao caminhar. Para peregrinar, há de se considerar que não se trata apenas do ato de se deslocar, é reconhecido que peregrinar carece caminhar movido por algo muito importante, determinante para a vida do peregrino. Para mais, não é "a flor", mas o "florescer". É muito mais verbo do que substantivo.

À vista disso, entre os possíveis recursos que podem ser utilizados por um artista, está a palavra, a escrita como meio para a movimentação de ideias. Da mesma maneira, ao escrever esta tese, tenho a escrita do texto como meu material de trabalho, e faço uso dela como um meio experimental de produzir conhecimento pela sensação, um movimento marcado por uma escrita diferente, inventiva, um texto que flerta com três proposições inspiradas do conceitual Deleuze-guattariano: afecto-afecção-criação ${ }^{1}$. Também vislumbro um leitor que possa se abrir para essa escritura, como algo a ser investido.

\footnotetext{
${ }^{1}$ A primeira consideração a ser realizada, é que a discussão sobre o conceito de afecto não visa apenas reproduzir um conhecimento filosófico, pois fazer filosofia para Deleuze é situar-se no pensamento para responder a um novo problema. Em Ética, principal obra de Espinoza escrita em latim, encontram-se dois termos distintos e com diferentes significados, o "affectus" (afecto) e "affectio" (afecções): "Afecção remete a um estado do corpo afetado e implica a presença do corpo afetante, ao passo que o afecto remete à transição de um estado a outro, tendo em conta variação correlativa dos corpos afetantes. Por afecto compreendo as afecções do corpo, pelas quais sua potência de agir é aumentada ou diminuída, estimulada ou refreada, e, ao mesmo tempo, as ideias dessas afecções. As afecções ou "signos escalares" são sempre "misturas de corpos" e indicam "o estado de um corpo que tenha sofrido a ação de um outro corpo." (DELEUZE, 1976, p. 56). Criar é a ação do pensamento, aquilo que o movimenta, revoluciona, faz com que ele aconteça. A criação, filha do criar, "toma o lugar do próprio conhecimento" (DELEUZE, 1976, p. 145). DELEUZE, G. Nietzsche e a filosofia. Rio de Janeiro: Editora Rio, 1976.
} 
Com o propósito de registrar um pouco sobre as experiências que vivi neste processo de produção intelectual, conto um pouco dessa professora que escreve acerca do seu encontro com a docência. Para falar de si, é importante recordar, não para redizer, apenas para traçar as linhas do meu próprio mapa, por meio de uma escrita carregada de sensações, desconstruções e transformações.

Ano de 1980, tempo em que eu brincava na rua, fazia tracejados nos quintais, no chão de terra e sentia nisso, uma força incrível que me colocava para produzir, para experimentar e para inventar. Filha de mãe professora, ao mesmo tempo, eu ansiava ir para a escola, e foi com muita expectativa que iniciei meus estudos em uma escola para descendentes de japoneses. Ensino tradicional, cujo lema era: "Determinação, perseverança e disciplina". Conservo ainda o calor do primeiro dia de aula em minha memória, ao vestir aquele uniforme tão desejado e costurado por minha avó paterna, ao carregar a mochila com os materiais escolares e a lancheira, as palavras de acolhida da diretora, os colegas da turma, entre tantos outros acontecimentos, recordo a cena quando deu-se o encontro, um encontro viral e de contágio com a primeira professora alfabetizadora. Fiquei encantada com sua pessoa e pela maneira como conduzia as atividades das aulas. De um só golpe, fui arrebatada pelo desejo de ser como ela. Desse dia em diante, persegui e realizei o sonho de ser professora. Passados 38 anos, reencontro essa professora, na mesma escola e, nesta ocasião, do mesmo modo, professora alfabetizadora de minha filha. Fui tomada pela emoção. Tive a oportunidade de contar-Ihe um pouco sobre meu trajeto profissional e de the ser grata por me inspirar.

Após a conclusão do Ensino Fundamental I, estudei em outra escola, porque a anterior só oferecia o antigo primário, então, iniciei meus estudos em um Colégio Salesiano dirigido por freiras. Na época, esta escola só aceitava jovens do sexo feminino e as atividades, portanto, além dos conteúdos curriculares, incluía aulas de canto, teatro, dança, culinária, entre outras. Além disso, assistíamos missas na capela da escola e nos confessávamos também. Uma escola cheia de normas e regras a seguir, não podíamos fazer nada que contrariasse os regulamentos fixados nos murais espalhados pela escola e nas salas de aula. Nunca me esqueço da irmãdiretora da escola que subia todas as manhãs no púlpito para fazer a acolhida lendo e explicando alguma passagem bíblica. No pátio, ficávamos enfileiradas e em silêncio absoluto ouvindo tudo, depois rezávamos o Pai Nosso e a Ave Maria, ainda 
cantávamos o Hino Nacional Brasileiro e o Hino do Estado de Mato Grosso do Sul, e seguíamos em fila pelos corredores cantando músicas religiosas até chegar na sala de aula. Conclui nessa escola o antigo Magistério e, dei o primeiro passo importante na minha vida profissional, me formei professora dos anos iniciais do Ensino Fundamental, um momento muito comemorado por mim e por meus familiares.

Do percurso da Graduação em Letras até chegar ao tão sonhado Doutorado se passaram 18 anos. Iniciei minhas atividades laborais como professora na Educação Básica por meio da aprovação em concurso público. Adiante, me dediquei ao trabalho com formação de professores na Secretaria Municipal de Educação de Campo Grande-MS, e confesso que, muitas foram as aprendizagens, cada ano escolar que se inicia e finaliza, leva consigo um pouco de nosso "professorado", e nos possibilita perceber que o conhecimento não tem limites, que percorre diversos caminhos, busca outras verdades, sem certezas, sem prescrições, produz novos jeitos de ser, de ver o outro e de habitar a contemporaneidade. Estamos em incessante formação do que somos, a cada acontecimento, a cada encontro, na contingência do cotidiano.

\section{A relevância da pesquisa}

Movida pelo desejo de produzir um estudo científico, explorando um tema que me é tão estimado e valoroso, esse trabalho traz em seu bojo inquietações sobre a construção de sentidos da carreira docente por alunos do 3 ano do Ensino Médio de escolas públicas estaduais de Mato Grosso do Sul, professores do Ensino Superior e Médio, técnicos da Secretaria Estadual de Educação de MS - SED/MS, e a pesquisadora.

Acerca dessas inquietações destaco que o desafio da educação brasileira não se restringe mais ao processo de escolarização de crianças e adolescentes, demanda também, encontrar quem se disponha a ensiná-los. Com base nessa preocupação, nas últimas décadas, a diminuição do interesse dos jovens pela carreira docente tem sido debatida em diversos países do mundo. E não tão recentemente, percebe-se uma evasão diferente: a de professores. Nesse sentido, a Organização para a Cooperação e Desenvolvimento Econômico - OCDE enfatiza que: 


\begin{abstract}
Muitas economias avançadas já enfrentaram (escassez de professores), e isso vai crescer em um futuro próximo, uma vez que um grande número de professores atinge a idade da aposentadoria. A oferta e a procura de professores em geral estão em desequilíbrio, muitos países enfrentam a falta de professores especialistas e a escassez de escolas que atendam as pessoas desfavorecidas ou de Comunidades². (OCDE, 2011, p.10, tradução minha).
\end{abstract}

Além dessa constatação, a OCDE (2011) retrata também os esforços de vários países em atrair professores qualificados para novos postos de trabalho, especialmente para substituir os professores que se aposentarão nas décadas seguintes. Verificou-se, da mesma forma, o problema da dificuldade em atrair jovens para docência, o que pode indicar mudança de valores para a escolha profissional associada às próprias mudanças nas relações de trabalho e suas condições.

Outro ponto que merece ser discutido e que tem gerado preocupação é como não só atrair jovens para a docência, mas igualmente como manter os professores em serviço. Não só pela literatura disponível, mas principalmente na mídia, frequentemente, temos acesso às notícias sobre os baixos salários dos professores, violência nas escolas, indisciplina dos alunos, precarização do trabalho docente, más condições de trabalho. Por outro lado, o trabalho do professor está cada vez mais complexo e exige responsabilidades cada vez maiores, seja em relação às atividades pedagógicas e burocráticas, ou em questões que não se restringem somente à mediação do conhecimento, como a violência, intervenção em conflitos entre alunos, drogas, indisciplina, entre outros.

Afora o cenário exposto, considero importante situar o contexto políticoeducacional que vivemos em nosso país, para tanto, de maneira sucinta, apresento um panorama das recentes políticas públicas educacionais, bem como faço uma

\footnotetext{
2 Many advanced economies already face (teacher shortages) and that will grow in the near future as large numbers of teachers reach retirement age. Even where general teacher supply and demand are in balance, many countries face shortages of specialist teachers and shortages in schools serving disadvantaged or isolated communitiesll. (OECD, 2011, p.10).
} 
breve análise de cada uma delas com o intuito de evidenciar o modus operandi das propostas do governo e seus efeitos no campo educacional.

\section{Políticas Públicas Educacionais}

Inicio a discussão pelo Decreto Lei no $13.415 / 17$ que trata da nova reformulação do Ensino Médio no tocante à formação dos jovens, questionando um conteúdo que tende a ampliar as desigualdades escolares, pautado em bases históricas elitistas, ligadas acentuadamente aos interesses privatistas.

Em maio de 2016, quando o vice-presidente Michel Temer assumiu a presidência do país, anunciou o slogan de seu governo: "Ordem e Progresso", com o intento de introduzir a ideia da necessidade de reorganizar as estruturas políticas, econômicas e sociais do Brasil.

Nesse sentido, O Ministério da Educação - MEC apresentou a reforma do Ensino Médio baseada em argumentos que enfatizam a importância da "flexibilidade" no percurso formativo do aluno, que nada mais é, na prática, a retirada de disciplinas importantes do currículo do Ensino Médio, bem como a necessidade de aumentar o tempo dos alunos na escola que antes era de 800 horas para atingir progressivamente 1,4 mil horas anuais, o que causaria segundo o governo, mais atratividade a essa etapa da educação. Conquanto, o MEC não sinalizou como tem que ser cumprida essa carga horária, mas instituiu o Programa de fomento à implementação de Escolas de Tempo Integral.

Antes da Base Nacional Comum Curricular (BNCC), o Brasil não tinha um currículo nacional obrigatório e as únicas disciplinas listadas por lei nos três anos do Ensino Médio eram Português, Matemática, Artes, Educação Física, Filosofia e Sociologia. Com a mudança, só o Português e a Matemática são obrigatórios e as demais disciplinas aparecem em Itinerários Formativos.

Desse modo, o currículo definido pela BNCC compreende as áreas que são nomeadas por cinco Itinerários Formativos: 1. Linguagens e suas tecnologias; 2. Matemática e suas tecnologias; Ciências da natureza e suas tecnologias; 4. Ciências humanas e sociais aplicadas e 5. Formação técnica profissional. Na prática, a escola pública, em razão de seu sucateamento, provavelmente não conseguirá oferecer todos os itinerários formativos, o que pode ocasionar a redução do potencial de 
escolha dos alunos, ampliando as desigualdades de oportunidades educacionais já existentes entre escolas privadas e públicas, diminuindo o acesso dos jovens de baixa renda ao Ensino Superior. Portanto, impelir a ideia de que todos poderão escolher um currículo mediante suas vocações, é uma falácia, pois ao contrário do que se tenta fazer acreditar, o acesso às profissões mais prestigiadas ficará limitado aos jovens das classes privilegiadas economicamente.

A não obrigatoriedade das disciplinas supramencionadas mostra uma visão de educação reducionista, positivista e não inclusiva, beneficiando o ensino tecnicista e profissionalizante em prejuízo a uma educação crítica e integradora com foco na formação autônoma e na agência dos sujeitos.

$E$ ainda, o que se faz necessário pensar é que, nessa perspectiva, 0 currículo focará em matemática e língua materna, pois não é uma escolha de cada comunidade local, mas um padrão global do que é legítimo aprender, em outras palavras, segue os padrões de governança internacional que, por efeito da modernização, a educação é reduzida as funções mínimas para as necessidades imediatistas dos interesses neoliberais.

Novamente, esta proposta, em seu conjunto, visa ofertar uma preparação linear e parcial com foco no mercado de trabalho, afastando dos jovens socialmente desfavorecidos, o direito ao conhecimento universal das distintas formas de expressão como a artística e estética, entre outras, o que poderá empobrecer e comprometer a sua criatividade e capacidade de crítica.

O ensino da Língua Inglesa se tornou obrigatório a partir do 6ํㅜ ano do Ensino Fundamental. Antes da reforma, a comunidade podia escolher entre o Inglês ou o Espanhol, ou a escola poderia oferecer ambos os idiomas, portanto, ao se retirar a obrigatoriedade do Espanhol não está se valorizando o país como um espaço cultural latino-americano, diminuindo a oportunidade de integração e aproximação de nossas divisas, especialmente, em Mato Grosso do Sul, em que fazemos fronteira com a Bolívia e o Paraguai, e temos, portanto, em parte das escolas, alunos dessas nacionalidades, e a aprendizagem do Espanhol pelos brasileiros facilitaria a integração desses alunos.

Outra questão relevante refere-se a Rota Bioceânica - corredor rodoviário bioceânico, que liga os oceanos Atlântico e Pacífico, e cujo traçado tem início na cidade de Porto Murtinho-MS e segue até o porto de Antofagasta, no Chile, 
passando por Mato Grosso do Sul e o norte do Paraguai e da Argentina. Em razão dessa realidade, a aprendizagem da Língua Espanhola assume importância no cenário econômico, turístico, internacional e político, uma vez que essa Rota aproximará esses quatro países, e o Brasil é o único país com língua materna diferente dos demais.

Em adição, o fim da obrigatoriedade da formação do professor em áreas específicas de atuação, ou seja, a permissão para que professores sem diploma específico ministrem aulas, o chamado "Notório saber", aprovado pelo Congresso, manteve a autorização para outros profissionais ministrarem aulas em cursos de formação técnica e profissional, relacionados às áreas de atuação destes. Mais um artefato de sucateamento dos cursos de licenciatura, desconsiderando que a docência é uma profissão, possui regulamentação e deve ser exercida por pessoas com formação específica que incluam domínio do conteúdo e o conhecimento pedagógico.

Outrora, para agravar a situação, definiu-se que os profissionais graduados sem licenciatura podem fazer uma complementação pedagógica para que se qualifiquem para ministrar aulas. Esse fato é uma afronta a toda política de formação docente comprometida. Essa medida não foi discutida democraticamente com a sociedade, simplesmente foi implementada por meio de Medida Provisória de maneira autoritária e unilateral, sem consulta aos atores envolvidos com a educação, desconsiderando anos de luta desta classe em manter a importância e a singularidade de sua profissão.

A partir desse cenário, é possível evidenciar o modus operandi com o qual o Ensino Médio está regulamentado, em que as portas estão abertas para o retrocesso e para os objetivos neoliberais do mercado, em que há um reducionismo curricular que tende a piorar o desempenho dos alunos e alargar a desigualdade escolar, além disso, alinha-se explicitamente aos interesses privatistas.

Adiante, faço um apanhado resumido sobre a política educacional do governo Bolsonaro. Inicio com a atuação do primeiro Ministro da Educação Ricardo Vélez Rodríguez, que ficou no cargo entre janeiro e março de 2019, e promoveu uma série de declarações exaltando a ditadura militar, com destaque para a orientação de que os novos livros didáticos de História apagassem a existência do período ditatorial brasileiro, devendo ser interpretado como "Movimento Cívico", e 
ainda propôs a comemoração do Golpe Militar de 1964 nas escolas. Os absurdos continuaram, pois o MEC enviou um comunicado para as escolas, solicitando que as crianças fossem enfileiradas e cantassem o Hino Nacional, e ainda, que fossem filmadas e, depois enviados ao MEC, os vídeos contendo essas imagens. Essa medida gerou tanta indignação e polêmica que o referido ministro teve que recuar dessa empreitada.

Outra polêmica causada por este governo foi a Revisão nos livros didáticos, na tentativa de retirar-Ihes as fontes científicas e dificultar à possibilidade de interpretações mais abertas e variadas de um mesmo fenômeno. É importante ressaltar que ao contrário das "Cartilhas", comuns no período da Ditadura Militar, os livros aprovados pelo Plano Nacional do Livro Didático (PNLD) e utilizados em todo país, passam por uma triagem feita pelo Instituto de Pesquisas Tecnológicas do Estado de São Paulo (IPT), e após essa etapa, são analisados por especialistas das diversas áreas do conhecimento. Portanto, essa proposta de "Revisão dos livros didáticos" nada mais é do que a recriação do modelo ditatorial brasileiro vigente nos anos de 1964 a 1985, um retrocesso, pois opera no sentido de reforçar valores conformadores dos papéis dos sujeitos na sociedade.

Para mais, foi proposta a Militarização de escolas com o objetivo de unir a disciplina dos alunos com o bom desempenho escolar. Por meio de recursos do Governo Federal, o Programa Nacional das Escolas Cívico-Militares (Pecim), Mato Grosso do Sul inaugurou no dia 2 de março de 2020, duas escolas de caráter cívicomilitar: EE Alberto Elpídio Ferreira Dias - Prof. Tito, localizada no Jardim Anache, e na EE Marçal de Souza, no Jardim Los Angeles, ambas em Campo Grande e em região periférica. Este trabalho foi iniciado por uma equipe multidisciplinar e intersetorial do Governo do Estado, coordenada pela SED/MS, composta por técnicos da Coordenadoria de Políticas Específicas para Educação (Copeed), pela Coordenadoria de Normatização das Políticas Educacionais (Conped), uma equipe do Corpo de Bombeiros e, também, da Polícia Militar.

De acordo com a SED/MS um diferencial em relação às demais escolas regulares, é a nova disciplina que é voltada para o estudo do civismo e nacionalismo, chamada "Educação para a Cidadania", que visa valorizar os símbolos nacionais, bem como a equipe do Corpo de Bombeiros e da PM darão apoio na gestão e eventos que acontecerem durante o ano letivo. De acordo com o MEC, os 
militares serão tutores nas disciplinas, e vão auxiliar no fortalecimento de valores éticos, morais e administrativos. O objetivo é melhorar a qualidade do Ensino Básico e, além disso, a meta é implementar cerca de 216 novas escolas com a mesma metodologia até 2023 no Brasil. Informo que em razão da suspensão das aulas por conta da pandemia, não consegui visitar as escolas para conhecer e entender na prática como se desenvolve o seu funcionamento, para então, após uma análise, emitir uma apreciação.

Outra controvérsia foi o Decreto Lei 9.765/19, idealizado por Carlos Nadalim, o qual tenta instituir a Política Nacional de Alfabetização baseada no Método Fônico, cujo princípio organizativo é a ênfase na relação direta entre fonema e grafema, isto é, entre o som da fala e da escrita. O objetivo seria desenvolver a capacidade de transpor a língua oral para escrita. Além disso, entendo também a necessidade de se desenvolver as práticas de Letramentos nesse processo, as quais pressupõem a participação ativa da criança no mundo da linguagem multimodal, lidando com os mais variados gêneros textuais, de modo que possa adquirir experiências ligadas à cultura escrita e as práticas sociais.

Houve também a tentativa de aprovar o Ensino Domiciliar e, recentemente, em razão da pandemia da COVID-19, ficou bastante evidente que o papel do professor é imprescindível para o processo de aprendizagem das crianças, uma vez que os próprios familiares dos alunos reconheceram que não conseguem ensinar seus filhos com a mesma eficiência dos professores. Sobre esse fato, os dados sobre o nível de escolaridade dos pais ou responsáveis desta pesquisa mostram que a maioria possui o Ensino Fundamental incompleto (até o 5a ano), então, é possível inferir a dificuldade desses pais em acompanharem as atividades escolares de seus filhos, ou seja, esse Ensino Domiciliar não condiz com a realidade de grande parte das famílias do MS, e arrisco a dizer do Brasil de modo geral.

O Exame Nacional do Ensino Médio - ENEM, criado em 1998, com o propósito de avaliar o desempenho dos alunos concluintes do Ensino Médio, a partir de 2004 passou a ser utilizado como instrumento para ingresso em instituições do Ensino Superior e, em 2010, por meio de sua inclusão no Sistema de Seleção Unificada - Sisu, foi reconhecido como o maior exame educacional do Brasil. Ao longo desse processo, o ENEM substituiu o tradicional vestibular tornando-se uma ferramenta para a concessão de bolsas de estudo parciais e integrais em faculdades 
particulares por intermédio do Programa Universidade para Todos - Prouni, bem como para os financiamentos disponibilizados pelo governo federal como o Fundo Estudantil - Fies. Esses programas facilitam a permanência de quem quer estudar em uma universidade pública ou necessita de um auxílio do governo para pagar a mensalidade em uma universidade particular. Contudo, o ministro Vélez teve a capacidade de afirmar que as universidades devem ser reservadas para a elite intelectual. Um verdadeiro retrocesso diante de todas as lutas e conquistas historicamente travadas pelas pessoas de baixa renda e grupos minoritários para o acesso e permanência nas universidades públicas.

Nesse ínterim, houve a troca do ministro da educação e de muitos cargos técnicos como do diretor do Instituto Nacional de Estudos e Pesquisas Educacionais Anísio Teixeira - INEP, responsável pelo Exame Nacional do Ensino Médio - ENEM. Em meados de abril do corrente ano, a atenção do país se voltou ao orçamento do MEC, com o anúncio do atual ministro da educação de que seriam "contingenciadas" as verbas das universidades federais que não tivessem desempenho satisfatório e promovessem "balbúrdia." Todavia, esse contingenciamento foi estendido também aos institutos federais, à concessão de bolsas e aos programas relacionados a Educação Básica, o que gerou críticas da comunidade acadêmica, de professores, alunos e pais de alunos, que foram para as ruas de todo o Brasil em protestos nos dias 15 e 30 de maio de 2019.

Para agravar a situação, o atual presidente chamou os manifestantes de "idiotas úteis", afirmando que estes "Não sabem a fórmula da água. São uns idiotas úteis, sendo usados como massa de manobra de uma minoria espertalhona que compõe o núcleo de muitas universidades federais no Brasil" (Bolsonaro, 15 de maio de 2019, publicado no site da BBC News Brasil.). Em razão da repercussão e da indignação de parte da sociedade em relação a declaração do presidente, em entrevista posterior, ele afirmou ter exagerado em chamar os alunos de "idiotas úteis", e que "o certo é que são inocentes úteis. São garotos inocentes, nem sabiam o que estavam fazendo lá." (Bolsonaro, 15 de maio de 2019, publicado no site da BBC News Brasil.)

Os embates não pararam por aí e, sobre as manifestações do dia 30 de maio de 2019, o presidente afirmou que "professores, servidores, funcionários, alunos, pais e responsáveis não são autorizados a divulgar e estimular protestos 
durante o horário de aulas e no ambiente escolar." (Bolsonaro, 30 de maio de 2019, publicado no site da BBC News Brasil.). Conquanto, em resposta, o Ministério Público Federal solicitou uma retratação pública do MEC, ao recomendar que "se abstenha de cercear a liberdade dos professores, servidores, estudantes, pais e responsáveis pela prática de manifestação livre de ideias e divulgação de pensamento." (Ministério Público, 30 de maio de 2019, publicado no site da BBC News Brasil.).

Outrora, no dia 11 de dezembro de 2019, o segundo ministro da educação, Weintraub, que veio a substituir Velez, afirmou a existência de plantações de maconha e laboratório de produções de drogas nas universidades. Na Câmara, o ministro defendeu ainda que há uma epidemia de drogas e reiterou que as estatísticas mostram que o consumo de drogas nas universidades é o dobro do uso geral do país, portanto na opinião dele, tem que haver interferência da Polícia Militar ao enunciar que "Agora, a PM tem que entrar nos campi." (WEITRAUB, 2019, publicado pelo site G1.globo.com). Declarou ainda que o MEC vive a maior revolução na área de ensino. Diante dessas declarações absurdas e de outras anteriores, o ministro foi convocado pela Comissão de Educação do Congresso para dar explicações sobre essas afirmações, uma vez que não há provas dessa evidência.

O ministro Weintraub foi também severamente criticado pela área de Educação ao mostrar sua antipatia pelo Patrono da Educação Brasileira Paulo Freire, e em seu discurso de posse no MEC, ao questionar o legado do educador pernambucano, reconhecido mundialmente no meio acadêmico e o segundo autor mais citado no mundo na área de educação, ao dizer: "Se temos uma filosofia de educação tão boa, Paulo Freire é uma unanimidade, por que temos resultados tão ruins?" (WEINTRAUB, 2019, publicado pelo site G1.globo.com). Depois, em entrevista ao programa Morning Show, da Jovem Pan (2019), Weintraub declarou não ter raiva de Paulo Freire, mas ironizou: "Tem um mural muito feio dele no MEC, assustando a criançada que passa por lá". Um agravo e uma desconsideração total a um dos pensadores mais notáveis na história da pedagogia mundial. Além do fato de ter sido um comentário inadequado, irônico e jocoso quanto ao referido mural, uma conduta que não condiz com a responsabilidade e liturgia do cargo público ocupado pelo Ministro. 
Outro tema que repercutiu como proposta de política educacional foi 0 combate a ideologia de gênero e a doutrinação ideológica nas escolas e universidades com a tentativa de retomada do Programa Escola sem Partido, o qual discuto a seguir.

No ano de 2016, de autoria do senador do estado do Espírito Santo Magno Pereira Malta, do Partido da República, foi apresentado no Senado Federal, o Projeto de Lei (PL) n 193/2016, que visou incluir entre as diretrizes e bases da educação nacional, o Movimento Escola sem Partido (ESP). No tocante ao objetivo maior desse movimento, afirma-se que foi criado para dar visibilidade a um problema gravíssimo que atinge a imensa maioria das escolas e universidades brasileiras - a instrumentalização do ensino para fins políticos, ideológicos e partidários.

\footnotetext{
É fato notório que professores e autores de materiais didáticos vêm se utilizando de suas aulas e de suas obras para tentar obter a adesão dos estudantes à determinadas correntes políticas e ideológicas para fazer com que eles adotem padrões de julgamento e de conduta moral especialmente moral sexual - incompatíveis com os que lhes são ensinados por seus pais ou responsáveis (Escola sem Partido, 2017, p. 11).
}

Para reverter esse quadro, segundo esse movimento, deve-se então, assegurar o direito dos pais a que seus filhos recebam a educação religiosa e moral acordante com suas próprias convicções, recomendando que a escola deve limitar sua atuação à instrução e instrumentalização de conhecimentos. A respeito dessa diferenciação, Apple (1993, p. 22) salienta que há sempre elementos políticos no conhecimento, principalmente no conhecimento escolhido e definido como escolar, mesmo que "sejam simples observações e descrições neutras do mundo". Por isso, educar os alunos para o entendimento de como as coisas são como são, de que o processo histórico é irreversível, é operar uma reflexão que diz respeito sobre o futuro da humanidade, sobre as relações com a natureza e entre os seres humanos em sua diversidade, portanto, separar essas duas dimensões não só é indesejável como impossível.

Com efeito, Arendt (2007) quando discute a educação e o totalitarismo, alerta que o que faz do ser humano um ser humano é a capacidade de ação e de inauguração, que é política, e cita como exemplo que as maiores atrocidades cometidas no passado seriam impossíveis sem que se tivessem conhecimentos 
técnicos, científicos e tecnológicos, porém, salienta que mesmo as pessoas sendo detentoras de conhecimentos altamente especializados podem não pensar, se não refletirem sobre os sentidos de seu fazer. O pensar não se limita a conhecer fatos da História e leis da Física, por exemplo, mas em problematizar o sentido das experiências e vivências humanas no mundo. Rememoro Nietzsche (2000, p. 198), sobre o espírito livre, "é aquele que pensa de modo diverso do que se esperaria com base em sua procedência, seu meio, sua posição e função, ou com base nas opiniões que predominam em seu tempo", por sua vez, a educação para o pensar precisa ser uma atividade essencial e uma necessidade da vida humana.

Em assentimento aos autores citados, Biesta (2013, p. 47) afirma que a "educação precisa ser vista como uma resposta ao que é diferente, ao que é extremo ao indivíduo, ao que desafia, irrita e perturba, ao que desassossega". Em outras palavras, é possível que ao longo do processo educativo, o indivíduo aprenda algo que não gostaria de aprender, inclusive algo sobre si, sobre seu grupo social e étnico, entretanto, não é aceitável o desrespeito ao outro que diverge da sua maneira de pensar e, nessa direção, o papel do professor é fundamental no sentido de orientar e mediar os possíveis desentendimentos e conflitos.

Diferente desse pensamento, o Movimento Escola sem Partido, manifesta o autoritarismo que remete ao tempo da educação oficial na Ditadura Militar, ao tentar coibir discussões de cunho ético, moral e político nos espaços escolares sob o argumento de assepsia ideológica e quer disseminar a ideia de que no mundo as transformações não advêm da ação livre dos sujeitos ou da coletividade, mas é o desdobramento de um processo incontrolável que sugere que algumas coisas nunca podem mudar, isto é, estabelece uma realidade fictícia e nega os fatos, ao tentar instituir seu domínio sobre a História e a Ciência, um discurso mutilador e enganador que quer afirmar que o mundo assim está porque não há outra alternativa, e que se não fosse dessa forma, o mundo seria muito pior.

Para ampliar essa discussão, apoio-me em Arendt (2003, p. 35), quando afirma que "a terrível novidade do totalitarismo é que os indivíduos praticavam/praticam o mal sem querer ou, então, acreditando estar fazendo o bem", ou melhor dizendo, todos seriam inocentes, porém só alguns têm o direito de existir. Assim o totalitarismo já vivenciado pela humanidade, evidencia sua obstinação em anular a própria história e a humanidade das pessoas, pois configura-se pela 
tentativa de neutralizar a pluralidade, essencial para a existência da vida política, no sentido de construir um mundo menos desigual. Por isso, o sujeito que não compreende a História e as disputas políticas que a possibilitaram, não consegue agir sobre ela e torna-se um refém dos acontecimentos, e passa a comportar-se conforme a normatividade. A lógica sustentada pela Escola sem Partido ameaça a liberdade de ação que é sempre política, para mais, ameaça também a liberdade do pensamento, ao propor que perspectivas científicas que não estejam adequadas às convicções da família não passam de mero ponto de vista e, como tal, devem ser abolidas em favor da crença familiar.

$\mathrm{Na}$ contramão dessa perspectiva, Arendt (2003) reforça que é a capacidade de ação que possibilita a inauguração, isto é, a capacidade unicamente humana de criar algo, portanto, não se pode admitir uma educação que não promova o pensamento e a ação. Além disso, como professora, penso que é inadmissível a defesa de qualquer opinião que legitime a desigualdade, a barbárie, a desumanidade, portanto, a escola não pode abdicar a sua função de formar sujeitos para o mundo, em toda a sua complexidade e pluralidade, ao entender a pluralidade como uma riqueza e não como um problema a ser resolvido, pois tudo o que já foi feito de atrocidades anteriormente, pode retornar e ser apresentado como algo novo, e precisamos estar atentos para esse fato.

Em continuidade, outra preocupação foi o Fundo de Manutenção e Desenvolvimento da Educação Básica e de Valorização dos Profissionais da Educação - FUNDEB, que é a fonte da maioria dos recursos que financiam a Educação Básica do país, cuja verba vem de impostos como o Imposto sobre Circulação de Mercadorias e Serviços - ICMS. A questão é que por lei, o FUNDEB expira no ano de 2020, colocando em pauta qual será o mecanismo de financiamento da educação a partir do próximo ano. Com efeito, no dia 21 de julho de 2020, o Plenário da Câmara dos Deputados aprovou em dois turnos, a Proposta de Emenda à Constituição (PEC) 15/15, que tornou o FUNDEB permanente e aumentou a participação da União no financiamento da Educação Infantil e dos Ensinos Fundamental e Médio. A proposta foi aprovada em primeiro turno por 499 votos a favor e 7 contrários; e em segundo turno por 492 votos a 6 . O texto seguiu para o Senado, e foi aprovado por unanimidade em dois turnos de votação no dia 25 de agosto do corrente ano. 
Ao recente registro histórico da educação, o lançamento do Programa "Future-se", foi outra atrocidade desse governo, uma vez que visa a privatização do Ensino Superior e Institutos Federais por meio de um mecanismo de financiamento com interesses empresariais, desobrigando o Estado a custear as instituições públicas sob sua responsabilidade. $O$ programa ainda coloca a pesquisa científica orientada aos interesses do mercado no intuito de aproximar as instituições das empresas, e propõe o desestímulo a pesquisa em humanidades. Outra proposta insensata é o fim dos concursos públicos e a precarização do plano de carreira docente, em troca da contratação de profissionais com base no regime de Consolidação das Leis do Trabalho (CLT), propondo a descaracterização do regime de dedicação exclusiva - ensino-pesquisa-extensão.

$O$ ataque em relação à pesquisa é outro ponto problemático desse governo, que suspendeu o edital de pesquisas do Conselho Nacional de Desenvolvimento Científico e Tecnológico (CNPQ) já aprovado em 2018 e que envolvia 2.516 bolsas de várias modalidades. A CAPES teve 4.798 bolsas de pesquisa cortadas. Para mais, em maio de 2020, novamente o CNQP publicou uma chamada para 25 mil bolsas do Programa Institucional de Bolsas de Iniciação Científica (PIBIC), em que exclui a área de Humanidades, Artes e Ciências Sociais. As bolsas serão destinadas exclusivamente às tecnologias prioritárias entendidas como as áreas relacionadas às temáticas tecnológicas, produtivas do desenvolvimento sustentável e da qualidade de vida, e para as Ciências Humanas e Sociais, só serão aceitas as pesquisas diretamente ligadas as tecnologias prioritárias. Uma afronta e uma estratégia política desse governo que avança no sentido de desestabilizar a educação pública, ao ignorar a relação transversal na produção científica das diversas áreas do conhecimento.

Antes disso, no dia 12 de dezembro de 2019, após o presidente afirmar que colocaria no "pau de arara' o ministro do seu governo que fosse pego em atos de corrupção, Bolsonaro voltou a atacar os universitários brasileiros dizendo "O que se faz em muitas universidades e faculdades do Brasil, o que o estudante faz? Faz tudo, menos estudar." (BOLSONARO, 2019, publicado pelo site G1.globo.com). Ainda enfatizou: "Entre as 200 melhores universidade do mundo, tem alguma brasileira? Não tem! Isso é um vexame." (BOLSONARO, 2019, publicado pelo site G1.globo.com). Apoiado no mito de que as universidades públicas brasileiras não 
produzem conhecimento, o que esse governo não quer tornar visível é que apesar dos desmontes da educação pública, mais de $80 \%$ dos cursos de pós-graduação no país são da rede pública e que no ranking das 50 instituições brasileiras que mais produzem trabalhos científicos nos últimos cinco anos, 43 são universidades públicas.

Outra apreensão é o Decreto ํㅜ 10.502, de 30 de setembro de 2020, que institui a Política Nacional de Educação Especial, cuja proposta do Governo Federal nada mais é do que incentivar a segregação de alunos com deficiência, uma vez que estes passarão a estudar em escolas e salas especiais, o que causou protesto de vários especialistas da área que convivem com a realidade e afirmam ser um retrocesso esse tipo de medida diante das conquistas que pautam a inclusão. A especialista Luiza Corrêa do Instituto Rodrigues Mendes alerta que "Temos $90 \%$ de alunos com deficiências incluídos na escola regular, e o decreto vem na contra mão." (Luiza Corrêa em entrevista para o Correio Braziliense, em 02 de outubro de 2020). Para mais, o professor Douglas Ferrari do Centro de Educação da Universidade Federal do Espírito Santo reforça que "Esse contato com o outro "diferente" é importante para ele e para aquela pessoa sem deficiência. Futuramente, nós teremos melhores médicos, melhores biólogos, melhores cientistas e melhores professores, porque tiveram contato com pessoa com deficiência". (Douglas Ferrari, em entrevista para o Correio Braziliense, em 02 de outubro de 2020). Nesse sentido, o governo, ao invés de publicar um decreto como este, poderia ter apresentado outras propostas como oferecer melhor capacitação para os professores, bem como implementar/melhorar a infraestrutura das escolas para atender com maior qualidade os alunos com deficiência.

Todas essas políticas educacionais ameaçam a autonomia e o funcionamento democrático das instituições de ensino, e não foram poucas as críticas dos profissionais de educação e alunos contra essas propostas, uma vez que foram estabelecidas sem debate público e diálogo prévio com a comunidade e especialistas, são medidas impositivas e antidemocráticas.

Em meio a esse contexto político-educacional e as considerações feitas sobre a crescente escassez de professores, a possível falta de interesse dos jovens pela carreira docente e a dificuldade de atraí-los para esta profissão, esta pesquisa focaliza a construção de sentidos da carreira docente sob a ótica de alunos do $3^{\text {o }}$ 
ano do Ensino Médio de escolas públicas de Mato Grosso do Sul, de professores do Ensino Médio e Superior, de Técnicos da Secretaria de Estado de Educação SED/MS e desta pesquisadora. Coerente com essa proposição, busco dar continuidade a um levantamento inicial em que foram priorizados dados estatísticos de grande alcance no referido Estado, em 2016. No referido levantamento inicial, descrevo o campo investigado com todo o detalhamento provido pelo instrumento desse processo. A continuidade prevê a retomada de parte dos dados mencionados e acréscimos de novos que, então, recebem o tratamento da metodologia de pesquisa qualitativa.

O interesse pelo tema da pesquisa deveu-se ao fato de ter trabalhado como professora em sala de aula na Educação Básica e, posteriormente, como técnica e professora-formadora da Secretaria Municipal de Educação de Campo Grande-MS (SEMED/MS), ao longo de 15 anos. O contato com gestores, equipe técnica, professores e alunos no chão da escola, durante esse período, me trouxe ricas experiências sobre a complexidade da educação e da instituição escolar. Como técnica da SEMED/MS tive a oportunidade de produzir, coordenar e pôr em prática diversos projetos de formação continuada para professores, de elaborar Referenciais Curriculares para os anos iniciais e finais do Ensino Fundamental e para a Educação de Jovens e Adultos, bem como de idealizar, executar e acompanhar projetos sociais para assistência de alunos de comunidades carentes.

Nessa direção, sempre desejei desenvolver uma pesquisa que tratasse do interesse ou não dos jovens pela carreira docente, uma vez que este sempre foi um tema polêmico nos encontros de formação com os colegas professores de Língua Inglesa, os quais manifestavam a preocupação sobre a falta de motivação dos jovens em se tornar professor. Concomitante a esse desejo, em contato de trabalho com a Secretaria de Estado de Educação de Mato Grosso do Sul - SED/MS, e da parte deste órgão, também houve o interesse em apoiar uma pesquisa que tratasse sobre a opção ou não do jovem pela docência. Nessa lógica, este estudo, se desenvolveu de maneira colaborativa entre SED/MS e a pesquisadora que faz parte do Programa de Pós-Graduação Stricto Sensu da Faculdade de Filosofia, Letras e Ciências Humanas da Universidade de São Paulo - USP, na Linha de pesquisa Linguagem, Educação e Sociedade.

Para a SED/MS, os dados iniciais gerados por meio do questionário de 
pesquisa constituem uma importante fonte de informações que pode ser utilizada para a elaboração, monitoramento e avaliação de políticas públicas na Educação Básica. Como primeira ação deste órgão, e por meio da Superintendência de Políticas Públicas - SUPED houve a publicação do primeiro volume do livro "Quem quer ser professor? Série de estudos sobre a atratividade da carreira docente", no ano de 2018, de autoria desta pesquisadora. Por se tratar de uma série, há a previsão da publicação de outro volume, após defesa da tese.

Para mais, consciente de que somos um grão de areia no imenso mar, como pesquisadora, assim como uma "garrafa lançada ao mar", sem saber onde se pode chegar, trago comigo o desejo de poder contribuir por meio deste estudo para ações futuras de valorização da carreira docente no estado de Mato Grosso do Sul.

\section{Objetivo Geral}

A presente pesquisa teve por objetivo geral:

Investigar a construção de sentidos da carreira docente na ótica de alunos concluintes do Ensino Médio de escolas públicas estaduais de MS, do Grupo de Discussão e da pesquisadora.

\subsection{Objetivos Específicos:}

1. Analisar e discutir por meio do Grupo de Discussão composto por professores do Ensino Médio e Superior, técnicos da SED/MS e a pesquisadora, o elenco das questões suscitadas pelos alunos ao responderem ao questionário da pesquisa;

2. Analisar quais aspectos os alunos participantes da pesquisa, destacam para justificar o interesse ou não pela carreira docente;

3. Analisar como o neoliberalismo e o Estado operam no sentido de afetar a escolha profissional e os rumos de como os sujeitos se comportam em uma sociedade capitalista, no caso, essa comunidade estudantil de Mato Grosso do Sul. 
Em corroboração aos objetivos desta pesquisa, reitero que formular um problema implica ser propositor de um dado conhecimento histórico e situado. Ao tomar como exemplo, a proposta da minha pesquisa, problematizar algo, como a construção de sentidos da carreira docente na ótica de alunos concluintes do Ensino Médio de escolas públicas estaduais de Mato Grosso do Sul, do Grupo de Discussão e desta pesquisadora, não quero dizer que farei a representação de um objeto preexistente, como um jogo de cartas marcadas, de olhares habituados a ver as mesmas coisas. Ao contrário disso, considero que as forças são móveis, os problemas são mutáveis, o pensamento é imanente e sofre transmutação, alterando o modo como o construímos.

\section{Questões norteadoras}

Apresento as questões que orientaram os caminhos para alcançar os objetivos propostos:

1. Como se constroem os sentidos sobre a carreira docente na ótica de alunos concluintes do Ensino Médio de escolas públicas estaduais de MS, do Grupo de Discussão e esta pesquisadora?

2. Quais aspectos os alunos participantes da pesquisa destacam para justificar o interesse ou não pela carreira docente?

3. Como os professores participantes do Grupo de Discussão e esta pesquisadora, por meio de suas vivências e experiências em contexto escolar situado, discutem e analisam a construção de sentidos da carreira docente na ótica de alunos concluintes do Ensino Médio de escolas públicas estaduais de MS?

4. Como o neoliberalismo e o Estado operam no sentido de afetar a escolha profissional e os rumos de como os sujeitos se comportam em uma sociedade capitalista, no caso, essa comunidade estudantil sul-mato-grossense?

\section{Modus Operandi: sobre a construção da pesquisa}

Antes de apresentar a expansão da metodologia de pesquisa que se encontra mais adiante na tese, no item 7.1, faço uma síntese dos principais tópicos abordados: 
- Análise qualitativa de levantamento estatístico realizado e apresentado em "Marco Zero", pela pesquisadora;

- Pesquisa com alunos concluintes do Ensino Médio de escolas públicas estaduais de MS, por meio de questionário eletrônico elaborado pela pesquisadora e aplicado pela SED/MS, sobre questões e aspectos destacados para interesse ou não na carreira docente;

- Análise do elenco de questões e dos aspectos destacados pelos alunos que evidenciam o interesse ou não na carreira docente, por meio de Grupo de Discussão composto por professores do Ensino Médio e Superior, técnicos da SED/MS e a pesquisadora;

- Análise do impacto do neoliberalismo nessa comunidade estudantil sulmato-grossense, pela pesquisadora, considerando-se a evidência do pensamento neoliberal nessa comunidade.

\subsection{Abrangência da pesquisa}

A pesquisa se voltou para as escolas públicas estaduais do Ensino Médio de Mato Grosso do Sul, incluindo as unidades de ensino das zonas urbana e rural. Os modelos de ensinos abrangidos contemplaram o Ensino Médio Regular, Educação de Jovens e Adultos e Ensino Médio Integrado a Educação Profissional.

Dos 79 municípios de MS, 75 participaram espontaneamente da pesquisa, com exceção dos municípios de Jaraguari com duas escolas, Rio Brilhante com três escolas, Sete Quedas com três escolas e Tacuru com uma escola, representados no mapa pelos números 44, 65, 72 e 75 . 
Infográfico 1: Mapa de MS com os municípios participantes e não participantes da pesquisa

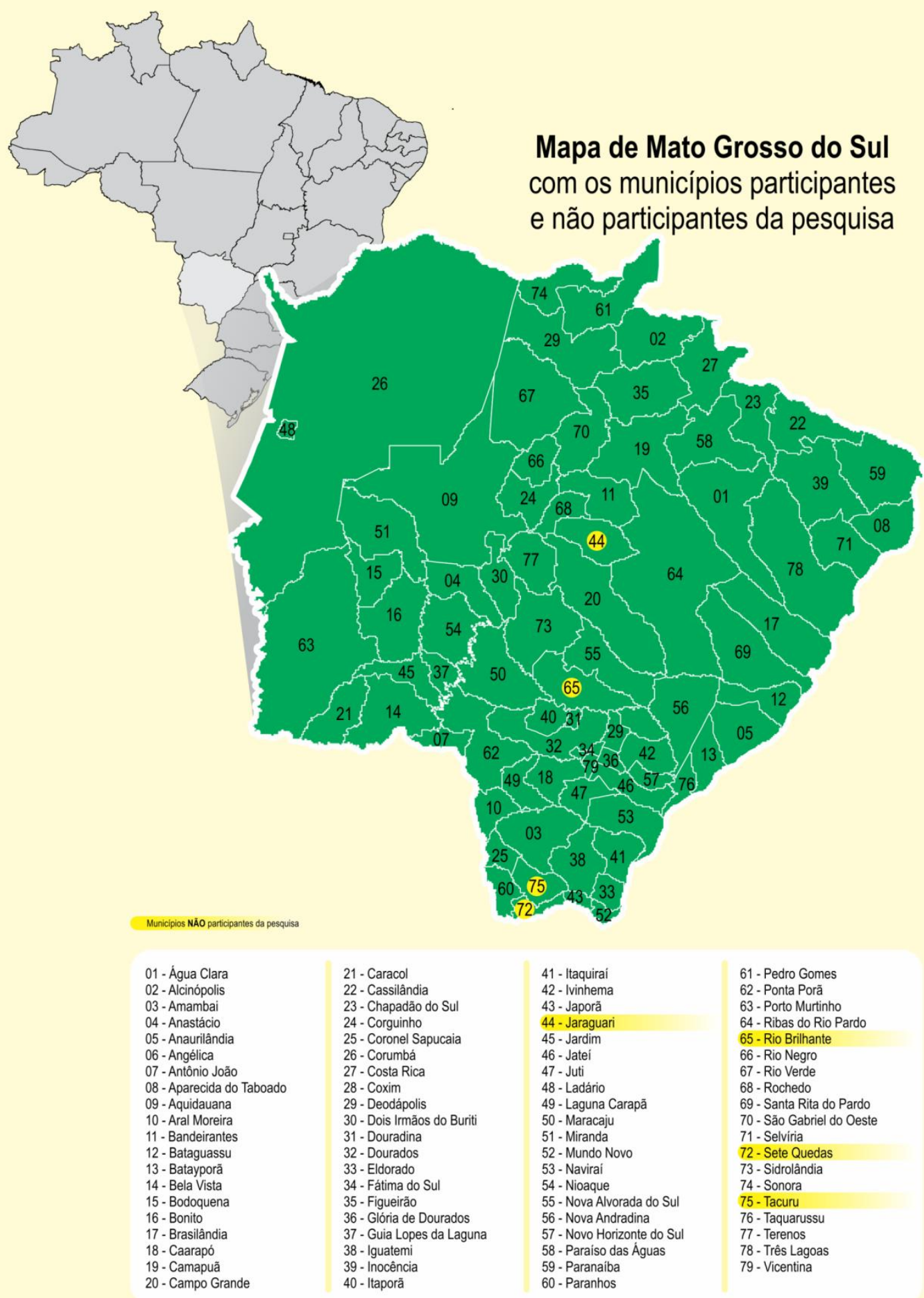

Fonte: Própria (2018) 
No ano de 2016, quando o questionário (anexo 1) da geração de dados da pesquisa foi aplicado, o número de unidades escolares em todo estado de MS era de 368 , sendo 317 escolas de zona urbana e 51 de zona rural. Em destaque estão as escolas com Educação Indígena que participaram da pesquisa: EE Indígena Mbo Eroy Guarani Kaiowá (Aldeia Amambai, Ponta Porã - MS); EE Indígena de EM Pascoal Leite Dias (Aldeia Limão Verde, Aquidauana - MS); EE Indígena de EM Pastor Reginaldo Miguel - Hoyenó (Aldeia Lagoinha, Aquidauana - MS); EE Indígena de EM Prof. Domingos V. Marcos - Mihin (Aldeia Bananal, Distrito de Taunay, Aquidauana - MS); EE Indígena Cacique Ndeti Reginaldo (Aldeia Água Azul, Dois Irmãos do Buriti - MS); EE Indígena Natividade Alcantara Marques (Aldeia Buriti, Zona Rural - Reserva Indígena, Dois Irmãos do Buriti - MS); EE Indígena de EM Int Guateka - Marçal de Souza (Aldeia Jaguapiru, Zona Rural, Reserva Indígena, Dourados - MS). Do total de 368 escolas, participaram da pesquisa 211 unidades (anexo 2 )

O quantitativo de alunos matriculados no $3^{\circ}$ ano do Ensino Médio foi de 22.800. O questionário foi respondido voluntariamente por 7.894 , sendo distribuídos nas seguintes modalidades de ensino: Ensino Médio regular (7.292 alunos); Educação de Jovens e Adultos - EJA (410 alunos) e Ensino Médio Integrado e Educação Profissional (192 alunos). 
Infográfico 2: Quantitativo de alunos matriculados no $3^{\circ}$ ano do Ensino Médio que participaram da pesquisa, distribuídos por modalidades de ensino

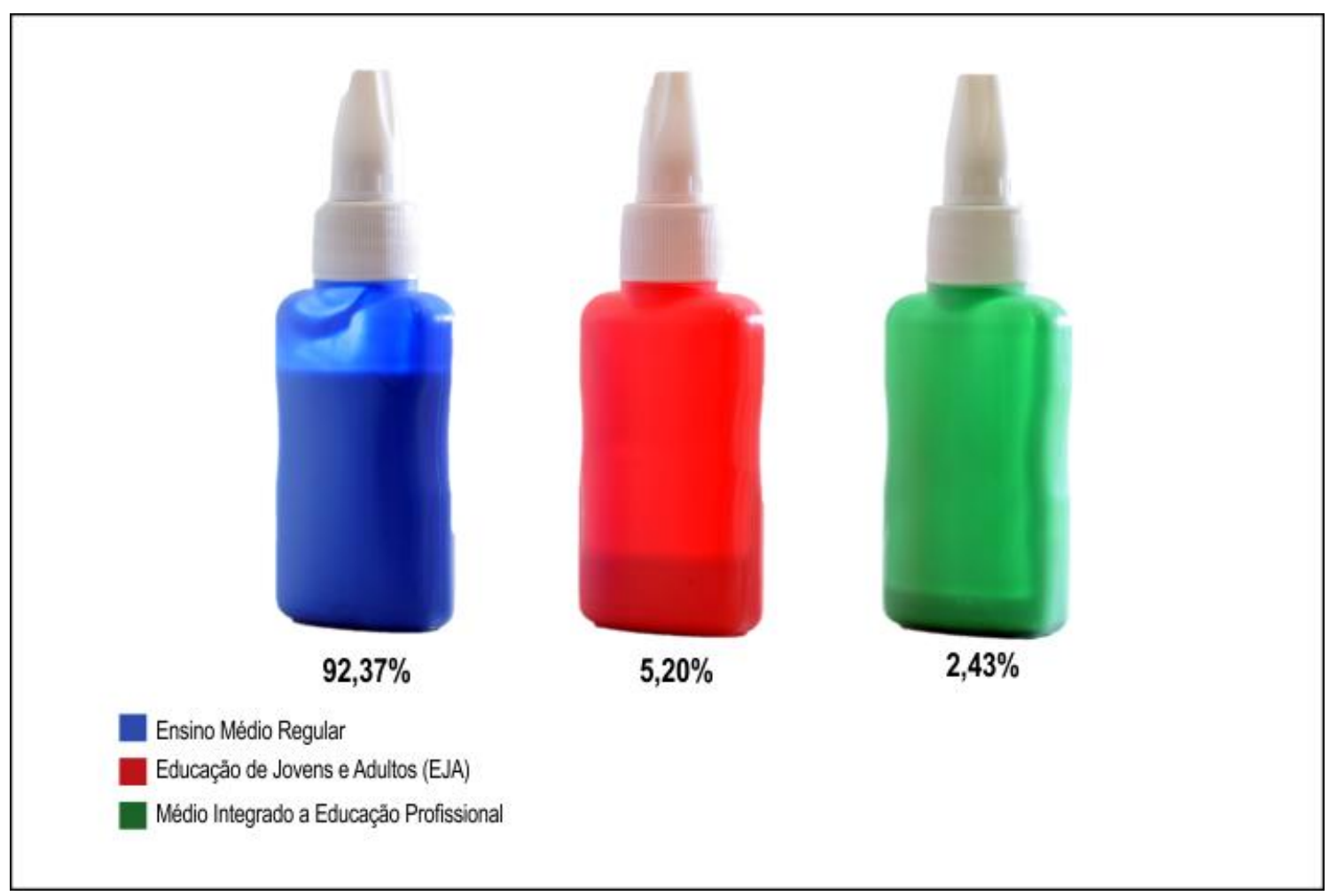

Fonte: Própria (2018)

Acerca do quantitativo de alunos matriculados no $3^{\circ}$ ano do Ensino Médio que participaram da pesquisa, em maior número (92,37\%) foram os alunos que cursavam o Ensino Médio Regular, etapa final da Educação Básica que destina-se a adolescentes e jovens concluintes do Ensino Fundamental. Em proporção bem menor $(5,20 \%)$, foram os alunos que frequentavam a EJA, a qual é destinada a jovens e adultos que não tiveram acesso ou não puderam efetuar os estudos na idade regular de conclusão do Ensino Fundamental e Médio. Apenas 2,43\% dos participantes da pesquisa, estudavam no Médio Integrado a Educação Profissional, período em que os alunos recebem a formação básica e profissional, bem como os preparam para inserção no mercado de trabalho.

Em conformidade com o Censo Escolar da Educação Básica (2016), a matrícula da rede pública na Educação Profissional se intensificou em 5,1\% e a do curso técnico integrado ao Ensino Médio da rede pública apresentou crescimento de 11\%. Ao aderir ao Programa do Governo Federal MedioTec, conforme a SED/MS (2018), este órgão atendeu no ano de 2017, 2.187 estudantes de 37 municípios, em 55 escolas e 4 Centros de Educação Profissional, nos cursos de Açúcar e Álcool, 
Administração, Agenciamento de Viagem, Agronegócio, Agropecuária, Celulose e Papel, Cozinha, Eletroeletrônica, Eletrotécnica, Enfermagem, Eventos, Hospedagem, Informática, Informática para Internet, Logística, Manutenção e Suporte em Informática, Qualidade, Química, Redes de Computadores e Restaurante e Bar.

\subsection{A geração de dados da pesquisa}

\subsubsection{A geração de dados da primeira fase da pesquisa}

Em sua fase inicial, para a geração de dados, fez-se uso de um questionário eletrônico elaborado pela pesquisadora e aplicado pela SED/MS, no mês de novembro de 2016, aos alunos do $3^{\circ}$ ano do Ensino Médio das escolas estaduais de 79 (setenta e nove) municípios de MS. O questionário foi composto por 22 (vinte e duas) questões, sendo 6 (seis) discursivas e 16 (dezesseis) objetivas, nas quais foram oferecidas opções de respostas.

O referido instrumento foi aplicado em horário de aula dos alunos e nas dependências das instituições de ensino, visando interrogar os contextos pessoal, familiar, social e escolar dos participantes da pesquisa, para tanto, indagou-se sobre: sexo, idade, raça, a quantidade de pessoas que vivem na sua casa; o grau de escolaridade do pai, mãe ou responsável; a renda familiar; modalidade de ensino; o período que estuda na escola; se estudou sempre em escola pública, ou iniciou em escola pública e mudou para escola particular, ou se iniciou em escola particular e mudou para pública; se trabalha e desde que idade trabalha. As demais perguntas do questionário integram o segundo foco deste trabalho: conhecer e analisar a continuidade do percurso acadêmico desses participantes, de modo a investigar seu interesse/desinteresse dos participantes pela carreira do magistério. Nesta parte, o questionário interrogou: ao terminar o Ensino Médio pretende fazer o quê; se está fazendo cursinho para o ENEM; em quais cursos pretende ingressar na Instituição de Ensino Superior; em quais Instituições; se em algum momento pensou ser professor; professor de qual nível de ensino; de qual disciplina; quais suas razões e não razões para escolher ser professor. Por ser tratar de um formulário on-line, a entrada de dados deu-se de maneira eletrônica. 
Conforme já explicitado, esclareço que, para tanto, foi necessário utilizar um questionário on-line, elaborado pela pesquisadora e aplicado pela SED/MS em novembro de 2016, para interrogar aos alunos concluintes do Ensino Médio acerca de suas construções de sentido sobre ser professor. O propósito de utilizar dados quantitativos na fase inicial da pesquisa se justifica pela indispensabilidade de colocar "sub judice" o que informam esses dados, bem como serviu de base para as discussões em grupo na fase qualitativa, tornando a materialidade do debate possível.

\subsubsection{Tabulação, Análise e Disseminação dos dados gerados}

A tabulação dos dados teve como base os fundamentos básicos da estatística (BUSSAB e MORETTIN, 1987; MONTGOMERY, 1997), estatística descritiva e modelagem econométrica (GUJARATI, 2006; TUKEY, 1977). A população desse experimento foi 0 total de alunos regularmente matriculados no terceiro ano do Ensino Médio nas escolas estaduais de Mato Grosso do Sul. A amostra foi a parcela de 7.894 de alunos que respondeu voluntariamente ao questionário. Cada característica da população citada foi considerada uma variável que, neste caso, contempla variáveis quantitativas que puderam ser medidas ou contadas e variáveis qualitativas que puderam ser evidenciadas. Para a representação, foi escolhido o agrupamento das escolas participantes da amostra em um mapa político anteriormente apresentado, por permitir correspondentes proporcionais aos números de observações obtidas de fácil visualização, bem como uma tabela de referência especificando cada município com suas unidades escolares participantes.

Para a análise inicial, esta pesquisa utilizou a abordagem quantitativa dos resultados da pesquisa empírica. Os dados foram analisados pelo procedimento conhecido como Análise Exploratória dos Dados (TUKEY, 1977), que buscou compreender o comportamento dos dados a partir da estatística descritiva. A estatística descritiva permitiu compreender as medidas de tendência central em grande quantidade de dados e explorar seus efeitos, utilizando infográficos descritivos. Efetivamente, por meio deste procedimento metodológico, foi possível fazer a descrição das características dos participantes da pesquisa, o que pôde 
proporcionar novas visões sobre o contexto investigado, o que discutirei mais adiante na tese.

\subsubsection{Algumas características dos alunos participantes da pesquisa}

Com a finalidade de construir as características gerais dos participantes da pesquisa por meio dos dados, o questionário incluiu questões sobre sexo, idade e raça, conforme os infográficos abaixo.

A amostra foi a parcela de 7.894 alunos. Reforço que a opção em utilizar infográficos se justifica pela importância de apresentar informações preponderantes por meio de elementos gráfico-visuais, integrados com texto sintético e dados numéricos. Todos os infográficos da tese são originais, foram criados pela pesquisadora, fotografados e formatados por um designer gráfico.

\section{Infográfico 3: Sexo}

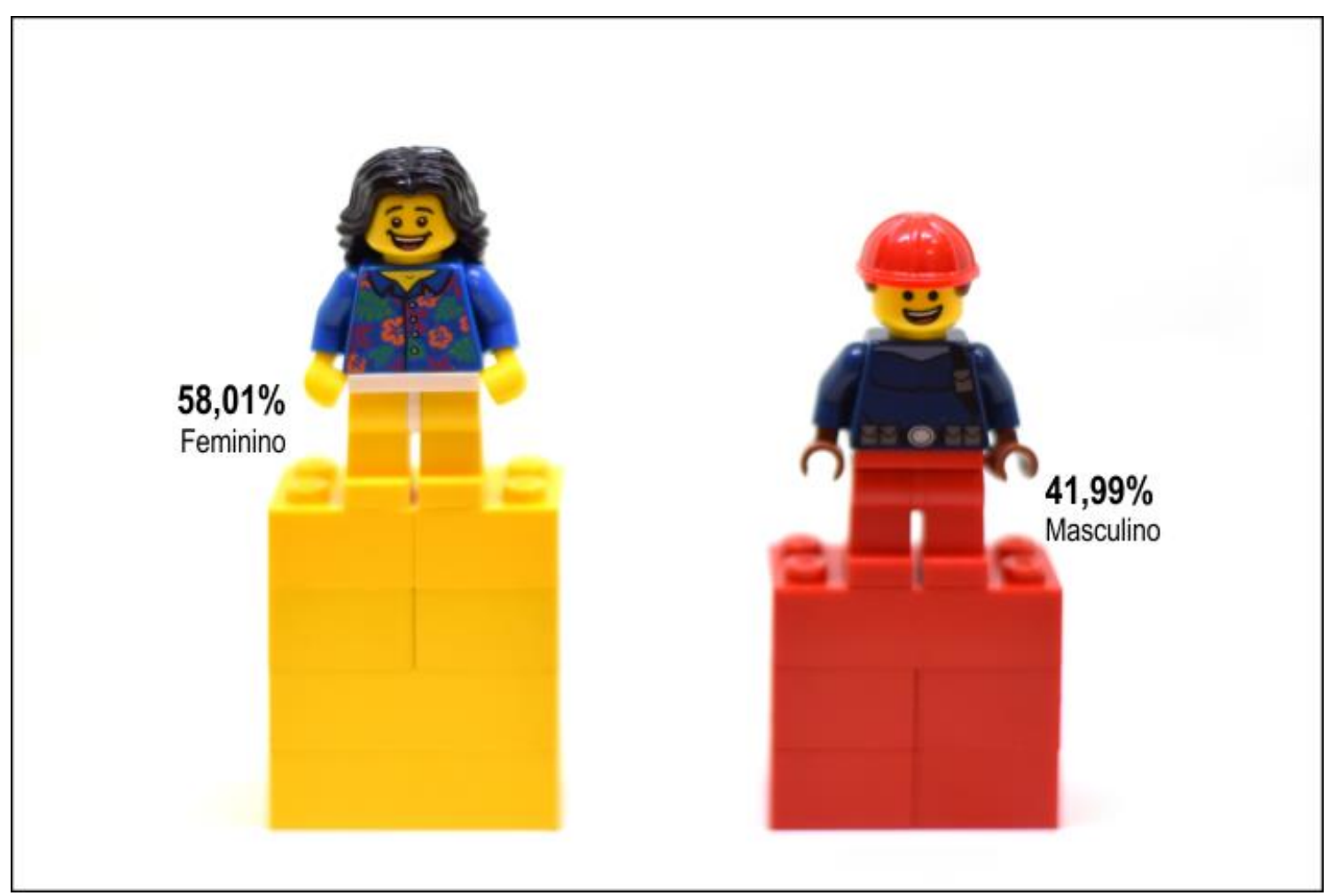

Fonte: Própria (2018)

O sexo feminino predomina entre os participantes da pesquisa com a soma de $58,01 \%$. O sexo masculino totaliza $41,99 \%$ dos participantes. Dados da última 
Pesquisa Nacional por Amostra de Domicílio, divulgada pelo Instituto Brasileiro de Geografia e Estatística - IBGE (2016) indicam que, nesse mesmo ano, viviam no Brasil 103,5 milhões de mulheres, o equivalente a $51,4 \%$ da população. No CentroOeste, $51,2 \%$ da população é feminina, sendo que em Mato Grosso do Sul é maior do que a masculina, são 28 mil mulheres a mais do que homens vivendo no Estado. Os números revelam que MS possui 2,595 milhões de habitantes e desses 1,312 milhões são mulheres e 1,284 milhões são homens.

Infográfico 4: Idade

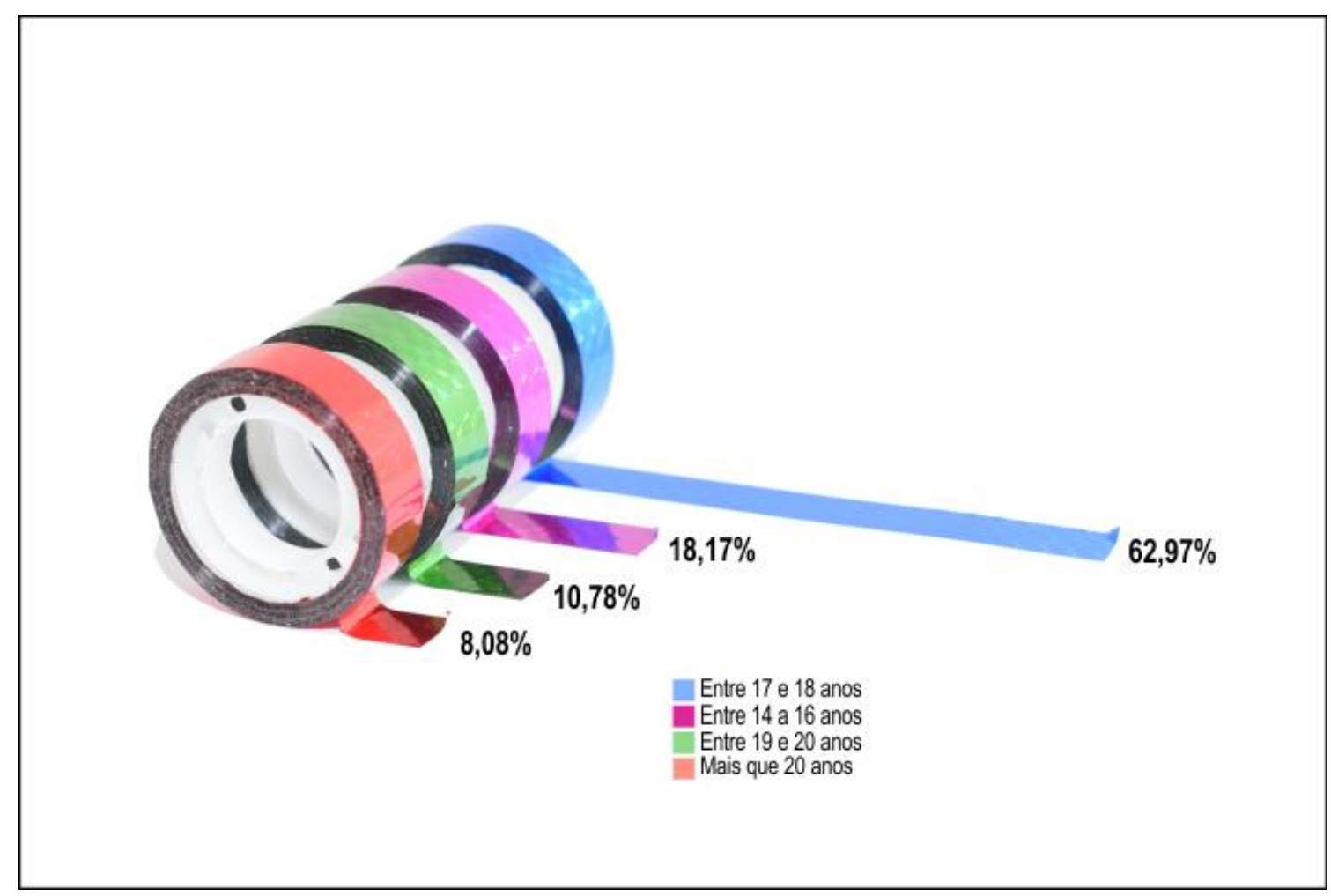

Fonte: Própria (2018)

A faixa etária da maioria dos participantes da pesquisa está entre 17 a 18 anos com $62,97 \%$. 18,17\% são os alunos que se encontram em idade entre 14 a 16 anos. No prosseguimento, estão àqueles com idade entre 19 e 20 anos, com $10,78 \%$. Em quantidade menor (8,08\%), são os com idade acima de 20 anos. 
Infográfico 5: Autodeclaração de raça

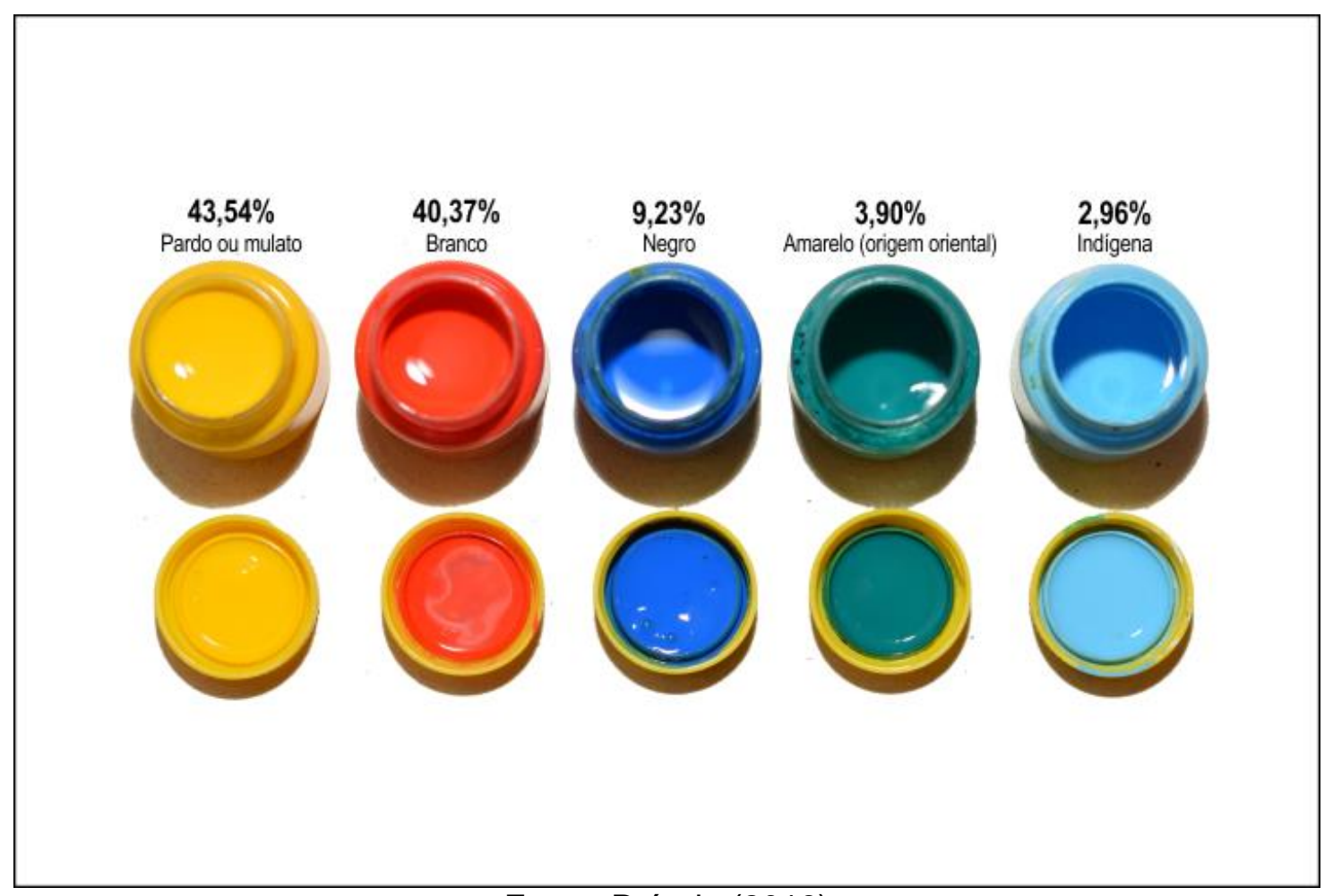

Fonte: Própria (2018)

No cômputo dos resultados sobre autodeclaração de raça dos participantes da pesquisa, os pardos ou mulatos representam maior número (43,54\%). Os brancos somam 40,37\%. Os negros totalizam 9,23\%. Em menores proporções estão os amarelos com 3,90\% e os indígenas com 2,96\%. Esclareço que esse item é importante porque faz referência as construções culturais de determinada comunidade de pessoas, o que será discutido no capítulo II.

Ainda conforme os dados do IBGE, o estado de MS possui a segunda maior população de indígena do País. No Brasil essa população soma 896,9 mil pessoas, de 305 etnias, que falam 274 línguas indígenas. A etnia predominante em MS é a Guarani-kaiowá, com aproximadamente 43 mil indígenas, dos quais 35 mil estão em terra indígena e 8,1 mil vivem em áreas urbanas. O Censo (2010) também revelou que $37,4 \%$ dessa população com mais de 5 anos de idade falam línguas indígenas, apesar de anos de contato com não indígenas, e cerca de 120 mil não falam português.

De acordo com dados do IBGE (2015), no Brasil, 45,22\% dos brasileiros se declaram como brancos, e $45,06 \%$ como pardos, $8,86 \%$ como pretos, $0,47 \%$ como 
amarelos e 0,38\% como indígenas. A raça dos moradores de MS, de acordo com a Pesquisa Nacional por Amostra de Domicílios - PNAD (2013) revelou que os pardos com 1,217 milhões predominam na população sul-mato-grossense. Em segundo lugar, são os brancos com 1,198 milhões, seguidos pelos pretos que somam 141 mil, a população indígena é de 61,737 mil e os amarelos totalizam 21 mil.

\subsubsection{A geração de dados da segunda fase da pesquisa}

Para a geração de dados qualitativos da pesquisa, um Grupo de Discussão foi composto pela pesquisadora e por outros nove integrantes: três professores do Ensino Médio da Rede Estadual de Ensino de MS, três professores do Ensino Superior de Universidades Públicas de MS e três técnicos da Secretaria de Estado de Educação de MS. A escolha desses profissionais se deve ao meu interesse em formar um grupo composto por três segmentos de maior importância para discutir sobre o tema.

Como experiência profissional, na qualidade de professora da Educação Básica e também de técnica da Secretaria de Municipal de Educação/SEMED, uma das maiores reclamações dos professores em sala de aula, era a falta de diálogo entre o órgão central e eles, ou seja, a SEMED pensa as ações sem consultá-los e eles têm que executar depois. Outro fator de reclamação dos professores é sobre o distanciamento da academia que, muitas vezes, teoriza e prescreve como eles devem desenvolver sua prática pedagógica, porém desconhece a realidade do chão da escola pública. Diante dessas observações, considerei que esses professores poderiam estreitar o diálogo e promover um debate profícuo, em um espaço democrático, no qual todos pudessem expressar e discutir abertamente suas inquietações.

O propósito foi desenvolver uma pesquisa em que se pretende gerar e analisar dados que emergem e se tornam relevantes ao longo do processo, fraturando as estruturas previamente pensadas por uma investigação pré-definida. $A$ esse modo de investigar, que pressupõe múltiplas conexões, incertezas, incompletudes, desconstruções, desterritorializações, bem como a abertura por parte do pesquisador sobre outras possibilidades de compreensão e 
problematização, não tão óbvias e de fácil eminência, sustenta o que me proponho a desenvolver.

Tendo em mente esta concepção, Ribeiro (2016, p. 1) reforça que "essa discussão é estratégica para formação de pesquisadores, pois viabiliza o debate sobre modos de pensamento e construção linguística de problemas educacionais, modulando outras políticas de verdade em educação." Em concordância com a autora, ao gerar os dados qualitativos da pesquisa, os movimentos em campo, de inspiração cartográfica, exigiram uma postura de abertura aos encontros com os sujeitos, o que justificou o uso de diferentes procedimentos para a geração de dados: composição de Grupo de discussão, registro em áudio e vídeo dos encontros, e transcrições (anexo 3), bem como Termo de Consentimento livre e esclarecido (anexo 4), e questionário (anexos 5, 6 e 7).

Destaco o Grupo de Discussão como meio de desenvolver um debate das questões que emergiram, interrogando: O que um encontro pode como potência? Ao fazer essa indagação, retomo a compreensão da dinâmica dos afetos que resulta do encontro entre corpos (DELEUZE, 2007). Dessa maneira, é necessário entender as causas e os resultados dos encontros e sua potência, e o conhecimento que esses corpos podem gerar ao se encontrarem, no caso desta pesquisa, o encontro entre os participantes do Grupo de Discussão, a pesquisadora e as temáticas problematizadas, em tempo e espaço situado. Por meio desse encontro, talvez seja possível que, ao interpretarmos, discutirmos e analisarmos em conjunto as questões suscitadas pelos alunos ao responderem o questionário de pesquisa, tenhamos a oportunidade de ressignificar o tema discutido com outros desafios da vida hodierna que, conjuntamente, abarcam a afecção dos encontros, das experiências vivenciadas e das contingências, com o propósito de realizar uma conexão com melhor sensibilidade às ideias dos demais, ampliando as possibilidades de compreensão dos sujeitos.

Em razão do processo supracitado, o(a) pesquisador(a) conta com sua própria sensibilidade para gerar categorias relevantes a partir dos dados, bem como para determinar posteriormente, quais outros dados ainda devem ser produzidos, criando um espaço de entendimento da realidade e do ato de analisar. O foco é a criação, portanto, não se trata de produzir uma versão mais autêntica da realidade do contexto situado investigado para dizer mais do mesmo. 


\subsubsection{Algumas características dos participantes do Grupo de Discussão}

Para construir algumas características dos participantes do Grupo de Discussão, foi aplicado um questionário que indaga sobre questões de idade, sexo, autodeclaração de raça, formação acadêmica, rede de ensino que atua ou atuou, tempo de docência e renda familiar. O referido questionário possui 15 questões discursivas (anexo 5) para os professores do Ensino Superior, e outro com 18 questões discursivas (anexos 6 e 7) para os professores do Ensino Médio e técnicos da SED/MS. Esclareço que há questões iguais nos três questionários, bem como outras específicas, em razão das diferentes atividades laborais dos participantes. Seus nomes foram preservados para garantir sigilo e ética, e todos assinaram um "Termo de Consentimento Livre e Esclarecido" da pesquisa. Para tanto, fiz uso das nomenclaturas: Professor (a) EM - Professor (a) do Ensino Médio; Professor (a) ES - Professor (a) do Ensino Superior e Técnico (a) da SED/MS.

Para esta fase da investigação, considerei relevante contar com um Grupo de Discussão para a interpretação, discussão, análise e problematização dos dados gerados, pois segundo Weller (2006) este é um instrumento de pesquisa que permite a obtenção de dados de maneira qualitativa em sessões em grupo. O objetivo é gerar, com base no diálogo e no debate com e entre os participantes, informações acerca de um tema específico, no caso, o interesse ou não da carreira docente, permitindo que eles expressem suas ideias, concepções, crenças e impressões sobre o assunto. Essa ação, conforme Weller (2006, p. 245), permite "conhecer não apenas as experiências e opiniões dos entrevistados, mas as vivências coletivas de determinado grupo". O autor reforça que as principais vantagens obtidas por meio de Grupo de Discussão é a possibilidade de nessas discussões, poder-se corrigir fatos distorcidos, posições radicais ou visões que não refletem a realidade socialmente compartilhada.

Algumas características dos participantes do Grupo de Discussão são apresentadas por meio dos infográficos abaixo: 
Infográfico 6: Características gerais dos professores do Ensino Médio

\section{PROFESSORES}

ENSINO MÉDIO

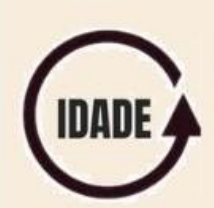

IDADE

Professor 1: 36 anos

Professor 2: 42 anos

Professor 3: 43 anos

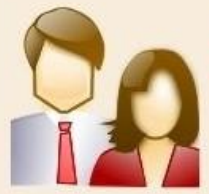

\section{SEXO}

Professor 1: masculino

Professor 2: masculino

Professor 3: feminino

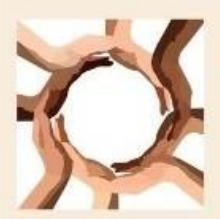

AUtOdEcLARAĢ̃̃o DE RAĢA

Professor 1: pardo

Professor 2: branco

Professor 3: pardo

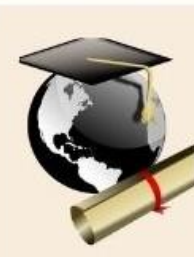

\section{FORMAĞ̃̃o}

Professor 1: Graduação em Letras, Especialização em Língua Inglesa e mestrando em Letras

Professor 2: Graduação em Letras, Especialização em

Multiletramentos

Professor 3: Graduação em Letras, duas especializações em Língua Inglesa e mestranda em Letras

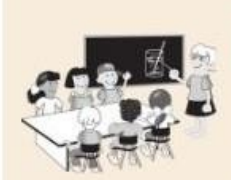

\section{REDE DE ENSINO}

Professor 1: Estadual e Municipal

Professor 2: Estadual e Particular

Professor 3: Estadual e Municipal

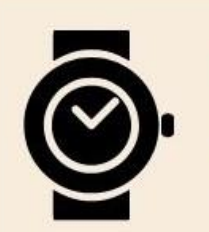

\section{TEMPO DE DOCÊNGIA}

Professor 1: 19 anos

Professor 2: 20 anos

Professor 3: 20 anos

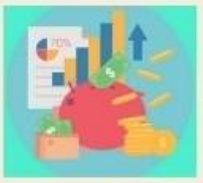

\section{RENDA FAMILIAR}

Professor 1: $\mathrm{R} \$ 12 \mathrm{mil}$

Professor 2: $\mathrm{R} \$ 15 \mathrm{mil}$

Professor 3: R\$14 mil

Fonte: Própria (2019) 
Infográfico 7: Características gerais dos professores do Ensino Superior

\section{PROFESSORES}

ENSINO SUPERIOR
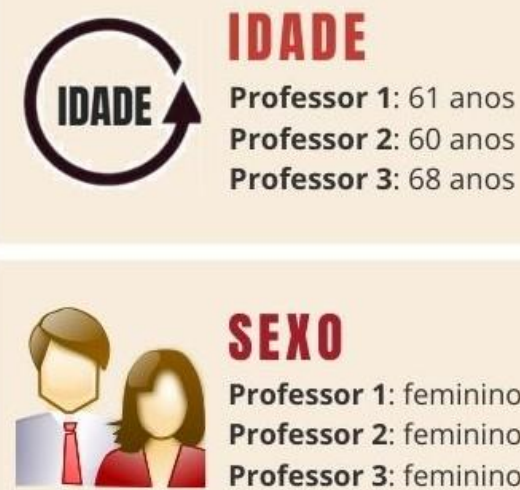

SEXO

Professor 1: feminino

Professor 2: feminino

Professor 3: feminino

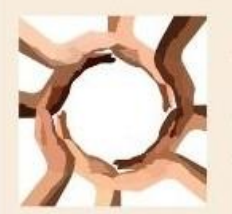

AUTODECLARAÇÃo DE RAÇA

Professor 1: negra ou parda

Professor 2: parda

Professor 3: parda

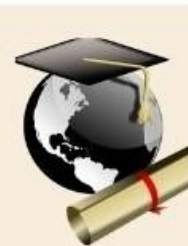

FORMAÇão

Professor 1: Graduação em Letras, Mestrado e Doutorado em Educação

Professor 2: Graduação em Psicologia, Especialização em Psicologia, Mestrado e Doutorado em Educação Professor 3: Graduação em Letras, Especialização, Mestrado e Doutorado em Educação

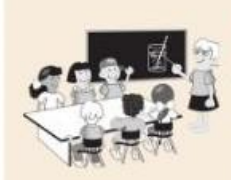

REDE DE ENSINO

Professor 1: Federal

Professor 2: Federal

Professor 3: Estadual

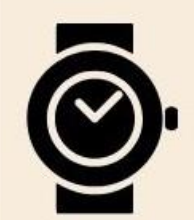

\section{TEMPO DE DOCÊNCIA}

Professor 1: 36 anos

Professor 2: 24 anos

Professor 3: 37 anos

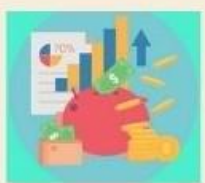

\section{RENDA FAMILIAR}

Professor 1: $\mathrm{R} \$ 16.000,00$

Professor 2: $\mathrm{R} \$ 16.900,00$

Professor 3: $\mathrm{R} \$ 12.500,00$

Fonte: Própria (2019) 
Infográfico 8: Características gerais dos técnicos da SED/MS

\section{TÉGNICOS}

\section{SED/MS}

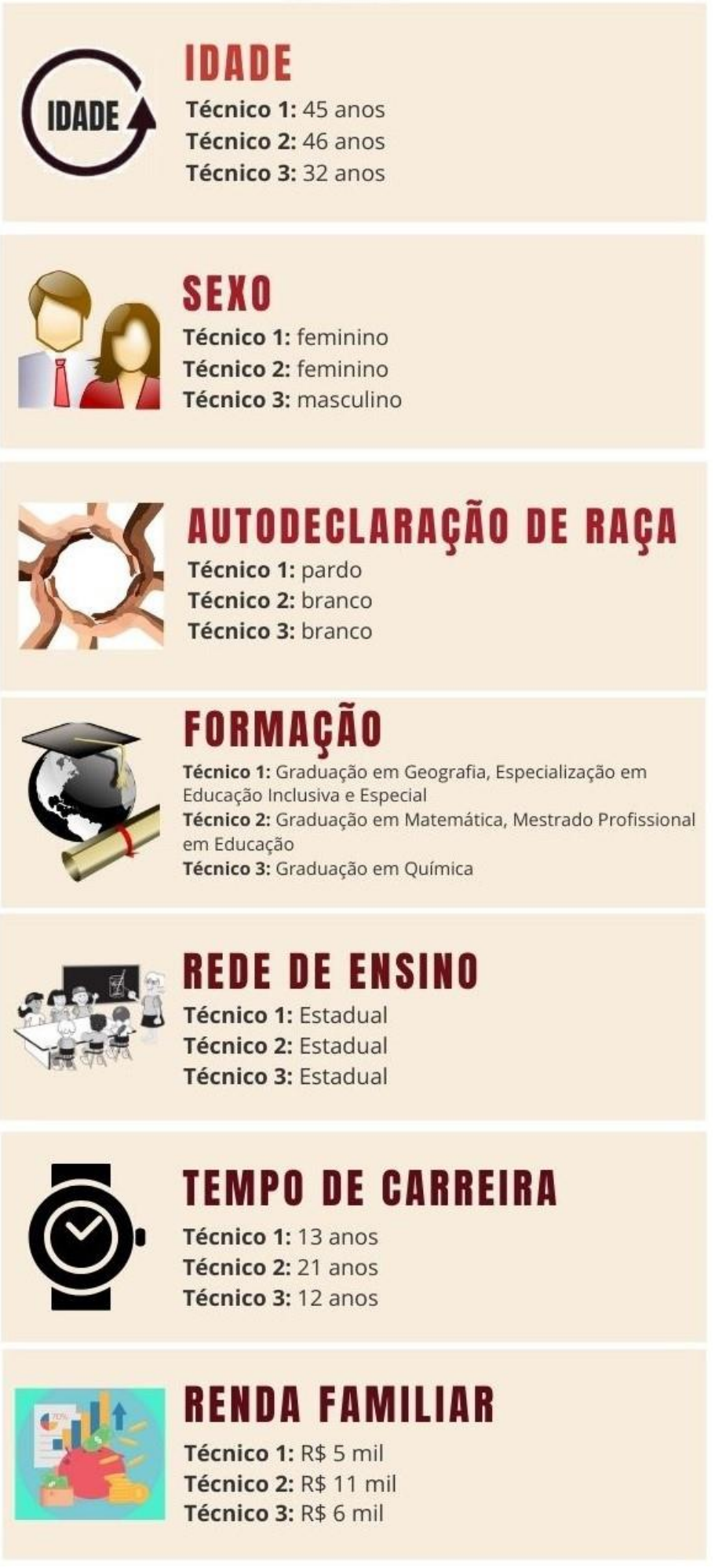

Fonte: Própria (2019) 
Após esta etapa, foram realizados os encontros do Grupo de Discussão com o objetivo de interpretar, discutir, analisar e problematizar as questões suscitadas pelos alunos ao responderem o questionário de pesquisa.

O cronograma proposto e executado para os encontros compreendeu a agenda de 6 (seis) encontros presenciais, com carga horária de 4 horas cada, distribuídos nos meses de março, abril, maio e junho de 2019. Também foi necessário fazer encontros à distância (20 horas) para as leituras teóricas sobre o tema (anexo 8). Informo que a SED/MS liberou tanto os técnicos como os professores do Ensino Médio de suas atividades profissionais, sem prejuízos financeiros ou de reposição de aulas e outras atividades, para que pudessem participar de todos esses encontros. O local dos encontros foi na Universidade Estadual de Mato Grosso do Sul - UEMS, unidade de Campo Grande - MS. Igualmente, informo que esta etapa da pesquisa só foi realizada depois de documentação (anexo 9) aprovada e autorizada pelo MINISTÉRIO DA SAÚDE Conselho Nacional de Saúde - Comissão Nacional de Ética em Pesquisa - CONEP, em 24 de setembro de 2018.

\section{Organização da Tese}

$\mathrm{Na}$ Introdução, discuto os aspectos filosóficos, epistemológicos e metodológicos que dão suporte a tese. Nessa direção, inicio a discussão, trazendo algumas considerações sobre a "desconstrução" proposta por Derrida, ao questionar a estrutura interna dos textos, que encobre outros significados e se refere à metafísica ocidental. Adiante, questiono de forma mais radical a noção de verdade com base nos postulados de Foucault e, por fim, tento flagrar como se deu o encontro Deleuze e Guattari e suas principais contribuições para o processo de investigação. Diante da presença forte dos autores supracitados, tenho como propósito, entrelaçar o diálogo entre eles, com o intento de enfocar o campo da educação linguística como espaço promissor para investigação científica.

$\mathrm{Na}$ subseção "Pesquisa quanti-qualitativa: para além do pensamento positivista", por entender que o caminho metodológico não é um desejo particular do pesquisador, mas antes de tudo, é construído pela necessidade de gerar dados que melhor se integrem para o processo de análise e de discussão teórica sobre os 
sujeitos participantes do estudo, e em razão da tese apresentar um levantamento de dados quantitativos, argumento que o quantitativo e o qualitativo podem ser utilizados conjuntamente na pesquisa em Ciências Humanas, possibilitando melhor compreensão sobre os sujeitos investigados. Para tanto, o texto destaca aspectos fundantes dos estudos de métodos mistos ou multimétodos (MINAYO e SANCHES, 1993; THIOLLENT, 1984; SANTOS FILHO, 1995; GRAMSCI, 1995; LAVILLE e DIONNE, 1999; ANDRÉ, 2002; DEMO, 2002; FLICK, 2004; GONZÁLEZ REY, 2005; DENZIN e LINCOLN, 2006; CLARK, 2007; CRESWELL, 2007; 2009 e 2012; TURANO, 2015).

No Capítulo I - "Conhecendo o campo investigado: a garrafa lançada ao mar", apresento uma descrição detalhada do campo investigado, por meio da articulação das respostas dos alunos extraídas do questionário de pesquisa, as experiências vividas pelos sujeitos e o contexto situado dessas experiências, bem como trago as discussões e análises realizadas pelo Grupo de Discussão e a pesquisadora a respeito das argumentações desses alunos, igualmente refletidas por meio de referencial teórico, cuja diretriz é o plano de imanência (DELEUZE e GUATTARI, 1995), ou seja, a própria vida cotidiana, sua contingência e o seu contexto situado, no espaço e no tempo em que acontecem. Nessa composição, considero as diferentes linhas que formam e deformam permanentemente o que é possível compreender, interpretar, problematizar, que em consonância com os objetivos da pesquisa, produzem um mapa "desmontável, conectável, reversível, modificável, com múltiplas entradas e saídas, com suas linhas de fuga” (DELEUZE; GUATTARRI, 1995, p. 32), perfazendo uma trama complexa, capaz de afecção.

No Capítulo II - "A construção de sentidos sobre a carreira docente pelos participantes da pesquisa", apresento e analiso os dados gerados que me permitiram verificar o interesse ou não pela carreia docente dos participantes da pesquisa. Para tanto, discuto a importância da escola como um espaço de fronteiras entre culturas e me baseio nos estudos Decoloniais (SILVA, 1997; BHABHA, 1998; SOUSA SANTOS, 2011; CASTRO-GÓMEZ, 2007; MIGNOLO, 2009 e 2017; SPIVAK, 2010; GAUTHIER 2012 e 2019; MENEZES DE SOUZA, 2018 e 2019), nos estudos dos Letramentos (KLEIMAN, 1995; ROJO, 2009; STREET, 2014; MONTE MÓR, 2008, 2014, 2018 e 2019), e nos Letramentos de Reexistência (SOUZA, 2011; ANASTÁCIO, 2018; PEREIRA, 2018; FRAGA, 2018, JOVINO, 2018; MUNIZ, 2018). 
Para argumentar sobre a necessidade de construir conhecimentos outros em nossas aulas, em que os saberes sejam considerados como diferentes e não em uma relação hierarquizante e de dominação, ao defender a ideia da necessidade de desconstrução das subalternidades e a reelaboração dos saberes e fazeres pedagógicos que possam espaçar os "entre lugares" (BHABHA, 1998), em que culturas outras, histórias outras e vozes outras, tenham a possibilidade de pronunciarem-se e de serem consideradas como válidas e legítimas.

No Capítulo III - "O interesse ou não pela carreira docente: desafios e perspectivas", apresento e analiso os dados gerados que me permitiram averiguar as razões e desrazões que os participantes da pesquisa justificam para optarem ou não em serem professores. A partir de uma análise sobre o neoliberalismo apoiada nas principais ideias de Arendt (1963), Bourdieu (2002), Nietzsche (2003) e Laval e Dardot (2016), busco mostrar a eficácia das ideologias neoliberais reinantes que vão fazer com que estes participantes tenham uma visão negativa da docência, bem como discuto como o neoliberalismo pode afetar a escolha profissional e os rumos de como os sujeitos se comportam em uma sociedade capitalista.

\section{O caminho que se conhece e se faz ao caminhar: aspectos filosóficos, epistemológicos e metodológicos.}

Os estudos pós-estruturalistas trazem importantes contribuições para 0 modo como fazemos pesquisa, pois provocam uma série de inquietações, descontinuidades, desconstrução, desterritorializações, deslocamentos e suspeitas que repercutem nos processos investigativos, ao mesmo tempo, que aguçam nosso pensamento a buscar outras formas de constituição dos saberes. Diante da presença forte de autores como Derrida, Foucault, Deleuze e Guattari, tenho como propósito, entrelaçar o diálogo entre eles, com o intento de enfocar o campo da educação linguística como espaço promissor para investigação científica. Para mais, busco pinçar e discutir algumas ideias dos autores supracitados e articulá-las às outras possibilidades de fazer pesquisa.

Para tanto, busco captar forças e sensações e transformá-las em palavras, atento-me em não fazer somente a mera reprodução de citações e apreciações 
sobre os autores, mas busco costurá-las aos elementos que emergem na contingência dos encontros, reconhecendo minhas próprias limitações, tentando compreender o que movimenta minha aprendizagem, vivendo a violência da transformação e as (de) formações sofridas no meu próprio modo de pensar.

Com efeito, destaco o excerto de um texto que me extasiou, e com o qual, luto para não incorrer no processo de pesquisa: (...) Quando alguém esconde algo detrás de um arbusto, volta a procurá-lo justamente lá onde escondeu e além de tudo o encontra, não há muito do que se vangloriar nesse procurar e encontrar "verdade" no domínio da razão. (NIETZSCHE, 2008, p. 36). Na presença do fragmento destacado e contaminada por ele, expresso o desejo de buscar meios para problematizar a própria experiência de criação do pensamento em uma pesquisa das multiplicidades, e que faz gerar multiplicidades, cuja natureza remete a um movimento de "desconstrução" do pensamento, enfim, uma pesquisa que dê vazão às linhas de fugas, às contingências, aos eventos aleatórios, à emergência e ao imprevisto.

Em vista disso, inicio essa discussão, trazendo algumas considerações sobre a "desconstrução" proposta por Derrida, ao questionar a estrutura interna dos textos, que encobre outros significados e se refere à metafísica ocidental. Adiante, questiono de forma mais radical a noção de verdade com base nos postulados de Foucault e, por fim, tento flagrar como se deu o encontro Deleuze e Guattari e suas principais contribuições para o processo de investigação.

A linguagem integra uma posição fundamental nas articulações filosóficas de Derrida, pois seu legado evidencia a desconstrução filosófica ocidental por meio da crítica da linguagem. Entendo com Derrida (1995), que "desconstruir" não significa negar os valores dados como universais pela filosofia ocidental, antes de tudo, tratase de buscar desfazer o modo ou caminho pelo qual um conceito ou uma visão foi construído(a), de modo a entender a própria construção dele ou dela.

Assumir o pós-estruturalismo como uma perspectiva epistemológica para a pesquisa em educação linguística, implica a desconstrução de metanarrativas construídas na modernidade que marcam a produção do conhecimento, quais sejam: discurso, verdade, poder, diferença, identidade e razão, e que têm sido desestabilizadas pela crítica pós-estruturalista. Ao colocar sob suspeita essas categorias, reforço que se trata de uma aposta na historicidade, na possibilidade de 
desconstruir algumas evidências naturalizadas que se apresentaram nos discursos dos participantes da pesquisa sobre a carreira docente, mostrando como foram produzidas, pois se algo foi sempre assim, nada determina que assim permaneça.

Entendo que o termo desconstrução não significa destruição, mas uma maneira de proceder que busca desorganizar e descentralizar os discursos empreendidos pela metafísica para dar-Ihes diferentes funcionamentos, pelo efeito também de uma leitura desconstrutora. Tal ação, me faz pensar que o discurso não é neutro, pelo contrário, é um campo tático de enfrentamento, controle e poder. Foucault (1996, p. 269) adverte que "[...] temos que ouvir o ronco surdo da batalha", o que me faz refletir que, mesmo em uma sociedade normalizadora e controladora, a resistência as práticas disciplinares e biopolíticas é sempre possível.

Com o mesmo olhar, Nietzsche (1998) reitera que, mesmo na submissão, há resistência, que a vontade de potência nunca é anulada nem eliminada, e ainda que essa vontade seja reativa, negativa, ou quando expressa a vontade de nada, ou seja, quando é niilista, "o homem preferirá querer o nada a nada querer" (NITZSCHE, 1998, p.149). Com o propósito de ampliar esse conceito, em sua emblemática obra "Assim falou Zaratrusta", escrita entre os anos de 1883 e 1885, Nietzsche apresenta três metamorfoses do espírito.

Na primeira sob o signo do camelo, encontra-se a vontade da submissão, ou seja, não há nada para além da aceitação, haverá apenas a sujeição e a obediência, e com todo o peso dos valores por sobre as costas, o camelo caminha para o deserto. Porém, é no solitário deserto que se dá a segunda metamorfose - um dragão aparece como a materialidade dos valores milenares e afirma: "- Não farás", " - Tu deverás", para qual o camelo sempre se submeteu, mas o leão não. Ele surge e ruge: "- Eu quero", “- Eu farei”, e põe fim em toda subordinação e cria sua própria liberdade. O leão deixa de ser camelo quando percebe suas capacidades e vontades e diz "não", este espírito que amou a devoção, agora apaixona-se por sua vontade e, de posse de direito, quer o "dizer - sim".

A terceira metamorfose do espírito, sob o signo da criança, pode o que nem o camelo ou o leão puderam: criar, brincar, jogar, sonhar livremente. E qual a importância da verdade para a criança? Nenhuma, pois a verdade está a serviço da vontade, não o contrário. A criança alerta que a vida é aqui e agora, com suas alegrias e sofrimentos, nada mais que isso e que querer qualquer coisa depois da 
vida é querer o nada, pois tudo é transitório, nada é fixo.

Esta obra me convida a refletir que devo vencer a mim mesma e que este combate não tem fim, nem descanso. Essa é a forma mais aguda do niilismo: o nada. Da mesma maneira, em nossas pesquisas, podemos caminhar pelo deserto de nossas investigações e estudos e sofrer metamorfoses, enfrentar nossos temores, demônios, inseguranças e dizer um gracioso "sim" para nossos desejos.

Em aproximação a esse olhar Nitzscheniano, penso que o conhecimento que busco produzir nesta pesquisa não é a descoberta de algo a ser revelado, mas é um ato de criação e invenção que nada tem de neutro e objetivo, pois é resultante da ação das forças que movem a vontade de potência em luta constante por imposição de sentido. Dessa maneira, a linguagem já não é mais concebida como um vínculo neutro e transparente de representação da realidade. Entender a linguagem como instável e indeterminada como pensa Derrida (1995), implica diretamente na questão das identidades e das diferenças, pois, se as identidades e as diferenças são definidas, em certa medida, por meio da linguagem, também são marcadas pela indeterminação e instabilidade. Em outras palavras, as identidades e as diferenças não podem ser fixas, determinadas e estabelecidas de uma vez por todas pelos sistemas discursivos e simbólicos, pois como vimos em Derrida (1995), a linguagem "vacila", em razão disso, Deleuze (1998) e Hall (1997) afirmam que as identidades e as diferenças dos sujeitos não são fixas, estáveis e imutáveis, esperando para serem exteriorizadas, descobertas, aturadas ou aceitas.

Essas considerações são suficientes para delinear a posição de Derrida, sobre a importância de pensar no quanto as palavras podem significar e não no que elas significam. É por isso que a linguagem, nos jogos de associação que ela enseja, realiza operações tão múltiplas, em razão da riqueza de seus diferentes significados, e rompe com a filosofia pautada nas relações binárias originadas da lógica.

Nessa perspectiva, uma aproximação pode ser feita com a própria criação literária, na medida em que a tomamos como fluidez do inconsciente, cheia de manifestações intuitivas ligadas ao prazer e a sensação, entretanto, essas acabam suprimidas pelo controle racional no instante mesmo que são codificadas, ou seja,no momento em que são transformadas em linguagem.

Feitas as ponderações sobre a importância de pensar no quanto as palavras 
podem significar e não no que elas significam, retorno a questão da metafísica na cultura Ocidental, a qual abarca valores tidos como universais, impondo verdades, em que o sujeito era pensado apenas sob o olhar do referencial masculino, de cor branca, heterossexual, e agora passa a ser visto com outras identidades, múltiplas, fluídas, cambiantes, às quais foram ocultadas historicamente pelo discurso hegemônico. Para Derrida (1995), nada mais são que construções arbitrárias de preconceitos e de pressuposições, mostrando que a indeterminação impede a possibilidade de qualquer verdade absoluta.

Sobre o conceito de verdade, em um debate realizado no Colégio Técnico de Eindhoven, no sul da Holanda, publicado no Brasil em 29 de novembro de 2014, Foucault alerta que:

\footnotetext{
O espírito do homem é feito para ver, para ter acesso à verdade. Por efeito de um certo número de inibições ou obstáculos (as condições econômicas e sociais, as diferentes formas de mentalidade, a credulidade, os velhos temas, os mitos religiosos, a moral), não conseguimos ver esta verdade, pois tais elementos constituem uma espécie de cegueira sobre nossos olhos, o que nos impede de capturar, de formular e de construir a verdade, à qual temos direito desde o princípio.
}

Considerando a afirmativa, para o autor, a questão não é saber se algo é verdadeiro, mas saber o porquê e como esse algo tornou-se verdadeiro, destacando que cada sociedade tem seu regime de verdade. Isto é, os modelos de discursos que essa sociedade acolhe e faz funcionar como verdadeiros, e que não estão isentos de um interesse político ou econômico, pois é também um espaço de enfrentamento social, cada lado defendendo seu ponto de vista sem se interrogarem como cada discurso se constituiu historicamente como experiência, ou seja, a verdade seria uma construção das instituições que as produzem. O questionamento se dá em razão de o porquê algumas coisas são consideradas verdades e outras não, e que não se trata da descoberta do que é verdadeiro ou não, mas das regras que possibilitam a construção do discurso de um sujeito sobre o que é verdadeiro ou falso em relação a determinado objeto, para tanto, rediscuto essa noção de verdade, e sugiro que este estudo é uma das possíveis verdades situadas na seara das pesquisas científicas.

Nessa perspectiva, o desenvolvimento de uma prática de pesquisa pósestruturalista exige do pesquisador um exercício constante de ruptura com as 
prescrições e normatizações dos modelos tradicionais de análise e interpretação de dados, para que possa fazer emergir outras formas de constituição de saberes, como nos avisa Corazza:

\begin{abstract}
Uma prática de pesquisa é um modo de pensar, sentir, desejar, amar, odiar; uma forma de interrogar, de suscitar acontecimentos, de exercitar a capacidade de resistência e de submissão ao controle [...]; de nos enfrentar com aqueles procedimentos de saber e com tais mecanismos de poder; de estarmos inseridas/os em particulares processos de subjetivação e individuação. Portanto, uma prática de pesquisa é implicada em nossa própria vida. A "escolha" de uma prática de pesquisa, entre outras, diz respeito ao modo como fomos e estamos subjetivadas/os, como entramos no jogo de saberes e como nos relacionamos com o poder. (CORAZZA, 2007, p. 121).
\end{abstract}

$\mathrm{O}$ ato de pesquisar problematizado pela autora, me convida a refletir que a escolha e a prática de uma metodologia em uma investigação estão intrinsecamente ligadas ao modo de pensar, de sentir, de reimaginar, de analisar, de resistir e reexistir do(a) pesquisador(a). Assim, se há um jogo de saberes e poder, há a possibilidade de criar linhas de fuga que apontem outras formas de produção de conhecimentos que subvertam o previsível e cartografem outras formas de constituição de saberes.

Em continuidade, tento flagrar por meio da literatura como se deu o encontro dos filósofos Deleuze e Guattari, um encontro com alto potencial criador, uma espécie de composição coletiva da enunciação, privilegiando uma dimensão performática da escrita e não mais sua representação, ou seja, o pensamento em ato - a escrita e o pensamento são o mesmo gesto, e cujo ato de pensar descreve processos de produtiva apropriação e produção de conhecimento.

$\mathrm{Na}$ pretensão de me aproximar dessa escrita, proposta pelos autores, esforço-me em romper com um jogo fácil do pensamento, removendo os excessos de reprodução de conceitos, extraindo o sumo do ato de pensar, seguindo o fluxo das contingências, inebriada pelos acontecimentos e o que emerge deles. Para expandir o entendimento sobre romper com o jogo fácil do pensamento no processo de investigação, para Deleuze (1988), o pensamento deve contemplar a diferença e estar relacionado ao ato de aprender e problematizar, que só se constitui a partir da criação e rompe com uma tradição do pensamento filosófico determinado pela representação. 
Diferente desse conceito desenvolvido pelo autor, o natural seria seguir os passos metodológicos seguros. Conquanto, para ele, as coisas já certas não forçam o pensar, é necessário querer mais, "o que é primeiro no pensamento é o arrombamento, a violência, é o inimigo, e nada supõe a Filosofia" (DELEUZE, 1988, p. 230), ou seja, o que funda o pensamento é o encontro com algo violento que força a pensar, o que desencadeia a paixão de pensar e não se pode fazer isso por reconhecimento, mas pela violência de algo estranho que é sentido em forma de afetividade em cada sujeito.

Dessa perspectiva, faço uso da escrita como uma ferramenta de provocação, em que busco expressar desmontes e transformações, habitando a incerteza, com poros abertos e movendo forças, consciente de que o problema a ser pesquisado é que inventa o caminho a ser percorrido em uma pesquisa, algo tateante que pede uma forma que não é pensada a priori, "um fora dentro", como as forças que se mobilizam de maneira não linear. Em vista disso, sendo a linguagem indissociável do pensamento, ela não representa o objeto, ela produz o próprio objeto e constrói a ambiência do pensamento.

O pesquisador ao problematizar um objeto, não o faz apenas por meio de um conceito, mas como um gesto investigativo, um objeto a ser debatido e revisitado, por recurso de um esforço de desdobramento em relação ao objeto. A problematização não surge como um conjunto de regras diretivas do pesquisar, mas como um ato do pensamento e pode assumir contornos para além daqueles postos por questões metodológicas, aceitando o devir e abrindo-se para o impensável.

Além disso, é um jeito de olhar para objetos e situações comuns com um distanciamento necessário para que haja uma desconstrução das noções de verdade, o que nos permite refletir sobre o que é normativo como algo criado socialmente por nós e pela cultura. Por consequência, a produção subjetiva de uma dada época, visa ditar verdades para que possamos ter referências e padrões que nos homogenizem, incluindo os devires e as produções do nosso próprio desejo de liberdade.

Nessa chave, um expoente da filosofia de Deleuze (2009) foi restituir ao pensamento sua potência criadora, ao evidenciar de que modo 0 ato de pensar encontra-se relacionado a um procedimento inventivo, combatendo a ideia de pensamento que se encontrava sufocada pela hegemonia da perspectiva 
representacional. Efetuando uma completa modificação nos principais conceitos do modelo da representação, o autor denuncia que o senso comum seria responsável por construir uma imagem do pensamento - o pensamento dogmático, pensamento que opera por imagem conhecida, uma espécie de representação universalizante do pensamento.

Afora desse pressuposto contido no senso comum, outra importante característica observada na imagem dogmática do pensamento é a recognição, cujo desígnio tem como função afirmar que conhecer é, na verdade, reconhecer. Com efeito, para o autor, pensar é algo além da recognição, por isso é uma violência de si mesmo, não é dar uma forma, mas é traçar um plano que se movimenta sobre o caos, que faz dobras, uma experiência de pensamento incomum que produz movências na escrita, cujo texto convoca o fora, o aberrante e o impensável.

De acordo com esse conceito de pesquisa criativa, o seu desenvolvimento não segue passos estabelecidos ou determinados de ordem lógica, mas busca evidenciar os aspectos relevantes que emergem da vivência com o contexto investigado, o que pode redefinir, sobretudo, os objetivos do estudo, bem como o corpus de análise, pois o contato com o contexto local pode fazer emergir fatos que ofereçam mais subsídios para a discussão da investigação, em razão da riqueza dos acontecimentos que vão surgindo e que não podem ser previstos. Considerando esta acepção, me questiono: Qual caminho escolhe um pesquisador quando seu olhar está comprometido com as multiplicidades que emergem a partir das experiências vivenciadas no contexto investigado?

Para responder a esse questionamento, em entrevista ao Jornal Libération sobre a obra Mil Platôs, Deleuze (1980) traz ricas contribuições sobre o que é e para que serve a filosofia, bem como discute sobre a importância da criação de novos conceitos que tenham aplicabilidade no mundo moderno, ao afirmar que esta ação sempre foi tarefa da filosofia, todavia, nunca esteve reservada aos professores de filosofia, pois é filósofo quem se torna um, isto é, quem se interessa por essas criações muito especiais na ordem dos conceitos. Mais adiante, o autor esclarece que tomou emprestado o termo rizoma da botânica para aplicá-lo a filosofia. 
O que Guattari e eu chamamos rizoma é precisamente um caso de sistema aberto. Volto à questão: o que é filosofia? Porque a resposta a essa questão deveria ser muito simples. Todo mundo sabe que a filosofia se ocupa de conceitos. Um sistema é um conjunto de conceitos. Um sistema aberto é quando os conceitos são relacionados a circunstâncias e não mais a essências. Mas por um lado os conceitos não são dados prontos, eles não preexistem: é preciso inventar, criar os conceitos, e há aí tanta invenção e criação quanto na arte ou na ciência. (DELEUZE, 1980, p. 20).

Com efeito, o filósofo, ao se inspirar no significado botânico do rizoma, enfatiza que as linhas que o constituiem são elementos provenientes das coisas, da realidade social e da pluralidade das experiências que podem ser vivenciadas no contexto a ser investigado, portanto, se torna necessário por parte do pesquisador, a compreensão dessa dinâmica. Então, como um movimento rizomático do pensamento pode me ajudar a desenvolver pesquisa na pós-modernidade? Para tentar responder a essa indagação, lanço-me ao encontro com uma experiência estética intensiva e me remeto à outra interpelação formulada por Deleuze, acerca de Espinoza: "O que pode um corpo? A estrutura de um corpo é a composição da sua relação. O que pode um corpo é a natureza e os limites do seu poder de ser afetado" (DELEUZE, 2017, p. 147). Para exemplificar esse encontro, exalto a renomada escultora Conceição dos Bugres ${ }^{3}$ que contava que começou a trabalhar com a madeira quando um dia se deparou com uma cepa de mandioca, que para ela tinha cara de gente:

\footnotetext{
3 Nasceu no Rio Grande do Sul, na localidade de Povinho de Santiago, em 1914. Aos seis anos mudou-se para o Mato Grosso, de onde nunca mais saiu, morou em Campo Grande - MS desde 1957. Criou "O Bugre", esculpido em madeira com golpes secos e retos de facão e recoberto com cera de abelhas, os cabelos e os detalhes do rosto foram feitos inicialmente com carvão e logo substituído por tinta preta. Por meio de um sonho, em que o marido havia colhido mel e, a partir dele feito a cera, no dia seguinte pediu a seu filho que fosse comprar o produto para usar em suas figuras. Ela já sabia do efeito pelo sonho. Com um pincel, começou a usar a cera e, desde então, nunca mais deixou, pois, para ela, representava a roupa. Antes o bugre andava nu e depois do uso da cera parecia vestido. O produto também protegia a obra do vento para que não rachasse. De modo inconsciente, Dona Conceição com sua obra, resgatou um trabalho já feito por indígenas da região do Chaco Paraguaio há centenas de anos. Considerada a maior escultora de Mato Grosso do Sul, teve seu trabalho reconhecido em âmbitos nacional e internacional. Depois de sua morte em 1984, aos 70 de idade, seu trabalho continuou sendo realizado pelo seu marido, depois por seu filho e atualmente por seu neto Mariano, e as obras são encontradas em museus e coleções particulares. (Biografia de Conceição dos Bugres. Catálogo das Artes, 2016).
} 
"Um dia, me pus sentada embaixo de uma árvore e perto de mim tinha uma cepa de mandioca, que tinha cara de gente. Pensei em fazer uma pessoa e fiz. Aí a mandioca foi secando e foi ficando parecida com uma cara velha. Gostei muito. Depois eu passei para a madeira. Começo a fazer e já vai saindo aquela forma de costume. Muitas vezes nem penso nisso e sai um rindo. Parece que a madeira é que quer sair assim. Acho que a madeira manda mais que eu." (CONCEIÇÃO DOS BUGRES apud CAMPSO, 2016, p. 1).

O meu contato inicial com a obra de Conceição dos Bugres se deu no Museu de Arte Contemporânea de Mato Grosso do Sul, onde muitas de suas esculturas compõem o acervo permanente do local. A primeira vista, fiquei imóvel diante de suas obras, algo se passou e outras forças tomaram conta do meu corpo, pois reconheci traços de minhas origens, dos meus antepassados, e que são tão evidentes e marcados em minha aparência. Esse reconhecimento me fez compreender a contingência de um encontro, a intensidade de um acontecimento, é quando a obra da autora nos mostra como a forma perde poder de informação para ganhar o registro dos acasos, das sensações e das forças.

Imagem 2: Conceição dos Bugres, "Bugre", madeira.

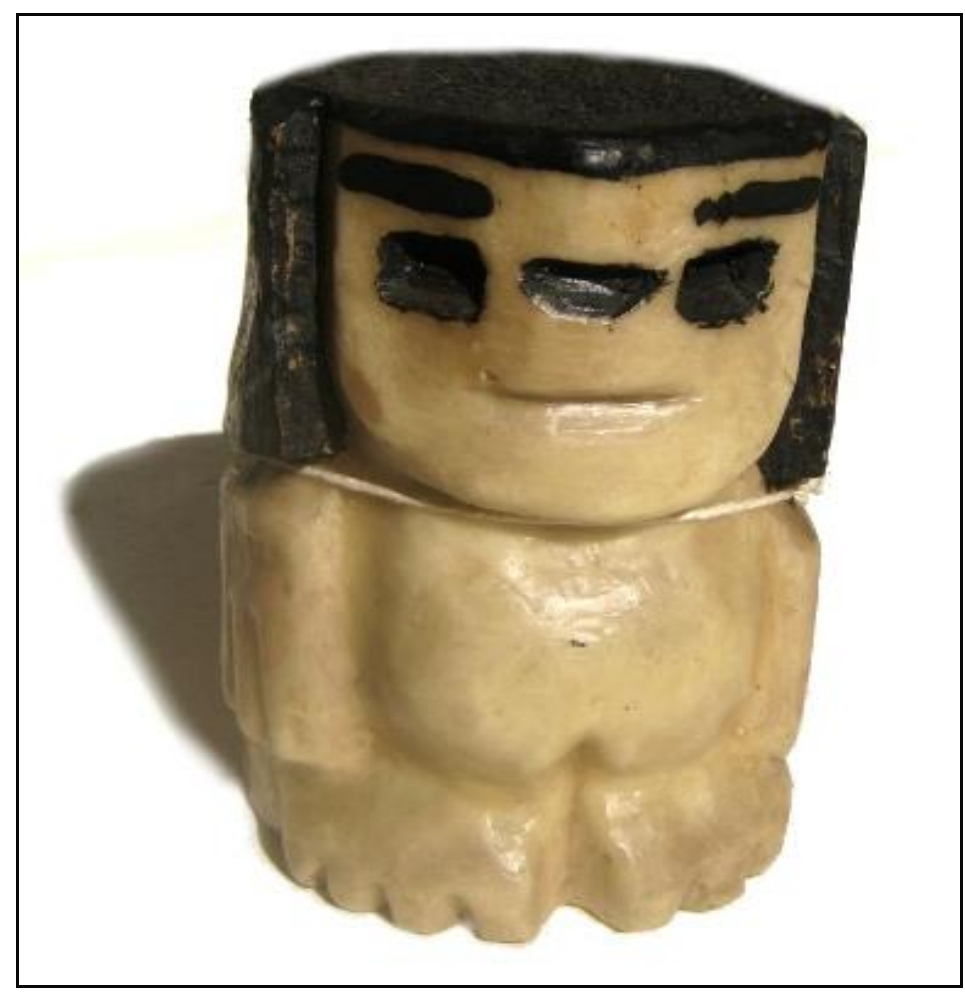

Foto: Edmar Neto 
De outra maneira, Francis Bacon sob o olhar de Deleuze (2007), em "Lógica da sensação", nos leva a pensar que a imagem anuncia que todo corpo que ela representa é possuidor de uma capacidade de negar a própria evidência narrativa, e que "a tarefa da pintura está definida como a tentativa de tornar visível as forças não visíveis" (DELEUZE, 2007, p. 38), na qual a essência não está escondida para ser descoberta.

Essa relação do pintor com o material e o seu pensamento é vital e conecta todos os elementos, em um espaço em que pintor também se torna material, pois o agenciamento é imponderável, conforme ressalta Conceição dos Bugres (2016), que tem a sensação de que a madeira determina como a escultura aparentará, ou melhor, o que Deleuze (2007, p. 42) formula com tanta intensidade "a força está em relação estreita com a sensação: é preciso que uma força se exerça sobre um corpo, na forma de uma onda, para que haja sensação". Essa relação nos faz pensar que a obra de Bacon é uma tentativa de captar forças por meio de traços manuais livres, como efeito de uma peregrinação, tornando a imagem desorganizada, improvável e deformada, uma criação, sobretudo, do modo como ele concebe $o$ ato de pintar. $\mathrm{O}$ que $\mathrm{o}$ artista sugere ao homem moderno?

No esforço de esboçar uma resposta para tal questionamento, faço uso das palavras de Deleuze (2007, p. 68), ao argumentar que Bacon é aquele que faz a "travessia da história da pintura para mostrar o que o homem moderno pode ainda esperar dela", sobretudo por meio de seus traços de sensações confusas, não representativos e não narrativos.

Assim sendo, o modo de fazer arte, rompe com a representação e busca a sensação, conforme Deleuze (2008) discute que a sensação configura o encontro do sujeito e do objeto, desconcertando nossa faculdade sensitiva, tornando o pensamento móvel e captando forças, isto é, tornando visíveis as forças que não o são e, como resultado, descortinando o que a representação ou a narração são incapazes de transparecer. Isso nos mostra outra maneira de apreciar e experienciar a arte, e de viver a vida.

Em consonância com o acima explicitado, surge a ideia da independência da obra de arte em relação a nós - público e artista, pois uma vez criada, conforme a asserção de Rancière (2000, p. 505), "a obra de arte assim o é na medida em que se mantém por si só", ou seja, a obra é matéria que está diante de nós e que tem 
dispensabilidade de nós, não depende de nós para seguir existindo e preservando a sua potência.

Desloco ainda, a reflexão de como a arte pode intervir na vida cotidiana, uma vez que apreciar uma imagem, assim como aconteceu comigo em referência a escultura "Bugre", pode fazer o espectador ver as coisas de forma diferente e assim mudar seu comportamento e sua visão de mundo, o que Rancière (2009, p. 60) acentua como a "distribuição do sensível", a qual define como os seres humanos vivem juntos e de como a arte tem o potencial para criar novas formas de expressão de uma comunidade e, ainda, como tem a faculdade de influir na política. $O$ autor alerta, no entanto, que não podemos presumir que o que vemos poderia ser lido sem ambivalência, ou seja, não há garantia de qual efeito a arte pode ter.

A experiência estética pode ser política, pois altera a cartografia do visível, do perceptível e do pensável. Essa relação entre política e estética discutida pelo autor, abrange a criação de dissensos ou desentendimentos, ao tornar visível o que não é, constituindo uma espécie de ação de resistência que busca encontrar modos de transformar o que é percebido como permanente e imutável.

Para mais, o conceito de "partilha do sensível" (Rancière, 2009), com sustentação no encontro discordante das percepções individuais, descreve a composição da comunidade política. Em razão disso, um regime político só pode ser democrático se estimular a multiplicidade de discursos dentro da comunidade, por isso, a política para o autor é, sobretudo estética e está instituída sobre o mundo sensível, tal como a expressão artística.

Ao defender uma escritura diferenciada para as pesquisas em educação, Silva (2002, p. 65) sublinha que:

Deve ser uma escrita com estilo. Não que se torne literária, acho que assim perderia sua especificidade, mas que se torne mais próxima de escrita literária. A escrita educacional não é nada disso, pelo contrário, é plana, feita para as proclamações da ação, muito baseada em citações, por exemplo. De maneira geral, a escrita educacional é muito pouco inspiradora.

Em assentimento com o autor, uma escrita inspiradora, investida de procedimentos literários pode arrebatar o leitor, ao mesmo tempo, pode inclusive, fomentar um pensar diferente. Desde criança, o texto literário sempre me foi boa companhia, gostava de ler, de me imaginar nos personagens das histórias e dos 
contos, e como profissional da área de Letras, expandi ainda mais o gosto pela Literatura que, para mim, também é uma prática educadora e uma possibilidade de incorporar novas experiências e aprendizagens. Dessa maneira, na escrita deste texto, sempre que possível, busco entrelaçar os conhecimentos científicos aos literários.

De natureza semelhante, Rancière (2002) defende uma educação emancipadora, reconhecendo que as inteligências têm capacidades similares de aprendizado mais autônomo. Todavia, em muitas circunstâncias, o mais complexo é romper com a disposição que algumas pessoas têm com a instrução, bem como em relação a submissão do aluno à inteligência do professor. Isso nos faz refletir que a comparação dos sujeitos hierarquiza a própria ordem social. Mas será que as pessoas estão dispostas a mudar essa ordem?

Reconhecer as diferenças entre os sujeitos não deveria conduzir a desigualdade, pois há a alternativa da sociedade reconhecer as diferenças e, portanto, a partir daí, pensar em justiça social. Defendo que a educação possa ser um dos caminhos para construir um discurso de justiça social. Em analogia acerca dessa discussão, em se tratando de pesquisa em educação, pode-se operar também de maneira mais autônoma, pois a emancipação é a capacidade de operação em todos os sentidos, uma vez que "tudo está em tudo" (RANCIÈRE, 2002, p. 32), ou ainda, aprender algo e desenvolver a capacidade de fazer conexão com todo o resto.

Diante desse cenário, insistentemente, me coloco na condição de pensar com Wittgenstein (2009, p. 35): "Diga-me como você procura e te direi o que você procura". Essa relação faz ressonância com o modo que busco fazer pesquisa em educação, consciente de que a criação se faz na própria experimentação, propondome o desafio de realizar uma pesquisa que fratura a ideia de existir o melhor método ou o mais seguro, consciente de que o método se faz no fazer, por meio do contágio que só acontece no "encontro" com o objeto e pressupõe uma transgressão das coisas, e que contempla um processo de análise que nos permite pensar outras questões a respeito do objeto, um pensamento eruptivo e não a explicação das coisas, ao assumir a arbitrariedade, pois a força da análise está em sua atmosfera fugidia que faz conexão imediata com o seguinte, por efeito das multiplicidades que crescem pelo movimento "e...e...e..." (DELEUZE; GUATTARI, 2011, p. 18), 
contrariando o binarismo que impõe o ou: ou isso ou aquilo.

Esses princípios estão relacionados com a amplitude e a complexidade dos acontecimentos, pois pensar sobre alguma coisa é estabelecer relações com as contingências. Dessa forma, um movimento de pensamento rizomático abarca diferentes pontos de partida, bem como considera, assimila e legitima diferentes pontos de vista em oposição à verdade única, o que implica expor acontecimentos vividos, determinações históricas, conceitos pensados e formações sociais.

Assim sendo, um rizoma não começa nem conclui, são círculos de convergência, move-se entre as coisas, em um movimento transversal. É um modelo de resistência, uma erva que cresce horizontalmente, não tem uma direção definida, trata-se de linhas e não de formas. Em função disso, o rizoma pode escapar, esconder-se e trinchar caminhos. Não tem talhe fechado, são linhas de intensidade, por isso, o pensamento rizomático se move e se abre, explode em todas as direções e se espalha. "Faça a linha e nunca o ponto! (DELEUZE e GUATTARI, 2011, p. 48). É mapa, um mapa é um esboço incompleto, por esse motivo requer incessantemente novos traços.

Além do mais, é um mapa que pode ser revisto, rediscutido, ressignificado e remapeado, sendo conectável em todas as suas dimensões visto que se configura mais por uma questão de performance, por isso, cada coisa e pessoa tem sua geografia, seu próprio mapa. Os autores reiteram ainda que "o que há de interessante numa pessoa são as linhas que a compõem, ou que ela compõe, que ela toma emprestado ou que ela cria." (DELEUZE E GUATTARI, 1980, p. 47). Em se tratando desta perspectiva do movimento do pensamento rizomático, Marques (2016) destaca ser importante atentar-se a essa multiplicidade ao gerar e analisar os dados, evidenciando suas conexões e heterogeneidade, buscando também ligações inusitadas existentes no cotidiano, procurando expandir o território da própria pesquisa, propondo uma investigação que possa ser pensada mais no campo da experimentação e menos como instrumentalização, na tentativa de romper com a hierarquização e compartimentabilização de ideias.

Consciente de que a cartografia rizomática não é um método, mas o pensamento rizomático (ZOURABICHVILI, 2012), busco em momentos pontuais do texto, expressar então, movimentos de pensamento rizomático. Primeiro, quando uso a figuração de um rizoma para construção de uma escrita com linhas de fugas, 
em atenção as conexões feitas com textos literários, ao interligar saberes outros, intensidades e afetos com as de outros corpos, e com alguns pressupostos teóricos que fundamentam a tese.

Segundo, quando mapeio as conexões entre os textos em análise e as histórias sobre ensino contadas por mim, pelos participantes da pesquisa e pelos textos acadêmicos sobre a construção de sentidos pelos jovens sobre a carreira docente.

Terceiro, quando o texto é tomado como um afecto, cujo intento não é o convencimento ou a explicação das coisas, mas a produção de um devir naquele que o encontra.

Quarto, quando no processo de análise dos dados gerados, conto com a colaboração de um Grupo de Discussão composto por professores do Ensino Superior, da Educação Básica e Técnicos da SED/MS, bem como o processo de análise proposto, refere-se a uma leitura que opta também por conceder ao leitor a possibilidade de acessar conhecimentos outros e experiências vivenciadas sobre o tema, passível de ser reconstruído e reanalisado conforme as contingências.

Quinto, quando renuncio à pretensão de solucionar um problema, ao invés disso, esforço-me em redescobrir os problemas que animam os acontecimentos que emergem, em um contexto situado.

Sexto, quando discuto a incompletude da pesquisa com suas linhas de fugas, como um mapa sempre em construção e, portanto, inacabado. Nessa direção, busco fazer uso dessa perspectiva ao produzir encontros experimentais de pesquisa e ao aguçar minha criatividade, minha reimaginação e minha sensibilidade na produção do texto acadêmico.

Em razão desse horizonte de pensamento, para o pesquisador, é profícuo ser receptivo e sensível às questões não previstas e inesperadas que emergem durante o processo de pesquisa, pois estas podem ser carregadas de significados "outros", enriquecendo, avolumando e descortinando outros saberes, pois "as mesmas coisas" deixam de ser "as mesmas" quando são examinadas em sua pluralidade, com um olhar atento também as ranhuras e fissuras. Assim como afirma Corazza (2007, p. 120), sobre os estudos das teorizações pós-estruturalistas: 
"Não encontro nenhum critério que autorize alguém a selecionar esta ou aquela metodologia de pesquisa. Justo porque não é por tal ou qual método que se opta, e sim por uma prática de pesquisa que nos toma no sentido de ser para nós significativa."

Entendo que o percurso de uma pesquisa, com base em uma perspectiva pós-estruturalista, se constitui como um caminho incerto a percorrer, uma vez que este caminho se constrói a partir do elenco de acontecimentos, saberes e experiências que emergem ao longo desse processo e que não se concluem, pois sempre haverá a incompletude do que não foi possível investigar.

Ademais, penso que é imprescindível dar vida ao pensamento, para poder matutar sobre as situações rotineiras que, comumente, não são objetos de reflexão, e que por força do hábito, podem fugir da minha atenção. Todas essas perspectivas moldam um tipo de pensamento sutil, que está sempre em trânsito, impermanente e aberto para aprender com a experiência e, que abrange as múltiplas interpretações coexistentes de um único acontecimento, em um encontro poroso e transformador.

Ao pesquisador que escolhe trabalhar com essa perspectiva, diante de um objeto desafiador, implica de sua parte, constantes questionamentos e rupturas frente a ele, uma espécie de exercício infernal do pensamento, sem conforto, um desassossego, um movimento incessante de desacomodação.

Após situar as contribuições do pensamento pós-estruturalista que orientam este estudo, e por entender que a epistemologia de pesquisa ocupa-se de problemas filosóficos que se apresentam no curso da investigação científica ou na reflexão sobre os problemas, métodos e teorias da ciência (TESSER, 1994), utilizo esse conceito para efetivar uma reflexão crítica sobre os processos de investigação e análise dos dados gerados por este estudo, portanto, adiante, discuto os aspectos metodológicos desta pesquisa.

\subsection{Pesquisa quanti-qualitativa para além do pensamento positivista}

Entendo que o caminho metodológico não é um desejo particular do pesquisador, antes de tudo, é construído pela necessidade de gerar dados que melhor se integrem para o processo de análise e de discussão teórica sobre os sujeitos participantes do estudo. Em razão da tese apresentar um levantamento de dados quantitativos, e após algumas leituras de artigos científicos sobre o tema, 
verifiquei que alguns autores âncoras entendem que o quantitativo e o qualitativo se complementam e podem ser utilizados conjuntamente na pesquisa em Ciências Humanas, possibilitando melhor compreensão sobre o objeto investigado, o que discuto a seguir. Todavia, esclareço que o meu propósito nesta pesquisa, também é trabalhar os eventuais conflitos entre o quantitativo e o qualitativo, o que será possível verificar na medida em que eu estiver analisando os dados, priorizando mostrar como todo sentido sobre o tema é construído pelos sujeitos em seus contextos históricos e situados.

A literatura brasileira segundo alguns autores como Minayo; Sanches (1993), Gamboa (1995), Gentil (2002), Turano (2015), Aguiar (2016), Souza; Kerbany (2017), Nascimento; Cavalcante (2018) carece de publicações científicas aprofundadas sobre a possibilidade de complementaridade entre abordagens quantitativa e qualitativa em pesquisa, tal fato por sua vez, contribui para reforçar um confronto entre essas abordagens. Para mais, Wooley (2008) enfatiza que a literatura pedagógica em português é bastante limitada sobre o tema, o que dificulta a efetiva compreensão e integração dessas abordagens.

Embora com nomeações diferentes como pesquisa quanti-qualitativa, qualiquantitativa, métodos mistos, métodos múltiplos, multimétodos e estudos triangulados (FLICK, 2004), o autor esclarece que, todas compartilham como propósito central a integração metodológica. Da mesma maneira, para situar o que significa trabalhar com método misto, Creswell afirma que:

Observe os desafios que essa forma de pesquisa coloca para 0 pesquisador. Estes incluem a necessidade de uma extensa coleta de dados, a natureza demorada de analisar ambos, textos e os dados numéricos, e a exigência de que o pesquisador esteja familiarizado com os dados quantitativos e formas qualitativas de pesquisa ${ }^{4}$. (CRESWELL, 2009, p. 40, tradução minha).

Em concordância com o autor, informo que essa forma de pesquisa, me propôs um grande desafio como profissional da área de humanas que, para tratar

4 Creswell $(2009$, p. 40$)$ "note the challenges this form of research poses for the inquirer. These include the need for extensive data collection, the time-intensive nature of analyzing both text and numeric data, and the requirement for the researcher to be familiar with both quantitative and qualitative forms of research" (Creswell, 2009, p. 40). 
das questões quantitativas da tese, fiz uma disciplina específica de Estatística Básica em um Programa de Pós-Graduação Stricto Sensu em Desenvolvimento Local na Universidade Católica Dom Bosco, bem como busquei orientações com alguns profissionais da área e li diversos artigos científicos para o melhor entendimento sobre a Ciência de dados e suas potencialidades para a pesquisa.

A priori de definir e apresentar as potencialidades da abordagem multimétodo (FLICK, 2004), é relevante revisitar a lógica contida nos métodos quantitativos e qualitativos. A Ciência Moderna proposta por Galileu (1623), segundo Turano $^{5}$ (2015), fez uma ruptura com os conhecimentos religiosos ao propor que fazer ciência é entender os fenômenos a partir deles mesmos, ou seja, o campo da ciência é a compreensão da natureza pela própria natureza, e não se constituem em conhecimentos construídos como alvo de uma relação humana e sobre-humana. 0 autor reforça que as Ciências Naturais têm aproximadamente 400 anos, enquanto as Ciências Humanas possuem quase 100 anos, são abordagens com tempos distintos, portanto com amadurecimentos diferentes, e ocupam na academia espaços diferenciados. O autor defende a complementaridade dos métodos quantitativos e qualitativos, uma vez que entende que essas abordagens são concebidas pelo sujeito, então são subjetivas.

A pesquisa quantitativa para Creswell (2012) tem a vantagem de trabalhar com números e indicadores que podem ser analisados com o auxílio da Estatística, exibindo informações úteis, rápidas e confiáveis a respeito de um número elevado de observações. Além disso, segundo o autor, quando se utiliza um questionário não só com questões de múltiplas escolhas, mas também discursivas, por exemplo, a própria resposta escrita pelos participantes que oferece diferentes representações sobre o tema, engloba os aspectos subjetivos do fenômeno.

Em conformidade com o autor, informo que utilizei um questionário com questões de múltiplas escolhas e discursivas (anexo 1). As primeiras tiveram como propósito obter informação objetiva que fosse suscetível de descrição e que adquiriram diferentes significados no curso da pesquisa por meio de sua relação

\footnotetext{
${ }^{5}$ Pesquisa quantitativa e qualitativa em saúde: cientificidade e peculiaridades. Aula ministrada pelo Prof. Dr. Egberto Ribeiro Turano, a convite do Programa de Pós-Graduação da Faculdade de odontologia de Piracicaba - UNICAMP, 2015.
} 
com outras informações, como, por exemplo, os aspectos relativos ao modo de vida, as preferências, renda familiar e formação, isto é, temas que podem ser descritos sobre o sujeito e que caracterizam aspectos objetivos e subjetivos de suas diversas atividades em contextos situados, formando parte de suas representações conscientes. As questões formuladas buscaram elementos da experiência que 0 sujeito pôde expressar de forma direta, assim sendo, o uso desse tipo de questionário esteve subordinado ao problema de pesquisa e aos seus objetivos, e as informações obtidas por este instrumento de geração de dados também pôde converter-se em indicadores de sentido subjetivo em outros contextos do desenvolvimento da própria pesquisa, conforme poderá ser visto na análise dos dados.

As questões discursivas do questionário foram direcionadas para facilitar a expressão ampla dos participantes da pesquisa, e orientadas para as construções do sujeito ao redor do tema tratado, bem como buscaram atender diferentes aspectos de informação que se completaram entre si, e que permitiram uma representação abrangente do que se pretendeu conhecer por meio do questionário.

Ainda sobre a pesquisa quantitativa, André (2002, p. 240) reitera que "o uso do termo pesquisa quantitativa para identificar uma pesquisa positivista de ciência parece-me no mínimo reducionista. Associar quantificação com positivismo é perder de vista que quantidade e qualidade estão intimamente relacionadas". A autora explica que o termo qualitativo para identificar uma perspectiva de conhecimento foi relevante como princípio de ampliação a uma visão estagnada do positivismo, mas esse emprego não pode ser reduzido ao estereótipo de oposição, pois há a indispensabilidade, no momento atual, de ir além da falsa dicotomia de quantitativoqualitativo.

Em assentimento a André (2002), a pesquisa qualitativa segundo González Rey (2005) emergiu como meio de romper com o ponto de vista estreito e opressivo do positivismo, entretanto, o autor reforça que nem sempre se tem confrontado com a necessidade de desenvolver uma fundamentação epistemológica sólida e que os problemas surgem quando os pesquisadores aderem à pesquisa qualitativa sem consciência epistemológica, por esse motivo, dediquei-me no texto anterior, a discorrer sobre qual base epistemológica fundamenta o processo de análise dos dados gerados por este estudo. Para mais, a epistemologia qualitativa defende o 
caráter construtivo e interpretativo do conhecimento, o que de fato implica compreender o conhecimento como produção e não como apropriação linear de uma realidade que se apresenta.

A seguir busco exemplificar algumas situações em que a combinação das abordagens quantitativa e qualitativa é analiticamente desejável, o que pode favorecer um desenho de pesquisa mais robusto. Para isso, discuto um exemplo do cotidiano, um paradigma de uma dor lombar para ilustrar como é possível integrar essas abordagens.

Imaginemos três pessoas diferentes que acordam em um determinado dia, com uma mesma dor lombar, vamos nomeá-las de pacientes A, B e C.

Paciente A: - Preciso ir ao médico com urgência, pois estou com uma dor lombar muito forte. Dor é perigoso! Tenho medo de morrer! Também não vou conseguir trabalhar, porque ninguém consegue trabalhar com tanta dor.

Paciente B: - Eu sou da família Pereira e o meu pai já dizia que os "Pereira" são fortes, não há dor que nos derrubem. Então, eu vou trabalhar normalmente, mesmo com essa dor lombar. Vou tomar um analgésico e, se eu piorar, aí vou procurar um médico.

Paciente C: - Misericórdia! Amanheci com essa dor lombar insuportável. Minha tia começou com uma dor dessas e acabou morrendo depois. Tenho medo, porque na minha família todo mundo morre cedo.

Nos exemplos acima, é possível perceber a mesma dor lombar representada de maneiras diferentes. Isto mostra o caráter simbólico de como se comportam os humanos em contextos socioemocionais e socioculturais, nos quais é possível observar perspectivas distintas para um mesmo fenômeno, isso é a subjetividade, a representação mental que somente o ser humano consegue e faz sobre determinada ocorrência. Quando perguntamos: O que essa dor representa para a pessoa? Em que essa dor interfere no seu dia a dia? Como ela se organiza a partir da ocorrência dessa dor? Tais questionamentos exemplificam como se desenvolve uma pesquisa de natureza qualitativa.

Suponhamos agora que os três pacientes A, B e C tenham ido ao médico. Chegando ao consultório, o médico faz uma série de perguntas buscando identificar possíveis causas da dor para, então, pensar em hipóteses diagnósticas. Após ouvir os relatos da dor dos pacientes, o médico pede exames como uma radiografia ou 
ressonância para confirmar o diagnóstico. Após essa confirmação, em conjunto com o que ele apurou sobre o paciente anteriormente, mediante suas descrições sobre a dor e os resultados dos exames, ele então, propõe o tratamento que poderá ser feito por meio de medicamentos e/ou terapias (por meios farmacológicos ou não farmacológicos, fisioterapia e psicoterapia). 0 médico diz ao paciente que se ele fizer tudo conforme o prescrito, as chances de curar a dor lombar será de $90 \%$. Logo, temos no procedimento do médico uma questão subjetiva/objetiva (a descrição da dor do paciente, e quando o médico tenta interpretar a parte subjetiva do paciente e transformá-la em algo objetivo para facilitar o seu raciocínio e a comunicação com outros profissionais), e três outras objetivas (exames, tratamentos e chances de cura), isso mostra que a junção de métodos qualitativo e quantitativo se relacionam e se complementam para um melhor entendimento e interpretação da doença.

Para além disso, conhecer o ser humano tem um sentido que transcende o natural, ou seja, se o médico não souber o simbólico da dor da pessoa (atendimento holístico), ele não consegue se comunicar com o paciente e passar de maneira correta o diagnóstico e, com isso, aumentar a aderência dele ao tratamento e as terapias (envolve confiança). A questão: Como dói? É de natureza qualitativa. Enquanto: Quanto dói? Desde quando dói? De onde vem essa dor? Qual o tratamento? Qual a dosagem de medicamento? Por quanto tempo devo usar o medicamento? São de natureza quantitativa, e para respondê-las, o médico precisa ter vários conhecimentos das Ciências Naturais para explicar a dor (subjetividade/ objetividade), e prescrever um tratamento (objetividade/subjetividade). Outra questão importante é que, nessas situações, o médico já diz como a pessoa vai evoluir do ponto de vista da natureza, pois ele trabalha com experimento e previsibilidade, isso significa que ele, ao prescrever o tratamento, faz uma intervenção no paciente e, ao mesmo tempo, consegue prever os resultados do tratamento, pois já atendeu outros casos semelhantes e se baseou em estudos quantitativos que permitem generalizações, mesmo assim, não há garantia de $100 \%$ de acerto, pois pode haver engano/erro, ou mesmo depender de como reage o(a) paciente.

Outro exemplo que posso citar e que aconteceu comigo recentemente, quando tive que fazer uma cirurgia e soube que seria feita com anestesia geral. 
Fiquei com muito medo porque realmente já tinha ouvido casos em que algumas pessoas morreram em razão da anestesia e não da cirurgia em si (subjetividade). Conversei bastante com o meu médico e ele me orientou para fazer uma consulta com o anestesista e tirar todas as minhas dúvidas para me sentir mais segura. $\mathrm{Na}$ consulta com o médico anestesista, ele me examinou, viu meus exames préoperatórios e disse que eu estava apta para fazer o procedimento com a anestesia geral. Ele ainda me esclareceu todos os detalhes sobre o processo e me mostrou dados estatísticos que comprovam a segurança desse tipo de anestesia (objetividade). Confesso que fiquei bem mais tranquila, houve um processo de desconstrução do simbólico que eu tinha sobre o medo da anestesia geral.

Todavia, o médico comentou comigo que há um índice significativo de pacientes que não por causa da anestesia desistem de fazer um procedimento cirúrgico, mas porque quando chegam no centro cirúrgico e veem aquele ambiente não familiar, com muitos aparelhos, luzes, odor de medicamentos, pessoas vestidas com toca, máscara, avental e luvas, entram em pânico e desistem de fazer a cirurgia pela ambiência do local, ou seja, o que para o médico é um ambiente de trabalho, na representação de algumas pessoas, esse ambiente pode se relacionar com a morte (subjetividade). Conquanto, o médico me disse que quando na consulta ele percebe que o paciente pode reagir dessa maneira, ele aplica um sedativo ainda no leito e leva o paciente para o centro cirúrgico já desacordado. Foi o que aconteceu comigo. Em outras palavras, o médico mesmo sabendo quais e o quanto de drogas faria uso para anestesia (objetividade), na consulta, por meio de uma conversa comigo (subjetividade), observou que eu seria uma candidata com tendência a desistir da cirurgia, caso fosse para o centro cirúrgico ainda consciente.

Esses exemplos mostram que objetividade pura não existe, a diferença é que as Ciências Naturais trabalham com o experimento e as generalizações são feitas a priori, ou seja, antes de ocorrer outros casos, o médico já faz uma previsibilidade de como os pacientes vão evoluir do ponto de vista da natureza. Para tanto, ele usa conhecimentos estabelecidos anteriormente para tratar o paciente por meio da abordagem matematizada de dosagem de medicamentos e por quanto tempo utilizá-los, fazendo uma intervenção no paciente, em uma relação de subjetividade com a objetividade, mesmo essa relação sendo matemática.

Já a subjetividade parte do princípio de que os resultados obedecem a lógica 
da multiplicidade de sentidos e simbolizações, na qual há diferentes perspectivas para um mesmo fenômeno, o que não seja passível de construir um discurso teórico, o que não significa que não seja científico. Para mais, constrói conceitos a posteriori, por exemplo, quando estou fazendo observações de uma pessoa que mostra uma dinâmica semelhante a daquela que outros colegas investigaram, porque li os trabalhos científicos, e isso me lança luz para eu entender o objeto pesquisado. A vantagem é que se há uma relação nova, é possível entender a dinâmica e as semelhanças entre os objetos investigados $e$ isso facilita 0 processo de interpretação. Outra questão, é a busca pela experiência (o vivido) de quem está sendo investigado e de como o pesquisador entende a manifestação de algo, ou melhor, como o pesquisador faz a interpretação dos fenômenos em termos dos significados que as pessoas a eles conferem (DENZIN; LINCOLN, 2006). Para mais, é um ser humano estudando outro, portanto, o que está em jogo é o conceito e não a objetividade e, isso é próprio do ser humano, a capacidade de simbolizar e de dar um sentido que transcende a natureza.

Nessa lógica, utilizar os métodos qualitativos nos pacientes descritos pôde permitir ao médico não só entender a dor e a doença como um todo e o que isso representa ao paciente, mas também fazer com que ele explique isso ao enfermo de maneira que o paciente $A$, por exemplo, não continue pensando que irá morrer e, assim, faça a adesão ao tratamento. No paciente $B$, a análise da questão subjetiva de uma pessoa que interpreta a dor como algo a ser superado sem medicamentos, pode fazer com que ela não tome medicamentos de maneira adequada e não faça os tratamentos alternativos que trariam melhora na sua qualidade de vida. No paciente $C$, a questão genética é objetiva, mas pode trazer questões subjetivas que o faz ter preocupações maiores que a necessária. Essas preocupações se não atendidas, podem alterar o curso do tratamento.

Os exemplos citados mostram que não há hierarquias entre procedimentos quantitativos e qualitativos, pois se prestam a funções diferentes, podendo ser complementares. A ideia de complementaridade dessas pesquisas, também é preconizada por Minayo e Sanches (1993, p. 247): 
A relação entre quantitativo e qualitativo, entre objetividade e subjetividade não se reduz a um continuum, ela não pode ser pensada como oposição contraditória. Pelo contrário, é de desejar que as relações sociais possam ser analisadas em seus aspectos mais ecológicos e concretos e aprofundadas em seus significados mais essenciais. Assim, o estudo quantitativo pode gerar questões para serem aprofundadas qualitativamente.

Para os autores, quantidade e qualidade não estão dissociadas na pesquisa, uma vez que a quantidade é conferida a grandeza do fenômeno que precisa ser interpretado qualitativamente, pois sem relação a algum referencial não pode ter significação em si. Esclareço que na tese, os dados quantitativos não são apresentados de maneira isolada, todos estão acompanhados dos discursos dos participantes da pesquisa, em razão do estudo quantitativo ter gerado questões que foram aprofundadas qualitativamente, dando consistência aos resultados da pesquisa, uma vez que a interação entre quantitativo e qualitativo pode propiciar melhores possibilidades analíticas. E ainda, sendo a realidade multifacetada, Thiollent (1984) reforça que não é superficial afirmar que dados gerados por métodos distintos podem ser agregados com o propósito de compreensão das várias faces da realidade, pois o fato social possui elementos que podemos descrever em termos quantitativos e qualitativos.

Entendo como Santos Filho (1995) que as abordagens qualitativas e quantitativas de pesquisa são igualmente legítimas. No campo filosófico atento a esta questão, Gramsci (1995, p. 50) argumenta:

\footnotetext{
Afirmar, portanto, que se quer trabalhar sobre a quantidade, que se quer desenvolver o aspecto "corpóreo" do real, não significa que se pretenda esquecer a "qualidade", mas, ao contrário, que se deseja colocar o problema qualitativo da maneira mais concreta e realista, isto é, deseja-se desenvolver a qualidade pelo único modo do qual tal desenvolvimento é controlável e mensurável.
}

O autor alerta que as abordagens quantitativas e qualitativas tratam de fenômenos reais e atribui sentido concreto aos seus dados. Objetivando sistematizar a utilização de pesquisa quanti-qualitativa, Creswell e Clark (2007) definem que essa integração pode se efetivar mediante três formas: por convergência, na sua fusão do quantitativo e qualitativo durante a fase de interpretação ou análise dos dados; por conexão, no qual a análise de um tipo de dado demanda um segundo tipo de dado; e por acoplamento que, por sua vez, resulta da introdução de um tipo tanto em um 
desenho, quanto em dados de outro tipo. Os autores salientam que a utilização concomitante dos métodos quantitativos e qualitativos proporciona mais credibilidade e legitimidade aos resultados encontrados, evitando o reducionismo a apenas uma opção.

Dessa maneira, para o pesquisador, não faz nenhum sentido desprezar o lado da quantidade, desde que bem feito. Em vez disso, segundo Demo (2002, p.35) "só tem a ganhar a avaliação qualitativa que souber se cercar inteligentemente de base empírica, mesmo porque qualidade não é a contradição lógica da quantidade, mas a face contrária da mesma moeda". Com efeito, é primordial que a escolha da abordagem esteja a serviço da pesquisa, portanto, há um consenso, segundo Laville; Dione (1999), quanto à ideia de que as abordagens qualitativas e quantitativas devem ser entendidas como complementares, em vez de mutuamente concorrentes.

Em meu percurso como pesquisadora, percebo que há uma lacuna significativa acerca da combinação dos métodos de pesquisa quantitativos e qualitativos, pois nunca vi uma oferta de disciplina nos cursos de Graduação ou PósGraduação nos quais estudei que abordasse, conjuntamente, os temas. Analiso que nesse sentido, também é necessário uma reestruturação dos currículos de Graduação e Pós-Graduação em oportunizar de maneira regular e intensiva, uma disciplina específica de como integrar ambas as abordagens, o que muito contribuiria para o melhor desenvolvimento das pesquisas, pois penso ser de suma importância o fortalecimento do debate acerca dos limites, desafios e potencialidades das abordagens quantitativas e qualitativas nas pesquisas que, no momento atual, podem suscitar reflexões relevantes acerca do tema.

Feitas as considerações, e entendendo as potencialidades $e$ as peculiaridades que essas abordagens podem oferecer, justifico a minha opção em trabalhar com o multimétodo nesta tese

\section{Rizoma da Introdução}

Antes de findar a Introdução, apresento a imagem de inspiração rizomática com base nos preceitos de Deleuze e Guattari (2011), a qual representa uma análise de similitudes textuais dos assuntos discutidos nesta seção. Importante esclarecer 
que as palavras estão conectadas umas as outras, por efeito de um movimento de pensamento rizomático, bem como as palavras estão nos círculos, retratando as que aparecem com maior frequência no texto, por isso, o tamanho dos círculos são variáveis, ou seja, quanto maior a frequência da palavra, maior o círculo que a representa. As diferentes cores não interferem nessa representação, elas apenas ilustram o rizoma.

Para produzir a imagem, foi utilizado o IRAMUTEQ, que é um software gratuito e com fonte aberta, desenvolvido por Pierre Ratinaud (Lahlou, 2012; Ratinaud \& Marchand, 2012), que permite fazer análises estatísticas sobre corpus textuais e sobre tabelas indivíduos/palavras. O software realiza a mineração de dados em textos, permitindo a obtenção de várias análises quantitativas dos corpos linguísticos como estatísticas textuais clássicas (contagem de palavras), pesquisa de especificidades de grupos, classificação descendente, análise de similitudes e nuvem de palavras.

A ideia de utilizar essa ferramenta para representar um rizoma, se deve às proveitosas e desafiadoras aulas do Curso de Estatística Básica do Programa de Pós-Graduação Stricto Sensu em Desenvolvimento Local, que fiz como ouvinte na Universidade Católica Dom Bosco - UCDB, com o objetivo de ampliar meus conhecimentos sobre essa Ciência que precisava compreender melhor para tratar das questões estatísticas presentes na tese. 
Imagem 3: Rizoma da Introdução

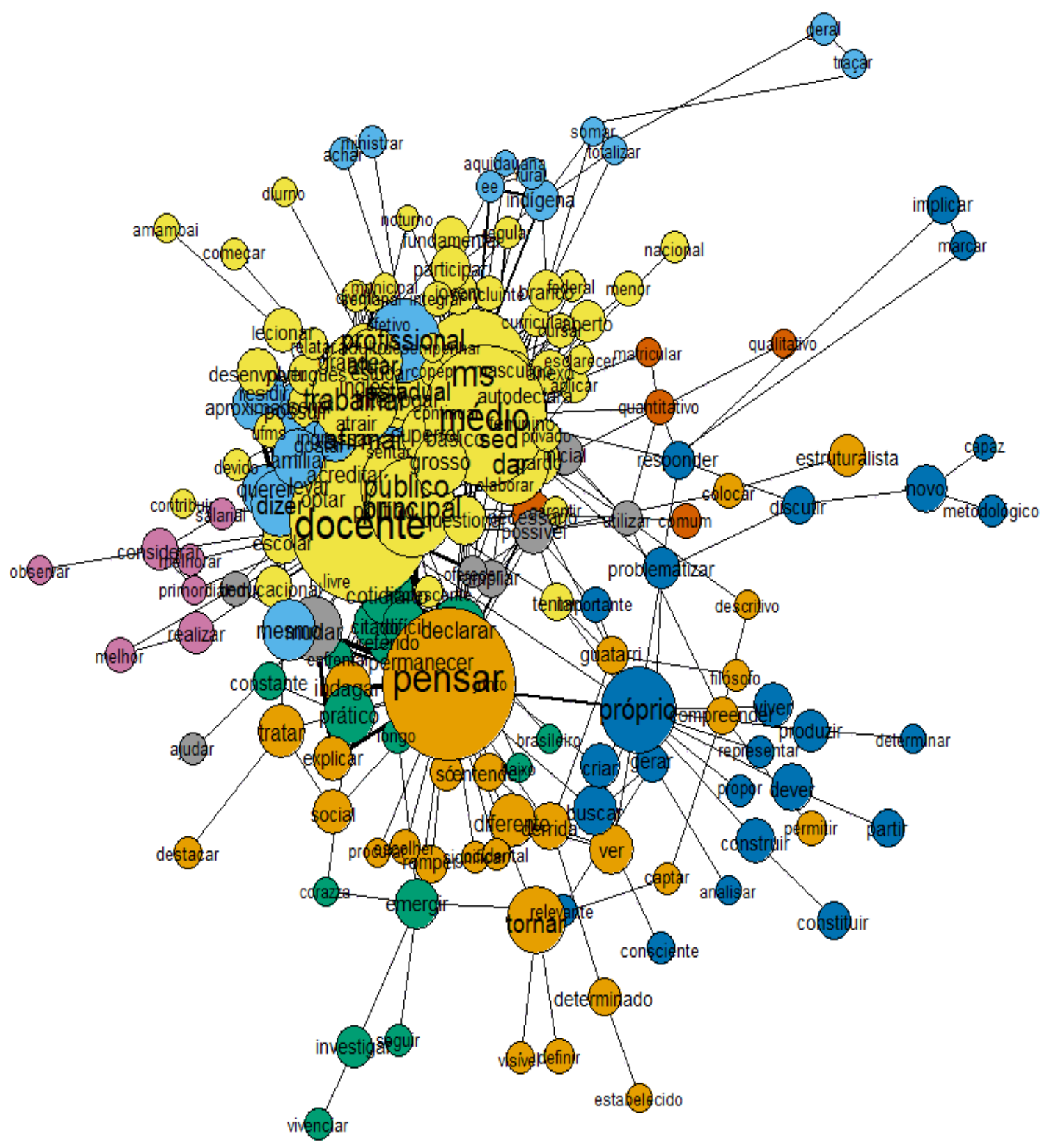

Fonte: Própria (2020)

No capítulo I, apresento uma descrição detalhada do campo investigado, por meio da articulação das respostas dos alunos extraídas no questionário de pesquisa, as experiências vividas pelos sujeitos e o contexto situado dessas experiências, bem como trago as discussões e problematizações realizadas pelo Grupo de Discussão e a pesquisadora a respeito das argumentações desses alunos, vinculadas aos autores que debatem o tema. 


\title{
CAPÍTULO I
}

\section{CONHECENDO O CAMPO INVESTIGATIVO: A GARRAFA LANÇADA AO MAR}

\begin{abstract}
Ponho estes seis versos em minha garrafa ao mar com o designo secreto de que algum dia chegue a uma praia quase deserta e uma criança a encontre e a destampe e no lugar de versos extraia pedrinhas e socorros e alertas e caracóis.
\end{abstract}

Mario Benedetti

Lançada ao mar pelo navio alemão Paula há 132 anos, a mais antiga garrafa com uma mensagem que se conhece no mundo dizia:

\begin{abstract}
Esta garrafa foi jogada em 12 de junho de 1886 a latitude de $32^{\circ} 49^{\prime}$ e longitude $105^{\circ} 25^{\prime}$ a oeste de Greenwich. Capitão: D [ilegível], na viagem de Cardiff a Macassar. Àquele que encontrar é solicitado que envie a nota na garrafa ao Observatório Naval alemão em Hamburgo ou ao consulado mais próximo para retorno à mesma agência depois de preencher as informações na parte de trás.
\end{abstract}

Despretensiosamente, uma família de Perth, na Austrália, enquanto caminhava pelas dunas de uma praia isolada, encontrou uma garrafa com um papel dentro, levaram-na para casa e secaram-na no forno, a princípio para fazê-la de objeto decorativo. Todavia, ao abrirem a garrafa, perceberam que havia um texto escrito à mão, pedindo ao leitor que entrasse em contato com o consulado alemão. Então, eles resolveram levá-la ao especialista do Western Australian Museum, Ross Anderson que confirmou que o achado era autêntico. Uma pesquisa de arquivo na Alemanha encontrou o Diário Meteorológico original do navio Paula e havia uma anotação feita pelo capitão, registrando que a garrafa foi lançada ao mar no sudeste do oceano Índico e, provavelmente, chegou à costa australiana 12 meses depois, onde ficou enterrada sob a areia.

Houve um tempo que, quando um navio estava em situação de perigo pelos oceanos do mundo, o capitão, em ato de desespero e sobrevivência, confiava a uma garrafa, a missão de levar uma mensagem de socorro no seu interior, para que 
alguém pudesse encontrá-la. Essa garrafa lançada ao mar carregava toda a esperança da tripulação, para mais, não se sabia a quantidade de dificuldades que a garrafa passava até chegar onde deveria - sem ter sua mensagem destruída, corrompida, deturpada, traída ou desviada, quiçá se sabia se chegava ao destino pretendido.

Essa narrativa, em aproximação com a escrita deste texto, me faz pensar que tenho uma mensagem na garrafa que quero transmitir para outras pessoas, apesar das dificuldades, do tempo, dos caminhos percorridos, quero que chegue ao seu destino - ao leitor, e este, de posse desta "garrafa", se desafie a abri-la e seja afetado pelo seu conteúdo, e possa também escrever sua própria mensagem, seu texto, sua ideia, seu desejo e lançar sua garrafa ao mar.

Neste capítulo, apresento e problematizo as questões que informam sobre a constituição familiar, a formação dos pais ou responsáveis, a renda familiar, o processo de escolarização e a intenção profissional pretendida dos alunos participantes da pesquisa. O propósito é mapear detalhadamente as questões supracitadas que são relevantes e subsidiam o processo analítico para a compreensão de outros assuntos que serão abordados mais adiante.

Feitas as considerações, o processo de problematização se desenvolve a partir das respostas dos alunos ao questionário de pesquisa, e das discussões realizadas pelo Grupo de Discussão e a pesquisadora, a respeito das argumentações desses estudantes, igualmente refletidas por meio de referencial teórico, cuja diretriz é o plano de imanência (DELEUZE; GUATTARI, 1995), ou seja, a própria vida cotidiana, sua contingência e o seu contexto situado. Nessa composição, considero as diferentes linhas que formam e deformam permanentemente o que é possível compreender, interpretar, problematizar, que em consonância com os objetivos da pesquisa, produzem um mapa "desmontável, conectável, reversível, modificável, com múltiplas entradas e saídas, com suas linhas de fuga" (DELEUZE; GUATTARI, 1995, p. 32), perfazendo uma trama complexa, capaz de afecção.

É imperioso ressaltar que o processo de problematização proposto, refere-se a uma leitura que opta por conceder ao leitor a possibilidade de acessar outros conhecimentos e experiências sobre o tema, passível de ser reconstruído e reinterpretado conforme as contingências, ou seja, uma leitura aberta e envolvente, 
resultante de um processo analítico da ordem da afecção, não à constatação de uma determinada certeza. Trata-se, portanto, de formas diversas de habitar o texto, possibilitando ao leitor erigir práticas de pensamento próprias. Decorre disso, o descerramento de um espaço de experimentação, uma paixão pelo pensar, uma busca constante pela multiplicidade e por um pensamento singular e ativo.

Sigo então a construção dessa trama, e reforço que o leitor tem um papel importante nesse processo, pois dele é que deverá emergir o impensável e o aberrante, uma vez que o texto é tomado como um afecto, cujo intento não é o convencimento ou a explicação das coisas, mas a produção de um devir naquele que o encontra. Portanto, traçar uma problematização implica um exercício crítico do pensamento, bem como a renúncia à pretensão de solucionar um problema, ao invés disso, me esforço em redescobrir os problemas que animam os acontecimentos que emergem.

\section{A constituição familiar dos participantes da pesquisa e o desafio da segurança alimentar}

Para melhor problematizar a questão da constituição familiar e o desafio da segurança alimentar, inicialmente, examino o quantitativo de pessoas que residem na mesma casa. De acordo com os dados gerados, a maior parte (65\%) dos participantes da pesquisa, pertence a uma família que se constitui por quatro ou mais de quatro pessoas. De acordo com dados do Instituto Brasileiro de Geografia e Estatística - IBGE (2010), a família brasileira vem se remodelando, o índice de casais sem filhos aumentou e existem cada vez mais famílias não tradicionais. A quantidade de mulheres que são chefes de família também se elevou e ainda, o número de filhos por mulher vem caindo no Brasil. No ano de 2010, a média foi de dois filhos por mulher, isso não quer dizer que todas as mulheres tenham menos de dois filhos, mas ao calcular o número de mulheres e o de nascimentos, foi possível verificar uma média de cada filho por mulher.

Para os participantes do Grupo de Discussão - em razão de suas vivências no contexto escolar - o quantitativo de pessoas que residem na mesma casa espelha uma estrutura de constituição familiar diferente da nuclear (pai, mãe e filhos), mostrando que esta formação ganha espaço para outras, na qual, muitas 
vezes, a mãe e os avós são arrimos de família, conforme citam os professores 7, 8, 3 e 2.

P7: Quatro ou mais de quatro pessoas, a gente pensa que pode ser a mãe e três filhos, ou alguém além disso, como avó, avô, tio etc. Hoje é muito comum famílias que se agrupam como podem, no mesmo terreno, na mesma casa, todo mundo junto.

P8: Muitos não conseguem manter uma casa e acabam voltando a morar com os pais. Hoje é muito comum ver os filhos adultos e os netos dependentes da aposentadoria dos avós.

P3: E às vezes é a mãe que cria, é uma realidade, porque o pai abandona, a mãe fica sozinha, às vezes não conhece o pai. E aí na ficha dele estava escrito assim, que eu faço a ficha: "Mãe tem, o pai não conheço e nunca vi, não tem referência".

P2: Eu ia tocar nesse assunto, na Educação Básica de modo geral, quando entra nesse assunto de gênero, a gente acaba chegando nesse assunto, e eu faço rápido e peço para levantar a mão quem mora só com o pai, depois com a mãe e o pai, e quando você fala quem mora só com a mãe, é uma chuva.

Analiso que em nossa sociedade é possível verificar as mudanças ocorridas na estrutura familiar, Bauman (2010) desenvolveu o conceito de "modernidade líquida", e é assim que ele se refere ao momento da História em que vivemos. Os tempos são "líquidos" porque tudo muda rapidamente. Nada é feito para durar, para ser "sólido". Disso resultaria, entre outras questões, a instabilidade dos relacionamentos amorosos, a exemplo do surgimento de famílias matriarcais, ou seja, mães solo que criam seus filhos sozinhas. Entretando também, há casais homoafetivos que adotam filhos legalmente, casamentos consecutivos com companheiros diferentes e filhos de outras uniões, entre outros. Fatores políticos, econômicos e sociais, a considerar, como a substituição da sociedade de base rural, na qual prevalecia a família paternalista marcada pela centralização e submissão dos membros da família à figura do pai, para a sociedade de base industrial na qual as mulheres começam a participar do orçamento do lar com trabalho remunerado, indo além do trabalho doméstico, ocasionou alterações acentuadas na estrutura do modelo familiar, e hoje, vivemos um período de liquidez dos laços familiares e humanos.

Por meio de um exame minucioso sobre a fragilidade dos laços humanos, Bauman (2004), nos convida a refletir que a pós-modernidade que consolida a lógica do consumo do capitalismo moderno, em busca da incessante satisfação das 
necessidades, caracteriza a ordenação individualista da sociedade e modifica a estrutura familiar.

Objetos de consumo servem a necessidades, desejos ou impulsos do consumidor. Assim também são os filhos. Eles não são desejados pelas alegrias do prazer paternal ou maternal que se espera que proporcionem alegrias de uma espécie que nenhum objeto de consumo, por mais engenhoso e sofisiticado que seja, pode proporcionar. (BAUMAN, 2004, p. 59).

Premente a afirmação do autor, analiso que a própria constituição da família vai se desvinculando das tradições e se torna também uma escolha, como a opção de ter ou não filhos. Contudo, o referido pensador nos alerta que "um filho é, acima de tudo, um ato de consumo emocional”. (BAUMAN, 2004, p. 59). A questão essencial do tema "filhos", e que diverge da essência da pós-modernidade, na qual tudo é passageiro, dinâmico e fulgas, é que o filho não possui caráter temporário.

Adiante, outro assunto iminente que merece destaque, se refere a insegurança alimentar dos alunos e seus reflexos:

P5: Muitas vezes essas mães que criaram os filhos sozinhas, só
conseguem fazer "bico", ou arrumar no máximo um emprego de diarista, e
ela acaba não conseguindo sustentar a família e leva os alunos para a
escola para eles terem onde ficar e também para poder se alimentarem, os
alunos sabem disso e comem o máximo que podem na escola.

P6: Verdade. Alguns alunos pedem para que os outros colegas que não querem lanchar, peguem o lanche para eles comerem, pois se solidarizam com o colega. Fico pensando no período de férias, como eles fazem para se alimentarem?

P1: Tem outra questão também que é a da higiene, a situação é tão precária que, as vezes, eles não têm condições de comprar itens básico de higiene como sabonete e pasta de dente. Eles não têm dinheiro nem para comprar remédio e muito menos para comprar roupas, isso acaba com a autoestima da criança que tem vergonha de ir para a escola nessas condições e vai se considerando inferior aos outros. Muito triste mesmo!

Em relação aos recortes $\mathrm{P} 5, \mathrm{P} 6$ e $\mathrm{P} 1$, rememoro o tempo que estive como professora em sala de aula na Educação Básica. Na escola em que estava lotada, em região periférica, de comunidade bastante carente e desassistida, os alunos da Educação Infantil, por exemplo, precisavam lanchar antes de iniciar as aulas, uma vez que uma parcela significativa deles não conseguia se concentrar e desenvolver as atividades sem se alimentarem antes. Outro fator que pode interferir no 
desempenho dos alunos são as questões de higiene pessoal, também elencadas, uma vez que alguns alunos chegam à escola, muitas vezes, com o mesmo uniforme dos dias anteriores, sem terem sidos lavados e, ainda, alguns dormem com 0 uniforme e chegam a fazer xixi nele e vem no outro dia para a escola. Percebia que os alunos nessas condições, muitas vezes se sentiam incomodados, desanimados e com vergonha dos colegas e professores. Não posso afirmar os motivos pelos quais eles assim se encontravam, mas sei que muitas famílias realmente não têm condições mínimas de comprar itens de higiene e medicamentos, pois a necessidade do alimento é urgente, não dá para esperar.

Uma recente reportagem da British Broadcasting Corporation (BBC NEWS) no Brasil (2019) destaca que há estimativas de que até 9 milhões de crianças vivem em situação de extrema pobreza em nosso país. O artigo nomeado "Sem merenda: quando férias escolares significam fome no Brasil", discute que muitas crianças têm a segurança alimentar ameaçada durante o recesso escolar, segundo relatos de pais, professores, gestores e especialistas, e com as férias escolares, as crianças deixam de ter acesso diário a merenda, fator que intensifica a vulnerabilidade social de muitas famílias e, nesse período sem aulas, é que a fome se torna uma atemorização a ser enfrentada. Em razão da epidemia do coronavírus, nos municípios do Estado de MS, as prefeituras, diante dessa realidade, fizeram cestas básicas de merenda escolar e distribuíram para os alunos de escolas públicas com maior vulnerabilidade.

$\mathrm{Na}$ contramão dessa realidade, o atual presidente da república afirmou na manhã do dia 19 de julho de 2019, "Ser uma grande mentira" dizer que as pessoas passam fome no país: "Falar que se passa fome no Brasil é uma grande mentira. Passa-se mal, não come bem. Aí eu concordo. Agora, passar fome, não. Você não vê gente mesmo pobre pelas ruas com físico esquelético como a gente vê em outros países" (Bolsonaro, 2019, em pronunciamento a Gazeta do Povo). Com vistas a esse "achismo" do presidente, a mais recente pesquisa sobre segurança alimentar do IBGE (2013) registrou que uma em cada cinco famílias brasileiras tinha restrições alimentares ou a preocupação com a possibilidade de não ter dinheiro para comprar comida. Segundo informações do Ministério da Saúde, ao todo, 5.653 pessoas morreram de desnutrição em 2017. Outrora, o Mapeamento da Insegurança Alimentar e Nutricional (Mapa InSAN, 2018) apontou que 427.551 crianças com 
menos de cinco anos atendidas pelo Bolsa Família tinham algum grau de desnutrição. As com altíssimo grau de desnutrição somaram 44.462 e com desnutrição alta 102.947. A valer, analiso que esses dados indicam que, de fato, não há como negar que parte das crianças em nossas escolas, frequenta as aulas também, ou especialmente, para se alimentarem.

\section{A formação dos pais ou responsáveis e a renda familiar podem influenciar nas escolhas profissionais dos alunos participantes da pesquisa?}

Com o propósito de investigar se a formação dos pais e a renda familiar podem influenciar nas escolhas profissionais dos alunos participantes da pesquisa, problematizo a questão por meio do cruzamento e da análise dos dados gerados sobre o grau de escolaridade dos pais ou responsáveis, bem como sobre a renda familiar e o quantitativo de pessoas que residem na mesma casa.

Inicio essa discussão mostrando o nível de instrução dos pais ou responsáveis dos participantes da pesquisa, e faço uma análise comparativa em relação ao grau de escolaridade entre eles.

Infográfico 9: Grau de escolaridade do pai ou responsável

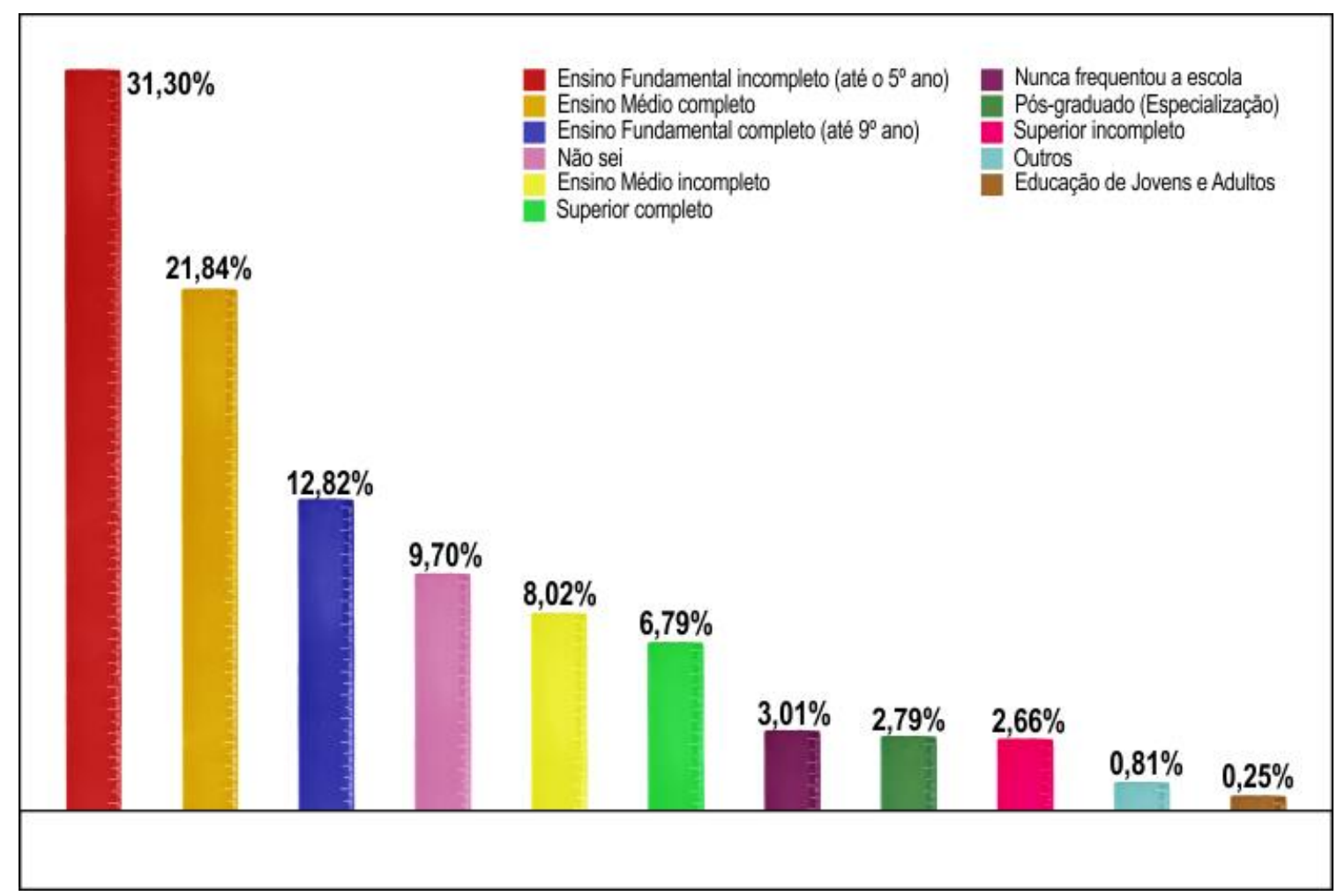

Fonte: Própria (2018) 
Em corroboração ao infográfico, os dados mostram que o grau de escolaridade do pai ou responsável que predomina, refere-se ao Ensino Fundamental incompleto (até o $5^{\circ}$ ano), com a soma de $31,30 \%$. Na sucessão, estão os que possuem o Ensino Médio completo com o total de 21,84\%. O Fundamental completo (até 9 ano) corresponde à quantia de 12,82\%. 9,70\% não sabem afirmar qual o grau de escolaridade do pai ou responsável. Já os que possuem ensino médio incompleto, somam 8,02\%. O nível de escolaridade Superior completo reúne a quantidade de $6,79 \%$ e o Superior incompleto de $2,66 \%$. Os que nunca frequentaram a escola participam na proporção de 3,01\%. Os que possuem Pósgraduação lato sensu totalizam $2,79 \%$. 0,81\% são os que responderam "outros", ou seja, o grau de escolaridade do pai ou responsável não contempla nenhum item descrito e os que frequentaram a Educação de Jovens e Adultos integram o montante de $0,25 \%$.

Para os participantes do Grupo de Discussão, o baixo grau de escolaridade do pai ou responsável está atrelado ao fator de ter como prioridade a sobrevivência. Às vezes, a pessoa quer fazer ou inicia uma faculdade, mas quando não consegue conciliar com o trabalho, acaba sendo obrigado a optar por sua subsistência e de sua família, conforme exibe o recorte do professor 9.

P9: E mais uma característica que eu consigo fazer uma ligação, justamente
quando você coloca a questão de perfil socioeconômico do pai e porque
muitas vezes ele não alcança o nível superior, isso tem uma influência muito
grande nas escolhas, o ser humano tem essa tendência a priorizar as
coisas, e nós ainda temos a questão de que a sobrevivência é uma
prioridade, então às vezes ele vai trabalhar porque ele precisa sobreviver, e
o estudo fica em segundo plano. [...] E você vê uma relação da formação do
pai e da mãe com a questão da renda, isso é muito nítido, com o grau de
instrução e o quanto eu consigo agregar valor a isso no meu dia a dia, como
que a questão da educação influencia diretamente na questão familiar,
principalmente na renda, e no que essas pessoas vão tendo acesso,
realmente ela mostra essa discrepância salarial, e a gente vê que a grande
maioria vai viver em uma faixa muito baixa do que a gente pode dizer de
qualidade de vida.

Em conformidade com a observação feita por P9, o fato de muitos pais priorizarem a questão da sobrevivência e, por consequência, abandonarem os estudos, foi uma situação possível de verificar nos dados gerados pela pesquisa, em que a maior parte dos pais estudou até o Ensino Fundamental incompleto (até o 5응 ano), com a soma de $31,30 \%$. Seguidos dos que possuem o Ensino Médio completo 
com o total de $21,84 \%$ e o Fundamental completo (até $9^{\circ}$ ano) corresponde ao índice de $12,82 \%$.

Há um outro estudo de campo que considero complementar ao que apresento neste trabalho. No ano de 2014, sob o título de "Um estudo com jovens: transição do Ensino Médio ao Ensino Superior", dos autores Zluhan e Raitz, pesquisa realizada com 438 estudantes do Ensino Médio de uma escola pública em Balneário Camboriú - SC apurou que 17\% dos 438 pais dos alunos participantes da pesquisa possuem o Ensino Fundamental completo, 24,5\% possuem o Ensino Médio completo, 9\% o Ensino Superior completo, 26\% não concluíram o Ensino Fundamental e 12,5\% não concluíram o Ensino Médio. A investigação concluiu que, esses pais, se viram obrigados, desde muito cedo, a ingressar no mercado de trabalho para compor a renda familiar, o que comprometeu a continuação de seus estudos. Analiso que esse mesmo fato, provavelmente pode ter ocorrido com os pais ou responsáveis dos participantes desta pesquisa, pois em comparação com os dados gerados por esta investigação, que apurou que os pais ou responsáveis que possuem o Ensino Fundamental incompleto somam $31,30 \%$, este percentual é relativamente próximo aos dados apresentados por Zluhan e Raitz (2014), que inferiu que $26 \%$ dos pais também não concluíram o Ensino Fundamental.

Sigo então, para o grau de escolaridade da mãe ou responsável dos alunos participantes da pesquisa, para posteriormente, fazer uma análise comparativa entre a escolarização de pais e mães ou responsáveis. 
Infográfico 10: Grau de escolaridade da mãe ou responsável

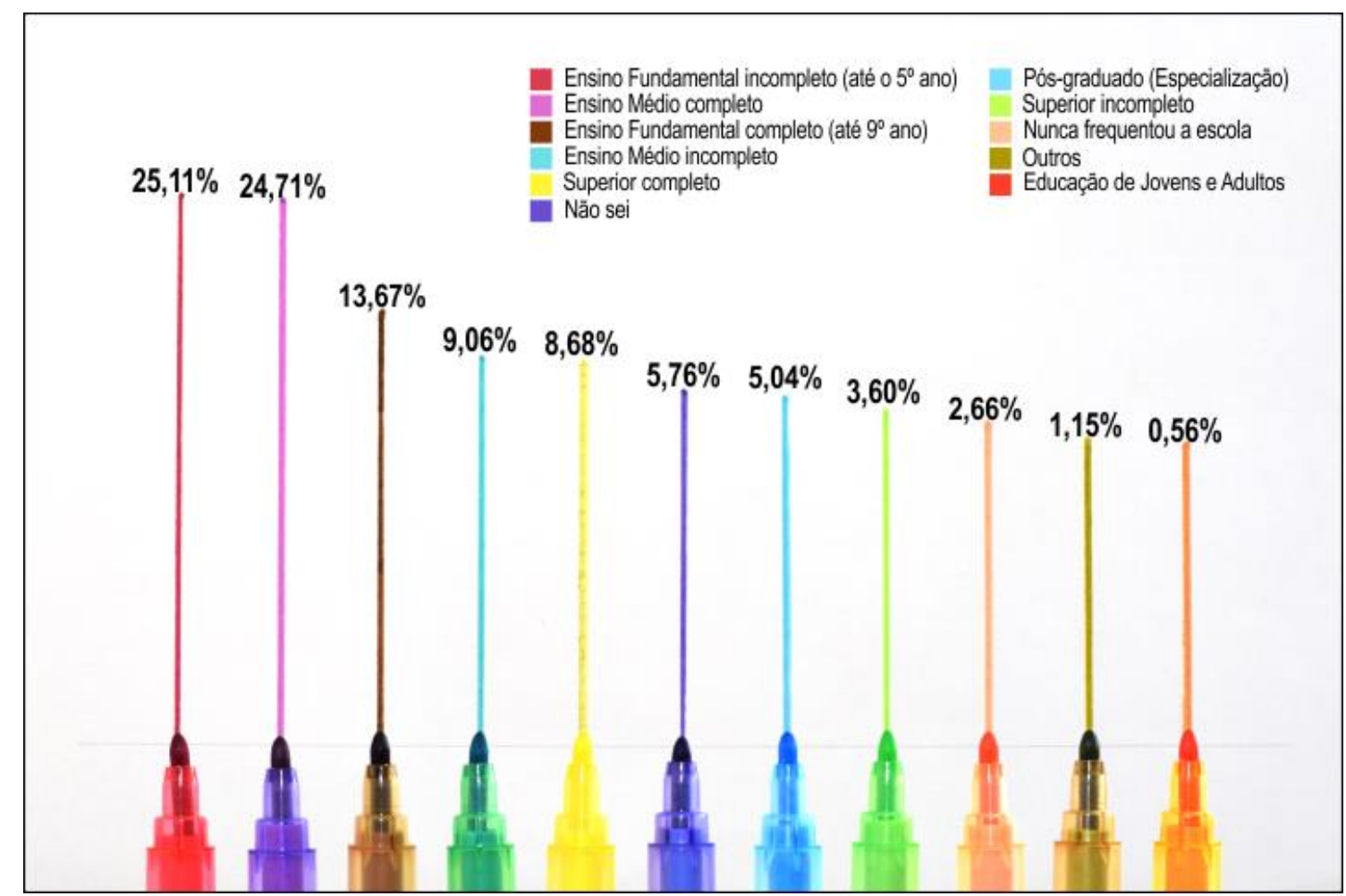

Fonte: Própria (2018)

Em relação ao grau de escolaridade da mãe ou responsável, o recorde trazido pela pesquisa, apresenta que o Ensino fundamental incompleto (até o 5음 ano) lidera a escala da tabela na quantidade de $25,11 \%$. Na sequência, na proporção de $24,71 \%$ são as que possuem o Ensino Médio completo. O total de 13,67\% compreende àquelas que cursaram o Ensino Fundamental completo (até o 9ำ ano). A soma de 9,06\% refere-se ao índice daquelas que possuem o Ensino Médio incompleto. A parcela de $8,68 \%$ corresponde as que concluíram o nível Superior completo. 5,76\% não sabem afirmar qual o grau de escolaridade da mãe ou responsável. As que portam diploma de Pós-graduação Lato Sensu totalizam 5,04\%. As que possuem o nível Superior incompleto somam $3,60 \%$. As que nunca frequentaram a escola expressam a quantia de 2,66\%. 1,15\% responderam "outros", isto é, o grau de escolaridade da mãe ou responsável não abrange nenhum dos itens mencionados. E as que estudaram na Educação de Jovens e Adultos constituem a soma de $0,56 \%$. 
Para os participantes do Grupo de Discussão, em muitos casos, a mãe cria sozinha os filhos, bem como promove o sustento da família e, ainda, possui um grau de escolaridade maior do que o pai.

P7: Mais uma vez eu posso me usar como exemplo, eu sou pai e mãe, eu criei a minha filha. Eu sempre criei ela sozinha, eu tenho estudo, e o pai não tem, ele fala errado, ele escreve errado, eu não sei em qual série ele parou, e acho que ela também não sabe, a mulher tem mais pulso firme e pensa mais no futuro, e o homem quer saber do agora, a maioria.

P9: Ela é mãe, pai, é a família toda, ela carrega toda essa responsabilidade, ela é multifuncional, e a gente acaba observando que o nível de instrução dela é um pouco maior de acordo com esses dados.

A tabela abaixo retrata essa realidade, da mãe com maior nível de instrução do que o pai, o que faz relação com as observações feitas pelos professores 7 e 9.

Tabela 1: Comparação entre o grau de escolaridade dos pais ou responsáveis dos participantes da pesquisa

\begin{tabular}{|l|l|l|}
\hline Grau de escolaridade & Pai/responsável & Mãe/responsável \\
\hline $\begin{array}{l}\text { Ensino Fundamental } \\
\text { incompleto (até o 5 ano) }\end{array}$ & $31,30 \%$ & $25,11 \%$ \\
\hline Ensino Médio completo & $21,84 \%$ & $24,71 \%$ \\
\hline $\begin{array}{l}\text { Ensino Fundamental completo } \\
\text { (até o 9ano) }\end{array}$ & $12,82 \%$ & $13,67 \%$ \\
\hline Ensino Médio incompleto & $9,06 \%$ & $8,02 \%$ \\
\hline Superior completo & $8,68 \%$ & $6,79 \%$ \\
\hline Pós-graduado (Especialização) & $5,04 \%$ & $2,79 \%$ \\
\hline Superior incompleto & $3,60 \%$ & $2,66 \%$ \\
\hline Educação de Jovens e Adultos & $0,56 \%$ & $0,25 \%$ \\
\hline
\end{tabular}

Fonte: Própria (2018)

Ao analisar o grau de escolaridade do pai ou responsável com a da mãe ou responsável, é possível verificar que em todos os níveis de escolaridade que compõe essa pergunta de pesquisa, a mãe ou responsável possui maior grau de 
escolarização do que o pai ou responsável, mas isso não significa que a mulher tenha melhor remuneração do que o homem no mercado de trabalho.

Condizente com o estudo de Estatísticas de Gênero: Indicadores sociais das mulheres no Brasil, divulgado pelo IBGE (2016), mesmo quando as mulheres têm um nível de escolaridade maior do que a dos homens, enfrentam a desigualdade no mercado de trabalho em relação ao homem. As mulheres têm rendimento habitual médio mensal de todos os trabalhos no valor de $\mathrm{R} \$ 1.764$, enquanto os homens têm o de $\mathrm{R} \$$ 2.306. Com efeito, as mulheres trabalham, em média, três horas por semana a mais do que os homens, associado aos trabalhos remunerados, afazeres domésticos e cuidados de pessoas. Apesar disso, e ainda com um nível educacional mais alto, elas ganham, em média, $76,5 \%$ do rendimento dos homens.

$O$ estado de MS tem a maior diferença salarial entre homens e mulheres do Brasil. A discrepância salarial é ainda mais crítica segundo dados do PNAD (2017), nas situações em que as mulheres recebem $27,8 \%$ a menos dos que os homens. Nesse mesmo ano, o rendimento médio mensal do homem foi $R \$ 2.297,00$ e o da mulher $\mathrm{R} \$ 1$. 658,00. Em análise, para equiparar as rendas, as mulheres teriam que trabalhar quatro meses e 18 dias a mais no ano para ter o mesmo rendimento do homem.

O próximo infográfico mostra a renda familiar dos participantes da pesquisa, e para efeito de análise apresento a tabela 2 mais abaixo, na qual fica mais evidente a divisão entre renda familiar e seus membros. 
Infográfico 11: Renda familiar aproximada

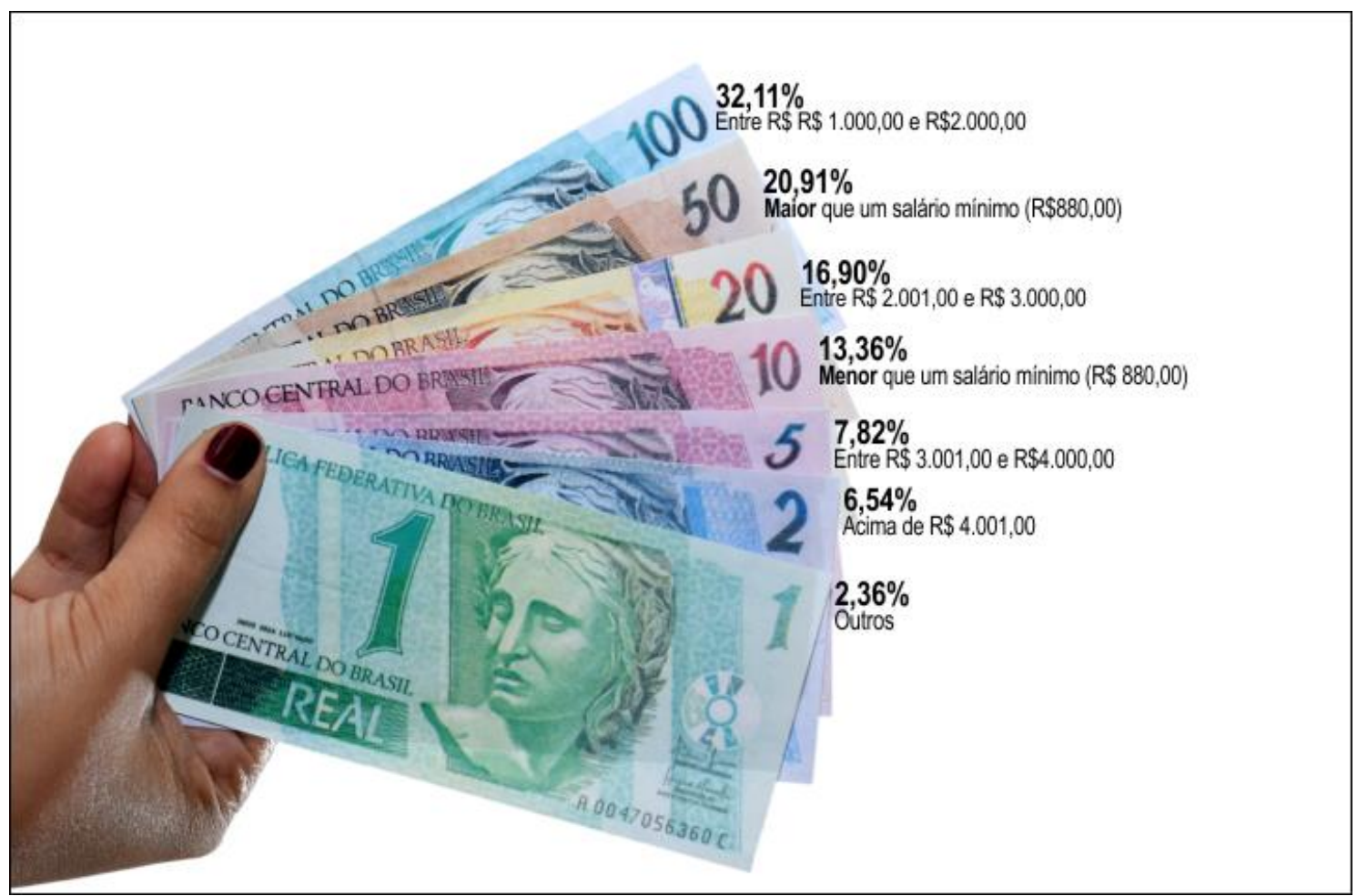

Fonte: Própria (2018)

A maior parte dos participantes da pesquisa (32,11\%) concentra a renda familiar entre $R \$ 1.000,00$ e $R \$ 2.000,00$. No quantitativo de $20,91 \%$, são os que possuem renda familiar superior a um salário mínimo ( $\mathrm{R} \$ 880,00)$. 16,90\% são os que contam com uma renda familiar entre $R \$ 2.001,00$ e $R \$ 3.000,00$. O valor de $13,36 \%$ corresponde aos que têm renda familiar inferior a um salário mínimo ( $R \$$ $880,00)$. Na soma de $7,82 \%$, são àqueles que portam renda familiar entre $R \$$ $3.001,00$ e $R \$ 4.000,00$. Menor é a proporção (6,54\%), dos que detêm renda familiar acima de $\mathrm{R} \$ 4.001,00.2,36 \%$ responderam "outros", ou seja, não se enquadram em nenhuma renda familiar expressa no infográfico.

No Brasil, conforme as estimativas de rendimento domiciliar per capita nominal mensal, no ano de 2018, a renda foi de $R \$ 1.373$, segundo cálculos com base nas informações da Pesquisa Nacional por Amostra de Domicílios Contínua (Pnad Contínua), divulgados pelo IBGE. A esclarecer, o rendimento domiciliar per capita é calculado com base em levantamentos de renda de trabalho e de outras fontes de rendimentos de membros de uma família. Mato Grosso do Sul é um dos estados brasileiros com maior renda domiciliar do Brasil, de acordo com PNAD 


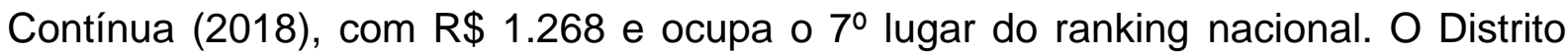
Federal lidera o ranking com $R \$ 2.548$, seguido por São Paulo com $R \$ 1.712$, Rio Grande do Sul com $R \$ 1.635$, Santa Catarina com $R \$ 1.597$, Paraná com $R \$ 1.472$ e Rio de Janeiro com $\mathrm{R} \$ 1.445$.

P6: Eu fico pensando nesses dados, como isso se arrasta por muito tempo, meu pai ia para roça na década de $40 \mathrm{com}$ meu irmão na frente dele, e ele dizia que ele não queria aquela vida para os filhos, mas ele ainda tinha uma chácara que ele vendeu e foi para cidade, e fez questão de dar educação para todo mundo, mas eu fico assustada que nesse país a gente continua com essa situação, de 1940 para 2019, é muito tempo e as coisas continuam desse jeito, talvez até pior muitas vezes, isso aqui nós estamos pensando em renda e escolaridade, mas onde mora esse povo? O que têm de condições de saneamento, qualidade de vida e saúde?

Em corroboração com a preocupação enunciada do participante P6 e seus questionamentos, apresento a tabela abaixo, na qual fica mais evidente a divisão entre renda familiar e seus membros. Para tanto, uso como exemplo o maior percentual $(32,11 \%)$ de renda familiar entre $R \$ 1.000$ e $R \$ 2.000$ e o maior quantitativo $(34,77 \%)$, de 4 pessoas que residem na mesma casa, referente aos municípios participantes da pesquisa em MS.

Tabela 2: Comparativo da quantidade de pessoas que residem na mesma casa e a renda familiar

\begin{tabular}{|l|l|l|}
\hline Renda familiar & $\begin{array}{l}\text { Quantitativo de } \\
\text { pessoas que residem } \\
\text { na mesma casa }\end{array}$ & $\begin{array}{l}\text { Distribuição de renda } \\
\text { por membro da mesma } \\
\text { família }\end{array}$ \\
\hline$R \$ 1.000$ & 4 & $\mathrm{R} \$ 250,00$ \\
\hline$R \$ 1.500$ & 4 & $\mathrm{R} \$ 375,00$ \\
\hline$R \$ 2.000$ & 4 & $\mathrm{R} \$ 500,00$ \\
\hline
\end{tabular}

Fonte: Própria (2018)

Analiso que os dados acima impressionam porque mostram a desigualdade social entre ricos e pobres no Brasil, e mais especificamente no estado de MS. Para se ter uma ideia, em 2016 conforme dados do IBGE, o ganho médio de uma pessoa que integra o grupo de $1 \%$ mais rico da população era equivalente a 36 vezes do ganho de uma pessoa que integra o grupo da metade mais pobre do país. 899 mil é o número de pessoas que integram o grupo de $1 \%$ mais rico e que teve rendimento médio de $R \$ 27.000 /$ mês, enquanto 44,4 milhões integram o grupo de $50 \%$ com 
renda de $\mathrm{R} \$ 747,00 /$ mês. Há um abismo entre os que têm mais e os que têm menos em nosso país. Choca mais ainda saber que o problema persiste ao longo dos anos como expõe o participante $\mathrm{P} 6$, passados 31 anos desde a redemocratização, a despeito das políticas públicas dos governos.

A persistência da desigualdade em nosso país motivou a ONG Oxfam a publicar um relatório no dia 25 de julho de 2019, intitulado "A distância que nos une. Um retrato das desigualdades brasileiras". No texto, a organização aponta que uma pessoa que recebe um salário mínimo mensal no Brasil, teria que trabalhar 19 anos para ganhar o salário de um mês de um brasileiro que faz parte do grupo (1\%) privilegiado mais rico do país e que apenas 6 pessoas têm uma riqueza equivalente ao patrimônio dos 100 milhões mais pobres, ou seja, metade da população.

Acordante ao Índice Gini (2017), que é um instrumento para medir o grau de concentração de renda em determinado grupo, bem como aponta a diferença entre os rendimentos dos mais pobres e dos mais ricos, variando de zero a um. O referido índice informou que o estado de MS obteve o quarto menor Índice Gini $(0,491)$, no ano de 2017, atrás apenas de Santa Catarina $(0,421)$, Rondônia $(0,455)$ e Mato Grosso $(0,481)$, ou seja, quanto menor o índice, menor a desigualdade.

O relatório da ONG Oxfam também sinaliza o que há de errado nesse sistema e apresenta um conjunto de ações para diminuir o problema. Sobre o que há de errado em suma, o relatório destaca: 1. O sistema tributário regressivo, que pesa muito sobre os mais pobres e a classe média; 2. As discriminações de raça e gênero que promovem violência cotidiana a mulheres e negros, negando seus direitos básicos; 3. A falta de espírito democrático e republicano do nosso sistema político, que concentra poder e é altamente propenso à corrupção. O que pode ser feito segundo os analistas da Oxfam: 1. Expansão de políticas públicas, em especial as sociais, para reduzir a pobreza e aumentar a renda familiar; 2. Investimento em educação para reduzir diferenças salariais; 3. Ampliação da cobertura de serviços para os mais pobres; 4. Política de valorização do salário mínimo; 5. Formalização do mercado de trabalho e queda do desemprego.

Ao analisar esses dados, percebo que além do Brasil ser um país muito desigual, é um país com uma história que perpetua a desigualdade social, pois as marcas da colonização permanecem presentes nos dias atuais, por meio da crença na existência de que apenas um único mundo e modo de vida são possíveis para se 
viver, cujos padrões são regulamentados por normas e valores ligados às ideologias dos grupos dominantes. Essa descrição também se aplica ao cenário observado no estado de MS. Nesse sentido, é importante destacar que os efeitos da descolonização foram apenas político-territoriais, pois as relações sociais não apresentaram significativa mudança social, ao considerar que a dominação social convencionada pelo sistema colonial mediante as questões de raça, classe, gênero e origem encontram-se praticamente da mesma forma, como mostra os dados desta pesquisa. Portanto, pode-se concluir que a colonialidade, independente do seu término como período e processo histórico, sobrevive e se reproduz no cenário das sociedades pós-coloniais, e opera reforçando as desigualdades sociais históricas.

Em análise, é necessário tornar visível que muitos conflitos que vivemos atualmente estão historicamente enraizados na sociedade e compõem parte de sua estrutura. No Brasil e, também, no estado de MS, por exemplo, as minorias brancas estão no controle dos meios de produção, na política, na jurisdição, entre outros espaços. Para mais, o domínio dessa minoria pode ser verificado também no que diz respeito à privação da luta pelo acesso à terra de movimentos indígenas, quilombolas e sem-terras, cujo processo de exclusão estabeleceu-se historicamente desde a colonização. Enfim, a perpetuação de diversas formas de exclusão sobretudo por meio da ideia de hierarquia construída por meio de uma visão eurocêntrica e sua legitimação mediante vários instrumentos sociais - afeta diretamente o modo de vida das pessoas, o que retomarei e aprofundarei no capítulo II.

Como professora, me orgulho de ter escolhido essa profissão, uma profissão promotora da aprendizagem e capaz de fomentar a igualdade de oportunidades entre as crianças e jovens, para que possam ter acesso aos diversos conhecimentos. Para mais, o professor tem a responsabilidade de preparar o aluno para ser um cidadão ativo e crítico socialmente, apto a questionar, debater e romper paradigmas. E, mesmo sem os investimentos necessários que deveriam ser feitos pelos governos, o professor é aquele capaz de gerar esperança, pois lida com sonhos e com seres humanos em formação.

Em última análise e respondendo a pergunta título desta seção: "A formação dos pais ou responsáveis e a renda familiar podem influenciar as escolhas profissionais dos alunos participantes da pesquisa?", apoio-me em uma pesquisa 
sobre formação dos pais e renda familiar fazem diferença no resultado do Enem realizada por Cafardo e Toledo (2018), que aponta que mais de $70 \%$ dos pais dos alunos que estão entre as mil melhores notas do Enem são formados no Ensino Superior ou Pós-graduação. Concomitantemente, quase 25\% destes têm renda familiar acima de $\mathrm{R} \$ 17.600,00$ e quase $90 \%$ de seus filhos nunca trabalharam, a escola privada possui cursinho integrado para o Enem, bem como essas famílias possuem a possibilidade de pagar por aulas particulares para complementar os estudos.

Os números acima mostram uma realidade muito diferente dos alunos participantes desta pesquisa, em que a maioria dos pais ou responsáveis $(56,41 \%)$ estudou até o $5^{\circ}$ ano do Ensino Fundamental, e que a maior parte $(32,11 \%)$ possui renda familiar entre $R \$ 1.000,00$ e $R \$ 2.000,00$. 90,01\% desses alunos sempre estudaram em escola pública, $32,58 \%$ exercem trabalho remunerado e $85,36 \%$ não fazem cursinho preparatório para o Enem. Em outras palavras, há de fato um abismo entre as oportunidades de ingresso no Ensino Superior de um aluno que pertence a elite social e econômica do país em relação a um aluno de classe desfavorecida, portanto, a escolaridade dos pais e a renda familiar são fatores que podem influenciar na escolha profissional. Por isso, o adiamento do Enem se faz necessário em tempo de pandemia, em razão da disparidade de condições e oportunidades de preparação para o exame entre a elite social e os desfavorecidos.

Ainda, acerca do quantitativo de alunos que fazem cursinho para prestar o Exame Nacional do Ensino Médio - ENEM, no estado de MS, uma parcela de 85,36\% dos participantes da pesquisa, não frequenta preparatórios para prestar o ENEM. Em escala menor 14,64\% são os alunos que fazem essa preparação.

$\mathrm{Na}$ percepção do professor $\mathrm{P} 4$, sobre a questão do cursinho, é possível imaginar que a baixa procura pelo curso está relacionada à questão financeira e pela impossibilidade de, muitas vezes, cobrir outros gastos para frequentar essas aulas. 
P4: A questão do cursinho é complicada. Quando observamos os infográficos anteriores, é possível deduzir que para frequentar um cursinho teria que agilizar outras coisas, como por exemplo, disponibilizar outro turno e cobrir gastos com translado, lanche, material, roupas etc... Porque quando ele afirma que não trabalha, acho que quer dizer, não trabalha fora com remuneração, mas, com certeza ele ajuda em casa de alguma forma, cuida de alguma criança, lava louças ou faxina a casa. E se não forem aprovados no Enem, de acordo com os dados, a opção que sobra é trabalhar, e de acordo com o infográfico 18 (o que fala sobre o que pretende fazer quando terminar o Ensino Médio), mesmo passando no Enem a principal intensão será estudar e trabalhar. Infelizmente, nesse contexto que você apresentou, frequentar o cursinho como ajuda para garantir a entrada na graduação, não está sendo viável ou possível para os estudantes que participaram da pesquisa.

Oferecido pela Secretaria de Estado de Educação (SED/MS), o Curso Estadual Preparatório para Ingresso na Educação Superior - CIES é um curso totalmente gratuito e que prepara o estudante para o ENEM e demais vestibulares. Conforme a SED/MS (2016), neste mesmo ano, foram oferecidas 3 mil vagas para o CIES, em 30 municípios do Estado, porém somente 14,64\%, o equivalente a 439 alunos se matricularam, ou seja, houve $85,36 \%$ - 2.561 de vagas ociosas. Entretanto, como afirma P4, é importante tornar visível que essas vagas ociosas estão relacionadas com as condições desses alunos em suprir os gastos com transporte, material, alimentação, entre outros, portanto, destaco a importância do órgão público não só oferecer o cursinho preparatório, mas garantir a acessibilidade, ou seja, as condições necessárias para a permanência desses alunos nesse curso. $\mathrm{Na}$ sequência, discuto sobre o processo de escolarização dos alunos participantes da pesquisa.

\section{O processo de escolarização dos alunos participantes da pesquisa e os desafios que alguns têm de conciliarem os estudos e o trabalho}

Sobre o processo de escolarização em rede pública ou privada, 90,01\% são os participantes da pesquisa que sempre estudaram em escola pública. Em conformidade com o Censo Escolar da Educação Básica (2016), com 6,9 milhões de matrículas, a rede estadual é responsável pelo total de $84,8 \%$ das matrículas no Ensino Médio, e somente 12,5\% das matrículas estão em escolas privadas.

Do ponto de vista dos professores 9 e 3 do Grupo de Discussão, o processo de escolarização em maior parte na rede pública $(90,01 \%)$, se deve ao fato da forma 
de ingresso nas universidades públicas, as quais destinam parte de suas vagas para alunos de escolas públicas.

\begin{abstract}
P9: Hoje a gente tem um movimento muito grande no país, principalmente na questão do ingresso nas universidades, mudaram sua forma de ingresso, a questão de destinar parte das suas vagas para alunos de escolas públicas, então a universidade juntamente com a educação básica tem feito essa articulação no sentido de que o aluno de escola pública tenha acesso ao nível superior, por exemplo, a USP e a UNESP destinam $50 \%$ das suas vagas para estudantes de escola pública, então é uma tendência, a gente observar estudantes de escolas particulares migrando para escola pública, isso já uma realidade.
\end{abstract}

P3: Eu perguntei o porquê ele não foi para escola particular. Ele falou: "Professora, meu objetivo é a Medicina, a concorrência, e tem o ENEM, eu queria concorrer estudando em escola pública." E agora ele está fazendo cursinho, ele passou em Odontologia, Fisioterapia, Direito, mas ele quer Medicina.

Após 21 anos de criação do Exame Nacional do Ensino Médio (ENEM), fazer a prova do ENEM é muito mais do que ingressar em um curso superior. O exame se tornou também a porta de entrada para outros programas do Ministério da Educação, como o Programa Nacional de Acesso ao Ensino Técnico e Emprego (Pronatec), Sistema de Seleção Unificada (Sisu), Programa Universidade para Todos (ProUni) e ao Ciência Sem Fronteiras. Para mais, o exame passou a ser critério para o estudante obter crédito do Fundo de Financiamento ao Estudante do Ensino Superior (Fies) e, ainda, para os jovens maiores de 18 anos que ainda não concluíram o Ensino Médio que podem obter a certificação de conclusão dessa etapa de ensino, utilizando a nota do ENEM desde 2012. Para se ter uma ideia, no ano de 2013, mais de 780 mil inscritos prestaram o exame com esse propósito, segundo os dados do Ministério da Educação (MEC).

Além disso, de acordo com o MEC, no ano de 2017, dados mais recentes, das 2.448 instituições públicas e privadas existentes no país, 1.481 utilizam o exame para preencher o quadro de vagas em curso de graduação. Positivamente, o exame é responsável por democratizar o acesso de estudantes às universidades, além de ser uma ferramenta para a concessão de cotas, pois a participação de pretos e pardos entre os inscritos passou de 29\% para 59\% nesses 21 anos, segundo dados do Instituto Nacional de Estudos e Pesquisas Educacionais Anísio Teixeira (Inep, 2017), responsável pelo ENEM. 
Diante do exposto, essa investigação aponta que a maioria dos jovens $(90,01 \%)$ participantes da pesquisa, que sempre estudou em escola pública, além de estar atentos a forma de ingresso nas universidades públicas, igualmente, essa escolha pode ser um reflexo da baixa renda familiar, problematizada anteriormente pelos professores 9 e 3 , o que pode comprometer seu ingresso em instituição privada de ensino.

Adiante, averiguo se os participantes da pesquisa exercem algum tipo de trabalho remunerado, ao mesmo tempo, que estudam. Acordante aos dados gerados, a maioria dos participantes $(56,84 \%)$ não exerce algum tipo de trabalho remunerado, seguido de $32,58 \%$ que exercem trabalho remunerado e $10,58 \%$ que às vezes trabalham.

Segundo os infográficos do IBGE (2016), sínteses de indicadores sociais do Mato Grosso do Sul, a ocupação dos jovens de 16 a 29 anos de idade, com relação ao tipo de atividade é: 19,8\% somente estudam, 15,4\% estudam e estão ocupados, $45 \%$ só estão ocupados e 19,5\% não estudam e não estão ocupados.

Ao analisar esses dados, é importante observar que apesar da renda familiar da maioria $(66,38 \%)$ dos participantes da pesquisa ser baixa (menor que um salário de $R \$ 880,00$, um pouco maior que o salário de $R \$ 880,00$, e entre $R \$ 1.000,00$ e $R \$$ $2.000,00$ ), a maioria dos alunos $(56,84 \%)$ não exerce algum tipo de trabalho remunerado para contribuir com as despesas pessoal ou familiar. Dado que diverge do IBGE (2016), sobre a ocupação dos jovens de MS, pois nesse mesmo ano, o instituto aferiu que 19,8\% somente estudam, ou seja, menos da metade dos $56,84 \%$ constatada por esta pesquisa. Outro dado divergente é que os alunos que estudam e trabalham somam $32,58 \%$, quase o dobro $(15,4 \%)$ dos dados levantados pelo IBGE (2016), na mesma questão.

Para mais, o questionário interrogou aos participantes da pesquisa $(32,58 \%)$ que estudam e trabalham concomitantemente, sobre qual a principal finalidade de trabalhar com remuneração.

A245: Eu ajudo a pagar o aluguel do barraco, pois minha mãe sozinha não dá conta, e ainda tem três irmãos menores.

A2300: Eu trabalho para ajudar comprar comida. Nunca chegamos a passar fome, mas sem a ajuda de todos da família, não daria para passar o mês. 
A5772: A gente divide as conta de água e luz, porque já chegou a cortar e daí a coisa fica complicada.

A4030: Sou pai de família e preciso trabalhar para garantir o sustento.

A1330: Tenho uma filha e pago pensão.

A3525: Eu trampo para poder sair nas baladas e beber todas.

A1620: Eu gosto de andar na moda e não gosto de pedir dinheiro para os outros, dou um jeito de fazer um bico para poder arrumar meu cabelo e comprar uma roupa nova.

Em consonância com as argumentações dos alunos, que alegam trabalharem para ajudar nas despesas básicas da família com aluguel, contas de água e luz e alimentação, para garantir o sustento de sua família, e o que paga pensão para filha, uma pesquisa do MEC (2017) intitulada "Juventude na escola por que frequentam?" em parceria com a Organização dos Estados Interamericanos (OEI) e a Faculdade Latino-Americana de Ciências Sociais (FLACSO), inferiu que no Ensino Médio 45,3\% dos estudantes só frequentam a escola, 28,9\% estudam e trabalham, 9,7\% realizam bicos e vão ao colégio, e 16,1\% já conciliaram as duas atividades, mas atualmente, se dedicam somente aos estudos. A pesquisa aponta também que o trabalho, além de ser uma questão presente na vida do jovem brasileiro, é um dos principais motivos para abandono escolar, principalmente entre os meninos. O estudo mostra que do total de jovens que abandonou o ensino formal, $36,1 \%$ dos meninos declararam que o motivo principal foi a necessidade de trabalho, apenas $1,3 \%$ dos meninos disseram que abandonaram o estudo para ser pai, e $16,4 \%$ alegaram a necessidade de resolver problemas familiares. Entre as jovens brasileiras, o índice é de $20,9 \%$ de abandono dos estudos, e elas elencam outros motivos que as fazem desistir da escola como gravidez $(18,1 \%)$ e questões familiares e laborais em $23,1 \%$.

Ao considerar os apontamentos acima, como técnica da SEMED/MS, e mediante acesso aos estudos internos feitos por este órgão, analiso que são amplas as causas de abandono escolar constatadas no dia a dia nas visitas as escolas e acompanhamentos pedagógicos, portanto, discuto alguns fatores de maior ocorrência como a gravidez e maternidade que pode causar constrangimentos sociais e limita o tempo disponível para os estudos. A respeito disso, quando estive como professora, em sala de aula, presenciei várias alunas desistirem dos estudos porque não conseguiam conciliar os cuidados com o bebê e as atividades escolares. 
Outro aspecto relevante é sobre as questões de violências físicas e psicológicas como "bullying", que pode gerar traumas e consequências que tornam a frequência dos alunos na escola uma experiência insuportável ou até mesmo impossível. Outro motivo que agrava a situação é o ingresso precoce e inadequado dos alunos menores de 16 anos no mundo do trabalho, o que discuto a seguir.

Para verificar se os alunos participantes da pesquisa fazem parte do triste índice dos que começam a trabalhar precocemente e os impactos disso em seus processos de escolarização, o questionário incluiu a questão: Desde qual idade você trabalha com remuneração?

Infográfico 12: Desde qual idade trabalha com remuneração

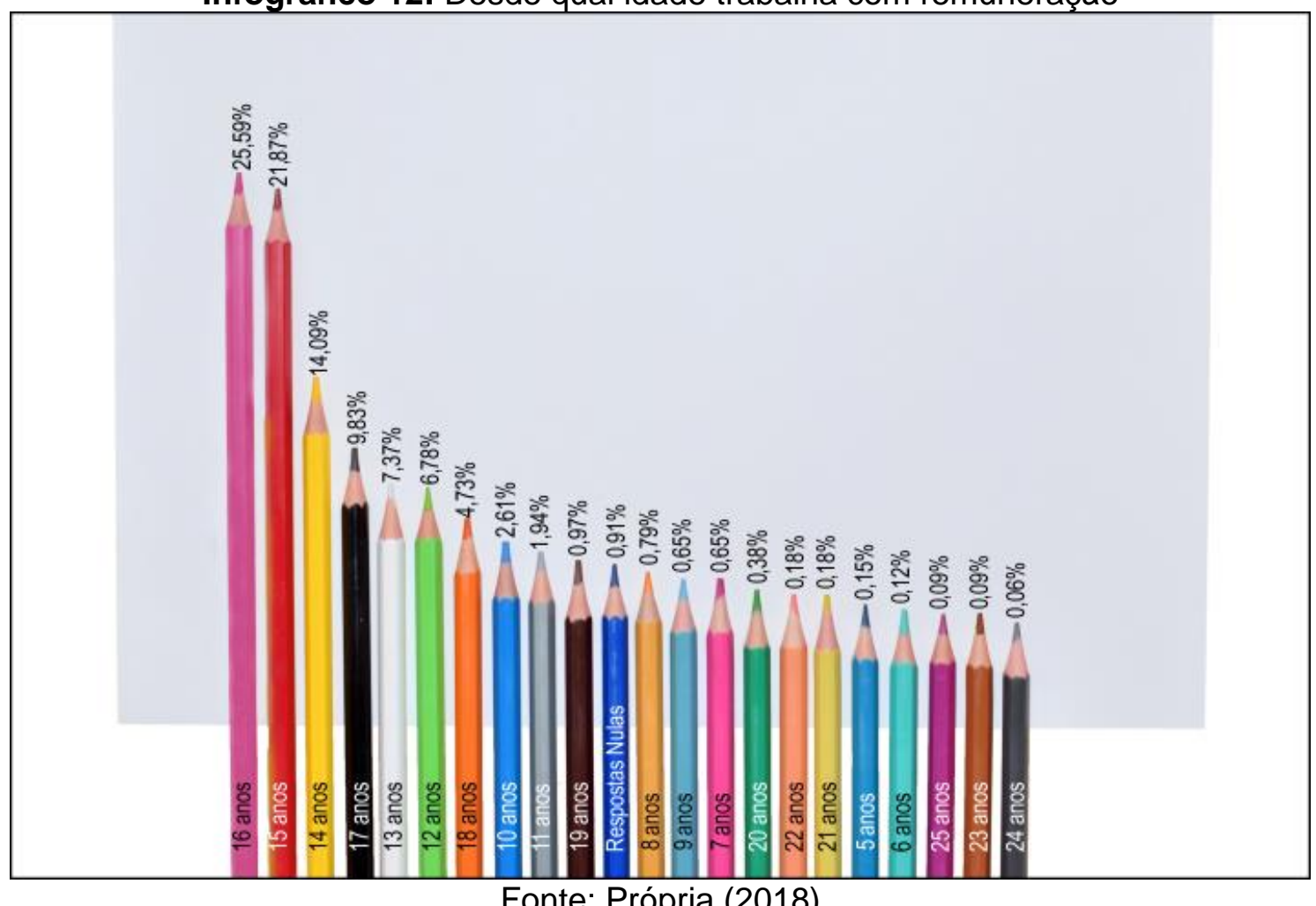

A maior parte dos jovens participantes da pesquisa que trabalha com remuneração encontra-se na faixa etária entre 16 anos (25,59\%) e 15 anos (21,87\%). Na sequência, são aqueles com 14 anos (14,09\%). 9,83\% são os que têm 17 anos de idade. $7,37 \%$ são os que possuem 13 anos de idade. $6,78 \%$ representam os com idade de 12 anos. 4,73\% reúnem o grupo dos que possuem 18 anos de idade. 2,61\% somam os de idade de 10 anos, seguidos dos que têm 11 anos com 1,94\%. Os demais se encontram abaixo de 1,0\% com as idades de: 19 
anos (0,97\%), 8 anos (0,79\%), 9 anos (0,65\%), 7 anos (0,65\%), 20 anos (0,38\%), 22 anos (0,18\%), 21 anos (0,18\%), 5 anos $(0,15 \%), 6$ anos $(0,12 \%), 25$ anos $(0,09 \%)$, $23(0,09 \%)$ e 24 anos (0,06\%). 0,91\% correspondem às respostas "nulas".

Consoante aos dados do IBGE (2013), as pessoas entre 14 a 17 anos de idade representavam 8,8\% daquelas em idade de trabalhar e os jovens de 18 a 24 anos de idade somavam $14,0 \%$, a seguir, que, o grupo etário de 25 a 39 anos, totalizava $29,6 \%$. A maior parte $(30,8 \%)$ integra o conjunto de pessoas com idade entre 40 a 59 anos. Aqueles com mais de 60 anos participam na proporção de $16,7 \%$.

\begin{abstract}
P3: Em uma escola de manhã eu estou como coordenadora, e a gente tem um projeto de pesquisa, um dos alunos do ano passado que já vem se destacando, no ano passado ele nos informou no final do ano que ele ia para o noturno para ajudar na renda, nós ficamos uma hora, sentamos nós quatro professores, para convencer ele da importância dos estudos, nos últimos dois anos tudo o que ele conseguiu desde que chegou no ensino médio, nós não escolhemos os melhores alunos, ele se destacou, ficamos uma hora e meia convencendo, e esse ano ele vai para Rondônia apresentar 0 trabalho, de que ele tem condições de estar em uma universidade, depois de um dia ele veio dizer que queria continuar no período matutino, mas que precisava trabalhar, a mãe precisava de ajuda, e eu tentei colocar para ele a importância dos estudos, o que ele tinha conseguido, ele falou que tinha acabado de comprar uma moto, eu falei que ele estava andando irregular por ter 17 anos, e como o professor mencionou, aquele negócio do imediato, nisso eu falei que ele ia trabalhar e ganhar um salário, mas e depois? Tivemos a notícia que ele ia continuar conosco na manhã, vai concluir o terceiro ano, e tem possibilidade de estar no ensino superior público.
\end{abstract}

Conforme excerto do professor P3 e também pela minha própria experiência como professora da Educação Básica, convivi com alunos que iniciaram um trabalho informal precocemente por necessidade de ajudar na renda familiar, e percebia que alguns estavam sempre cansados, outros não conseguiam desenvolver as atividades solicitadas a contento, uns eram faltosos e acabavam reprovados e outros abandonaram os estudos. Analiso que o trabalho precoce aumenta o risco de abandono dos estudos ou compromete a qualidade da aprendizagem, porque o jovem precisa se dividir entre o trabalho e as atividades da escola. Essa situação acaba por impactar o futuro profissional dos alunos, uma vez que, quanto menor o grau de escolarização, ele tende a ocupar postos de trabalho mais instáveis, indefinidos, precários e com remunerações menores. Dados da PNAD (2015) mostram que aproximadamente $9,3 \%$ das pessoas ocupadas nesse mesmo ano, 
começaram a trabalhar com 9 anos ou menos, 34,7\% de 10 a 14 anos, 29,4\% de 15 a 17 anos, $16,6 \%$ de 18 a 19 anos. Ressalte-se que apenas 9,9\% das pessoas ocupadas entraram no mercado de trabalho com 20 anos ou mais.

É importante avivar que o trabalho antes dos 14 anos é ilegal, a Lei 10.097, de 2000, estabelece no Art. 403 que no Brasil "é proibido qualquer trabalho aos menores de dezesseis anos de idade, salvo na condição de aprendiz, a partir dos quatorze anos". A redação dada por essa Lei estabelece ainda que "o trabalho do menor não poderá ser realizado em locais prejudiciais à sua formação, ao seu desenvolvimento físico, psíquico, moral e social e em horários e locais que não permitam a frequência à escola". Os dados gerados por esta pesquisa mostram que $21,06 \%$ dos participantes da pesquisa informaram que trabalham com remuneração com idade abaixo dos 14 anos, o que não é permitido por lei. Na contramão do que diz a Lei, para esse jovem que inicia a trabalhar precocemente, em geral, o trabalho que ele consegue é informal, com todas as suas desvantagens.

Outro aspecto que merece destaque sobre a precocidade do trabalho no Brasil, é que conforme dados do IBGE (2016), enquanto os analfabetos em média começaram a trabalhar com aproximadamente 12 anos, os diplomados em nível superior ingressaram nas atividades laborais, em média, entre 17 e 18 anos de idade. Ainda de acordo com dados da PNAD 2015, no grupo de pessoas que começaram a trabalhar antes dos 9 anos de idade, cerca de $74 \%$ alcançaram no máximo o Ensino Fundamental completo. Em comparação com os dados gerados pela tese, é possível inferir que o mesmo tenha acontecido com a maioria dos pais dos alunos participantes da pesquisa, uma vez que a maior parcela só conseguiu estudar até o Ensino Fundamental (até o 5aa), ou seja, o trabalho precoce pode causar a impossibilidade das pessoas continuarem os seus estudos.

Esses dados chocam porque mostram a desigualdade de condições e oportunidades entre os mais pobres e os mais ricos, e não faltam evidências, como explicitei anteriormente sobre minha própria experiência, de que o trabalho precoce interfere na qualidade do aprendizado, bem como na quantidade de anos de estudos que os alunos tendem a permanecer na escola por motivo de distorção idade/série e, acabam, muitas vezes, tendo que aderir a programas de correção de fluxo, como a Educação de Jovens e Adultos - EJA, por exemplo. 
Um artigo publicado na Associação Nacional de Pós-Graduação e Pesquisa em Educação ANPED SUL, no ano de 2014, "Um estudo com jovens: transição do Ensino Médio ao Ensino Superior" traz considerações importantes sobre o processo de transição dos jovens do Ensino Médio ao Ensino Superior, bem como as dificuldades e expectativas dos jovens para se inserir no Ensino Superior e seus projetos de acesso. A pesquisa foi realizada com 438 estudantes do Ensino Médio de uma escola pública em Balneário Camboriú - SC. Por meio de uma análise das expectativas dos jovens em relação ao ingresso no Ensino Superior, Zluhan e Raitz (2014), autoras desse estudo, evidenciam que a faixa etária desses jovens é caracterizada como um período de conflitos, divergências e desordens, para mais, as suas escolhas fazem relação com a diversidade e a complexidade que permeiam a constituição desses sujeitos, "estão diretamente relacionadas aos fatores históricos, culturais e sociais". (ZLUHAN e RAITZ, 2014, p. 2). Nessa direção, é vital considerar que essa expectativa pode mudar conforme a necessidade desse jovem contribuir com a renda familiar e se tem incentivo da família para dar continuidade aos estudos, uma vez que, a família, preferindo que o jovem trabalhe e ajude no pagamento das despesas, pode deixar de motivá-lo a ingressar no Ensino Superior. Essa investigação aferiu que $26 \%$ dos 438 jovens que responderam ao questionário estão inseridos no mercado de trabalho e, concomitantemente, estudam e, para esta parcela de jovens, trabalhar é a solução de seus problemas imediatos de subsistência.

Para construir o caminho profissional pretendido pelos participantes da pesquisa, o questionário incluiu questões que abordaram sobre a aspiração de atividade para quando terminar o Ensino Médio, a intenção de ingresso no Ensino Superior e as escolhas profissionais, e a pretensão de ingresso em quais Instituições de Ensino Superior, o que discuto a seguir.

\section{O mapeamento sobre a intenção profissional pretendida dos alunos participantes da pesquisa}

Com relação à pretensão de atividade dos participantes da pesquisa para quando terminar o Ensino Médio, por meio dos dados gerados, foi possível verificar que a maior parte $(74,39 \%)$ deles deseja estudar e trabalhar concomitantemente. 
No entendimento dos professores 9 e 4, sobre a pretensão de atividade para quando terminar o Ensino Médio, em que a maioria afirma que deseja estudar e trabalhar ao mesmo tempo, retrata o anseio em ingressar formalmente para 0 mercado de trabalho e também de atender uma demanda cultural da sociedade que insiste em alegar que para ser alguém na vida, é preciso ter nível superior. Outra questão suscitada é que, sendo a escolha por um curso noturno, há a possibilidade de trabalhar durante os outros períodos.

P9: A sociedade diz que você tem que ter nível superior para ser alguém na
vida. Os cursos técnicos também têm se fortalecido dentro desse processo,
quer dizer, hoje já não é mais interessante para o indivíduo ter uma
graduação porque tem pessoas que não têm graduação ganhando muito
mais do que gente com doutorado. Então, essas referências sociais têm
impactado muito dentro dessas decisões da sociedade, do que eu quero, e
a gente entra em uma concepção, o que é sucesso para mim? Sucesso é
eu ter uma graduação? Ou é ter uma casa, um carro e estar dentro da
sociedade?
P4: Eles estão prestes a passar para outro patamar, e podem pensar: já sou
quase adulto e muitos cursos de graduação são noturnos, posso conciliar o
estudo e o trabalho.

Muito embora a pretensão da maioria dos alunos seja continuar os estudos em nível superior e ao mesmo tempo trabalhar como aponta esta pesquisa, parte dos jovens brasileiros não consegue ingressar ou concluir um curso de nível superior devido às condições socioeconômicas desfavoráveis, ou ao início precoce no mercado de trabalho, segundo a pesquisa realizada pelo Interdisciplinaridade e Evidências no Debate Educacional (IEDE), que - com base nos questionários do Programa Internacional de Avaliação de Alunos (PISA, 2015) - indicou que apenas 4 em cada 10 adolescentes entre 15 e 16 anos de escola pública ambicionam concluir um Curso Superior. Além da baixa autoexpectativa de chegar ao Ensino Superior, os números informam que o Brasil tem um pouco mais de $15 \%$ de sua população entre 25 e 35 anos formada nessa etapa de ensino. Essa proporção é uma das menores quando comparada a outros 44 países, conforme dados da OCDE (2015), Censo (2010) e PNAD (2014), o Brasil está entre os três piores países, ficando na frente apenas da África do Sul e Indonésia.

Um ponto que requer destaque é uma análise da pesquisa "Panorama sobre Educação 2013", realizada também pela OCDE (2013), e que concluiu que há vantagem entre os que possuem diploma universitário comparados somente aos que 
têm a Educação Básica. As taxas de emprego entre os que terminaram o Ensino Superior são $15 \%$ maiores em relação aos que só terminaram o Ensino Médio e $18 \%$ quando comparado aos que não o concluíram. Para mais, a pesquisa verificou que a formação superior afeta a renda, ou seja, a população entre 25 e 64 anos com diploma universitário, ganha 157\% a mais do que aquela apenas com Ensino Médio.

Outra distinta pesquisa da Fundação Getúlio Vargas (FGV, 2010), sobre os resultados da Pesquisa Mensal de Emprego (PME) do IBGE (2010), revelou que quando comparado os que têm curso profissionalizante e os com Ensino Médio completo, a chance de conseguir um emprego é $48 \%$ maior entre os que contam com curso profissionalizante, e o salário chegaria a $13 \%$ a mais do que os formados apenas no Ensino Médio.

$\mathrm{Na}$ seção seguinte, apresento e analiso a intenção de ingresso do Ensino Superior e as escolhas profissionais dos participantes da pesquisa, com destaque aos cursos de licenciatura.

Infográfico 13: A intenção de ingresso no Ensino Superior e as escolhas profissionais

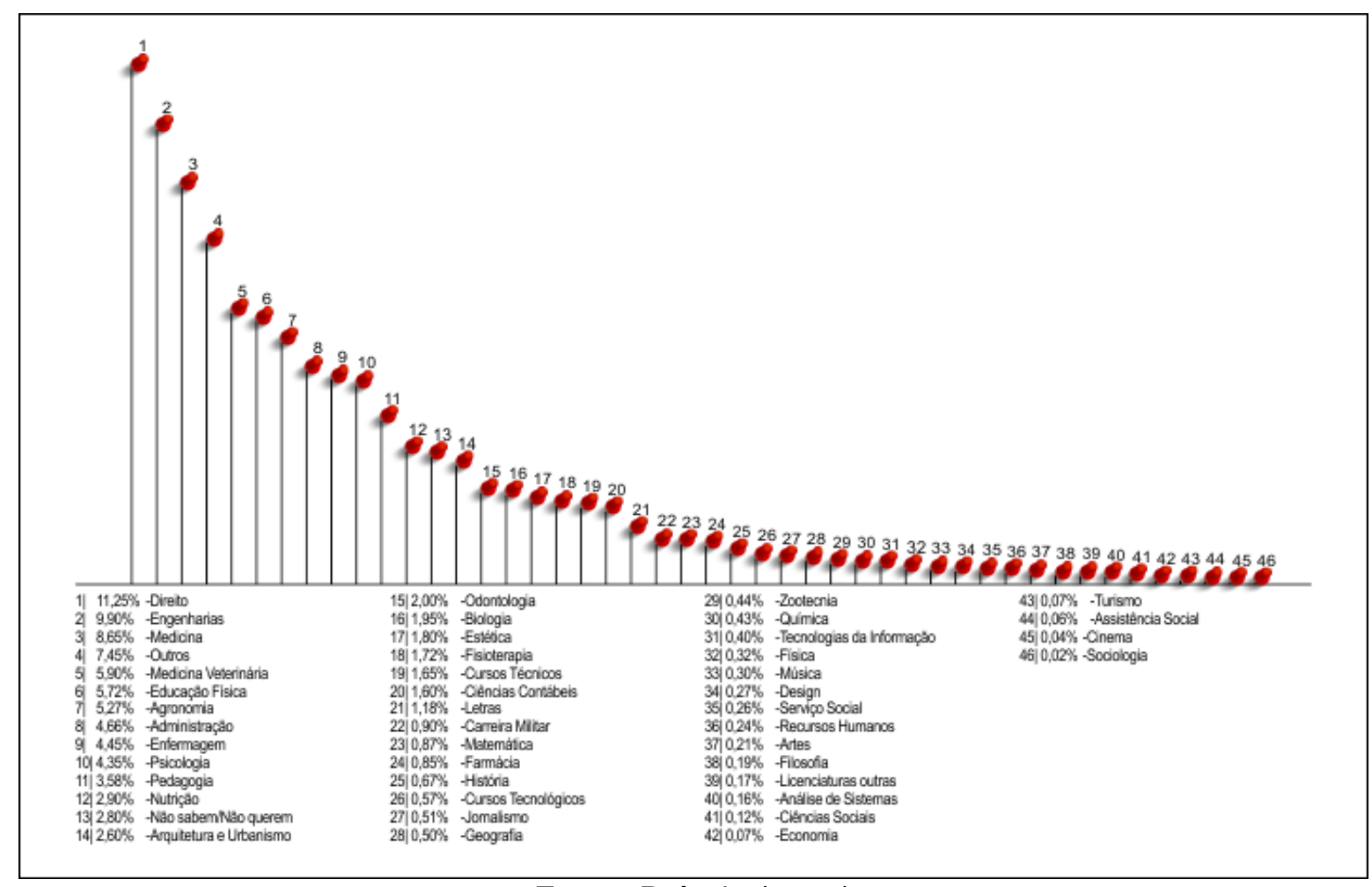

Fonte: Própria (2018) 
Em relação à pretensão de cursos para ingressar na Instituição de Ensino Superior, o curso de Direito tem a preferência da maioria dos participantes da pesquisa com 11,25\%. A Engenharia (diversas áreas) soma a parcela de 9,90\% das

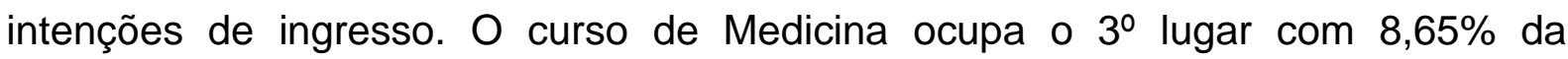
pretensão de ingresso. O conjunto de "outros cursos" não descritos individualmente corresponde à percentagem de 7,45\% quando somados. A Medicina Veterinária reúne $5,90 \%$ do desejo dos ingressantes no curso. Educação Física integra 5,72\% da preferência de ingresso nos cursos. $5,27 \%$ é o percentual dos que almejam cursar Agronomia. O curso de Administração totaliza 4,66\% das intenções de ingresso. 4,45\% reúne a quantia dos que querem cursar Enfermagem. Psicologia apresenta $4,35 \%$ da vontade dos ingressantes. 3,58\% exprime a quantidade dos que aspiram cursar Pedagogia. Nutrição representa 2,90\% referente à opção de cursos dos ingressantes. Não sabem ou não querem cursar totalizam 2,80\%. Com 2,60\%, Arquitetura e Urbanismo é o curso escolhido pelos ingressantes. Odontologia é apontada com $2,00 \%$ de predileção de ingresso. 1,95\% é a percentagem que sinaliza a propensão de ingresso no curso de Biologia. Estética engloba 1,80\% do desejo de ingressar neste curso. Fisioterapia possui a soma de 1,72\% da intenção dos que anseiam ingressar no curso. Os Cursos Técnicos (diversas áreas) correspondem à quantia de $1,65 \%$ da escolha de ingresso. 1,60\% expressa à quantidade dos que querem cursar Ciências Contábeis. O curso de Letras representa a opção dos ingressantes com o total de 1,18\%.

$\mathrm{Na}$ continuidade, estão às intenções de ingressos nos cursos com a percentagem menor que 1,0\%: Carreira Militar (0,90\%), Matemática $(0,87 \%)$, Farmácia $(0,85 \%)$, História $(0,67 \%)$, Cursos Tecnológicos (diversas áreas) $(0,57 \%)$, Jornalismo $(0,51 \%)$, Geografia $(0,50 \%)$, Zootecnia $(0,44 \%)$, Química $(0,43 \%)$, Tecnologia da Informação (diversas áreas) $(0,40 \%)$, Física $(0,32 \%)$, Música $(0,30 \%)$, Design (diversas áreas) $(0,27 \%)$, Serviço Social $(0,26 \%)$, Recursos Humanos $(0,24 \%)$, Artes $(0,21 \%)$, Filosofia $(0,19 \%)$, Licenciaturas outras $(0,17 \%)$, Análise de Sistemas $(0,16 \%)$, Ciências Sociais $(0,12 \%)$, Economia $(0,07 \%)$, Turismo $(0,07 \%)$, Assistência Social $(0,06 \%)$, Cinema $(0,04 \%)$ e Sociologia $(0,02 \%)$. Embora o meu propósito seja destacar os cursos de licenciatura, porque este é um dos focos deste estudo, considerei significativo apresentar também um panorama geral com todas as preferências de cursos informados pelos participantes, uma pequena contribuição 
para outros pesquisadores que venham a discutir o tema com interesse em outros cursos.

De acordo com o Censo da Educação Superior (2016), nesse mesmo ano, 34.366 cursos de graduação foram ofertados em 2.407 Instituições de Ensino Superior no Brasil (IES), sendo que 2,4\% das IES oferecem 100 ou mais cursos de graduação e 28,3\% das IES oferecem até 2 cursos de graduação. Em média, as IES oferecem 14 cursos de graduação. 93\% dos cursos são na modalidade presencial. O grau acadêmico predominante dos cursos de graduação é o bacharelado (58,7\%). Ainda segundo o Censo da Educação Superior (2016), os dez maiores cursos de graduação em número de matrículas nas IES no Brasil são: Direito (862.243), Administração (710.984), Pedagogia (679.286), Engenharia Civil (360.425), Enfermagem (273.444), Psicologia (253.594), Formação de professor de Educação Física (185.554), Arquitetura e Urbanismo (167.271) e Engenharia da produção (165.677). Ao delinearmos um paralelo com a pesquisa realizada em MS, com o dado trazido pelo Censo da Educação Superior (2016) sobre o curso de Direito que possui maior número de matrículas nas IES do Brasil, o referido curso também tem a preferência da maior parte dos estudantes de MS com 11,25\%. Os resultados de dessas pesquisas mostram a preferência pelo curso de Direito tanto em âmbito nacional como estadual.

Para o professor 9, participante da pesquisa, a escolha do curso superior está atrelada a ideia sobre o que o aluno entende que a sociedade acredita que é uma profissão de sucesso. Outra questão em evidência é quando ele presta o ENEM e outros vestibulares e não consegue a pontuação necessária para ingressar no curso de sua preferência. Então, ele opta por outro curso em que a pontuação é suficiente para ele cursar, por exemplo, como os cursos de licenciatura que exigem menor pontuação para ingresso, entretanto o professor 9 interroga: "Poxa, será que todas essas pessoas queriam fazer licenciatura ou elas estão escolhendo porque elas não conseguiram aquilo que elas gostariam? [...] Eu sempre digo assim, seja professor, educador porque você quer ser educador, não porque lhe faltou opção na vida". Além disso, a professora 4 ressalta uma outra problemática vivida por ela na universidade, quando o aluno decide fazer o curso de Letras "porque o pai mandou por ser gratuito, para fazer Medicina ou Engenharia depois, pois lá ele iria aprender português e redação, ou seja, estão aprendendo para poder prestar a prova de novo 
para mudar de curso." Analiso que a escolha profissional em um país como o nosso, em desenvolvimento, está relacionada as realidades sociais existentes, pois não é possível simplesmente escolher uma profissão de forma independente das condições sociais, que são desiguais, e restringem as opções das pessoas em cursarem o que realmente gostariam, haja visto, o distanciamento entre as oportunidades das classes dominantes em relação as subalternas, como será discutido no próximo capítulo por meio dos estudos Decoloniais. Diante dessa realidade, a luta pela sobrevivência se torna maior do que o sonho e o desejo, dada a materialidade do mundo capitalista que impede a vida pretendida, o que será discutido mais adiante também no capítulo III.

Outra questão levantada pelo professor 9: Como a professora comentou, formou quatro, desses quatro, todos tiveram dificuldade para fazer o Trabalho de Conclusão de Curso - TCC, é esse professor que volta lá para a Educação Básica para ensinar o aluno? Analiso que esta questão é muito preocupante, uma vez que esse profissional é que terá a responsabilidade de formar crianças e jovens na Educação Básica. Novamente em pauta a discussão feita no parágrafo anterior, pois muitas vezes, esse aluno que optou pela licenciatura, foi o que não conseguiu a pontuação necessária para ingressar no curso que realmente gostaria, ou não tem condições financeiras para custeá-lo, então, para não ficar fora da universidade, ele acaba fazendo outro curso, porém como uma segunda opção, o que pode ocasionar a desmotivação pelas atividades propostas e a desistência do aluno, uma vez que os objetivos são outros.

Em análise, mais uma vez, é possível perceber que a ideia que o neoliberalismo prega, na qual o homem é "livre" para fazer suas escolhas, busca encobrir as desigualdades sociais, permitindo na realidade, só que alguns consigam fazer determinadas escolhas, a maioria não tem essa opção, ou seja, prega uma falsa verdade que o sujeito tudo pode, basta crer e ter fé. Contudo, o importante é conscientizar os alunos dessa realidade que vivemos, porque muitos só conseguem enxergar o topo do iceberg, porém o que está imerso, fica escondido e, nós professores, temos que orientá-los por meio do conhecimento, fazendo-os entender que há algo significativo que condiciona a efetivação de uma escolha de uma profissão: a realidade sócio-econômica. Esse fator não impede que o destino de um jovem economicamente desfavorecido escolha a profissão que deseja, mas pode reduzir a 
probabilidade dele atingir essa meta a curto prazo ou conforme pretendido, pode até mesmo, modificar suas escolhas, adaptando-as para conseguir se inserir no Ensino Superior e no mercado de trabalho, como citado pelos participantes da pesquisa.

\begin{abstract}
P9: Ele vai verbalizar aquilo que está mais próximo dele ou acredito que aquilo que ele entende que a sociedade acredita que é a profissão do sucesso, porque todas são profissões de sucesso, em todas, a gente pode ter o sucesso profissional. [...] O que é que sucesso para o estudante [...] Olha, em relação as licenciaturas, eu percebo um processo histórico, muitas vezes, assim, ele quer fazer um outro curso, porém ele presta um vestibular, ele presta um ENEM e as vezes a pontuação não alcança aquilo que ele gostaria. Logo, eu passo a tentar escolher um curso que enquadre dentro daquilo que eu tirei enquanto nota e aí o que é que acontece? Se a gente faz uma avaliação das notas dos cursos de licenciatura nos vestibulares, vamos pensar, e no ENEM você vai ver que são notas baixas, não são notas altas. Então assim, é difícil você olhar isso e dizer assim: "Poxa, será que todas essas pessoas queriam fazer licenciatura ou elas estão escolhendo porque elas não conseguiram aquilo que elas gostariam?". [...] Eu sempre digo assim, seja professor, educador porque você quer ser educador, não porque the faltou opção na vida. Como a professora comentou, formou quatro, desses quatro, todos tiveram dificuldade para fazer o TCC, é esse professor que volta lá para a Educação Básica para ensinar o aluno? Isso nós ainda temos que mudar, as bases acadêmicas da nossa educação, esse diálogo precisa ser conjunto, academia juntamente com a educação básica, para que desenvolva de fato essa competência, e se eu não desenvolvo a competência do indivíduo lá na educação básica, ele vai ter dificuldade, ele não tem pesquisa, ele não tem leitura, não tem autoria, não tem autonomia, ele só repete o que ele escutou. $E$ a gente tem vivenciado hoje dentro das academias, dentro de algumas instituições educacionais, às vezes até mesmo na escola, professores com uma postura não autônoma do conhecimento, isso realmente tem acontecido.

P4: [...] eu tenho muitos questionários de primeiros anos de Letras lá, com 90 alunos, e perguntava se eles queriam esse curso, $40 \%$ não queria, foi porque o pai mandou por ser gratuito, para fazer Medicina ou Engenharia depois, pois lá ele ia aprender português e redação, ou seja, estão aprendendo para poder prestar a prova de novo para mudar de curso, não tem o curso como objetivo, é maior, é uma coisa muito maior.
\end{abstract}

Ao analisar ainda os dados sobre pretensão de curso para ingressar nas IES, verifiquei que do total de alunos que manifestam o interesse pelos cursos que oferecem a licenciatura, posso afirmar que somente a escolha pelo curso de Pedagogia com o percentual de 3,58\% (282 alunos) não apresentou ambiguidade de escolha, pois o referido curso só oferece a licenciatura. Os demais cursos citados como Educação Física, Biologia, Letras, Matemática, História, Geografia, Química, Física, Música, Artes, Filosofia, Ciências Sociais, Sociologia e Licenciatura outras que somam 11,82\% (933 alunos) são cursos que possuem licenciatura e bacharelado, conquanto, os participantes não expressam essa diferença ou escolha 
em suas respostas nesse item. A respeito do interesse dos alunos em cursar Pedagogia, destaco algumas justificativas citadas por eles:

A379: Primeiramente eu gosto de ensinar as pessoas, segundo adoro crianças e me identifico com a profissão de Pedagogia.

A1037: Sou apaixonada por crianças e me dou super bem, gosto muito de Pedagogia, acho uma profissão maravilhosa e, respeito e admiro quem cursa.

A4872: Adoro criança, brincadeiras de crianças e por isso vou me formar em Pedagogia.

A5376: A minha influência seria porque eu gosto de criança e gosto de ensiná-las também. Por isso, gostaria de me profissionalizar em Pedagogia.

A7035: Primeiramente, as razões que me fizeram querer ser professor foi que sou apaixona por crianças, e tenho muita vontade de ser professora, por isso, quero fazer Pedagogia.

Os participantes da pesquisa afirmam que o principal motivo para optarem em fazer o curso de Pedagogia, está relacionado ao fato de gostarem e/ou terem afinidade com crianças. Dados do Censo da Educação Superior (2017) revelaram que, neste mesmo ano, mais de 3,2 milhões de pessoas ingressaram em um curso superior no Brasil. Desse total, 9,2\% (296.776) escolheram o curso de Pedagogia, por ser o foco deste curso a primeira infância. Entendo como a coordenadora do curso de Pedagogia da UNICAMP, Débora Jeffrey (2017), em entrevista ao G1, ao ressaltar que "Muitos entram na faculdade porque gostam de criança, mas a profissão não se restringe a isso." A coordenadora explica que com essa formação é possível trabalhar na EJA, na elaboração de materiais didáticos, em cursos à distância, em cargos de gestão escolar como diretor, coordenador ou orientador pedagógico, no Recurso Humano - $\mathrm{RH}$, na Educação Especial, na Pedagogia Hospitalar, na Pedagogia Empresarial, em ONGS. Analiso que o mercado de trabalho extraclasse para o pedagogo é amplo, conquanto, as universidades que oferecem o referido curso devem estar atentas em preparar também esse profissional para atuar em outros espaços que não seja somente o ambiente escolar, expandindo suas oportunidades de trabalho.

O infográfico seguinte mostra a pretensão de ingresso em quais Instituições de Ensino Superior. 
Infográfico 14: Pretensão de ingresso em quais Instituições de Ensino Superior

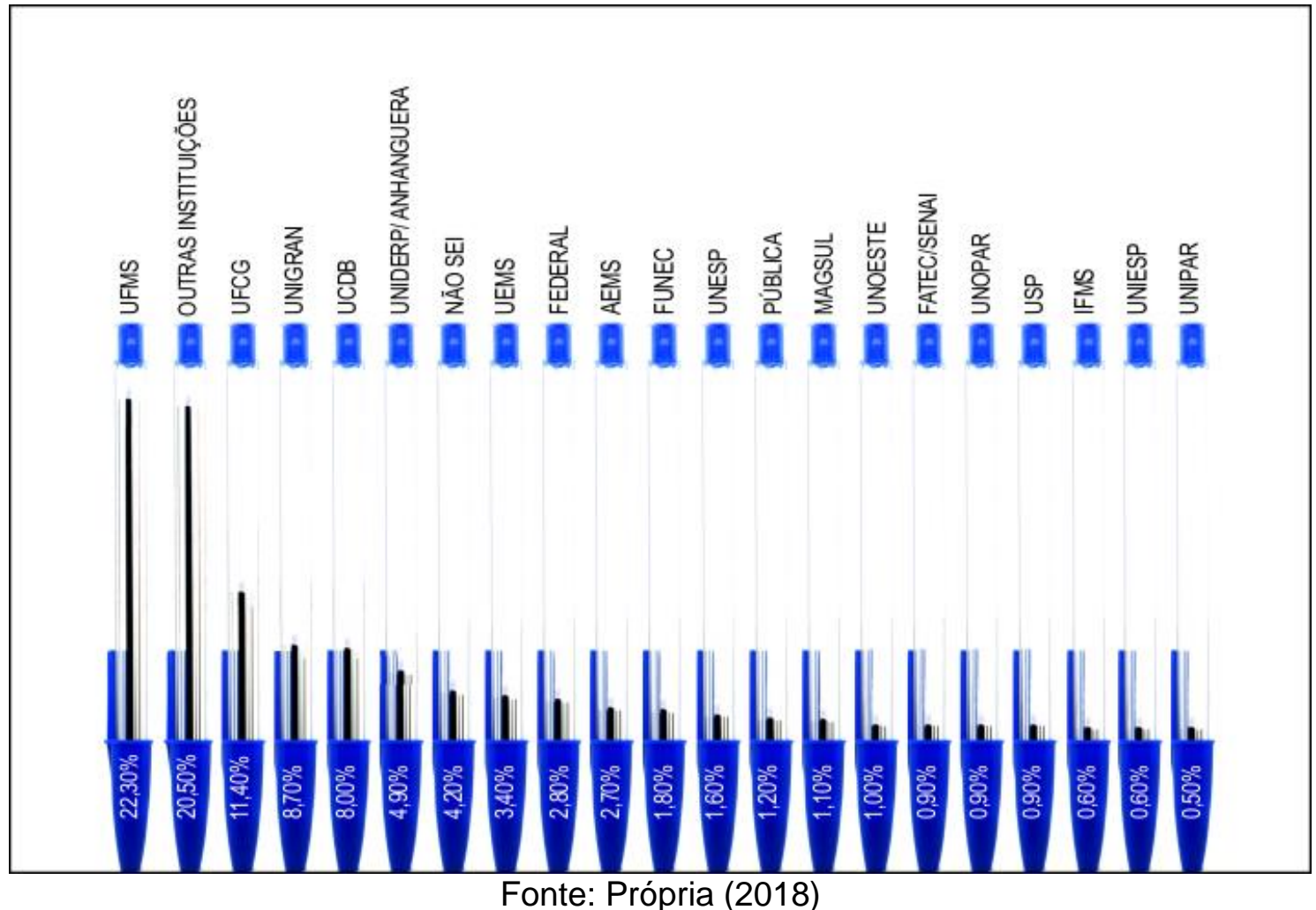

A parcela $(22,30 \%)$ dos participantes da pesquisa tem a intenção de ingressar em cursos da Universidade Federal de Mato Grosso do Sul - UFMS. Na sucessão, está o grupo de outras instituições que, juntas, somam $20,50 \%$, mas que foram citadas em menor índice de 0,50\% individualmente. A Universidade Federal da Grande Dourados - UFGD reúne o total de $11,40 \%$ de pretensão de ingresso. O Centro Universitário da Grande Dourados - UNIGRAN integra 8,70\% do desejo de ingresso. Com 8,00\% da preferência de ingresso, está a Universidade Católica Dom Bosco - UCDB. $4,90 \%$ é a quantia dos que têm preferência por ingresso na Universidade para o Desenvolvimento do Estado e da Região do Pantanal UNIDERP/ANHANGUERA. 4,20\% constituem o percentual do grupo dos que não sabem responder. A Universidade Estadual de Mato Grosso do Sul - UEMS soma $3,40 \%$ do anseio de ingresso. A quantidade de $2,80 \%$ exprime a opção dos que intencionam ingressar em universidades federais de todo país. Na proporção de 2,70\%, são àqueles que têm a aspiração de ingressar nas Faculdades Integradas de Três Lagoas - AEMS. 1,80\% refere-se à quantidade daqueles que desejam ingressar nas Faculdades Integradas de Santa Fé do Sul - FUNEC. A somatória de 
$1,60 \%$ engloba aqueles que anseiam em ingressar na Universidade Estadual Paulista - UNESP. 1,20\% incluem a soma dos que têm vontade de ingressar em universidades públicas estaduais ou federais do Brasil. 1,10\% abrange a percentagem dos que intencionam ingressar nas Faculdades Integradas de Ponta Porã - MAGSUL. A Universidade do Oeste Paulista - UNOESTE tem a preferência de $1,00 \%$ dos ingressantes. Em escala menor de 1,0\% na pretensão de ingresso estão as seguintes instituições: Faculdade de Tecnologia - FATEC/SENAI $(0,90 \%)$, Universidade Norte do Paraná - UNOPAR (0,90\%), Universidade de São Paulo USP (0,90\%), Instituto Federal de Mato Grosso do Sul - IFMS (0,60\%), União das Instituições Educacionais do Estado de São Paulo - UNIESP (0,60\%), Universidade Paranaense - UNIPAR (0,50\%).

Em conformidade com o Censo da Educação Superior (2016), 87,7\% das Instituições de Educação Superior são privadas. Das 2.407 IES, 2.111 são privadas e 296 são públicas. Em relação às IES públicas, 41,6\% (123 IES) são estaduais, $36,1 \%$ (107 IES) são federais e 22,3\% (66) são municipais.

Sobre a intenção de ingresso em Instituição de Ensino Superior, para os alunos participantes da pesquisa, $45,1 \%$ pretende estudar em uma IES pública, e $30,20 \%$ na privada. Dos $45,1 \%$ que pretendem estudar em uma IES pública, 22,30\% intencionam ingressar na UFMS. Criada em 1962, na cidade de Campo Grande, a UFMS é a mais antiga universidade de MS. Atualmente, segundo dados oficiais da própria instituição, esta oferta 148 Cursos de Graduação (anexo 10), e além da sede na capital do Estado, possui 9 câmpus em outros municípios do interior, conforme indica tabela abaixo. 
Tabela 3: Quantitativo de Cursos de Graduação ofertados pela UFMS.

\begin{tabular}{|c|c|}
\hline UFMS - Câmpus & $\begin{array}{l}\text { Quantidade } \\
\text { cursos }\end{array}$ \\
\hline CÂMPUS DE AQUIDAUANA & 13 \\
\hline CÂMPUS DE CHAPADÃO DO SUL & 3 \\
\hline CÂMPUS DE COXIM & 4 \\
\hline CÂMPUS DE NAVIRAÍ & 3 \\
\hline CÂMPUS DE NOVA ANDRADINA & 5 \\
\hline CÂMPUS DE PARANAÍBA & 3 \\
\hline CÂMPUS DE PONTA PORÃ & 6 \\
\hline CÂMPUS DE TRÊS LAGOAS & 20 \\
\hline CÂMPUS DO PANTANAL & 14 \\
\hline $\begin{array}{l}\text { ESCOLA DE ADMINISTRAÇÃO E } \\
\text { NEGÓCIOS }\end{array}$ & 7 \\
\hline $\begin{array}{l}\text { FACULDADE DE ARTES, LETRAS E } \\
\text { COMUNICAÇÃO }\end{array}$ & 13 \\
\hline $\begin{array}{lrr}\text { FACULDADE } & \text { DE } & \text { ClÊNCIAS } \\
\text { FARMACÉUTICAS, } & \text { ALIMENTOS } \\
\text { NUTRIÇÃO } & & \end{array}$ & 4 \\
\hline FACULDADE DE CIÊNCIAS HUMANAS & 5 \\
\hline FACULDADE DE COMPUTAÇÃO & 6 \\
\hline FACULDADE DE DIREITO & 2 \\
\hline FACULDADE DE EDUCAÇÃO & 10 \\
\hline \begin{tabular}{lrr} 
FACULDADE & DE & \multicolumn{2}{c}{ ENGENHARIAS, } \\
ARQUITETURA & $\mathrm{E}$ & URBANISMO \\
GEOGRAFIA & & \\
\end{tabular} & 10 \\
\hline FACULDADE DE MEDICINA & 1 \\
\hline $\begin{array}{lcl}\text { FACULDADE } & \text { DE } & \text { MEDICINA } \\
\text { VETERINÁRIA E ZOOTECNIA }\end{array}$ & 2 \\
\hline FACULDADE DE ODONTOLOGIA & 2 \\
\hline INSTITUTO DE BIOCIÊNCIAS & 3 \\
\hline INSTITUTO DE FÍSICA & 4 \\
\hline INSTITUTO DE MATEMÁTICA & 3 \\
\hline INSTITUTO DE QUÍMICA & 3 \\
\hline INSTITUTO INTEGRADO DE SAÚDE & 2 \\
\hline TOTAL & 148 \\
\hline
\end{tabular}

Fonte: www.ufms.br (2019)

Ao considerar a tabela acima, é possível supor que a preferência da maioria dos participantes da pesquisa pelo ingresso na UFMS se justifica pela diversidade de cursos, por ser uma universidade pública e pela abrangência da distribuição dos 
câmpus em outros municípios, o que facilita o acesso aos jovens que residem no interior de MS.

A escolha da IES, na apreciação dos professores P9 e P4, está relacionada principalmente à questão financeira dos jovens, que vão preferir cursar uma universidade pública, em razão da grande maioria não ter como arcar com as despesas de mensalidade, materiais, deslocamento, alimentação, entre outras, estando em uma universidade privada. Também por esses motivos, outro fator que preocupa, é o fato do jovem não conseguir ingressar no curso pretendido e acabar fazendo outro, sem vontade, porque é um curso noturno e ele consegue trabalhar durante o dia, conforme esclarece o professor 4.

\begin{abstract}
P9: Um primeiro fator que a gente pode relacionar é justamente a questão monetária por ser uma instituição gratuita, mas eu acredito que por uma via hoje de políticas públicas, então quer dizer, um Prouni, um vale universitário, $50 \%$ de bolsa, porque hoje as universidades particulares elas têm facilitado essa questão de $50 \%$, outras oportunidades para o aluno, então, mas ainda assim as públicas elas têm esse peso tanto pelo seu fator eu acredito que pela cultura de ensino, de pesquisa. Então para mim esse peso ainda da instituição pública por ser uma federal, uma estadual, ainda isso pesa bastante na escolha dos alunos, e a questão financeira mesmo, eu acho que a questão financeira é que pesa na hora de eu fazer a escolha, porque como que eu vou pagar um curso com a minha renda. Então como que eu vou pagar uma particular? Estou saindo do terceiro ano, estou tendo que trabalhar, não tenho como pagar esse curso.
\end{abstract}

P4: E também essa questão, às vezes o curso que ele quer fazer é caro, não tem na federal, ou é o dia todo e ele precisa trabalhar, então ele tem que escolher, ou ele faz o curso que ele quer, ou ele trabalha, e as vezes acaba fazendo um curso que ele não quer porque é de noite, porque durante o dia ele precisa trabalhar, mas ele acaba não concluindo, porque não é aquilo que ele quer.

Em concordância com os recortes acima, uma pesquisa divulgada pela Associação Brasileira de Mantenedoras de Ensino Superior (ABMES, 2017), com 1.200 pessoas entre pais, estudantes de Ensino Médio e egressos desta etapa nas cinco regiões do país, revelou que $70 \%$ dos estudantes brasileiros entrevistados que se formaram no Ensino Médio, não ingressaram em uma faculdade por falta de dinheiro, e $23 \%$ não prosseguiram com os estudos porque não conseguiram passar em uma instituição pública.

Outro estudo feito pela Pró-reitoria de Graduação da USP (2016) apresentou informações sobre o ingresso de estudantes no vestibular 2016 que, aprovou 34,6\% de alunos da rede pública de ensino. Entretanto, esse percentual revelou também 
uma grande variação entre os cursos das 42 unidades de ensino da USP. Ao passo que algumas unidades têm metade de egressos da escola pública, outras ainda estão com o percentual abaixo do esperado como é o caso da Escola de Engenharia de São Carlos (EESC), na qual apenas 14,1\% dos calouros cursaram o Ensino Médio em rede pública. A faculdade de odontologia de Ribeirão Preto (FORP) também apresentou baixo percentual de $17,5 \%$ de ingressantes de escola pública. $O$ Instituto de Química de São Carlos (IQSC) obteve somente a aprovação de 18,3\%. Em compensação, a Faculdade de Educação (FE) apresentou índice de 55,6\% de estudantes oriundos de escolas públicas, na sucessão, a Escola de Enfermagem de Ribeirão Preto (EERP), com 51,6\%, e a Escola de Artes, Ciências e Humanidades $(\mathrm{EACH})$, com $50,8 \%$.

A disseminação de ações afirmativas no processo de seleção dos estudantes brasileiros para o ingresso em universidades públicas nos últimos 15 anos, tem produzido efeitos que não se limitam à meta de ampliar o acesso de alunos vindos de escolas públicas, mas tem priorizado também a garantia de representatividade de negros, pardos e indígenas nos cursos de graduação. $O$ último Censo do Ensino Superior (2016), elaborado pelo Inep, indica o aumento de matrículas de estudantes negros, pretos ou pardos em cursos de graduação, em 2011, do total de 8 milhões de matrículas, 11\% foram feitas por alunos pretos ou pardos. Já em 2016, o percentual destes, subiu para 30\%. Pioneira na adoção de cotas raciais, para o professor Nelson Inocêncio, que integra o Núcleo de Estudos Afro-brasileiros, da Universidade de Brasília - UNB ressalta que houve um crescimento no percentual de jovens negros que ingressaram em cursos de graduação, ao mesmo tempo, pondera que é preciso pensar outras políticas para minimizar o abismo que há entre o nível de educação entre negros e brancos.

\footnotetext{
Antes de falar em igualdade racial, temos que pensar em equidade social, que exige políticas diferenciadas. Se a política de cotas não for suficiente, ainda que diminua o abismo entre brancos e negros, a gente vai ter que ter outras políticas. Não é possível que esse país, continue, depois de 130 anos de abolição da escravatura, com essa imensa lacuna entre negros e brancos. (INOCÊNCIO, 2018, p. 3).
}

Com efeito, as cotas universitárias já fazem parte da realidade brasileira, conforme destaca Inocêncio (2018), e como medida de ação afirmativa, de finalidade 
reparatória, configura-se como um caminho possível para promover a inserção do estudante em situação de desvantagem social e ética nos espaços acadêmicos.

Entendo como Soares (2007), que o acesso à educação é qualificado como um dos fatores mais importantes para o enfrentamento da violência. $O$ autor alerta ainda que, os avanços precisam ser mantidos, pensados e aperfeiçoados como bem coletivo, e que deve considerar as expectativas de vida e de futuro dos jovens, igualmente, urge que haja um efetivo engajamento social, ou seja, a sociedade deve utilizar espaços de reivindicação e de criação de novas possibilidades de incluir.

No próximo capítulo, me dedico em apresentar e analisar os dados gerados que me permitem averiguar construção de sentidos sobre a carreira docente pelos participantes da pesquisa. Para tanto, no que se refere ao campo teórico para análise, trago as discussões sobre os estudos Decoloniais, os estudos dos Letramentos e Letramentos de Reexistência, apoiada nos autores que discorrem sobre o tema. 


\section{CAPÍTULO II}

\section{A CONSTRUÇÃO DE SENTIDOS SOBRE A CARREIRA DOCENTE PELOS PARTICIPANTES DA PESQUISA}

\begin{abstract}
Quando chegaram as grandes canoas dos ventos (as caravelas portuguesas), tentaram banir o espírito do tempo, algemando-o no pulso do homem da civilização. Dessa época em diante, o tempo passou a ser contado de modo diferente. Esse modo de contar o tempo gerou a História, e mesmo a História passou a ser contada sempre de modo como aconteceu para alguns e não do modo como aconteceu para todos.
\end{abstract}

Kaka Werá Jerupé

Há que partir da existência, a existência como pedagogia, que é uma existência paradoxal e aí o papel do lugar avulta porque a sua história não se dá apenas como os passos vividos, mas os passos de vida. Os passos de vida são o da experiência sempre renovada, essa experiência existencial que deveria ser 0 fundamento da nossa teorização ao invés de estarmos, como continuamos fazendo, copiando de fora sugestões para encontrar a interpretação do que somos que permita a reavaliação das heranças e a indagação serena e exaltada, sempre que necessário, sobre o presente e sobre o futuro.

Milton Santos

Neste capítulo, em consonância com um dos objetivos e perguntas de pesquisa, apresento e analiso os dados gerados que me possibilitaram averiguar a construção de sentidos sobre a carreira docente pelos participantes da pesquisa que pensam em se formar professores. Para tanto, discuto a importância da escola como um espaço de fronteiras entre culturas, e me baseio nos estudos Decoloniais (SILVA, 1997; BHABHA, 1998; SOUSA SANTOS, 2011; CASTRO-GÓMEZ, 2007; MIGNOLO, 2009 e 2017; SPIVAK, 2010; GAUTHIER 2012 e 2019; MENEZES DE SOUZA, 2018 e 2019), nos estudos dos Letramentos (KLEIMAN, 1995; ROJO, 2009; STREET, 2014; MONTE MÓR, 2008, 2014, 2018 e 2019;), e nos Letramentos de 
Reexistência (SOUZA, 2011; ANASTÁCIO, 2018; PEREIRA, 2018; FRAGA, 2018, JOVINO, 2018; MUNIZ, 2018), para a análise dos dados gerados. Observei, diante dos dados, que esses estudos seriam os que se mostravam mais adequados para a análise requerida.

Nesse sentido, argumento sobre a necessidade da valorização de outros saberes nas aulas, uma vez que a maioria dos currículos escolares parte de uma perspectiva eurocêntrica de conhecimento, ou seja, os conhecimentos são oriundos quase que totalmente do Ocidente e da Ciência Moderna (SILVA, 1997). A escola ao excluir ou silenciar os saberes de outras culturas acaba reforçando a opressão e o preconceito em relação a alguns grupos sociais sulbalternos (SPIVAK, 2010), que inclui indígenas, quilombolas e negros, reproduzindo e reforçando a colonialidade. Mediante as diferenças registradas pelos dados da pesquisa, percebi a coerência em defender a ideia de desconstrução das subalternidades e a reelaboração dos saberes e fazeres pedagógicos que possam espaçar os "entre lugares" (BHABHA, 1998), em que culturas outras, histórias outras e vozes outras, tenham a possibilidade de pronunciarem-se e de serem consideradas como válidas em suas alteridades.

\section{Os estudos Decoloniais como um caminho possível para uma educação emancipadora}

$\mathrm{Na}$ análise de Mignolo (2017), o denominado Terceiro Mundo não foi concebido pelas pessoas que o habitam, mas por homens, instituições, línguas, culturas e pensamentos do Primeiro Mundo. Para ampliar o campo de análise da afirmação feita pelo autor, me baseio na explicação realizada por Menezes de Souza ${ }^{6}$ (2019), sobre três perspectivas distintas: Anticolonial, Pós-colonial e Decolonial.

\footnotetext{
${ }^{6}$ As citações com mais de três linhas de Menezes de Souza (2019, p.s/n), ao longo do texto, foram extraídas da Palestra "Fazendo e Desfazendo Sentidos: uma perspectiva decolonial", proferida pelo Prof. Dr. Lynn Mario Trindade Menezes de Souza/USP, no IV Seminário Estadual de Cultura e Educação, no dia 25 de novembro de 2019, na cidade de Campo Grande-MS. Em razão disso, não constam número de página.
} 
Para o referido autor, a perspectiva Anticolonial ocorrida na África e na Ásia na década de 60 , tentou reverter o processo colonial ao anunciar a própria cultura, a própria língua e as próprias verdades, enfatizando a ideia de que não seria mais necessário viver sob a influência da herança europeia. Contudo, essa possibilidade de inverter a colonização não foi possível porque os colonizados, mesmo os nativos colonizados, não puderam fugir do processo histórico, e quando finalmente conseguiram a independência, eles esqueceram que foram formados dentro do sistema colonial e, principalmente, a elite independente continuou agindo como se fossem colonizadores, ou seja, tratando seus próprios povos como inferiores/subalternos.

A perspectiva Pós-colonial surgiu em reação a essa situação, na qual se reconheceu que não seria possível inverter o processo de colonização, já que foram colonizados e o poder estava nas mãos da elite descolonizada, ao reproduzirem as verdades coloniais disfarçados de independentes e descolonizados. Com efeito, essa perspectiva enfatizou os aspectos do discurso, da cultura e do hibridismo, ao afirmar que foram colonizados, mas que nunca poderiam voltar às culturas précoloniais, porque estas sofreram influências durante séculos e modificaram sua própria cultura. Por último, a teoria Pós-colonial não tomou nenhuma posição política e focalizou em demasia o discurso e a cultura.

A teoria Decolonial emergiu na América Latina e no sul da Europa, em Portugal; muito embora este país tenha sido poder colonial, também se vê como inferiorizado diante do resto da Europa. Essa perspectiva defende, em conformidade com Menezes de Souza (2019), o aspecto que o significado e o sentido têm história, pois depende de quem está falando, bem como tece uma crítica à visão única de verdade, ao citar o exemplo dos povos indígenas no Brasil que viveram/vivem na condição de colonizado e, por isso, sabem que existe mais de uma verdade.

A perspectiva decolonial se difere das outras em razão da grande maioria da população ser descendente dos colonizadores, nesse sentido, o supracitado autor alerta que é fácil dizer que fomos colonizados, mas quem realmente foi colonizado e continua sendo colonizado são os povos indígenas, porque os demais povos são cúmplices do processo colonial. E é nesse aspecto da cumplicidade, que a decolonialidade se diferencia das perspectivas Anticolonial e Pós-colonial. 


\begin{abstract}
Especialmente na academia e nas elites sociais usamos esses discursos do norte, citamos as teorias do norte e tomamos como naturais toda a herança cultural do norte, só que a gente se vê como colonizado, nesse aspecto nós somos cúmplices. O primeiro passo proposto pela teoria Decolonial é fazer uma análise interna ao se questionar: Em que sentido eu sou colonizado? Como eu ajo como colonizado e colonizador? Precisamos nos conscientizar como nós fomos afetados por essas influências coloniais para reduzir seus efeitos. (MENEZES DE SOUZA, 2019, p. s/n.)
\end{abstract}

As palavras do autor me fazem refletir que realmente precisamos nos conscientizar de como nós vemos e agimos no mundo pelos olhos do colonizador. Penso que um outro passo possível seja o de nos desprendermos dessa visão, e para fazer isso, segundo Mignolo (2017, p. 20), "precisamos ser epistemologicamente desobedientes". Para tanto, é necessário pensar nas histórias locais e confrontá-las aos projetos globais e universalizantes do norte. Rememoro o célebre chamamento de Frantz Fanon (1979, p.192), ao findar seu livro Pele negra, máscaras brancas: "- Oh corpo meu, faz de mim, sempre, um homem que se interrogue!" De maneira prática, é exercitar constantemente a capacidade de questionar os enunciados (Por que? Para quê? Para quem? Onde? Quando? Qual? Como? De que maneira? Etc).

Seguindo esse pensamento, será necessário caminhar adiante, e questionar a normalidade e a naturalidade a que somos submetidos o tempo todo, pois apesar da colonização clássica ter acabado oficialmente, seus efeitos persistem e são visíveis nas formas das desigualdades. Como exemplo, cito a questão dos sinais do racismo epistêmico que refere-se as limitações a acessibilidade de negros e indígenas nas universidades, bem como a desconsideração do conhecimento produzidos por eles. Para o professor Medeiros (2019, p. 2), de Sociologia do Instituto de Filosofia e Ciências Humanas (IFCH) da Unicamp, a desconsideração das contribuições científicas trazidas por essas pessoas origina uma faceta muito cruel do "racismo que é a perda de memória coletiva e social. Se a gente não tem memória científica de pessoas negras, a gente diz que elas nunca existiram e pessoas que hoje estão na universidade não têm em quem se espelhar. Isso é muito grave". Em concordância com essa afirmativa, Jeffrey (2019) enfatiza que o racismo epistêmico "é uma discussão que, oficialmente, não se faz presente", ao argumentar que a presença de alunos negros nos cursos de graduação e pós-graduação estimula mudanças e discussões, mas que estas ainda não são familiares a maior 
parte dos pesquisadores. Diante desse cenário, Menezes de Souza (2019, p. s/n.) orienta algumas etapas a serem realizadas para romper com esse paradigma:

\begin{abstract}
Estratégia crítica decolonial em três etapas: 1. Identificar a colonialidade, por exemplo, nas teorias que eu uso: Quantas dessas teorias que eu uso são escritas por homens brancos europeus? Quantas são escritas por homens brancos brasileiros? A gente percebe como a colonialidade está na produção de saber. Quantas mulheres aparecem na produção de saber? Quantas pessoas não brancas aparecem na produção do saber que nós valorizamos na academia? Identificar a colonialidade naquilo que a gente acha natural; 2. Interrogar e questionar a validade e a naturalidade dessa desigualdade; 3 . Interromper essa colonialidade, buscando outras teorias, produzidas em outros contextos, por outras pessoas.
\end{abstract}

Entendo como o autor que é fundamental pensar a partir das margens da colonialidade e pensar junto com os grupos excluídos, cujos os saberes foram excluídos. E ainda, é importante revelar a diversidade epistêmica escondida pela colonialidade nas produções acadêmicas, ao desconstruir as autonarrativas da modernidade. Vou além, penso que os estudos decoloniais possam ser um projeto de vida que me possibilita viver e conviver com maior responsabilidade em relação a todos os seres vivos e ao planeta que habito. Relembro alguns trechos da marcante canção "Latinoamérica7", que faz referência a essa dinâmica:

\footnotetext{
${ }^{7}$ Em 2011, o grupo Porto-Riquenho, Calle 13, apresentou ao mundo o resultado de suas viagens pela América Latina por meio de uma composição "Latinoamérica". A música tem início e é a partir daí que compreendemos que se trata de um protesto que varia seu discurso entre crítica social, construção da identidade de um povo e todos os valores e dores que constroem seu orgulho. Conta uma breve história sobre a rotina de um povo sofrido que não deixa de erguer a sua cabeça e que segue prosseguindo não importa a situação. Esta música pode servir como uma porta com a possibilidade de um retorno às suas origens e raízes. E podemos ir além se pensarmos que talvez fosse mais fácil construirmos nossa identidade cultural por aqui do que tentar copiar a identidade de outros lugares, com outras histórias, na ilusão de que isso solucionaria as coisas. Ainda no plano dos questionamentos como resultado da música: Será que alguns de nós não continuamos a roubar o resto da sobra que outros deixaram para trás? Reproduzindo assim o que fizeram conosco durante tanto tempo? O Grupo "Calle 13" alcançou essa façanha com a produção do videoclipe "Latinoamerica" em 2011 que, apesar de ter mais de 50 milhões de visualizações no Youtube, (e dois Grammy's Latino) ainda é desconhecido para muitos. Felipe Hansell. Disponível em: http://obviousmag.org/o_silencio_que_vem_primeiro/2016/calle-13latinoamerica-somos-todos-filhos-de-tudo.html\#ixzz66rrTs2R0 Acesso em: 2 de dezembro de 2019.
} 
Sou, sou o que deixaram/ Sou toda a sobra do que te roubaram/ Um povo escondido no topo/ Minha pele é de coro, por isso aguenta qualquer clima. ${ }^{8}$

Sou o que sustenta minha bandeira/ A espinha dorsal do planeta é a minha cordilheira/ Sou o que me ensinou meu pai/ O que não ama a sua pátria, não ama a sua mãe/ Sou a América Latina/ Um povo sem pernas, mas que caminha.

Não se pode comprar o vento / Não se pode comprar o sol / Não se pode comprar a chuva / Não se pode comprar o calor / Não se pode comprar as nuvens / Não se pode comprar as cores / Não se pode comprar minha'legria / Não se pode comprar minhas dores.

Essa música expressa muito mais do que a minha capacidade de interpretação e análise. São saberes que não podem permanecer em silêncio, o que me desafia a desenhar novos caminhos, a caminhar com maior responsabilidade diante do valor da vida de todos os seres vivos, reconhecendo os saberes outros, na luta constante pelos direitos iguais desses saberes, em uma ação de reexistência, no dever ético de nunca julgar a cultura do outro, mas de entender os caminhos que esse outro percorreu e aprender por meio de minhas próprias experiências.

Para os teóricos citados anteriormente, o propósito da decolonialidade é descolonizar o pensamento a partir da crítica ao modelo imperialista eurocentrado, por meio da análise da imposição dos conhecimentos dos países colonizadores sobre os povos colonizados, uma vez que muito do que dizemos e fazemos é provido dos discursos de dominação, e isso implica também em condutas discriminatórias aos povos originários e/ou escravizados, colocando-os sempre como subalternos, subservientes e selvagens.

Em suma, pensar decolonialmente consiste na tomada de consciência do que foi o projeto civilizatório para embasar as produções teóricas voltadas para um

\footnotetext{
${ }^{8}$ Soy, soy lo que dejaron / Soy toda la sobra de lo que se robaron / Un pueblo escondido en la cima / Mi piel es de cuero / por eso aguanta cualquier clima.

Soy lo que sostiene mi bandera / La espina dorsal del planeta, es mi cordillera / Soy lo que me enseñó mi padre / El que no quiere a su patría, no quiere a su madre / Soy américa Latina, un pueblo sin piernas, pero que camina.
}

Tú no puedes comprar al viento/ Tú no puedes comprar al sol/ Tú no puedes comprar la lluvia/ Tu no puedes comprar el calor/ Tú no puedes comprar las nubes/ Tú no puedes comprar los colores/ Tú no puedes comprar mi alegria/ Tú no puedes comprar mis dolores. 
novo contexto de análises críticas em relação à colonização do Ocidente, principalmente sobre a Ásia, África e América Latina.

Nesse sentido, os estudos decoloniais buscam não só denunciar as mazelas da cultura europeia sobre os povos ditos subalternos, mas de pensarem na inclusão da cultura e dos saberes desses povos por meio de um novo paradigma epistêmico. Entretanto, Spivak (2010) previne que não cabe ao intelectual a função de falar pelo outro, pois corremos o risco de reafirmar as estruturas de poder colonial, ocasionando o silenciamento dos grupos subalternizados como se esses não fossem capazes de fazer suas próprias reivindicações.

Entendo que ninguém pode falar de dada experiência tanto quanto quem a vivencia, e que é importante ouvir esses grupos excluídos no espaço escolar para que haja uma relação dialógica entre os saberes escolares, os estudos coloniais, decoloniais e os saberes outros, uma vez que, conforme Kleiman (2006) e Rojo (2009) fomos formados na crença que só na escola é que se constrói o conhecimento válido, ou seja, constitui-se como valorizado apenas um letramento, o escolarizado. Essa ação significa colocar em evidência e legitimar histórias outras, sujeitos outros, feitos outros e reexistências outras, com o cuidado de não gerarmos um binarismo e uma ampliação das diferenças, pois "não há saber mais, nem saber menos, há diferentes saberes" (FREIRE, 1987, p. 68), portanto, pensar em ações de formação docente a partir dos estudos decoloniais, é primordial para a construção de uma sociedade que compreenda as diferenças como possibilidades de convivência e respeito.

Trata-se de partir da realidade local para produzir ou ressignificar conhecimentos que foram subalternizados pela colonialidade/modernidade, ao reconhecer que o conhecimento científico moderno não é o único capaz de possibilitar a compreensão do mundo, pois existe uma diversidade de modos de pensar, ser e sentir (GAUTHIER $\left.{ }^{9}, 2019\right)$. É sobre a importância da complementação

\footnotetext{
9 Palestra "Metodologia da pesquisa sociopoética, estudos transculturais e decolonialidade" proferida pelo Prof. Dr. Jacques Henri Maurice Gauthier, no IV Seminário Estadual de Cultura e Educação, no dia 25 de novembro de 2019, na cidade de Campo Grande-MS. Sem número de página.
} 
entre um conhecimento e outro, o que Sousa Santos (2011) define como ecologia dos saberes e tradução intercultural, ou seja, que é possível criar uma inteligibilidade recíproca entre diferentes saberes e cosmovisões. Para mais, Menezes de Souza (2019, p.s/n) provoca o seguinte questionamento:

\footnotetext{
O Humanismo europeu sempre enfatizou que os únicos seres que valem mesmo são os seres humanos, porque eles pensam. A racionalidade é um fator importante das culturas e produzem a ciência, portanto, outros sujeitos não humanos não podem produzir ciência, como por exemplo, os minerais, as plantas e os animais etc. A ciência que nós herdamos, nós mesmos reproduzimos por meio das nossas orientações de mestrado e doutorado, com as nossas exigências de metodologia de pesquisa, e assim, reproduzimos essas questões da ciência moderna e, com isso, não questionamos a universalidade e a singularidade dessa forma de pensar.
}

Em relação ao discurso acadêmico, Menezes de Souza (2019) alerta para o fato que este é apoiado na dicotomia de sujeito e objeto, em razão da valorização ou compreensão do objeto como neutro e universal. Para além disso, o autor reitera que se olha para a natureza como um recurso e não como algo essencial para uma relação de interatividade contínua e dinâmica com os seres vivos, sendo que, a natureza inclui todas as outras fontes possíveis de saber. E, é por isso, que na perspectiva decolonial, é preciso trazer de volta o corpo, Gauthier (2012, p. 13) reforça que "a tradição científica eurodescendente cortou o corpo sensível e emocional, assim como a cabeça intuitiva, da cabeça racional, a ciência para existir deve ser cortada da espiritualidade." Para resgatar o corpo, segundo Menezes de Souza (2019, p. s/n), "devemos situar o lócus de enunciação, o espaço a partir do que falamos". O autor reforça que falar de um espaço significa falar de um corpo localizado no espaço e no tempo, um corpo com memória, com experiência, um corpo exposto a vários conflitos da história. Em outras palavras, tanto os conhecimentos abstratos como os conhecimentos por meio da emoção, afeto e sensação são importantes, o que Gauthier (2012, p.12) chama a reflexão para o fato de que: 
As pessoas não são mais objetos de pesquisa, e sim sujeitos responsáveis pelo desenvolvimento da mesma, pelos dados que eles produzem e pela análise e interpretação desses dados. Eles, como grupo-sujeito é um pesquisador coletivo. O pesquisador acadêmico é facilitador, os demais membros do grupo-pesquisador são copesquisadores de um intelectual coletivo. Queria romper com a reificação das pessoas que se encontra em muitas pesquisas, onde essas produzem os dados que serão a base da existência do pesquisador acadêmico. De fato, elas são exploradas como produtoras de saber, por estarem privadas do uso e controle dos dados que produzem e por permitirem a criação de uma forma de mais valia de conhecimento, colocada à disposição da carreira do pesquisador acadêmico.

O autor explica que o pesquisador precisa realizar uma crítica na sua forma de olhar, aceitando a integração do olhar não acadêmico na elaboração científica de suas pesquisas, bem como refletir sobre a necessidade de se fazer um exame em relação aos seus próprios saberes. Nessa direção, penso que talvez seja necessário decolonizar a universidade para construir uma sociedade outra, conquanto, CastroGoméz (2007) faz um alerta ao definir a estrutura da universidade como arbórea, isso significa que as fronteiras epistêmicas não podem ser rompidas e a instituição é que decide quais são os conhecimentos úteis, legítimos e válidos, em concordância com a lógica monocultural eurocêntrica. Segundo o autor, os saberes que se originam de grupos subalternos são excluídos do debate acadêmico, reforçando, ao invés de romper com a colonialidade do saber, do ser e do poder. Essa constatação feita pelo autor é bastante preocupante, pois é a universidade que forma nos cursos de licenciaturas, os futuros professores que atuarão nas escolas e que, por conseguinte, muitas vezes, vão continuar ensinando por meio de uma lógica monocultural eurocêntrica.

Nessa chave, Menezes de Souza $(2019$, p. s/n.) enfatiza que o termo "reimaginação é algo extremamente importante, porque imaginar e ser criativo não são coisas que estamos acostumados a fazer na academia, em razão de sermos empiristas e da concepção de que apenas observamos os fatos e fazemos conclusões". Com efeito, para o autor, imaginar é ser capaz de sair da aprendizagem estabelecida e buscar algo novo, sem isso, a aprendizagem não acontece. É ainda, romper com o modelo de normalidade e naturalidade que se adquire no discurso acadêmico.

Outro ponto que merece destaque é sobre os inúmeros conhecimentos diferentes no mundo, Monte Mór e Menezes de Souza (2018) discutem que esses conhecimentos podem não estar em conformidade com os modelos de racionalidade 
da ciência moderna e que, por isso, são vistos como ignorância, como ciência não organizada e inexistente como conhecimento. Os autores explicam apoiados no conceito de ignorância de Sousa Santos (1999), que esse termo implica ver o conhecimento sempre como parcial e local, e nunca em sua totalidade, por meio de uma ação de respeito ao outro e ao conhecimento alheio, e que o conhecimento inclui a ignorância do mesmo modo que a ignorância inclui o conhecimento.

Ademais, na construção cooperativa do conhecimento, o cruzamento de leituras acadêmicas dos dados produzidos com leituras inspiradas em culturas de resistência (dominadas e/ou colonizadas) é de fundamental importância para a descolonização do saber (GAUTHIER, 2012). Em concordância com o supracitado autor, Menezes de Souza (2019) entende que é de maneira colaborativa e solidária que devemos reconhecer a multiplicidade de conhecimentos, de modo a não excluir um tipo de conhecimento para dar preferência a outro, bem como sobre a importância do lócus de enunciação e como todo o conhecimento é situado, e retratado no tempo e no espaço que emerge.

Percebo que as escolas e as universidades são locais estratégicos para se consolidar uma proposta de educação que permita o diálogo entre o conhecimento científico e os saberes outros, sendo que a diversidade cultural configura-se como peça central, pois reflete o "rosto mais plural dos educandos, sujeitos culturais de linguagens, vivências, valores, concepções, imaginários múltiplos" (ARROYO, 2003, p. 41). A cultura que cada aluno traz consigo para a escola alerta que eles não são apenas receptores passivos de um conhecimento neutro, menos ainda são a reprodução de um modelo hegemônico, pelo contrário, são sujeitos políticos, sociais e culturais, que por meio da interculturalidade , gritam por uma relação de igualdade, de diálogo, de respeito e da legitimidade de seus saberes.

Penso que é na escola e durante as aulas, que ao professor é possível promover constantes questionamentos sobre as formas de subalternização, desumanização, opressão, violência e preconceito, e discutir com os alunos sobre as relações de poder que inviabilizam as diferentes formas de saber e ser, oportunizando a eles outras formas de ler o mundo, de se apropriar da história contada pelos "outros" (grupos subalternos), para que possam refletir sobre o seu e contextos outros, bem como para que consigam pensar em construir uma sociedade outra. Ao promover os questionamentos mencionados acima, o professor pode 
desenvolver, conjuntamente com os alunos, discussões que conduzam a uma ressignificação e ampliação dos saberes.

Outro ponto que merece ser discutido é o da mestiçagem, especialmente, em razão da maioria dos participantes da pesquisa se autodeclarar pardos ou mulatos (43,54\%), em relação aos brancos que somam $40,37 \%$, os negros totalizam $9,23 \%$, os amarelos $3,90 \%$ e os indígenas 2,96\%. Em entrevista, Risério (2008) esclarece que "mestiçagem não é sinônimo de igualdade, nem de harmonia social. Não exclui o preconceito, o conflito". O autor faz um alerta de que nossas práticas são racistas, embora, insistamos em não enxergarmos que elas existem.

Em relação ao alerta do autor, relato um fato que aconteceu comigo nas primeiras aulas de uma disciplina que fiz no doutorado. Certo dia, no intervalo da aula, um colega da turma se aproximou de mim e disse se poderia me fazer uma pergunta. Eu respondi que sim. Ele perguntou assim: - Você é indígena, né? Eu imediatamente respondi que sim, que era descendente de indígena, de negro e de amarelo, que era mestiça. E comecei a contar um pouco da minha miscigenação. Porém o colega me interrompeu e disse: “- Eu só queria ter certeza que você era mesmo indígena. Com licença, agora eu preciso ir". O colega nunca mais falou comigo. Eu fiquei sem ação, porque não esperava que em um ambiente universitário, cursando uma disciplina de Pós-Graduação, fosse ser abordada dessa forma. Após refletir sobre o fato, analiso que a questão de confirmar se eu era indígena mesmo, pode ser apenas uma curiosidade do outro, ou, pode fazer relação com o fato do colega pensar que aquele ali não era lugar para mim. Como se quisesse me perguntar com o olhar: "O que você está fazendo aqui? Como assim? Como conseguiu passar em um processo de seleção que não tem cotas?". Pelas inúmeras situações iguais a essa que possam ocorrer no ambiente acadêmico e em outros, entendo que pensar a educação alicerçada em uma visão decolonial se torna vital para romper com o preconceito e promover o respeito às diferenças, e os Letramentos críticos e de Reexistência podem colaborar para o processo de acolhimento de alunos oriundos dos grupos subalternos, e ainda, como reforça Street (2014), de como lidar e incluir os letramentos outros - periféricos, não hegemônicos, socialmente desvalorizados e não legitimados.

Com efeito, não é possível esquecer que a colonização linguística, significou o linguicídio de muitas línguas ameríndias e africanas, por sua vez, apesar dos 
marcos legais para o ingresso de grupos subalternos nas escolas e universidades, isso não garante uma política de inclusão linguística. Para se ter uma ideia, como técnica da SEMED acompanhei, por vários anos, alunos indígenas na Educação Básica, os quais têm a língua indígena como materna e falam o português somente na escola, e constatei que há uma dificuldade por parte desses alunos especialmente em relação à escrita da língua portuguesa.

Para entendermos melhor essa dificuldade dos alunos indígenas, apoio-me em Menezes de Souza (2018, p. 1), ao explicar que "a escrita pode ser vista como uma forma de interação pela qual uma ação das mãos (com ou sem instrumento) deixa traços numa superfície qualquer, nesse sentido, a escrita pode ser concebida como uma forma não alfabética para representar ideias, valores ou eventos". O autor reforça que a escrita concebida dessa maneira, sempre esteve presente nas culturas indígenas no Brasil e que a escrita alfabética foi introduzida pela colonização europeia, porém, somente nas duas décadas que surgiu "o fenômeno da escrita indígena no sentido do aparecimento de um conjunto de textos alfabéticos escritos por autores indígenas" (MENEZES DE SOUZA, 2018, p. 1). Entendido isso, observei a dificuldade que pode ser para um aluno indígena, o domínio da norma culta da língua portuguesa, tendo em vista que até os alunos não indígenas apresentam dificuldades no processo de escrita de sua língua materna. Acerca desse fato, uma das professoras participante da pesquisa analisa que:

P4: A gente repara esses reflexos na universidade, eu fiquei quase 20 anos na universidade, e fiquei esse mesmo tanto no Ensino Fundamental e Médio, eu passei na rede municipal de séries iniciais ao Ensino Médio quando tinha o Ensino Médio na rede, e a gente observa a questão desses alunos, que realmente eles chegam com uma defasagem de vocabulário na sala de aula. O vocabulário da escola é bem diferente do vocabulário da casa, isso reflete muito, e vai sendo carregado por eles até onde eles aguentam, quando eles não suportam mais, acontece isso, eles desistem de estudar. Eu acabei de comentar isso com a colega, do nível dos alunos que estão entrando no curso de Letras, o que está acontecendo na universidade hoje, é que a nossa geração está toda aposentando, está entrando um grupo de professores novos. Você vê aquele seu aluno voltando do doutorado, é outra geração, uma geração que nunca foi para uma escola pública. Ele chega na graduação achando que ele vai dar uma aula como se fosse de doutorado para aqueles alunos, essa disparidade está acontecendo. Eu acho que assusta um professor que vem da academia, que passou com bolsa, depois com bolsa para mestrado, bolsa para doutorado, e sai da graduação e da pós-graduação de uma maneira que ele não tem experiência em ensinar alunos da Educação Básica da escola pública. 
Analiso ser benéfico que o professor dê continuidade a sua formação a nível stricto sensu, contudo, penso ser basilar que possa também estar atento a realidade de cada aluno, por meio de um olhar de inclusão e ações de acolhimento que colaborem para o bom desenvolvimento das atividades acadêmicas. Nesse sentido, apoiar os alunos com dificuldades implica entender o caminho que ele percorreu até seu ingresso na universidade e, a partir daí, criar situações de aprendizagem que atendam as necessidades dos diferentes alunos. Da mesma maneira, a universidade pode não só garantir o acesso desses alunos aos cursos, mas principalmente, garantir a acessibilidade, ou seja, a permanência deles nos cursos.

Em assentimento a declaração da professora 4, para a sociolinguista Zavala (2010, p. 74), que trabalha com educação intercultural bilíngue de estudantes indígenas no Peru, o letramento acadêmico "é só uma das formas de se usar a linguagem como parte de uma prática social que ganhou legitimidade por razões ideológicas que se enquadram em relações de poder." A autora esclarece que a universidade considera como desviantes, não legítimas ou equivocadas as outras formas de leitura, de escrita e mesmo cosmovisões. Para além disso, com base no conceito de Linha Abissal de Sousa Santos (2011), Menezes de Souza (2019) explica que esta concepção produz a ideia que separa e fundamenta um sistema de distinções entre raças, saberes, línguas, gêneros, manifestações artísticas etc. Isso quer dizer que de um lado está tudo o que é visível e válido em termos de conhecimento, e do outro lado da linha, tudo o que é produzido se torna invisível, e portanto, deixa de ser objeto de crítica. O que mais caracteriza o pensamento abissal é a impossibilidade de co-presença de ambos os lados da linha, impossibilidade de aceitar a pluralidade. É o que Paz (2006, p. 44), entende por "nenhumação", isso é, "uma operação que consiste em fazer de Alguém, Nenhum":

\footnotetext{
É inútil que Nenhum fale, publique livros, pinte quadros, coloque-se à cabeça. Nenhum é a ausência dos nossos olhares, a pausa da nossa conversa, a reticência do nosso silêncio. É o nome que sempre esquecemos por uma estranha fatalidade, o eterno ausente, o convidado que não convidamos, o vazio que não enchemos. É uma omissão.
}

Entendo como os autores que se trata de uma ontologia, de uma forma de existir porque quando o do lado de cima da linha invisibiliza os outros, nega a existência desses outros, não é uma questão de dizer que os saberes deles é que valem, o efeito disso é afirmar que a existência deles é a única que vale, os outros não merecem nem existir, um pensamento perverso de exclusão. 


\section{Os grupos minoritários e os desafios dos processos de escolarização na visão deles mesmos.}

A partir da necessidade de vozes que rompam com a narrativa dominante, e pela necessidade de tornar visível os que encontram-se do outro lado da linha, Potiguara (2004), por meio da sua produção literária e de sua militância política, busca defender os direitos dos povos indígenas ao resgatar o que thes foi tomado pelos colonizadores e preservar sua cultura. Em seu livro "Metade cara, metade máscara" (2004), a personagem principal não é uma única mulher, mas inúmeras, que comungam uma história de violência, deslocamento e alienação, mas que de outra forma, constroem uma afirmação identitária de luta pela preservação de sua cultura e ancestralidade, e enfatiza: "gosto de ser identificada sempre como indígena que é a força maior que eu tenho na minha família, que é minha identidade enquanto povo indígena, povo Potiguara de origem indígena potiguara" (Potiguara, 2008, p. 4). Em consonância com a autora, trago o recorte da aluna indígena 7214 participante desta pesquisa quando enfatiza que: "Sou Guarani Kaiowá com muito orgulho! Simplesmente e orgulhosamente sou indígena. Em águas tranquilas as coisas se refletem com uma mente tranquila." Em razão da migração forçada pelo neocolonizador e a falta de condições de sobrevivência nas aldeias, ao índio é posto o desafio de viver longe de sua terra: "Eu não tenho minha aldeia/Minha aldeia é minha casa espiritual/Deixada pelos meus pais e avós/A maior herança indígena/Essa casa espiritual/É onde vivo desde tenra idade/Ela me ensinou os verdadeiros valores." (POTIGUARA, 2004, p. 131). Para expandir essa discussão, trago o poema "Brasil", presente no livro "Metade cara, metade máscara" de Potiguara (2004), no qual a autora questiona a visão identitária frente à sociedade e o resgate da ancestralidade como uma ferramenta de afirmação cultural do povo indígena diante da contemporaneidade.

Para mais, sua produção literária fala de memória, das experiências, vivências e saberes de grupos marginalizados e invisibilizados ao longo da história. Denuncia os sofrimentos em referência ao desenraizamento forçado pela colonização, obrigando-os também a abandonar a cosmovisão que orientava suas vidas, querendo, como afirma Glissant (2005), impor uma raiz única que mata todas as outras a sua volta, por isso, o rizoma é a raiz que vai ao encontro de outras raízes. 
Que faço com a minha cara de índia? E meus espíritos, e minha força, e meu tupã, e meus círculos?

Que faço com minha cara de índia? E meu toré, e meu sagrado, e meus "cabôcos" e minha terra?

Que faço com minha cara de índia? E meu sangue, e minha consciência, e minha luta e nossos filhos? (...) barriga brasileira, ventre sagrado, povo brasileiro, ventre que gerou o povo brasileiro, hoje está só...a barriga da mãe fecunda e os cânticos que outrora cantavam, hoje são gritos de guerra contra o massacre imundo.

Nosso ancestral dizia: temos vida longa, mas caio da vida e range o armamento contra nós. Mas enquanto eu tiver o coração aceso, não morre a indígena em mim, e nem tampouco os compromissos que assumi perante os mortos, de caminhar com minha gente passo a passo e firme em direção ao sol. (POTIGUARA, 2004, p. 102).

Este poema me faz pensar que o que se faz pelo outro, não é por um outro em abstrato, mas com quem se tem um compromisso definido por valores morais, em que o coletivo e o social não entram em contradição com o individual, o que a aluna indígena Guarani Kaiowá 7214 participante da pesquisa diz em outras palavras ao afirmar que: "Quero ser professora de línguas, porque o meu povo tem muita dificuldade em aprender a língua portuguesa e, sei que, dessa forma, estarei ajudando as pessoas da minha aldeia a superarem essa dificuldade". Analiso que trata-se de desenvolver os interesses individuais de maneira que eles coincidam com as necessidades sociais de seu povo e de sua comunidade. Além disso, é preciso reconhecer a importância do movimento indígena iniciado em 1970, pois segundo Munduruku (2012, p. 222), em sua tese de doutorado "O caráter educativo do movimento indígena brasileiro (1970-1990)", defende que este movimento foi responsável por conquistas institucionais a respeito dos direitos dos povos nativos:

Talvez a maior contribuição que o movimento indígena ofereceu à sociedade brasileira foi a de revelar - e, portanto, denunciar a existência da diversidade cultural e linguística. $\mathrm{O}$ que antes era visto somente como uma presença genérica, passou a ser encarado como um fato real, obrigando a política oficial a reconhecer os diversos povos como experiências coletivas e como frontalmente diferentes da concepção de unidade nacional.

Em diálogo com a importância do movimento indígena, destaco também a obra "Oré awê roiru'a ma: todas as vezes que dissemos adeus", de Jecupé (2002), na qual há a preocupação de defender as heranças culturais do povo indígena por meio da literatura, bem como denunciar a incompreensão do branco sobre os 
saberes indígenas e sua incapacidade de preservar a natureza. O autor enfatiza a necessidade do índio em ajudar o branco a salvar o meio ambiente e, nesse sentido, o saber do índio é superior ao do branco, uma vez que o indígena construiu e desenvolveu sua civilização conectado à natureza. Nesta obra, o autor traz a sua história por meio de memórias, para encontrar as raízes ancestrais e encontrar-se a si mesmo, uma memória seletiva que escolhe elementos importantes a partir de fatores emocionais ou sociais.

\begin{abstract}
Apresento-me como txucarramãe pelo fato de ser um guerreiro sem armas (...) comecei uma tarefa, a partir dos ensinamentos que foram passados, de difundir a tradição, plantando agora, para o próximo ciclo da natureza cósmica, nesta terra chamada Brasil, sementes ancestrais para o florescimento de uma nova tribo. (JECUPÉ, 2002, p. 12).
\end{abstract}

A escrita da narrativa é, para Jecupé, uma maneira de manter a cultura indígena na sociedade brasileira. Quando escolarizado, o autor relata que foi obrigado a mudar seus costumes e teve que usar uniforme, sapatos e adotar um nome não indígena, ou seja, sofreu um processo forçado de aculturação. Contudo, ele descobriu na escola a aprendizagem da escrita e, por meio dessa ferramenta, ele defende a desconstrução de imagens estereotipadas de seu povo. Assim, rememora as palavras de seu pai:

\footnotetext{
O Pai me disse que era uma maneira de nos defendermos. Perguntei o que era escola. Me respondeu que era um lugar onde se riscava com traços o que se falava, e que qualquer um podia dizer exatamente o que se havia falado olhando para aqueles traços, mesmo que se passassem sóis e luas. Isso me deixou encantado. (JECUPÉ, 2002, p. 21)
}

Por meio de suas obras, Jecupé faz uso da escrita para combater os preceitos construídos com a colonização, e luta por um espaço em que a convivência de diferentes vozes e saberes possa existir, no qual os diferentes povos possam cooperar na construção de um Brasil inclusivo na ação de aceitar o "outro". Saliento a importância desse pensamento em um momento político que vai na direção contrária de um país mais inclusivo. Trago para o texto acadêmico alguns autores indígenas também para desconstruir a ideia de que são apenas "contadores de histórias", como alguns pensam, ao contrário disso, são produtores de conhecimentos. 
Em continuidade ao processo de análise, destaco duas afirmações de dois alunos indígenas participantes desta pesquisa, quando interrogados sobre o porquê querem ser professores e de qual disciplina. Os alunos responderam que querem ser professores de Letras Português/Inglês para:

A03: Melhorar a qualidade do ensino na minha aldeia.

A6932: Para ajudar na educação nas aldeias.

Em meu percurso como professora da Educação Básica, tive a oportunidade de ser docente em região periférica em que havia alunos indígenas estudando em escola para alunos não indígenas. Diferente das respostas dos outros alunos que gostariam de se formar para ter seu próprio escritório ou consultório e ganhar bastante dinheiro, os alunos indígenas pensavam em se formar professores, médicos, advogados e engenheiros agrônomos para poderem retornar a sua aldeia e aplicar os conhecimentos adquiridos para a melhoria de sua comunidade como um todo, conforme já explicitado anteriormente pela aluna indígena 7214. Percebo outras formas de pensamento - 0 da coletividade e da solidariedade nas declarações dos alunos 03, 6932 e 7214. Ainda sobre a importância do estudo da língua portuguesa, como também exposto por Jecupé (2002), e em consonância com os alunos supramencionados:

\begin{abstract}
A importância do estudo da língua portuguesa para nós como alunos é uma conquista tanto para nós como alunos e para a comunidade. Aprender escrever, ler, interpretar, e aprender a usar a língua portuguesa como defesa da comunidade. Para que nós saibamos avançar o inimigo e lutar sobre o direito indígena que está ocorrendo sempre no preconceito. Também para aprender e trazer o desenvolvimento a comunidade como projeto sustentável e outro que nossa comunidade precisa. Isso que eu particularmente sempre pensei para desenvolver durante o curso de licenciatura na UFG, mesmo que seja complicado. Mas temos que avançar, conquistar a dificuldade que nós passamos. (TAPIRAPÉ apud NASCIMENTO, 2012, p. 313).
\end{abstract}

Sobre o papel da língua na educação indígena no Brasil e da disseminação da alfabetização e da escrita, Menezes de Souza (2019) discute que essas estão ancoradas em um lócus de enunciação não indígena, isso se torna aparente na falta de apreciação ou compreensão da tradição oral indígena e chama a atenção para o fato de que as gramáticas são produtos da escrita e de uma cultura letrada e, como tal, pressupõem a superioridade do conhecimento representado na escrita em 
relação ao conhecimento da oralidade, "e essa superioridade deve-se à natureza descontextualizada do conhecimento escrito que, uma vez retirado de seu local de origem, permite um exame racional e abstrato" (MENEZES DE SOUZA, 2006, p. 5). Para o autor, dizer que essas culturas e suas línguas não são normativas não significa que para elas não há normas ou regras; significa rejeitar conceito de norma fixa, estática e descontextualizada. Outro ponto relevante a se refletir é que "mesmo quando o linguista (informado e consciente) acredita estar analisando do ponto de vista do nativo, o resultado drástico desse desconhecimento é a perpetuação da diferença colonial" (MENEZES DE SOUZA, 2006, p. 8). Considerando-se que a escrita alfabética registra a fala, mas não o falante, separando e distanciando a fala do falante, descontextualiza a informação ou o conhecimento que pretende representar, ou seja, do ponto de vista indígena, informação descontextualizada não pode ser conhecimento e precisa ser ancorada por imagens de perspectivismo e contexto situado.

Desse modo, para os indígenas, o aprendizado se desenvolve por meio da participação e observação das ações dos outros, e ouvindo narrativas. Entretanto, na visão eurocêntrica, as línguas indígenas sem gramáticas escritas, são formas menores de linguagem. Para mudar esse cenário, Menezes de Souza (2019) sugere que é necessário trazer para as aulas os conceitos da Linguística Aplicada no ensino de Língua Estrangeira (LE), cuja visão vê a escrita como uma série de práticas e discursos sociais, na qual grande parte da metodologia usada no desenvolvimento da LE também pode ser utilizada com as devidas adaptações em contextos de língua materna ou segunda língua. Para ampliar esse debate por meio de um outro ponto de vista, cito um recorte de uma entrevista de uma aluna negra:

\footnotetext{
É muito difícil, para quem luta pela visibilidade, esconder-se atrás de um padrão de escrita em que os textos, por vezes, não carregam a nossa identidade, porque em algumas situações não nos é permitido explorar nossos limites; e nossas palavras hermeticamente rebuscadas aplacam nossos sentimentos que, envidraçados, se desidratam e se mumificam. (SÔNIA, estudante negra, mestranda em Educação Ambiental apud PONSO, 2018, p. 1533).
}

Reflito sobre a necessidade das universidades estarem atentas a esse tipo de situação enunciada por esta aluna, pois as atividades acadêmicas muitas vezes podem causar retraimento e bloqueios em alguns alunos. Se os alunos do meio 
urbano têm dificuldades para compreenderem a convenção da escrita acadêmica, a situação se agrava ainda mais com estudantes indígenas ou quilombolas, oriundos de culturas predominantemente orais (MENEZES DE SOUZA, 2006). Em outras palavras, esses grupos não têm a mesma exposição anterior às práticas de letramentos que os outros estudantes universitários urbanos. Sobre essa questão, Street (2014) distingue o letramento colonial que é transmitido de uma sociedade externa para uma sociedade iletrada, e o letramento dominante que é difundido pelo grupo dominante a outros membros e subculturas dentre de uma sociedade. Para problematizar essa questão, destaco a resposta ao questionário de pesquisa dessa aluna sobre a principal razão pela qual ela deseja ser professora.

A6005: Meu pai nunca terminou o $1^{\circ}$ ano do Ensino fundamental, e isso pra mim não é vergonha e sim uma oportunidade para poder ensiná-lo outra vez. Sou paciente, amo ensinar, pois o conhecimento é algo que ninguém nunca vai tirar de você, quero ser professora.

Para melhor analisar a questão sobre a preocupação dessa aluna em ajudar seu pai no processo de escolarização, destaco algumas características dessa família extraídas do questionário de pesquisa: pai negro e trabalha na roça; mãe parda, do lar e possuiu o Ensino Fundamental II incompleto; a renda familiar é um pouco maior que um salário mínimo e a família é constituída por quatro pessoas; a aluna se autodeclara mulata ou parda, sempre estudou em escola pública, trabalha desde os 12 anos de idade para ajudar nas despesas. Reflito ao pensar que essa é a realidade de uma parcela significativa da população sul-mato-grossense, pessoas que não tiveram condições de concluir seus estudos, porque a necessidade do alimento na mesa sempre foi e continua sendo uma urgência, uma questão de sobrevivência. Entretanto, apesar de todas as dificuldades, essa aluna consegue compreender a importância do conhecimento como algo que "ninguém poderá tirar dela". Isso é tocante, uma vez que seus pais não tiveram essa oportunidade e ela luta para que isso não aconteça consigo. Analiso também que ela relata um fato relevante para a escolha de sua profissão, uma vez que enuncia a problemática do pai que ainda não conseguiu terminar o $1^{\circ}$ ano do Ensino Fundamental e ela quer ajudá-lo a superar essa questão. Entendo que o relevante pode ser tanto uma experiência positiva como negativa, pois relevante é tudo o que deixa uma marca na história de vida da pessoa e, nesse sentido, percebo que se formar professora para 
esta jovem, é uma das possibilidades por meio das quais ela acredita que pode superar as experiências difíceis.

Em face a esse cenário, recordo-me do meu avô, negro e sem escolaridade, mas com muita sabedoria e que tinha o sonho de ver os filhos formados em uma universidade. Ele não mediu esforços para isso, trabalhou na roça e no garimpo, se sacrificou para que os filhos conseguissem estudar. Na época, no estado de Mato Grosso não havia universidade, então meu pai teve que migrar para outro Estado. No ano de 1967, meu pai se formou Engenheiro Agrônomo na Universidade Federal do Paraná - PR. Conta meu pai que muitas foram as dificuldades, às vezes, ele só se alimentava uma vez ao dia, e muitos foram os preconceitos por conta da cor da sua pele, em uma capital de predominância branca, mas mesmo assim ele não desistiu.

Do outro lado, meus avós por parte de mãe, que vieram do Japão para o Brasil para construírem uma nova vida. Tiveram sete filhos e todos foram alfabetizados pelos próprios pais na Língua Japonesa, pois moravam na roça. Conta minha mãe que foi para a escola brasileira aos 8 anos de idade, na qual, aos poucos foi sendo alfabetizada na Língua Portuguesa. Aos 12 anos, para continuar os estudos, teve que sair da roça e ir trabalhar de babá e morar na casa de uma família. Quando atingiu a maioridade, sempre trabalhando, conseguiu cursar o magistério e se formar professora. Conto um pouco dessas histórias neste trabalho, pois significam muito para mim e quando me encontro em alguma situação adversa, recordo essas histórias, entre tantas outras que ouvi ao longo da vida de outras pessoas, e isso me faz superar as adversidades da vida.

Inspirada na emblemática música El condor passa, prefiro ser como 0 condor que voa nas alturas, que se arrisca e que é símbolo da liberdade - entendida neste texto como a liberdade de expressar minhas ideias, meus saberes outros, minha ancestralidade, meus sentimentos, minha espiritualidade, aquilo que me constitui como um ser único e que jamais quero ou posso me desvencilhar.

Retomo por meio dos exemplos citados anteriormente sobre as dificuldades de grupos oriundos de culturas predominantemente orais, a discussão sobre o caráter minoritário da língua desterritorializada, quando Deleuze e Guattari (2002, p. 28) afirmam que: 
Sendo estrangeiro na própria língua, envergonhando-se, gaguejando, deixando emergir o sotaque e o estranhamento de quem fala fora do lugar $e$ ainda assim aceita e assume o não-lugar como seu deserto, na impossibilidade de uma origem.

Em concordância com as observações dos autores, analiso que os problemas enfrentados por esses grupos minoritários (indígenas e quilombolas) são amplos ao considerar que fica sob a incumbência deles o aprendizado da língua do outro com todos os seus aparatos formais (escrita, gramática e convenções), o que pode, para alguns, implicar a desistência dos cursos nas universidades, conforme mencionou a professora 4 , por meio de sua experiência de mais de 40 anos tanto com alunos da Educação Básica quanto da universidade. Portanto, o desenvolvimento de ações de permanência que valorize as experiências culturais e os saberes desses grupos, deve fazer parte do processo de acolhimento das universidades, pois segundo Milton Santos (1999, p. 5), "a cultura é, ao mesmo tempo, uma imagem projetada do mundo e de cada eu. Ela é também um traço de união entre cada qual, a interioridade, o lugar, a exterioridade imediata da natureza". Analiso que as cobranças sobre esses grupos de que "sejam como tal" revelam uma ignorância da sociedade branca, uma vez que a maneira de pensar e de agir de parte desses grupos estão ligadas ao coletivo, a territorialidade, ao respeito a natureza e aos animais, a ancestralidade, a reverência aos conhecimentos e experiências dos mais velhos, valores que os que se dizem "superiores" deveriam aprender com eles e não o contrário.

Para ampliar o campo teórico sobre a discussão em voga, recorro ao conceito de Letramento de Reexistência pensado por Souza (2011, p. 36):

Os Letramentos de Reexistência mostram-se singulares, pois ao capturarem a complexidade social e histórica que envolve as práticas cotidianas de uso da linguagem, contribuem para a desestabilização do que pode ser considerado como discurso já cristalizado em que as práticas validadas sociais de uso da língua são apenas as ensinadas e aprendidas na escola formal.

A autora afirma que é preciso reexistir em um contexto sócio-políticoeconômico opressor e que a linguagem tem papel fundamental, pois envolve modos de produção de conhecimento a partir da insurgência, da resistência e da necessidade de um olhar contra-hegemônico, antirracista e decolonial, da 
desobediência epistêmica, da autonomia e do protagonismo na reinvenção da palavra por meio de práticas educadoras criativas, acolhedoras e interventoras.

Em concordância com Souza (2011), Anastácio, Pereira e Fraga (2017, p. 3), no processo de reexistência "é fundamental que reencontremos nossas vozes, as quais foram silenciadas, porque somente com nossas vozes é que poderemos contar nossas histórias - do passado e do presente - a partir do nosso ponto de vista". Isso quer dizer que a reexistência é uma prática de letramento que não ocorre em uma enunciação individualizada, mas coletiva, comprometida com o próprio grupo e suas lutas, na qual a consciência crítica denuncia-se por meio de uma escrita questionadora, consciente do seu lugar de fala e propositora de ações.

\footnotetext{
É preciso REEXISTIR. E reexistir ainda mais e mais em um contexto social, político e econômico que nos oprime cotidianamente exigindo reposicionamentos de nossos lugares de atuação, de proposição e de ação política na qual a linguagem tem papel fundamental. (Souza, Jovino, Muniz, 2018, p. 1).
}

Acordante aos autores, penso que nesse sentido, os estudos dos Letramentos também sejam importantes para a restituição do lugar de fala, da originalidade de pensamento e de escrita, da produção teórica desses grupos que até então foram vistos como destituídos da condição de fala e da produção de conhecimentos válidos, o que discuto a seguir.

\section{A decisão por ser professor na área de Línguas e os estudos dos Letramentos}

A perspectiva dos estudos dos Letramentos compreende as práticas de letramentos como múltiplas e historicamente situadas. Nessa acepção, Kleiman (1995, p. 11) esclarece que essa perspectiva está para além das habilidades de ler e escrever, e podem ser compreendidas como "um conjunto de práticas sociais, cujos modos específicos de funcionamento têm implicações importantes para as formas pelas quais os sujeitos envolvidos nessas práticas constroem relações de identidade e de poder". Entendo com a autora que essa concepção considera os contextos locais, os referenciais culturais específicos dos diversos grupos e seus diferentes saberes, o que contribui para o entendimento dos múltiplos sentidos atribuídos a linguagem, por isso, os letramentos são múltiplos e, também, são críticos. 
Em relação à perspectiva dos Multiletramentos na aprendizagem de Línguas Estrangeiras, Maciel; Takaki; Ávila e Faustino (2019) defendem que podemos ressignificar as formas de ensinar, considerando a participação e interação dos alunos por meio de análises críticas e construção de sentidos de textos multimodais, com o propósito de torná-los coautores de sua própria aprendizagem. Como exemplo, por meio de uma pesquisa realizada em uma escola pública estadual periférica de Campo Grande - MS, com alunos do $2^{\circ}$ ano do Ensino Médio, cujo objetivo foi discutir de que maneira os alunos se apropriam do gênero discursivo propaganda, os autores concluíram que os alunos ao compreenderem que o texto multimodal traz realidades, conseguiram fazer uma avaliação ao comparar essas realidades com as de suas comunidades e, por meio desse exercício, expandiram a construção de sentidos sobre diversos gêneros textuais.

Outro estudo realizado por Marques, Cintra e Camargo (2019), com alunos da Educação de Jovens e Adultos - EJA, em uma escola pública estadual, localizada em área industrial a $25 \mathrm{~km}$ de Campo Grande - MS, teve a preocupação de oportunizar a esses alunos a ampliação do processo de leitura crítica de diversos tipos de textos multimodais. Os autores verificaram que os alunos tinham uma visão limitada sobre texto, pois para eles, texto seria algo impresso e não uma imagem, um gráfico, entre outros. Por meio de diversas atividades com textos multimodais, os alunos conseguiram expandir os processos de leitura crítica e produção textual, desenvolvendo-as a partir de sua realidade local. Os autores ressaltaram ainda que trabalhar com multiletramentos desafia duas grandes perspectivas: a multiplicidade das formas de comunicação usadas para a construção de sentidos, e o aumento da diversidade linguística e cultural que caracteriza a sociedade atual.

Por meio de análises e reflexões sobre como o professor ressignifica as teorias de letramentos, multiletramentos e ensino crítico, Maciel, Ono, Silva e Cuellar (2019) realizaram um estudo com uma turma do 5ํano do Ensino Fundamental de uma escola pública no município de Ribas do Rio Pardo - MS, em que buscou-se oportunizar o desenvolvimento da autoria das crianças de modo que elas pudessem observar e analisar seu próprio processo de aprendizagem, por meio de diversas atividades com textos multimodais sobre o "Dia Mundial da Água". Os autores verificaram que a partir da proposição dessas atividades, foi possível ampliar o trabalho pedagógico do professor em sala de aula, bem como de possibilitar 
aprendizagens com foco na agência dos alunos. Além disso, os autores destacaram o prazer dos alunos com as atividades multimodais produzidas por eles mesmos, como a criação de histórias, paródias, desenhos e vídeos em um ambiente de colaboração.

Os autores supramencionados são acadêmicos no estado de MS e vêm desenvolvendo Letramentos Críticos em suas aulas e pesquisas, obtendo resultados interessantes que poderão gerar reflexões ou até mesmo ressignificações no processo de aprendizagem dos estudantes.

Acerca da importância dos estudos dos Letramentos, Monte Mór (2009, p. 1) destaca duas grandes contribuições:

"As pluralizações (o reconhecimento da heterogeneidade, da diversidade, do hibridismo) e a perspectiva crítica (a percepção das relações de poder no discurso; que a língua não é neutra, é política). Isto é, ela reflete uma visão de sociedade, via as suas várias instituições.

Para problematizar sobre a importância de desenvolver atividades com ênfase nos Letramentos Críticos, conforme enfatiza a autora, trago para discussão alguns recortes dos participantes desta pesquisa quando justificam o porquê gostariam de se formar professores de Língua Inglesa.

A1894: A vontade de aprender a falar inglês fluente como um nativo e de querer viajar pelo mundo e trabalhar com estrangeiros levando uma renda boa para mim e para minha família.

A ideia de dominar um idioma e falar como um nativo como interpreta 0 aluno sobre a finalidade principal de aprender o Inglês, sempre foram objetivos do ensino de línguas no Brasil, conquanto Monte Mór (2019, p. 2) explica que esse conceito se deslocou em razão dos estudos sobre decolonialidade e que "espera-se que um professor saiba bem o idioma estrangeiro que ensina, sem que precise se tornar um falante nativo." Nessa direção, a visão anterior de aprender inglês para falar como um nativo pode ser ressignificada, uma vez que faz referência a uma perspectiva de colonialidade, conforme discutida no início deste capítulo.

Vejamos um outro ponto de vista em que o aluno pensa que aprender o Inglês é muito mais do que falar como um nativo, mas uma possibilidade de ampliar conhecimentos e aprender sobre diferentes culturas. 
A3964: Eu escolheria ser professor de inglês porque é uma área muito rica em relações de conhecimento e cultura, e eu aperfeiçoaria com toda eficácia possível, pois é uma coisa na qual eu gosto.

Em relação aos objetivos da aprendizagem da Língua Inglesa na Educação Básica, Monte Mór (2019) destaca que aprender um idioma estrangeiro representa muito mais do que estar inserido em um mundo globalizado ou na possibilidade de viajar algum dia para um país falante de Inglês, mas significa uma experiência com o outro, portanto, "integrar o aprendizado de línguas com a formação cidadã passa a ser prioridade". (MONTE MÓR, 2019, p. 1). A autora enfatiza que esse aprendizado pode promover ainda a melhor compreensão do aluno sobre as diferenças e a diversidade linguística e cultural, por meio de interações e de um aprendizado colaborativo, o que a aluna em questão, enfatizou em outras palavras.

Cito outra declaração do aluno que quer ser professor de Inglês porque pretende morar no exterior.

A5320: Porque quero morar nos EUA ou Canadá, pois a vida nesses países é muito melhor e será mais fácil se eu for professor de inglês.

Nesta asserção, é possível verificar que o aluno pensa que imigrar para outro país, poderá resolver os problemas vivenciados por ele no país de origem. Amplio essa análise ao refletir que a colonização de muitos países por algumas potências europeias e as formas atuais de neocolonização e dominação imperial chamadas de globalização constituem-se no mais característico traço da desigualdade social, "na qual as populações sofrem migrações em grande escala, seja fugindo da miséria e da fome, seja procurando um eldorado em cidades do primeiro mundo". (GAUTHIER, 2012, p. 17). Com o objetivo de uma releitura crítica da visão cultural herdada dos europeus, Monte Mór (2008, p. 178) sublinha ser necessário disponibilizar aos alunos "teorias que possibilitem uma intervenção ou ruptura no modo de pensar e tratar a cultura, dentro e fora do âmbito escolar e acadêmico, fato este que se concretiza em proporções talvez restritas em relação ao que se desejaria que fosse". Em corroboração com a autora e a afirmação do aluno, ainda é reduzido o modo como nós, professores, discutimos essas questões de imigração em nossas aulas, um exemplo disso é sobre o crescente número de refugiados que vivem hoje no Brasil e os quais, na maioria das vezes, tratamos como colonizados, subalternos e inferiores. 
Sobre o aspecto do desenvolvimento crítico nas escolas e universidades, Monte Mór (2018) ressalta que essas instituições não são as únicas responsáveis por promover a criticidade, uma vez que há também pessoas sem escolarização, porém críticas, de outro lado, há escolarizados que apoiam a neutralidade científica. A autora reforça que faz parte das atividades do docente promover momentos de ampliação do processo de leitura e construção de sentidos que favoreçam o desenvolvimento crítico do aluno, uma vez que saber ler e escrever é necessário para o exercício da cidadania.

Analiso a seguir, a afirmação do aluno que entende que o Inglês é a língua mais importante de todas.

A3497: Porque o inglês é a língua que domina o mundo, quero dizer, é a língua mais importante que existe, por isso quero ser professor de inglês.

Mesmo que atualmente haja esforços por parte de muitos professores em promover as formas plurais de conhecimentos e a diversidade cultural, linguística e social nas aulas, os currículos escolares permanecem inalterados, ainda se baseiam em uma proposta que prioriza a homogeneidade e a normatividade linguística e cultural, apoiados em uma ideia eurocêntrica e conteudista, o que se revela na afirmação do aluno. Dessa maneira, penso que como professores de línguas, podemos reduzir esses efeitos quando abordamos textos que enfatizam as diferentes culturas de diversos povos, pois segundo Monte Mór (2014, p. 244), "na concepção de cultura segundo a noção da diversidade, a aprendizagem de uma língua estrangeira pode favorecer a promoção de uma educação crítica". Outrora, não se pode negar a visão colonialista impregnada em vários conceitos de ensino da Língua Inglesa, portanto, seu ensino não pode se restringir a uma visão monolíngue em que esse idioma se sobreponha as outras línguas, pois assim, reforça-se a ideia do colonizador. Diferentemente, pode-se incentivar a perspectiva crítica oportunizada pelas experiências que evolvem a aprendizagem de outros idiomas.

A proposta do Letramento Crítico a ser desenvolvida com alunos da Educação Básica e das universidades, segundo Monte Mór (2018, p. 307) envolve o repensar dos mais variados textos e a "necessidade de desenvolver o olhar, a percepção crítica, de maneira a the possibilitar a visibilidade de cenas que, então, Ihe pareciam imperceptíveis". Entendo como a autora que a proposta do Letramento Crítico em nossas aulas, pode contribuir sobremaneira para que os alunos busquem 
outras interpretações possíveis para os diversos textos no ambiente escolar e, também, fora dele, uma vez que a escola não representa mais o único lugar no qual se desenvolve a aprendizagem dos alunos.

Para que essas ações possam se materializar, no cenário atual de lutas por igualdade de direitos, de questionamentos sobre a distribuição desigual de poder e da marginalização de alguns grupos sociais, Monte Mór (2019, p. 12) alerta que "os programas de formação docente encontram-se - ou deveriam se encontrar - sob revisão, de forma a preparar professores preocupados em aproximar a educação da sociedade e de refletir sobre as diferentes mentalidades". Acerca dessa preocupação, recentemente, participei como docente de um curso de PósGraduação em Multiletramentos e Processos autorais na Educação Básica em parceria com a UEMS e a SED/MS, cujos objetivos voltaram-se para a promoção de uma educação linguística com vistas a heterogeneidade, alteridade, autoria e agência dos participantes em espaços transculturais de aprendizagem formal e informal.

Ao final do curso, os professores participantes da Educação Básica de escolas públicas estaduais de MS publicaram um livro sobre as experiências vivenciadas por eles e por seus alunos no processo de ensino e aprendizagem de leitura crítica e construção de sentidos de diversos tipos de textos multimodais. Iniciativas como essa são importantes porque oportunizam ao docente ser pesquisador de sua prática pedagógica, bem como produtor de teorias.

\section{A construção de sentidos sobre a carreira docente pelos participantes da pesquisa que em algum momento pensam em ser professor.}

Na sequência discuto sobre a parcela de 36,62\% dos alunos participantes da pesquisa que alegam que em algum momento pensam em ser professor.

Para os participantes da pesquisa que em algum momento pensam em ser professores, conforme os excertos abaixo, organizados em categorias, o interesse em se tornar professor está relacionado a: A) Gosto pela profissão, pela ação de ensinar e por gostarem de trabalhar com crianças; B) Por admiração e influência de bons professores; C) É um sonho de criança; D) Por ser a profissão que forma todas as outras; E) Por acreditar que é possível melhorar a educação no país. 


\section{A) Gosto pela profissão, pela ação de ensinar e por gostarem de trabalhar com crianças:}

A961: Pois é uma área que necessita de profissionais, como eu gosto de ensinar seria um bom trabalho para mim, e eu estaria sempre aprendendo.

A37: Gosto do trabalho dos professores de ensinar os alunos, e gostaria de trabalhar com crianças ou até mesmo adolescentes.

A3357: Porque gosto de ensinar o que sei, tenho uma experiência já que ensino línguas orientais (chinês, coreano e japonês) a quem deseja aprender, e os interessados sempre aprendem e dizem que meu sistema de ensino é de qualidade.

A5302: Minha vontade de ensinar, meu amor por crianças e por ainda acreditar numa educação melhor.

A6188: Para ensinar as crianças a ter caráter e um futuro prospero longe de drogas, da prostituição, furtos etc.

A6399: Por amar as crianças, e acreditar que a educação ainda vale a pena e o quanto ela pode mudar a vida de um aluno, tanto como pessoa quanto profissionalmente.

B) Por admiração e influência de bons professores:

A6118: Amor por ensinar, amor em crianças e por achar lindo a forma de trabalhar da minha tia nessa profissão.

A6288: Sempre gostei de crianças, bem como de alfabetizar. Uma profissão que admiro muito e tenho vontade de exercer.

C) É um sonho de criança:

A6024: É um sonho de criança, ser professora.

A4588: Para ser professor requer muito conhecimento, e também é uma vontade de criança. Gosto de me envolver com crianças e pessoas. Sei que ser professor não é fácil, tive um pouco de experiência uma vez e gostei. E nunca sabemos tudo, sempre é bom aprender com as pessoas.

A6130: Porque gosto de interagir com as pessoas, não tenho timidez e sempre quis ser professor desde pequeno.

D) Por ser a profissão que forma todas as outras:

A2166: Porque o professor é à base de todas as outras profissões e gosto de passar os meus conhecimentos adiante, sei que essa profissão não é fácil, pois tem muitos alunos problemas nas escolas, espero poder ajudá-los assim como meus professores me ajudam, desejo passar isso a frente.

A6049: Por ser a profissão de maior importância na vida de uma pessoa, pois sem um professor não teria médico, engenheiro, advogado entre outras profissões, pois todos requer um ensino desde pequenos, por isso digo se caso fosse pra me tornar professora, eu seria professora de educação infantil, pois é na infância que começam a se formar os ideais de uma pessoa, e outra, adoro crianças. 
A7878: Porque eu gosto. A minha mãe é professora e eu já trabalhei como menor aprendiz em uma escola, gosto e me identifiquei na área.

\section{E) Por acreditar que é possível melhorar a educação no país:}

A498: Gosto de ensinar, acho que a educação é a base para a melhoria do nosso país.

A6936: Por necessidade de ensinar e torna as crianças pessoas melhores e tornar o Brasil forte na educação.

P9: Eu quero ser professor porque eu gosto de falar, eu gosto de ensinar, eu gosto de socializar com os outros aquilo que eu tenho", então existe esses estudantes, esse perfil de estudante, o estudante que dentro das suas práticas pedagógicas ele consegue se destacar numa oratória, numa explicação, aquilo que o professor não conseguir ele vai lá e explica, e aí ele vai se percebendo professor eu acho, ele vai se percebendo que ele gosta de ensinar o outro. [...] Então assim, essa identificação com o professor, com a metodologia do professor, com a empatia que esse professor possui e com esse desejo, porque assim, o ser professor é sempre um desejo, quando eu tenho um perfil de empatia eu fico querendo desenvolver essa profissão, porque eu vejo a realização do outro por meio das minhas ações. [...] "Eu quero ser professor porque eu tinha uma professora na educação infantil que era assim e assim", então isso traz memórias positivas e isso pesa muito no meu campo de escolhas, a gente escolher por aquilo que nos traz bem-estar.

Para ampliar o campo de análise, trago algumas justificativas expressas pelos professores do Grupo de Discussão ao optarem pela carreira docente.

P6: O gosto pela docência. Desde pequena dava aulas para as minhas bonecas de pano e tive também a influência de uma professora da quarta série do primário que, pela sua atuação me encantou e contagiou. Pode parecer do senso comum, mas é muito bom poder mediar o aprendizado dos estudantes e contribuir com a sua formação profissional. Tive proposta e sugestão da família e de amigos para atuar na área do Direito, mas não era o que eu queria.

P2: Ao estar prestes a terminar a graduação em Direito senti a necessidade de trabalhar. Estava de volta à casa dos meus pais e não tinha perspectiva alguma na área de formação. Sendo assim, ao analisar meus certificados e diplomas, comecei a me lembrar o quanto gostava de participar da vida da escola em que estudava Inglês em minha cidade natal (Bauru/SP). Refleti por um mês a respeito da decisão de encarar algo tão diferente do que havia estudado. Participei das entrevistas de emprego e de um treinamento. Conquistei a vaga e passei a lecionar das 13:00 às 22:00. Isso aconteceu em 1999. Depois de trabalhar por anos e anos em cursos de Inglês como segunda língua (em meados de 2010), resolvi cursar a graduação em Letras para me tornar então, professor da Educação Básica. Ao longo do curso, prestei o concurso público e, assumi minha vaga dias após a colação de grau em 2015.

$\mathrm{P} 1: \mathrm{Na}$ época em que me inscrevi para o processo seletivo na universidade, eu já ministrava aulas de Inglês em um curso de idiomas em minha cidade natal. O curso de licenciatura em Letras - Hab. Port./Inglês era o que mais me atraía dentre as opções de cursos e universidades públicas mais próximas de minha cidade natal. 
P9: Fiz graduação em Química tendo em vista a possibilidade dessa formação me possibilitar atuação em outras áreas como Indústria. Todavia, surgiu a oportunidade de ministrar aulas, então comecei a dar aulas e descobri que também gosto da docência.

P3: Antes de ingressar na universidade eu já dava aula particular e tinha empatia em ajudar meus colegas quando estudada, e outro fato era que adorava/adoro ler ao invés de ficar assistindo televisão.

P7: Sempre gostei de ensinar, e a principal razão é levar conhecimento às pessoas principalmente às crianças e adolescentes, para que estes possam desenvolver o pensamento crítico e o conhecimento de mundo.

P5: Relacionar com pessoas; possibilidades de crescer e amadurecer profissional e pessoalmente; salário fixo; concursada pelo estado de Mato Grosso do Sul; possibilidade de trabalhar em uma universidade, fazer pesquisas e chance de fazer pós-graduação; tinha chance de continuar em consultório de psicologia, posteriormente, mais madura e mais estruturada teoricamente.

Em simetria com os recortes acima, Bohoslavsky (1977) reforça que quando o sujeito pensa em uma profissão, ele pensa em algo que se relaciona com a realização pessoal, a felicidade, a alegria de viver. Nesse sentido, a motivação e o desejo são determinantes na hora da escolha de uma profissão. Será que a asserção desse autor justifica os depoimentos em A (Gosto pela profissão, pela ação de ensinar e por gostarem de trabalhar com crianças), em B (Por admiração e influência de bons professores), em C (É um sonho de criança), em D (Por ser a profissão que forma todas as outras); em $E$ (Por acreditar que é possível melhorar a educação no país)? E também de P6, P2, P1, P9, P3, P7?

Entretanto, analiso como Bourdieu (1989), que as escolhas profissionais não são apenas frutos de uma decisão pessoal, consciente e racional do sujeito, mas de uma operação de senso prático, orientada pela estrutura interiorizada que produziu toda a história anterior e que ainda conduz o presente.

Nesse sentido, alguns professores-participantes deixam pistas sobre essa "operação de senso prático" ou "estrutura interiorizada que produz a história", "momento histórico e ambiente sociocultural favoráveis", como em P2: "Ao estar prestes a terminar a graduação em Direito senti a necessidade de trabalhar"; em P9: "Fiz graduação em Química tendo em vista a possibilidade dessa formação me possibilitar atuação em outras áreas como Indústria. Todavia, surgiu a oportunidade de ministrar aulas"; em P5: "Relacionar com pessoas; possibilidades de crescer e amadurecer profissional e pessoalmente; salário fixo e concursada [...]; possibilidade de trabalhar em uma universidade, fazer pesquisas e chance de fazer pós- 
graduação; e chance de continuar em consultório de psicologia posteriormente, mais madura e mais estruturada teoricamente". O referido autor salienta que o destino de uma pessoa não se detém unicamente às características de sua personalidade vocação, caráter, aptidão, dons, como afirmam os participantes da pesquisa, mas depende também de se ter nascido em um certo momento histórico e ambiente sociocultural, determinado por elementos estruturais bem precisos como os de ordem política, econômica e educacional. Com efeito, esses elementos pesam sobre as opções de cada sujeito e, portanto, da mesma forma, podem orientar sua escolha profissional, conforme discutido também na análise anterior sobre a intenção de ingresso na Instituição de Ensino Superior e as escolhas profissionais.

Em razão das escolhas profissionais dos participantes estarem conectadas ao afeto e o desejo como afirma Bohoslavsky (1977), adenso ao campo político e analiso essa questão também por meio da obra "O circuito dos afetos: corpos políticos, desamparo e o fim do indivíduo" de Safatle (2018), quando o autor esclarece que uma forma de organização política, econômica e social alimentam um certo ritmo de nossos desejos e um circuito de afeto se naturaliza. Presos aos mesmos afetos de sempre não somos capazes de criar novas formas sociais, pois estamos acostumados a colocar a dimensão dos afetos apenas no que diz respeito a vida individual de nós sujeitos. Será que também a asserção desse autor justifica os depoimentos em A (Gosto pela profissão, pela ação de ensinar e por gostarem de trabalhar com crianças), em B (Por admiração e influência de bons professores), em C (É um sonho de criança), em D (Por ser a profissão que forma todas as outras); em $E$ (Por acreditar que é possível melhorar a educação no país)? E também os depoimentos de P6, P2, P1, P9, P3, P7? No entanto, como adverte Safatle (2018), nós sujeitos é que formamos a coletividade e o tempo todo afetamos e somos afetados, pois os afetos circulam entre nós e muitos deles são usados como instrumentos políticos para gerar determinados efeitos sociais, é o que discuto a seguir.

Antes de mais nada, é necessário entender também que a política é um problema de circuito de afetos, como afirma Safatle (2018), e envolve a questão de como somos afetados - o que nós sentimos e não sentimos, o que nós vemos e não vemos. Portanto, precisamos organizar o campo do que é visível, sensível e percebível, porque agimos por afetos e não por argumentos, ou seja, o que causa o 
nosso julgamento sobre algum fato é o afeto, como exemplo, cito a imagem emblemática de 1993, no Sudão, que mostra uma criança em desnutrição com um urubu a espreita. A imagem levantou uma série de discussões sobre a fome da população local, e com isso, o autor da fotografia Kevin Carter, sucumbiu ao julgamento público que o acusou de não ter ajudado a criança, e suicidou-se anos depois.

Será que é possível agirmos desafectados? Há uma racionalidade dos afetos, isto é, para Safatle (2018), aquilo que afeta a consciência de fora e leva a agir e a julgar não é resultado puro e simplesmente da nossa autonomia, porque estamos presos a uma certa concepção de autonomia que ao invés de ser um sinal de expressão da liberdade, é na verdade, uma expressão mais acabada de uma servidão. Somos causados por aquilo que vem de fora, porém nem tudo é involuntário, em outras palavras, nem tudo nos coloca em uma situação de servidão e sujeição, e é a capacidade de nos reconhecermos no que nos é involuntário, que é na verdade a figura maior da nossa liberdade.

Outro ponto discutido pelo autor é sobre a nossa miséria de imaginação política, nossa incapacidade de pensar criativamente a política que vem do fato de estarmos completamente presos a uma certa imagem conformista da vida social, ao explicar que os sujeitos são afetados primeiramente a partir de dois afetos: o medo e a esperança.

O medo como afeto político de coesão da vida social, porque todos os sujeitos são impulsionados por um desejo, um desejo que tem direito a tudo e como todos têm direito a tudo, chegamos em uma situação concorrencial, o que pode provocar a imanência de uma guerra de todos contra todos, e a única maneira de impedirmos essa guerra seria constituindo um poder soberano, o poder do Estado.

Esse poder do Estado prega ou diz que vai proteger os cidadãos uns dos outros, mas para isso, precisa do controle absoluto do poder, precisa da unidade do poder, da soberania encarnada na figura de um líder, e o medo funciona como esse elemento de coesão, em razão dos sujeitos terem medo uns dos outros, eles admitem a constituição de um poder que vai ter como função central transformar a insegurança em segurança, e assim "proteger o cidadão", ao lembrar ao sujeito que se ele não estivesse ali, o caos se instalaria. 
Além disso, é importante questionar como os sujeitos foram produzidos? O que é necessário perder para se tornar um sujeito? Que tipo de experiência é necessário deixar de se ter para se tornar um sujeito? Essas são questões importantes deste século para pensar, pois segundo Safatle (2018), os sujeitos não procuram apenas sua confirmação no outro, procuram a sua reinvenção no outro, talvez essa visão explicaria a busca pela profissão docente por influência de bons professores que os participantes tiveram no passado, para mais, eles procuram a capacidade de viver aquilo que ainda não conseguiram pensar. Querem uma imagem, mas que não seja uma imagem simplesmente atual deles mesmos, querem uma imagem que está disposta da virtualidade, que está sempre latente no presente, também este é um dado importante para que nós possamos saber criticar, ou colocar em evidência os afetos que nos colonizam, porque uma vida social baseada no medo como afeto político central, sempre verá o outro como invasor.

Sobre os dois afetos: medo e esperança, Spinoza (2015, p. 37) alerta que "não há medo sem esperança e nem há esperança sem medo. Medo e esperança são dois afetos que se articulam de maneira muito insidiosa", ou melhor dizendo, o medo é a expectativa de que um mal futuro ocorra, todavia, há a possibilidade que esse mal não ocorra, então, tem-se esperança de que o mal não se realize. Essa afirmativa também explicaria a busca pela profissão docente por influência de professores que tiveram no passado? Professores bem-sucedidos do passado poderiam ser indicadores de caminhos bem sucedidos, trazendo a esperança de uma escolha acertada? Do mesmo modo, já quem tem expectativa que um bem ocorra, sabe que esse bem pode não ocorrer, então, tem-se o medo de que essa expectativa não se realize. Logo, o medo e a esperança são dois afetos ligados a uma mesma temporalidade, e nós carecemos nos livrar da temporalidade da expectativa e da projeção de futuro para conseguirmos determinar nossa força e a nossa potência de atuação no presente. Com efeito, a nossa ausência de imaginação política, a nossa miséria de criação política vem do fato de nós não conseguirmos sair de um circuito de afetos ligados ao medo e a esperança, e ser capaz de ter uma imaginação mais produtiva.

Entendo com Rancière (2000), que política também implica a questão de se compreender porque em determinados momentos, as pessoas olham para si 
mesmas e acham que não têm mais nenhuma capacidade e nenhuma força para transformar nada, e passam a acreditar que são incapazes de produzir algo novo, porque quando elas realmente acreditam que são capazes de produzir, elas não precisam de uma imagem do que vão produzir. De outra forma, Adorno (1975, p. 75), ao pensar sobre a problemática do tédio, vai dizer que "nós chegamos em um momento no campo das Artes, em que nós devemos ser capazes de produzir aquilo que nós não sabemos o que é”. Essa afirmação me faz refletir que parte de nossas ações deveria ser impulsionada por alguma coisa que é da ordem do não sabido.

Na prática, quando desconfiamos de nossa capacidade de fazer, de fato não fazemos, não conseguimos mais fazer, não é só uma questão de falta de vontade ou de confiança, mas também de ignorar a dimensão da experiência e das condições para que aconteça. Com força, Safatle (2018) sinaliza que se por um lado existe um circuito de afetos que organiza uma sociedade e estrutura sua forma de vida, há acontecimentos que quebram esse circuito de afetos e abre para uma possibilidade de transformação, por isso, é indispensável exercitarmos a nossa capacidade de viver afetos que não conseguimos controlar, que nos despossuem e admitir um tempo que nos desampara.

Penso ser importante termos a consciência de que o nosso presente não é simplesmente o que aparece no instante agora, nosso presente é um tempo vivo de camadas profundas e nós ficamos, muitas vezes, só observando o que emerge na superfície, todas essas múltiplas camadas, todos as contradições e conflitos que é próprio de uma outra compreensão do presente, não conseguimos enxergar, e nos sentimos impotentes em relação ao tempo e aos acontecimentos. Essas camadas profundas de nosso tempo vivo é o que busco mostrar em minhas análises, porque não é possível fazer uma análise justa, sem revirar o que tem abaixo da superfície.

Em face a essas considerações, qual é a posição do professor em relação a esses conceitos de afeto e desejo? O professor pode ajudar o aluno a refletir sobre o seu contexto e, consequentemente, ajudá-lo a ampliar seu entendimento sobre a carreira docente, pois se o aluno pensa ser ruim formar-se professor, mas como ele seria/estaria se não estivesse aprendendo? 
Um aspecto importante de análise é que esses alunos que em algum momento pensam em ser professor ou até mesmo os que nunca pensaram nessa hipótese, mesmo que optem por um curso de graduação diferente da licenciatura no tempo presente, isso não significa que eles ao longo de suas vidas, posteriormente, decidam ser professor, conforme afirma o P2 que fez a graduação em Direito como sua primeira opção e após refletir muito descobriu seu interesse pela docência, iniciando a ministrar aulas em curso de línguas e depois, fez a graduação em Letras e, tornou-se também professor da Educação Básica. Também o P9 que fez graduação em Química com o intuito de trabalhar no setor industrial e, depois, surgiu-the a oportunidade de ministrar aulas e ele percebeu que gostava da docência; e no participante da pesquisa A3798, que declarou: "Não gosto, mas talvez serei professor de Direito na universidade".

Em meu percurso como professora, conheci alguns colegas para quem a opção pela licenciatura deu-se ao longo de sua trajetória profissional. Então, em relação a esses participantes da pesquisa, considero que nada impede que alguns se formem professores ao longo de seu curso profissional, mesmo que atualmente não seja esta sua opção. Nesse sentido, penso que pode haver um conflito entre o quantitativo mostrado e o qualitativo, uma vez que, o quantitativo neste caso, só pode mostrar o retrato atual da situação, e não uma projeção que considera mudança no pensar dos jovens sobre sua escolha profissional.

No capítulo seguinte, apresento e analiso os dados gerados que me permitem explorar as razões e desrazões que os participantes da pesquisa justificam para optarem ou não em se formarem professores. A partir de uma análise sobre o neoliberalismo, busco mostrar a eficácia das ideologias neoliberais reinantes que podem afetar a escolha profissional e os rumos de como os sujeitos se comportam em uma sociedade capitalista. 


\title{
CAPÍTULO III
}

\section{O INTERESSE OU NÃO PELA CARREIRA DOCENTE: DESAFIOS E PERSPECTIVAS}

\author{
Pois de amor andamos todos precisados, \\ em dose tal que nos alegre, nos reumanize, \\ nos corrija, nos dê paciência e esperança, força, \\ capacidade de entender, perdoar, ir para frente. \\ Amor que seja navio, casa, coisa cintilante, \\ que nos vacine contra o feio, o errado, o triste, o mau, \\ o absurdo e o mais que estamos vivendo ou presenciando.
}

Carlos Drumond de Andrade

O propósito deste capítulo, em conformidade com os objetivos da pesquisa, é apresentar e analisar os dados gerados que me possibilitaram verificar as razões e desrazões que os participantes da pesquisa justificaram para optarem ou não em se formarem professores. E ainda, inicio essa análise discutindo por meio das principais ideias de Arendt (1963), Bourdieu (2002), Nietzsche (2003) e Laval e Dardot (2016), sobre como o neoliberalismo e o Estado operam no sentido de afetar a escolha profissional e os rumos de como os sujeitos se comportam em uma sociedade capitalista, no caso, essa comunidade estudantil sul-mato-grossense. A minha intenção é tornar visível como opera o Estado em relação às instituições de ensino no sentido que estas sirvam aos interesses do mercado neoliberal.

\section{Como a eficácia das ideologias neoliberais reinantes pode afetar as escolhas profissionais?}

O neoliberalismo entendido por Laval e Dardot (2016), não é uma evolução do liberalismo, não é uma ideologia e nem uma economia política, mas é uma racionalidade porque atravessa de fato toda uma sociedade, portanto, estrutura a 
forma como os governantes atuam e também como os governados se colocam na sociedade. Os sujeitos submetidos a um regime de concorrência em todos os níveis, principalmente na forma de gestão das empresas, o crescimento acelerado do desemprego e a precariedade nas relações de trabalho, entre outros, são fatores determinantes para inibir/impedir a ação coletiva destes, ocasionado uma concorrência inter-individual que define novos modos de subjetivação, em que a polarização entre os que são bem sucedidos economicamente mina a sociedade e a cidadania.

O sofrimento causado por essa sujeição neoliberal, a mutilação que ela opera na vida comum, no trabalho e fora dele são tais que "não podemos excluir a possibilidade de uma revolta antineocolonial de grande amplitude em muitos países." (LAVAL E DARDOT, 2016, p. 30). Entendo com os autores que não podemos ignorar as mutações subjetivas provocadas pelo neoliberalismo que operam no sentido do egoísmo social, da negação da solidariedade e da desumanização que podem desembocar em movimentos reacionários, pois as condições de um confronto de grande amplitude entre lógicas contrárias e forças adversas em escala mundial estão se avolumando, haja vista, a pandemia da Covid-19 que tem revelado como o Governo Federal brasileiro opera no sentido de não preservar vidas, e justifica que essa ação se deve a importância do crescimento econômico que não pode desacelerar.

O neoliberalismo ameaça a destruição do imaginário democrático e coletivo, portanto, seria ingênuo pensar que este é somente a expansão do mercado em detrimento do Estado. Em outras palavras, o Estado sairia de cena para o neoliberalismo agir, mas é o próprio Estado que se transforma por meio das normas em um neoliberalismo. Laval e Dardot (2016) usam o termo Corporate state (Estado gerenciador) ao dizerem que este agiria como uma empresa, pois ele deixa de levar em consideração os anseios da população e ao fazer isso, mata a cidadania. Este Estado gerenciador se funda em um princípio que não é pelo povo, mas está a serviço da empresa que faz da competitividade um princípio constitucional, em que tudo se privatiza.

Sendo a lógica neoliberal a maior quantidade de lucro com pouco gasto, esse sistema se mostra muito astuto e adaptável. Esse fato instaura uma ditadura do corpo, como Arendt (1963, p. 72) alerta: 


\begin{abstract}
A pobreza é mais do que a privação, é um estado de constante necessidade e de miséria aguda cuja ignomínia consiste na sua força desumanizadora; a pobreza é abjeta porque coloca os homens sob ditadura absoluta dos seus corpos, isto é, sob a ditadura da necessidade tal como todos os homens a conhecem a partir da sua mais íntima experiência e independência de todas as especulações.
\end{abstract}

Esse excerto me leva a interrogar: O que fazer quando se é um escravo do próprio corpo e de suas necessidades? Acordante aos depoimentos dos alunos participantes da pesquisa que estudam e trabalham concomitantemente como em A245: "Eu ajudo a pagar o aluguel do barraco"; A2300: "Eu trabalho para comprar comida"; A5772: "A gente divide as contas de água e luz"; A4030: "Sou pai de família e preciso trabalhar para garantir o sustento"; e A1330: "Tenho uma filha e pago pensão", portanto, como analisou Arendt (1963), a pobreza é muito mais que a privação ou a renúncia, mas uma condição de incessante necessidade que obriga os sujeitos a viverem sob a ditadura da urgência.

Assim vivem as pessoas nesse sistema, desesperançosos, subjugados, desempregados, escravos modernos transformados em produtos, como bem apurou Arendt. Onde e quando haverá trabalho suficiente para todos se a lógica que impera é essa? É evidente que não há/haverá emprego para todo esse contingente. O Estado nada faz porque está preso e comprometido mediante acordos com grandes multinacionais, uma espécie de coadjuvante, e promete políticas públicas para o aumento do emprego, porém depende do capital dessas multinacionais que não têm uma preocupação social, o que importa mesmo é quanto se ganha ou se perde.

Sobre a conturbada conjuntura global recente, marcada pela ascensão daquilo que denominam como o "momento hiperautoritário" do neoliberalismo, Laval e Dardot (2016) sinalizam que este se personifica em líderes políticos, como no caso de Bolsonaro e Trump. Nesse sentido, o neoliberalismo não está morto, ele é plástico, muda de tom e ao mesmo tempo é plural, pois se desenvolve na história e se metamorfoseia conforme vão surgindo obstáculos e crises.

Além disso, os autores advertem que somos dominados por normas, por formas de vida que o capitalismo impõe na própria economia política por meio de dois princípios: a lógica da concorrência que se torna o princípio da vida em sociedade e o modelo da empresa que se impõe a todas as instituições mediante determinados dispositivos precisos e concretos como a nova gestão pública. No 
caso das instituições de Estado, o que caracteriza esse modo de governo neoliberal é o fato de se fortalecer e radicalizar-se a medida das crises. Talvez essa asserção explicaria a preferência por certas profissões em detrimentos de outras como mostrou o infográfico 13 no capítulo I, em que a intenção de ingresso dos participantes da pesquisa no Ensino Superior e as escolhas profissionais se concentram primeiramente nos cursos de Direito, Engenharia e Medicina. Conquanto, alguns participantes da pesquisa justificaram que querem ser professor por entenderem que: A5762: "Gosto da área e seria uma boa oportunidade de serviços aqui na minha região"; A6771: "Uma excelente oportunidade de emprego"; A5020: "Porque é uma área muito boa para concurso"; A3334: "[...] fácil ingresso no mercado de trabalho"; A2486: "Pois é uma ótima profissão e por estar em falta no mercado de trabalho, tenho mais oportunidades de trabalho"; A4868: "Vasta oportunidade de emprego apesar do salário não ser o melhor". Com efeito, apesar de alguns cursos como Direito, Engenharia e Medicina serem a preferência da maioria dos participantes da pesquisa, seja porque gostam, por questões salariais, ou pelo status, há também os que percebem a carreira docente como uma boa oportunidade profissional.

Atualmente, para Laval e Dardot (2016), se assiste a uma crise da democracia liberal clássica pelo advento de governos autoritários e hiperautoritários, e nesse sentido, a vitória do Trump não teria sido um acidente histórico e marca uma data importante na história neoliberal. Outro exemplo é o Brasil com Bolsonaro, a vitória da direita desses governos tem uma retórica, um discurso nacionalista, autoritário, xenófobo, racista, homofóbico e violento que são referências explícitas ao fascismo, conforme analisado por Laval e Dardot (2016). Fomenta também um discurso de desprezo pela ciência, pela educação, pela intelectualidade, conforme foi possível verificar nas declarações de alguns alunos participantes da pesquisa como em A2768: "Falta de atenção e desvalorização do poder público"; A7246: "[...] professores com salários baixos e oprimidos pelo governo"; A5475: "[...] pelo fato de que o governo quer reduzir gastos e com isso cortar os salários dos professores"; A3369: "[...] E agora com uma nova lei a ser aprovada, para congelar o salário do professor, essa lei é absurda, esse país de merda só valoriza vagabundo"; A3958: "[...] não tem valor para a sociedade e nem para o governo que paga milhões de reais a um juiz que não faz nada e um salário baixo a um professor que muda o país 
e que tem uma das profissões mais importantes"; A2504: "Salário horrível e a falta de investimento do Estado na educação". Essas asserções mostram a consciência desses alunos no que se refere ao desprezo, a omissão e a desatenção do governo em relação à realidade vivenciada por seus professores em contexto local.

Para mais, o que é espantoso é que esses governos favorecem as empresas e os ricos e desprezam os pobres, as matérias ecológicas, os indígenas, os grupos minoritários e os excluídos em geral. O cidadão se sente abandonado e não vê mais significado na participação política. Contudo, nas eleições, manifesta sua frustração e vota em candidatos que lhe promete uma grande faxina, uma assepsia, rompendo com o sistema político que não lhe garante mais segurança social, por meio de um discurso suicida.

Nessa direção, Trump e Bolsonaro foram eleitos para conduzir uma política favorável aos mais ricos, exemplo de neoliberalismo que opera como uma estratégia de guerra contra a sua própria população por meio de um discurso de chantagem, por exemplo, no Brasil, com a reforma da previdência aprovada no ano de 2019, quando houve um discurso por parte dos governantes de que se não fosse feita essa reforma, os outros fariam isso e nós é que perderíamos, ou seja, muda-se a própria lei para criar uma política para alterar o marco constitucional ou legal em que se exerce a atividade econômica e social.

Abro uma brecha para trazer a representativa canção Sólo le pido a Dios do compositor argentino León Gieco (1978), e consagrada na voz de Mercedes Sosa que ilustra esse contexto e convida a uma reflexão importante: 
Eu só peço a Deus ${ }^{10}$

Que a dor não me seja indiferente

Que a morte não me encontre um dia

Solitário, sem ter feito o que eu queria.

Eu só peço a Deus

Que a injustiça não me seja indiferente

Pois não posso dar a outra face

Se já fui machucado brutalmente.

Eu só peço a Deus

Que a guerra não me seja indiferente

É um monstro grande, pisa forte

Toda pobre inocência desta gente.

Eu só peço a Deus

Que a mentira não me seja indiferente

Se um só traidor tem mais poder que um povo

Que este povo não esqueça facilmente.

Eu só peço a Deus

Que o futuro não me seja indiferente

Sem ter que fugir desenganado

Pra viver numa cultura diferente.

Trazer essa canção neste estudo é bastante apropriado para o momento histórico que estamos vivendo, em meio a pandemia da COVID-19, na qual o Brasil ultrapassou a marca de 150 mil pessoas mortas, e temos um presidente omisso, que não cumpre o seu dever de proteger e preservar vidas dos cidadãos de seu próprio país, e está mais preocupado com questões econômicas. Nesse cenário, as pessoas clamam pelo direito de viver, e essa canção elucida sobre a necessidade de se ter consciência da luta constante diante da injustiça, da mentira, da guerra, da

10 Sólo le pido a Dios//Que El dolor no me sea indiferente//Que La reseca muerte no me encuentre//Vacio y solo sin haber hecho lo suficiente.

Sólo le pido a Dios//Que lo injusto no me sea indiferente//Que no me abofete en la outra mejilla// Después que uma garra me arañó esta suerte.

Sólo le pido a Dios//Que la guerra no me sea indiferente//Es um monstruo grande y oisa fuerte// Toda la pobre inocência de la gente.

Sólo le pido a Dios//Que el engaño no me sea indiferente//Si um traidor puede más que unos cuantos//Que esos cuantos no lo olviden fácilmente.

Sólo le pido a Dios//Que el futuro no me sea indiferente//Desahuciado está el que tiene que marchar// A vivir uma cultura diferente. Disponível em: https://www.sul21.com.br/colunas/raulellwanger/2017/08/cancoes-de-compromisso-eu-so-peco-deus Acesso em: 24 de julho de 2020. 
dor, da morte, da desinformação, da ignorância, do discurso de ódio e de tudo mais que possa nos desumanizar.

No entanto, mesmo quando os sujeitos não percebem, não compreendem ou não acreditam que tudo isso é feito por meio de dispositivos anti-democráticos, não podemos culpá-los, pois a linguagem em vigor utilizada por esses governos é de guerra econômica. Fazem com que se acredite - como no caso das reformas do direito trabalhista - que há uma urgência em se realizar isso porque estamos cercados por inimigos, que são nossos concorrentes e como estamos em guerra econômica, os direitos humanos têm apenas um valor relativo a tudo isso. $\mathrm{O}$ neoliberalismo tenta sustentar uma esperança de retomada econômica e de prosperidade que não pode fazer acontecer. Vive em um estado de hipocrisia, como analisou Laval e Dardot (2016), o qual quando descoberto, se metamorfoseia para o cinismo, promete sempre mais para um futuro próximo, tudo aquilo que não pode e nem pretende realizar, um verdadeiro teatro de enganações.

No campo educacional, há o boicote praticado contra a educação pública e a ciência, ao mesmo tempo em que o governo fala de liberdade e moralidade, e clama por justiça social, mas na realidade, faz uso de um verniz para disfarçar as atrocidades cometidas. Para manter esse sistema, usa como seu aliado também a educação, por meio das formulações como a Lei de Diretrizes e Bases (LDB), Nova Base Nacional Comum Curricular (BNCC), Escola sem Partido, entre outros já discutidos na introdução dessa tese, um modelo de ensino organizado pelas elites que trata pais e alunos como consumidores, e professores como agentes mantenedores da transmissão dos conhecimentos organizados por eles.

Outro exemplo, é o índice de analfabetismo no país, em que se faz aprovações automáticas, a fim de mascarar o crescimento na educação, mas que no entanto, não passa de uma falácia, pois parte dos alunos não estão aprendendo e a taxa de analfabetos funcionais cresce a cada ano. Sobre aprovações automáticas, rememoro um fato que aconteceu comigo no primeiro ano que assumi o concurso público de professora da Educação Básica, em que a diretora da escola me convocou e também a outros colegas professores para refazer o canhoto do $4^{\circ}$ bimestre, solicitando-nos a aprovação de uma lista de alunos. Ficamos indignados com a situação e nos recusamos a atender o pedido da diretora, porém os colegas professores contratados foram obrigados a refazer o canhoto e aprovar os alunos. 
Um verdadeiro abuso de autoridade, mas acontece em parte das escolas, não é um fato isolado. $O$ intento é fazer aprovações automáticas para cumprir o índice de aprovação imposto pelo governo, bem como manter-se no cargo e não perder a bonificação que a gestão recebe quando se consegue alcançar bons índices de aprovação.

Com a participação do Banco Mundial nas políticas públicas educacionais no Brasil, segundo Marrach (1996), há a recomendação que se reduzam os investimentos na educação pública, para que os pais matriculem seus filhos em escolas privadas, pois estas é que garantem um ensino de qualidade, relacionando a ideia de escola como empresa. Doravante, essa estratégia de desresponsabilização do Estado com a educação, reflete-se na redução das ofertas dos serviços educacionais à população brasileira. Dessa forma, a educação vai deixando de ser um direito universal e passa a ser condição de privilégio, tornandose excludente e seletiva.

A escola, por sua vez, por meio dos currículos impostos martela na cabeça dos alunos que é preciso estudar, se qualificar para o mercado de trabalho, uma vez que as outras pessoas a sua volta são concorrentes em potencial, reforçando a individualidade e a competição. Todavia, os dados informaram que o grau de escolaridade da maioria dos pais ou responsáveis dos alunos participantes é o Ensino Fundamental incompleto (até o $5^{\circ}$ ano), ou seja, não conseguiram dar continuidade aos seus estudos. Já os alunos, quando indagados sobre a pretensão de atividade para quando terminar o Ensino Médio, perfazendo uma parcela de $74,39 \%$ informou que planeja estudar e trabalhar concomitantemente. 14,01\% querem só estudar e $4,09 \%$ só desejam trabalhar. Nesse sentido, o currículo transforma a escola também em um espaço que produz e legitima os interesses econômicos e políticos das elites empresariais.

Analiso também que os jovens são os mais atingidos nesse sistema, porque são direcionados a acreditar que este sistema é o único possível, com metas impossíveis de serem alcançadas, em uma sociedade que cobra qualificação, mas que esta não existe para a maioria deles. Desse modo, o neoliberalismo com seus disfarces e meia-verdades, culpa as próprias vítimas, e faz com que esses jovens carreguem esse peso por toda vida, até ao ponto deles mesmos aceitarem que a responsabilidade é deles pela falta de oportunidades e condições miseráveis em que 
vivem. Sendo alarmante o número de desempregados atualmente no país, as estatísticas governamentais parecem ter interesse em mascarar essa realidade social, contudo, é visível o crescimento do trabalho informal e dos moradores de ruas.

E para agravar a situação, as pessoas, de um modo geral, são indiferentes às angústias dos jovens, por isso, tento ressignificar um fenômeno para além do que mostram os índices, evito julgamentos ou conclusões precipitadas, e busco analisar as forças não visíveis existentes nesse contexto. Sigo adiante, entristecida, afetada, ansiosa por um despertar para a realidade, em que as pessoas consigam enxergar o mundo desumano em que vivemos, sem valores, sem solidariedade, sem compaixão, em que tudo se baseia no interesse e no quanto se pode lucrar. Luto por uma educação que não produza um sujeito acrítico, oco, indiferente a tudo e a todos, desumanizado, incapaz de questionar a política e a ideologia pela qual dá a sua vida.

Afora esse cenário, parece existir um sentimento de omissão dos pais que delegam a educação de seus filhos somente para a escola, em uma ação de não responsabilidade para com seus filhos, acordante às declarações dos alunos $A 3470$ : “[...] o professor não é mais respeitado, o salário não é adequado, já que os riscos que os professores correm quanto aos seus alunos que em muitas vezes não têm uma base educacional familiar, acabam por agredir psicologicamente e até fisicamente o professor em sala"; A2946: "Muito desvalorizado, salário baixo e muita dor de cabeça com alunos e pais mal educados"; A3198: "O salário não é de acordo com a profissão. Medo de levar cadeirada dos alunos"; e A611: "Porque professor sofre bastante, em relação ao salário e as várias humilhações que eles passam". Faço o seguinte questionamento: Esses pais não foram produzidos por esse mesmo sistema? Então, será que podemos culpá-los?

A partir da minha realidade como professora da Educação Básica, entendo que esses pais vivem a urgência de manter sua família, e aceitam o emprego que Ihes oferecem, sem poder negociar ou reivindicar melhores condições de trabalhos ou salário, pois sabem que a qualquer momento podem ser mandados embora e substituídos por outra pessoa que aceita condições mais precárias ainda de trabalho. Esse sistema impede que possa existir entre os trabalhadores uma tomada de consciência e de ação em relação à realidade em que vivem na sociedade, e 
também é um esgotador da noção de solidariedade, de coletividade, de justiça e de moralidade entre as pessoas.

Por meio de uma análise minuciosa sobre a origem social do educando, Bourdieu (2002) afirma que o desempenho escolar do sujeito não depende apenas de dons individuais, mas de fatores como classe social, etnia, sexo, local de moradia, entre outros. O autor alerta para o fato de que a massificação do ensino na década de 60 repercutiu na desvalorização dos títulos escolares, e com isso adveio também a elevada frustração dos jovens das classes médias e populares, em que a educação, ao perder seu papel de transformadora e democratizadora, passou a ser uma instituição que legitima os privilégios sociais, uma vez que a escola ao definir seu currículo, seu método e sua avaliação passa a reproduzir as desigualdades socias e não minimizá-las.

Outra importante questão apontada por Bourdieu (2002), sobre o contexto familiar no processo de aprendizagem do sujeito - ao discutir e analisar a bagagem cultural e o sucesso escolar como sendo esta bagagem herdada - são três os fatores a considerar: o capital econômico, em que o sujeito tem acesso aos bens e serviços a partir desse capital; o capital social, como sendo o conjunto de valores e influências que são mantidas pelos familiares; e o capital cultural institucionalizado, os títulos escolares que são obtidos nas instituições educacionais.

Por meio dessa análise, Bourdieu (2002) afirma que as crianças oriundas de meios favorecidos terão maior facilidade de aprendizado escolar, diferente das crianças de meios menos favorecidos que, ao estarem no mesmo processo de educação, poderão não ter o mesmo significado, pela distância da realidade em que vivem. Para exemplificar essa situação, retomo alguns dados gerados por esta pesquisa, em que a renda familiar da maioria é entre $R \$ 1.000,00$ e $R \$ 2.000,00$, o grau de escolaridade da maior parte dos pais ou responsáveis é o Ensino Fundamental incompleto (até o 5aa) e o maior número das famílias é composta por quatro ou mais pessoas. Como essas pessoas poderão ter acesso aos capitais econômico, social e cultural? Quando o autor afirma que as crianças oriundas de meios favorecidos terão maior facilidade de aprendizado escolar, ilustro essa afirmação com o momento que estamos vivendo com a pandemia da COVID-19, em que as escolas públicas de MS, estão imprimindo atividades para os alunos buscarem na escola para que possam continuar seus estudos, uma vez que não há 
a possibilidade de se fazer aulas ao vivo na modalidade remota e, mesmo que houvesse, muitos não conseguiriam acessar, pois não têm condições de pagar a internet. Já os alunos de escolas particulares estão tendo regularmente aulas remotas ao vivo, além disso, têm acesso a internet e também o contato dos professores, caso queiram tirar dúvidas de algum assunto que não compreenderam.

Em uma última análise, Bourdieu (2002) conclui que as classes populares que são carentes em capital cultural, social e econômico, investem menos na educação de seus filhos, em razão da oportunidade reduzida de sucesso, uma vez que o retorno do investimento será incerto. A esta situação, o autor denomina de "adoção do liberalismo", em que a trajetória escolar dos filhos da classe popular não teria uma cobrança ou acompanhamento regular dos pais para a obtenção do sucesso escolar, mas se preocupam somente com o necessário para a sua subsistência na sociedade. Para ilustrar essa visão trago o depoimento de A6005: "Meu pai nunca terminou o $1^{\circ}$ ano do Ensino Fundamental". Esse pai negro que sempre trabalhou na roça, cuja renda familiar é um pouco maior que um salário mínimo, com uma família composta de quatro pessoas para sustentar, representa também a realidade de uma parcela da população sul-mato-grossense. Esse pai que não teve condições de dar continuidade aos seus estudos em razão da urgência em alimentar sua família, reflete o que Bourdieu (2002) chama de "adoção do liberalismo", condição em que se torna inviável investir na educação de seus filhos.

Então, faço a seguinte indagação: Quais condições de vida e de trabalho nós educadores temos nesse sistema, uma vez conscientes dessa realidade política, social e econômica?

Penso que os professores e os profissionais da educação vivem uma dura realidade entre o desprezo do governo pela educação e o desprestígio do trabalho docente pela sociedade, como pode ser visto nas declarações dos participantes da pesquisa: A1942: "Salário pequeno, profissional desvalorizado no país"; A2089: "Porque essa profissão não tem retorno financeiro favorável, já que não é tão valorizada"; A2768: "[...] Se dedica muito e as pessoas não dão um devido valor, não têm muitos direitos e o salário nem se fala"; AA315: "Por ser uma profissão que não tem a importância que deveria, e por não ter o salário que se merece"; A132: "Professor forma os jovens para o futuro promissor e não são valorizados, salários baixos para alguém que muda a vida das pessoas"; A3217: No país em que 
vivemos, os professores não são respeitados, há um descaso muito grande". Em corroboração com as alegações dos alunos, este profissional, com baixos salários e que trabalha em várias escolas e turnos, fica sem tempo para dar conta de tudo com a qualidade devida e acaba rotinizando seu trabalho, isto é, ministrando as mesmas aulas sem tempo de atualizá-las, e tende assim, a perpetuar a transmissão mecânica dos conteúdos.

\begin{abstract}
No processo de degradação das atividades profissionais do educador escolar, com a consequente desqualificação de seu trabalho e o aviltamento de seus salários, deu-se algo de semelhante; na medida em que não interessava à classe detentora do poder político e econômico, pelo menos no que diz respeito à generalização para as massas trabalhadoras, mais que um ensino de baixíssima qualidade, o Estado, como porta voz dos interesses dessa classe, passou a dar cada vez menor importância a educação pública (PARO, 1986, p. 131.)
\end{abstract}

Analiso como o autor que a ideia de desqualificação está relacionada a intensificação maçante do trabalho docente, e o professor passa a ser um sujeito proletário a todas as mudanças do mercado de trabalho, por efeito de uma lógica neoliberal em que o investimento é mínimo, portanto, a desqualificação dos educadores é uma excelente condição para a manutenção desse sistema.

Expropriado do saber e pressionado de todas as formas, ainda assim o professor necessita ter consciência política para lutar por sua revalorização social e econômica nesse sistema. De outro lado, está o Estado, descomprometido com a educação, difundindo seu discurso privatista, debochado e insolente, agravando as desigualdades.

Como educadora esse caos me afeta e provoca perplexidade, indignação, tristeza e reflexão. Penso que o primeiro passo a ser dado, é estarmos conscientes dos problemas sociais que nos afetam para podermos orientar nossas ações no sentido de problematizar essas questões com nossos alunos. Diante disso, o papel do professor é indispensável para a formação de cidadãos mais conscientes e críticos de sua realidade, bem como de pensar conjuntamente com os alunos os problemas causados por este sistema que tenta distorcer a realidade. A seguir, dou continuidade ao processo de análise por meio das justificativas dos participantes da pesquisa para a escolha da docência. 


\section{As principais justificativas dos alunos participantes da pesquisa para serem professores}

Para melhor fluidez do processo de análise das questões sobre as principais justificativas para serem professores, em um primeiro momento, faço as apresentações desses pontos por meio das respostas dos alunos ao questionário de pesquisa. Após essa etapa, prossigo então, com a análise teórica conjunta das razões e desrazões apontadas por esses alunos sobre o interesse ou não em se formarem professores. Informo que nesta seção, em razão da quantidade expressiva de dados gerados, selecionei por meio de categorias apenas alguns. Entretanto, os dados completos se encontram nos anexos 11 e 12 .

\section{Transmitir conhecimentos para as pessoas}

A1324: Eu quero poder transmitir todo o conhecimento que eu vou adquirir durante a minha carreira para os meus alunos, e assim, fazer eles se apaixonarem pelo que ensino. Além disso, quero poder ajudar as gerações futuras na escolha de suas carreiras.

A3417: A arte de ensinar é bela e transmitir o conhecimento é importante, como também ver pessoas interessadas irem em busca de seus sonhos.

A5695: Transmitir novos conhecimentos às novas gerações, incentivar crianças e jovens a ter maior paixão pelas artes e pelo pensamento coletivo e criativo.

\section{Gostam de trabalhar com crianças}

A792: Porque adoro ensinar, trabalhar com crianças e acredito que com amor, podemos ter jovens mais conscientes e melhores.

A4949: Ensinar ao próximo e principalmente as crianças tudo que aprendi, para que elas tenham muita sabedoria e se sintam preparados para 0 futuro.

A6640: Sempre gostei de crianças, já trabalhei em uma escola de educação infantil particular em Limeira.

\section{Identificam-se e/ou gostam dessa profissão}

A140: Pelo convívio no meio de professores, no caso de minha mãe e avó materna exercerem tal profissão. $O$ gosto pela área fui adquirido no ensino fundamental ainda, quando já obtinha facilidade em ensinar, tanto colegas de classe, quanto minha irmã caçula com seus deveres.

A920: Por causa que é uma profissão que eu gosto e quando, você gosta de uma coisa, você consegue trabalhar bem e dar uma boa aprendizagem. 
E poder ajudar no futuro do Brasil, e poder ver os meus alunos tudo formado, em uma faculdade, isso levou eu a escolher essa profissão.

A6595: Gosto muito de ler, ensinar, amo desenvolver projetos e os colocar em prática. Gosto da profissão, embora particularmente eu a ache muito desvalorizada, tal motivo que me colocou em dúvida sobre esse curso, porém quando nos identificamos com algo, não devemos esconder nosso talento.

\section{Gostam de determinada disciplina do currículo}

Tabela 4: Razões pelas quais os alunos querem ser professor de disciplina específica.

\begin{tabular}{|l|l|}
\hline Disciplinas & \multicolumn{1}{|c|}{ Razões para escolha } \\
\hline Física & $\begin{array}{l}\text { A1950: Pelo fato de gostar bastante de esportes, acredito que teria facilidade nessa } \\
\text { área. E estaria ensinando aos meus alunos da melhor forma possível, pois estaria } \\
\text { fazendo o que gosto! }\end{array}$ \\
& $\begin{array}{l}\text { A7137: Fazer com que os alunos melhorem e procurem a melhorar sua saúde e } \\
\text { paixão pelo esporte e pela prática de atividades físicas. } \\
\text { A7156: Para ensinar os alunos, e motivar a praticar esportes e pegar gosto pela } \\
\text { atividade física, o número de obesos está crescendo a cada ano e muitas vezes por } \\
\text { falta de incentivo de alguém. }\end{array}$ \\
\hline Matemática & $\begin{array}{l}\text { A1554: Por ter no meu conceito que é uma ótima profissão e eu gosto de Matemática } \\
\text { e também admiro a bravura de ser professor. }\end{array}$ \\
$\begin{array}{l}\text { A3599: Gosto de Matemática e tudo que envolve cálculos. Além de poder ajudar } \\
\text { outras pessoas. } \\
\text { A5222: Primeiro, para ensinar a matéria que gosto para outras pessoas. Segundo, } \\
\text { porque as pessoas pensam que a Matemática é uma matéria muito chata, e poder } \\
\text { demonstrar para elas que a Matemática é divertida. }\end{array}$ \\
$\begin{array}{l}\text { A2448: Primeiro porque eu amo História, segundo porque é muito bom fazer amizade } \\
\text { com os alunos e interagir com eles. } \\
\text { H3261: Gostaria de dar aulas, explicar a matéria História que eu gosto, ensinando os } \\
\text { meus alunos o que o passado deixou para o presente de hoje, e acho bacana } \\
\text { aprender de onde viemos. Ter uma conclusão de que somos de culturas diferentes } \\
\text { talvez. } \\
\text { A5460: Gosto do que o estudo abrange, a História é fundamental para formação do } \\
\text { indivíduo na sociedade. }\end{array}$ \\
$\begin{array}{l}\text { A1651: Na minha cidade tem a Universidade que disponibiliza o curso de } \\
\text { Licenciatura em Biologia. Por isso, eu conseguiria cursá-la, e além do mais, gosto } \\
\text { bastante da matéria. Mas se tivesse o curso de Engenharia Civil eu iria cursar sem } \\
\text { dúvida. Amo a área que faz parte da natureza, me encanto com todo esse meio. E } \\
\text { também um cálculo me chama muita atenção. Na verdade, temos poucas escolhas } \\
\text { em cidades pequenas como a nossa. }\end{array}$ \\
\hline Biologia
\end{tabular}




\begin{tabular}{|c|c|}
\hline & $\begin{array}{l}\text { A2383: Pretendo exercer essa função por eu ter um gosto por ensinar as pessoas, e } \\
\text { ser fascinado por Biologia e tudo que envolve a vida. } \\
\text { A4802: Gosto muito de Biologia e me dou muito bem com pessoas, sou muito } \\
\text { paciente. }\end{array}$ \\
\hline $\begin{array}{l}\text { Língua } \\
\text { Portuguesa }\end{array}$ & $\begin{array}{l}\text { A1376: Porque eu gostaria de ser professor para ensinar norte-americanos a falarem } \\
\text { Português. } \\
\text { A1822: Paixão pela língua nacional, facilidade para aprender as regras e normas. } \\
\text { Interação com pessoas, disciplina, rigidez, entre outros pontos. } \\
\text { A3804: Por ter influência familiar, e também por ter mais afinidade em Português. }\end{array}$ \\
\hline Geografia & A19: Gosto muito mesmo de Geografia. \\
\hline Física & $\begin{array}{l}\text { A6345: Eu gosto da Física, e das suas aplicações, gosto de criar coisas, de aprender } \\
\text { mais, quero ser um Engenheiro Mecatrônico e um professor de Física. } \\
\text { A6507: Por causa que tenho um certo gosto em saber e ensinar Física a alguém, } \\
\text { pois se tornou a minha paixão. }\end{array}$ \\
\hline Inglês & $\begin{array}{l}\text { A2194: Professora de Inglês em alguma escola de idiomas. } \\
\text { A3964: Eu escolheria ser professor de Inglês porque é uma área muito rica em } \\
\text { relações de conhecimento e eu aperfeiçoaria com o toda eficaz possível, pois é uma } \\
\text { coisa na qual eu gosto. } \\
\text { A5049: Pois eu gosto da Língua Inglesa e já estudo ela a algum tempo. }\end{array}$ \\
\hline Artes & $\begin{array}{l}\text { A5695: Transmitir novos conhecimentos às novas gerações, incentivar crianças e } \\
\text { jovens a ter maior paixão pelas Artes e pelo pensamento coletivo e criativo. } \\
\text { A7422: Gosto do conteúdo de Arte, e de desenhar é uma matéria gostosa de estudar, } \\
\text { por isso gostaria de investir no que gosto, e essa matéria seria um exemplo. }\end{array}$ \\
\hline Química & $\begin{array}{l}\text { A476: Gosto muito de Química e tenho facilidade. } \\
\text { A3362: Para ensinar aos alunos como a Química pode ser importante em nossas } \\
\text { vidas. } \\
\text { A6731: Por ter habilidade em Química, acredito que serei uma ótima professora. }\end{array}$ \\
\hline Filosofia & A7530: Gostar de aulas de Filosofia. \\
\hline Literatura & $\begin{array}{l}\text { A1340: Eu acho incrível o contato que o professor tem com os alunos. O } \\
\text { relacionamento de orientador, sentir que você pode fazer a diferença na vida de } \\
\text { alguém. Além disso, eu gosto muito de me expressar publicamente e gostaria de } \\
\text { propor coisas totalmente diferentes para meus alunos, despertando o interesse deles } \\
\text { para a literatura, uma área que bem poucos gostam. } \\
\text { A7670: Gosto muito de Literatura, e gostaria muito de estimular as pessoas a lerem } \\
\text { mais e mais. }\end{array}$ \\
\hline Sociologia & o pelas Ciências Sociais. \\
\hline Ciências & e Ciências e sempre gostei de estudar. \\
\hline
\end{tabular}




\section{Profissão digna, com boas oportunidades de emprego e estabilidade financeira}

A1786: Acho que essa profissão pode abrir várias oportunidades na vida.

A4715: Uma profissão digna de respeito e importância para sociedade.

A4868: Vasta oportunidade de emprego apesar do salário não ser o melhor. A5020: Porque é uma área muito boa para concurso.

A5762: Gosto da área e seria uma boa oportunidade de serviços aqui na minha região.

\section{Admiração pelos professores}

A487: É a profissão mais importante, pois é a base para todas as outras. Tenho grande admiração, e sei que está cada vez mais diminuindo os profissionais nesta área. Acho lindo a ideia de compartilhar meu conhecimento com outras pessoas.

A4570: Ser professor realmente algo de grande valor, pois vai depender de você para outras pessoas ficarem alfabetizadas. Admiro!

A6339: A admiração pelos professores que tenho e que ao longo dos anos eu tive. É uma profissão maravilhosa, ensinar o que sabe e juntamente com os alunos aprender.

\section{Melhorar a qualidade do ensino público no país}

A1714: Por acreditar em um ensino humanizado. Onde passando o conhecimento e incentivando a criatividade, as crianças passam a ter uma nova maneira de pensar, podendo até mudar o nosso futuro.

A2375 - Quero de alguma forma, poder contribuir, com o conhecimento adquirido na faculdade, à melhora da educação, não só no Mato Grosso do Sul, como também no Brasil, pois o ensino em nosso país está regredindo. As instituições de ensino precisam de novas ideias, vindas de novos professores, para tentar tornar a educação atrativa novamente para realidade dos jovens de hoje.

A6142: Melhorar o pensamento e a cultura no Brasil.

\section{Facilidade de comunicação e interação com as pessoas}

A2499: Gosto de falar com as pessoas e também tenho facilidade em ensinar as pessoas, gosto muito de ler e me atualizar.

A2524: Porque eu gosto do contato com as pessoas e gosto de ensinar e ajudar as pessoas ao meu redor, nesse caso ensiná-los algo em que eu me destaco. Dar a elas um pouco de meu conhecimento, ajudar naquilo que posso.

A5017: Gosto muito de ensinar, gosto de me relacionar e tenho facilidade para falar em público. 
Em continuidade, apresento as razões pelas quais os participantes da pesquisa justificam a não escolha pela docência.

\title{
3. As principais justificativas dos alunos participantes da pesquisa para não serem professores
}

\author{
Não se identificam, não tem vocação ${ }^{11}$, ou não gostam \\ dessa profissão
}

A344: Nunca tive interesse, nem vocação. Exige didática e paciência e são coisas que eu realmente não domino.

A5821: Não é uma profissão que me identifico, por esse motivo não pretendo fazer algo que não gosto a fim de ser um profissional frustrado ou um mau professor.

A5905: Nada contra! A profissão é muito bonita. Temos que ensinar os alunos a pensar e não a obedecer, mas não me identifico sendo uma professora, porque já escolhi minha área.

\section{Falta de paciência para ensinar}

A348: Porque não tenho muita paciência para enfrentar a realidade que nossos professores enfrentam hoje em dia.

A425: Requer muito conhecimento, paciência e amor, e eu infelizmente não tenho paciência para ensinar.

${ }^{11}$ A palavra vocação tem origem no Latim Vocatio que significa "um chamamento". Em um artigo científico intitulado "O processo de orientação vocacional frente ao século XXI: perspectivas e desafios", em que Andrade; Meira e Vasconcelos (2002) discutem sobre as perspectivas e desafios do processo de orientação vocacional (OV) diante do século XXI, os autores defendem a ideia de que OV tem por objetivo ajudar os sujeitos a encontrar uma identidade profissional, bem como auxiliar na estruturação de sua identidade pessoal, contribuindo para a elaboração de um projeto de vida. Para tanto, a finalidade da OV não deve apenas informar sobre as profissões, mas trabalhar o autoconhecimento e a questão da escolha em si. Entretanto, os autores salientam que no decorrer da história, teve-se que colocar as pessoas certas nos locais certos, e que nem sempre o homem pôde escolher trabalhar naquilo que tinha vocação ou realmente gostaria, dadas as suas condições sociais, culturais e econômicas. ANDRADE, J. M. DE; MEIRA, G. R DE JESUS; VASCONCELOS, Z. B. O processo de orientação vocacional frente ao século XXI: perspectivas e desafios. Brasília: Revista Psicologia: Ciência e profissão. Vol. 22, ํo3, 2002. Disponível em: https://www.scielo.br/scielo.php?pid=S1414-98932002000300008\&script=sci arttext\&tlng=pt. Acesso em: 07 de agosto de 2020. 


\section{Desvalorização dessa profissão pela sociedade, principalmente pelos governantes}

A1222: Não tenho paciência para aguentar alunos mal educados, e o governo não investe na educação, e os professores não são valorizados como deveriam ser.

A2351: É desrespeitado constantemente e, às vezes, é menosprezado mesmo tendo grande importância na sociedade.

A2768: Falta de atenção e desvalorização do poder público. Se dedica muito e as pessoas não dão um devido valor, não tem muitos direitos.

\section{Salário ruim/baixo}

A407: Pelo fato do salário ser pouco valorizado, sendo que um professor deveria ganhar melhor pelo fato ser a segunda família ensinando você a seguir um rumo na vida.

A2846: Pois além de ser uma das profissões mais importantes para a sociedade, nela os profissionais sofrem muito e, além disso, é uma profissão muito pouca valorizada, com um salário muito baixo.

A3955: Porque o professor não é valorizado, recebe salário baixíssimo, não tem os direitos reconhecidos, muitas vezes são tratados mal por alunos e etc. E agora com uma nova lei a ser aprovada, para congelar o salário de professor, essa lei é absurda, esse país de merda só valoriza vagabundo.

A4146: Professores não são valorizados, e ganham um salário muito baixo, apesar de ser umas das profissões que mais exigem da sua capacidade física e mental.

\section{Profissão muito estressante, rotina cansativa e carga horária de trabalho extensa}

A2403: Carga horária de trabalho com pouco descanso e o estresse diário.

A5492: Esforço elevado. Horários de trabalho absurdos.

A7246: Porque os professores vivem presos nas salas de aulas sem nenhum recurso tecnológico, o mais simples, a internet nos falta. Salas de aulas pequenas e lotadas, sem ventilação, alunos desmotivados...

A315: Por ter que trabalhar até em casa fazendo planejamentos e diários, então essa profissão tem uma carga horária extensa.

\section{Preferem outros cursos}

A376: O que eu quero realmente é me formar em Direito e ser delegada ou juíza, por razões pessoais...mas nada contra ser professora. 
A2285: Porque eu sempre quis ser dentista e nunca me passou pela cabeça em fazer outro curso a não se Odontologia.

A3818: Porque o que eu quero mesmo é fazer faculdade de Medicina e Enfermagem.

\section{Alunos indisciplinados e desrespeito dos alunos com os professores}

A200: Vejo como aluna, que o professor não é muito valorizado, não só em questão de salário, mas com relação a falta de respeito que muitos sofrem. Mesmo com boas intenções para ser um bom educador, muitos não conseguem atingir suas metas porque não têm a ajuda dos alunos. Tornase uma profissão cansativa demais, para quem nunca teve o sonho de ser um educador.

A1955: Particularmente, acho que o Professor tem um papel muito importante em uma sociedade, pois trabalha com a educação da população. Porém, sofre com o desrespeito e com a desvalorização da sua profissão.

A3238: As dificuldades de ensinar aos alunos não interessados na matéria ou o desrespeito com o educador.

\section{Dificuldade de ensinar pessoas}

A401: Tenho muita dificuldade de falar com o público, explicar.

A1768: Dificuldade para ensinar as pessoas.

A2804: Porque tenho dificuldades em explicar as coisas, então não me daria bem.

Como procedimento de análise, retomo uma das perguntas propostas por este estudo: Quais aspectos os alunos participantes da pesquisa destacam para justificar o interesse ou não pela carreira docente? Após essa retomada, sigo então, para uma análise colaborativa das respostas dos alunos a estas questões, conjuntamente refletidas por meio de referencial teórico de autores que discutem o tema em contextos distintos e situados.

Em um segundo momento trago duas reflexões, a primeira, por meio da obra "Na segunda consideração intempestiva: da utilidade e desvantagem da história para vida", de Nietzsche (2003), sobre a educação de seu tempo e os desafios de pensarmos em nosso tempo sobre a importância da educação para a vida. A segunda, intitulada "O idealizado e o Realizado", em que discuto que há um distanciamento entre o discurso que valoriza a educação para a construção de uma sociedade melhor, e o desprestígio da profissão docente. 


\section{A construção de sentidos sobre a carreira docente: uma análise colaborativa}

Nesta seção, trago algumas contribuições de outros autores que investigaram sobre o tema em contextos distintos e situados e teço uma análise dos principais resultados dessas investigações com os meus, com o intento de dialogar sobre os achados deles e os deste estudo, bem como de buscar trazer uma contribuição nova relativa ao assunto abordado.

Em sua pesquisa que tratou da atratividade da carreira docente no Brasil pela ótica de alunos concluintes do Ensino Médio em escolas públicas e particulares de cidades de grande e médio porte das diferentes regiões do país, Gatti (2009) apontou algumas das razões pelas quais os participantes da pesquisa se sentiram motivados em ser professor, sendo a principal delas, a possibilidade de ensinar e transmitir conhecimento com $40 \%$. Na progressão, foi o interesse por área específica do conhecimento com 19\%. Outro aspecto se relacionou à identificação profissional com a docência com 13\%. Ao analisar os resultados da pesquisa de Gatti (2009), com os resultados desta pesquisa no Estado de MS, em ambas, transmitir conhecimento refletiu a principal razão para aqueles que escolheram ser professor. O interesse por área específica do conhecimento e a identificação com a profissão, da mesma forma fizeram ressonância em relação aos resultados das duas pesquisas, conforme mostraram os itens 2.1, 2.4, 2.3.

Para expandir a discussão sobre a ideia de transmissão do conhecimento citada pelos participantes da pesquisa como a principal razão para ser professor, a educação, tal como proposta por Wallon (1986), é uma formação para o desenvolvimento da noção de cidadania, na qual o "outro", o professor, considera como ensino não apenas a transmissão do já conhecido, mas o processo que leva à capacidade de observação e de reflexão crítica. Para o autor, nenhum conhecimento ou conteúdo de ensino pode ser desvinculado da análise da realidade social e política na qual estão inseridos os alunos, para tanto, a prática pedagógica deve valorizar a expressão do "eu" sem acentuar as tendências competitivas e individualistas. Deve ainda ensinar conteúdos que não mascarem a realidade e as contradições sociais e que permitam à criança e ao jovem discernirem valores sociais e morais que não resultem em submissão e conformismo, mas que promovam o desenvolvimento do sujeito, nas suas dimensões individual e social. 
Nessa concepção, o ensino e a aprendizagem são como um processo único, interativo e dialógico, pois não há ensino sem transmissão de conhecimento a um outro, assim como não há aprendizagem sem a mediação de um outro, portanto, ensinar e aprender constituem, concomitantemente, um processo e uma relação de dialogicidade.

"O diálogo é este encontro dos homens, imediatizados pelo mundo, para pronunciá-lo, não se esgotando, portanto, na relação eu-tu. Esta é a razão por que não é possível o diálogo entre os que querem a pronúncia do mundo e os que não querem; entre os que negam aos demais o direito de dizer a palavra e os que se acham negados deste direito" (FREIRE, 1987, p. 91).

O diálogo para Freire (1987) é a essência da educação como prática da liberdade. Na escola, os conteúdos curriculares necessitam dar-se no diálogo, em que os saberes de todos devem ser valorizados, e ainda, toda ação educativa é uma ação política, que leva a um compromisso social de transformação e libertação. Ao contrário disso, se a educação é neutra e pura repetição, está longe da ação reflexiva e da práxis, pois quando há a ausência de liberdade, há também a ausência de conscientização, portanto, uma política educacional que não contempla a consciência crítica dos estudantes está longe de ser educacional, é, antes de tudo, massificadora e manipuladora das consciências.

Em continuidade, ainda sobre o estudo de Gatti (2009) e a presente pesquisa, algumas das justificativas dos estudantes para a falta de interesse em ser professor se relacionaram nas duas investigações, em que $48 \%$ foram os que consideraram que não se identificam com a docência. A baixa remuneração se destacou como a segunda razão do desentusiasmo pela carreira docente com $25 \%$. A desvalorização da profissão e o desinteresse e desrespeito dos alunos somaram a parcela de 17\%. Em análise, ao tomar como parâmetro a pesquisa de Gatti (2009), a principal razão para não escolher ser professor, em ambas as pesquisas, se justificou pela ausência de identificação com a profissão. A questão da desvalorização da profissão, do desrespeito dos alunos, da baixa remuneração também foi evidenciada nos resultados das duas pesquisas como justificativa para não escolher ser professor, acordante aos itens 3.1, 3.4, 3.3 e 3.6.

Em uma pesquisa sobre o interesse de estudantes de pedagogia pela docência, de Brandão e Pardo (2016), em que se propuseram a analisar as representações de 120 estudantes de licenciatura em pedagogia da Universidade 
Federal de Sergipe - UFS, acerca da profissão professor, bem como compreender o interesse dos mesmos em relação ao exercício da docência, dentre os principais resultados, foi possível observar que os acadêmicos atribuíram a indiscutível importância do professor para a sociedade, porém, reconheceram também que a profissão não é valorizada socialmente, motivo apontado como uma das principais justificativas para a insatisfação com a escolha do curso de licenciatura. Solicitados a informarem cinco aspectos favoráveis e desfavoráveis à carreira docente, eles citaram como pontos positivos: a realização pessoal, a percepção de que têm vocação para profissão, o papel do professor para a promoção da mudança social no país, e caso o filho (a) demonstrasse interesse em ser professor, teria o incentivo para seguir essa profissão. Sobre os pontos negativos, eles destacaram: a dificuldade de ingresso no mercado de trabalho após a formatura, a remuneração insatisfatória, a impotência em produzirem uma mudança na sociedade, atividade frustrante e ambiente de trabalho estressante.

Como mais um movimento de análise, nas duas pesquisas como razões para ser professor, a percepção de que se identificam ou gostam da docência foram contempladas. Igualmente, o aspecto do papel do professor para promoção da mudança social no país foi citado. Outrora, ambas as investigações trouxeram dados segundo os quais, optar em ser professor é um dos caminhos para melhorar a qualidade do ensino público no país. A respeito dos pontos negativos como a remuneração insatisfatória, a atividade frustrante e ambiente de trabalho estressante, conforme explicitado nos itens 3.4 e 3.5 coincidem nos dois estudos, porém, a impotência em produzir uma mudança na sociedade, não foi citada na geração de dados desta pesquisa. Outro ponto discordante foi que no estudo de Brandão e Pardo (2016), os participantes citaram a dificuldade de ingresso no mercado de trabalho após a formatura. Entretanto, nos dados apurados por esta investigação, os participantes apontaram como sendo esta uma boa razão para ser professor - o fato da carreira docente propiciar satisfatórias oportunidades de emprego e estabilidade financeira, conforme explicitado no item 2.5. Analiso que a questão de ingressar no mercado de trabalho após a formatura é um desafio enfrentado por muitas pessoas no nosso país, uma vez que vivemos uma crise econômica e, consequentemente, o aumento do desemprego. Entendo que a empregabilidade é uma preocupação importante da comunidade acadêmica, pois 
esse índice é também um indicar de sucesso da universidade. Para Paulo Filho (2018, p.1), "a verdadeira educação superior vai além de conferir um diploma, tem caráter de inserção", ao defender que as instituições precisam acompanhar o estudante também após a formatura, funcionando como plataforma de apoio permanente e, cita o exemplo das Faculdades Integradas da União Educacional do Planalto Central (Faciplac), que tem um setor de acompanhamento de egressos e empregabilidade, o qual faz contato com todos os alunos após a formatura e continuam em contato até ter um feedback positivo.

Outro ponto importante, conforme esclarece Capelato (2018, p. 2), “a empregabilidade para quem tem Ensino Superior não diminuiu, mas os graduados estão pegando posições que não aceitariam em momentos de pleno emprego, estão indo para o subemprego", ou seja, ter um diploma de graduação ainda é vantagem comparativa para concorrer a posições que não exigem nível superior. Em relação aos que se formam em cursos de licenciatura, Capelato $(2018$, p. 3) esclarece que "os professores, pessoal das licenciaturas, não estão sofrendo muito com o desemprego porque há menos gente querendo trabalhar com isso, já que a carreira é muito desvalorizada e o mercado é ruim", para ele, esses fatores podem indicar o desinteresse dos jovens em se formarem professores, o que diminui a concorrência por vagas no mercado de trabalho.

Em outro estudo sobre as aspirações de estudantes do Ensino Médio sobre ser professor, no interior do Paraná, os pesquisadores Fillos, Zen e Caetano (2016) analisaram os motivos e influências que levaram os estudantes a desejar ou não a carreira docente. Os dados gerados indicaram que os estudantes julgaram a profissão docente de muita importância e responsabilidade, todavia, a grande maioria não escolheu se formar professor. Sobre as razões que os levaram a descartar a docência, os alunos alegaram: a falta de respeito pelos professores, 0 estresse a que são submetidos os docentes, a desvalorização, a baixa remuneração, a falta de identificação pessoal ou profissional com a carreira. A investigação também apontou que os poucos candidatos à docência eram de escola pública, com renda familiar menor que $R \$ 2.000$ reais e filhos de mães com Ensino Fundamental incompleto.

Ao analisar os dois estudos, a falta de respeito pelos professores, 0 estresse, a desvalorização, a baixa remuneração e a falta de identificação com a 
carreira docente foram averiguadas em ambas as pesquisas quando os participantes evidenciaram as razões pelo desinteresse em se formar professores, em conformidade com os itens 3.7, 3.5, 3.3, 3.4 e 3.1. A questão da renda familiar baixa, também fez eco em ambas as pesquisas, uma vez que esta investigação apurou que a maioria dos participantes $(32,11 \%)$ possui renda familiar entre $\mathrm{R} \$ 1.000,00 \mathrm{e}$ $\mathrm{R} \$ 2.000,00$. Quanto ao grau de escolaridade da mãe ou responsável, os dados gerados confirmam, de maneira igual nas duas pesquisas, que a maioria das mães $(25,11 \%)$ possui o Ensino Fundamental incompleto.

Em uma investigação sobre o desinteresse nas licenciaturas no município de Miguel do Iguaçu - PR, com alunos de escolas públicas e privadas do $3^{\circ}$ ano do Ensino Médio, com a finalidade de analisar os motivos que causaram o desinteresse pela licenciatura, Ferreira (2015) verificou que dos alunos entrevistados, 25\% cursariam um curso de licenciatura, enquanto $75 \%$ não cursariam nessa área, embora todos os participantes tenham considerado importante a profissão de professor. Questionados se a escola deveria incentivar os alunos a ser professor, $51 \%$ disseram que sim, e $49 \%$ afirmaram que a escola não deveria incentivar essa escolha, uma vez que entendem que deve ocorrer a vontade particular de cada aluno. Em relação aos fatores que causaram desinteresse dos alunos pela licenciatura, eles elencaram: a baixa remuneração, o desrespeito dos alunos, as más condições de trabalho, a desvalorização do professor pela sociedade e em relação às outras profissões. Sobre os motivos pelos quais desejariam ser professor, os alunos listaram: adquirir conhecimento, profissão gratificante e que cria laços de amizade, para tornar um cidadão crítico, boas condições de trabalho em razão de benefícios como férias e recessos prolongados.

Em análise, sobre a opção dos que cursariam licenciatura e os que não cursariam essa área, a proporção entre ambas as pesquisas mostram que a maioria não faria a opção por um curso de licenciatura. Os motivos pelos quais desejariam ser professor como adquirir conhecimentos, a profissão gratificante, para tornar o cidadão crítico e boas condições de trabalho foram expressas nas duas investigações, o que pôde ser verificado nos itens 2.3, 2.5 e 2.7. Acerca dos fatores do desinteresse dos alunos pela licenciatura, foi possível constatar que a baixa remuneração, o desrespeito dos alunos, as más condições de trabalho e a desvalorização do professor pela sociedade e em relação às outras profissões, 
também foram verificadas neste estudo, em concordância aos itens 3.4, 3.7, 3.5 e 3.3.

Com efeito, a cada 110 jovens que ingressam em cursos de pedagogia e licenciatura no Brasil, apenas 51 concluem o curso e, desses, apenas 27 manifestam o interesse em seguir a docência, segundo levantamento do Inep (2017). Em uma pesquisa realizada na Faculdade de Educação da USP, verificou-se que metade dos alunos dos cursos de licenciatura em Física e Matemática não se interessaram em ser professor da Educação Básica, conforme estudo do Instituto de Matemática e Estatística da USP - IME (2012). Os acadêmicos alegaram que entraram nesses cursos pelo fato da USP ser gratuita e que esses conhecimentos poderiam ser úteis no mercado de trabalho, bem como tinham a opção de seguir carreira acadêmica, fazendo Pós-graduação ou ir para outras profissões. Os alunos de medicina também foram ouvidos e 15\% manifestaram que se interessaram pela docência, porém não a seguiriam devido aos salários baixos e as condições de trabalho. A pesquisa apurou, entretanto que, todos os alunos que não escolheram a docência, manifestaram grande respeito pela profissão de professor, afirmando ser este o principal responsável pela aprendizagem social e cognitiva das crianças e adolescentes.

Em outro artigo científico sobre a escolha da carreira docente, que teve como objetivo analisar os fatores intervenientes na escolha dessa profissão, Sales e Chamon (2011) observaram forte influência de ideários sociais nas concepções elaboradas pelos sujeitos sobre a docência. A pesquisa envolveu 964 sujeitos matriculados no curso de Pedagogia de uma instituição privada de Ensino Superior localizada em Belém - PA. Entre os fatores motivadores para a escolha da profissão, destacou-se a melhoria do ensino, o prazer de ensinar, o contato com as pessoas, ter uma carreira em geral e o tipo de trabalho. Os participantes também foram indagados sobre os fatores determinantes para a escolha da carreira docente e enfatizaram: a aprendizagem constante, a importância para a sociedade, por opção, a formação de outras pessoas, o prazer de explicar e se fazer entender, pelas oportunidades do mercado de trabalho, o aproveitamento das capacidades pessoais, a intenção de ter um futuro estável, ter autonomia, por falta de opção e para ter responsabilidade. 
Essa investigação também apontou que o grupo pesquisado era pertencente a classes sociais desfavorecidas, devido à baixa renda pessoal e familiar. Com relação aos fatores motivadores para a escolha da docência, eles listaram: a melhoria do ensino, o prazer de ensinar, o contato com as pessoas e a identificação com o tipo de trabalho, igualmente contemplados nesta pesquisa por meio dos itens 2.7, 2.1, 2.8, 2.3. Sobre os fatores determinantes para a escolha dessa profissão, os participantes justificaram: a aprendizagem constante, a importância para a sociedade, a formação de outras pessoas, o prazer de explicar e se fazer entender, as oportunidades do mercado de trabalho e intenção de ter um futuro estável, aspectos que também foram encontrados nesta pesquisa como apurados nos itens $2.1,2.7,2.8$ e 2.5 .

Mais um estudo que objetivou investigar os fatores que levaram os jovens a escolherem a profissão de professor, de Passos, Martins e Arruda (2005) - realizado com 38 alunos do curso de licenciatura em Matemática da Universidade Estadual de Londrina - PR - apontou os principais motivos que induziram a escolha pela docência: a influência de bons professores, ou seja, a maneira de ser de uma professora que o aluno passou a construir e buscar por aquilo que queria ser. Outro apontamento refere-se à necessidade de trabalhar durante o período diurno, pelas circunstâncias financeiras que os acometem, o que já selecionou a relação de cursos que esses alunos poderiam escolher. A admiração pelos professores de determinada disciplina e o fato de idealizarem um futuro semelhante ao desses mestres. Também quanto a escolha da profissão docente, houve influências da família tanto positivas como negativas e, por último, a necessidade de se definir por uma profissão, momento marcado pela angústia e lutas internas. A pesquisa concluiu que são muitos os tipos de escolhas, variados desejos e diferentes caminhos que conduzem as pessoas a se formarem professores.

Comparativamente, ao analisar os motivos que induziram a escolha pela docência, nas duas investigações, a influência de bons professores coincidiu. Sobre a necessidade de trabalhar durante o período diurno, não houve essa ocorrência neste estudo, aspecto discordante da investigação feita por Passos, Martins e Arruda (2005). Já a admiração aos professores é um fator acordante em ambas as pesquisas tal qual informou o item 2.6. 
Com publicação em revista, um artigo que tratou sobre a carreira do magistério como uma escolha profissional, Valle (2006) analisou a dinâmica que determinou essa preferência ao elucidar as motivações que influíram na decisão desses professores. Os achados mostraram que esses professores optaram em seguir a docência em razão de valores altruístas e de realização pessoal, relacionadas ao dom e a vocação, ao amor pelas crianças e pelo outro. Ao amor pela profissão e pelo saber, à necessidade de conquistar autonomia financeira, o sonho de criança em tornar-se professora, as lembranças de práticas vividas no círculo familiar, a admiração pelos professores, os bons professores que serviram de inspiração, o destino e as situações inesperadas, os horários flexíveis, a liberdade de ação, o prestígio em relação às ocupações manuais. A origem social desses professores também foi investigada e, é consideravelmente modesta, pois a grande maioria descende da população em transição entre as zonas rurais e os centros urbanos, passando pelas ocupações manuais às profissões intelectuais. O estudo verificou que a escolha de uma profissão é sempre uma escolha de vida e representa a antecipação das aspirações profissionais, mas concluiu-se que essa escolha não existe verdadeiramente quando se vem de uma classe desfavorecida.

Analiso por meio das observações evidenciadas que, em outro tempo, as pessoas, de certa forma, já tinham sua profissão determinada pela própria família, pois sua ocupação dependia das atividades desenvolvidas por seus membros, por exemplo, quem morara em zona rural, muito provavelmente trabalhava em atividades relacionadas, ou seja, a pessoa tinha poucas possibilidades de escolha, como elucida Yoba (2004), que os filhos conforme a posição social da família, tinham a possibilidade de se tornarem como seus pais, avós ou membros da família mais próximos. Conquanto, Bock (2002) alerta que com o capitalismo, o sujeito tem a possibilidade de libertar-se dos laços de família, pois este promove a ideia de que todos são capazes de decidir por si só qual lugar ocupar na sociedade. Mas até que ponto esse sujeito é livre para escolher? Respondo essa questão com a afirmação feita por Soares (2002, p. 4), "a possibilidade de escolha está completamente determinada pelo capitalismo, pela condição da classe social a qual pertencemos". Em outras palavras, não há liberdade de escolha para todos e nem igualdade de oportunidades em nossa sociedade, conforme já discutido antes neste capítulo. 
Por fim, a investigação de Valle (2006) verificou que em relação às razões que levaram os professores a optarem em seguir a docência, destacou-se o dom e a vocação, o amor pelas crianças, pela profissão e pelo saber, a necessidade de conquistar autonomia financeira, o sonho de criança, a influência familiar e de bons professores, admiração pelos professores, todas acordantes com esta pesquisa e podem ser verificadas conjuntamente nos itens 2.2, 2.1, 2.3 2.5, 2.6. Os pontos não contemplados neste estudo se concentraram em dois destaques: o destino e as situações inesperadas e o prestígio da profissão em relação às ocupações manuais.

Ao examinar a questão do abandono do magistério público na rede de ensino de São Paulo, o estudo de Lapo e Bueno (2003) buscou investigar também o modo pelo qual a profissão docente foi escolhida por um grupo de 29 professores. A pesquisa verificou que nenhum desses profissionais queria ser realmente professor, ou seja, ser professor foi uma escolha possível no início da vida profissional, uma alternativa plausível do sonhar-se médico, advogado, arquiteto, veterinário, entre outros. Contudo, mesmo não sendo a ocupação sonhada por esses professores, a maior parte afirmou que se empenhou em realizar o trabalho da melhor maneira possível, bem como tentou adaptar-se na função e encontrar satisfação e autorrealização na docência.

Sobre os aspectos enfatizados pelos professores como fonte de insatisfação com o magistério foram: a sobrecarga do trabalho, a falta de apoio dos pais dos alunos, o sentimento de inutilidade em relação ao trabalho, os baixos salários, a má organização do sistema educacional, a impossibilidade de participar das decisões sobre o rumo do ensino, o controle do trabalho do professor, a escassez de recursos e materiais para as aulas, excesso de burocracia, falta de apoio das instâncias superiores do sistema educacional e falta de incentivo ao aprimoramento profissional. Em análise, como fonte de insatisfação com o magistério, os professores evidenciaram dois aspectos mencionados pelos participantes deste estudo: a sobrecarga de trabalho e os baixos salários, em consonância aos itens 3.4 e 3.5. Verifiquei que embora os sujeitos desta pesquisa tenham uma certa percepção sobre a carreira docente, os que já estão nela, confirmaram em suas vivências algumas hipóteses levantadas pelos alunos. Em outras palavras, é perceptível que, quando se está em efetivo exercício profissional, o campo de entendimento sobre a profissão se amplia. 
Destaco o item a respeito da falta de incentivo ao aprimoramento profissional, e abro um parêntese para explicitar uma triste realidade que vivemos em nosso Estado sobre fazer curso de Pós-Graduação Stricto Sensu. Por meio da minha experiência e a dos colegas que participaram do Grupo de Discussão, e que, estando em uma Secretaria de Educação, trabalhando como formadores e técnicos, não fomos/somos dispensados por este órgão a contento, para darmos continuidade a nossa formação em nível Stricto Sensu. Os professores que estão em sala de aula, também, não têm apoio do órgão central, e quando ingressam em cursos de Pós-Graduação são obrigados a pagar professores substitutos para conseguirem cumprir com as atividades do programa.

Sobre meus interesses em estudos pós-graduados, eu mesma cheguei a ouvir que professor da Educação Básica não tem que fazer Mestrado e Doutorado, que só uma especialização já basta. Rememoro que no ano de 2017, uma colega professora que estava fazendo Doutorado e trabalhava no órgão central, ao solicitar a dispensa para os dias das atividades do programa (aulas e orientações), não foi atendida e, diante da situação começou a passar mal na sala da chefia, foi socorrida, mas infelizmente veio a óbito horas depois. Foi muito traumatizante para nós enquanto colegas, presenciarmos o ocorrido. Ao considerarmos esse cenário, realmente é desmotivador para nós professores, continuarmos o nosso processo de formação continuada a nível Stricto Sensu, pois não temos como pedir licença remunerada e também não podemos ser bolsistas, porque estamos em exercício da profissão e, sobretudo, em razão de não termos apoio e nem liberação do órgão responsável. No entanto, mesmo com todos esses obstáculos, e sob ameaça dos gestores em colocar falta no livro ponto, nos arriscamos para dar continuidade a nossa formação, o que aliás, deveria ser um direito. Entretanto, ao contrário disso, trabalhamos dobrado para compensar os dias em que participamos das atividades dos programas de Pós-Graduação, ou quando isso não é possível, temos o dia de trabalho descontado em folha de pagamento.

Como mais um movimento de deslocamento de análise, problematizo as duas questões mais citadas como motivos para o desinteresse pela carreira docente, segundo os participantes deste estudo e da literatura pesquisada: o baixo salário e a desvalorização do professor. 
No ano de 2018, a OCDE divulgou por meio do relatório "Políticas eficientes para Professores" que apenas 2,4\% dos jovens brasileiros de 15 anos querem se formar professores. Importante destacar que este mesmo percentual era de 7,5\% há dez anos. Os dados gerados por esta pesquisa evidenciaram que $36,62 \%$ dos participantes já pensaram em ser professor. Os principais motivos que levaram esses jovens a falta de interesse pela docência foram: a baixa remuneração e a falta de valorização dos professores.

Atualmente, o piso nacional do magistério, aprovado no ano passado pelo Governo Federal, segundo o MEC (2018), é de R\$2.455,35, para uma jornada de 40 horas semanais, porém esses valores variam dependendo do município, pois alguns governos não cumprem a Lei do piso em sua integralidade. Se compararmos os valores pagos aos professores no Brasil e em países desenvolvidos, a diferença é assustadora. Os docentes em início de carreira da Educação Básica de escolas públicas no nosso país recebem, em média, 10.375 dólares/ano. Em Luxemburgo, a título de exemplo, o salário é de 66.085 dólares/ano, conforme dados trazidos de uma pesquisa da Education at a Glance (2014), que mapeia números sobre a educação em 34 países, incluindo o Brasil. Até mesmo a Hungria, penúltimo lugar no ranking, recebe 14 mil dólares/anos, porém após 15 anos de exercício da docência ganham cerca de 20 mil dólares/ano. Outro dado desolador é o da Confederação Nacional dos Trabalhadores em Educação - CNTE (2018), que verificou que o salário dos professores brasileiros representava cerca de $60 \%$ da média salarial de outras profissões.

Feitas essas considerações, o salário de um professor da Rede Estadual de Ensino de MS, conforme tabela (anexo 13), da Federação dos Trabalhadores em Educação de Mato Grosso do Sul - FETEMS (2019) tem o salário base atual fixado no valor $R \$ 4.052,78$ por 40 horas semanais de trabalho, para um professor em início de carreira e sem Pós-Graduação, mas essa base salarial era melhor até o início de julho/2019.

No dia 11 de julho de 2019, foi aprovada pelos Deputados Estaduais de MS, a Lei Complementar n.266/19, que reduz o salário dos professores convocados em $32,55 \%$, ou seja, anteriormente a Lei, os docentes recebiam $R \$ 6.079,00$ por 40 horas semanais e com a redução, passaram a receber $R \$ 4.100,00$, um decréscimo de $R \$ 1.979,00$. A saber, o número de professores temporários é de 11 mil, maior 
do que o de concursados (7 mil). Essa redução além de desestimular o docente, pesa muito no orçamento doméstico do trabalhador que terá que buscar outras formas de complementar sua renda. Contratado ou concursado, o professor é um servidor público e mantém uma relação jurídico-administrativa com o Estado. O juiz Odilon de Oliveira, em reportagem a um jornal local, afirmou que "é flagrantemente inconstitucional a norma jurídica estadual redutora dos ganhos do professor temporário", pois a Constituição (art. $5^{\circ}$ ) traz uma regra primária de que todos são iguais perante a lei, sem distinção de qualquer natureza.

Como professora, fiquei indignada com a aprovação dessa Lei, uma vez que estabelece uma desigualdade brutal entre o concursado e o convocado, sendo que as atribuições são exatamente iguais para ambos, então, a remuneração não poderia ser diferenciada. O convocado já sofre inúmeras pressões na sua rotina de trabalho, desde o momento de sua contratação, como pude presenciar várias vezes, colegas professores implorando aulas nas escolas, além disso, trabalham sobre intimidação no sentido de serem os mais cobrados pela equipe técnica escolar em relação ao desempenho dos alunos, por exemplo. Também em reuniões de conselho de classe, são os últimos a terem voz e, frequentemente, são discriminados por outros colegas porque não conseguiram aprovação em concurso público.

Em prosseguimento ao processo de análise, destaco a segunda maior ocorrência que desestimula os jovens a optarem pela carreira docente - a desvalorização do professor. Por meio de um estudo realizado por Lucyk e Graupmann (2017), sobre a desvalorização do trabalho docente, verificou-se que os principais fatores que contribuíram para esse processo foram: a proletarização da profissão, a massificação da educação e a inserção das mulheres no quadro docente. Para as autoras, este é ainda um assunto novo entre os pesquisadores, ao considerar que começou a ser investigado nos últimos 20 anos. Sobre a desvalorização salarial, elas destacaram que esse fator reflete diretamente na qualidade do ensino, uma vez que o professor se vê obrigado a dobrar ou triplicar sua jornada de trabalho para atingir uma remuneração digna, e o tempo com a preparação das aulas é prejudicado. A falta de tempo também pode ter impacto no seu processo de formação continuada, pois se trabalha em diversos turnos para melhorar sua renda, muito provavelmente, não sobrará tempo para se dedicar à realização de cursos. 
A respeito da inserção de mulheres no quadro docente, as autoras supramencionadas explicam que em razão da luta das mulheres em busca de acesso à educação e ao trabalho remunerado, diante do capitalismo com suas numerosas fábricas e por aceitarem trabalhar por salários muito baixos, não havia opção, ou trabalhavam nas fábricas, ou em trabalhos domésticos, e considerando essa realidade, o magistério surgiu como uma opção atrativa aos olhos femininos. A expansão do ensino também influenciou a entrada da mulher no magistério, pois com a necessidade de mais docentes, as mulheres foram uma ótima solução para equilibrar o orçamento, com seus salários muito inferiores ao dos homens.

Em relação a massificação da educação, os problemas estão ligados à falta de investimento do governo, como as condições precárias do trabalho dos educadores com edifícios escolares e equipamentos deteriorados, classes lotadas, falta de segurança nas escolas e escassez de recursos de toda ordem. Para que esse quadro seja revertido, segundo as autoras, há a necessidade de uma reforma educacional na elaboração de políticas educacionais sólidas e a revalorização do seu estatuto, bem como a melhoria dos planos de carreira, o oferecimento de uma remuneração compatível ao nível de formação, investimento em formação continuada e melhoria das condições de atuação do docente.

Em outra investigação sobre a desvalorização social da profissão docente a partir da percepção que os professores trazem do espaço laboral da escola pública, Souza (2011) averiguou que os professores participantes da pesquisa apontaram como formas de ver a desvalorização social da profissão desde a culpabilidade do próprio professorado, que demonstra socialmente atitudes de conformismo e passivismo, perpassando pelas ausentes e precárias políticas de governos que circunscrevem o valor da categoria profissional somente nos discursos oficias, e ao distanciamento da sociedade, por meio da figura dos pais e alunos que relegam as reinvidicações para a classe docente. O estudo também revelou que apesar dos professores valorizarem o magistério como profissão, não estão satisfeitos com ela em razão do descaso dos alunos; da falta de comprometimento dos pais em acompanhar e valorizar a educação; a falta de reconhecimento da sociedade contribui para que a classe docente venha a adoecer, e a crescente desvalorização social da profissão por meio de políticas educacionais descompassadas do cotidiano da escola pública. 
Acerca da desvalorização do professor, um outro estudo foi feito pela Fundação Varkey (2018), denominado Global Teacher Status 2018, em 35 países, incluindo o Brasil. No balanço geral, essa fundação identificou que houve uma queda do Brasil de penúltimo para último lugar no quesito valorização dos professores, em relação ao levantamento feito em 2013. O estudo também avaliou o respeito dos alunos pelos professores e o Brasil foi o último colocado, pois menos de $10 \%$ dos entrevistados acreditavam que os alunos respeitavam seus professores.

Outro levantamento feito pelo Ibope Inteligência (2018), em parceria com a ONG Todos pela Educação, apontou que metade dos professores brasileiros não recomenda a carreira docente. Mais uma questão que reflete o desprestígio dessa profissão é o fato de pessoas não formadas na área, ministrarem aulas. Em outras palavras, dá a impressão que qualquer pessoa pode ser professor. Condizente com essa realidade, o Anuário Brasileiro da Educação Básica (2019), verificou que apenas 48,7\% dos professores de Ensino Fundamental II tinham formação superior compatível com as disciplinas que lecionavam em 2018 e no Ensino Médio, a soma foi de $56,3 \%$.

Adicionalmente, os frequentes casos de violência física e verbal na escola contra professores é outro fator que pode afastar o jovem do interesse em se formar professor, como mostrou um levantamento realizado por meio de um questionário aplicado da Prova Brasil (2015), o qual abrangeu 262 mil professores e aferiu que 22,6 mil destes docentes foram ameaçados por estudantes, e mais de 4,7 mil sofreram atentados à vida nas escolas que trabalham. Este mesmo estudo revelou também que $71 \%$ (183,9 mil) dos professores relataram ter sofrido agressão física e verbal de alunos e, ainda 2,3 mil docentes afirmaram que estudantes frequentaram as aulas com armas de fogo e mais de 12 mil disseram que havia alunos portando armas brancas como facas e canivetes.

Presenciar a violência contra os docentes é pavoroso e constitui um poderoso desestímulo para seguir esta profissão. Sobre isso, relembro dois acontecimentos que acompanhei na escola, o primeiro, de um colega professor que, ao sair da instituição de ensino após o término das aulas, dirigindo seu carro, duas quadras depois do estacionamento, foi alvejado com três disparos de arma de fogo por um aluno do $6^{\circ}$ ano, com idade de 12 anos, e que não aceitou a nota baixa no boletim escolar. De sorte, os tiros só atingiram o carro do professor. Contudo, esse 
docente começou a apresentar problemas psicológicos e, após passar por vários tratamentos, nunca mais conseguiu retornar a ministrar aulas, sendo readaptado definitivamente em outra função na escola.

O segundo acontecimento ocorreu quando eu estava na sala dos professores de uma escola pública, fazendo acompanhamento pedagógico com duas colegas professoras e, de repente, um aluno acendeu um cigarro de maconha e soltou a fumaça para dentro da sala. Nesse momento, uma das professoras alertou o aluno dizendo que ele não poderia fumar na escola. $O$ aluno respondeu da seguinte forma: "- Fica na tua, porque eu matei meu irmão na semana passada". Fiquei chocada diante da situação e perguntei para a professora se isso que ele havia dito era mesmo verdade, ou se era só para "causar", como dizem os jovens de hoje quando querem impressionar alguém. A professora afirmou que sim, que ele havia matado o irmão por conta de um desentendimento relacionado ao uso de drogas.

Cenas como essas não são fatos isolados, a mídia tem noticiado frequentemente casos de violência contra os professores em todas as partes do país. Como professora formadora da SEMED/MS ao longo de mais de 15 anos de trabalho, muitos outros colegas professores relataram-me momentos de extrema indisciplina, ameaças verbais e falta de respeito e educação por parte dos alunos. Em vista disso, alguns profissionais acabaram se servindo de longas licenças médicas por estarem com depressão e estressados, outros, pediram exoneração de seus cargos, uns estudam para passar em concursos públicos de outras áreas que não seja da educação, e outros fazem uma graduação diferente para mudar de profissão.

\section{A compreensão Nietzschiana sobre a educação de seu tempo e os desafios de pensarmos em nosso tempo sobre a importância da educação para a vida}

$\mathrm{Na}$ obra de 1873, intitulada "Na segunda consideração intempestiva: da utilidade e desvantagem da história para vida", Nietzsche (2003) critica a educação de seu tempo ocorrida nas instituições de ensino ao constatar que esta objetivou formar sujeitos para servir aos interesses do Estado e do mercado, em detrimento do desenvolvimento das singularidades e do potencial criativo deles, pois um 
aspecto marcante dessa educação se apoiava no uso excessivo da memorização dos conteúdos. Ao contrário disto, o autor sugere uma educação que promova as capacidades intelectuais, afetivas, criativas, artísticas e físicas de cada aluno, uma educação promotora da cultura e da vida. Entretanto, o filósofo em suas análises, concluiu que a educação ministrada nas instituições de ensino era apoiada em valores antivitais, sendo um dos instrumentos mais eficazes não só para promover o distanciamento entre o sujeito e a vida, bem como para o empobrecimento da existência humana. Esse excesso de memorização de conteúdos, de informações, de fatos, de datas, produz um sujeito passivo, sem ação, carente de singularidades, incapaz de vivificar o presente, ao invés disso, produz um sujeito possuidor de um saber artificial e superficial.

O autor ainda evidencia três egoísmos que orientaram a educação de sua época: 1. O egoísmo dos comerciantes - cuja ideia de felicidade estava atrelada e sintetizada na equação: produção, lucro, consumo e felicidade. Para tanto, a educação deveria ser técnica e rápida, para que os homens pudessem produzir, ganhar dinheiro e consumir mais e mais, asserção que se aproxima das motivações neoliberais; 2. O egoísmo do Estado - a Educação Básica deveria ser lecionada para o maior número possível de pessoas, porém de forma reduzida, pois eram apenas ministrados os conhecimentos para que se formassem sujeitos que pudessem servir e serem úteis ao Estado, não havia preocupação com uma formação crítica; e 3. O egoísmo da Ciência - que destaca a ciência como sinônimo de conhecimento, o qual potencializa os problemas do conhecimento científico em detrimento dos problemas humanos, pautando-se em elaborações técnicas e questões abstratas, esquecendo-se das questões concretas da existência. Para o pensador, ao perceber esses três egoísmos, a educação de sua época tinha o objetivo evidente de formar sujeitos para servir a esses três egoísmos.

Diferentemente da educação para os três egoísmos, Nietzsche (2003) entende o sujeito como pluralidade de forças em permanente devir, isto é, não há uma substância ou essência fixa nos sujeitos, mas forças em constante transformação, tendo em vista que ao estar no mundo e no devir, o sujeito se modifica a todo instante em contato com os outros e com o mundo. Assim, será necessária a desconstrução do que nos foi incutido como verdade absoluta e o 
"esquecimento" dessas verdades fixas em prol do cultivo de outras forças que nos potencializem como seres criativos e críticos.

Diante das considerações feitas, será mesmo que o professor é aquele incompetente que não progrediu na vida? Aquele que não seria professor se houvesse outra opção melhor? Será que o desapreço pela educação e pelo professorado é uma influência neoliberal? Será que se pode ser professor sem gostar? Ou esse gostar se aprende?

A análise dessas questões é importante para aclarar que, quando os participantes da pesquisa justificam as razões e desrazões pelas quais querem ou não se formarem professor, todas essas justificativas nascem em contextos materiais como a linguagem, por isso tentei registrar essas circunstâncias. $\mathrm{O}$ meu propósito não foi usar os dados gerados para discutir o baixo interesse dos jovens em se formarem professores, muito menos de responsabilizá-los por esse desinteresse, mas de mostrar a eficácia das ideologias neoliberais reinantes amplamente discutidas neste trabalho que vão funcionar contra o próprio jovem, e fazer com que ele tenha uma visão negativa da docência.

Para mais, interrogo: Por que temos que pensar o mundo em termos de mercado? Essa pergunta não se faz, pois o medo da educação transformadora por parte dos neoliberais, é que se questione o mundo como mercado. Quando se transfere a educação para o plano privado que pressupõe outros valores como conforto, riqueza e todos os luxos da vida que estão lá justamente para que essas pessoas se beneficiem da metáfora do mercado, é muito provável que essas pessoas não venham a questioná-la. Se questionarem, vão perceber o risco que correm se acabarem com essa metáfora, pois vão perder a sua riqueza e vão ter que falar em justiça social e redistribuição de renda, por isso, como professora, penso ser primordial que essa ideologização seja questionada em nossas aulas.

\section{O Idealizado e o Realizado}

Diante dos resultados deste estudo e do cenário apresentado, analiso que há um distanciamento entre o discurso que valoriza a educação para a construção de uma sociedade melhor e o desprestígio da profissão docente, como foi possível verificar nas alegações de alguns participantes da pesquisa: 
A2947: Reconheço que o professor é uma das áreas profissionais mais importantes, afinal, sem grandes mestres não haveria excelentes profissionais. Porém, não me vejo em sala de aula como tal, eu tenho vontade de aprender, também tenho paciência para ensinar, porém não consigo me ver limitada a uma sala de aula.

A2846: Pois além de ser uma das profissões mais importantes para a sociedade, nela os profissionais sofrem muito e, além disso, é uma profissão muito pouco valorizada, com um salário muito baixo.

A1955: Particularmente, acho que o Professor tem um papel muito importante em uma sociedade, pois trabalha com a educação da população. Porém, sofre com o desrespeito e com a desvalorização da sua profissão.

A2351: Salário baixo, e é desrespeitado constantemente e, às vezes, é menosprezado mesmo tendo grande importância na sociedade.

A5905: Nada contra! A profissão é muito bonita. Temos que ensinar os alunos a pensar e não a obedecer, mas não me identifico sendo uma professora.

A487: É a profissão mais importante, pois é a base para todas as outras. Tenho grande admiração, e sei que está cada vez mais diminuindo os profissionais nesta área.

Acordante aos recortes dos participantes da pesquisa, sincronicamente em que a profissão docente é entendida como de fundamental importância para a formação de todos os profissionais, também sofre uma acentuada desvalorização social. A crise na educação, segundo o autor argentino Gentilli (2009), em seu artigo "O direito à educação e as dinâmicas de exclusão na América Latina" tem sido marcada por uma cultura política pautada pelo desprezo aos direitos humanos e pela redução do valor da escolaridade aos efeitos que tem na concorrência pelos melhores postos no mercado de trabalho.

Outro aspecto discutido pelo autor, é que historicamente se produziu a negação do direito à educação dos mais pobres, hoje, esse direito continua negado quando se limitam as condições efetivas para uma educação de qualidade, o que o autor nomeia de "exclusão includente" (GENTILLI, 2009, p. 1061). Para ele, os altos níveis de pobreza e exclusão, associados à persistente desigualdade e à injustiça social, às péssimas condições de vida e de saúde impedem uma oportunidade real de democratização dos direitos humanos e o trânsito pelas instituições escolares. Para mais, essas condições são vistas como normais para os governos e parte da população elitizada e, tornam-se ocultas aos olhos da população, em que o pobre tem acesso à escola, mas não há nenhuma garantia na qualidade de ensino. 
Aliado a essa problemática, recai sobre o (a) professor (a) a culpa pela falta de qualidade no ensino, como informa Gentilli (2008, p. 47):

\begin{abstract}
O quadro se torna ainda mais dramático quando observamos a ofensiva ideológica conservadora lançada contra os professores nos últimos anos. Eles são responsabilizados pela profunda crise dos sistemas escolares e Ihes é atribuída a culpa pelas péssimas condições de aprendizagem dos alunos e alunas, pelas altas taxas de repetência, pelas escassas oportunidade de inserção no trabalho para os recém-saídos do sistema escolar, pela violência dentro e fora da escola e pela falta de participação cidadã nas questões mais relevantes que nossas sociedades devem enfrentar.
\end{abstract}

Diante da realidade exposta por este autor, e sobre a função da escola e do trabalho do professor, Paro (1986, p. 111) esclarece que "a escola, na verdade, não possui de modo nenhum esse poder de corrigir as injustiças provocadas pela ordem capitalista". Outrora, Libâneo (2003), explica que a falta de compromisso dos governos com a educação pública foi e continua sendo a responsável pela deterioração do salário dos educadores e das péssimas condições de trabalho, o que tem provocado a emigração de muitos educadores para outras profissões. Além disso, existe uma cultura instalada no nosso país que não separa a crise educacional da figura do docente.

Para reduzir esses efeitos, Aranha (2006) entende que o primeiro passo é cuidar da formação do professor. Nesse sentido, Delors (2003, p. 160) reforça que "a qualidade do ensino é determinada tanto ou mais pela formação contínua dos professores do que pela formação inicial." Outra questão seria melhorar as condições de trabalho do professor, com horários ampliados para o planejamento das aulas, bem como para momentos de estudo e pesquisa. Outro aspecto pertinente refere-se também a declaração feita por A7246: "Porque os professores vivem presos nas salas de aulas sem nenhum recurso tecnológico, o mais simples, a internet nos falta. Salas de aulas pequenas e lotadas, sem ventilação...”, o que discuto a seguir.

Na prática como professora da Educação Básica, por várias vezes, vivenciei com os alunos, o quanto o clima pode interferir nas aulas. Em dias em que o calor alcança os $40^{\circ} \mathrm{C}$, por exemplo, se torna um desafio para o professor ensinar e para os alunos desenvolverem a contento as atividades. O desconforto é evidente, sala de aula sem infraestrutura adequada, com poucas janelas para a passagem do ar, sem cortinas para abrandar a entrada do sol na sala, um ou dois ventiladores 
funcionando precariamente, acordante as observações feitas por A7246. Os alunos pedem a cada minuto para beberem água ou irem ao banheiro se refrescarem. $O$ jeito é ir fazendo o que é possível para diminuir a sensação de calor e tentar cumprir com o planejado para a aula.

Em sua pesquisa sobre formação continuada de professores e momentos de tensão em sala de aula, realizada com alunos do $9^{\circ}$ ano do Ensino Fundamental de uma escola municipal de Campo Grande - MS, Marques (2016, p. 84) perguntou aos alunos como seria, na opinião deles, a escola ideal e, um foi enfático em dizer: "Seria uma escola que deixe o aluno à vontade, mas que realmente invista no aluno. Também se possível, colocar um Springer Carrier de 24.000 btus na sala." A investigação ainda evidenciou que, o espaço físico da escola com salas pequenas, pouco ventiladas e com muita interferência de ruídos externos, ventiladores insuficientes e barulhentos, cadeiras sem assento almofadado, somado ao excessivo número de alunos por turma, impacta de modo significativo no processo de aprendizagem dos alunos.

Em uma das escolas que acompanhei como técnica responsável da SEMED, por conta do calor insuportável nas salas de aula - tendo em vista que no estado de MS, o clima quente é o que predomina - a diretora e os professores tiveram a ideia de fazer gincanas, festas e eventos para arrecadar dinheiro para a compra de alguns aparelhos de ar condicionado para minimizar o problema. Após três anos de trabalho, a equipe escolar, alunos e a comunidade conseguiram o valor necessário para a aquisição dos aparelhos. Enfim, foi um momento festejado na escola. Para a surpresa de todos, quando o técnico foi fazer a instalação dos aparelhos, verificou que em razão da fiação elétrica ser muito antiga, não seria possível fazê-la, a menos que fosse refeita inteiramente, valor que a escola não teria como arcar. A diretora desesperada agendou um horário com o prefeito e foi pedirIhe ajuda. Infelizmente, o prefeito disse que o município não tinha recurso suficiente para atender a solicitação e que nada poderia ser feito. A diretora retornou abalada para a escola e teve que dar a triste notícia de que não seria possível instalar os aparelhos. Por fim, eles resolveram vender os aparelhos de ar condicionado e usar o valor para outras melhorias na escola.

O fato é que essas condições prejudicam o desenvolvimento das aulas e, consequentemente, o processo de ensino e aprendizagem. Se houvesse maior 
empenho e investimento por parte dos gestores públicos, esse problema poderia ser atenuado. Ainda, não se pode deixar de citar a melhoria do salário do professor, tendo em vista, que todas as pesquisas citadas como referência neste estudo apontaram esse indicador como um dos principais desmotivadores pela falta de interesse dos jovens em ser professor. Entretanto, não percebo indícios de interesse das políticas públicas educacionais vigentes em melhorar essa realidade, especialmente considerando o atual governo.

Apesar das dificuldades supramencionadas enfrentadas no dia a dia do professorado, como disse o brilhante pensador pernambucano Ariano Suassuna "Como sou pouco e sei pouco, faço o pouco que me cabe me dando por inteiro". Assim sigo em frente e resisto, na luta constante pelo reconhecimento do trabalho do professor perante a sociedade e ao governo, com vistas a (re)conquistar a tão merecida valorização. 


\section{CONSIDERAÇÕES FINAIS}

Combati o bom combate, terminei a corrida, guardei a fé.

(2 TIMÓTEO 4:7)

A maior riqueza do homem é a sua incompletude. Não aguento ser apenas um sujeito que abre portas, que puxa válvulas, que olha o relógio. Perdoai!

Mas eu preciso ser Outros.

Manoel de Barros

Inicio as considerações finais desta tese, com o verso do poeta pantaneiro, do "poeta da palavra" como se autodefiniu Manoel de Barros, "A maior riqueza do homem é a sua incompletude", assim me sinto ao findar este texto, um texto incompleto. Poderia ter escrito mais, sem dúvida, poderia ter dito muito mais, muito ficou pelo caminho.

Inspirada em Timóteo sobre o apóstolo Paulo, comparo esta escrita como uma corrida. Durante essa corrida, passei por momentos de cansaço, de dor, de exaustão, o corpo pediu para parar, mas resisti porque me preparei para correr e chegar até o final. "Firmei o corpo". Busquei coragem e força para enfrentar todas as dificuldades e, pela fé, encontrei a paz que precisei nos momentos de turbulência. Não desisti do combate. Um combate que travei comigo mesma, e que valeu a pena viver e batalhar por ele. Cheguei ao final e com um sentimento de gratidão que não cabe em palavras.

Analogamente, como na obra "Assim falou Zaratustra", de Nietzsche (2012), posso dizer que sofri as três metamorfoses do espírito. Primeiro fui camelo, carreguei o peso de fazer um processo de seleção para o doutorado na mais importante universidade do país e, confesso que, muitas vezes, disse a mim mesma: “- Esse lugar não é para você. Só em sonho mesmo!". Subestimei minha capacidade. Sofri a segunda metamorfose, fui leão, ao me deslocar toda semana durante um ano por aproximadamente $1000 \mathrm{~km}$ para cumprir as atividades do curso, ao caminhar pelo deserto da cidade grande, ao enfrentar o medo de estar longe da 
minha família, medo também das minhas crises de labirintite, o desafio de conciliar o trabalho com as atividades do doutorado, e não descuidar do cuidado com minha filha, meu marido e os meus pais idosos. Mas quando chegava a universidade para as aulas, batia aquela sensação de felicidade, de alegria, de gratidão, e compensava toda e qualquer dificuldade. Por fim, sofri a terceira metamorfose, fui criança: criei, brinquei, joguei, dancei, sonhei livremente, alimentei-me de alegria e das boas amizades que fiz com os professores e colegas de turma. Tracei meu mapa, fiz meu caminho, esculpi meu próprio "Bugre", vivi intensamente e dei o melhor de mim.

Em consonância com os objetivos deste estudo e por meio do processo da análise das questões que envolveram a construção de sentidos sobre a carreira docente pelos participantes da pesquisa, bem como suas justificativas para serem ou não professores, e conjuntamente com a contribuição de outras investigações realizadas que serviram de base para as discussões, assim como de um referencial teórico extenso, os quais produziram um efeito de alerta em relação ao assunto tratado, discorro sobre os principais resultados deste estudo.

Com o intento de convidar o leitor a traçar sua própria linha de fuga em relação ao que lhe foi exposto por esta investigação - a carreira docente como uma área sensível às transformações sociais, com seus sabores e dissabores, este texto se converge para o interesse em avivar a temática tratada, considerando as contingências e os fatores que emergiram durante a fase de geração dos dados, e com os quais me deparei e me permiti afetar por uma ideia ou conceito. Em aproximação com Nietzsche (2003), acerca da educação de seu tempo e do propósito em formar sujeitos para servir os interesses do Estado e do mercado, o autor nunca afirmou que esta educação seria para sempre, longe disso, ele advertiu que esta cederia espaço para outra coisa. Nessa direção, desejosa de que os resultados desta pesquisa cedam espaço, no futuro, para outra coisa, pois "sou uma realista esperançosa" (Ariano Suassuna), faço uma síntese do que este estudo apurou.

Como primeiro objetivo de pesquisa, busquei investigar a construção de sentidos dos participantes da pesquisa sobre a carreira docente, e de modo geral, não só nesta pesquisa, mas em todas as outras que citei como suporte teórico para as análises, independente do interesse ou não em se formar professor, e das razões ou desrazões que levam uma pessoa a optar em seguir a docência, os participantes 
manifestaram grande respeito pela profissão de professor, bem como a consideraram de muita responsabilidade, compreendendo a relevância do professor na sociedade e na formação holística dos sujeitos.

Apesar de afirmarem o valor do professor na sociedade, uma parcela significativa $(63,38 \%)$ alegou que em nenhum momento pensou em ser professor. Já os que chegaram a pensar em ser professor somaram 36,62\%, contudo, quando indagados sobre a pretensão de curso para ingressar em uma Instituição de Ensino Superior, 3,58\% afirmaram que queriam fazer Pedagogia. As demais áreas do conhecimento citadas (Educação Física, Biologia, Letras, Matemática, História, Geografia, Química, Física, Música, Artes, Filosofia, Ciências Sociais, Sociologia e licenciatura outras) com índice total de $11,82 \%$, são cursos que possuem licenciatura e bacharelado, conquanto, os participantes não expressaram essa diferenciação ou escolha em suas respostas, dessa forma, não foi possível apurar com precisão o quantitativo dos que realmente fariam uma licenciatura.

Um aspecto importante analisado é que esses alunos que em algum momento pensaram em ser professor ou até mesmo os que nunca pensaram nessa alternativa, mesmo que optem por um curso de graduação diferente da licenciatura no tempo presente, não significa que, ao longo de suas vidas, posteriormente, decidam ser professor, pois os dados gerados só mostraram o retrato atual da situação e não uma projeção que considera mudança no pensar dos jovens sobre sua escolha profissional. Portanto, para esta análise me apoiei nos dados qualitativos quando mostraram as afirmações de alguns professores do Grupo de Discussão que confirmaram que, a decisão em ser professor se deu ao longo de seu percurso profissional.

A respeito do interesse dos alunos em cursar Pedagogia, única licenciatura que consta no índice dos 10 primeiros cursos na preferência dos participantes da pesquisa conforme mostrou o infográfico 13, eles afirmaram que o principal motivo para optarem em fazer o curso de Pedagogia está relacionado ao fato de gostarem e/ou terem afinidade com crianças. Para mais, este curso possibilita trabalhar na EJA, na elaboração de materiais didáticos, em cursos à distância, em cargos de gestão escolar como diretor, coordenador ou orientador pedagógico, no Recurso Humano - RH, na Educação Especial, na Pedagogia Hospitalar, na Pedagogia Empresarial, em ONGS. Analiso que o mercado de trabalho extraclasse para o 
pedagogo é amplo, conquanto, as universidades que oferecem o referido curso devem estar atentas em preparar também esse profissional para atuar em outros espaços que não seja somente o ambiente escolar, expandindo suas oportunidades de trabalho.

Em referência ao curso de Letras, 1,18\% dos alunos participantes da pesquisa informaram o desejo de cursá-lo. Após a apuração dos dados gerados, foi possível verificar que $0,41 \%$ desses alunos, ou seja, 32 alunos dos 7.894 gostariam de se formar professores de Inglês, conforme exibido no infográfico 24. Sobre a decisão de serem professores de línguas, a maioria justificou essa escolha por questões que envolveram a concepção do Inglês como língua dominante no mundo e, portanto, aprender esse idioma como um nativo abre portas para migrar para outros países e melhorar as condições de vida e, na opinião deles, sendo professor de Inglês, esse trajeto poderá ser mais fácil. Um participante apenas escolheria ser professor de Inglês porque é uma área muito rica em relações de conhecimento e cultura. Os aspectos elencados por esses alunos nos alerta para a importância de revisitar os objetivos do ensino de Inglês, principalmente nos programas de formação docente, uma vez que muito do que é dito por esses alunos mostra uma visão colonialista, portanto, o ensino do Inglês não pode se restringir a uma visão monolíngue em que esse idioma se sobreponha as outras línguas, pois assim, reforça-se a ideia da colonialidade. Mesmo que atualmente haja esforços por parte de muitos professores em promover as formas plurais de conhecimentos e a diversidade cultural, linguística e social nas aulas, os currículos escolares permanecem inalterados, ainda se baseiam em uma proposta que prioriza a homogeneidade e a normatividade linguística e cultural, apoiados em uma ideia eurocêntrica e conteudista. Ao contrário disso, pode-se incentivar a perspectiva crítica oportunizada pelas experiências que envolvem a aprendizagem de outros idiomas, bem como promover a melhor compreensão do aluno sobre as diferenças e a diversidades linguística e cultural.

Sobre a escolha de um Curso Superior, os professores do Grupo de Discussão evidenciaram outras duas questões importantes, a primeira, quando o aluno presta o ENEM e outros vestibulares e não consegue a pontuação necessária para ingressar no curso de sua preferência, então, opta por outro curso em que a pontuação é suficiente para ele cursar, como por exemplo, os cursos de licenciatura 
que exigem menor pontuação para ingresso. Além disso, outra problemática vivenciada é quando o aluno decide fazer o curso de Letras, a título de exemplo, porque o pai mandou, por ser gratuito e para fazer medicina ou engenharia depois, pois ele aprenderia/aperfeiçoaria português e redação, para poder prestar a prova novamente para o curso pretendido.

Destaco também o interesse dos indígenas participantes da pesquisa em se formar professores de línguas como explicitou a aluna indígena Guarani Kaiowá 7214 participante da pesquisa ao afirmar que: "Quero ser professora de línguas, porque o meu povo tem muita dificuldade em aprender a Língua Portuguesa e, sei que, dessa forma, estarei ajudando as pessoas da minha aldeia a superarem essa dificuldade", bem como dos alunos que afirmaram querer ser professores de Letras Português/Inglês para: "A03: Melhorar a qualidade do ensino na minha aldeia e A6932: Para ajudar na educação nas aldeias”. Concluo que para esses alunos, tratase de desenvolver os interesses individuais de maneira que eles coincidam com as necessidades sociais e locais de seu povo e de sua comunidade, uma vez que a aprendizagem de línguas e da escrita pode ser uma ferramenta para a desconstrução de imagens estereotipadas de seu povo, bem como para combater os preceitos e preconceitos construídos pela colonização. Percebo neles outras formas de pensamento - o da coletividade e da solidariedade, e saliento a importância desses pensamentos em um momento político que vai em direção contrária a de um país mais inclusivo, plural e liberto da ignorância e de todas as formas de preconceitos.

No tocante aos problemas enfrentados por grupos minoritários (indígenas e quilombolas), sobre seu processo de escolarização, no ingresso e na permanência no Curso Superior, verifiquei que estes são amplos ao considerar que fica sob a incumbência deles o aprendizado da língua do outro com todos os seus aparatos formais (escrita, gramática e convenções), o que pode, para alguns, implicar a desistência dos cursos, conforme mencionou a professora 4, por meio de sua experiência de mais de 40 anos tanto com alunos da Educação Básica quanto da universidade. Portanto, o desenvolvimento de ações de permanência que valorize as experiências culturais e os saberes desses grupos, bem como o entendimento dos desafios de sua escolarização, é necessário fazer parte do processo de acolhimento desses grupos nas universidades. 
Como outro objetivo de pesquisa, busquei investigar as razões e desrazões que os alunos justificaram para escolherem ou não serem professores. Por meio das respostas dos alunos às questões discursivas do questionário de pesquisa, foi possível apurar que os aspectos positivos para essa escolha se concentraram na possibilidade de transmitir conhecimentos para as pessoas, pelo gosto de trabalhar com crianças, porque se identificam ou gostam da profissão, consideram uma profissão digna - com boas oportunidades de emprego e estabilidade financeira, por admiração aos professores, para melhorar a qualidade do ensino público no país e pela facilidade de comunicação e interação com as pessoas. A partir da premissa de que a transmissão do conhecimento é revisitada na atualidade, entendo que o ensino está para além disso, pois o conhecimento não pode ser ensinado desarticulado de uma análise da realidade social, política e econômica dos estudantes.

Quanto aos motivos de desinteresse pela carreira docente, os participantes da pesquisa afirmaram que não se identificam, não tem vocação, ou não gostam dessa profissão, a falta de paciência para ensinar, a desvalorização dessa profissão pela sociedade, principalmente pelos governantes, o salário ruim/baixo, profissão muito estressante, rotina cansativa e carga horária de trabalho extensa, preferem outros cursos, alunos indisciplinados e desrespeito dos alunos com os professores e dificuldade de ensinar.

Feitas essas observações, os discursos dos alunos me permitiram concluir que o interesse ou não pela carreira docente não tem razões isoladas, mas se relacionam, se complementam e se articulam entre si e compõem um movimento de reações e de sentimentos que evidenciam a complexidade desse tipo de escolha, no momento em que os alunos precisam decidir sobre sua profissão, em meio às situações de incertezas, conflitos e liquidez.

Essa complexidade ocorre em razão da docência ser uma experiência profundamente humana, na qual o sujeito e sua história estão imbricados, isso pode significar que a escolha em ser ou não professor, como em qualquer decisão pessoal, não tem suas dúvidas visíveis e saciadas a priori. Reconhecer essa complexidade e compreender suas implicações direcionou o meu olhar para os múltiplos sentidos que afloraram nos discursos dos participantes diante da escolha de ser ou não professor, como um rizoma que faz conexões sem cessar e se 
movimenta para todos os lados por meio de linhas de fuga e que nunca se fecha ou se completa, pelo contrário, abre-se para novas possibilidades de conexão e para as multiplicidades, um mapa inacabado, sempre em construção. Assim também entendo o que ocorre com as pessoas e a escolha por uma profissão, estamos sempre em movimento, traçando linhas de fuga, fazemos novas conexões, nos abrimos para novas oportunidades, estamos sempre em processo de construção, portanto, estamos incessantemente traçando um novo caminho em nosso mapa. Isso mostra a incompletude que somos, e por isso, entendo o conhecimento como fonte inesgotável, como algo que pode fazer com que nós, por meio dele, mudemos nossas ideias - renovando-nos, transformando-nos, colocando-nos no lugar do outro e conseguindo ser "outros".

Como último objetivo de pesquisa, busquei tornar visível como opera o neoliberalismo e o Estado no sentido de afetar a escolha de uma profissão e de como os sujeitos se comportam em uma sociedade neoliberal. Como resultados, sobre essa comunidade estudantil pesquisada sul-mato-grossense, trago inicialmente a questão da formação dos pais ou responsáveis e a renda familiar que influenciam nas escolhas profissionais dos alunos participantes da pesquisa. São números claros que mostraram uma dura realidade em a maioria dos pais ou responsáveis $(56,41 \%)$ estudou até o $5^{\circ}$ ano do Ensino Fundamental, cuja maior parte (32,11\%) possui renda familiar entre $R \$ 1.000,00$ e $R \$ 2.000,00$. 90,01\% desses alunos sempre estudaram em escola pública, 32,58\% exercem trabalho remunerado e 85,36\% não fazem cursinho preparatório para o Enem. Em outras palavras, a escolha profissional em uma país como o nosso, subdesenvolvido, está relacionada as realidades sociais existentes, pois não é possível simplesmente escolher uma profissão de forma independente das condições sociais, que são desiguais, e restringem as opções das pessoas em cursarem o que realmente gostariam, haja visto, o distanciamento entre as oportunidades das classes dominantes em relação as subalternas.

Os dados gerados por esta pesquisa mostraram também que $21,06 \%$ dos participantes da pesquisa informam que trabalham remuneradamente com idade abaixo dos 14 anos, o que não é permitido por lei. É importante avivar que o trabalho antes dos 14 anos é ilegal. A Lei 10.097, de 2000, estabelece no Art. 403 que no Brasil "é proibido qualquer trabalho aos menores de dezesseis anos de idade, salvo 
na condição de aprendiz, a partir dos quatorze anos". A redação dada por essa Lei estabelece ainda que "o trabalho do menor não poderá ser realizado em locais prejudiciais à sua formação, ao seu desenvolvimento físico, psíquico, moral e social e em horários e locais que não permitam a frequência à escola". Na contramão do que diz a Lei, para esse jovem que inicia a trabalhar precocemente, em geral, o trabalho que ele consegue é informal, com todas as suas desvantagens. Mais um agravo, pois conforme dados do IBGE (2016), enquanto os analfabetos em média começaram a trabalhar com aproximadamente 12 anos, os diplomados em nível superior ingressaram nas atividades laborais, em média, entre 17 e 18 anos de idade. Ainda de acordo com dados da PNAD 2015, no grupo de pessoas que começaram a trabalhar antes dos 9 anos de idade, cerca de $74 \%$ alcançaram no máximo o Ensino Fundamental completo. Em comparação com os dados gerados pela tese, é possível inferir que o mesmo tenha acontecido com a maioria dos pais dos alunos participantes da pesquisa, uma vez que a maior parcela só conseguiu estudar até o Ensino Fundamental (até o 5ano), ou seja, o trabalho precoce pode causar a impossibilidade das pessoas continuarem os seus estudos.

Esses dados chocam porque mostram a desigualdade de condições e oportunidades entre os mais pobres e os mais ricos e não faltam evidências de que o trabalho precoce interfere na qualidade do aprendizado, bem como na quantidade de anos de estudos que os alunos tendem a permanecer na escola por motivo de distorção idade/série e acabam, muitas vezes, tendo que aderir a programas de correção de fluxo, como a EJA, por exemplo. Nessa direção, a expectativa que o aluno tem de continuar os estudos pode mudar conforme a necessidade desse jovem em contribuir com a renda familiar, uma vez que, a família preferindo que o jovem trabalhe e ajude no pagamento das despesas, pode deixar de incentivá-lo a continuar os estudos e ingressar em um Curso Superior.

Diante dessa realidade, a luta pela sobrevivência se torna maior do que o sonho e o desejo, dada a materialidade do mundo capitalista que impede a vida pretendida. A ideia que o capitalismo prega, na qual o homem é "livre" para fazer suas escolhas, busca encobrir as desigualdades sociais, permitindo na realidade, só que alguns consigam fazer determinadas escolhas, a maioria não tem essa opção, ou seja, prega uma falsa verdade que o sujeito tudo pode, basta crer e ter fé. Esses fatores não impedem que o destino de um jovem economicamente desfavorecido escolha a 
profissão que deseja, mas pode reduzir a probabilidade dele atingir essa meta a curto prazo ou conforme pretendido, pode até mesmo, modificar suas escolhas, adaptandoas para conseguir se inserir no Ensino Superior e no mercado de trabalho, como citado pelos participantes da pesquisa.

Verifiquei que os jovens são os mais atingidos nesse sistema, porque são direcionados a acreditar que este sistema é o único possível, com metas impossíveis de serem alcançadas, em uma sociedade que cobra qualificação, mas que esta não existe para a maioria deles. Dessa forma, o neoliberalismo com seus disfarces e inverdades, culpa as próprias vítimas, e faz com que esses jovens carreguem esse peso por toda vida, até ao ponto deles mesmos aceitarem que a responsabilidade é deles pela falta de oportunidades e condições miseráveis em que vivem.

E para agravar a situação, as pessoas, de um modo geral, são indiferentes às angústias dos jovens, por isso, tento ressignificar um fenômeno para além do que mostram os dados gerados, evitei julgamentos ou conclusões precipitadas e busquei analisar as forças não visíveis existentes nesse contexto, portanto, ao discutir o baixo interesse dos jovens em se formarem professores, não tive como propósito recriminá-los sobre como pensam, mas compreender por que pensam do modo pelo qual pensam. Sendo assim, procurei mostrar a eficácia das ideologias neoliberais reinantes amplamente discutidas neste trabalho que vão funcionar contra o próprio jovem e fazer com que este tenha uma visão negativa da docência.

Nesse sentido, sobre o neoliberalismo e a obra "Assim falou Zaratrusta", analiso o camelo representado pela submissão, depois o leão que ruge, querendo tomar as rédeas de sua própria vida, mas que continua acreditando em uma verdade absoluta, obedecendo as regras do jogo. Esse leão que tem juba e ruge brinca como uma criança, mas continua seguindo ordens, não é realmente livre, é submisso, não questiona, não é uma criança, porque a criança questiona a existência da verdade e vai dizer: - Vamos brincar? Porque a verdade se relaciona com o desejo, o que Nietzsche (2003) chama de vontade de potência. Para o neoliberal a verdade é o mercado, é a competição, é a meritocracia, ou seja, as regras impostas impedem a liberdade individual.

Qual é a posição do professor nesse contexto? O professor pode ajudar o aluno a refletir sobre o contexto social, econômico e político, e consequentemente, ajudá-los a ampliar seu entendimento sobre a carreira docente, pois se o aluno 
pensa ser ruim formar-se professor, como ele seria/estaria se não estivesse aprendendo? Outro questionamento a ser feito é por que temos que pensar o mundo em termos de mercado? Quero explicitar que luto por uma educação que não produza um sujeito acrítico, oco, indiferente a tudo e a todos, desumanizado, incapaz de questionar a política e a ideologia pela qual dá a sua vida. Como educadora, esse caos me afeta e provoca perplexidade, indignação, tristeza e reflexão. Penso que um passo a se dar é estarmos conscientes dos problemas sociais que nos afetam para podermos orientar nossas ações no sentido de problematizar essas questões com nossos alunos para que possam pensar diferente do sistema que os marginaliza, por isso, o papel do professor é indispensável para a formação de cidadãos conscientes e críticos de sua realidade.

Como uma flecha lançada para o futuro, penso com Nietzsche (2003) que a educação deveria oportunizar aos sujeitos formarem-se a si mesmos e contra si mesmos, por meio da criação de novos hábitos que lhes permitam se desfazerem de práticas adquiridas ainda nos primeiros contatos com outros homens, na infância. Isso é o mais difícil de ser modificado, pois são valores passados pela tradição e que são incutidos como verdades ainda na primeira infância, junto com o aprendizado da língua materna. Assim, será necessária a desconstrução do que nos foi incutido como verdade absoluta e o "esquecimento" dessas verdades fixas em prol do cultivo de outras forças que nos potencializem como seres criativos e críticos.

Esses foram os principais resultados que pude verificar ao longo desse estudo. Esclareço que me orientei por um Modus operandi construído a partir da necessidade de melhor discutir e analisar os dados gerados, por isso, percorri um caminho específico. Ao findar esse percurso, não defendo uma verdade essencial, mas quero dizer que por esse meu trajeto, foi isso que aprendi e verifiquei. São verdades locais, são verdades que conclui conversando com esses participantes da pesquisa, mas não com todas as pessoas. Portanto, o meu trabalho não produziu verdades que valem para todos, mas produziu ideias que podem nos ajudar a refletir, bem como ideias que possam contribuir para o nosso conceito de política e, quem sabe transformar e/o aprender a conviver com o dissenso que nos reina, e quiçá trouxe uma contribuição nova relativa ao tema investigado. Para mais, "Cada um de nós compõe a sua história e cada ser em si carrega o dom de ser capaz e ser feliz. [...] Hoje me sinto mais forte, mais feliz, quem sabe? Só levo a certeza de que 
muito pouco eu sei, ou nada sei" (ALMIR SATER E RENATO TEIXEIRA, 1990), assim encerro este texto, com o verso que exprime minha experiência de escrita da tese e expressa também a consciência da incompletude que sou, pois essa, sem dúvida alguma, foi para mim uma experiência emancipadora que me oportunizou metamorfosear. 


\section{REFERÊNCIAS}

ADORNO, W. T. Textos escolhidos. In: Os pensadores. São Paulo: Abril Cultural, 1975.

ANASTÁCIO, J.; PEREIRA, R.; FRAGA, L. (2018) Reexistência indígena na Universidade Estadual de Ponta Grossa: para além do acesso ao ensino superior. In: Souza, A. L.; Silva, I. J.; Muniz, K. Letramentos de reexistência - um conceito em movimentos negros. Revista da Associação Brasileira de Pesquisadores/as Negros/as (ABPN), [S.I.], v. 10, p. 01-11.

ANDRADE, J. M. DE; MEIRA, G. R DE JESUS; VASCONCELOS, Z. B. O processo de orientação vocacional frente ao século XXI: perspectivas e desafios. Brasília: Revista Psicologia: Ciência e profissão. Vol. 22, ㄲo3, 2002. Disponível em: https://www.scielo.br/scielo.php?pid=S1414-

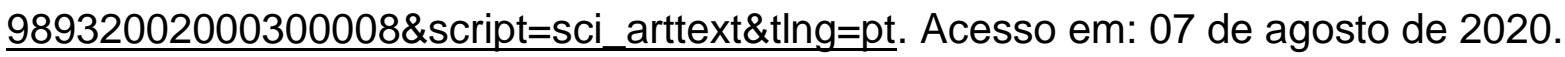

ANDRÉ, M. E. D. A. de. Etnografia da prática escolar. 7. ed. Campinas: Papirus, 2002.

ARANHA, M. L. A. Filosofia da Educação. 2 ed. São Paulo: Moderna, 2006.

ARENDT, H. Entre o passado e o futuro. 5 ed. São Paulo: Perspectiva, 2003.

A condição humana. Rio de janeiro: Forense Universitária, 2007.

. Sobre a revolução. Tradução de Denise Bottmann. São Paulo: Companhia das Letras, 2011.

ARROYO, M.G. Pedagogias em movimento - o que temos a aprender dos Movimentos Sociais? Currículo sem Fronteiras, v.3, n. 1, 2003, p. 28-49.

ASSOCIAÇÃO BRASILEIRA DE MANTENEDORAS DE ENSINO SUPERIOR ABMES. Maioria dos alunos não entrou em universidade por falta de dinheiro. ABMES, 2017. Disponível em:

https://abmes.org.br/noticias/detalhe/2110 Acesso em 10 de março de 2019.

BAUMAN, Z. Amor Líquido: Sobre a Fragilidade dos Laços Humanos. Rio de Janeiro: Zahar, 2004.

BBC NEWS. Os seis números que resumem os seis meses da Educação na gestão Bolsonaro, 2019. Disponível em: https://www.bbc.com/portuguese/brasil48699037 Acesso em 10 de outubro de 2019.

BHABHA, H. O local da cultura. Belo Horizonte: UFMG, 1998. 
BOCK, S. D. Orientação Professional: a abordagem sócio-histórica. 2ª ${ }^{\text {a }}$ Edição: Cortez. São Paulo, 2002.

BRASIL. Decreto no 10.502. 30 de setembro de 2020. Brasília: Diário Oficial da União. Publicado em 01 de outubro de 2020. Edição: 189, Seção: 1, p. 6, 2020. Disponível em: https://www.in.gov.br/en/web/dou/-/decreto-n-10.502-de-30-desetembro-de-2020-280529948 Acesso em: 1 de outubro de 2020.

BRASIL. Lei 10.097 de 2000, Art. 403. Da proteção do trabalho do menor (Art 402 ao 441). Disponível em: https://www.direitocom.com/clt-comentada/titulo-iii-dasnormas-especiais-de-tutela-do-trabalho-do-artigo-224-ao-artigo-441/capitulo-iv-daprotecao-do-trabalho-do-menor/artigo-403 Acesso em 25 de julho de 2019.

BRASIL. Lei de Diretrizes de Bases. Lei 9306/96, de 20 de dezembro de 1996. Disponível em: http://www.planalto.gov.br/ccivil_03/leis/L9394.htm. Acesso em 19 de novembro de 2019.

BRASIL. Instituto Brasileiro de Geografia e Estatística - IBGE (2010). Censo Demográfico.Informações estatísticas de gênero. Disponível em:

https://7a12.ibge.gov.br/vamos-conhecer-o-brasil/nosso-povo/numero-de-homens-emulheres.html. Acesso em 10 de dezembro de 2017.

Instituto Brasileiro de Geografia e Estatística - IBGE (2010). Censo Demográfico. Rendimento nominal mensal domiciliar per capita da população residente, segundo as Unidades da Federação - 2015. Pesquisa Nacional por Amostra de Domicílios Contínua - PNAD 2015. Disponível em:

https://censo2010.ibge.gov.br/noticiascenso.html ?busca=1\&id=1\&idnoticia=3107\&t=i bge-divulga-rendimento-domiciliar-capita-segundo-pnad-continua-fpe\&view=noticia.

Acesso em: 15 de dezembro de 2017.

. Instituto Brasileiro de Geografia e Estatística - IBGE (2010). Censo Demográfico. Características da população e dos domicílios. Disponível em:

https://7a12.ibge.gov.br/vamos-conhecer-o-brasil/nosso-povo/familias-edomicilios.html. Acesso em: 17 de dezembro de 2017.

. Instituto Brasileiro de Geografia e Estatística - IBGE (2010). Pesquisa mensal de emprego - PME. Disponível em:

https://www.ibge.gov.br/estatisticas/sociais/trabalho/9180-pesquisa-mensal-deemprego.html?=\&t=0-que-e Acesso em 15 de janeiro de 2018.

. Instituto Brasileiro de Geografia e Estatística - IBGE (2013). Censo Demográfico. Trabalho e rendimento. Disponível em:

https://ww2.ibge.gov.br/home/estatistica/indicadores/trabalhoerendimento/pnad conti nua/primeiros resultados/analise02.shtm. Acesso em: 15 de dezembro de 2017.

Instituto Brasileiro de Geografia e Estatística - IBGE (2013). Censo Demográfico. Pesquisa Nacional por Amostra em Domicílios (2013). Disponível em: https://biblioteca.ibge.gov.br/visualizacao/periodicos/59/pnad 2013 v33 br.pdf.

Acesso em: 16 de dezembro de 2017. 
. Instituto Brasileiro de Geografia e Estatística - IBGE (2013). Censo Demográfico. Síntese de indicadores sociais. Disponível em:

http://www.brasil.gov.br/cidadania-e-justica/2015/03/mulheres-sao-maioria-dapopulacao-e-ocupam-mais-espaco-no-mercado-de-trabalho. Acesso em 16 de dezembro de 2017.

Instituto Brasileiro de Geografia e Estatística - IBGE (2013). Censo Demográfico. Segurança Alimentar. Disponível em:

https://ww2.ibge.gov.br/home/estatistica/populacao/seguranca alimentar 2013/defa ult.shtm. Acesso em: 15 de maio de 2019.

Instituto Brasileiro de Geografia e Estatística - IBGE (2014). Censo Demográfico. Pesquisa Nacional por Amostra em Domicílios (2014). Disponível em: https://agenciadenoticias.ibge.gov.br/media/com mediaibge/arquivos/8ff41004968ad 36306430c82eece3173.pdf Acesso em: 10 de janeiro de 2018.

. Instituto Brasileiro de Geografia e Estatística IBGE (2015). Censo Demográfico. Cor ou raça. Disponível em: https://teen.ibge.gov.br/sobre-obrasil/populacoa/cor-ou-raca.html. Acesso em: 16 de dezembro de 2017.

Instituto Brasileiro de Geografia e Estatística - IBGE (2015). Censo Demográfico. Pesquisa Nacional por Amostra em Domicílios (2015). Disponível em: https://biblioteca.ibge.gov.br/visualizacao/periodicos/60/pnad 2015 v22 br.pdf.

Acesso em: 10 de janeiro de 2018.

Instituto Brasileiro de Geografia e Estatística - IBGE (2016). Censo Demográfico. População no último censo. Disponível em:

https://cidades.ibge.gov.br/brasil/ms/pesquisa/45/6320. Acesso em: 15 de dezembro de 2017.

Instituto Brasileiro de Geografia e Estatística - IBGE (2018). Pesquisa Nacional por Amostra de Domicílios Contínua - PNAD Contínua (2018). Disponível em:https://www.ibge.gov.br/estatisticas/sociais/habitacao/17270-pnadcontinua.html?=\&t=0-que-e Acesso em: 5 de dezembro de 2018.

BRASIL. Instituto Nacional de Estudos e Pesquisas Educacionais Anísio Teixeira - INEP. Resultados do Saeb/Prova Brasil (2015). Ministério da Educação DF, setembro de 2016. Disponível em: http://portal.inep.gov.br/artigo//asset publisher/B4AQV9zFY7Bv/content/inep-apresenta-resultados-do-saeb-provabrasil-2015/21206. Acesso em setembro de 2018.

Instituto Nacional de Estudos e Pesquisas Educacionais Anísio Teixeira - INEP. Censo da Educação Básica (2016). Notas Estatísticas. Ministério da Educação. Brasília - DF, fevereiro de 2017. Disponível em: http://download.inep.gov.br/educacao basica/censo escolar/notas estatisticas/2017 Inotas estatisticas censo escolar da educacao basica 2016.pdf. Acesso em: 20 de agosto de 2017. 
Instituto Nacional de Estudos e Pesquisas Educacionais Anísio Teixeira - INEP. Censo da Educação Superior (2016). Divulgação. Ministério da Educação. Brasília - DF, 31 de agosto de 2017. Disponível em: https://abmes.org.br/arquivos/documentos/apresentacao censo educacao superior. pdf. Acesso em 05 de novembro de 2017.

Instituto Nacional de Estudos e Pesquisas Educacionais Anísio Teixeira - INEP. Censo da Educação Superior (2016).Notas Estatísticas. Ministério da Educação. Brasília- DF, fevereiro de 2017. Disponível em: http://download.inep.gov.br/educacao superior/censo superior/documentos/2016/no tas sobre o censo da educacao superior 2016.pdf. Acesso em: 05 de agosto de 2017.

Instituto Nacional de Estudos e Pesquisas Educacionais Anísio Teixeira - INEP. Censo da Educação Superior (2017). Notas Estatísticas. Ministério da Educação. Brasília - DF, fevereiro de 2017. Disponível em: http://download.inep.gov.br/educacao superior/censo superior/documentos/2017/no tas sobre o censo da educacao superior 2017.pdf. Acesso em: 05 de agosto de 2018.

BRASIL. MINISTÉRIO DA EDUCAÇÃO. Juventude na escola - por que frequentam? Brasília: Janeiro de 2016. Disponível em: https://educacaointegral.org.br/reportagens/pesquisa-aponta-maioria-dos-jovensbrasileiros-concilia-trabalho-estudo/. Acesso em: 21 de julho de 2019.

BRASIL. MINISTÉRIO DA EDUCAÇÃO. Brasil no PISA 2015 Análises e reflexões sobre o desempenho dos estudantes brasileiros. Brasília - DF, 2015. Disponível em: http://download.inep.gov.br/acoes internacionais/pisa/resultados/2015/pisa2015 co mpleto final baixa.pdf Acesso em: 10 de dezembro de 2018.

BRASIL. MINISTÉRIO DA SAÚDE. Mapeamento da Insegurança Alimentar e Nutricional com foco na Desnutrição a partir da análise do Cadastro Único, do Sistema Nacional de Vigilância Alimentar e Nutricional (SISVAN) e do Sistema de Informação da Atenção à Saúde Indígena (SIASI). Brasília - DF, 2018. Disponível em:

https://aplicacoes.mds.gov.br/sagirmps/noticias/arquivos/files/Estudo\%20T\%C3\%A9 cnico\%20CAISAN\%20Mapalnsan\%20versao final.pdf Acesso em 10 de novembro de 2018.

BRASIL. Todos pela Educação. Professores brasileiros não recomendam a carreira docente. São Paulo: Ibope Inteligência, 2018. Disponível em: https://www.todospelaeducacao.org.br/pag/iniciativa-profissao-professor Acesso em: setembro de 2019.

BARROS, M. Livro de pré-coisas: roteiro para uma excursão poética no pantanal. 4ํe․ Rio de Janeiro: Record, 2003. 
BIESTA, G. Para além da aprendizagem: educação democrática para um futuro humano. Rio de Janeiro: Autêntica, 2013.

BOHOSLAVSKY, R. Orientação vocacional: a estratégia clínica. São Paulo: Martins Fontes, 1977.

BOURDIEU, P. La noblesse d'État: grandes écoles et esprit de corps. Paris: Minuit, 1989.

BOURDIEU, P.; PASSERON, J. A Reprodução: elementos para uma teoria do sistema de ensino. Trad. Reynaldo Bairão. Rio de Janeiro: Francisco Alves Editora S/A, 1975.

BRANDÃO, D. F.; PARDO, M. B. L. O interesse de estudantes de pedagogia pela docência. Revista Educação e Pesquisa, São Paulo, v. 42, n 42. 2016.

BUSSAB, W. O.; MORETTIN, P. A. Estatística Básica. 4ª Edição. Atual Editora, 1987.

CAFARDO, R.; TOLEDO, L. F. Formação dos pais e renda familiar fazem diferença no resultado do Enem. Estadão, 2018. Disponível em: https://noticias.uol.com.br/ultimas-noticias/agencia-estado/2018/01/14/formacao-dospais-faz-a-diferenca.htm. Acesso em: 10 de abril de 2020.

CALLE 13. Latinoamérica. Intérpretes: Susana Baca, Maria Rita, Totó La Momposina. Porto Rico: Sony BMG, 2010, 1 CD.

CÂMARA DE VEREADORES DE CAMPO GRANDE - MS. Sancionada a Lei que define o Marco Zero de Campo Grande. Campo Grande - MS, 2018. Disponível em: https://camara.ms.gov.br/noticias/sancionada-lei-que-define-o-marco-zero-decampo-grande-projeto-de-autoria-do-vereador-delegado-wellington. Acesso em: 07 de agosto de 2020.

CAMPO GRANDE. Prefeito aprova Marco Zero em Campo Grande em frente ao monumento "Carro de Boi". CAMPO GRANDE NEWS, 2018. Disponível em: https://www.campograndenews.com.br/cidades/capital/prefeito-aprova-marco-zeroem-campo-grande-em-frente-ao-monumento-carro-de-boi. Acesso em: 7 de agosto de 2020.

CAMPSO, C. Biografia de Conceição dos Bugres. Campo Grande - MS: Catálogo das Artes, 2016.

CAPELO, R. Entrevista "Com diploma, mas sem emprego", por Ana Paula Lisboa, para o Correio Braziliense, em 17 de junho de 2018. Disponível em: https://www.correiobraziliense.com.br/app/noticia/eu-estudante/trabalho-e formacao/2018/06/17/interna-trabalhoeformacao-2019,689082/apos-sair-dafaculdade-recem-formados-enfrentam-desemprego-e-subempre.shtml Acesso em: 13 de outubro de 2019. 
CASTRO-GÓMEZ, S. Descolonizando la universidade. La hybris del punto cero y el diálogo de saberes. In: CASTRO-GÓMEZ, S; GROSFOGUEL, R. (Org.). El giro decolonial: reflexiones para una diversidad epistémica mas allá del capitalismo global. Bogotá: Siglo del Hombre Editores, 2007, p. 79-93.

CONFEDERAÇÃO NACIONAL DOS TRABALHADORES EM EDUCAÇÃO - CNTE. O salário dos professores. Disponível em: https://www.cnte.org.br/ Acesso em: agosto de 2019.

CONSTITUIÇÃO FEDERAL DO BRASIL. Art 403 Consolidação das Leis do Trabalho. Decreto Lei $5452 / 43$ de $1^{\circ}$ de maio de 1943. Disponível em https://www.jusbrasil.com.br/topicos/10720275/artigo-403-do-decreto-lei-n-5452-de01-de-maio-de-1943 Acesso em: 20 de janeiro de 2019.

CORAZZA, S. M. Labirintos da pesquisa, diante dos ferrolhos. In: COSTA, Marisa Vorraber (org.). Caminhos investigativos I. Rio de Janeiro: Lamparina Editora, 2007.

CORRÊA, L. Nova política de educação especial propõe separação de alunos. Entrevista. Brasília: Correio Braziliense, 2020. Disponível em: https://www.correiobraziliense.com.br/euestudante/2020/10/4879645-nova-politicade-educacao-especial-propoe-separacao-de-alunos.html Acesso em: 02 de outubro de 2020.

CRESWELL, J. W.; CLARK, V. L. Pesquisa de métodos mistos. Porto Alegre: Penso, 2007.

CRUZ, P.; MONTEIRO, L. Anuário da Educação Básica. São Paulo: Moderna, 2019. Disponível em:

https://www.todospelaeducacao.org.br/ uploads/ posts/302.pdf Acesso em: junho de 2019.

DARDOT, P.; LAVAL, C. A nova razão do mundo: ensaio sobre a sociedade neoliberal. São Paulo: Editora Boitempo, 2016.

DELEUZE, G.; GUATTARI, F. Mil Platôs: capitalismo e esquizofrenia. Tradução de Ana Lúcia de Oliveira, Aurélio Guerra Neto e Celia Pinto Costa. São Paulo: Editora 34, vol. 1, 2 ${ }^{\mathrm{a}}$ ed, 2011.

. Mil Platôs: volume 1. São Paulo: Editora 34, 1995.

Kafka: por uma literatura menor. Tradução de Júlio Castañon Guimarães. Rio de Janeiro: Editora Imago, 2002.

DELEUZE, G . A imagem do pensamento. In:_. Diferença e repetição. São Paulo: Graal, 2009, p. 189-240.

Diferença e repetição. Rio de Janeiro: Graal, 1998. 
Nietzsche e a filosofia. Rio de Janeiro: Editora Rio, 1976.

Francis Bacon: lógica da sensação. equipe de tradução, Roberto Machado (coordenação). Rio de Janeiro: Jorge Zahar Ed., 2007.

. Espinosa e o problema da expressão. Tradução de GT Deleuze - 12. Coordenação de Luiz B. L. Orlandi. São Paulo: Editora 34: Coleção Trans, 2017. . Mil Platôs não formam uma montanha. Journal Libération. Entrevista concedida a Christian Descamps, Didier Eribon e Robert Maggiori. 23 de outubro de 1980. Disponível em: https://books.google.com.br/books. Acesso em: 23 de junho de 2018.

DELORS, J. Educação: um tesouro a descobrir. 8 ed. São Paulo: Cortez, 2003.

DEMO, P. Avaliação qualitativa. $7^{\mathrm{a}}$ ed. Campinas: Autores Associados, 2002.

DERRIDA, J. A escritura e a diferença. 2. Ed. São Paulo: Perspectiva, 1995.

ECCO, I.; KARPINSKI, L. C. Por que ser professor? Ou das razões que motivam a escolha da profissão docente. Web Artigos. Rio Grande do Sul, 2010. Disponível em: https://www.webartigos.com/artigos/por-que-ser-professor/39528. Acesso em julho de 2019.

E-CIDADANIA. Consulta Pública: PLS 193/2016. Disponível em: https://www12.senado.leg.br/ecidadania/visualizacaomateria?id=125666\&nbsp; Acesso em: 04 de maio de 2020.

EMPRESA BRASILEIRA DE PESQUISA AGROPECUÁRIA - Embrapa. Guia Clima. Dourados - MS, 2019. Disponível em: https://clima.cpao.embrapa.br/ Acesso em 29 de julho de 2019.

ESPINOSA, B. Ética. Tradução de M. Chaui et al. São Paulo: Edusp, 2015.

FEDERAÇÃO DOS TRABALHADORES EM EDUCAÇÃO DE MATO GROSSO DO SUL - FETEMS. Tabela de Salários. Disponível em: https://www.fetems.org.br Acesso em: agosto de 2019.

FERRARI, D. Nova política de educação especial propõe separação de alunos. Entrevista. Brasília: Correio Braziliense, 2020. Disponível em: https://www.correiobraziliense.com.br/euestudante/2020/10/4879645-nova-politicade-educacao-especial-propoe-separacao-de-alunos.html Acesso em: 02 de outubro de 2020.

FERREIRA, G. Desinteresse nas licenciaturas: análise no ensino médio do município de São Miguel do Iguaçu - PR. XII Congresso Nacional de Educação. Paraná: Pontifícia Universidade Católica, 2016. 
FILLOS, L. M.; ZEN, P. D.; CAETANO, J. J. Profissão docente: aspirações de estudantes do ensino médio sobre ser professor de matemática. Revista Brasileira de Ensino de Ciência e Tecnologia. Ponta Grossa, v.9, n 2, 2016.

FLICK, U. Uma introdução à pesquisa qualitativa. 2. ed. Porto Alegre: Bookman, 2004.

FOUCAULT, M. Vigiar e Punir. 14. Ed. Petrópolis: Vozes, 1996.

Debate de Noam Chomsky e Michael Foucault sobre a natureza humana. Disponível em: https://www.youtube.com/watch?v=2ZlzoWBVqkE. Acesso em: 31 de Outubro de 2018.

FREIRE, Paulo. Pedagogia do Oprimido. $17^{\mathrm{a}}$ ed. Rio de Janeiro, Paz e Terra, 1987.

GATTI, B. A. Atratividade da carreira docente no Brasil. In: Fundação Victor Civita. Estudos e pesquisas educacionais. São Paulo: FVC, 2009, v. 1, n. 1.

GAMBOA, S. S. Quantidade-qualidade: para além de um dualismo técnico e de uma dicotomia epistemológica. In: SANTOS FILHO, J. C.; GAMBOA, S. S. (Org.). Pesquisa educacional: quantidade-qualidade. São Paulo: Cortez, 1995.

Editora, 2002.

A construção da pesquisa em educação no Brasil. Brasília: Plano

GAUTHIER, J. H. M. O oco dos ventos: metodologia de pesquisa sociopoética e estudos transculturais. Curitiba, PR. Editora CRV, 2012.

Palestra "Metodologia da pesquisa sociopoética, estudos transculturais e decolonialidade" proferida pelo Prof. Dr. Jacques Henri Maurice Gauthier, no IV Seminário Estadual de Cultura e Educação, no dia 25 de novembro de 2019, na cidade de Campo Grande-MS. Sem número de página.

GAZETA DO POVO. Bolsonaro diz que fome no Brasil é discurso populista. Por Gazeta do Povo, 2019 https://www.gazetadopovo.com.br/republica/breves/bolsonaro-fome-brasil-discursopopulista/ Acesso em: 19 de julho de 2019.

GENTILLI, P. Desencanto e Utopia: A educação no labirinto dos novos tempos. Petrópolis: Vozes, 2008.

. O direito à educação e as dinâmicas de exclusão na América Latina. Educ. Soc., Campinas, vol. 30, n. 109, p. 1059 - 1079, set./dez, 2009. Disponível em: http://www.scielo.br/scielo.php?pid=S010173302009000400007\&script=sci abstract \&tlng=pt Acesso em: 05 de novembro de 2019. 
GEORGES, R.; MAIA, K. A distância que nos une: um retrato das desigualdades brasileiras. São Paulo: Brief Comunicação Publicado, 2019. Disponível em: https://oxfam.org.br/um-retrato-das-desigualdades-brasileiras/a-distancia-que-nosune/ Acesso em: 30 de julho de 2019.

GIECO, L. Sólo le pido a Dios. Intérpretes: Mercedes Sosa e Beth Carvalho. Argentina: Polygram, 1978. 1 Disco.

GLISSANT, E. Introdução a uma poética da diversidade. Tradução de Enilce Albergaria Rocha. Juiz de Fora: editora da UFJF, 2005.

GROULX, L. H. Contribuição da pesquisa qualitativa à pesquisa social. In: POUPART, Jean et al (Org.). A pesquisa qualitativa: enfoques epistemológicos e metodológicos. Petrópolis: Vozes, 2008.

GUJARATI, D. N. Econometria Básica. 4를 Edição. Ed. Campus, 2006.

GUNTHER, $H$. Pesquisa qualitativa versus pesquisa quantitativa: esta é a questão? Psicologia: Teoria e Pesquisa, Brasília, v. 22, n. 2, p. 201-210, 2006.

G1. Novas declarações do Ministro da Educação Weitraub, 2019. Disponível em: https://g1.globo.com/educacao/noticia/2019/12/11/weintraub-reafirma-existencia-deplantacoes-de-maconha-e-laboratorios-de-droga-nas-universidades-federais-emcomissao-na-camara.ghtml Acesso em 11 de dezembro de 2019.

. Bolsonaro volta a atacar os universitários brasileiros, 2019. Disponível em: https://g1.globo.com/educacao/noticia/2019/12/11/weintraub-reafirma-existencia-deplantacoes-de-maconha-e-laboratorios-de-droga-nas-universidades-federais-emcomissao-na-camara.ghtml Acesso em 11 de dezembro de 2019.

HALL, S. A identidade cultural na pós-modernidade. 10. Ed. Rio de Janeiro: DP\&A, 2005.

IDOETA, P. A.; SANCHES, M. Sem merenda: quando férias escolares significam fome no Brasil. British Broadcasting Corporation - BBC NEWS: São Paulo, 2019. Disponível em: https://www.bbc.com/portuguese/brasil-48953335. Acesso em: 18 de julho de 2019.

INOCÊNCIO, N. Cotas foram revolução silenciosa no Brasil. Entrevista a EBC. Brasília - DF. Publicada em 27 de maio de 2018. Disponível em: http://agenciabrasil.ebc.com.br/educacao/noticia/2018-05/cotas-foram-revolucaosilenciosa-no-brasil-afirma-especialista Acesso em 23 de julho de 2019.

JECUPÉ, K. W. A terra dos mil povos: história indígena do Brasil contada por um índio. São Paulo: Petrópolis, 1998.

Oré Até roiru'a ma - todas as vezes que dissemos adeus. São Paulo: Fundação Phytoervas, 2002. 
JEFFREY. D. Para ser pedagogo precisa gostar de criança? Entrevista ao G1. São Paulo, 2017. Disponível em: https://g1.globo.com/educacao/guia-decarreiras/noticia/pedagogia-e-para-quem-gosta-de-crianca-vai-dar-aula-e-topaganhar-pouco-veja-mitos-e-verdades-sobre-a-carreira.ghtml. Acesso em: junho de 2019.

Racismo no mundo acadêmico: um tema para se discutir na universidade. Por Felipe Mateus. Entrevista ao Jornal da Unicamp. Campinas, 2019. Disponível em: $\quad$ https://www.unicamp.br/unicamp/ju/noticias/2019/11/19/racismo-no-mundoacademico-um-tema-para-se-discutir-na-universidade. Acesso em: 25 de novembro de 2019.

KLEIMAN, A. B. Os significados do letramento: uma nova perspectiva sobre a prática social da escrita. Campinas: Mercado das Letras, 1995.

LARROSA, J. Nietzsche e a educação. Belo Horizonte: Autêntica, 2002.

LAVILLE, C.; DIONNE, J. A construção do saber: manual de metodologia da pesquisa em ciências humanas. Belo Horizonte: UFMG, 1999.

LIBÂNEO, J. C.; OLIVEIRA, J. F.; TOSCHI, M. S. Educação escolar: políticas, estrutura e organização. São Paulo: Cortez, 2003.

LUCYK, V. P. K.; GRAUPMANN, E. H. Desvalorização do trabalho docente brasileiro: uma reflexão de seus aspectos históricos. Revista Perspectiva Online: Humanas \& Sociais Aplicadas, dezembro de 2017, Vol. 7, oㅡ 20, p. 11-27.

LAHLOU, S. Text Mining Methods: An answer to Chartier and Meunier. Paperson Social Representations, 2012.

LAPO, F. R.; BUENO, B. O. Professores, desencanto com a profissão e abandono do magistério. Cadernos de Pesquisa. São Paulo, n. 118, 2003.

LEME, L. F. A atratividade do magistério para a educação básica: estudos com ingressantes de cursos superiores da Universidade de São Paulo. Dissertação de Mestrado. São Paulo: USP, 2012. Disponível em: www.teses.usp.br. Acesso em: 10 de maio de 2019.

MACIEL, R. F.; TAKAKI, N. H.; ÁVILA, A. R. D.; FAUSTINO, A. P. Multiletramentos e o gênero propaganda em aulas de língua Inglesa: discutindo processo de construção de sentidos. MACIEL, R. F.; MARQUES, N. (Orgs). Multiletramentos e processos autorais na Educação Básica. Campinas, SP: Pontes Editores, 2019.

MACIEL, R. F.; ONO, F. T. P; SILVA. M. A.C.R; CUELLAR, I. G. Hashtags, paródias, tirinhas e vídeos: autoria e processos de construções de sentidos com alunos do $5^{\circ}$ ano do Ensino Fundamental. MACIEL, R. F.; MARQUES, N. (Orgs). Multiletramentos e processos autorais na Educação Básica. Campinas, SP: Pontes Editores, 2019. 
MARQUES, N. Da formação continuada de professores aos momentos de tensão em sala de aula: Rizoma, Emergência e Letramentos. Campinas, SP: Pontes Editores, 2016.

Quem quer ser professor? Série de estudos sobre a atratividade da carreira docente. Consultores estatísticos: OLIVEIRA, M. A. C; WEBER, V. A. M. 1 ed., vol. 1., Campo Grande - MS: Secretaria de Estado de Educação, 2018.

MARQUES, N.; CAMARGO, E.L.; CINTRA, S. L. A. D. Multiletramentos críticos ema aulas de Língua Portuguesa na Educação de Jovens e Adultos: o processo de construção de sentidos dos alunos por meio de textos multimodais. MACIEL, R. F.; MARQUES, N. (Orgs). Multiletramentos e processos autorais na Educação Básica. Campinas, SP: Pontes Editores, 2019.

MARRACH, S. Neoliberalismo e educação. In: GUIRALDELLI JR, P. Infância, educação e neoliberalismo. São Paulo: Cortez, 1996.

MENEZES DE SOUZA, L. M. T. Decolonial Pedagogies, Multilingualism and Literacies. In: BOCK, Z. STROUD, C. Multilingual Margins. A journal of Multilingualism from the periphery. Centre for Multilingualism and Diversities Research, University of the Western Cape, 2019.

. Global Languages, Coloniality and Globalization from below. In: GUILHERME, M. MENEZES DE SOUZA, L. M. T. Global Languages and Critical Intercultural Awareness. The South answers back. New York: Routledge, 2019.

. Entering a Culture Quietly: Writing and cultural survival in Indigenous education in Brazil. In: PENNYCOOK, A.; MAKONI, S. (Orgs). Disinventing and Reconstituting Languages. Publisher: Multilingual Matters, 2006.

. Uma outra história, a escrita indígena no Brasil. Revista Povos indígenas no Brasil, $2018 . \quad$ Disponível em: https://pib.socioambiental.org/Uma outra historia, a escrita indigena no Brasil. Acesso em: 02 de novembro de 2019.

. Palestra "Fazendo e Desfazendo Sentidos: uma perspectiva decolonial", proferida pelo Prof. Dr. Lynn Mario Trindade Menezes de Souza/USP, no IV Seminário Estadual de Cultura e Educação, no dia 25 de novembro de 2019, na cidade de Campo Grande-MS. Sem número de página.

MENEZES DE SOUZA, L. M. T. ; MONTE MÓR, WALKYRIA . Still Critique? Revista Brasileira de Linguística Aplicada, v. 18, p. 445-450, 2018.

MIGNOLO, W. Desafios decoloniais hoje. In: BORSANI, M. E.; QUITERO, P. (ORGS). Los desafios decoloniais de nuestros dias: pensar colectivo. Neuquén: EDUCO - Universidade Nacional Del Comahue, 2017.

MINAYO, M. C. S; SANCHES, O. Quantitativo-qualitativo: oposição ou complementaridade? Cadernos de Saúde Pública, Rio de Janeiro, v. 9, n. 3, p. 239-262, jul./sep.1993. 
MONTE MÓR, W. Eu e o outro: imagens refletidas. Um estudo sobre identidade e alteridade na percepção das culturas. Interfaces Brasil/Canadá (Impresso), v. 8, p. 161-180, 2008.

. Convergência e diversidade no ensino de línguas: expandindo visões sobre a 'diferença'. Polifonia, v. 21, p. 234-253, 2014.

- Expansão de perspectiva e desenvolvimento do olhar: um exercício de letramento crítico. In: MACIEL, R. F.; TÍLIO, R.; JESUS, D. M.; BARROS, A. L. E.C. (Orgs) Linguística Aplicada para a além das fronteiras. Campinas, SP: Pontes Editores, 2018.

- Línguas, linguagens e sociedade heterogênea e plural: pela expansão da vivência e da convivência social. In: MACIEL, R. F.; MARQUES, N. (Orgs). Multiletramentos e processos autorais na Educação Básica. Campinas, SP: Pontes Editores, 2019.

. Entrevista "Escolas devem juntar idiomas com cidadania". Por Alex Gomes e Ocim_ara Balmant São Paulo, SP: Estadão, 12 de outubro de 2019. Disponível em: https://educacao.estadao.com.br/noticias/geral,escolas-devem-juntar-idiomas-comcidadania-diz-professora-da-usp,70003047143 Acesso em: 12 de outubro de 2019.

- Entrevista com Walkyria Monte Mor. Por Associação Brasileira de Linguística Aplicada - ABRALIN NOTícIAS. São Paulo, SP: ABRALIN, 08 de dezembro de 2019. Disponível em: www.abralin.org. Acesso em: 08 de dezembro de 2019.

MONTGOMERY, D. C. Design and Analysis of Experiments. Fourth Edition. Ed. John Wiley\& Sons, 1997.

MUNDURUKU, D. O caráter educativo do movimento indígena brasileiro (19701990). São Paulo: Paulinas, 2012.

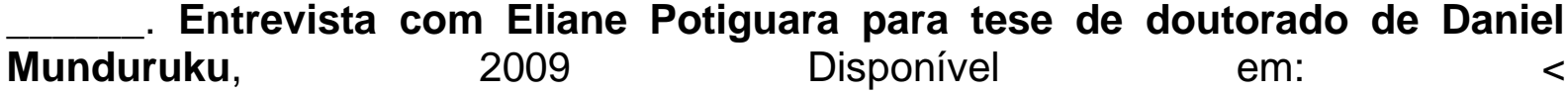
http://elianepotiguara.blogspot.com/p/entrevistas.html> Acesso em 02 de novembro de 2019.

NASCIMENTO, A. M. do. (2012). Português Intercultural: fundamentos para a educação linguística de professores e professoras indígenas em formação superior específica numa perspectiva intercultural. Tese (Doutorado em Letras). UFG, Faculdade de Letras.

NASCIMENTO, F. S.; COUTINHO, T. C.; PINHEIRO, J. A. Exame Nacional do Ensino Médio - ENEM: um olhar dos discentes do $3^{\circ}$ ano do Ensino Médio e sua preparação para o ingresso no ensino superior. Educação em Revista, Marília, v. 14, n. 2, 2013. 
NIETZCHE, F. Sobre verdade e mentira extra-moral. In.: Sobre verdade de mentira. São Paulo: Editora Hedra, 2008, p.35-41.

. Genealogia da moral. São Paulo: Companhia das Letras, 1998.

Segunda consideração intempestiva: da utilidade e desvantagem da história para a vida. Rio de Janeiro: Relume Dumará, 2003.

Escala, 2008.

Da utilidade e do inconveniente da História para a vida. São Paulo:

OLIVEIRA. O. A redução do salário dos professores em MS. Campo Grande: Jornal A Crítica, 2019. Disponível em: http://www.acritica.net/mais/opiniao-dos-leitores/areducao-do-salario-dos-professores-em-ms/391517/ Acesso em: julho de 2019.

ORGANISATION FOR ECONOMIC COOPERATION AND DEVELOPMENT OECD. Building a High-QualityTeaching Profession. Lesson from around the word, 2011. Disponível em:

http://www.oecd.org/edu/school/programmeforinternationalstudentassessmentpisa/b uildingahigh-qualityteachingprofessionlessonsfromaroundtheworld.htm. Acesso em: 05 de janeiro de 2017.

. Panorama sobre a Educação. Disponível em:

http://www.oecd.org/education/Brazil EAG2013\%20Country\%20Note\%20(PORT).pd f. Acesso em: 20 de janeiro de 2018.

. Efficient Teacher Policies. Disponível em: https://www.oecd.org . Acesso em: agosto de 2018.

Education at a Glance, 2014. Disponível em: https://www.oecd.org . Acesso em: agosto de 2018.

Programme for Internacional Student Assessment. Results from PISA, 2015. Disponível em: https://www.oecd.org/pisa/PISA-2015-Brazil-PRT.pdf . Acesso em: setembro de 2018.

PARO, V. H. Administração escolar: introdução crítica. São Paulo: Cortez, 1986.

PASSOS, M. M.; MARTINS, J. B.; ARRUDA. S. M. Ser professor de Matemática: escolhas, caminho, desejos...Revista Ciência e Educação. Londrina, v. 11, n. 3, 2005.

PAULO FILHO, W. Entrevista "Com diploma, mas sem emprego", por Ana Paula Lisboa, para o Correio Braziliense, em 17 de junho de 2018. Disponível em: https://www.correiobraziliense.com.br/app/noticia/eu-estudante/trabalho-e formacao/2018/06/17/interna-trabalhoeformacao-2019,689082/apos-sair-dafaculdade-recem-formados-enfrentam-desemprego-e-subempre.shtml Acesso em: 13 de outubro de 2019. 
PAZ, Octavio. O Labirinto da Solidão e Post Scriptum. 4 ed. Tradução de Eliane Zagury. São Paulo: Paz e Terra, 2006.

PONSO, L. C. Letramento acadêmico indígena e quilombola: uma política linguística voltada à interculturalidade crítica. Campinas: Revista Trabalhos em Linguística Aplicada, n. 57, p. 1512-1533, 2018. Disponível em: https://periodicos.sbu.unicamp.br/ojs/index.php/tla/article/view/8653744. Acesso em 12 de outubro de 2019.

POTIGUARA, Eliane. Metade cara, metade máscara. São Paulo: Global, 2004.

PRESIDÊNCIA DA REPÚBLICA. Decreto Lei no 13.415/17. Disponível em: http://www.planalto.gov.br/ccivil 03/ ato2015-2018/2017/lei//13415.htm Acesso em: 01 de maio de 2020.

RANCIÈRE, J. 2000. Existe uma estética deleuzeana? In: ALLIEZ, E. (org.). Gilles Deleuze: uma vida filosófica. São Paulo: Ed. 34, pp. 505-516. York: Verso, 2009.

The Emancipated Spectator. Translation Gregory Elliott. London/New

O Mestre Ignorante: cinco lições sobre a emancipação intelectual. Trad. Lílian do Valle. Belo Horizonte: Autêntica, 2002.

RATINAUD, P., \& MARCHAND, P. Application de la méthode ALCESTE à de "gros" corpus et stabilité des "mondes lexicaux": analyse du "Cable-Gate" avec IraMuTeQ. In: Actes des 11eme Journées internationales d'Analyse statistique des Données Textuelles (p. 835-844). Liège, Belgique. Retrieved April 13, 2012.

RESUMO TÉCNICO: CENSO DA EDUCAÇÃO SUPERIOR 2016. - Brasília: Instituto Nacional de Estudos e Pesquisas Educacionais Anísio Teixeira, 2016.

RIBEIRO, C. R. O agenciamento Deleuze-Guatarri: considerações sobre método de pesquisa e formação de pesquisadores em educação. Revista Educação Unisinos, vol. 20, nำ1, janeiro-abril, 2016.

RISÉRIO, A. Risério n'o tempo. In: SALAMALANDRO, Gonçalves Léo. Entrevista cedida em março de 2008.2 Disponível em: http://www.salamalandro.redezero.org/riserio-no-tempo. Esta referência foi retirada de uma entrevista online e na mesma não consta página. Acesso em 15 de outubro de 2019.

ROBLES, D. A. El cóndor pasa. Letra: Julio de La Paz. Intérprete: Léo Rojas, 1913.

ROJO, R. Letramentos múltiplos, escola e inclusão social. São Paulo: Parábola Editorial, 2009.

SAFATLE, V. O circuito dos afetos: corpos políticos, desamparo e o fim do indivíduo. São Paulo: Autêntica, 2018. 
SALES, A. de C. M.; CHAMON, E. M. Q. de O. Escolha da carreira docente e processo de construção da identidade profissional docente. Educação em Revista. Belo Horizonte, v. 27, n. 03, 2011.

SANTOS, B.S. Epistemologias del Sur. Utopía e Praxis Latinoamericana, ano 16, no 54, 2011, p. 17- 39.

SANTOS FILHO, J. C. Pesquisa quantitativa versus pesquisa qualitativa: o desafio paradigmático. In: SANTOS FILHO, José Camilo; GAMBOA, S. S. (Org.). Pesquisa educacional: quantidade/qualidade. São Paulo: Cortez, 1995.

SANTOS, M. Aula inaugural do ano letivo de 1999 da Universidade Federal da Bahia. Seminário Milton Santos e o Brasil. Bahia: Salvador, de 17 a 19 de julho de 2002. Disponível em: http://miltonsantos.com.br/site/wpcontent/uploads/2011/04/Aula-inaugural-do-ano-letivo-de-1999-da-

UFBA MiltonSantos.pdf Acesso em: 15 de outubro de 2019.

SATER, A.; TEIXEIRA, R. Tocando em frente. Intérpretes: Almir Sater e Renato Teixeira. Rio de Janeiro: Philips Records, 1990, 1 CD.

SECRETARIA ESTADUAL DE EDUCAÇÃO - SED/MS (2016). Curso Estadual Preparatório para o Ingresso na Educação Superior - CIES. Campo Grande MS, 22 de maio de 2016. Disponível em: http://www.sed.ms.gov.br/curso-estadualpreparatorio-para-o-ingresso-na-educacao-superior-inicia-inscricoes-nesta-tercafeira/. Acesso em: 04 de novembro de 2017.

SECRETARIA ESTADUAL DE EDUCAÇÃO - SED/MS (2017). Educação Profissional. Campo Grande - MS, 9 de janeiro de 2018. Disponível em: http://www.sed.ms.gov.br/educacao-profissional-prepara-o-estudante-para-o-mundodo-trabalho/. Acesso em: 20 de janeiro de 2018.

SILVA, M. A. M. Racismo no mundo acadêmico: um tema para se discutir na universidade. Por Felipe Mateus. Entrevista ao Jornal da Unicamp. Campinas, 2019. Disponível em: https://www.unicamp.br/unicamp/ju/noticias/2019/11/19/racismo-no-mundoacademico-um-tema-para-se-discutir-na-universidade. Acesso em: 25 de novembro de 2019.

SILVA, T.T. Descolonizar el currículo: estrategias para una pedagogía crítica (Dos o tres comentarios sobre el texto de Michael Apple). In: GENTILI, P. et.al. Cultura, política y currículo (Ensayos sobre la crisis de la escuela pública). Buenos Aires: Editorial Lozada, 1997, p. 1-9.

- Identidade e diferença: impertinências. In: Educação \& Sociedade. Campinas, v.23, n. 79, agosto, 2002.

SOARES, D. H. P. A escolha Profissional: do jovem ao adulto. São Paulo: Summus, 2002. 
SOUZA, A. L. S. (2011). Letramento da reexistência. Poesia, grafite, música, dança: hip-hop. São Paulo: Parábola.

SOUZA, Ana Lúcia S. JOVINO, lone S., MUNIZ, Kassandra S., Revista da ABPN v. 10, Ed. Especial - Caderno Temático: Letramentos de Reexistência. Janeiro de 2018, p.01-11.

SOUZA, L. A. A. Desvalorização social da profissão docente no cotidiano da escola pública no discurso do professor. $\mathbf{X}$ Congresso Nacional de Educação EDUCERE. I Seminário Internacional de Representações Sociais, Subjetividade e Educação - SIRSSE. Pontifícia Universidade Católica do Paraná. Curitiba, 2011.

SOARES, S. S. D. Educação: um escudo contra o homicídio. Brasília: Instituto de Pesquisa Econômica Aplicada, 2007. Disponível em:

http://www.ipea.gov.br/portal/images/stories/PDFs/TDs/td 1298.pdf. Acesso em: 13 de junho de 2019

SPIVAK, G. C. Pode o subalterno falar? Tradução: Sandra Regina Goulart Almeida. Marcos Feitosa Pereira e André Pereira Feitosa. Editora UFMG, Belo Horizonte, 2010. p.11.

STREET, B. V. (1995). Letramentos sociais: abordagens críticas do letramento no desenvolvimento, na etnografia e na educação. São Paulo: Parábola Editorial, 2014.

TESSER, G. J. Principais linhas epistemológicas contemporâneas. Curitiba: Educar em Revista, n. 10, 1994. Disponível em: http://www.scielo.br/scielo.php?script=sci arttext\&pid=S0104-40601994000100012

Acesso em: 10 de outubro de 2019.

THIOLLENT, M. J. M. Aspectos qualitativos da metodologia de pesquisa com objetivos de descrição, avaliação e reconstrução. Cadernos de Pesquisa, São Paulo, n. 49, p. 45-50, 1984.

TUKEY, J. W. Exploratory data analysis. Reading, Mass, v.2, 1977.

UNIVERSIDADE DE SÃO PAULO - USP. Resultados do processo seletivo 2016. Pró-Reitoria de Graduação. Sala de Imprensa. Disponível em: https://www.usp.br/imprensa/?p=57700 Acesso em: 15 de janeiro de 2019.

UNIVERSIDADE FEDERAL DE GOIÁS. A baixa procura por cursos de licenciatura ameaça o futuro da docência. Pró-Reitoria de Graduação. Goiás, 2014. Disponível em: www.ufg.br. Acesso em: novembro de 2018.

VALLE, I. R. Carreira do magistério: uma escolha profissional deliberada? Revista Brasileira de Estudos Pedagógicos. Brasília, v. 87, n. 216, 2006.

VARKEY FOUNDATION. Global Teacher Status. London, 2018. Disponível em: https://www.varkeyfoundation.org/pt Acesso em: julho de 2019. 
ZAVALA, V. (2010). Quem está dizendo isso?: letramento acadêmico, identidade e poder no ensino superior. In: Vóvio, C. L.; Sito, L. S.; De Grande, P. B. Letramentos: rupturas, deslocamentos e repercussões de pesquisas em Linguística Aplicada. Campinas, SP: Mercado de Letras. pp. 71-95.

WALLON, H. O papel do outro na consciência do eu. Em: Psicologia e educação da criança. Lisboa: Editorial Vega, 1986.

WITTGENSTEIN, L. Investigações Filosóficas. Tradução: Marcos G. Montagnoli. Petrópolis: Vozes, 2009.

Yoba, Carlos Pedro Cláver. Caracterizacion de los Niveles de la Motivacion Profesional de los Estudiantes de Preuniversitario del Colegio Elizangela Filomena. Tesis presentada para la obtencion del titulo de Master en Educacion. Instituto Superior Pedagógico Enrique José Varona. Ciudad de la Havana - Cuba, 1998.

ZLUHAN, M. R.; RAITZ,T. R. Um estudo com jovens: transição do Ensino Médio ao Ensino Superior. X ANPED SUL, Florianópolis, outubro de 201 
ANEXOS 


\begin{abstract}
Anexo 1
Questionário do aluno e Termo de Consentimento Livre e Esclarecido
\end{abstract}

\title{
Caro Aluno (a),
}

Convido-o (a) a participar voluntariamente desta pesquisa que desenvolvo em conjunto com a Secretaria Estadual de Educação de Mato Grosso do Sul. O objetivo inicial da pesquisa é gerar, descrever e analisar dados sobre a configuração identitária e profissional dos alunos do Ensino Médio do Estado de MS. As informações concedidas e a identidade dos participantes serão confidenciais e preservadas de identificação. Uma cópia da pesquisa com os resultados finais do estudo será entregue a Secretaria Estadual de Educação de MS.

Agradeço sua colaboração, que deverá ser consentida no Termo de Consentimento Livre e Esclarecido, no final do questionário e disponibilizo o e-mail nelagley@gmail.com para contato.

Atenciosamente,

Profa. Nelagley Marques

Antes de iniciar o questionário, quero reiterar sobre a importância de você responder todas as perguntas, bem como de expressar sua opinião sincera e espontânea em relação às questões, o que contribuirá para a transparência dos resultados desta pesquisa.

\section{Questionário eletrônico}

Escola:

Série:

Cidade:

\section{1) Você está matriculado no:}

( ) Ensino Médio Regular

( ) Educação de Jovens e Adultos

( ) Médio integrado a Educação Profissional 


\section{2) Na sua casa vivem quantas pessoas?}

( ) Só eu

( ) Duas pessoas

( ) Três pessoas

( ) Quatro pessoas

( ) Mais de quatro pessoas

3) Qual o grau de escolaridade do seu pai ou responsável?

( ) Nunca frequentou a escola

( ) Ensino Fundamental incompleto (até o 5ำ ano)

( ) Ensino fundamental completo (até $9^{\circ}$ ano)

( ) Educação de Jovens e Adultos

( ) Ensino Médio incompleto

( ) Ensino Médio completo

( ) Superior incompleto

( ) Superior completo

( ) Pós-graduado (Especialização)

( ) Não sei

( ) Outro

4) Qual o grau de escolaridade de sua mãe ou responsável?

( ) Nunca frequentou a escola

( ) Ensino Fundamental incompleto (até o $5^{\circ}$ ano)

( ) Ensino fundamental completo (até $9^{\circ}$ ano)

( ) Educação de Jovens e Adultos

( ) Ensino Médio incompleto

( ) Ensino Médio completo

( ) Superior incompleto

( ) Superior completo

( ) Pós-graduado (Especialização)

( ) Não sei

( ) Outro 
5) Qual é aproximadamente a renda familiar total (em reais - $R \$$ )?

( ) Menor que um salário mínimo $(\mathrm{R} \$ 880,00)$

( ) Maior que um salário mínimo ( $\mathrm{R} \$ 880,00)$

( ) Entre $R \$ R \$ 1.000,00$ e $R \$ 2.000,00$

( ) Entre $R \$ 2.001,00$ e $R \$ 3.000,00$

( ) Entre $R \$ 3.001,00$ e $R \$ 4.000,00$

() Acima de $R \$ 4.001,00$

() Outro valor

6) Em que período você estuda na escola?

( ) Matutino

( ) Vespertino

( ) Noturno

( ) Maior parte no diurno

( ) Maior parte no noturno

7) Você estudou:

( ) Sempre em escola pública

( ) Iniciou em escola particular e mudou para pública

( ) Iniciou em escola pública e mudou para particular

8) Você trabalha?

() $\mathrm{Sim}$

( ) Não

() Às vezes

Se a sua resposta foi não, vá para a questão 13.

9) Você trabalha:

( ) Para ajudar a família

() Para ser mais independente

() Outro 
11) Quando você terminar o Ensino Médio você pretende?

() somente continuar estudando

() somente trabalhar

( ) continuar estudando e trabalhar

( ) ainda não sei

12) Você está fazendo cursinho para o Exame Nacional do Ensino Médio?
( ) Sim
( ) Não

13) Para qual(is) curso (s) você pretende ingressar na Instituição Superior? 1.

2.

3.

14) Em quais Instituições? 1.

2.

3.

15) Você pensou em algum momento ser professor?
( ) Sim
( ) Não

16) (Se sim) Você pensou em ser professor:

( ) Da Educação Infantil

() De $1^{\circ}$ a $5^{\circ}$ ano

( ) De alguma disciplina específica (6ํa aำ e/ou Ensino Médio).

( ) Do Ensino Superior.

17) Se pensou em ser professor de 6ㅇ ao $9^{\circ}$ e/ou Ensino Médio, qual seria a disciplina?

18) Quais suas razões para escolher ser professor? 
19) (Se não) Quais suas razões para escolher não ser professor?

20) Sexo:

() Masculino ( ) Feminino

21) Qual é sua idade?

() Entre 14 a 16 anos

( ) Entre 17 e 18 anos

() Entre 19 e 20 anos

() Mais que 20 anos

22) Você se autodeclara

( ) Amarelo (origem oriental)

( ) Branco

() Indígena

( ) Negro

() Pardo ou mulato

FIM

\section{Termo de Consentimento Livre e Esclarecido}

Este termo tem por objetivo confirmar sua participação voluntária como sujeito, ao responder o questionário acima, que faz parte da coleta de dados iniciais da supracitada pesquisa. Para tanto, é garantido que as informações concedidas e a sua identidade será confidencial e preservada de identificação.

Você confirma sua participação voluntária como Sujeito, ao responder o questionário?

( ) $\operatorname{sim}$

( ) não

Nome: 


\section{Anexo 2}

Tabela 5: Escolas públicas estaduais de MS participantes da pesquisa

\begin{tabular}{|c|c|c|c|}
\hline MUNICÍPIO & TOTAL & MUNICÍPIO & TOTAL \\
\hline Água Clara & 1 & Dourados & 6 \\
\hline EE MAL CASTELO BRANCO & & EE PRES GETÚLIO VARGAS & \\
\hline Alcinópolis & 1 & $\begin{array}{ll}\text { EE PRES } & \text { TANCREDO } \\
\text { NEVES } & \\
\end{array}$ & \\
\hline EE PROF $\cong$ ROMILDA COSTA CARNEIRO & & EE PRES VARGAS & \\
\hline Amambai & 5 & $\begin{array}{l}\text { EE PROF CELSO MULLER } \\
\text { DO AMARAL }\end{array}$ & \\
\hline EE CEL FELIPE DE BRUM & & $\begin{array}{l}\text { EE PROF }{ }^{\mathrm{a}} \text { FLORIANA } \\
\text { LOPES }\end{array}$ & \\
\hline EE DOM AQUINO CORRÊA & & $\begin{array}{l}\text { EE RAMONA } \text { DA } \\
\text { PEDROSO }\end{array}$ & \\
\hline EE DR FERNANDO CORRÊA DA COSTA & & Eldorado & 2 \\
\hline EE INDÍGENA MBO EROY GUARANI KAIOWA & & EE ELDORADO & \\
\hline EE VESPASIANO MARTINS & & EE SILO VARGAS BATISTA & \\
\hline Anastácio & 3 & Fátima do Sul & 2 \\
\hline EE CARLOS DRUMMOND DE ANDRADE & & EE VICENTE PALLOTTI & \\
\hline EE MARIA CORRÊA DIAS & & EE VILA BRASIL & \\
\hline EE ROBERTO SCAFF & & Figueirão & 1 \\
\hline Anaurilândia & 1 & $\begin{array}{l}\text { EE DR ARNALDO ESTEVÃO } \\
\text { DE FIGUEIREDO }\end{array}$ & \\
\hline EE PROF EZEQUIEL BALBINO & & Glória de Dourados & 3 \\
\hline Angélica & 3 & $\begin{array}{l}\text { EE PROF }{ }^{a} \text { EUFROSINA } \\
\text { PINTO }\end{array}$ & \\
\hline EE DR JOSÉ MANOEL FONTANILLAS FRAGELLI & & $\begin{array}{lcc}\text { EE } & \text { PROF }^{a} & \text { VÂNIA } \\
\text { MEDEIROS LOPES } & \\
\end{array}$ & \\
\hline EE LUÍS VAZ DE CAMÕES & & EE WEIMAR TORRES & \\
\hline EE SEN FILINTO MULLER & & Guia Lopes da Laguna & 1 \\
\hline Antônio João & 1 & EE ALZIRO LOPES & \\
\hline EE PANTALEÃO COELHO XAVIER & & Iguatemi & 1 \\
\hline Aparecida do Taboado & 3 & EE PAULO FREIRE & \\
\hline EE ERNESTO RODRIGUES & & Inocência & 2 \\
\hline EE FREI VITAL DE GARIBALDI & & $\begin{array}{l}\text { EE PROF JOÃO PEREIRA } \\
\text { VALIM }\end{array}$ & \\
\hline EE GEORGINA DE OLIVEIRA ROCHA & & $\begin{array}{l}\text { ESCOLA ESTADUAL JOÃO } \\
\text { PONCE DE ARRUDA }\end{array}$ & \\
\hline Aquidauana & 5 & Itaporã & 2 \\
\hline $\begin{array}{lrl}\text { CENTRO DE } & \text { EDUCAÇÃO } & \text { PROFISSIONAL DE } \\
\text { AQUIDAUANA } & \text { GERALDO } & \text { AFONSO GARCIA } \\
\text { FERREIRA } & & \\
\end{array}$ & & EE EDSON BEZERRA & \\
\hline EE INDÍGENA DE EM PASCOAL LEITE DIAS & & EE SEN SALDANHA DERZI & \\
\hline $\begin{array}{l}\text { EE INDÍGENA DE EM PASTOR REGINALDO } \\
\text { MIGUEL - HOYENÓ O }\end{array}$ & & Itaquiraí & 2 \\
\hline $\begin{array}{l}\text { EE INDÍGENA DE EM PROF DOMINGOS V } \\
\text { MARCOS - MIHIN }\end{array}$ & & $\begin{array}{l}\text { EE MANOEL GUILHERME } \\
\text { DOS SANTOS }\end{array}$ & \\
\hline
\end{tabular}




\begin{tabular}{|c|c|c|c|}
\hline EE PROF ${ }^{a}$ DORIS MENDES TRINDADE & & \begin{tabular}{|l} 
EE PROF JOSÉ JUAREZ \\
RIBEIRO DE OLIVEIRA
\end{tabular} & \\
\hline Aral Moreira & 2 & Ivinhema & 3 \\
\hline EE DR FERNANDO CORRÊA DA COSTA & & EE ANGELINA JAIME TEBET & \\
\hline EE JOÃO VITORINO MARQUES & & $\begin{array}{l}\text { EE JOAQUIM GONÇALVES } \\
\text { LEDO }\end{array}$ & \\
\hline Bandeirantes & 2 & EE REYNALDO MASSI & \\
\hline EE ERNESTO SOLON BORGES & & Japorã & 1 \\
\hline EE JOÃO RIBEIRO GUIMARÃES & & EE JAPORÃ & \\
\hline Bataguassu & 3 & Jaraguari & 0 \\
\hline EE MANOEL DA COSTA LIMA & & Jardim & 2 \\
\hline EE PERI MARTINS & & $\begin{array}{|ll|}\text { EE ANTÔNIO PINTO } \\
\text { PEREIRA }\end{array}$ & \\
\hline EE PROF LADISLAU DEAK FILHO & & EE CEL JUVÊNCIO & \\
\hline Batayporã & 2 & Jateí & 2 \\
\hline EE BRAZ SINIGAGLIA & & $\begin{array}{|lcc|}\text { EE } & \text { PROF } & \text { JOAQUIM } \\
\text { ALFREDO SOARES VIANNA }\end{array}$ & \\
\hline EE JAN ANTONIN BATA & & $\begin{array}{l}\text { EE PROFa } \text { BERNADETE }^{\text {B BNTOS LEITE }} \\
\text { SANT }\end{array}$ & \\
\hline Bela Vista & 4 & Juti & 1 \\
\hline EE CASTELO BRANCO & & EE 31 DE MARCO & \\
\hline EE DR JOAQUIM MURTINHO & & Ladário & 2 \\
\hline EE ESTER SILVA & & EE 2 DE SETEMBRO & \\
\hline EE PROFa VERA GUIMARÃES LOUREIRO & & EE LEME DO PRADO & \\
\hline Bodoquena & 1 & Laguna Carapã & 1 \\
\hline EE JOÃO PEDRO PEDROSSIAN & & $\begin{array}{l}\text { EE ÁLVARO MARTINS DOS } \\
\text { SANTOS }\end{array}$ & \\
\hline Bonito & 2 & Maracaju & 1 \\
\hline EE BONIFÁCIO CAMARGO GOMES & & 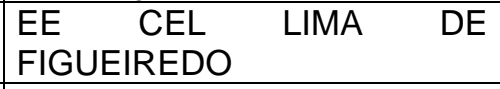 & \\
\hline EE LUIZ DA COSTA FALCÃO & & Miranda & 2 \\
\hline Brasilândia & 2 & EE CAETANO PINTO & \\
\hline EE ADÍLSON ALVES DA SILVA & & 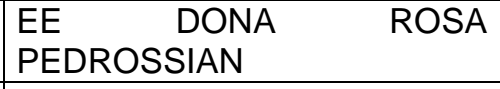 & \\
\hline EE DEBRASA & & Mundo Novo & 1 \\
\hline Caarapó & 2 & EE MAL RONDON & \\
\hline EE PROF JOAQUIM ALFREDO SOARES VIANNA & & Naviraí & 4 \\
\hline $\begin{array}{l}\text { EE PROF } \\
\text { GALHARDO }\end{array}$ & & EE ANTÔNIO FERNANDES & \\
\hline Camapuã & 3 & $\begin{array}{|ll|}\text { EE EURICO } & \text { GASPAR } \\
\text { DUTRA } & \\
\end{array}$ & \\
\hline EE ABADIA FAUSTINO INÁCIO & & EE PRES MÉDICI & \\
\hline EE CAMILO BONFIM & & EE VINÍCIUS DE MORAES & \\
\hline EE JOAQUIM MALAQUIAS DA SILVA & & Nioaque & 2 \\
\hline Campo Grande & 37 & $\begin{array}{l}\text { EE ODETE IGNÊZ RESSTEL } \\
\text { VILLAS BOAS }\end{array}$ & \\
\hline EE 11 DE OUTUBRO & & EE UIRAPURU & \\
\hline EE 26 DE AGOSTO & & Nova Alvorada do Sul & 2 \\
\hline EE ADVENTOR DIVINO DE ALMEIDA & & EE ANTÔNIO COELHO & \\
\hline
\end{tabular}




\begin{tabular}{|c|c|c|c|}
\hline EE ADVOGADO DEMOSTHENES MARTINS & & $\begin{array}{l}\text { EE DELFINA NOGUEIRA DE } \\
\text { SOUZA }\end{array}$ & \\
\hline EE AMANDO DE OLIVEIRA & & Nova Andradina & 4 \\
\hline EE AMÉLIO DE CARVALHO BAÍS & & $\begin{array}{l}\text { EE AUSTRÍLIO CAPILE } \\
\text { CASTRO }\end{array}$ & \\
\hline EE ARACY EUDOCIAK & & EE LUIZ SOARES ANDRADE & \\
\hline EE BLANCHE DOS SANTOS PEREIRA & & EE MAL RONDON & \\
\hline EE CORAÇÃO DE MARIA & & $\begin{array}{l}\text { EE PROF LUIZ CARLOS } \\
\text { SAMPAIO }\end{array}$ & \\
\hline EE GAL MALAN & & Novo Horizonte do Sul & 1 \\
\hline EE HÉRCULES MAYMONE & & $\begin{array}{|lrl|}\text { EE } & \text { DORCELINA } & \text { DE } \\
\text { OLIVEIRA FOLADOR } & \\
\end{array}$ & \\
\hline EE JOÃO CARLOS FLORES & & Paraíso das Águas & 1 \\
\hline EE JOAQUIM MURTINHO & & EE VER KENDI NAKAI & \\
\hline EE JOSÉ BARBOSA RODRIGUES & & Paranaíba & 6 \\
\hline EE JOSÉ FERREIRA BARBOSA & & $\begin{array}{l}\text { EE ARACILDA CÍCERO } \\
\text { CORREA DA COSTA }\end{array}$ & \\
\hline EE JOSÉ MAMEDE DE AQUINO & & $\begin{array}{lll}\text { EE } & \text { DR } & \text { ERMÍRIO } \\
\text { GARCIA }\end{array}$ & \\
\hline EE LINO VILLACHÁ & & $\begin{array}{l}\text { EE GUSTAVO RODRIGUES } \\
\text { DA SILVA }\end{array}$ & \\
\hline EE MAESTRO FREDERICO LIEBERMANN & & EE JOSÉ GARCIA LEAL & \\
\hline EE MANOEL BONIFÁCIO NUNES DA CUNHA & & EE MANOEL GARCIA LEAL & \\
\hline EE PADRE JOÃO GREINER & & $\begin{array}{l}\text { EE WLADISLAU GARCIA } \\
\text { GOMES }\end{array}$ & \\
\hline EE PADRE JOSÉ SCAMPINI & & Paranhos & 1 \\
\hline EE PADRE MÁRIO BLANDINO & & EE SANTIAGO BENITES & \\
\hline EE POLO FRANCISCO CÂNDIDO DE REZENDE & & Pedro Gomes & 1 \\
\hline EE PROF EMYGDÍO CAMPOS WIDAL & & $\begin{array}{|ll|}\text { EE PROF } & \text { CLEUZA } \\
\text { TEODORO } & \\
\end{array}$ & \\
\hline EE PROF SÍLVIO OLIVEIRA DOS SANTOS & & Ponta Porã & 6 \\
\hline EE PROF ${ }^{a}$ ALICE NUNES ZAMPIERE & & EE ADE MARQUES & \\
\hline EE PROFa CLARINDA MENDES DE AQUINO & & $\begin{array}{lcrc}\text { EE } & \text { DEP } & \text { FERNANDO } & \text { C } \\
\text { CAPIBERIBE SALDANHA } & \\
\end{array}$ & \\
\hline EE PROFa FAUSTA GARCIA BUENO & & EE NOVA ITAMARATI & \\
\hline EE PROF ${ }^{a}$ FLAVINA MARIA DA SILVA & & $\begin{array}{l}\text { EE PEDRO AFONSO } \\
\text { PEREIRA GOLDONI }\end{array}$ & \\
\hline EE PROFa IZAURA HIGA & & $\begin{array}{l}\text { EE PROF CARLOS PEREIRA } \\
\text { DA SILVA }\end{array}$ & \\
\hline $\begin{array}{lllll}\text { EE PROF } & \text { a MARIA DE LOURDES } & \text { TOLEDO } \\
\text { AREIAS } & & & \\
\end{array}$ & & \begin{tabular}{|l} 
EE \\
PROF JOSÉ ÉDSON \\
DOMINGOS DOS SANTOS
\end{tabular} & \\
\hline $\begin{array}{l}\text { EE PROF }{ }^{a} \text { MARIA RITA DE CASSIA PONTES } \\
\text { TEIXEIRA }\end{array}$ & & Porto Murtinho & 1 \\
\hline EE PROFa THEREZA NORONHA DE CARVALHO & & EE JOSÉ BONIFÁCIO & \\
\hline EE PROFa ZÉLIA QUEVEDO CHAVES & & Ribas do Rio Pardo & 2 \\
\hline EE RUI BARBOSA & & $\begin{array}{l}\text { EE DR JOÃO PONCE DE } \\
\text { ARRUDA }\end{array}$ & \\
\hline EE SEBASTIÃO SANTANA DE OLIVEIRA & & $\begin{array}{|lr|}\text { EE } & \text { EDUARDO } \\
\text { AMORIM } & \text { BATISTA } \\
\end{array}$ & \\
\hline EE WALDEMIR BARROS DA SILVA & & Rio Brilhante & 0 \\
\hline Caracol & 1 & Rio Negro & 1 \\
\hline
\end{tabular}




\begin{tabular}{|c|c|c|c|}
\hline EE DR RUBENS DE CASTRO PINTO & & $\begin{array}{l}\text { EE LEONTINO ALVES DE } \\
\text { OLIVEIRA }\end{array}$ & \\
\hline Cassilândia & 1 & Rio Verde de Mato Grosso & 2 \\
\hline EE HERMELINA BARBOSA LEAL & & $\begin{array}{l}\text { EE THOMAZ BARBOSA } \\
\text { RANGEL }\end{array}$ & \\
\hline Chapadão do Sul & 2 & $\begin{array}{l}\text { EE VERGELINO MATEUS DE } \\
\text { OLIVEIRA }\end{array}$ & \\
\hline EE AUGUSTO KRUG NETTO & & Rochedo & 1 \\
\hline ESCOLA ESTADUAL JORGE AMADO & & EE JOSÉ ALVES RIBEIRO & \\
\hline Corguinho & 1 & Santa Rita do Pardo & 1 \\
\hline EE JOSÉ ALVES QUITO & & EE JOSÉ FERREIRA LIMA & \\
\hline Coronel Sapucaia & 1 & São Gabriel do Oeste & 1 \\
\hline EE CEL SAPUCAIA & & $\begin{array}{ll}\text { EE } & \text { BERNARDINO } \\
\text { FERREIRA DA CUNHA }\end{array}$ & \\
\hline Corumbá & 9 & Selvíria & 1 \\
\hline EE CARLOS DE CASTRO BRASIL & & EE ANA MARIA DE SOUZA & \\
\hline EE DOM BOSCO & & Sete Quedas & 1 \\
\hline EE DR GABRIEL VANDONI DE BARROS & & EE GUIMARÃES ROSA & \\
\hline EE DR JOÃO LEITE DE BARROS & & Sidrolândia & 4 \\
\hline EE JÚLIA GONÇALVES PASSARINHO & & $\begin{array}{l}\text { EE PAULO EDUARDO DE } \\
\text { SOUZA FIRMO }\end{array}$ & \\
\hline EE MARIA HELENA ALBANEZE & & $\begin{array}{l}\text { EE PROF } \text { CATARINA DE }^{\mathrm{a}} \text { ABREU } \\
\text { ABRE }\end{array}$ & \\
\hline EE MARIA LEITE & & $\begin{array}{l}\text { EE SIDRÔNIO ANTUNES DE } \\
\text { ANDRADE }\end{array}$ & \\
\hline EE NATHÉRCIA POMPEO DOS SANTOS & & EE VESPASIANO MARTINS & \\
\hline EE OCTACÍLIO FAUSTINO DA SILVA & & Sonora & 1 \\
\hline Costa Rica & 2 & $\begin{array}{lr}\text { EE } & \text { COMANDANTE } \\
\text { MAURÍCIO } & \text { COUTINHO } \\
\text { DUTRA } & \\
\end{array}$ & \\
\hline EE JOSÉ FERREIRA DA COSTA & & Tacuru & 0 \\
\hline EE SANTOS DUMONT & & Taquarussu & 1 \\
\hline Coxim & 3 & $\begin{array}{l}\text { EE } \quad \text { DR } \\
\text { MARQUES }\end{array}$ & \\
\hline EE PADRE NUNES & & Terenos & 1 \\
\hline EE PEDRO MENDES FONTOURA & & $\begin{array}{l}\text { EE ANTÔNIO NOGUEIRA DA } \\
\text { FONSECA }\end{array}$ & \\
\hline EE VIRIATO BANDEIRA & & Três Lagoas & 10 \\
\hline Deodápolis & 4 & EE AFONSO PENA & \\
\hline EE 13 DE MAIO & & EE DOM AQUINO CORREAA & \\
\hline EE JOÃO BAPTISTA PEREIRA & & $\begin{array}{l}\text { EE EDWARDS CORREA E } \\
\text { SOUZA }\end{array}$ & \\
\hline EE LAGOA BONITA & & EE FERNANDO CORREAA & \\
\hline EE SCILA MÉDICI & & $\begin{array}{l}\text { EE JOÃO } \\
\text { FILGUEIRAS }\end{array}$ & \\
\hline Dois Irmãos do Buriti & 3 & $\begin{array}{lll}\text { EE JOÄO } & \text { PONCE } & \text { DE } \\
\text { ARRUDA } & & \\
\end{array}$ & \\
\hline EE ESTEFANA CENTURION GAMBARRA & & EE JOSÉ FERREIRA & \\
\hline EE INDÍGENA CACIQUE NDETI REGINALDO & & EE PADRE JOÃO TOMES & \\
\hline EE INDÍGENA NATIVIDADE ALCANTARA & & EE PROF JOÃO MAGIANO & \\
\hline
\end{tabular}




\begin{tabular}{|l|l|l|l|}
\hline MARQUES & \multicolumn{2}{|l|}{ PINTO } & \\
\hline Douradina & $\mathbf{1}$ & $\begin{array}{l}\text { EE PROF LUIZ LOPES DE } \\
\text { CARVALHO }\end{array}$ & \\
\hline EE BARÃO DO RIO BRANCO & & Vicentina & $\mathbf{3}$ \\
\hline Dourados & $\mathbf{9}$ & EE EMANNUEL PINHEIRO & \\
\hline EE FLORIANO VIEGAS MACHADO & & EE PADRE JOSÉ DANIEL & \\
\hline $\begin{array}{l}\text { EE INDÍGENA DE EM INT GUATEKA - MARCAL } \\
\text { DE SOUZA }\end{array}$ & & EE SÃO JOSÉ & \\
\hline EE MIN JOÃO PAULO DOS REIS VELOSO & & Total Geral & $\mathbf{2 1 1}$ \\
\hline
\end{tabular}

Fonte: http://www.sed.ms.gov.br/ (2016) 


\section{Anexo 3}

Transcrições do Grupo de discussão

As transcrições das CONVERSAS/ENTREVISTAS CONSTAM NO VOLUME II DOS ANEXOS (acrescentar número da página)

Obs: As transcrições foram feitas pela Audiotex Serviços e Cia. Ltda.

\section{PARTICIPANTES}

Professor do Ensino Médio - Prof.do EM 1 - P1

Professor do Ensino Médio - Prof.do EM 2 - P2

Professora do Ensino Médio - Profa ${ }^{\text {. }}$ do EM 3 - P3

Professora do Ensino Superior - Prof ${ }^{a}$ do ES 1 - P4

Professora do Ensino Superior - Prof ${ }^{\underline{a}}$ do ES 2 - P5

Professora do Ensino Superior - Prof ${ }^{\underline{a}}$ do ES 3 - P6

Técnica da Secretaria de Estado de Educação - Técnica da SED/MS 1 - P7

Técnica da Secretaria de Estado de Educação - Técnica da SED/MS 2 - P8

Técnico da Secretaria de Estado de Educação - Técnico da SED/MS 3 - P9

Pesquisadora - P

\section{MODALIDADE DE TRANSCRIÇÃO}

Padrão

\section{LEGENDA}

$\ldots \rightarrow$ pausa ou interrupção.

(inint) [hh:mm:ss] $\rightarrow$ palavra ou trecho ininteligível.

(palavra) [hh:mm:ss] $\rightarrow$ incerteza da palavra transcrita / ouvida.

A Audiotext Serviços e Cia. Ltda se reserva o direito da imprecisão dos nomes escritos, uma vez que os locutores serão identificados conforme a pronúncia de seu nome. O cliente tem o direito de fazer quaisquer alterações que julgar necessárias nas identificações aqui utilizadas. 


\section{Anexo 4}

Termo de Consentimento Livre e Esclarecido - Grupo de discussão

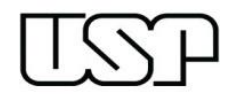

\section{Universidade de São Paulo \\ Faculdade de Filosofia, Letras e Ciências Humanas}

\section{Termo de Consentimento Livre e Esclarecido}

\section{Caro professor (a),}

Este termo tem por objetivo confirmar sua participação voluntária como sujeito desta pesquisa que desenvolvo no Doutoramento em Letras na Universidade de São Paulo - USP, sob a orientação da Prof ${ }^{a}$ Dra. Walkyria Monte Mór, intitulada: "Quem quer ser professor? A atratividade pela carreira docente sob a ótica dos alunos do $3^{\circ}$ ano do Ensino Médio do Estado de Mato Grosso do Sul". Um dos objetivos da pesquisa é gerar, descrever e analisar dados sobre a configuração identitária e profissional dos professores participantes, bem como discutir os dados iniciais gerados por meio de um questionário de pesquisa elaborado pela pesquisadora e aplicado pela Secretaria de Estado de Educação de Mato Grosso do Sul - SED/MS aos alunos do 3ํano do Ensino Médio de escolas públicas estaduais de MS, por meio de um Grupo de discussão.

Informo que o caráter ético desta pesquisa assegura que as informações concedidas e a identidade dos participantes serão confidenciais e preservadas de identificação. Uma das metas para a realização deste estudo é o comprometimento da pesquisadora em possibilitar, aos participantes, um retorno dos resultados da pesquisa. Solicito ainda a permissão para a divulgação desses resultados e suas respectivas conclusões, em forma de pesquisa, preservando sigilo e ética.

Agradeço sua colaboração e disponibilizo 0 e-mail para contato: nelagley@gmail.com 
Atenciosamente,

Prof ${ }^{a}$ Nelagley Marques

Você confirma sua participação voluntária como Sujeito desta pesquisa?

( ) $\operatorname{sim}$

( ) não

Nome:

Obrigada pela sua participação! 


\section{Anexo 5}

Questionário de pesquisa - Professores do Ensino Superior

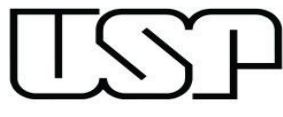

\section{Universidade de São Paulo}

Faculdade de Filosofia, Letras e Ciências Humanas

Antes de iniciar o questionário, quero reiterar sobre a importância de você responder todas as perguntas, bem como de expressar sua opinião sincera e espontânea em relação às questões, o que contribuirá para a transparência dos resultados desta pesquisa.

\section{QUESTIONÁRIO DE PESQUISA}

1.Quantas pessoas vivem na sua casa?

2.Qual é aproximadamente a sua renda familiar?

3.O seu processo de escolarização se deu em rede pública e/ou privada?

4.Há quantos anos você é professor (a)?

5.Em qual área do conhecimento você atua como professor (a)?

6.A escolha pela docência foi sua primeira opção ao ingressar na universidade?

7.Cite quais as razões que te levaram a optar pela docência?

8.Quais os motivos que te fizeram permanecer na carreira docente?

9.Quais os aspectos que você elenca como os mais difíceis do cotidiano docente? 10.Você já pensou em mudar de profissão? Se sim, por quais motivos e qual seria a profissão?

11.Você acredita que os alunos com os quais você trabalhou, se sentiam atraídos pela carreira docente? Justifique sua resposta.

12.Como docente na universidade, o que pensa ser necessário fazer para que os cursos de licenciaturas sejam mais atrativos para os alunos?

13.Sexo:

14.Idade:

15.Você se autodeclara: 


\section{Anexo 6}

Questionário de pesquisa - Professores do Ensino Médio

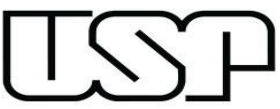

\section{Universidade de São Paulo}

Faculdade de Filosofia, Letras e Ciências Humanas

Antes de iniciar o questionário, quero reiterar sobre a importância de você responder todas as perguntas, bem como de expressar sua opinião sincera e espontânea em relação às questões, o que contribuirá para a transparência dos resultados desta pesquisa.

\section{QUESTIONÁRIO DE PESQUISA}

1. Quantas pessoas vivem na sua casa?

2.Qual é aproximadamente a sua renda familiar?

3.O seu processo de escolarização se deu em rede pública e/ou privada?

4.Há quantos anos você é professor (a)?

5.Em qual área do conhecimento você atua como professor (a)?

6.Você possui Cursos de Especialização, Mestrado ou Doutorado?

7.Em qual município de Mato Grosso do Sul você é professor(a) efetivo(a) da Secretaria de Estado de Educação - SED/MS?

8.Em quais períodos você ministra aulas?

9.A escolha pela docência foi sua primeira opção ao ingressar na universidade? 10.Cite quais as razões que te levaram a optar pela docência?

11. Quais os motivos que te fizeram permanecer na carreira docente?

12.Quais os aspectos que você elenca como os mais difíceis do cotidiano docente?

13.Quais elementos que você considera como primordiais para melhorar a carreira docente?

14. Você já pensou em mudar de profissão? Se sim, por quais motivos e qual seria a profissão? 
15.Você acredita que os alunos com os quais você trabalhou, se sentiam atraídos pela carreira docente? Justifique sua resposta.

16.Sexo:

17.Idade:

18.Você se autodeclara: 


\section{Anexo 7}

Questionário de pesquisa - Técnicos da Secretaria de Estado de Educação

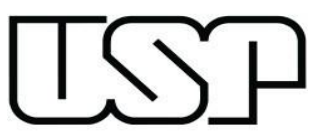

\section{Universidade de São Paulo}

\section{Faculdade de Filosofia, Letras e Ciências Humanas}

Antes de iniciar o questionário, quero reiterar sobre a importância de você responder todas as perguntas, bem como de expressar sua opinião sincera e espontânea em relação às questões, o que contribuirá para a transparência dos resultados desta pesquisa.

\section{QUESTIONÁRIO DE PESQUISA}

1.Quantas pessoas vivem na sua casa?

2.Qual é aproximadamente a sua renda familiar?

3.O seu processo de escolarização se deu em rede pública e/ou privada?

4.Há quantos anos você é professor (a)?

5.Em qual área do conhecimento você atua como professor (a)?

6.Você possui Cursos de Especialização, Mestrado ou Doutorado?

7.Quanto tempo você atuou como professor em sala de aula e quanto tempo você desempenha a função de técnico da SED/MS?

8.A escolha pela docência foi sua primeira opção ao ingressar na universidade?

9.Cite quais as razões que te levaram a optar pela docência?

10.Quais os motivos que te fizeram permanecer na carreira docente?

11.Quais os aspectos que você elenca como os mais difíceis do cotidiano docente? 12. Você já pensou em mudar de profissão? Se sim, por quais motivos e qual seria a profissão? 
13. Você acredita que os alunos com os quais você trabalhou, se sentiam atraídos pela carreira docente? Justifique sua resposta.

Na função de técnico (a):

14.Na função de técnico, quais os principais desafios você enfrenta no cotidiano? 15.Na sua opinião, quais as principais ações que a SED/MS tem feito para a melhoria da qualidade da Educação Básica, mais especificamente no Ensino Médio? 16.Sexo:

17.Idade:

18. Você se autodeclara: 


\section{Anexo 8}

\section{Textos para o Grupo de discussão}

\section{DIÁRIO OFICIAL DA UNIẢO - Seçāo 1}

\begin{tabular}{c}
\hline Ministério da Educaçāo \\
\hline GABNETE DO MiNisTho
\end{tabular}

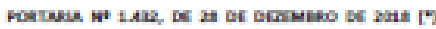

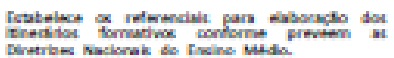

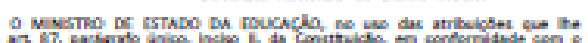

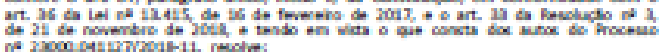

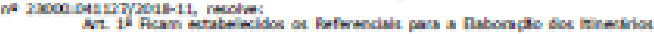

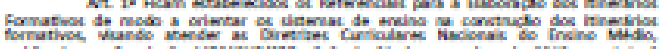

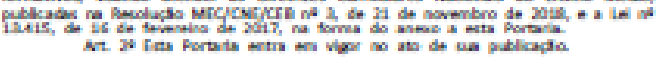
mowno vturz mocokisucz

ances

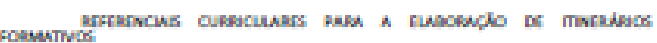

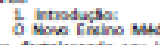

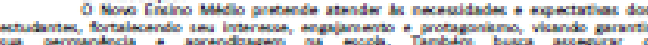

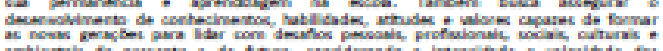

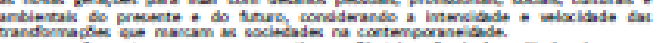

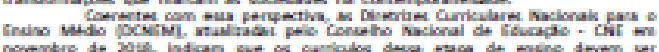

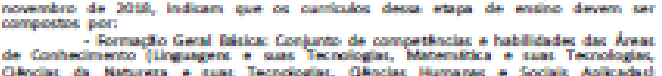

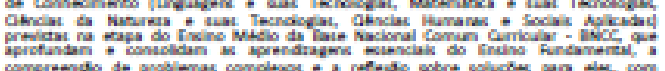

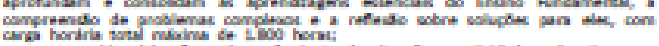

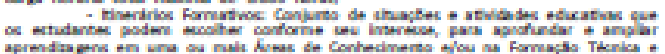

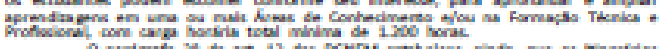

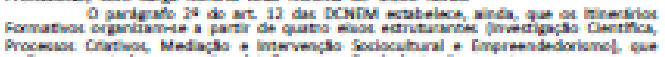

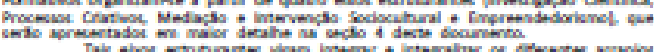

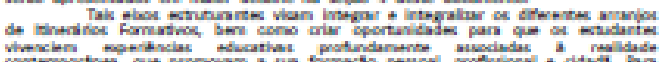

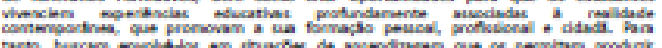

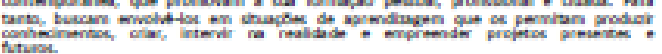

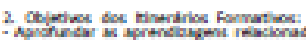

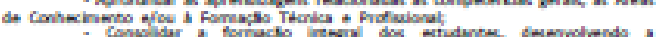

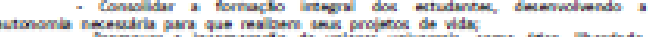

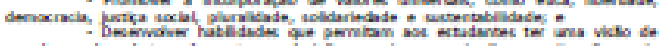

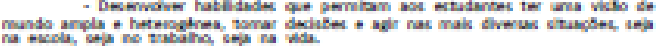

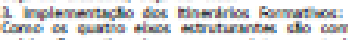

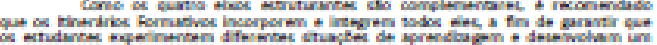

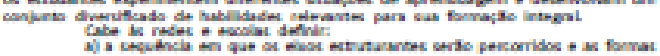

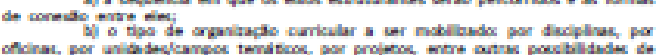

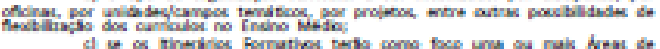

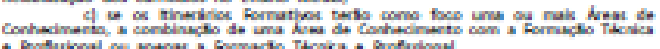

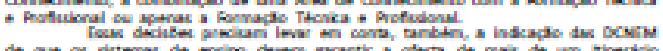

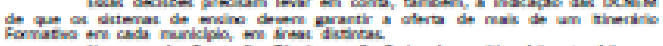

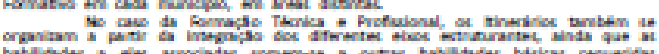

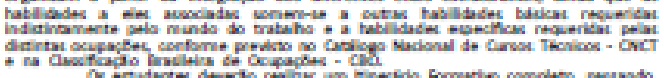

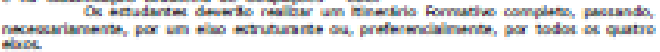

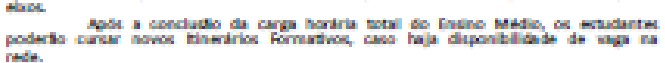

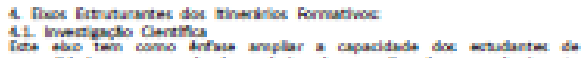

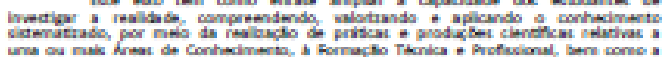

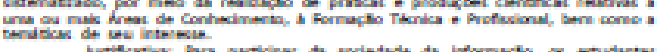

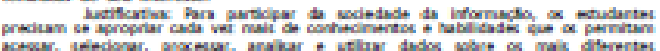

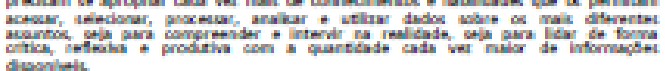

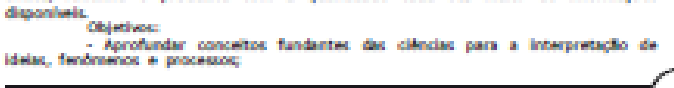

BSN $1677-7042$

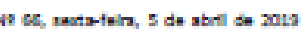

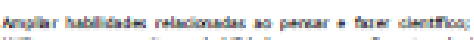

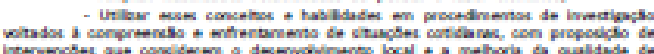
we de comuliais

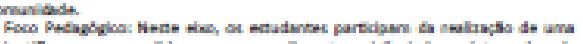

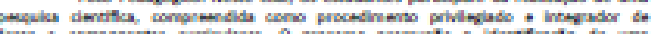

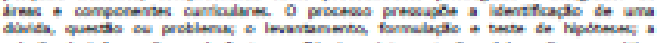

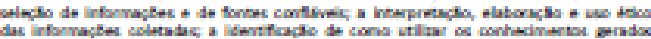

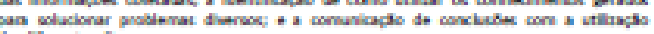
2.2. Hockewes criation

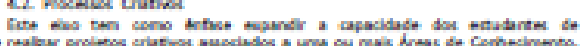

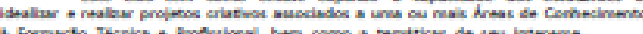

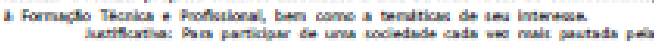

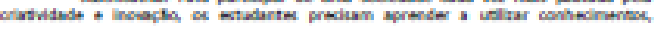

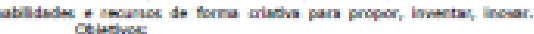

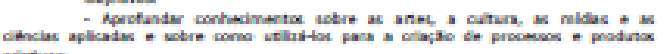
contives

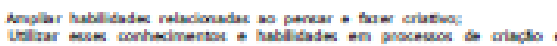

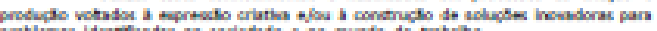

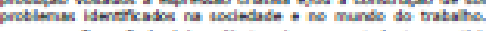

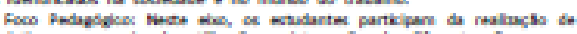

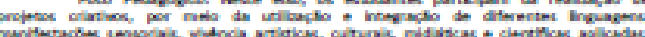

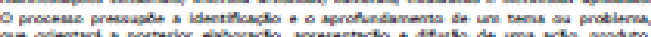

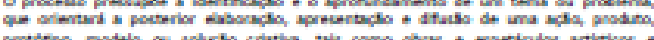

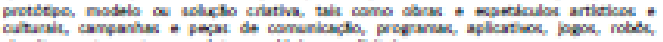

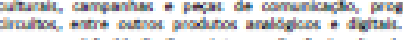

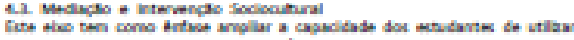

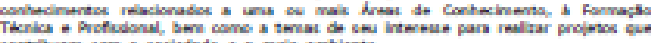

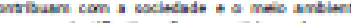

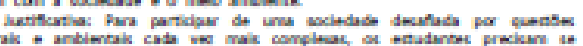

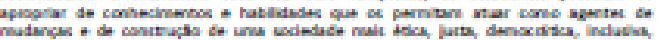
mudincas od conitus

Otjotvoc

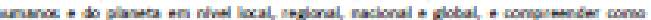

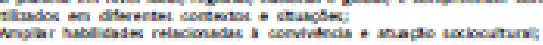

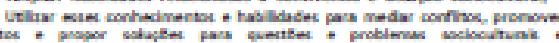

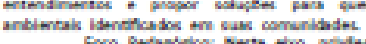

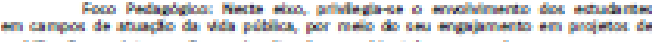

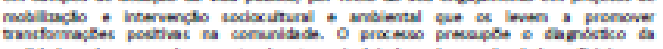

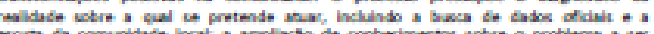

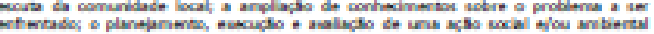

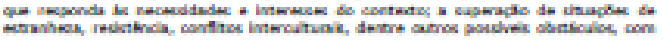

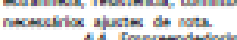

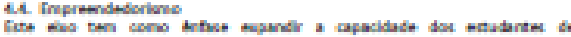

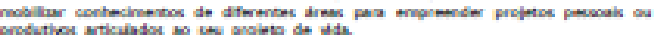

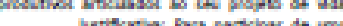

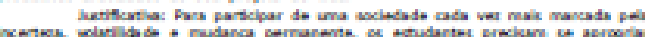

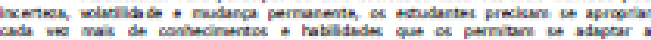

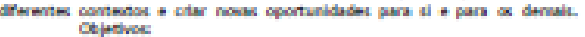

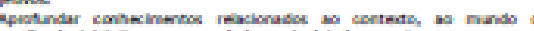

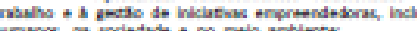

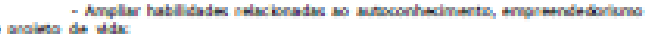

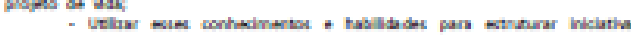

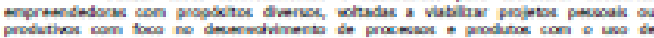

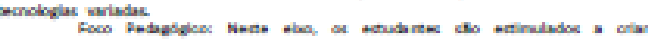

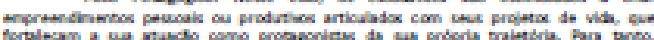

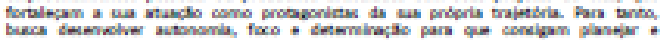

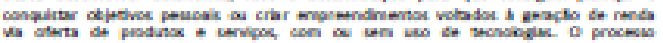

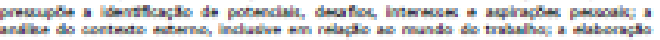
.

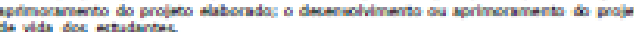

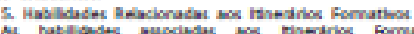

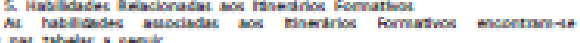

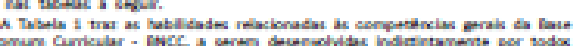

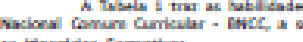

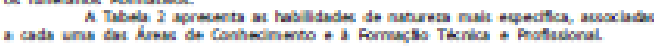


DIÁRIO OFICIAL DA UNIĀOO- Sę̧̄o 1

BSN $1677-7042$

No U6, watratein, 5 de abent be 2019

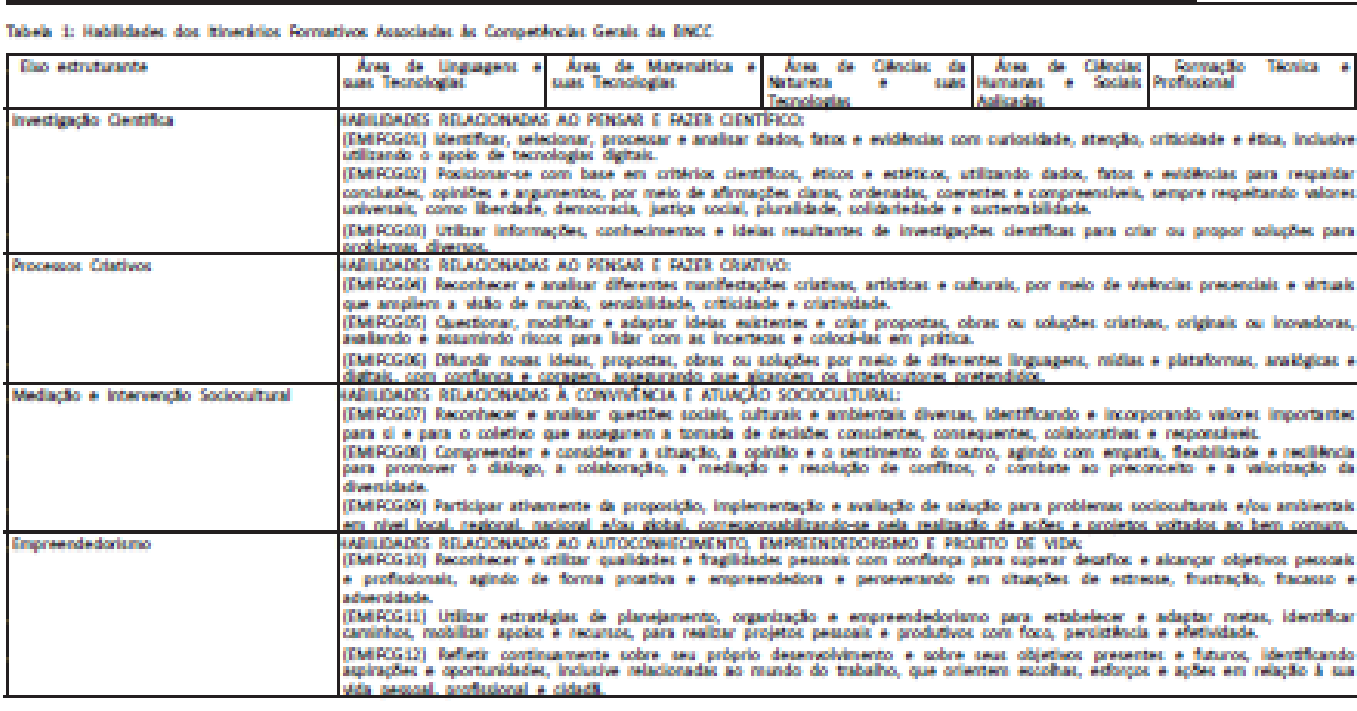

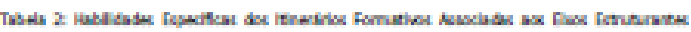

\begin{tabular}{|c|c|c|c|c|c|}
\hline Das ednutrarts & 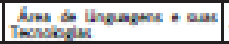 & 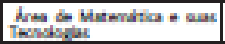 & 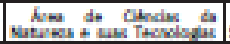 & 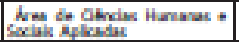 & 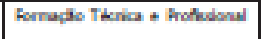 \\
\hline 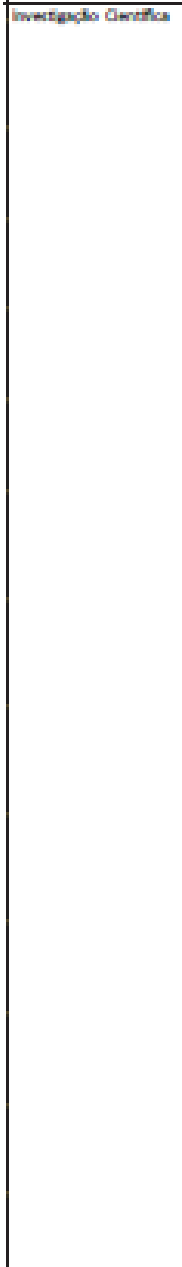 & 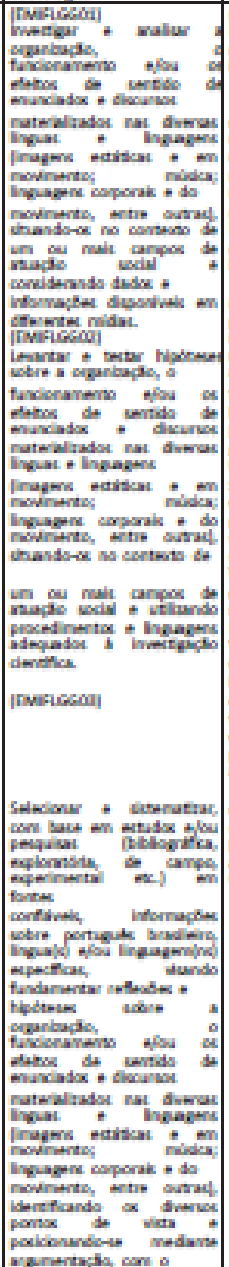 & 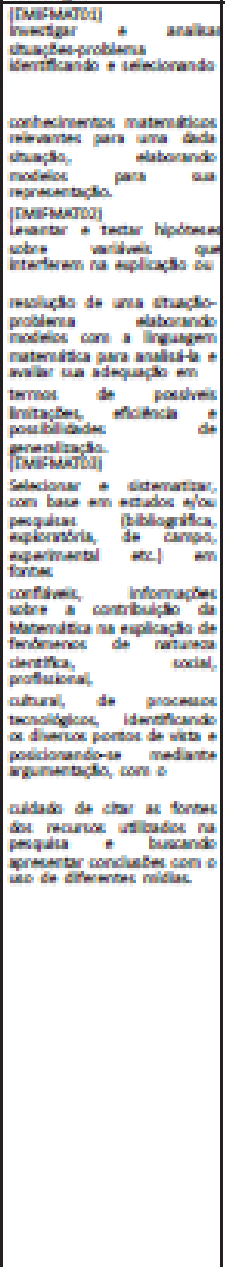 & 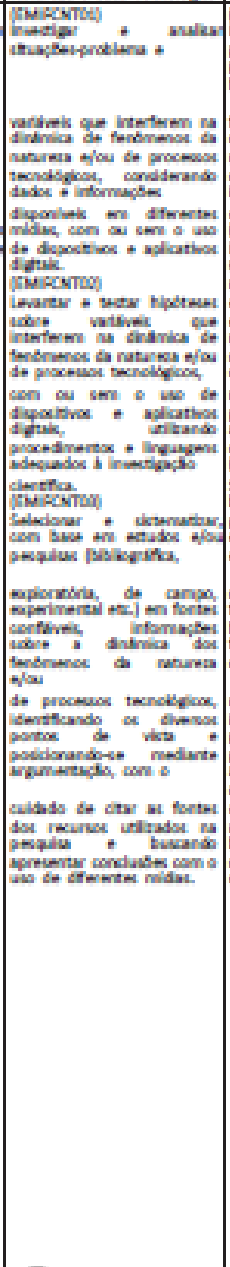 & 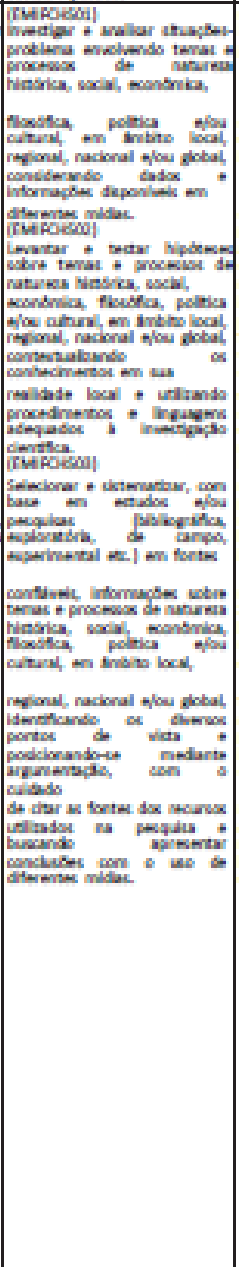 & 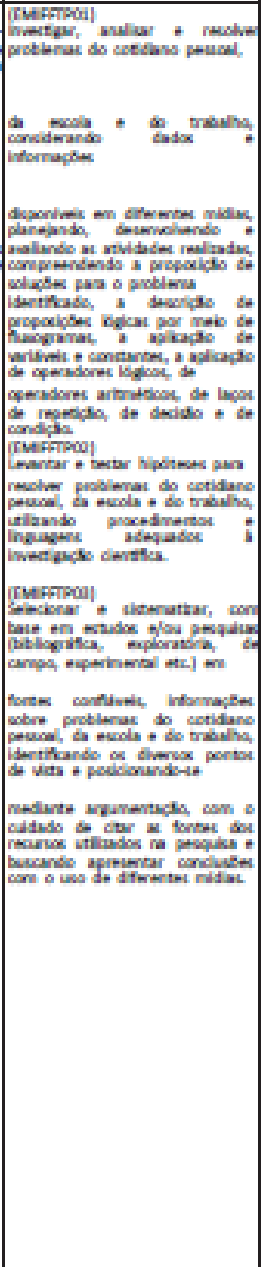 \\
\hline
\end{tabular}


DIÁRIO OFICIAL DA UNIÃ̄O- seçāo 1

BSN $1677-7042$

No Uc, wats-tein, 5 de sbrit se ans

\begin{tabular}{|c|c|c|c|c|c|}
\hline & 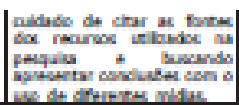 & & & & \\
\hline Prockuios Coatios & 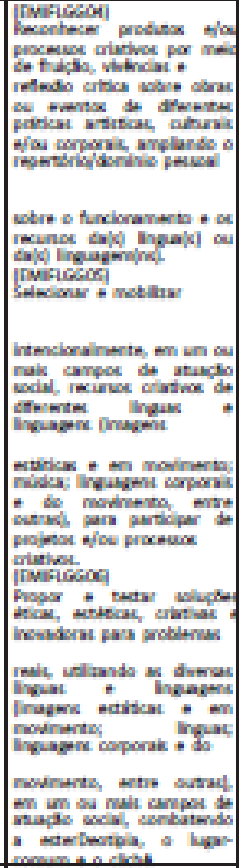 & 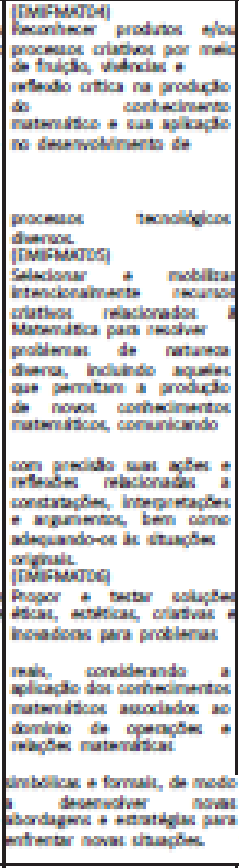 & 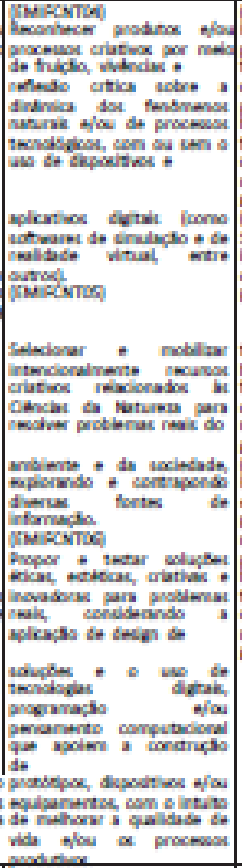 & 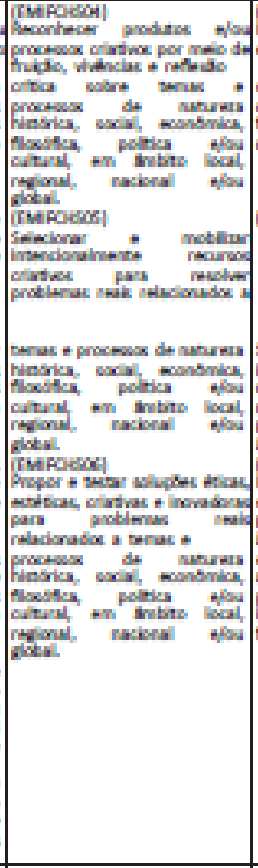 & 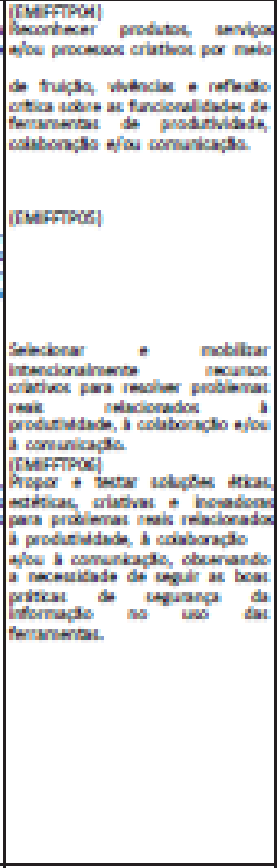 \\
\hline $\begin{array}{l}\text { Madacko of intmenclo } \\
\text { Sochenharal }\end{array}$ & 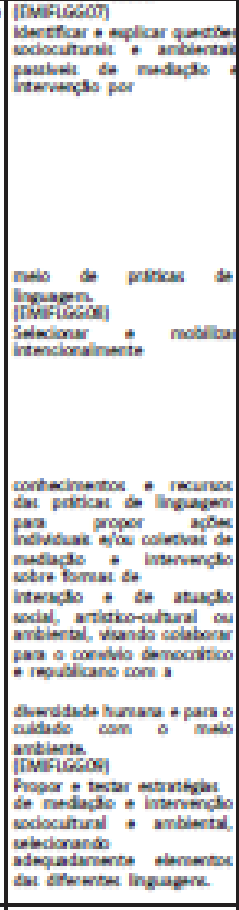 & 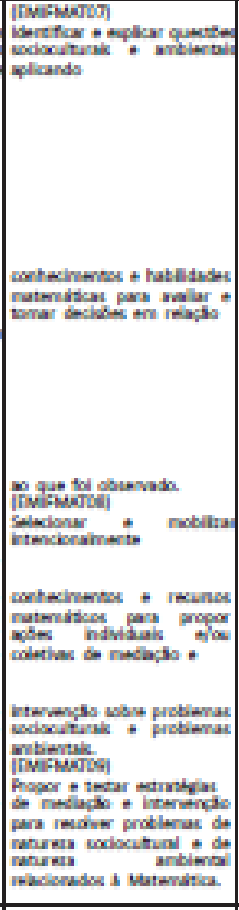 & 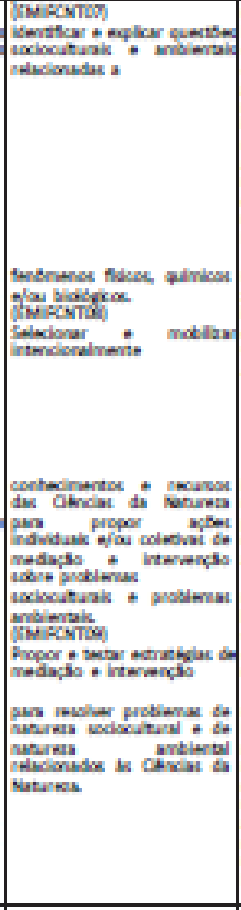 & 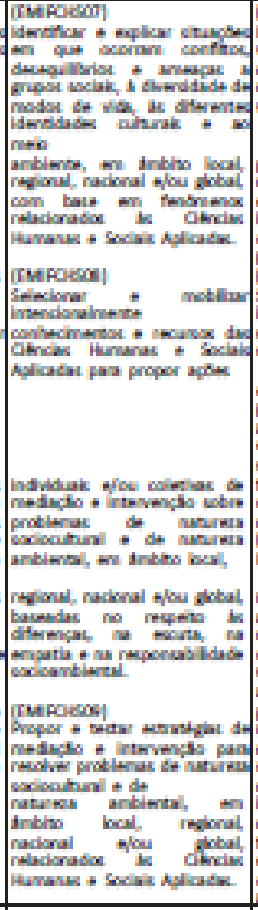 & 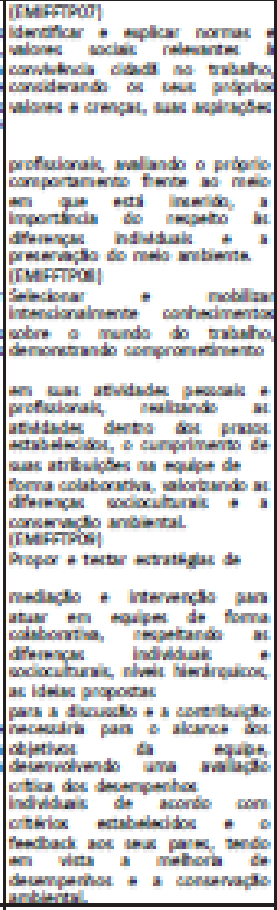 \\
\hline Finprentenderikns & 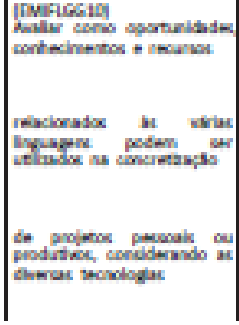 & 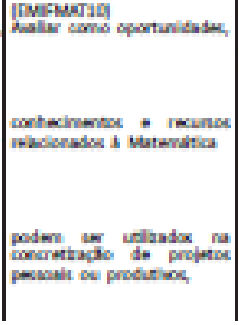 & 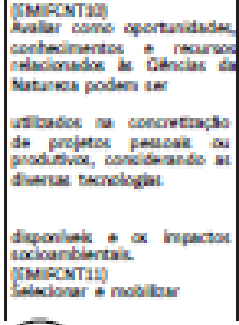 & 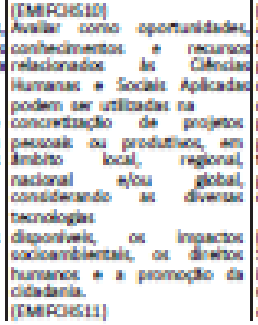 & 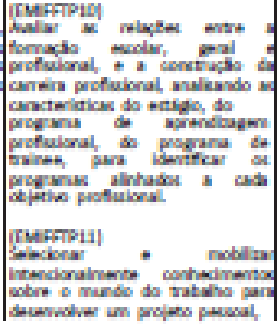 \\
\hline
\end{tabular}


DIÁRIO OFICIAL DA UNIĀo - seçāo 1

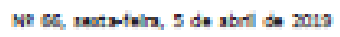

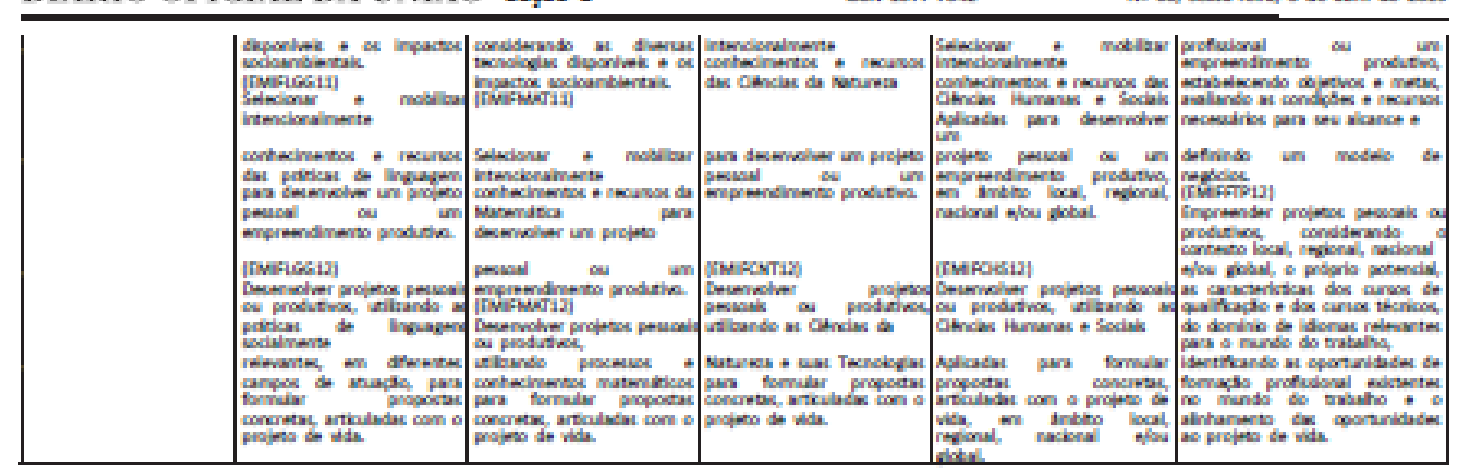

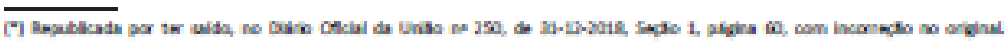

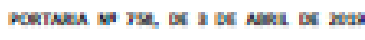

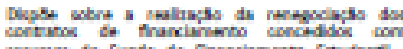

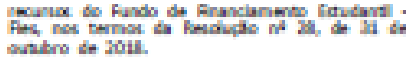

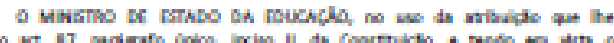

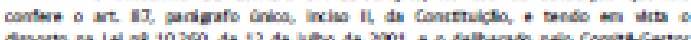

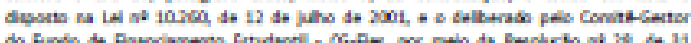

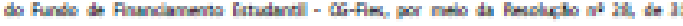

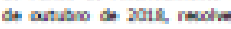

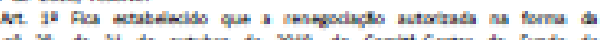

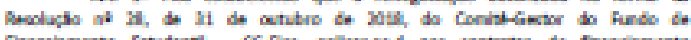

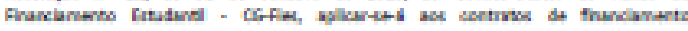

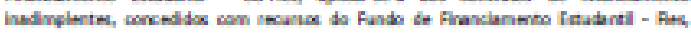

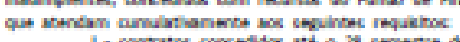

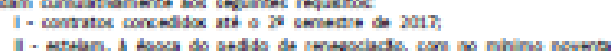
1- - wetaph, i bosa do pods

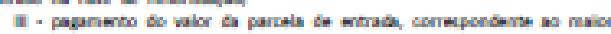

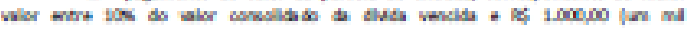
rations

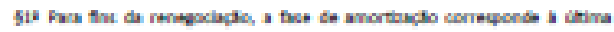

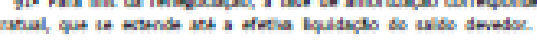

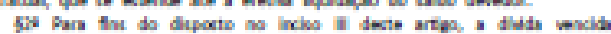

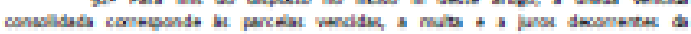
mors

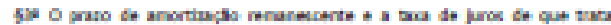

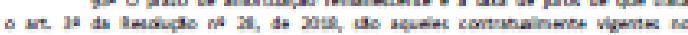

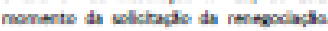

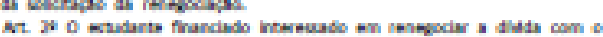

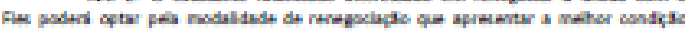
is papanterta.

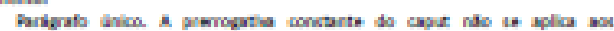

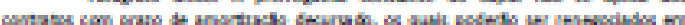

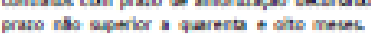

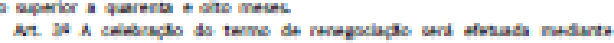

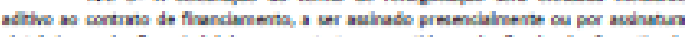

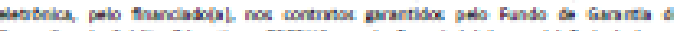

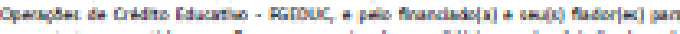

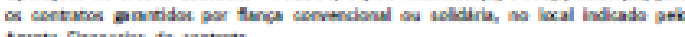
Nevete Anancilio de cortrisa.

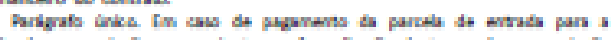

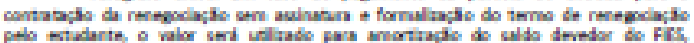

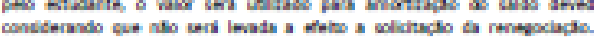

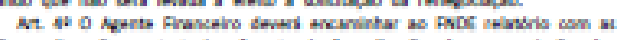

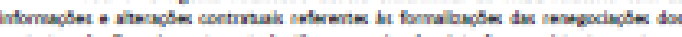

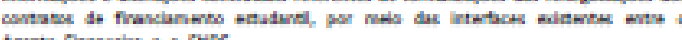

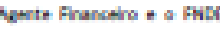

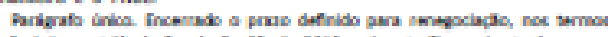

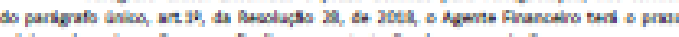

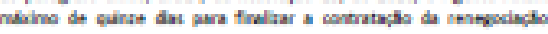

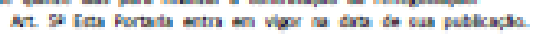

mecubo ving mocakicun?

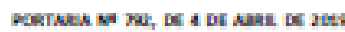

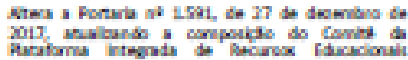

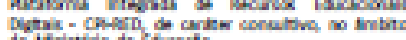

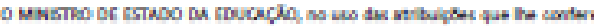

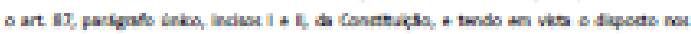

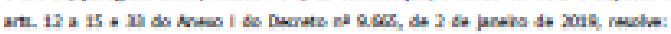

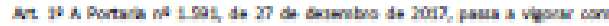
ac eagirts abracter:

sart $>$

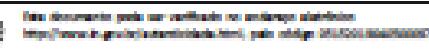

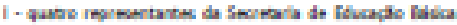

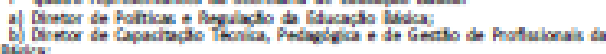

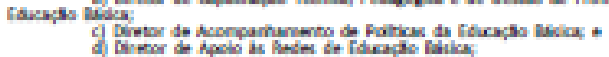

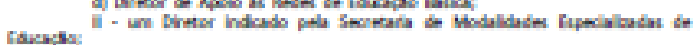

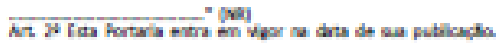
macrovo vitur acoukiger

SECRETARIA DE REGULACBO E SUPERVISL DA EDUCACTLO SUPERIOR

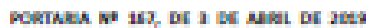

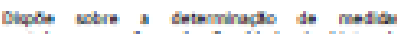

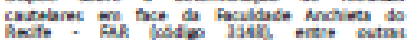

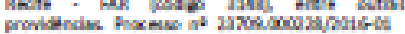

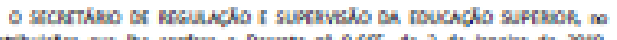

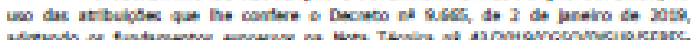

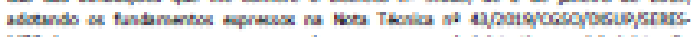

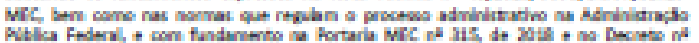
e.2nerped7, desemina:

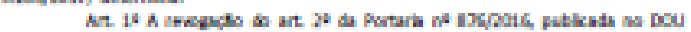
on 1lipapaie.

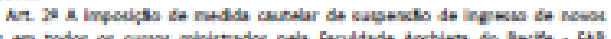

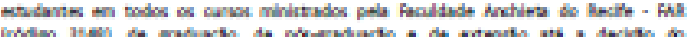

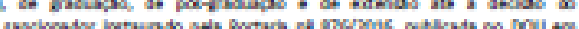
il/12pase

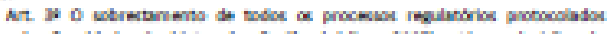

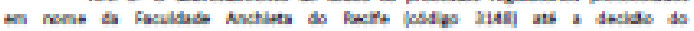

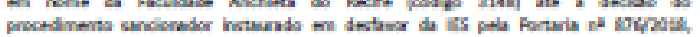

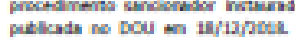

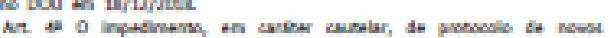

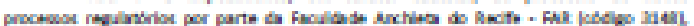

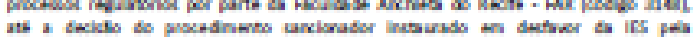

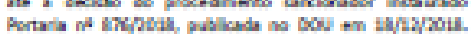

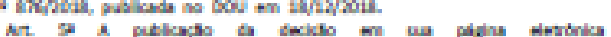

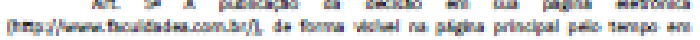

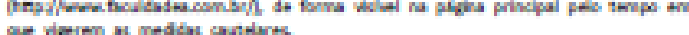
in medicat castidurt

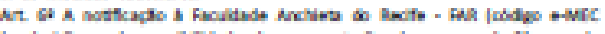

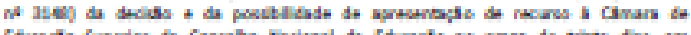

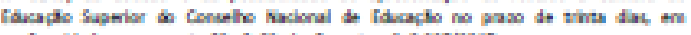

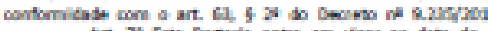

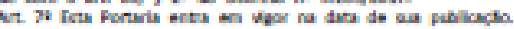

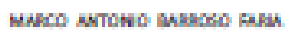

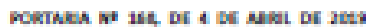

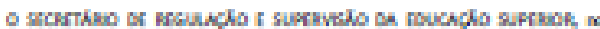

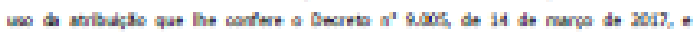

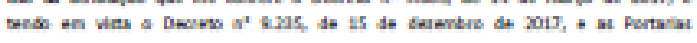

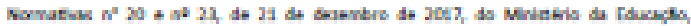

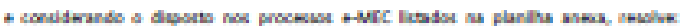

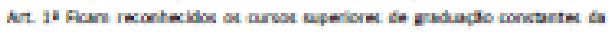

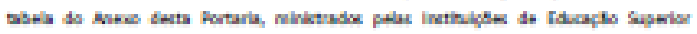

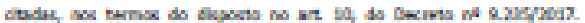

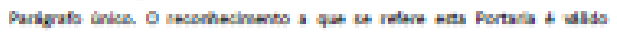

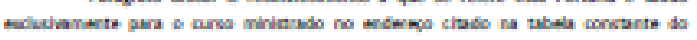
Newes dents Roraris.

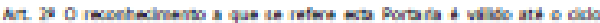
aslivivo weginta.

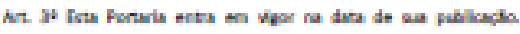

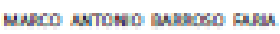




\section{COMPETÊNCIAS GERAIS}

Base National Comum Cumicular

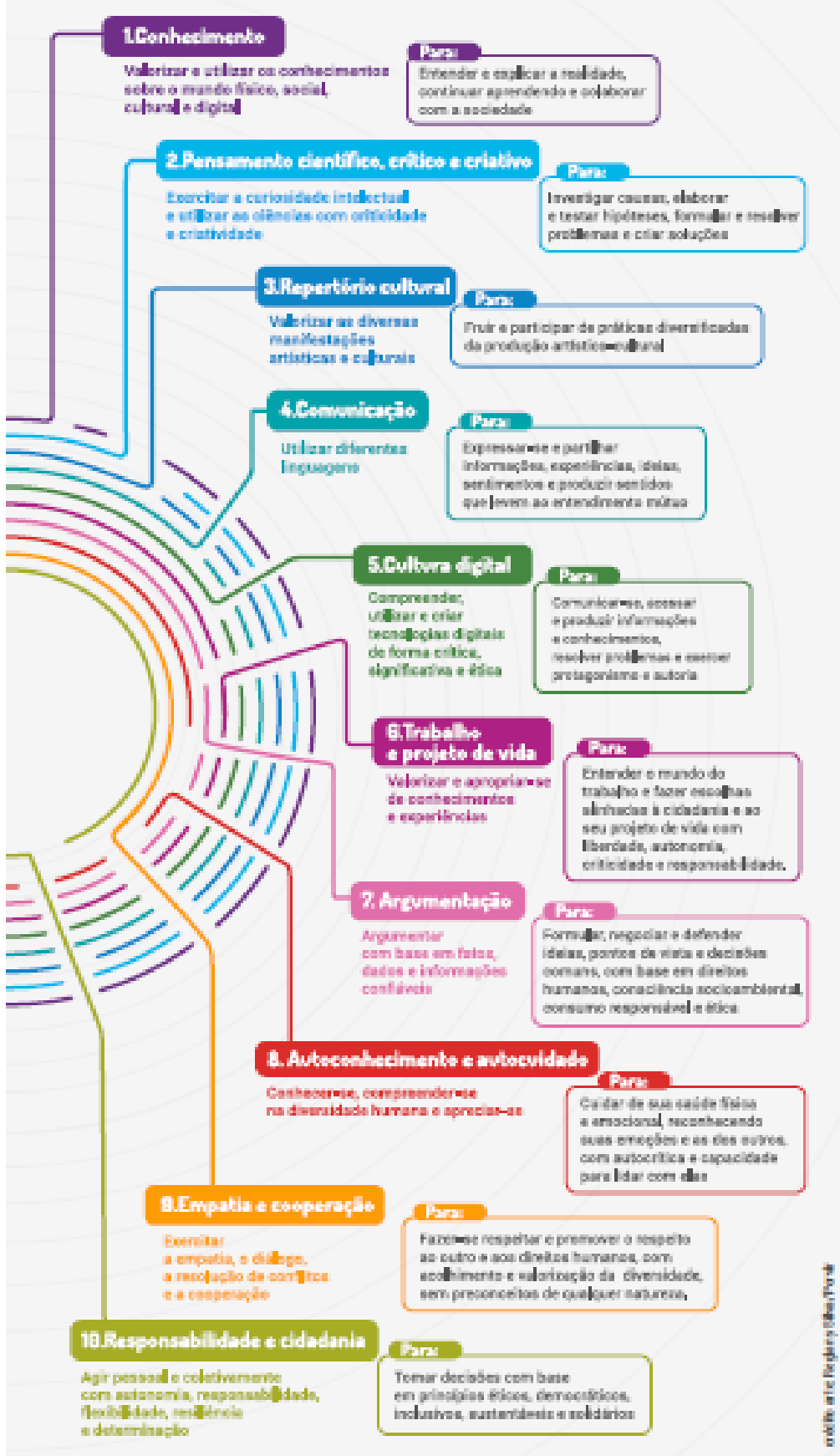

COM O PROPJSTO DE

Contr buir para a construçâa de uma sotiedade mais ética. democrabica. respoesabel inchusiva, subterkàvel esolidar a que respelte e proerwova a dversidade e 05 dreibos humanos, sem preconceìcos de qualover natureas. 
Anexo 9

Parecer Consubstanciado do CEP

\section{USP- INSTITUTO DE PSICOLOGIA DA UNIVERSIDADE DE SÃO}

\section{PARECER CONSUBSTANCIADO DO CEP}

\section{DADOS DO PROJETO DE PESQUISA}

Título da Pesquisa: QUEM QUER SER PROFESSOR? A ATRATIVIDADE, DA CARREIRA DOCENTE SOB A ÓTICA DE ALUNOS DO $3^{\circ}$ ANO DO ENSINO MÉDIO DE ESCOLAS PÚBLICAS ESTADUAIS DE MATO GROSSO DO SUL

Pesquisador: NELAGLEY MARQUES

Área Temática:

Versão: 1

CAAE: 98672718.4.0000.5561

Instituição Proponente:UNIVERSIDADE DE SAO PAULO

Patrocinador Principal: UNIVERSIDADE DE SAO PAULO

\section{DADOS DO PARECER}

Número do Parecer: 2.979 .706

Apresentaçäo do Projeto:

Trata-se de projeto de pesquisa em nivel de Doutorado apresentado ao Programa de Pós-Graduação em Estudos Linguísticos e Literários em Inglês da FFLCH-USP.

O estudo tem por objetivo, em sua fase inicial, a análise dos resultados de um questionário de pesquisa de domínio público aplicado pela Secretaria Estadual de Educação de Mato Grosso do Sul, em novembro de 2016, sobre a atratividade ou não da carreira docente sob a ótica dos alunos do $3^{\circ}$ ano do ensino médio de escolas públicas do Estado de MS. Do total de 22.800 alunos matriculados, o questionário foi respondido voluntariamente por 7.894 , de 77 municipios participantes.

Em sua fase final, o estudo pretende discutir e problematizar os principais resultados do questionário a partir da discussảo com um grupo de professores do ensino superior de universidades públicas, de professores em serviço do ensino médio de escolas públicas estaduais e técnicos da SEDMM.

\section{Objetivo da Pesquisa:}

Objetivo Primário

Investigar a percepçäo sobre ser professor em alunos concluintes do ensino médio no MS.

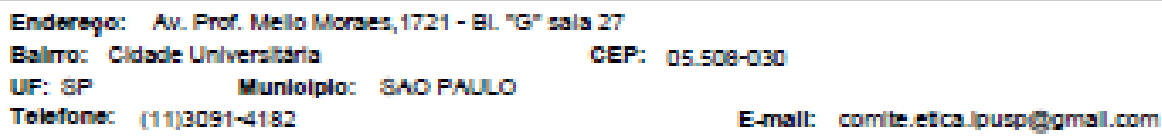




\section{USP- INSTITUTO DE PSICOLOGIA DA UNIVERSIDADE DE SÃO}

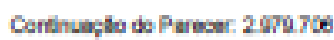

\section{Objetivo Secundário}

1.Identificar, a partir da análise do questionário de pesquisa aplicado pela SED/MS, os aspectos que os alunos destacam para justificar a atração ou não pela carreira docente

2.Analisar os dados do questionário de pesquisa aplicado pela SEDMS com a finalidade de traçar o perfil dos jovens que desejam optar pela carreira do docente

3.Discutir e problematizar os dados do questionário por meio de grupo de discussão composto por professores do ensino médio e do ensino superior de instituições públicas e técnicos da SED/MS.

\section{Avaliação dos Riscos e Beneficios:}

\section{Riscos}

De acordo com a pesquisadora, "o termo risco refere-se à possibilidade de ocorréncia de dano aos participantes"; portanto, "provavelmente näo haverá nenhum tipo de dano físico, psicológico, social ou económico aos participantes dessa pesquisa, dada a ausència de intencionalidade."

De acordo com a resoluçăo 468/12, toda pesquisa envolvendo seres humanos implica em riscos, ainda que mínimos. É importante relacioná-los e esclarecer as providências a serem tomadas em caso de dano material, físico ou psicológico.

\section{Beneficios}

De acordo com a pesquisadora, os benefícios săo os seguintes

- $O$ conhecimento gerado com a realizaçăo da pesquisa

- Valor atribuido aos possiveis resultados por participantes, comunidade, instituição de pesquisa e outros pesquisadores;

- Conhecimento procedente da pesquisa que poderá contribuir para o desenvolvimento de alternativas efetivas para intervençăo no futuro:

- De modo mais específico, os resultados dessa pesquisa constituirão uma importante fonte de informaçöes que podem ser utilizadas para a elaboração, monitoramento e avaliaçäo de políticas públicas tanto na Educaçäo Básica quanto no Ensino Superior.

\section{Comentários e Considerações sobre a Pesquisa:}

Serăo examinadas as respostas de um questionário de domínio público aplicado pela Secretaria Estadual de Educação do Mato Grosso do Sul, no mês de novembro de 2016, aos alunos do $3^{\circ}$ ano do Ensino Médio das escolas estaduais de 75 municipios do MS. As questöes indagam sobre: a quantidade de pessoas que vivem na casa; o grau de escolaridade do pai, măe ou responsável; a renda famīar, modalidade de ensino; o periodo que estuda na escola; se sempre estudou em

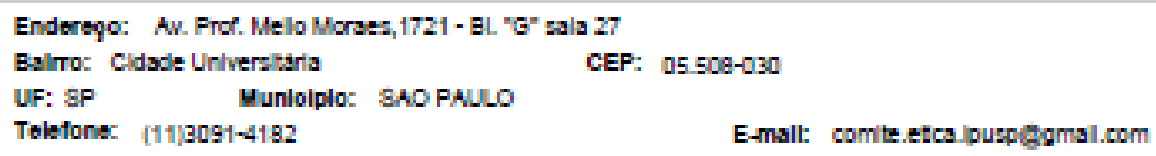




\section{USP- INSTITUTO DE PSICOLOGIA DA UNIVERSIDADE DE SÃO}

Centinuacto do Paracer. 2979700

escola pública; se trabalha; desde que idade trabaha; ao terminar o Ensino Médio pretende fazer o quê;; se está fazendo cursinho para o ENEM; em quais cursos pretende ingressar na Instituição de Ensino Superior. em quais Instituiçōes; se em algum momento pensou ser professor; de qual nivel de ensino; de qual disciplina; quais suas razöes para escolher (ou năo) ser professor, sexo; idade; raça.

O questionário foi aplicado proposto a 22.800 alunos de 211 unidades escolares, tendo sido respondido por 7.894 .

Na etapa final do processo, será realizado um grupo focal com professores em serviço de escolas públicas estaduais e universidade públicas, técnicos da SEDMMS, a fin de discutir e problematizar as respostas. 0 grupo será composto por 12 participantes.

Considerações sobre os Termos de apresentação obrigatória:

O TCLE encontra-se bem formulado e traz todas as informaçōes necessárias referentes à confidencialidade, aos riscos e aos objetivos da pesquisa.

Recomendaçōes:

Nä̊o há recomendaçöes.

Conclusōes ou Pendências e Lista de Inadequaçōes:

O projeto está aprovado.

Considerạ̧ões Finais a critério do CEP:

Este parecer foi elaborado baseado nos documentos abaixo relacionados:

\begin{tabular}{|c|c|c|c|c|}
\hline Tipo Documento & Arquivo & Postagem & Autor & Situaçǟo \\
\hline $\begin{array}{l}\text { Triormacoes Basicas } \\
\text { do Projeto }\end{array}$ & 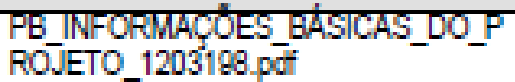 & $\begin{array}{c}27 / 02 / 2018 \\
12: 34: 33\end{array}$ & & Aceito \\
\hline Cronograma & CRONOGRAMA.POF' & $\begin{array}{c}27 / 08 / 2018 \\
12-33: 47\end{array}$ & $\begin{array}{l}\text { NELAGLEY } \\
\text { MARQUES }\end{array}$ & Aceito \\
\hline Outros & CARTASDEAIVUENCIA.PDF & $\begin{array}{c}27 / 08 / 2018 \\
12-19-09\end{array}$ & $\begin{array}{l}\text { NELAGLEY } \\
\text { MARQUES }\end{array}$ & Aceito \\
\hline $\begin{array}{l}\text { Dedaração de } \\
\text { Pesquisadores }\end{array}$ & PESQUISADOR.PDF & $\begin{array}{l}27 / 08 / 2018 \\
11: 57: 35\end{array}$ & $\begin{array}{l}\text { NELAGLEY } \\
\text { MARQUES }\end{array}$ & Aceito \\
\hline $\begin{array}{l}\text { Declaraçá de } \\
\text { Instituiçáo e } \\
\text { Infraestruturar }\end{array}$ & INFRAESTRUTURA.PDF & $\begin{array}{c}27 / 08 / 2018 \\
11: 56: 25\end{array}$ & $\begin{array}{l}\text { NELAGLEY } \\
\text { MARQUES }\end{array}$ & Aceito \\
\hline Folha de Rosto & FOLHADEROSTOALTERADA_PDF & $\begin{array}{c}27 / 08 / 2018 \\
11-54: 04\end{array}$ & $\begin{array}{l}\text { NELAGLEY } \\
\text { MARQUES }\end{array}$ & Aceito \\
\hline
\end{tabular}

Enderspe: AV. Prof. Melo Morses, 1721 - El. "G" sals 27

Balmo: Cidade Unlverataria

CEP: $05.509-030$

UF: $s P$

Munloiplo: SAO RAULO

Tolefone: (11)3091-41B2

E-mall: comite.etca.pusp(bamal.com 


\section{USP- INSTITUTO DE \\ PSICOLOGIA DA UNIVERSIDADE DE SÃO}

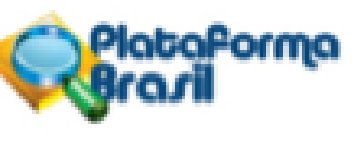

Centinuacto de Parecer. 297970

\begin{tabular}{|l|l|c|l|l|}
\hline $\begin{array}{l}\text { Projeto Detalhado / } \\
\text { Brochura } \\
\text { Investigador }\end{array}$ & Projeto.pdf & $\begin{array}{c}24 / 08 / 2018 \\
16: 4248\end{array}$ & $\begin{array}{l}\text { NELAGLEY } \\
\text { MARQUES }\end{array}$ & Aceito \\
\hline $\begin{array}{l}\text { TCLE/Temos de } \\
\text { Assentmento / } \\
\text { Justificativa de } \\
\text { Ausencia }\end{array}$ & TCLE poff & $24 / 08 / 2018$ & NELAGLEY & Aceito \\
\hline
\end{tabular}

Situação do Parecer:

Aprovado

Necessita Apreciação da CONEP:

Nă้

SAO PAULO, 24 de Outubro de 2018

Assinado por:

Jose de Oliveira Siqueira

(Coordenador(a))

Endereqge: Av. Prof. Melo Morses, 1721 - EL. "G" sals 27

Balro: Cldade Univerataria

CEP: $05.500-030$

UF: SP MUnloiplo: SAOPAULO

Telefone: (11)3091-4182

E-mall: comite.etca.puspegrmal.com 


\section{Anexo 10}

Tabela de Cursos de Graduação da UFMS

\begin{tabular}{|c|c|c|}
\hline Código & Curso & Turno \\
\hline \multicolumn{2}{|c|}{ CÂMPUS DE AQUIDAUANA } & 13 cursos \\
\hline 450 & ADMINISTRAÇÃO - BACHARELADO & Noturno \\
\hline 446 & CIÊNCIAS BIOLÓGICAS - LICENCIATURA & Noturno \\
\hline 451 & GEOGRAFIA - BACHARELADO & Vespertino \\
\hline 443 & GEOGRAFIA - LICENCIATURA & Noturno \\
\hline 439 & HISTÓRIA - LICENCIATURA & Noturno \\
\hline 413 & $\begin{array}{l}\text { LETRAS - LICENCIATURA - HABILITAÇÃO } \\
\text { EM PORTUGUÊS E ESPANHOL }\end{array}$ & Noturno \\
\hline 432 & $\begin{array}{l}\text { LETRAS - LICENCIATURA - HABILITAÇÃO } \\
\text { EM PORTUGUÊS E INGLÊS }\end{array}$ & Noturno \\
\hline 441 & $\begin{array}{l}\text { LETRAS - LICENCIATURA - HABILITAÇÃO } \\
\text { EM PORTUGUÊS E LITERATURA }\end{array}$ & Noturno \\
\hline 465 & $\begin{array}{l}\text { LICENCIATURA } \\
\text { INDÍGENA }\end{array}$ & Integral \\
\hline 447 & MATEMÁTICA - LICENCIATURA & Vespertino \\
\hline 457 & PEDAGOGIA - LICENCIATURA & Vespertino \\
\hline 448 & TURISMO - BACHARELADO & Matutino \\
\hline 464 & TURISMO - BACHARELADO & Vespertino \\
\hline CÂMPUৎ & DÃO DO SUL & 3 cursos \\
\hline 1304 & ADMINISTRAÇÃO - BACHARELADO & Noturno \\
\hline 1303 & AGRONOMIA - BACHARELADO & $\begin{array}{l}\text { Integral (Matutino e } \\
\text { Vespertino) }\end{array}$ \\
\hline 1302 & $\begin{array}{ll}\text { ENGENHARIA } & \text { FLORESTAL } \\
\text { BACHARELADO } & \end{array}$ & $\begin{array}{l}\text { Integral (Matutino } \quad \mathrm{e} \\
\text { Vespertino) }\end{array}$ \\
\hline
\end{tabular}




\begin{tabular}{|c|c|c|}
\hline \multicolumn{2}{|l|}{ CÂMPUS DE COXIM } & 4 cursos \\
\hline 804 & ENFERMAGEM - BACHARELADO & $\begin{array}{l}\text { Integral (Matutino e } \\
\text { Vespertino) }\end{array}$ \\
\hline 801 & HISTÓRIA - LICENCIATURA & Noturno \\
\hline 805 & LETRAS - PORTUGUÊS - LICENCIATURA & Noturno \\
\hline 803 & $\begin{array}{l}\text { SISTEMAS DE INFORMAÇÃO } \\
\text { BACHARELADO }\end{array}$ & Noturno \\
\hline CÂMPUS DE NAVIR/ & & 3 cursos \\
\hline 1703 & ADMINISTRAÇÃO - BACHARELADO & Noturno \\
\hline 1701 & CIÊNCIAS SOCIAIS - LICENCIATURA & Noturno \\
\hline 1702 & PEDAGOGIA - LICENCIATURA & Noturno \\
\hline CÂMPUS DE NOVA & ANDRADINA & 5 cursos \\
\hline 1405 & ADMINISTRAÇÃO - BACHARELADO & Noturno \\
\hline 1407 & CIÊNCIAS CONTÁBEIS - BACHARELADO & Noturno \\
\hline 1406 & $\begin{array}{l}\text { CURSO SUPERIOR DE TECNOLOGIA EM } \\
\text { GESTÃO FINANCEIRA }\end{array}$ & Noturno \\
\hline 1408 & ENGENHARIA DE PRODUÇÃO & Integral \\
\hline 1404 & $\begin{array}{l}\text { HISTÓRIA } \\
\text { LICENCIATURA }\end{array}$ & Noturno \\
\hline & CÂMPUS DE PARANAÍBA & 3 cursos \\
\hline 901 & $\begin{array}{l}\text { ADMINISTRAÇÃO } \\
\text { BACHARELADO }\end{array}$ & Noturno \\
\hline 904 & $\begin{array}{l}\text { MATEMÁTICA } \\
\text { LICENCIATURA }\end{array}$ & Noturno \\
\hline 903 & $\begin{array}{l}\text { PSICOLOGIA } \\
\text { BACHARELADO }\end{array}$ & $\begin{array}{l}\text { Integral } \\
\text { (Vespertino } \\
\text { e Noturno) }\end{array}$ \\
\hline & CÂMPUS DE PONTA PORÃ & 6 cursos \\
\hline 1804 & $\begin{array}{l}\text { CIÊNCIA } \\
\text { COMPUTAÇÃO } \\
\text { BACHARELADO }\end{array}$ & $\begin{array}{l}\text { Integral } \\
\text { (Matutino e } \\
\text { Vespertino) }\end{array}$ \\
\hline 1805 & $\begin{array}{lr}\text { CIÊNCIA } & \text { DA } \\
\text { COMPUTAÇÃO } & - \\
\text { BACHARELADO } & \end{array}$ & $\begin{array}{l}\text { Integral } \\
\text { (Vespertino } \\
\text { e Noturno) }\end{array}$ \\
\hline 1801 & $\begin{array}{l}\text { MATEMÁTICA } \\
\text { LICENCIATURA }\end{array}$ & Noturno \\
\hline 1803 & PEDAGOGIA & Vespertino \\
\hline
\end{tabular}




\begin{tabular}{|c|c|c|}
\hline & LICENCIATURA & \\
\hline \multirow[t]{2}{*}{1829} & PEDAGOGIA & \multirow[t]{2}{*}{ Noturno } \\
\hline & LICENCIATURA & \\
\hline \multirow[t]{3}{*}{1802} & SISTEMAS & \multirow[t]{3}{*}{ Noturno } \\
\hline & INFORMAÇÃO & \\
\hline & BACHARELADO & \\
\hline \multicolumn{2}{|c|}{ CÂMPUS DE TRÊS LAGOAS } & 20 cursos \\
\hline \multirow[t]{2}{*}{793} & \multirow{2}{*}{$\begin{array}{l}\text { ADMINISTRAÇÃO } \\
\text { BACHARELADO }\end{array}$} & \multirow[t]{2}{*}{ Noturno } \\
\hline & & \\
\hline \multirow[t]{3}{*}{788} & \multirow{3}{*}{$\begin{array}{l}\text { CIÉNCIAS BIOLÓGICAS - } \\
\text { LICENCIATURA }\end{array}$} & Integral \\
\hline & & (Matutino e \\
\hline & & Vespertino) \\
\hline \multirow[t]{2}{*}{795} & \multirow{2}{*}{$\begin{array}{l}\text { CIÊNCIAS CONTÁBEIS - } \\
\text { BACHARELADO }\end{array}$} & \multirow[t]{2}{*}{ Noturno } \\
\hline & & \\
\hline \multirow[t]{3}{*}{739} & \multirow[t]{3}{*}{ DIREITO - BACHARELADO } & Integral \\
\hline & & (Matutino e \\
\hline & & Vespertino) \\
\hline 781 & DIREITO - BACHARELADO & Noturno \\
\hline \multirow[t]{3}{*}{798} & \multirow{3}{*}{$\begin{array}{l}\text { ENFERMAGEM } \\
\text { BACHARELADO }\end{array}$} & Integral \\
\hline & & (Matutino e \\
\hline & & Vespertino) \\
\hline \multirow[t]{3}{*}{799} & ENGENHARIA & Integral \\
\hline & PRODUÇÃO & (Matutino e \\
\hline & BACHARELADO & Vespertino) \\
\hline \multirow[t]{2}{*}{701} & GEOGRAFIA & \multirow[t]{2}{*}{ Noturno } \\
\hline & BACHARELADO & \\
\hline \multirow[t]{3}{*}{780} & \multirow{3}{*}{$\begin{array}{l}\text { GEOGRAFIA } \\
\text { BACHARELADO }\end{array}$} & \multirow{3}{*}{$\begin{array}{l}\text { Integral } \\
\text { (Matutino e } \\
\text { Vespertino) }\end{array}$} \\
\hline & & \\
\hline & & \\
\hline \multirow[t]{2}{*}{796} & GEOGRAFIA & \multirow[t]{2}{*}{ Noturno } \\
\hline & LICENCIATURA & \\
\hline \multirow[t]{2}{*}{783} & HISTÓRIA & \multirow[t]{2}{*}{ Noturno } \\
\hline & LICENCIATURA & \\
\hline 742 & LETRAS - LICENCIATURA - & Noturno \\
\hline & HABILITAÇÃO EM & \\
\hline & PORTUGUÊS & \\
\hline & ESPANHOL & \\
\hline
\end{tabular}




\begin{tabular}{|c|c|c|}
\hline \multirow[t]{3}{*}{784} & LETRAS - LICENCIATURA - & \multirow[t]{3}{*}{ Noturno } \\
\hline & HABILITAÇÃO EM & \\
\hline & PORTUGUÊS E INGLÊS & \\
\hline \multirow[t]{3}{*}{722} & LETRAS - LICENCIATURA - & \multirow[t]{3}{*}{ Noturno } \\
\hline & HABILITAÇÃO EM & \\
\hline & PORTUGUÊS/ESPANHOL & \\
\hline \multirow[t]{3}{*}{745} & LETRAS - LICENCIATURA - & \multirow[t]{3}{*}{ Noturno } \\
\hline & HABILITAÇÃO EM & \\
\hline & PORTUGUÊS/INGLÊS & \\
\hline \multirow[t]{3}{*}{740} & LETRAS - LICENCIATURA - & \multirow[t]{3}{*}{ Noturno } \\
\hline & HABILITAÇÃO EM & \\
\hline & PORTUGUÊS/LITERATURA & \\
\hline \multirow[t]{2}{*}{789} & MATEMÁTICA & \multirow[t]{2}{*}{ Noturno } \\
\hline & LICENCIATURA & \\
\hline \multirow[t]{4}{*}{744} & MEDICINA & \multirow{4}{*}{$\begin{array}{l}\text { Integral } \\
\text { (Matutino, } \\
\text { Vespertino } \\
\text { e Noturno) }\end{array}$} \\
\hline & BACHARELADO & \\
\hline & & \\
\hline & & \\
\hline \multirow[t]{2}{*}{728} & PEDAGOGIA & \multirow[t]{2}{*}{ Noturno } \\
\hline & LICENCIATURA & \\
\hline \multirow[t]{3}{*}{743} & SISTEMAS & \multirow[t]{3}{*}{ Noturno } \\
\hline & INFORMAÇÃO & \\
\hline & BACHARELADO & \\
\hline & DO PANTANAL & 14 cursos \\
\hline \multirow[t]{2}{*}{547} & ADMINISTRAÇÃO & \multirow[t]{2}{*}{ Noturno } \\
\hline & BACHARELADO & \\
\hline \multirow[t]{2}{*}{552} & CIÊNCIAS BIOLÓGICAS - & \multirow[t]{2}{*}{ Vespertino } \\
\hline & LICENCIATURA & \\
\hline \multirow[t]{2}{*}{548} & CIÊNCIAS CONTÁBEIS - & \multirow[t]{2}{*}{ Noturno } \\
\hline & BACHARELADO & \\
\hline 541 & DIREITO - BACHARELADO & Noturno \\
\hline \multirow[t]{3}{*}{569} & EDUCAÇÃO FÍSICA & \multirow{3}{*}{$\begin{array}{l}\text { Integral } \\
\text { (Matutino e } \\
\text { Vespertino) }\end{array}$} \\
\hline & LICENCIATURA & \\
\hline & & \\
\hline \multirow[t]{2}{*}{549} & GEOGRAFIA & \multirow[t]{2}{*}{ Noturno } \\
\hline & LICENCIATURA & \\
\hline \multirow[t]{2}{*}{550} & HISTÓRIA & \multirow[t]{2}{*}{ Noturno } \\
\hline & LICENCIATURA & \\
\hline
\end{tabular}




\begin{tabular}{|c|c|c|}
\hline \multirow[t]{4}{*}{513} & LETRAS - LICENCIATURA - & \multirow[t]{4}{*}{ Matutino } \\
\hline & HABILITAÇÃO EM & \\
\hline & PORTUGUÊS E & \\
\hline & ESPANHOL & \\
\hline \multirow[t]{3}{*}{525} & LETRAS - LICENCIATURA - & \multirow[t]{3}{*}{ Noturno } \\
\hline & HABILITAÇÃO EM & \\
\hline & PORTUGUÊS E INGLÊS & \\
\hline \multirow[t]{3}{*}{553} & MATEMÁTICA & Integral \\
\hline & LICENCIATURA & (Vespertino \\
\hline & & e Noturno) \\
\hline \multirow[t]{3}{*}{568} & PEDAGOGIA & Integral \\
\hline & LICENCIATURA & (Vespertino \\
\hline & & e Noturno) \\
\hline \multirow{3}{*}{562} & PSICOLOGIA & Integral \\
\hline & BACHARELADO & (Matutino e \\
\hline & & Vespertino) \\
\hline \multirow[t]{3}{*}{570} & SISTEMAS & Integral \\
\hline & INFORMAÇÃO & (Matutino e \\
\hline & BACHARELADO & Vespertino) \\
\hline \multirow[t]{3}{*}{571} & SISTEMAS & Noturno \\
\hline & INFORMAÇÃO & \\
\hline & BACHARELADO & \\
\hline \multicolumn{2}{|c|}{ ESCOLA DE ADMINISTRAÇÃO E NEGÓCIOS } & 7 cursos \\
\hline \multirow[t]{3}{*}{2501} & \multirow{3}{*}{$\begin{array}{l}\text { ADMINISTRAÇÃO } \\
\text { BACHARELADO }\end{array}$} & Integral \\
\hline & & (Matutino e \\
\hline & & Vespertino) \\
\hline \multirow[t]{2}{*}{2502} & \multirow{2}{*}{$\begin{array}{l}\text { ADMINISTRAÇÃO } \\
\text { BACHARELADO }\end{array}$} & Noturno \\
\hline & & \\
\hline \multirow[t]{2}{*}{2591} & ADMINISTRAÇÃO & $(\mathrm{EAD})$ \\
\hline & PÚBLICA - BACHARELADO & \\
\hline \multirow[t]{2}{*}{2504} & \multirow{2}{*}{$\begin{array}{l}\text { CIÊNCIAS CONTÁBEIS - } \\
\text { BACHARELADO }\end{array}$} & Noturno \\
\hline & & \\
\hline \multirow[t]{3}{*}{2506} & \multirow{3}{*}{$\begin{array}{l}\text { CIÊNCIAS ECONÔMICAS - } \\
\text { BACHARELADO }\end{array}$} & Integral \\
\hline & & (Matutino e \\
\hline & & Vespertino) \\
\hline \multirow[t]{3}{*}{2505} & CURSO SUPERIOR EM & \multirow[t]{3}{*}{ Noturno } \\
\hline & TECNOLOGIA EM & \\
\hline & PROCESSOS GERENCIAIS & \\
\hline
\end{tabular}




\begin{tabular}{|c|c|c|}
\hline 2503 & $\begin{array}{l}\text { TURISMO } \\
\text { BACHARELADO }\end{array}$ & Matutino \\
\hline & $\begin{array}{l}\text { FACULDADE DE ARTES, LETRAS E } \\
\text { COMUNICAÇÃO }\end{array}$ & 13 cursos \\
\hline 2904 & $\begin{array}{l}\text { ARTES VISUAIS - } \\
\text { BACHARELADO } \\
\text { HABILITAÇÃO EM ARTES } \\
\text { PLÁSTICAS }\end{array}$ & $\begin{array}{l}\text { Integral } \\
\text { (Matutino e } \\
\text { Vespertino) }\end{array}$ \\
\hline 2901 & $\begin{array}{l}\text { ARTES VISUAIS - } \\
\text { LICENCIATURA } \\
\text { HABILITAÇÃO EM ARTES } \\
\text { PLÁSTICAS }\end{array}$ & $\begin{array}{l}\text { Integral } \\
\text { (Matutino e } \\
\text { Vespertino) }\end{array}$ \\
\hline 2911 & $\begin{array}{l}\text { AUDIOVISUAL } \\
\text { BACHARELADO }\end{array}$ & Integral \\
\hline 2903 & $\begin{array}{lr}\text { COMUNICAÇÃO } & \text { SOCIAL } \\
\text { BACHARELADO } & - \\
\text { HABILITAÇÃO } & \text { EM } \\
\text { JORNALISMO } & \end{array}$ & $\begin{array}{l}\text { Integral } \\
\text { (Vespertino } \\
\text { e Noturno) }\end{array}$ \\
\hline 2907 & $\begin{array}{l}\text { JORNALISMO } \\
\text { BACHARELADO }\end{array}$ & $\begin{array}{l}\text { Integral } \\
\text { (Matutino e } \\
\text { Vespertino) }\end{array}$ \\
\hline 2905 & $\begin{array}{lr}\text { LETRAS - LICENCIATURA - } \\
\text { HABILITAÇÃO } \\
\text { PORTUGUÊS } \\
\text { ESPANHOL }\end{array}$ & $\begin{array}{l}\text { Integral } \\
\text { (Matutino e } \\
\text { Vespertino) }\end{array}$ \\
\hline 2991 & $\begin{array}{lr}\text { LETRAS - LICENCIATURA - } \\
\text { HABILITAÇÃO } \\
\text { PORTUGUÊS } \\
\text { ESPANHOL }\end{array}$ & (EAD) \\
\hline 2902 & $\begin{array}{l}\text { LETRAS - LICENCIATURA - } \\
\text { HABILITAÇÃO EM } \\
\text { PORTUGUÊS E INGLÊS }\end{array}$ & $\begin{array}{l}\text { Integral } \\
\text { (Matutino e } \\
\text { Vespertino) }\end{array}$ \\
\hline 2909 & $\begin{array}{l}\text { LETRAS - LICENCIATURA - } \\
\text { HABILITAÇÃO EM } \\
\text { PORTUGUÊS E INGLÊS }\end{array}$ & $\begin{array}{l}\text { Integral } \\
\text { (Matutino e } \\
\text { Vespertino) }\end{array}$ \\
\hline 2908 & $\begin{array}{l}\text { LETRAS - LICENCIATURA - } \\
\text { HABILITAÇÃO EM } \\
\text { PORTUGUÊS/ESPANHOL }\end{array}$ & $\begin{array}{l}\text { Integral } \\
\text { (Matutino e } \\
\text { Vespertino) }\end{array}$ \\
\hline
\end{tabular}




\begin{tabular}{|c|c|c|}
\hline \multirow[t]{3}{*}{2912} & LETRAS - LICENCIATURA - & \multirow[t]{3}{*}{ Matutino } \\
\hline & HABILITAÇÃO EM & \\
\hline & PORTUGUÊS/ESPANHOL & \\
\hline \multirow[t]{3}{*}{2913} & LETRAS - LICENCIATURA - & \multirow[t]{3}{*}{ Matutino } \\
\hline & HABILITAÇÃO EM & \\
\hline & PORTUGUÊS/INGLÊS & \\
\hline \multirow[t]{3}{*}{2906} & MÚSICA - LICENCIATURA - & \multirow[t]{3}{*}{ Noturno } \\
\hline & HABILITAÇÃO EM & \\
\hline & EDUCAÇÃO MUSICAL & \\
\hline \multicolumn{2}{|c|}{$\begin{array}{l}\text { FACULDADE DE CIÊNCIAS FARMACÊUTICAS, } \\
\text { ALIMENTOS E NUTRIÇÃO }\end{array}$} & 4 cursos \\
\hline \multirow[t]{3}{*}{2603} & CURSO SUPERIOR DE & \multirow[t]{3}{*}{ Noturno } \\
\hline & TECNOLOGIA & \\
\hline & ALIMENTOS & \\
\hline \multirow[t]{3}{*}{2604} & ENGENHARIA & Integral \\
\hline & ALIMENTOS & (Matutino e \\
\hline & BACHARELADO & Vespertino) \\
\hline \multirow[t]{3}{*}{2601} & FARMÁCIA & Integral \\
\hline & BACHARELADO & (Matutino e \\
\hline & & Vespertino) \\
\hline \multirow[t]{3}{*}{2602} & \multirow{3}{*}{$\begin{array}{l}\text { NUTRIÇÃO } \\
\text { BACHARELADO }\end{array}$} & Integral \\
\hline & & (Matutino e \\
\hline & & Vespertino) \\
\hline \multicolumn{2}{|c|}{ FACULDADE DE CIÊNCIAS HUMANAS } & 5 cursos \\
\hline \multirow{3}{*}{3001} & \multirow{3}{*}{$\begin{array}{l}\text { CIÊNCIAS SOCIAIS }- \\
\text { BACHARELADO }\end{array}$} & Integral \\
\hline & & (Matutino e \\
\hline & & Vespertino) \\
\hline \multirow[t]{2}{*}{3005} & CIÉNCIAS SOCIAIS & \multirow[t]{2}{*}{ Matutino } \\
\hline & BACHARELADO & \\
\hline \multirow[t]{2}{*}{3004} & FILOSOFIA & \multirow[t]{2}{*}{ Noturno } \\
\hline & LICENCIATURA & \\
\hline \multirow[t]{2}{*}{3002} & HISTÓRIA & \multirow[t]{2}{*}{ Noturno } \\
\hline & LICENCIATURA & \\
\hline \multirow[t]{3}{*}{3003} & PSICOLOGIA & \multirow{3}{*}{$\begin{array}{l}\text { Integral } \\
\text { (Matutino e } \\
\text { Vespertino) }\end{array}$} \\
\hline & BACHARELADO & \\
\hline & & \\
\hline & E DE COMPUTAÇÃO & 6 cursos \\
\hline
\end{tabular}




\begin{tabular}{|c|c|c|}
\hline 1904 & $\begin{array}{lr}\text { CIÊNCIA } & \text { DA } \\
\text { COMPUTAÇÃO } & - \\
\text { BACHARELADO } & \end{array}$ & $\begin{array}{l}\text { Integral } \\
\text { (Matutino e } \\
\text { Vespertino) }\end{array}$ \\
\hline 1902 & $\begin{array}{lr}\text { CURSO SUPERIOR } & \text { DE } \\
\text { TECNOLOGIA } & \text { EM } \\
\text { ANÁLISE } & \text { E } \\
\text { DESENVOLVIMENTO } & \text { DE } \\
\text { SISTEMAS } & \end{array}$ & Noturno \\
\hline 1901 & $\begin{array}{l}\text { CURSO SUPERIOR DE } \\
\text { TECNOLOGIA EM REDES } \\
\text { DE COMPUTADORES }\end{array}$ & Noturno \\
\hline 1905 & $\begin{array}{lr}\text { ENGENHARIA } & \text { DE } \\
\text { COMPUTAÇÃO } & - \\
\text { BACHARELADO } & \end{array}$ & $\begin{array}{l}\text { Integral } \\
\text { (Matutino e } \\
\text { Vespertino) }\end{array}$ \\
\hline 1906 & $\begin{array}{lr}\text { ENGENHARIA } & \text { DE } \\
\text { SOFTWARE } & - \\
\text { BACHARELADO } & \end{array}$ & $\begin{array}{l}\text { Integral } \\
\text { (Vespertino } \\
\text { e Noturno) }\end{array}$ \\
\hline 1907 & $\begin{array}{lr}\text { SISTEMAS } & \text { DE } \\
\text { INFORMAÇÃO } & - \\
\text { BACHARELADO } & \end{array}$ & Noturno \\
\hline & ADE DE DIREITO & 2 cursos \\
\hline 2001 & DIREITO - BACHARELADO & $\begin{array}{l}\text { Integral } \\
\text { (Matutino e } \\
\text { Vespertino) }\end{array}$ \\
\hline 2002 & DIREITO - BACHARELADO & Noturno \\
\hline & JE DE EDUCAÇÃO & 10 cursos \\
\hline 3108 & $\begin{array}{l}\text { EDUCAÇÃO DO CAMPO - } \\
\text { LICENCIATURA }\end{array}$ & Integral \\
\hline 3104 & $\begin{array}{lr}\text { EDUCAÇÃO DO } & \text { CAMPO } \\
\text { LICENCIATURA } & - \\
\text { HABILITAÇÃO } & \text { EM } \\
\text { CIÊNCIAS HUMANAS } & \text { E } \\
\text { SOCIAIS } & \end{array}$ & Integral \\
\hline 3105 & $\begin{array}{l}\text { EDUCAÇÃO DO CAMPO - } \\
\text { LICENCIATURA } \\
\text { HABILITAÇÃO } \\
\text { LINGUAGENS E CÓDIGOS }\end{array}$ & Integral \\
\hline
\end{tabular}




\begin{tabular}{|c|c|c|}
\hline 3106 & $\begin{array}{l}\text { EDUCAÇÃO DO CAMPO - } \\
\text { LICENCIATURA } \\
\text { HABILITAÇÃO } \\
\text { MATEMÁTICA }\end{array}$ & Integral \\
\hline 3107 & $\begin{array}{l}\text { EDUCAÇÃO FÍSICA - } \\
\text { BACHARELADO }\end{array}$ & Integral \\
\hline 3102 & $\begin{array}{l}\text { EDUCAÇÃO FÍSICA } \\
\text { LICENCIATURA }\end{array}$ & $\begin{array}{l}\text { Integral } \\
\text { (Matutino e } \\
\text { Vespertino) }\end{array}$ \\
\hline 3192 & $\begin{array}{l}\text { EDUCAÇÃO FÍSICA - } \\
\text { LICENCIATURA }\end{array}$ & (EAD) \\
\hline 3101 & $\begin{array}{l}\text { PEDAGOGIA } \\
\text { LICENCIATURA }\end{array}$ & $\begin{array}{l}\text { Integral } \\
\text { (Matutino e } \\
\text { Vespertino) }\end{array}$ \\
\hline 3103 & $\begin{array}{l}\text { PEDAGOGIA } \\
\text { LICENCIATURA }\end{array}$ & Noturno \\
\hline 3191 & $\begin{array}{l}\text { PEDAGOGIA } \\
\text { LICENCIATURA }\end{array}$ & (EAD) \\
\hline ARQ & $\begin{array}{l}\text { DE ENGENHARIAS, } \\
\text { IRBANISMO E GEOGRAFIA }\end{array}$ & 10 cursos \\
\hline 2101 & $\begin{array}{l}\text { ARQUITETURA } \\
\text { URBANISMO } \\
\text { BACHARELADO }\end{array}$ & $\begin{array}{l}\text { Integral } \\
\text { (Matutino e } \\
\text { Vespertino) }\end{array}$ \\
\hline 2107 & $\begin{array}{ll}\text { CURSO SUPERIOR } & \text { DE } \\
\text { TECNOLOGIA } & \text { EM } \\
\text { CONSTRUÇÃO } & \text { DE } \\
\text { EDIFÍCIOS } & \end{array}$ & Noturno \\
\hline 2105 & $\begin{array}{ll}\text { CURSO SUPERIOR } & \text { DE } \\
\text { TECNOLOGIA } & \text { EM } \\
\text { ELETROTÉCNICA } & \\
\text { INDUSTRIAL } & \end{array}$ & Noturno \\
\hline 2108 & $\begin{array}{ll}\text { CURSO SUPERIOR } & \text { DE } \\
\text { TECNOLOGIA } & \text { EM } \\
\text { SANEAMENTO } & \\
\text { AMBIENTAL } & \end{array}$ & Noturno \\
\hline 2104 & $\begin{array}{l}\text { ENGENHARIA AMBIENTAL } \\
\text { - BACHARELADO }\end{array}$ & $\begin{array}{l}\text { Integral } \\
\text { (Vespertino } \\
\text { e Noturno) }\end{array}$ \\
\hline
\end{tabular}




\begin{tabular}{|c|c|c|}
\hline 2102 & $\begin{array}{l}\text { ENGENHARIA CIVIL } \\
\text { BACHARELADO }\end{array}$ & $\begin{array}{l}\text { Integral } \\
\text { (Matutino e } \\
\text { Vespertino) }\end{array}$ \\
\hline 2111 & $\begin{array}{lll}\text { ENGENHARIA } & \text { CIVIL } & - \\
\text { BACHARELADO } & & \end{array}$ & $\begin{array}{l}\text { Integral } \\
\text { (Vespertino } \\
\text { e Noturno) }\end{array}$ \\
\hline 2106 & $\begin{array}{lr}\text { ENGENHARIA } & \text { DE } \\
\text { PRODUÇÃO } & - \\
\text { BACHARELADO } & \end{array}$ & $\begin{array}{l}\text { Integral } \\
\text { (Vespertino } \\
\text { e Noturno) }\end{array}$ \\
\hline 2103 & $\begin{array}{l}\text { ENGENHARIA ELÉTRICA - } \\
\text { BACHARELADO }\end{array}$ & $\begin{array}{l}\text { Integral } \\
\text { (Matutino e } \\
\text { Vespertino) }\end{array}$ \\
\hline 2109 & $\begin{array}{l}\text { GEOGRAFIA } \\
\text { BACHARELADO }\end{array}$ & Noturno \\
\hline & DE DE MEDICINA & 1 curso \\
\hline 1002 & $\begin{array}{l}\text { MEDICINA } \\
\text { BACHARELADO }\end{array}$ & $\begin{array}{l}\text { Integral } \\
\text { (Matutino, } \\
\text { Vespertino } \\
\text { e Noturno) }\end{array}$ \\
\hline \multicolumn{2}{|c|}{$\begin{array}{l}\text { FACULDADE DE MEDICINA VETERINÁRIA E } \\
\text { ZOOTECNIA }\end{array}$} & 2 cursos \\
\hline 1201 & $\begin{array}{l}\text { MEDICINA VETERINÁRIA - } \\
\text { BACHARELADO }\end{array}$ & $\begin{array}{l}\text { Integral } \\
\text { (Matutino e } \\
\text { Vespertino) }\end{array}$ \\
\hline 1203 & $\begin{array}{l}\text { ZOOTECNIA } \\
\text { BACHARELADO }\end{array}$ & $\begin{array}{l}\text { Integral } \\
\text { (Matutino e } \\
\text { Vespertino) }\end{array}$ \\
\hline & DE ODONTOLOGIA & 2 cursos \\
\hline 1101 & $\begin{array}{l}\text { ODONTOLOGIA } \\
\text { BACHARELADO }\end{array}$ & $\begin{array}{l}\text { Integral } \\
\text { (Matutino e } \\
\text { Vespertino) }\end{array}$ \\
\hline 1102 & $\begin{array}{l}\text { ODONTOLOGIA } \\
\text { BACHARELADO }\end{array}$ & $\begin{array}{l}\text { Integral } \\
\text { (Matutino e } \\
\text { Vespertino) }\end{array}$ \\
\hline & DE BIOCIÊNCIAS & 3 cursos \\
\hline 2701 & $\begin{array}{l}\text { CIÊNCIAS BIOLÓGICAS - } \\
\text { BACHARELADO }\end{array}$ & $\begin{array}{l}\text { Integral } \\
\text { (Matutino e } \\
\text { Vespertino) }\end{array}$ \\
\hline
\end{tabular}




\begin{tabular}{|c|c|c|}
\hline 2703 & $\begin{array}{l}\text { CIÊNCIAS BIOLÓGICAS - } \\
\text { LICENCIATURA }\end{array}$ & Noturno \\
\hline 2791 & $\begin{array}{l}\text { CIÊNCIAS BIOLÓGICAS - } \\
\text { LICENCIATURA }\end{array}$ & (EAD) \\
\hline \multicolumn{2}{|r|}{ INSTITUTO DE FÍSICA } & 4 cursos \\
\hline 2406 & ENGENHARIA FÍSICA & Integral \\
\hline 2402 & FÍSICA - BACHARELADO & $\begin{array}{l}\text { Integral } \\
\text { (Matutino e } \\
\text { Vespertino) }\end{array}$ \\
\hline 2401 & FÍSICA - LICENCIATURA & $\begin{array}{l}\text { Integral } \\
\text { (Matutino e } \\
\text { Vespertino) }\end{array}$ \\
\hline 2403 & FÍSICA - LICENCIATURA & Noturno \\
\hline \multicolumn{2}{|r|}{ INSTITUTO DE MATEMÁTICA } & 3 cursos \\
\hline 2201 & $\begin{array}{l}\text { MATEMÁTICA } \\
\text { LICENCIATURA }\end{array}$ & $\begin{array}{l}\text { Integral } \\
\text { (Matutino e } \\
\text { Vespertino) }\end{array}$ \\
\hline 2202 & $\begin{array}{l}\text { MATEMÁTICA } \\
\text { LICENCIATURA }\end{array}$ & Noturno \\
\hline 2291 & $\begin{array}{l}\text { MATEMÁTICA } \\
\text { LICENCIATURA }\end{array}$ & $(\mathrm{EAD})$ \\
\hline \multicolumn{2}{|r|}{ INSTITUTO DE QUÍMICA } & 3 cursos \\
\hline 2304 & $\begin{array}{l}\text { ENGENHARIA QUÍMICA - } \\
\text { BACHARELADO }\end{array}$ & Integral \\
\hline 2302 & $\begin{array}{l}\text { QUÍMICA - BACHARELADO } \\
\text { EM } \\
\text { TECNOLÓGICA }\end{array}$ & $\begin{array}{l}\text { Integral } \\
\text { (Matutino e } \\
\text { Vespertino) }\end{array}$ \\
\hline \multirow[t]{2}{*}{2301} & QUIIMICA - LICENCIATURA & \multirow{2}{*}{$\begin{array}{l}\text { Noturno } \\
2 \text { cursos }\end{array}$} \\
\hline & INSTITUTO INTEGRADO DE SAÚDE & \\
\hline 2801 & $\begin{array}{l}\text { ENFERMAGEM } \\
\text { BACHARELADO }\end{array}$ & $\begin{array}{l}\text { Integral } \\
\text { (Matutino e } \\
\text { Vespertino) }\end{array}$ \\
\hline 2802 & $\begin{array}{l}\text { FISIOTERAPIA } \\
\text { BACHARELADO }\end{array}$ & $\begin{array}{l}\text { Integral } \\
\text { (Matutino e } \\
\text { Vespertino) }\end{array}$ \\
\hline
\end{tabular}




\section{Anexo 11}

\section{As principais justificativas dos alunos participantes da pesquisa para serem professores}

\section{Transmitir conhecimentos para as pessoas}

A809: Paixão por transmitir conhecimento.

A1324: Eu quero poder transmitir todo o conhecimento que eu vou adquirir durante a minha carreira para os meus alunos, e assim, fazer eles se apaixonarem pelo que ensino. Além disso, quero poder ajudar as gerações futuras na escolha de suas carreiras.

A1699: Poder formar profissionais e poder transmitir meu conhecimento para formação de profissionais futuros.

A3042: Minhas razões são transmitir todo o conhecimento possível e estimular o desejo dos próximos em conhecer.

A3334: Facilidade em transmitir conhecimento; salário bom; fácil ingresso no mercado de trabalho.

A3417: A arte de ensinar é bela e transmitir o conhecimento é importante, como também ver pessoas interessadas irem em busca de seus sonhos.

A3954: Ter gosto por educar, transmitir conhecimento adquirido e com isso tornar o mundo melhor.

A5695: Transmitir novos conhecimentos às novas gerações, incentivar crianças e jovens a ter maior paixão pelas artes e pelo pensamento coletivo e criativo.

\section{Gostam de trabalhar com crianças}

A37: Gosto do trabalho dos professores de ensinar os alunos, e gostaria de trabalhar com crianças ou até mesmo adolescentes.

A605: Gosto de crianças e acho uma boa profissão, penso que professor aprende a cada dia algo novo.

A792: Porque adoro ensinar, trabalhar com crianças e acredito que com amor, podemos ter jovens mais conscientes e melhores.

A3428: Gosto de crianças, minha família é desse ramo.

A4764: Porque tenho uma paixão muito grande por ensinar e cuidar de crianças.

A4787: Sempre tive esse sonho, ensinar e aprender ao mesmo tempo, por amor as crianças. 
A4884: Porque gosto muito de criança e acho muito bonito o ato de ensinar. A4949: Ensinar ao próximo e principalmente as crianças tudo que aprendi, para que elas tenham muita sabedoria e se sintam preparados para o futuro.

A5397: Sempre gostei muito de criança, e gosto de ensinar coisas novas para as que estão mais próximas de mim, como minha irmã e meus primos.

A5423: Ter paciência e poder ajudar crianças a se apaixonarem pelo estudo desde a infância.

A5611: Adoro crianças e quero passar para elas tudo o que eu aprendi na escola e poder ensinar muitas coisas para elas que vão precisar futuramente.

A5687: Pois deve ser gratificante ensinar os valores éticos para uma criança.

A5713: Gostar de crianças e talvez não conseguir fazer arquitetura e urbanismo.

A5786: As minhas razões são por gostar de crianças e por apreciar a educação.

A5886: Bom ensinar crianças e pré-adolescente deve ser um máximo! Principalmente na área de maternais e crianças de até 10 anos, pois sou uma pessoa apaixonada em crianças! Me encaixaria muito bem :)

A6039: Porque eu tenho mais facilidade de comunicação com crianças e é uma coisa que eu gostaria de fazer no dia a dia.

A6640: Sempre gostei de crianças, já trabalhei em uma escola de educação infantil particular e Limeira.

\section{Identificam-se e/ou gostam dessa profissão}

A140: Pelo convívio no meio de professores, no caso de minha mãe e avó materna exercerem tal profissão. O gosto pela área fui adquirido no ensino fundamental ainda, quando já obtinha facilidade em ensinar, tanto colegas de classe, quanto minha irmã caçula com seus deveres.

A326: Pois gosto muito de estudar, e por isso poderia ser uma boa profissão para exercer.

A749: Me identifico com a profissão, e tenho influência em casa.

A920: Por causa que é uma profissão que eu gosto e quando, você gosta de uma coisa, você consegue trabalhar bem e dar uma boa aprendizagem. E poder ajudar no futuro do Brasil, e poder ver os meus alunos tudo formado, em uma faculdade, isso levou eu a escolher essa profissão.

A1915: Eu gosto muito do ambiente escolar, me sinto bem.

A2313: Estabilidade financeira, identificação com o curso, oportunidade de aprender e ensinar! 
A3079: Me identifico com a profissão.

A3342: Pois tenho capacidade e responsabilidades, e me identifico nessa área.

A3910: Passar para o próximo o conhecimento por mim adquirido e fazer com que tomem gosto pelo conhecimento, o qual os fará melhor.

A3932: Gosto do trabalho exercido por um professor.

A4835: Porque amo essa profissão e gosto de ensino.

A5698: Porque eu gosto de ensinar, gosto de ter contato com as pessoas, de transmitir algo. E me adaptaria bem na escola ensinando aos alunos.

A6595: Gosto muito de ler, ensinar, amo desenvolver projetos e os colocar em prática. Gosto da profissão, embora particularmente eu a ache muito desvalorizada, tal motivo que me colocou em dúvida sobre esse curso, porém quando nos identificamos com algo, não devemos esconder nosso talento.

\section{Gostam de determinada disciplina do currículo}

Tabela 6: Razões pelas quais os alunos querem ser professor de disciplina específica.

\begin{tabular}{|l|l|}
\hline Disciplinas & \multicolumn{1}{|c|}{ Razões para escolha } \\
\hline Educação & $\begin{array}{l}\text { A612: Gosto muito dessa disciplina desde quando comecei a estudar, gosto de } \\
\text { praticar exercícios. } \\
\text { A1206: Gosto do esporte, jogos, gosto do ar livre. } \\
\text { A1950: Pelo fato de gostar bastante de esportes, acredito que teria facilidade nessa } \\
\text { área. E estaria ensinando aos meus alunos da melhor forma possível, pois estaria } \\
\text { fazendo o que gosto! } \\
\text { A2572: Porque gosto de atividades físicas. } \\
\text { A3279: Gosto de Educação Física, de início iria trabalhar como professora e depois } \\
\text { que me formar, iria montar minha própria academia. } \\
\text { A3914: Eu gosto de praticar esporte. } \\
\text { A6727: Por gosto, e prazer em ensinar sobre o esporte. } \\
\text { A6690: Pois gosto da Área de Educação Física. } \\
\text { A7137: Fazer com que os alunos melhorem e procurem a melhorar sua saúde e } \\
\text { paixão pelo esporte e pela prática de atividades físicas. } \\
\text { A7156: Para ensinar os alunos, e motivar a praticar esportes e pegar gosto pela } \\
\text { atividade física, o número de obesos está crescendo a cada ano e muitas vezes por } \\
\text { falta de incentivo de alguém. } \\
\text { A7329: Gosto de esporte, e não pretendo sair dessa área. }\end{array}$ \\
\hline
\end{tabular}




\begin{tabular}{|c|c|}
\hline & $\begin{array}{l}\text { A7426: Porque eu gosto de esporte, pois eu pratico e acho que seria uma boa } \\
\text { começar e ensinar sobre o que eu mais gosto. } \\
\text { A7473: Gosto de esporte "Prof. Educacão Física." }\end{array}$ \\
\hline Matemática & $\begin{array}{l}\text { A640: Gosto de Matemática. } \\
\text { A1282: Porque eu gosto de Matemática. } \\
\text { A1554: Por ter no meu conceito que é uma ótima profissão e eu gosto de } \\
\text { Matemática e também admiro a bravura de ser professor. } \\
\text { A2148: Me disseram que sou boa em explicar Matemática, e eu gosto dessa } \\
\text { matéria. } \\
\text { A3436: Porque gosto muito de exatas e pensei em fazer Matemática. } \\
\text { A3599: Gosto de Matemática e tudo que envolve cálculos. Além de poder ajudar } \\
\text { outras pessoas. } \\
\text { A4107: Porque gosto de me interagir com as pessoas, e amo explicar sobre } \\
\text { Matemática. } \\
\text { A4642: Gosto da disciplina de Matemática, e gostaria de ver os alunos futuros a } \\
\text { aprender juntos comigo. } \\
\text { A5222: Primeiro, para ensinar a matéria que gosto para outras pessoas. Segundo, } \\
\text { porque as pessoas pensam que a Matemática é uma matéria muito chata, e poder } \\
\text { demonstrar para elas que a Matemática é divertida. }\end{array}$ \\
\hline História & $\begin{array}{l}\text { A651: Gosto de História e passar conhecimento à frente. } \\
\text { A2139: Gosto de História e acho que sou bom nela também. } \\
\text { A2448: Primeiro porque eu amo História, segundo porque é muito bom fazer } \\
\text { amizade com os alunos e interagir com eles. } \\
\text { A3261: Gostaria de dar aulas, explicar a matéria História que eu gosto, ensinando } \\
\text { os meus alunos o que o passado deixou para o presente de hoje, e acho bacana } \\
\text { aprender de onde viemos. Ter uma conclusão de que somos de culturas diferentes } \\
\text { talvez. } \\
\text { A3781: Por ser uma atividade que me chama muita atenção, e ainda por eu ser } \\
\text { fascinado na História. } \\
\text { A5460: Gosto do que o estudo abrange, a História é fundamental para formação do } \\
\text { indivíduo na sociedade. } \\
\text { A7526: Porque gosto muito dessa matéria, e gostaria de aprender mais sobre a } \\
\text { História e poder passa o meu ensino para o próximo. }\end{array}$ \\
\hline Biologia & $\begin{array}{l}\text { A1651: Na minha cidade tem a Universidade que disponibiliza o curso de } \\
\text { Licenciatura em Biologia. Por isso, eu conseguiria cursá-la, e além do mais, gosto } \\
\text { bastante da matéria. Mas se tivesse o curso de Engenharia Civil eu iria cursar sem } \\
\text { dúvida. Amo a área que faz parte da natureza, me encanto com todo esse meio. E } \\
\text { também um cálculo me chama muita atenção. Na verdade, temos poucas escolhas } \\
\text { em cidades pequenas como a nossa. }\end{array}$ \\
\hline
\end{tabular}




\begin{tabular}{|c|c|}
\hline & $\begin{array}{l}\text { A2383: Pretendo exercer essa função por eu ter um gosto por ensinar as pessoas, e } \\
\text { ser fascinado por Biologia e tudo que envolve a vida. } \\
\text { A4802: Gosto muito de Biologia e me dou muito bem com pessoas, sou muito } \\
\text { paciente. } \\
\text { A5884: Minha razão seria porque gosto muito de Biologia e é uma matéria que me } \\
\text { interesso muito, e gostaria muito de dar aula desta matéria. } \\
\text { A7562: Gosto de ensinar e amo Biologia. }\end{array}$ \\
\hline $\begin{array}{l}\text { Língua } \\
\text { Portuguesa }\end{array}$ & $\begin{array}{l}\text { A1376: Porque eu gostaria de ser professor para ensinar norte-americanos a } \\
\text { falarem Português. } \\
\text { A1822: Paixão pela língua nacional, facilidade para aprender as regras e normas. } \\
\text { Interação com pessoas, disciplina, rigidez, entre outros pontos. } \\
\text { A3804: Por ter influência familiar, e também por ter mais afinidade em Português. } \\
\text { A5798: Ensinar as formas de se obter um bom futuro com a sabedoria adquirida em } \\
\text { seu curso, de sua Língua Portuguesa. } \\
\text { A6827: Sempre gostei de Português. } \\
\text { A7132: O fato de eu gostar da matéria de Língua Portuguesa. }\end{array}$ \\
\hline Geografia & $\begin{array}{l}\text { A19: Gosto muito mesmo de Geografia. } \\
\text { A7090: Gosto muito de Geografia. }\end{array}$ \\
\hline Física & $\begin{array}{l}\text { A6345: Eu gosto da Física, e das suas aplicações, gosto de criar coisas, de } \\
\text { aprender mais, quero ser um Engenheiro Mecatrônico e um professor de Física. } \\
\text { A6507: Por causa que tenho um certo gosto em saber e ensinar Física a alguém, } \\
\text { pois se tornou a minha paixão. } \\
\text { A6651: Gosto de Física. }\end{array}$ \\
\hline Inglês & $\begin{array}{l}\text { A2194: Professora de Inglês em alguma escola de idiomas. } \\
\text { A3497: Gosto da área da Língua Inglesa. } \\
\text { A3964: Eu escolheria ser professor de Inglês porque é uma área muito rica em } \\
\text { relações de conhecimento e eu aperfeiçoaria com o toda eficaz possível, pois é uma } \\
\text { coisa na qual eu gosto. } \\
\text { A4914: Amo Inglês, acho uma disciplina espetacular. } \\
\text { A5049: Pois eu gosto da Língua Inglesa e já estudo ela a algum tempo. }\end{array}$ \\
\hline Artes & $\begin{array}{l}\text { A538: Gosto de desenhar. } \\
\text { A3760: Porque eu gosto de Arte. } \\
\text { A5129: Porque gosto muito de desenhos e pinturas. } \\
\text { A5695: Transmitir novos conhecimentos às novas gerações, incentivar crianças e } \\
\text { jovens a ter maior paixão pelas Artes e pelo pensamento coletivo e criativo. }\end{array}$ \\
\hline
\end{tabular}




\begin{tabular}{|c|c|}
\hline & $\begin{array}{l}\text { A7422: Gosto do conteúdo de Arte, e de desenhar, é uma matéria gostosa de } \\
\text { estudar, por isso gostaria de investir no que gosto, e essa matéria seria um } \\
\text { exemplo. }\end{array}$ \\
\hline Química & $\begin{array}{l}\text { A476: Gosto muito de Química e tenho facilidade. } \\
\text { A3362: Para ensinar aos alunos como a Química pode ser importante em nossas } \\
\text { vidas. } \\
\text { A5743: Porque gosto de Química. } \\
\text { A6731: Por ter habilidade em Química, acredito que serei uma ótima professora. }\end{array}$ \\
\hline Filosofia & A7530: Gostar de aulas de Filosofia. \\
\hline Literatura & $\begin{array}{l}\text { A1340: Eu acho incrível o contato que o professor tem com os alunos. O } \\
\text { relacionamento de orientador, sentir que você pode fazer a diferença na vida de } \\
\text { alguém. Além disso, eu gosto muito de me expressar publicamente e gostaria de } \\
\text { propor coisas totalmente diferentes para meus alunos, despertando o interesse } \\
\text { deles para a literatura, uma área que bem poucos gostam. } \\
\text { A2138: Sou apaixonada por Literatura. } \\
\text { A5333: Sempre gostei muito de Literatura. Com certeza teria um dom. } \\
\text { A6106: Porque eu gosto de Literatura. } \\
\text { A7670: Gosto muito de Literatura, e gostaria muito de estimular as pessoas a lerem } \\
\text { mais e mais. }\end{array}$ \\
\hline Sociologia & A2199: Gosto pelas Ciências Sociais. \\
\hline Ciências & $\begin{array}{l}\text { A2007: Amo tudo que envolve Ciências e sempre gostei de estudar. } \\
\text { A3298: Amor a Ciências Biológicas. }\end{array}$ \\
\hline
\end{tabular}

Fonte: Própria (2018)

\section{Profissão digna, com boas oportunidades de emprego e estabilidade financeira}

A495: Salário bom, oportunidades de emprego e porque gosto.

A506: Porque é uma profissão digna e bonita. O início de tudo e todos.

A1786: Acho que essa profissão pode abrir várias oportunidades na vida.

A2313: Estabilidade financeira, identificação com o curso. Oportunidade de aprender e ensinar!

A2486: Pois é uma ótima profissão e por estar em falta no mercado de trabalho, tenho mais oportunidades de trabalho.

A3132: É uma profissão que apresenta oportunidades de emprego, além de ajudar a educar alunos para o mundo melhor. 
A4715: Uma profissão digna de respeito e importância para sociedade.

A4868: Vasta oportunidade de emprego apesar do salário não ser o melhor.

A5020: Porque é uma Área muito boa para concurso.

A5486: Por ser uma profissão digna, onde o professor é o educador e tem o privilégio de ensinar aos seus alunos sobre a sua matéria de conhecimento. A5762: Gosto da área e seria uma boa oportunidade de serviços aqui na minha região.

A6771: Uma excelente oportunidade de emprego.

A7347: É uma profissão digna e de muito respeito.

\section{Admiração pelos professores}

A487: É a profissão mais importante, pois é a base para todas as outras. Tenho grande admiração, e sei que está cada vez mais diminuindo os profissionais nesta área. Acho lindo a ideia de compartilhar meu conhecimento com outras pessoas.

A500: A admiração e respeito que tenho por essa profissão. Também o fato que gosto de transmitir aos outros, o que sei e o que penso ser útil, assim como foi para mim.

A2528: A admiração por um professor dedicado e que me ajudou nos meus momentos de dúvida.

A4103: Porque gosto de ensinar e tenho muita paciência, e sempre admirei meus professores.

A4570: Ser professor realmente algo de grande valor, pois vai depender de você para outras pessoas ficarem alfabetizadas. Admiro!

A5716: Eu gosto de ver meus professores lecionando!!! Admiro!!!

A6339: A admiração pelos professores que tenho e que ao longo dos anos eu tive. É uma profissão maravilhosa, ensinar o que sabe e juntamente com os alunos aprender.

\section{Melhorar a qualidade do ensino público no país}

A1241: Para poder ajudar a melhorar a educação no meu país.

A1714: Por acreditar em um ensino humanizado. Onde passando o conhecimento e incentivando a criatividade, as crianças passam a ter uma nova maneira de pensar, podendo até mudar o nosso futuro.

A2375 - Quero de alguma forma, poder contribuir, com o conhecimento adquirido na faculdade, à melhora da educação, não só no Mato Grosso do Sul, como também no Brasil, pois o ensino em nosso país está regredindo. As instituições de ensino precisam de novas ideias, vindas de novos professores, para tentar tornar a educação atrativa novamente para realidade dos jovens de hoje. 
A2744 - Para melhorar a qualidade dos estudantes do nosso país, pois a carência na educação está em alta, tanto no aprendizado dos alunos quanto aos professores brasileiros.

A3442: Contribuir para melhorar a educação do Brasil, tentando ser o melhor professor e sendo exemplo para as gerações futuras.

A5366: Para melhorar o ensino público.

A5907: Gosto de ensinar e ajudar o próximo, quero um futuro melhor para a educação.

A6142: Melhorar o pensamento e a cultura no Brasil.

A7447: Tentar de alguma forma melhorar a qualidade de ensino.

A7672: Ajudar com o conhecimento que tenho e melhorar a sociedade.

A7799: Para ajudar a melhorar o desempenho dos alunos.

\section{Facilidade de comunicação e interação com as pessoas}

A51: A minha facilidade de comunicação e de gostar de ensinar, passar novos conhecimentos.

A2499: Gosto de falar com as pessoas e também tenho facilidade em ensinar as pessoas, gosto muito de ler e me atualizar.

A2524: Porque eu gosto do contato com as pessoas e gosto de ensinar e ajudar as pessoas ao meu redor, nesse caso ensiná-los algo em que eu me destaco. Dar a elas um pouco de meu conhecimento, ajudar naquilo que posso.

A2782: Gosto de interagir com as pessoas.

A3190: Eu gosto de comunicar, realizar seminário e outros relacionados.

A3612: Eu gosto muito de conviver em harmonia com as pessoas e sou muito brincalhão. Acho que daria certo eu ser professor!!

A4534: Gosto de me comunicar e compartilhar o que aprendi, com novas pessoas.

A5017: Gosto muito de ensinar, gosto de me relacionar e tenho facilidade para falar em público.

A5232 - Pois gosto de me dedicar ensinando as pessoas, e tenho uma boa comunicação.

A5660: Eu gosto de passar o meu conhecimento às outras pessoas sobre os assuntos que me agradam, e que são interessantes. Também tenho facilidade em falar na frente das pessoas. 
Anexo 12

\section{As principais justificativas dos alunos participantes da pesquisa para não serem professores}

\section{Não se identificam, não tem vocação, ou não gostam dessa profissão}

A344: Nunca tive interesse, nem vocação. Exige didática e paciência e são coisas que eu realmente não domino.

A489: Pelo fato de não me identificar com a área!

A683: Não tenho vontade, e nem vocação, porque para ser professor tem que querer, pois é muito importante.

A2373: Acredito não ter vocação para ensinar, e acho a carreira muito sofrida.

A2407: Porque não é o que eu gosto, pois para ser professor é necessário gostar daquilo que faz e ter paciência e eu não tenho vocação para professor.

A3111: Porque não tenho vocação para exercer a função de professor.

A3244: Porque não é a área que eu gosto, e exige muita paciência, e no caso eu não tenho.

A3710: Não teria gosto pelo trabalho e o mais importante para um profissional é gostar da sua profissão.

A4243: Porque não me identifico com essa profissão, não gosto de ensinar e etc.

A5821: Não é uma profissão que me identifico, por esse motivo não pretendo fazer algo que não gosto a fim de ser um profissional frustrado ou um mau professor.

A5905: Nada contra! A profissão é muito bonita. Temos que ensinar os alunos a pensar e não a obedecer, mas não me identifico sendo uma professora, porque já escolhi minha área.

\section{Falta de paciência para ensinar}

A93: Porque não tenho paciência com as pessoas, inclusive crianças.

A248: É muito desgastante, não tenho paciência.

A250: Não tenho paciência, acredito que pra ser professor tem que ter amor a profissão e isso não há em mim. 
A348: Porque não tenho muita paciência para enfrentar a realidade que nossos professores enfrentam hoje em dia.

A425: Requer muito conhecimento, paciência e amor, e eu infelizmente não tenho paciência para ensinar.

A622: Não ter paciência e não gostar desta profissão para eu ser, mas é uma profissão muito digna e que exige muito que a pessoa goste do que esteja fazendo.

\section{Desvalorização dessa profissão pela sociedade, principalmente pelos governantes}

A1942: Salário pequeno, profissional desvalorizado no país, stress desnecessário.

A1222: Não tenho paciência para aguentar alunos mal educados, e o governo não investe na educação, e os professores não são valorizados como deveriam ser.

A2089: Porque essa profissão não tem um retorno financeiro favorável já que não é tão valorizada; os jovens não respeitam os professores e, provavelmente, eu não teria paciência com os alunos.

A2351: É desrespeitado constantemente e, às vezes, é menosprezado mesmo tendo grande importância na sociedade.

A2768: Falta de atenção e desvalorização do poder público. Se dedica muito e as pessoas não dão um devido valor, não tem muitos direitos.

A3217: No país em que vivemos, os professores não são respeitados, há um descaso muito grande, e não teria paciência pra ensinar criança barulhenta.

A4157: Não tenho paciência, e pelo que os meus professores me falam a respeito disso, eles não são devidamente remunerados e não possuem um trabalho digno e respeitado, muitas vezes eles tiram do próprio bolso os materiais para dar ao aluno.

\section{Salário ruim/baixo}

A1: O salário ruim, más condições de trabalho, alunos indisciplinados.

A132: Professor forma os jovens para um futuro promissor e não são valorizados, salários baixos para alguém que muda a vida das pessoas tchall brigaaaado rsrsrsr.

A315: Por ser uma profissão que não tem a importância que deveria, e por não ter o salário que se merece, por ter que trabalhar até em casa fazendo planejamentos e diários, então essa profissão tem uma carga horária extensa. Ou seja, não concordo com o salário dessa classe que sofre e batalha para ter o que comer. 
A407: Pelo fato do salário ser pouco valorizado, sendo que um professor deveria ganhar melhor pelo fato ser a segunda família ensinando você a seguir um rumo na vida.

A2504: Salário horrível e a falta de investimento do Estado na educação.

A2846: Pois além de ser uma das profissões mais importantes para a sociedade, nela os profissionais sofrem muito e, além disso, é uma profissão muito pouca valorizada, com um salário muito baixo.

A3369: Salário é uma merda, moleque mal educado, escola sem infraestrutura, governo não investe em educação, etc.

A3955: Porque o professor não é valorizado, recebe salário baixíssimo, não tem os direitos reconhecidos, muitas vezes são tratados mal por alunos e etc. E agora com uma nova lei a ser aprovada, para congelar o salário de professor, essa lei é absurda, esse país de merda só valoriza vagabundo.

A3958: Salário baixo, os alunos devidamente não o respeitam, não tem valor para a sociedade e nem para o governo que paga milhões de reais a um juiz que não faz nada e um salário baixo a um professor que muda 0 país e que tem uma das profissões mais importantes!

A4146: Professores não são valorizados, e ganham um salário muito baixo, apesar de ser umas das profissões que mais exigem da sua capacidade física e mental.

A5475: Primeiramente pelo horário de trabalho, pelo fato de que o governo quer reduzir gastos e com isso cortar salários dos professores e porque eu não quero mesmo.

\section{Profissão muito estressante, rotina cansativa e carga horária de trabalho extensa}

A322: Baixo salário, péssimo remuneração, carga de horário abusiva.

A546: O Baixo salário e a grande carga horária.

A955: É porque o salário é ruim e é estressante.

A2403: Carga horária de trabalho com pouco descanso e ao estresse diário.

A2854: Salário baixo, ocupação de tempo fora do expediente e falta de respeito no ambiente de trabalho dos alunos.

A2946: Muito desvalorizado, salário baixo, e muita dor de cabeça com alunos e Pais mal educados.

A3198: O salário não é de acordo com a profissão. Medo de levar cadeirada dos alunos.

A3470: Pela questão da desvalorização de tal profissão. Atualmente o ensino educacional está muito difícil, direitos estão sendo invertidos na escola. O professor não é mais respeitado, o salário não é adequado, já que os riscos que os professores correm quanto aos seus alunos que em muitas vezes não tem uma base educacional familiar, acabam por agredir psicologicamente e até fisicamente o professor em sala. 
A3979: Porque ganha pouco, passa fome, raiva, governo não presta, morre cedo, nunca se aposenta, contribui com o salário todo para ver político rico e ele pobre.

A5492: Esforço elevado. Horários de trabalho absurdos.

A7246: Porque os professores vivem presos nas salas de aulas sem nenhum recurso tecnológico, o mais simples a internet, nos falta. Salas de aulas pequenas e lotadas, sem ventilação, alunos desmotivados e professores com baixos salários oprimidos pelo governo. As aulas se resumem as apostilas que o estado disponibiliza.

A7314: Por causa das questões precárias em que se encontra a educação, por causa do salário, e fora o stress psicológico que essa profissão pode causar.

\section{Preferem outros cursos}

A376: O que eu quero realmente é me formar em Direito e ser delegada ou juíza, por razões pessoais...mas nada contra ser professora.

A748: É um curso muito bom mais eu pretendo, especializar em outra área.

A1030: Não é um trabalho que vai me satisfazer, prefiro áreas da Medicina.

A1253: Me interesso somente em Administração.

A1333: Não consigo me ver exercendo outra profissão que não seja Medicina.

A2285: Porque eu sempre quis ser dentista e nunca me passou pela cabeça em fazer outro curso a não se Odontologia.

A3798: Não gosto, mas talvez serei professor de direito na universidade.

A3818: Porque o que eu quero mesmo é fazer faculdade de Medicina e Enfermagem.

A4039: Porque gosto mais de Engenharia do que de professor.

A5525: Pois desde que sou criança sonho em cursar Medicina e não Pedagogia.

A6562: Pois não tenho vontade de exercer essa profissão, pois gosto do ramo da Medicina.

A6716: Pretendo ingressar em instituições de Engenharia, ou em consultórios de Fisioterapia e outros.

A7077: O sonho de Enfermagem anula todos os outros.

A7130: Não sei, nunca pensei em ser professora, sempre tive sonho em fazer Medicina. 


\section{Alunos indisciplinados e desrespeito dos alunos com os professores}

A1: O salário ruim, más condições de trabalho, alunos indisciplinados.

A108: Falta de respeito dos alunos com os professores.

A200: Vejo como aluna, que o professor não é muito valorizado, não só em questão de salário, mas com relação a falta de respeito que muitos sofrem. Mesmo com boas intenções para ser um bom educador, muitos não conseguem atingir suas metas porque não têm a ajuda dos alunos. Tornase uma profissão cansativa demais, para quem nunca teve o sonho de ser um educador.

A611: Porque professor sofre bastante, em relação ao salário e as várias humilhações que eles passam.

A977: Não serviria para suportar as pressões que um professor vivi, desde o salário ao desrespeito dos alunos.

A998: Sendo uma profissão pouco valorizada e desgastante, não gostaria de passar por dificuldades diariamente.

A1955: Particularmente, acho que o Professor tem um papel muito importante em uma sociedade, pois trabalha com a educação da população. Porém, sofre com o desrespeito e com a desvalorização da sua profissão.

A3238: As dificuldades de ensinar aos alunos não interessados na matéria ou o desrespeito com o educador.

A4283: As instituições que hoje estão cada vez mais precárias e o desrespeito com essa profissão.

A5295: A baixa qualidade de ensino no Brasil, e o desrespeito com a profissão, e por não ser tão valorizada, embora deveria ser.

\section{Dificuldade de ensinar pessoas}

A401: Tenho muita dificuldade de falar com o público, explicar, ter paciência.

A1768: Dificuldade para ensinar as pessoas.

A2804: Porque tenho dificuldades em explicar as coisas, então não me daria bem. 


\section{Anexo 13}

Tabela Salarial dos Professores e Especialistas em Educação da Rede Estadual de Ensino - Vigente a partir de $1^{\circ}$ de Dezembro/2018

\section{(O) ACP}

TABELA SALARIAL DOS PROFESSORES E ESPECIALISTAS EM EDUCAÇÃO DA REDE ESTADUAL DE ENSINO - VIGENTE A PARTIR DE $1^{\circ}$ DE DEZEMBRO/2018

Lei n. 5.168 - D.O. 9.629 - página 08 / Lei n. 5.173 - D.O. 9.631 - página 09

\begin{tabular}{|c|c|c|c|c|c|}
\hline \multicolumn{2}{|c|}{ PROFESSOR 20H } & \multicolumn{2}{c}{2026,39} & \multicolumn{1}{c|}{ PERCENTUAL DE REAJUSTE: 5,47\% } \\
\hline \multicolumn{2}{|c|}{ NIVEIS } & I & II & II & IV \\
\hline CLASSE & COEF. & & & & \\
\hline A & 1,00 & $2.026,39$ & $3.039,59$ & $3.242,22$ & $3.343,54$ \\
\hline B & 1,15 & $2.330,35$ & $3.495,52$ & $3.728,56$ & $3.845,08$ \\
\hline C & 1,32 & $2.674,83$ & $4.012,25$ & $4.279,74$ & $4.413,48$ \\
\hline D & 1,38 & $2.796,42$ & $4.194,63$ & $4.474,27$ & $4.614,09$ \\
\hline E & 1,44 & $2.918,00$ & $4.377,00$ & $4.668,80$ & $4.814,70$ \\
\hline F & 1,50 & $3.039,59$ & $4.559,38$ & $4.863,34$ & $5.015,32$ \\
\hline G & 1,55 & $3.140,90$ & $4.711,36$ & $5.025,45$ & $5.182,49$ \\
\hline H & 1,61 & $3.262,49$ & $4.893,73$ & $5.219,98$ & $5.383,11$ \\
\hline \multicolumn{5}{|l|}{} \\
\hline
\end{tabular}

\begin{tabular}{|c|c|c|c|c|c|}
\hline \multicolumn{2}{|l|}{ PROFESSOR 40H } \\
\hline \multicolumn{2}{|c|}{ NIVEIS } & I & II & III & IV \\
\hline CLASSE & COEF. & & & & \\
\hline A & 1,00 & $4.052,78$ & $6.079,17$ & $6.484,45$ & $6.687,09$ \\
\hline B & 1,15 & $4.660,70$ & $6.991,05$ & $7.457,12$ & $7.690,15$ \\
\hline C & 1,32 & $5.349,67$ & $8.024,50$ & $8.559,47$ & $8.826,95$ \\
\hline D & 1,38 & $5.592,84$ & $8.389,25$ & $8.948,54$ & $9.228,18$ \\
\hline E & 1,44 & $5.836,00$ & $8.754,00$ & $9.337,61$ & $9.629,41$ \\
\hline F & 1,50 & $6.079,17$ & $9.118,76$ & $9.726,67$ & $10.030,63$ \\
\hline G & 1,55 & $6.281,81$ & $9.422,71$ & $10.050,89$ & $10.364,98$ \\
\hline H & 1,61 & $6.524,98$ & $9.787,46$ & $10.439,96$ & $10.766,21$ \\
\hline
\end{tabular}

\begin{tabular}{|c|c|c|c|c|}
\hline \multicolumn{5}{|c|}{ ESPECIALISTA EM EDUCAČÃO $36 \mathrm{H}$} \\
\hline \multicolumn{2}{|c|}{ NIVEIS } & I & II & III \\
\hline CLASSE & COEF & & & \\
\hline $\mathrm{A}$ & 1,00 & $6.079,17$ & $6.484,45$ & $6.687,09$ \\
\hline B & 1,15 & $6.991,05$ & $7.457,12$ & $7.690,15$ \\
\hline $\mathrm{C}$ & 1,32 & $8.024,50$ & $8.559,47$ & $8.826,95$ \\
\hline D & 1,38 & $8.389,25$ & $8.948,54$ & $9.228,18$ \\
\hline $\mathrm{E}$ & 1,44 & $8.754,00$ & $9.337,61$ & $9.629,41$ \\
\hline $\mathrm{F}$ & 1,50 & $9.118,76$ & $9.726,67$ & $10.030,63$ \\
\hline $\mathrm{G}$ & 1,55 & $9.422,71$ & $10.050,89$ & $10.364,98$ \\
\hline$\vec{H}$ & 1,61 & $9.787,46$ & $10.439,96$ & $10.766,21$ \\
\hline
\end{tabular}

\begin{tabular}{|c|c|c|c|c|}
\hline \multicolumn{5}{|c|}{ ESPECIALISTA EM EDUCAÇÄO $30 \mathrm{H}$} \\
\hline \multicolumn{2}{|c|}{ NIVEIS } & I & II & III \\
\hline CLASSE & COEF. & & & \\
\hline $\mathrm{A}$ & 1,00 & $4.559,38$ & $4.863,34$ & $5.015,32$ \\
\hline B & 1,15 & $5.243,28$ & $5.592,84$ & $5.767,61$ \\
\hline $\mathrm{C}$ & 1,32 & $6.018,38$ & $6.419,60$ & $6.620,22$ \\
\hline D & 1,38 & $6.291,94$ & $6.711,40$ & $6.921,14$ \\
\hline $\mathrm{E}$ & 1,44 & $6.565,50$ & $7.003,20$ & $7.222,05$ \\
\hline $\mathrm{F}$ & 1,50 & $6.839,07$ & $7.295,00$ & $7.522,97$ \\
\hline G & 1,55 & $7.067,04$ & $7.538,17$ & $7.773,74$ \\
\hline $\mathrm{H}$ & 1,61 & $7.340,60$ & $7.829,97$ & $8.074,66$ \\
\hline
\end{tabular}


TESE - VOLUME II DOS ANEXOS 


\section{VOLUME II DOS ANEXOS}

\section{Anexo 3}

Transcrições do Grupo de Discussão

Obs: As transcrições foram feitas pela Audiotex Serviços e Cia. Ltda.

\section{PARTICIPANTES}

Professor do Ensino Médio - Prof.do EM 1 - P1

Professor do Ensino Médio - Prof.do EM 2 - P2

Professora do Ensino Médio - Prof ${ }^{a}$. do EM 3 - P3

Professora do Ensino Superior - Prof ${ }^{a}$ do ES 1 - P4

Professora do Ensino Superior - Prof ${ }^{\mathrm{a}}$ do ES 2 - P5

Professora do Ensino Superior - Prof ${ }^{\mathrm{a}}$ do ES 3 - P6

Técnica da Secretaria de Estado de Educação - Técnica da SED/MS 1 - P7

Técnica da Secretaria de Estado de Educação - Técnica da SED/MS 2 - P8

Técnico da Secretaria de Estado de Educação - Técnico da SED/MS 3 - P9

Pesquisadora - $\mathrm{P}$

\section{MODALIDADE DE TRANSCRIÇÃO}

Padrão

\section{LEGENDA}

... $\rightarrow$ pausa ou interrupção.

(inint) [hh:mm:ss] $\rightarrow$ palavra ou trecho ininteligível.

(palavra) [hh:mm:ss] $\rightarrow$ incerteza da palavra transcrita / ouvida.

A Audiotext Serviços e Cia. Ltda se reserva o direito da imprecisão dos nomes escritos, uma vez que os locutores serão identificados conforme a pronúncia de seu nome. O cliente tem o direito de fazer quaisquer alterações que julgar necessárias nas identificações aqui utilizadas. 
(INÍCIO)

[00:00:00]

Pesquisadora: Bom dia a todos! Primeiramente, eu quero agradecer a disponibilidade dos senhores em participar deste grupo de discussão que faz parte da geração de dados da pesquisa que estou desenvolvendo sobre a atratividade da carreira docente sob a ótica de alunos concluintes do Ensino Médio de escolas públicas estaduais de Mato Grosso do Sul. Esclareço que os encontros serão gravados em vídeos, porém os participantes terão suas identidades preservadas por uma questão de ética e sigilo, necessárias para o processo da pesquisa. Reitero a minha gratidão aos senhores que voluntariamente se dispuseram a estar nos encontros que acontecerão aos sábados, conforme cronograma sugerido, que apesar de suas obrigações familiares e rotina de trabalho, não mediram esforços para participar desse projeto junto comigo. Quero dizer que estou me sentindo em casa, uma vez que o grupo é composto por colegas de trabalho e pelas minhas exprofessoras da Graduação e do Mestrado, o que muito me honra. Gostaria de iniciar, solicitando que vocês se apresentem. Podemos começar?

Prof $^{-}$ES 1: Eu comecei no magistério em 1977, (inint) [00:00:11], depois entrei na (inint) [00:00:15] em 78, no estado em 80, fiquei por quase 16/17 anos, antes em fui para o INDEP, trabalhei uns $4 / 5$ anos lá, depois fui para a federal em 96 e me aposentei há três anos na federal, professora de linguagem de ensino, acompanhamento de estágio, toda a parte de formação de professores, e a minha formação toda é em educação, trabalhando com formação de professores de língua estrangeira.

Prof. EM 2: Eu sou professor da rede estadual de língua inglesa, trabalho na escola (inint) [00:01:04] Correia, e assumi o concurso em 2015 logo depois de terminar a graduação, por sorte pude cursar a especialização ano retrasado e passado e concluir.

Prof. EM 1: Eu atuo com língua inglesa na rede estadual, nas escola José Barbosa Rodrigues e Euvínio Matias de Oliveira, do sexto ano ao terceiro do ensino médio, eu trabalho com um pouco de cada, acabo de concluir a pós-graduação em multiletramentos e processos autorais na educação básica em parceria UEMS e SED [00:01:50], sou calouro do mestrado na área de linguística aplicada na UEMS. 
Profạ. EM 3: Minha formação está com 20 anos, no município eu estou como professora de língua inglesa, e pelo estado faz dois anos que eu estou na coordenação, o ano passado eu terminei a pós-graduação em multiletramentos, e agora eu estou (inint) [00:02:39] mestrado em letras $n$ UEMS.

Técnico SED/MS 3: Minha formação acadêmica é em química, eu iniciei a minha carreira profissional na área docente em 2010 na rede estadual como professor, em 2013 eu assumi o concurso, em 2015 eu iniciei uma jornada na secretaria do estado de educação, lá eu comecei como técnico, tanto do ensino médio, depois fui para (inint) [00:03:12], trabalhei com a equipe do Mais Educação, que era um projeto de (inint) [00:03:16] de ampliação de carga horária nas escolas, posterior a gente assumiu a baixa de gestão da educação básica do estado em 2016, posterior e fui da coordenadoria de formação continuada, onde a gente trabalhou toda o processo de formação dos estados nos últimos dois anos, e atualmente eu estou na equipe do ensino médio, nós estamos nessa jornada dentro da secretaria nessa parte de formação de professores, com implementação de políticas públicas, e até aqui a gente conseguiu fazer o nosso trabalho com excelência, e sou muito privilegiado de estar participando dessa pesquisa, quando eu vi eu achei interessante pela temática, porque é um desafio muito grande para nós, justamente manter os estudantes na escola, e conseguir depois acompanhar o resultado final do processo acadêmico dele.

Técnica SED/MS 1: Eu me formei em geografia em 2006 na (inint) [00:04:29] passei no concurso em 2013, só que eu fui chamada em 2014, (inint) [00:04:47], fiquei dois anos na escola, e então fui chamada na sede, agora eu faço parte da equipe técnica do ensino médio, e estou (inint) [00:05:01], agradeço pelo convite, e também me sinto lisonjeada em estar participando(inint) [00:05:09].

Pesquisadora: Então vamos lá, passaremos as discussões agora. Só para situar vocês, essa pesquisa faz parte da faculdade de filosofia, letras e ciências humanas da USP, e a minha orientadora é a professora Walkyria Monte Mór, eu acho que todos os professores que fizeram a pós-graduação a conhecem, porque ela esteve em um módulo com a gente. Então, qual é o objetivo desse grupo de discussão? É gerar dados da pesquisa qualitativa, o título da minha pesquisa é Quem quer ser professor? A atratividade da carreira docente sobre a ótica de alunos do terceiro ano do ensino médio de escolas públicas estaduais de Mato Grosso do Sul, eu acho que 
é um tema bastante interessante, e eu já começo com essa pergunta bastante provocativa: Quem quer ser professor nos dias atuais? O objetivo geral da minha pesquisa é investigar a percepção dos alunos concluintes do ensino médio das escolas estaduais de Mato Grosso do Sul sobre ser professor e os aspectos que eles destacam para justificar a atração ou não pela carreira docente. Continuando, esses são os horários, o nosso cronograma de encontros de março, abril e maio, eu já enviei para vocês, mas acho sempre bom relembrá-los. Quem participa desse grupo além de vocês, é a professora do ensino superior..., que está doente, a outra professora do ensino superior, que está chegando, eu só vou justificar que ela tem uma mãe de 108 anos, e é ela que cuida, então ela precisa fazer toda a parte de higiene pela manhã para depois vir para cá. Da secretaria de estado de educação, estão também os professores e técnicos..., a outra técnica está com dengue, ela falou comigo. Antes de a gente começar a discutir, eu vou apresentar o panorama geral da abrangência da pesquisa, que isso é muito importante, dos 79 municípios de Mato Grosso do Sul, 75 participaram voluntariamente da pesquisa, só quatro ficaram fora porque eles estavam em semana de avaliação, eu devo dizer que deu muito trabalho para a sede coletar esses dados, porque segundo o responsável técnico, eles ficaram duas semanas tirando os alunos, levando para o laboratório para poder responder o questionário, e do total de 378 escolas, 211 participaram da pesquisa, então é muito abrangente mesmo, o quantitativo de alunos foram 22 mil e 800 alunos que estavam regularmente matriculados no ano que o questionário foi aplicado, e 7 mil 894 responderam o questionário. O resultado da pesquisa, são esses dados que vamos que discutir conjuntamente, e o quantitativo de alunos matriculados no ensino médio que participaram da pesquisa, aqui tem o ensino médio regular, a secretaria divide em educação jovens e adultos, médio e integrado a educação profissional, do ensino médio regular, que é a maioria, 7 mil 292 alunos responderam, depois a EJA com 410 e o médio integrado 192 alunos. Agora a gente começa a traçar o perfil socioeconômico dos participantes da pesquisa, no questionário que vocês responderam, eu também abordei essa questão socioeconômica de formação de renda, o quantitativo de pessoas que residem na mesma casa. Vamos as respostas, quatro pessoas que moram na casa 2 mil 745, mais de quatro pessoas 2 mil 386, três pessoas 1.896, duas pessoas 784, e sozinha 83, essa é a questão das pessoas que residem, porque isso implica diretamente na 
renda familiar, de com quanto a pessoa está vivendo e quantas pessoas tem na casa. Fiquem à vontade para fazer uma observação sobre isso, porque o importante é que se discutam esses dados, e não eu só ficar apresentando.

Prof. do EM 1: Quatro ou mais de quatro pessoas, a gente pensa que pode ser a mãe e três filhos, ou alguém além disso, como avó, avô, tio etc.

Prof. do EM 2: Hoje é muito comum famílias que se agrupam como podem, no mesmo terreno, na mesma casa, todo mundo junto.

Prof. do EM 3: Muitos não conseguem manter uma casa e acabam voltando a morar com os pais. Hoje é muito comum ver os filhos adultos e os netos dependentes da aposentadoria dos avós.

Prof. do ES 4: Outra questão é aquela mãe com três filhos, um de cada pai. Isso é comum verificar na escola, quando tem irmãos estudando na mesma escola e você pega a ficha do aluno e percebe que os pais das crianças são diferentes. $O$ pai acaba abandonando o filho e sobra para mãe cuidar sozinha e, muitas vezes, essa mãe só tem apoio dos próprios pais.

Prof. do ES 5: Outra questão, é a quantidade de crianças na escola com pais presidiários por tráfego de drogas e outros crimes, daí sobra para a mãe criar sozinha os filhos também.

Prof. do ES 6: Muitas vezes essas mães que criaram os filhos sozinhas, só conseguem fazer "bico", ou arrumar no máximo um emprego de diarista, e ela acaba não conseguindo sustentar a família e leva os alunos para a escola para eles terem onde ficar e também para poder se alimentarem, os alunos sabem disso e comem o máximo que podem na escola.

Técnico da SED/ MS 7: Verdade. Alguns alunos pedem para que os outros colegas que não querem lanchar, peguem o lanche para eles comerem, pois se solidarizam com o colega.

Técnico da SED/MS 8: Tem outra questão também que é a da higiene, a situação é tão precária que, as vezes, eles não têm condições de comprar itens básico de higiene como sabonete e pasta de dente, eles não têm dinheiro nem para comprar remédio e muito menos para comprar roupas, isso acaba com a autoestima da criança que tem vergonha de ir para a escola nessas condições e vai se considerando inferior aos outros. Muito triste mesmo.

Profa ${ }^{-}$do ES 1: Isso é referente aos 7 mil 292? 
Pesquisadora: Isso, aos alunos, a gente sempre coloca a contagem e a porcentagem ali do lado. Eu acho que é super importante a gente analisar o grau de escolaridade do pai ou responsável, isso aqui é só do pai, depois vamos para a mãe, ensino fundamental completo, $31,3 \%$ dos pais desses alunos, ensino médio completo $21,84 \%$, ensino fundamental completo até o nono ano $12,82 \%$, e tem uns que não sabem, a gente não sabe se é porque não mora com o pai, ou porque ele realmente não sabe, fica uma lacuna, ensino médio incompleto $8,2 \%$, superior completo $6,79 \%$, nunca frequentou a escola $3 \%$, é alto, pós-graduação em nível lato sensu quase $3 \%$, superior incompleto $2,76 \%$, por que será que não conseguem terminar? Outros responderam essas questões, e que fizeram a educação de jovens e adultos $0,25 \%$, ou seja, estava com distorção da série, e depois retomou esses estudos.

Prof $^{a}$ do ES 1: A gente repara esses reflexos na universidade, eu fiquei quase 20 anos na universidade, e fiquei esse mesmo tanto no ensino fundamental e médio, eu passei na rede municipal de séries iniciais, o ensino médio quando tinha o ensino médio na rede, e a gente observa a questão dos pais, que realmente eles chegam com uma defasagem de vocabulário na sala de aula, eu estava utilizando (inint) [00:13:31], e entrava na minha sala uma menina nervosa na porta, ela perguntava (inint) [00:13:36], era curso de contabilidade, eu perguntei se ela estudou, ela falou que sim, mas que ela não conseguia fazer a diferença entre débito e crédito, como que calcula o juros e quanto tem de desconto, a gente vê a vivência da casa, o vocabulário da escola é bem diferente do vocabulário da casa, isso reflete muito, e vai sendo carregado por eles até onde eles aguentam, quando eles não suportam mais, acontece isso.

Técnica da SED/MS 1: Nessas que foram respondidos não sei, a percepção é que não há diálogo, as vezes a interação desse aluno com o familiar dele, como não saber qual a situação de escolaridade dos pais?

Professor do EM 1: Às vezes até a cobrança da mãe e do pai em relação ao estudo definha, porque ele mesmo não tem, não teve a oportunidade ou não foi para escola, então por que cobrar?

Técnico da SED/MS 3: A influência maior que eu vejo nessa questão de grau de escolaridade, é um processo histórico, antes não tinha acesso à escola, agora (inint) [00:15:04] escola é para todos, e a gente observa que quanto maior o grau de 
instrução do responsável, eu consigo dar um direcionamento para esse estudante, isso impacta diretamente no diálogo, na maturidade do pai em relação a orientação desse aluno, desse estudante, o pai que muitas vezes acompanha o menino ou não, a gente tem uma pessoa do acompanhamento que (inint) [00:15:31], ele já é um menino mais independente, então não existe esse acompanhamento mais próximo do pai, o fundamental ainda tem aquele hábito de levar na escola, trazer, no primeiro ano do ensino médio parece que o pai se isenta dessa responsabilidade, e quando o pai não tem essa instrução, isso é muito mais característico nisso de deixar o menino seguir, porque ele tem que estudar e ser alguém na vida, mas se o pai não tem essa orientação, fica difícil de orientar esse adolescente na escola, é justamente nessa fase que ele tem muitos questionamentos da vida, e muitos conflitos, e se o pai não tem instrução dessa formação integral de que o papel da escola é justamente ofertar o desenvolvimento do ser humano enquanto ser social e emocional, se o pai não tem esse formação, ele não consegue fazer isso, então realmente alguns dados mostram que a gente vai ter um grande desafio em recuperar esses pais, que é justamente o que os projetos de correção de fluxos tenta fazer na nossa rede hoje.

Técnica da SED/MS 1: (inint) [00:16:54], quando eu era criança, o meu pai também parou de estudar na oitava série, ou na quarta até, e minha mãe não queria continuar naquela vida pobre, ela voltou a estudar e foi fazer curso de noite, então ela estudou, e eu via que ela estava se esforçando, e eu me espelhei nela, então eu falava que eu não queria aquela vida para mim, então eu ia estudar e me formar, só que de seis filhos, só eu pensei assim, mas eu me espelhei naquela pessoa da casa que estava querendo algo melhor, porque eu acho que o filho acaba se espelhando no melhor que tem na casa, essa questão dessa diferença da série, o pai que está frequentando a escola (inint) [00:17:51] ele está ativando esse desejo de continuar estudando, eu acredito que o estímulo começa em casa.

Técnico da SED/MS 3: E mais uma característica que eu consigo fazer uma ligação, justamente quando você coloca a questão de perfil socioeconômico do pai e porque muitas vezes ele não alcança o nível superior, isso tem uma influência muito grande nas escolhas, o ser humano tem essa tendência a priorizar as coisas, e nós ainda temos a questão de que a sobrevivência é uma prioridade, então as vezes ele vai trabalhar porque ele precisa sobreviver, e o estudo fica em segundo plano, a 
questão da sobrevivência ainda é muito forte, por que nós temos muitos alunos do ensino médio hoje estudando para ajudar na renda familiar? Isso é uma característica que faz com que o aluno que está no ensino diurno migre para o ensino noturno ou para uma EJA, justamente porque ele precisa auxiliar nessa renda familiar, então tem uma relação direta da questão da renda familiar também com o perfil do pai, o quanto que esse menino contribui dentro de casa.

Profa do ES 1: E também essa questão, as vezes o curso que ele quer fazer é caro, não tem na federal, ou é o dia todo e ele precisa trabalhar, então ele tem que escolher, ou ele faz o curso que ele quer, ou ele trabalha, e as vezes acaba fazendo um curso que ele não quer porque é de noite, porque durante o dia ele precisa trabalhar, mas ele acaba não concluindo, porque não é aquilo que ele quer.

Prof. do EM 1: As dificuldades de se entrar na universidade pública também.

Prof $^{a}$ do ES 1: Você tem a média da faixa etária desses pais desses alunos?

Pesquisadora: Não, só dos alunos.

Profa ${ }^{a}$ do ES 1: Porque não deve ser uma geração velha. Quando chegar na idade dos alunos, mais ou menos a gente consegue calcular a idade dos pais. É uma geração bem recente.

Pesquisadora: Olha o ensino fundamental incompleto, e a gente percebe esses dados, eu vou passar agora para o grau de escolaridade da mãe ou do responsável. Eu vou interromper um pouco para a professora se apresentar, eu tenho essa honra, ela foi minha professora na graduação e no mestrado.

Profa do ES 3: Eu sou professora aposentada, só que todo dia de manhã é mais difícil de sair mais cedo, porque tem uma menina de 108 anos em casa que nós temos todo um ritual de manhã, por isso que eu atrasei.

Pesquisadora: Vamos passar para os dados da mãe agora. É a mesma situação do pai, ensino fundamental incompleto até o quinto ano, 25,11\% a maioria, depois o médio completo, $24 \%$, se vocês compararem um com o outro, a mulher está em uma situação melhor que o pai, fundamental completo até o nono ano 13,67\%, ensino médio incompleto $9 \%$, superior completo, 8,68\%, aqueles que não sabem dizer, especialização $5 \%$, superior incompleto $3,60 \%$, nunca frequentou a escola, olha esse dado, 2,66\%, educação de jovens e adultos 0,56\%, para vocês verem que ainda precisa ampliar esse espaço da EJA para poder recuperar todo esse 
processo, é muito complicado, então eu vou deixar vocês discutirem, comparando a questão do pai com a mãe.

Técnico da SED/MS 3: Essa questão do não sei, o anterior era qual porcentagem?

Técnica da SED/MS 1: Eles tem mais acesso a mãe do que ao pai.

Prof $^{a}$ do EM 3: E as vezes é a mãe que cria, é uma realidade, porque o pai abandona, a mãe fica sozinha, as vezes não conhece o pai.

Prof. do EM 2: Eu ia tocar nesse assunto, na educação básica de modo geral, quando entra nesse assunto de gênero, a gente acaba chegando nesse assunto, e eu faço rápido e peço para levantar a mão quem mora só com o pai, depois com a mãe e o pai, e quando você fala quem mora só com a mãe, é uma chuva.

Técnico da SED/MS 3: Ela é mãe, pai, é a família toda, ela carrega toda essa responsabilidade, ela é multifuncional, e a gente acaba observando que o nível de instrução dela é um pouco maior de acordo com esses dados.

Técnica da SED/MS 1: Mais uma vez eu posso me usar como exemplo, eu sou pai e mãe, eu criei a minha filha, e no começo o pai não dava mesada, agora ele dá, mas agora ela está com 18, depois que eu voltei a morar em Campo Grande ele começou a dar, porque ele era casado e a mulher não deixava, ele separou da mulher e começou a contribuir, dar a pensão para ela, mas eu nunca cobrei, mas eu deixei a minha filha com a minha irmã em Campo Grande com três anos para ir para (inint) [00:24:21] fazer faculdade lá, e agora ela foi e me deixou, ela está fazendo história. Eu sempre criei ela sozinha, eu tenho estudo, e o pai não tem, ele fala errado, ele escreve errado, eu não sei em qual série ele parou, e acho que ela também não sabe, porque ela não tem contato direto com ele, agora depois de grande que está tendo, então essa é a realidade, assim como eu estou passando, acho que a maioria passa por isso, a mulher tem mais pulso firme e pensa mais no futuro, e o homem quer saber do agora, a maioria.

Técnico da SED/MS 3: Muitas vezes nesses lares onde a mãe carrega a criança, ainda tem a avó, a figura da mulher está sempre ali, correndo atrás, ajudando.

Pesquisadora: Aqui a renda familiar aproximada, isso também é um dado muito interessante de a gente observar, colocamos entre mil e 2 mil reais é a maioria 35\%, quando a gente fala em renda familiar, são todos os membros da família juntos, não é do pai ou da mãe, é a renda de todos total, maior que um salário mínimo, na época que eu fiz esse questionário ele estava a 880 reais, 20,91\%, entre 2 mil e 3 mil 
16,9\%, menor que um salário mínimo 13,36\%, como é que fica esse aluno na escola? Entre 3 mil e 4 mil, que é um valor interessante $7,82 \%$, e acima de 4 mil, que seria entre aspas o ideal, minoria, 6,54\%.

Técnico da SED/MS: E você vê uma relação da formação do pai e da mãe com a questão da renda, isso é muito nítido, com o grau de instrução e o quanto eu consigo agregar valor a isso no meu dia a dia, como que a questão da educação influencia diretamente na questão familiar, principalmente na renda, e no que essas pessoas vão tendo acesso, realmente ela mostra essa discrepância salarial, e a gente vê que a grande maioria vai viver em uma faixa muito baixa (inint) [00:27:48] do que a gente pode dizer de qualidade de vida, então como eu estudo, como eu gero esperança, e entra naquilo, é muito mais interessante eu trabalhar e sobreviver. Porque pensar no futuro? Porque o futuro ainda é muito distante para um menino adolescente, e a gente tem uma cultura muito imediatista, nós queremos para agora, e isso tem mudado muito com a questão da sociedade, do contexto cultural hoje, que é muito mais forte (inint) [00:28:23] de si, eu vejo claro nessa pesquisa essa questão da formação do pai e da renda familiar, que vai fazer com que o menino tenha que trabalhar para ajudar nessa renda.

Prof. do EM 2: E mesmo com o estudo, muitas vezes a dificuldade de se conseguir uma renda mensal ideal, tem uma diferença muito grande entre o quanto de títulos que você tem e o quanto de dinheiro que você consegue fazer, em diferentes profissões.

Prof $^{a}$ do EM 3: Em uma escola de manhã eu estou como coordenadora, e a gente tem um projeto de pesquisa, um dos alunos do ano passado que já vem se destacando, no ano passado ele nos informou no final do ano que ele ia para o noturno para ajudar na renda, nós ficamos uma hora, sentamos nós quatro professores, para convencer ele da importância dos estudos, nos últimos dois anos tudo o que ele conseguiu desde que chegou no ensino médio, nós não escolhemos os melhores alunos, ele se destacou, ficamos uma hora e meia convencendo, e esse ano ele vai para Rondônia apresentar o trabalho, de que ele tem condições de estar em uma universidade, depois de um dia ele veio dizer que queria continuar no período matutino, mas que precisava trabalhar, a mãe precisava de ajuda, e eu tentei colocar para ele a importância dos estudos, o que ele tinha conseguido, ele falou que tinha acabado de comprar uma moto, eu falei que ele estava andando 
irregular por ter 17 anos, e como o professor mencionou, aquele negócio do imediato, nisso eu falei que ele ia trabalhar e ganhar um salário, mas e depois? Tivemos a notícia que ele ia continuar conosco na manhã, vai concluir o terceiro ano, e tem possibilidade de estar no ensino superior público.

Prof $^{\text {a }}$ do ES 3: Eu fico pensando nesses dados, como isso se arrasta por muito tempo, meu pai ia para roça na década de $40 \mathrm{com}$ meu irmão na frente dele, e ele dizia que ele não queria aquela vida para os filhos, mas ele ainda tinha uma chácara que ele vendeu e foi para cidade, e fez questão de dar educação para todo mundo, mas eu fico assustada que nesse país a gente continua com essa situação, de 1940 para 2019, é muito tempo e as coisas continuam desse jeito, talvez até pior muitas vezes, isso aqui nós estamos pensando em renda e escolaridade, mas onde mora esse povo? O que tem de condições de saneamento, qualidade de vida e saúde?

Pesquisadora: Eu vou passar para o próximo slide. O período que estuda na escola, porque isso impacta também na qualidade da aprendizagem do aluno, a maioria está no período matutino, isso eu acho que é bem produtivo, $61 \%$, no noturno $28 \%$, vespertino $9 \%$, a maior parte no diurno com $1,63 \%$, e a maior parte no noturno $0,25 \%$, só o terceiro ano do ensino médio.

Técnico do EM 3: Eu acredito que a maior parte das escolas oferece o matutino, por isso que deu a maioria.

Prof ${ }^{a}$ do ES 1: Você tem a média de meninos e meninas?

Pesquisadora: Tenho, lá no final.

Técnica da SED/MS 1: Por exemplo, na escola que eu trabalhei, só tinha ensino médio de manhã mesmo, e muitas escolas não tem, e a tarde era só o fundamental. Força a não trabalhar nesse período.

Técnico da SED/MS 3: O ensino médio integral ainda não é maioria. Estamos acho que com 55 escolas.

Técnica da SED/MS 1: Esse que coloca a maior parte no diurno, ele integra esse integral, de manhã e de tarde, você vê que por ali é 1,63, e diurno quer dizer isso.

Prof ${ }^{a}$ do ES 1: E no integral também pode ser considerado noturno e vespertino?

Técnico da SED/MS 3: Não. Tem esse projeto de escolas integrais, ele tende a no terceiro ano acabar com o período noturno. O noturno ainda existe por causa da rede. Mas politicamente falando, a política atende a necessidade da sociedade, então a gente entende que o estado precisa (inint) [00:35:11] desse ensino médio, 
se eu tenho uma demanda social que necessita estar estudando nesse período, então não tem como você finalizar isso, a tendência talvez é que a gente consiga fazer com que essa pessoas que estão (inint) [00:35:30] na diurna concluam, e a partir de então a gente avance, porque entende-se hoje que já nesse período, 0,25\% ainda não é uma porcentagem exorbitante de pessoas (inint) [00:35:44], porque a EJA já vem fazendo esse processo há mais de 10 anos, então muitas daquelas pessoas que não tinham, já conseguiram concluir esse ensino médio e fundamental, então se consegue que esse menino avance até o terceiro ano e saia, eu tenho a tendência a esses projetos de correção de fluxos, que deverão ser temporários, sejam finalizado, se eu for pensar em uma linha política, criar um projeto temporário para corrigir, você avança o ensino médio, porque se você tem um ensino médio que consegue segurar esse menino até o final, eu não tenho porque ter um projeto de correção de fluxo, a tendência, eu acredito que não é acabar com o ensino noturno, mas ajustar essas etapas e modalidades.

Técnica da SED/MS 1: Porém, pegando os dados anteriores, tem alunos que estão deixando a escola para trabalhar, e quando eles resolverem estudar? Eles vão entrar nessa (inint) [00:36:57], dificilmente vai acabar, mas pode diminuir.

Técnico da SED/MS 3: Eu acredito que continue também. Por isso, eu acho que tem mudado muito essa questão de trabalhar, essa concepção de (inint) [00:37:22] na vida do aluno, é justamente você dar a esse indivíduo essa competência sócio emocional dele poder entender a importância de estar na escola, para que ele não abandone ou desista por uma questão imediata, mas que ele tenha um projeto de vida, que ele consiga olhar o resultado a curto, médio e longo prazo e saber fazer escolhas, e também está muito relacionado com a questão do papel da escola, mudou-se muito essa concepção, hoje a escola tem inúmeras funções que antes não tinham, como por exemplo a ausência da família, (inint) [00:38:22], a parte de formação humana cabia a família, hoje isso se inverteu, a escola assumiu outros papéis, isso tudo influencia no processo de decisão do estudante, e nessa questão de período, existe a questão climática também, é muito mais interessante eu estudar de manhã que é mais agradável do que estar de tarde em uma sala que talvez não tenha ar-condicionado ou ventilador, os fatores climáticos, de região influenciam muito nessa questão, a gente também pode fazer essa relação. 
Pesquisadora: Vamos passar para o próximo dado. O processo de escolarização na rede pública ou privada, como se deu desses alunos, sempre em escola pública $90 \%$, iniciou em escola particular e mudou para pública 9,37\%, iniciou em escola pública e depois mudou para particular 0,62\%.

Técnico da SED/MS 3: Hoje a gente tem um movimento muito grande no país, principalmente na questão do ingresso (inint) [00:40:02] e das universidades mudaram sua forma de ingresso, a questão de destinar parte das suas vagas para alunos de escolas públicas, então a universidade juntamente com a educação básica tem feito essa articulação no sentido de que o aluno de escola pública tenha acesso ao nível superior, por exemplo, a USP e a UNESP destinam $50 \%$ das suas vagas para estudantes de escola pública, então é uma tendência a gente observar estudantes de escolas particulares migrando para escola pública, isso já uma realidade, porque quando ele vai para ampla concorrência, ele está concorrendo com o estudante que estudou a vida inteira em uma escola particular e teve acesso a muitas outros estímulos e situações que na escola pública não tem, porém se eu tenho um aluno que estuda em particular e dependendo da faixa da renda, ele entra na pública, faz um cursinho (inint) [00:41:07] esse dado tende a aumentar com o tempo, essa migração dos alunos das escolas particulares para a escola pública.

Prof ${ }^{\mathrm{a}}$ do ES 1: Outro ponto que nós temos que observar é a renda.

Pausa [00:41:30] 


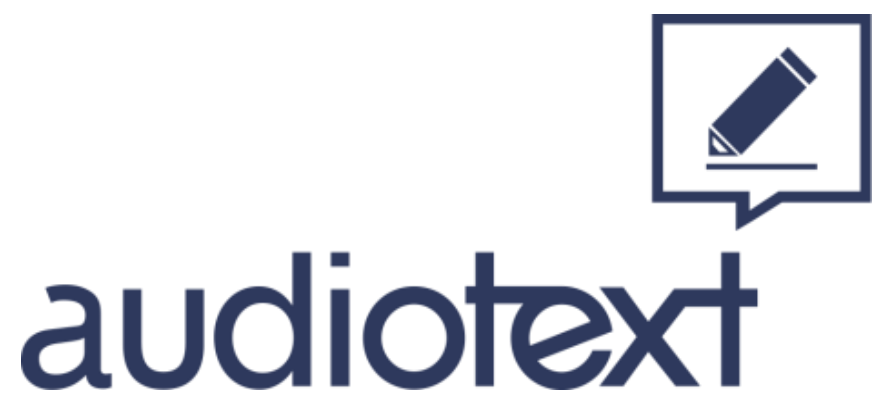

Audiotext Serviços e Cia. LTDA

CNPJ: 17.429.373/0001-85

(41) 3363-3220

falecom@audiotext.com.br audiotext.com.br 
TRANSCRIÇÃO 


\section{PARTICIPANTES}

Professor do Ensino Médio - Prof.do EM 1 - P1

Professor do Ensino Médio - Prof.do EM 2 - P2

Professora do Ensino Médio - Prof ${ }^{a}$. do EM 3 - P3

Professora do Ensino Superior - Prof ${ }^{a}$ do ES 1 - P4

Professora do Ensino Superior - Prof ${ }^{\mathrm{a}}$ do ES 2 - P5

Professora do Ensino Superior - Prof ${ }^{\mathrm{a}}$ do ES 3 - P6

Técnica da Secretaria de Estado de Educação - Técnica da SED/MS 1 - P7

Técnica da Secretaria de Estado de Educação - Técnica da SED/MS 2 - P8

Técnico da Secretaria de Estado de Educação - Técnico da SED/MS 3 - P9

Pesquisadora - $\mathrm{P}$

\section{TEMPO DE GRAVAÇÃO}

23 minutos e 48 segundos

\section{MODALIDADE DE TRANSCRIÇÃO}

Padrão

\section{LEGENDA}

$\ldots \rightarrow$ pausa ou interrupção.

(inint) [hh:mm:ss] $\rightarrow$ palavra ou trecho ininteligível.

(palavra) [hh:mm:ss] $\rightarrow$ incerteza da palavra transcrita / ouvida.

A Audiotext Serviços e Cia. Ltda se reserva o direito da imprecisão dos nomes escritos, uma vez que os locutores serão identificados conforme a pronúncia de seu nome. $O$ cliente tem o direito de fazer quaisquer alterações que julgar necessárias nas identificações aqui utilizadas. 
(INÍCIO)

[00:00:00]

Prof ${ }^{a}$ do EM 3: Eu perguntei porque ele não foi para escola particular, ele falou: "Professora, meu objetivo é a medicina, a concorrência, e tem o ENEM, eu queria concorrer estudando em escola pública", e agora ele está fazendo cursinho, ele passou em odontologia, fisioterapia, direito, mas ele quer medicina.

Prof. do EM 1: Essa semana eu dei aula para uma senhora que tem alguns amigos que são professores, e parece que durante o fim de semana do encontro, houve a discussão da qualidade dos alunos que estavam entrando pela cota, a fala dela foi bem separatista, mas eu quis ouvir, eles estavam discutindo que a disparidade entre quem vem da escola pública e particular para dentro da universidade, não tem muitas vezes nem conhece aquele vocabulários dos livros para poderem participar das discussões, entrar nos grupos, eles acabam sendo excluídos dentro da própria sala, eu fiquei só observando, porque eram os professores comentando. A universidade também precisa fazer algumas ações para integrar esses alunos de uma melhor forma.

Prof ${ }^{\mathrm{a}}$ do ES 1: Eu acabei de comentar isso com a colega, do nível dos alunos que estão entrando no curso de letras, o que está acontecendo na universidade hoje, é que a nossa geração está toda aposentando, está entrando um grupo de professores novos, eu saí, eu fiquei três anos depois que eu poderia ter aposentado, (inint) [00:02:14] você vê aquele seu aluno voltando do doutorado, é uma outra geração, uma geração que nunca foi para uma escola pública, ele chega na graduação achando que ele vai dar uma aula como se fosse de doutorado para aqueles alunos, essa disparidade está acontecendo, é difícil observar isso, por exemplo, do curso de letras inteiro da UFMS, tem uma professora que entrou junto comigo, não tem mais ninguém, o curso acabou, a nossa geração saiu toda, são todos professores novos, recém doutores, e muito inteligentes, eles são fantásticos, e tem um choque de realidade, é um conjunto de tudo, eles são quase da mesma idade dos alunos que estão entrando, eles se chocam até no estilo de vida, está sendo muito difícil, eu acho que a tendência vai ser ficar um pouco mais critica, até alguém descobrir, começar a pesquisar isso, não adianta eles colocarem (inint) 
[00:04:00] universidade tem aula de reforço para os alunos que estão chegando, mas os alunos não vão.

Profa do ES 3: E entra aqueles projetos de extensão.

Prof $^{a}$ do ES 1: Mas não é nem de extensão, é de ensino mesmo, que não deu certo, os alunos não iam, os professores chegavam e continuavam dando aquela mesma aula de nível altíssimo, então foi meio complicado isso, mas essa crise está acontecendo, e eu acabei de perguntar para a colega, com a questão do ENEM, não são só os alunos das escolas públicas que estão chegando lá um pouco mais perdidos, licenciatura e bacharelado, qual a diferença? Os alunos das escolas particulares também, eu tenho muitos questionários de primeiros anos de letras lá, com 90 alunos, e perguntava se eles queriam esse curso, 40\% não queria, foi porque o pai mandou por ser gratuito, para fazer medicina ou engenharia, lá ele ia aprender português e redação, então aprendendo para poder prestar a prova de novo para mudar de curso, não tem o objetivo do curso, é maior, é uma coisa muito maior.

Prof $^{a}$ do ES 3: Tem aqueles para dizer que foram aprovados e entraram na universidade, tem de tudo, e a gente chega, como nós tivemos agora, conversando com a colega, que nós tivemos a formatura da turma do ano passado, a gente olhando, sendo chamados determinados cursos, quatro alunos em uma licenciatura, você ainda pensa que é uma coisa mais complexa, mas não, é licenciatura, uma pedagogia, que tem um belíssimo projeto, você não consegue formar o aluno, tem gente que fica pendurado no TCC, gente que fala que saiu sem saber o que é plano de ensino e plano de aula, é uma coisa impressionante, é curso de artes formando três ou quatro, curso de letras, que tem três cursos de letras e você começa com uma sala de quarenta, cinquenta, você forma dez, até menos, é uma coisa assustadora.

Técnica da SED/MS 1: A questão da redenção também, um exemplo, a minha filha (inint) [00:07:46] história em (inint) [00:07:47], porque ela não conseguiu passar para jornalismo, ela quer, mas ela entrou nas vagas remanescentes, porque ela acha mais fácil conseguir migrar do que ano que vem fazer a prova de novo, e ela não quer pagar, ela quer fazer público, porque ela tem consciência de que é caro, era queria publicidade e propaganda na (inint) [00:08:14], porque ela já viu muitos comentários, pesquisou, mas ela não quer que eu pague, porque ela sabe que as 
condições financeiras não estão fáceis, a gente tem muita conta, sou só eu, e ela mudou para jornalismo, que tem na federal, só que ela não conseguiu entrar, na hora de comprovar renda, ela não passa por causa da minha renda bruta, somos só eu e ela, se eles forem calcular o líquido entra, mas o bruto não, e ela se matriculou em história, ela não quer ser professora de jeito nenhum, ela está fazendo história, ela tem o curso de inglês completo, ela poderia dar aula de inglês lá, mas ela não quer, porque ela fala que não leva jeito para ser professora, e ela não quer passar o que eu passo em sala de aula, o professor não é reconhecido, o aluno não respeita, ela não iria ter paciência, pai também não respeita, o governo, ninguém respeita, professor é ele e ele mesmo, então ela está fazendo história, mas a intenção é migrar para jornalismo.

Técnico da SED/MS 3: (inint) [00:09:45] eu senti essa questão cultural, nós estamos vivendo um processo de aculturação no nosso país, aversão a cultura, esses dias passando nas entrevistas, o quanto de livros voltados para a área de filosofia, de artes, de linguagens, que estão sendo vendidos de forma que o preço não paga nem o material da impressão, e você tem os e-books, mas mesmo assim, a leitura, o aprofundamento não acontece.

Prof $^{a}$ do ES 3: Eu prefiro livro físico, mas todas as editoras estão sofrendo essa crise, daqui a pouco nós não vamos mais ter livraria, como já não temos banca de revista e jornal.

Técnico da SED/MS 3: Eu vejo que o desenvolvimento da interpretação de texto, da competência da lógica, do raciocínio, os dados mostrou que eu tenho $7 \%$ dos estudantes do Brasil aprendendo matemática, como que o aluno vai se formar em engenharia? Como ele vai passar na primeira disciplina de física se ele não sabe matemática? Vai fazer uma análise histórica e filosófica se ele nem conhece a Grécia antiga, não tem como, (inint) [00:11:30] zero, quer dizer, eu passo pelo chute, eu quero consultar, mas a minha pontuação deu essa, eu tenho imediatismo, como a sociedade diz que você tem que ter nível superior para ser alguém na vida, o que hoje já tem se investido nesse processo, porque os cursos técnicos também tem se fortalecido dentro desse processo, quer dizer, hoje já não é mais interessante para o indivíduo ter uma graduação porque tem pessoas que não tem graduação ganhando muito mais do que gente com doutorado, então essas referências sociais tem impactado muito dentro dessas decisões da sociedade, do que eu quero (inint) 
[00:12:14], e a gente entra em uma concepção, o que é sucesso para mim? Sucesso é eu ter uma graduação? Ou é ter uma casa, um carro e estar dentro da sociedade? As vezes eu tenho uma graduação, e não tenho trabalho, isso realmente é uma questão muito profunda, e a Base Nacional Comum Curricular vem trazendo justamente essas concepções, que você pega o documento (inint) [00:12:47], qual a função da escola se não desenvolver no indivíduo as suas capacidades plenas, será que nós enquanto instituição educacional, universidade, educação básica, estamos fazendo isso? Ou nós estamos (inint) [00:13:03], porque o aluno vem, como a professora comentou, formou quatro, desses quatro, todos tiveram dificuldade para fazer o TCC, é esse professor que volta lá para a educação básica para ensinar o aluno, isso nós ainda temos que mudar, as bases acadêmicas da nossa educação, nesse sentido que a educação tem tentado avançar hoje, esse diálogo precisa ser conjunto, academia juntamente com a educação básica, para que desenvolva de fato essa competência, porque o modelo educacional brasileiro hoje é competitivo, fica quem tem competência e se desenvolveu, e se eu não desenvolvo a competência do indivíduo lá na educação básica, ele vai ter dificuldade, ele não tem pesquisa, ele não tem leitura, não tem autoria, não tem autonomia, ele só repete o que ele escutou, a gente tem vivenciado hoje dentro das academias, dentro de algumas instituições educacionais, as vezes até mesmo na escola, professores com uma postura não autonomia do conhecimento, isso realmente tem acontecido (inint) [00:14:22].

Prof ${ }^{a}$ do ES 3: Eu acho que assusta o professor que vem da academia, que passou com bolsa (inint) [00:14:35], depois com bolsa para mestrado, bolsa para doutorado, sai da graduação de uma maneira que ele não tem experiência, porque o nosso papel também é muito importante, eu tive uma experiência no último ano que eu dei aula na pedagogia, que eu tinha dois orientandos de TCC, a menina não aparecia, eu fui chamando, porque tinha data para entregar, data para terminar, um dia o outro orientando falou para mim que ela ia desistir, eu chamei ela e falei que ela não ia desistir, que ela ia fazer o TCC, que eu ia ajudar mas ela ia fazer, que ela não ia ficar para o ano que vem de jeito nenhum, eu não desisto do ser humano, posso desistir de qualquer coisa, e não ia desistir dela, e falei para ela o que ela tinha que fazer, ela ficou em choque, foi fazendo, e eu fiquei no pé dela, chegou e ela fez, e eu falei que foi um TCC tão tranquilo de fazer, as leituras foram, se precisava de mais 
orientação era só vir que nós conversávamos toda semana, quando ela foi para defesa do TCC, ela (inint) [00:16:29], eu perguntei o que ela imaginava da vida dela quando ela foi para lá, e ela falou que imaginava tirar um sete, e ela saiu com nove e meio, ela me abraçava e falava: "Professora, que bom que a senhora não desistiu de mim", falei claro, ela tem competência, eu fiz pressão para ela tomar um rumo na vida, eu tenho ela no Facebook, agora eu vejo uma vitória aqui, outra vitória lá, se eu desistisse dela e deixasse ela sem fazer, porque as vezes a gente também quer se poupar de serviço, mas a gente tem que ir atrás, eu considero isso, eu acho que do ser humano a gente não pode desistir em momento nenhum, e a professora que era coordenadora da pedagogia, eu falava que ela era muito amiga, porque todo mundo que ia ficando, estava pendurado, eu dizia para ela tomar conta porque era dela, porque a gente também tem que ajudar, e eu acho que esse pessoal novo não vem com esse gás de querer ajudar, chamar para a vida, a gente vê o potencial e tem que chamar para a vida, para tomar rumo.

Prof $^{\text {a }}$ do ES 1: A faixa etária deles é muito próxima, é impressionante.

Profa do ES 3: (inint) [00:18:35] eu fiz tudo isso, por que ele não pode fazer? Por que eu tenho que ficar insistindo tanto?

Prof $^{a}$ do ES 1: Mas voltando naquele assunto, graduação e diploma realmente não é garantia de emprego, as vezes quanto maior a formação da pessoa, mais difícil de ela arrumar emprego, porque ela tem o direito de ganhar mais, se ela tem um doutorado ela vai ganhar mais, e não consegue emprego,

Prof. do EM 1: Muitas vezes a pessoa tem até que se sujeitar a aceitar o valor a menos, porque ou ela aceita ou fica sem emprego.

Profa do ES 1: Eu fui convidada para uma seleção de professores (inint) [00:19:30], tinham 63 candidatos, eu recusei de cara, pensa, 63 doutores para fazer a prova em Corumbá? É aquela situação do pessoal ir passando com bolsa e saindo totalmente sem vivência, sem experiência, você chegou no topo, é uma situação semelhante ao soldado que segue carreira, chega a capitão, tenente, (inint) [00:20:24].

Profa do EM 3: Eu tive uma situação ontem, de uma aluna na coordenação, depois da conversa que eu tive com ela, ela me chamou para conversar, falou que nós estamos na era digital, e o professor pediu uma lista de exercício (inint) [00:21:05] peguei no WhatsApp, mas era para pesquisar no dicionário, e ela não tinha dicionário, então ela foi pesquisar no celular, mas professor está o tempo todo no 
computador ou no celular dele, e me chamou atenção, ele falou que o professor não explicou e ele não estava entendendo, e falou que aquilo não estava certo. Eu estou na coordenação há dois anos e as vezes eu vejo a formação do professor, fica mais de 20 anos tendo aquela postura de levar exercício, senta e faz, e hoje nós estamos recebendo alunos hoje que estão multidigitais, ele pediu para pesquisar no dicionário, e não tem dicionário na escola, e ele falou que não podia usar o celular, mas se eu não posso usar um dicionário online, por que o professor pode usar o celular, o computador dele na sala de aula?

Prof $^{\mathrm{a}}$ do ES 3: As vezes o professor não soube passar qual era a intenção dele, a intenção dele é que o aluno aprenda aquela ordem alfabética, saber procurar, antigamente tinha lista telefônica, e a gente não sabia procurar na lista telefônica, era complicado, igual ao dicionário, e as vezes o professor queria que ele desenvolvesse aquilo, porque no online é fácil, ele digita e ela aparece.

Técnico da SED/MS 3: Falando em lista telefônica, me ajudou muito a aprender a ordem alfabética, porque eu queria achar o nome das pessoas.

Prof $^{\mathrm{a}}$ do ES 1: E as vezes o professor chega ali, e ele sabe muito, mas não sabe passar para o aluno, tem um choque de gerações.

Pesquisadora: Alguém mais quer contribuir? Eu vou fazer uma pausa para tomar um café e depois continuamos.

[00:23:48] 


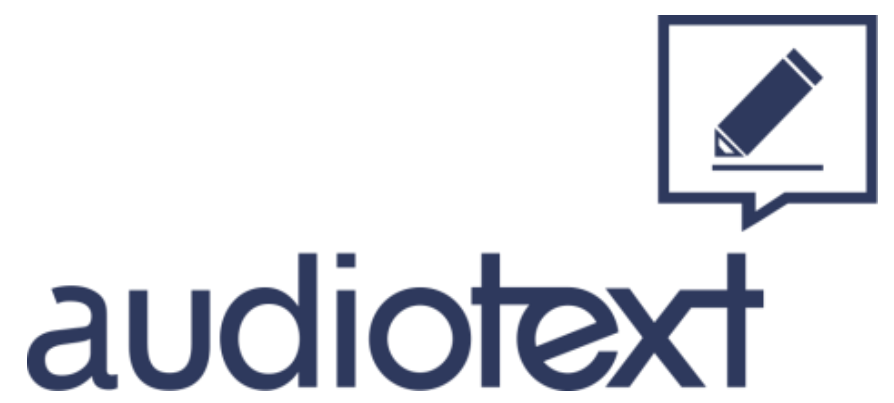

Audiotext Serviços e Cia. LTDA

CNPJ: 17.429.373/0001-85

(41) 3363-3220

falecom@audiotext.com.br

$\underline{\text { audiotext.com.br }}$ 


\section{PARTICIPANTES}

Professor do Ensino Médio - Prof.do EM 1 - P1

Professor do Ensino Médio - Prof.do EM 2 - P2

Professora do Ensino Médio - Profa . Do EM 3 - P3

Professora do Ensino Superior - Profado ES 1 - P4

Professora do Ensino Superior - Profa do ES 2 - P5

Professora do Ensino Superior - Profádo ES 3 - P6

Técnica da Secretaria de Estado de Educação - Técnica da SED/MS 1 - P7

Técnica da Secretaria de Estado de Educação - Técnica da SED/MS 2 - P8

Técnico da Secretaria de Estado de Educação - Técnico da SED/MS 3 - P9

Pesquisadora - $\mathrm{P}$

TEMPO DE GRAVAÇÃO

09 minutos e 56 segundos

MODALIDADE DE TRANSCRIÇÃO

Padrão

\section{LEGENDA}

... $\rightarrow$ pausa ou interrupção.

(inint) [hh:mm:ss] $\rightarrow$ palavra ou trecho ininteligível.

(palavra) [hh:mm:ss] $\rightarrow$ incerteza da palavra transcrita / ouvida.

A Audiotext Serviços e Cia. Ltda se reserva o direito da imprecisão dos nomes escritos, uma vez que os locutores serão identificados conforme a pronúncia de seu nome. $O$ cliente tem o direito de fazer quaisquer alterações que julgar necessárias nas identificações aqui utilizadas. 
(INÍCIO)

[00:00:00]

Técnico da Sed/MS 3: Então nós tínhamos que comprar os livros para estudarmos, uniforme também, tínhamos que pagar o passe de ônibus, não existia (inint) [00:00:13] como os estudantes daqui, as vezes eu fico pensando nesse paralelo, isso é uma realidade nossa, e não são todos os estados brasileiros que arcam com a despesa do estudante de matéria, passe de ônibus, uniforme. Então, eu posso dizer que a nossa rede e o nosso estado são privilegiados, porque tem muitos estados que não alcançaram nem o patamar de vale-transporte, isso é muito sério, e eu acho que os professores podem até fazer essa conscientização.

Prof $^{\mathrm{a}}$ do EM 3: Eu acho que o professor na verdade tinha que propor um projeto de pesquisa com os alunos, fazer eles pesquisarem isso.

Técnica da SED/MS 1: Porque tudo o que vem de graça não é valorizado.

Prof. do EM 1: Nem é de graça no final.

Profa do ES 3: É porque não sai diretamente do meu salário, é isso que a gente tem que mostrar, é por isso que não respeita os bens, não respeita nada que é público, porque acha que tudo pode vandalizar.

Prof. do EM 2: A própria comida na hora do lanche, muitos alunos jogam fora. Existiu uma situação, que a nossa (inint) [00:01:52] as vezes o professor come ali para mostrar que não é uma merenda ruim, porque ele fica com fome e não come, fica com vergonha de comer na escola, quando ele vê essa prática, é o social, o quanto que isso impacta no comportamento dos outros, e a merenda da escola é muito boa, claro que tem dias que é biscoito, até porque tem o cardápio.

Prof $^{\mathrm{a}}$ do EM 3: Eu acho que nos pequenos ela é mais reforçada, e eles não tem vergonha, todos pegam, é diferente do ensino médio, todos esperam com muita felicidade aquele momento da merenda.

Técnico da SED/MS 3: Nós temos escolas hoje que a merenda é servida selfservice, o aluno se serve sozinho, para você ver o nível que tem alcançado as nossas escolas, não são todas, mas estamos começando um processo, onde 
essa temática da socialização da merenda, é importante para o aluno, ele se serve, repete, fica disponível para ele.

Pesquisadora: Vamos parar por aqui as atividades do dia de hoje, porque eu não quero passar o tempo que a gente combinou. Eu estou achando maravilhoso, ainda bem que vocês estão vindo e achando bom, porque é ruim quando você fica olhando toda hora para o relógio esperando acabar. No próximo encontro a gente vai analisar outros dados, que entra na pretenção de cursos, sobre as razões que ele seria ou não professor, então são vários slides a serem analisados.

Profa do EM 3: Devido a reforma, a gente começou tem duas semanas (inint) [00:04:48], eu queria fazer um questionário para ver a pretensão do curso.

Pesquisadora: Sim, você pode fazer, tudo contribui para a nossa análise. E o produto do nosso trabalho não é simplesmente analisar dados, mas que a gente sente e escreva um documento com algumas ações do que é possível melhorar na rede estadual de educação, porque essa foi uma conversa que eu tive com a professora Cecilia, a secretária de educação, ela espera esse documento de nós, porque ela também está como presidente do CONSED, ela abrange o Brasil todo, e a partir desse trabalho, nós produziremos um documento, que vai chegar na professora Cecilia, e dentro dessa gestão que ela assume agora por mais quatro anos, para ver o que nós conseguimos implementar a partir do que o grupo produziu, há essa possibilidade, não é uma hipótese, ela já me garantiu, inclusive ela quer levar o que for produzido aqui para o CONSED, como exemplo para outros espaços, com outros secretários de educação, então é um trabalho muito importante, muito gratificante, para mim, para o grupo, pensando na educação do nosso Estado, eu acho que é uma coisa possível de realizar, que não vai morrer no papel, a minha esperança é que a gente consiga chegar até lá. No encontro que vem, que é um encontro super importante, que é quando o aluno discorrem sobre as razões, porque ele quer ser professor, porque ele não seria, quais os cursos que ele quer, e a gente finaliza essa parte de análise. Os dois últimos encontros são para produzir esse documento colaborativo, o quanto antes a gente conseguir escrever e chegar isso na secretária de educação, eles vão 
poder trabalhar com a equipe técnica, quais ações que são possíveis implementar nesses quatro anos de gestão. Sempre pensando no estudante principalmente, porque é o que a gente quer, que ele aprenda, então é super importante a gente estar discutindo, e não só discutir, mas ter um produto dessa discussão, do que a gente pensa que pode fazer, e conversando com a secretária de educação e a equipe técnica da SED/MS, a gente vai ver o que é possível implementar nesse prazo que eles tem de gestão. Eu super agradeço, muito obrigada, eu fico super feliz de ter esse grupo, e eu espero que seja leve para vocês esse momento, são pessoas que têm muita qualidade para discutir e bem objetivas, então agradeço, desejo um ótimo fim de semana para todos, e para o próximo encontro, eu vou sempre mandar um lembrete, não é que eu esteja cobrando, mas é porque está tão corrido, que eu adotei esse negócio de mandar o cronograma pelo WhatsApp.

[00:09:56] 


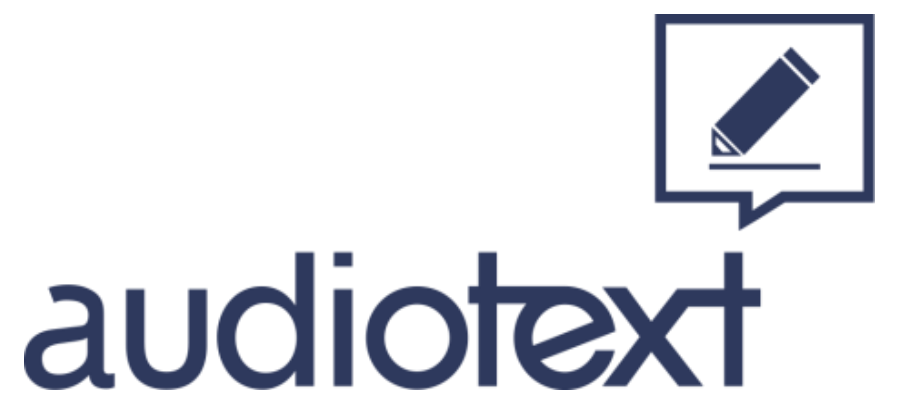

Audiotext Serviços e Cia. LTDA

CNPJ: 17.429.373/0001-85

(41) 3363-3220

falecom@audiotext.com.br

audiotext.com.br 


\section{PARTICIPANTES}

Técnico da Secretaria de Estado de Educação - Técnico da SED/MS 3 - P9

Pesquisadora - $\mathrm{P}$

\section{TEMPO DE GRAVAÇÃO}

25 minutos e 28 segundos

\section{MODALIDADE DE TRANSCRIÇÃO}

Padrão

\section{LEGENDA}

$\ldots \rightarrow$ pausa ou interrupção.

(inint) [hh:mm:ss] $\rightarrow$ palavra ou trecho ininteligível.

(palavra) [hh:mm:ss] $\rightarrow$ incerteza da palavra transcrita / ouvida.

A Audiotext Serviços e Cia. Ltda se reserva o direito da imprecisão dos nomes escritos, uma vez que os locutores serão identificados conforme a pronúncia de seu nome. O cliente tem o direito de fazer quaisquer alterações que julgar necessárias nas identificações aqui utilizadas. 
(INÍCIO)

[00:00:00]

Pesquisadora: Então vamos lá. Esse aqui são dados que mostram a pretensão de cursos para ingressar na universidade, no ensino superior. Então eu listei todos os cursos que eles fizeram a opção e vou dar um destaque maior nesses dez primeiros aí. Como você pode ver então direito é o curso de maior interesse deles, depois a engenharias diversas áreas, medicina, que a gente sempre pensa que primeiro é a medicina, mas aí no ranking está em terceiro lugar. Esses outros foram que não deram porcentagem, abaixo de zero vírgula alguma coisa a gente junta. Medicina veterinária, e o primeiro curso de licenciatura, eu coloquei em destaque ali que eles listam, é o de educação física, agronomia, administração, engenharia, psicologia, então quer dizer, o que é que importante observar aqui que nesse ranking de dez só aparece um curso de licenciatura que é do interesse deles. Depois, vamos lá. Nutrição, ainda 2,80\% não sabem o que querem cursar, aí a gente vem com arquitetura e urbanismo, odontologia que era um curso realmente que eu pensei que estivesse entre os dez e não estaria, biologia que aí vem uma próxima licenciatura, estética, fisioterapia, cursos técnicos das diversas áreas, ciências contábeis, aí vem a letras 1,18, quer dizer, uma quantidade pequena de alunos, a carreira militar que eu achei que fosse algo que estaria ali no ranking entre os dez não está, matemática 0,87 , que seria outra licenciatura, história também, a geografia onde aparece, química também bem poucos, que é a sua área, não é Tom, a química. Física também, música, artes, filosofia e licenciatura outras quando não atinge uma porcentagem. Eu acho que é isso. Aí eu gostaria que você... se pudesse comentar para mim na sua visão.

Técnico da SED/MS 3: Nós temos o direito ganhando ainda assim a gente vê que por mais que a gente tenha o direito, a engenharia e a medicina ainda são aquelas profissões que geram não só o impacto no âmbito de conhecimento, mas também de status na sociedade, então eu acredito que isso está muito 
relacionado ao próprio status que a sociedade dá em função da profissão. $E$ as outras profissões elas vão se agregando ali de uma certa maneira como, as vezes no terceiro ano o aluno nem tem muito essa ideia do que ele realmente quer, durante a sua trajetória talvez ele tenha se identificado com uma situação, porque também você vê administração com 368 também é um número razoável em função de você ter aí hoje muito desses estudantes participando de empresas privadas, o que impacta eu acho que diretamente dentro desse processo. Porque eu lembro exatamente quando eu estava no ensino médio eu participei de estágios dentro do Correios e Telegrafo, então quando você está naquele mundo e você vai desenvolvendo atividade, você vai vivenciando aquilo, as vezes você fala assim: "Nossa, eu gosto de fazer isso aqui", e aí por um lado você olha e fala assim: "Eu acho que eu quero fazer administração", é tanto que num teste vocacional que eu fiz da época, por ter participado de estágios em empresas o perfil profissional que eu tinha da época era para administração de empresas. Então assim, eu vejo que o meio ele vai moldando também essa escola do estudante e hoje enquanto, por exemplo, técnico, formador, eu tenho determinadas facilidades em lidar com demandas administrativas, porém existe um outro desejo, um outro sonho dentro desse processo. Então eu vejo que o ser humano, ainda mais o adolescente que está nesse processo de formação, de escolha, ele vai fazer a sua opção ou verbalizar isso eu acredito que talvez não seja nem assim o desejo, vamos dizer assim de vida mesmo, mas ele vai verbalizar aquilo que está mais próximo dele ou acredito que aquilo que ele entende que a sociedade acredita que é a profissão do sucesso, porque todas são profissões de sucesso, em todas as gente pode ter o sucesso profissional. Então isso é onde a gente trabalha muito essa questão do projeto de vida, realmente é isso que você quer fazer? A gente tem a doce ilusão "Ah, porque é médico, é isso", mas você sabe o quanto que essa pessoa trabalha, quantos plantões eu preciso fazer, será que eu estou disposto a essa rotina de vida, de (inint) [00:05:47] "Eu quero ser juiz", quanto que eu vou ter que estudar? Será que eu tenho noção desse caminhar aqui? Então eu acredito que ainda há uma tendência muito pela 
questão social e até mesmo por desconhecer, porque todas as profissões há possibilidade de sucesso, todas, eu acho que é uma concepção de a gente trabalhar muito isso, o que é ter sucesso para mim? O que é que sucesso para o estudante? E fazer com que dentro dessa formação dele ele, de fato, consiga identificar o que ele mais gostaria de fazer, porque muitas vezes eu posso fazer uma medicina, uma engenharia e um direito e no final das contas eu terminar e dizer assim: "Poxa, não era isso que eu queria", e aí? Então essa questão da maturidade na escolha da profissão vinculada as experiências de vida que eu tenho eu acredito que é o que faz refletir um pouco nessa estatística.

Pesquisadora: Então, uma coisa que eu queria te perguntar voltado mais para a pesquisa, você viu que só aparece um curso de licenciatura ali nos dez primeiros.

Técnico da SED/MS 3: Sim.

Pesquisadora: Por que você acha que acontece isso e porquê a educação física?

Técnico da SED/MS 3: Pela experiência de sala de aula e a mim enquanto educador eu vejo assim, na escola a gente vê muito essa questão assim do aluno "Amei a aula de educação física", inclusive eu tenho uma experiência do ano passado onde eu precisei utilizar a aula de educação física do professor e foi um transtorno tipo ter que usar uma aula de educação física eles não queriam, os alunos não queriam liberar aquela aula. Então assim, eu tive que ceder a minha próxima aula para eles poderem ter a aula de educação física deles. Então quer dizer era para eles a educação física era justamente a disciplina onde eles conseguiam ter esse divertimento vamos dizer assim, só que de uma certa maneira eu vejo assim, a educação física além dos jogos do futsal, e isso é muito característico que os meninos querem jogar bola, querem jogar futsal, eu vejo que ela precisa ampliar a sua perspectiva, porque eu posso pensar que eu quero fazer educação física em função das minhas práticas esportivas da escola, que são legais, são divertidas, mas quando eu vou para um curso de educação física tenho química, quando eu vou para um curso de educação física eu tenho a parte de nutrição, eu tenho a parte de anatomia, eu 
tenho uma série de outros componentes que não está atrelado somente as atividades físicas, mas justamente uma parte da saúde do ser humano e aí, as vezes, ele vai para o curso de educação física, esse aluno vai e ele chega lá e as vezes ele se frustra, porque ela fala: "Poxa, eu vou ter que estudar química? Como assim? Eu vou ter que estudar química biológica? Eu vou ter que estudar anatomia? Mas eu achei que eu só ia estudar os jogos". Então eu vejo que a educação física, dentro do seu processo de ensino e aprendizagem ela não pode se reduzir simplesmente a atividades esportivas, mas ela precisa ampliar a sua concepção em termo de saúde, saúde mesmo, saúde física, saúde mental, nutrição, que eu acredito que os professores da rede tenham buscado fazer esse trabalho. Mas eu vejo que essa atratividade maior, que inclusive é uma coisa que a gente precisa até analisar, esses 452 são meninos, são meninas? Então se existe uma equidade dentro desses valores porque a tendência é que os meninos tenham maior pré-disposição para fazer, apesar que hoje eu acho que essa diferença entre meninos e meninas no curso de educação física já tem mudado bastante. $E$ hoje também se tem muito a questão do que é a beleza, do que é o corpo e aí você tem um bum de academias, então quer dizer "Eu quero ser um personal. Eu quero ser um instrutor". Então eu vejo que é atrativo para o adolescente, principalmente para os meninos que estão nessa fase, porque você tem ainda uma cultura do corpo, da beleza e que hoje as academias têm infestado em muitos lugares.

Pesquisadora: A mídia também, não é?

Técnico da SED/MS 3: A mídia e a própria concepção de beleza mudou, o que é belo hoje? E aí eu fazer isso no sentido também daquilo que me atraí enquanto... por isso que eu digo que o impacto dentro da sociedade em função daquilo que você tem de uma cultura e de um valor ele vai fazer com que você tenha uma tendência a fazer uma escolha, mas eu vejo que a educação física tem grande influência até mesmo pelo seu caráter lúdico, pelo seu caráter que vai fazer... é onde eles, vamos dizer assim, é onde eles têm um maior...

Pesquisadora: Sair fora da sala de aula. 
Técnico da SED/MS 3: Aula de Educação Física é também liberdade para ser quem eles querem ser, para extravasar aquela energia toda. Então eu vejo que aí tem sim uma forte influência das atividades esportivas nessa escolha.

Pesquisadora: Ótimo. Aí então o que é que eu queria te perguntar, você percebe aqui que há pouca escolha em relação aos cursos de licenciatura de um modo geral, você acha que isso é preocupante para a sociedade? Como que você vê essa questão?

Técnico da SED/MS 3: Olha, em relação as licenciaturas, eu percebo um processo histórico, muitas vezes, assim, ele quer fazer um outro curso, porém ele presta um vestibular, ele presta um ENEM e as vezes a pontuação não alcança aquilo que ele gostaria, logo eu passo a tentar escolher um curso que enquadre dentro daquilo que eu tirei enquanto nota e enquanto de conhecimento e aí o que é que acontece, se a gente faz uma avaliação das notas do cursos de licenciatura nos vestibulares, vamos pensar, e no ENEM você vai ver que são notas baixas, não são notas altas. Então assim, é difícil você olhar isso e dizer assim: "Poxa, será que todas essas pessoas queriam fazer licenciatura ou elas estão escolhendo porque elas não conseguiram aquilo que elas gostariam?". E aí existe um fator primordial que eu vejo que é o imediatismo, eu terminar o meu terceiro e eu achar que eu já tenho que entrar na universidade, eu achar que eu já tenho que "Ah, eu já preciso partir para a universidade", então não vou me dar a oportunidade de estudar um pouco mais e ir para aquele curso que eu realmente gostaria de ir. E em relação ao quantitativo de escolha pelas licenciaturas muitas vezes eu vejo assim, hoje dentro do processo, como eu até escrevi na pesquisa, eu acho que o aluno vê aquele contexto de sala de aula, que não é um contexto tão simples, é um contexto complexo e eles devem observar o professor nessa dinâmica de tipo: "Como que você consegue lidar com esses 40 alunos, com esses 35 alunos dentro de sala de aula, e ainda, vamos pensar assim, ter a vida que você tem?", porque aí entra muito essa questão, principalmente do capitalismo eu vejo assim, o capitalismo tem uma forte influência nessas escolhas porque uma vez em sala um aluno me perguntou assim: "Poxa professor, mas você não tem 
carro?", aí eu pensei qual que era a razão de um aluno me perguntar se eu tinha carro ou não, então quer dizer, eu falei assim: "Será que ele acha que eu nunca vou ter um carro por ser professor?". Então existem esses estereótipos também, só que eu acho que o aluno desconhece a estrutura e a política hoje para os professores do nosso país, e principalmente do nosso estado de Mato Grosso Sul que, hoje, ele é um dos professores mais bem remunerados do Brasil em termos salariais comparado, fazendo um paralelo aos outros estados. Então não faz mais sentido eu dizer que eu não vou ser professor porque eu vou ganhar mal ou porque eu não vou ter uma qualidade de vida e que não é qualidade de vida estar... Não, isso já não faz mais sentido, mas para o aluno que está ali que só vê o imediatismo eu acredito que faz sim, ele vai observar esse professor, essa dinâmica, como que ele vai dar aula em uma escola e em uma outra, e ele se vê naquela condição, ele fala... ele está numa condição de adolescente, ele vê outro adolescente e ele fala: "Nossa, como que eu vou ter que lidar com esse monte de adolescente? Como que você aguenta, professor?", as perguntas são essas, porque são inúmeras situações, às vezes, de indisciplina dentro da sala de aula, inúmeras situações de problemas sociais dentro da escola e o aluno vivencia isso eu acho que ele olha aquilo e fala assim: "Eu não quero lidar com isso, porque eu já não consigo lidar nem com os problemas, imagina como que eu vou lidar com esse monte de gente". Só que naquele momento ele não tem consciência que quando ele, vamos pensar que ele seguiu a profissão, quando ele estiver na profissão ele vai ter uma outra maturidade, ele vai ter uma outra cabeça, ele vai ter uma formação e um suporte para lidar com isso. Então eu vejo que essa escolha ela está relacionada a esse contexto e é uma tendência muito grande é a gente querer sair do contexto que a gente está hoje, que é um contexto problemático, as vezes eu estou num problema e eu não quero vivenciar mais isso, eu quero partir para outras, então outros desafios, outras oportunidades. Então eu já passei a minha vida inteira na escola eu quero voltar para a escola enquanto professor? Então eu vejo que tem esses pensamentos enquanto adolescente, então "Poxa, eu já vivi tudo isso aqui na escola eu tenho que voltar para a 
escola, mas agora como professor?". Mas a carreira docente realmente ela é um desafio, para você conseguir escolher isso com profissão, vamos pensar assim, a carreira como profissão o aluno ele tem que ter... E o que a gente vai ver muito aí são os trabalhos de apresentação, aqueles alunos que gostam de apresentar, que gosta de falar, que tem uma retórica muito bem, vamos dizer, fundamentada aí por base de trabalho, geralmente esses alunos tem uma tendência assim: "Eu quero ser professor porque eu gosto de falar, eu gosto de ensinar, eu gosto de socializar com os outros aquilo que eu tenho", então existe esses estudantes, esse perfil de estudante, o estudante que dentro das suas práticas pedagógicas ele consegue se destacar numa oratória, numa explicação, aquilo que o professor não conseguir ele vai lá e explica, e aí ele vai se percebendo professor eu acho, ele vai se percebendo que ele gosta de ensinar o outro. E esse ensinar o outro perpassa justamente pela empatia de querer entender que o outro não entendeu e que eu posso, de alguma maneira, promover algum mecanismo que você entenda aquilo que alguém falou de um jeito, mas que eu estou te falando de outro e que você entende. Então existe muito isso, mas porque a linguagem entre os pares ali ela é muito próxima, então as vezes aquele aluno que está um pouquinho, vamos dizer, cognitivamente um nível acima de complexidade, de abstração nas suas competências, ele consegue perceber aquilo que o professor traz e ele ainda tem uma outra habilidade que é transpor isso na linguagem do colega, porque ele está na mesma linguagem e no mesmo pensamento. Então eu vejo que a profissão aí das licenciaturas, não seria das licenciaturas, mas das áreas de conhecimento em si elas perpassam por essa questão, eu pontuaria assim, da questão do imediatismo dentro dos vestibulares, dentro daquilo que eu não consegui alcançar eu vou fazer logo porque a sociedade quer que eu seja alguém e para ser alguém eu preciso ter uma graduação, então isso ainda é muito forte. A questão de eles se verem enquanto adolescentes cuidando de outros adolescentes, essa transposição de futuro ainda é muito longínqua para ele, vamos dizer assim. E principalmente aqueles que se destacam e que querem isso. Eu sempre digo assim, seja professor, educador porque você 
quer ser educador, não porque the faltou opção na vida. Então eu carrego sempre isso comigo e eu sempre coloco isso para os alunos: seja educador porque você ser quer ser um educador e não porque the faltou opção de escolha, porque dá a entender muitas vezes que quem cai na licenciatura é porque the falou opção de vida, não é isso, a gente tem um perfil de muitos profissionais frustrados hoje porque não era isso que eles queriam fazer, se você faz uma pesquisa. Eu já vi muito algumas pesquisas nessa área "Ah, mas eu queria ser tal coisa, mas aí eu caí na licenciatura", então, poxa, será que realmente era isso que você queria fazer? E eu fico pensando no tanto de prejuízo emocional que gera na vida das pessoas de eles fazerem isso, aí a gente tem em todas as áreas a gente tem profissionais frustrados, mas na educação assim a gente finda encontrando um número maior por essas questões de escolha lá do passado e eu acredito que para os meninos é a mesma coisa.

Pesquisadora: Ok. Então vamos lá para o próximo slide, passado. Aqui mostra a intenção de ingresso em instituições de ensino superior, então você percebe que a UFMS em primeiro lugar ali, 22,30\%, outras instituições que somando dá aquele $20,50 \%$, aí nós temos aqui no estado a UFGD, o CDB, Unigram, alguns não sabem, aí a UMS, a UNIDERP, Federal, AMS, tem um outro quadro aqui, Anhanguera, Funec, Unesp, pública ele coloca, enfim, outras aí por baixo, IFMS, (inint) [00:20:49] lá embaixo. E eu gostaria assim que você comentasse, o que é que você acha olhando esse quadro?

Técnico da SED/MS 3: Bom, a gente vê ainda que as instituições públicas elas ainda são as mais citadas.

Pesquisadora: Citadas.

Técnico da SED/MS 3: Um primeiro fator que a gente pode relacionar é justamente a questão monetária por ser uma instituição gratuita, e as outras instituições públicas elas entram aí em segundo plano, mas eu acredito que por uma via hoje de políticas públicas, então quer dizer, um Prouni, um vale universitário, $50 \%$ de bolsa, porque hoje as universidades particulares elas têm facilitado essa questão de $50 \%$, outras oportunidades para o aluno, então, mas 
ainda assim as públicas elas têm esse peso tanto pelo seu fator eu acredito que pela cultura de ensino, de pesquisa, porque é uma diferença muito grande, ainda a gente vê que as pesquisas nas universidades públicas elas ainda avançam nesse sentido e ainda são atrativas para quem quer se desenvolver. Eu lembro exatamente que eu precisei fazer essa escolha no passado aonde eu passei num curso de administração com uma bolsa 100\% e passei numa federal, na minha cabeça em química, por ser numa federal, era, olha só, eu tinha passado em administração 100\% com uma bolsa num programa chamado Jovem Talento do estado de Rondônia em Porto Velho, não ia ter nenhum custo para cursar administração e passei no mesmo tempo na federal para química. Então entre a administração de empresa que foi o perfil destacado na época e a federal, eu escolhi a federal por uma questão de peso, na realidade era uma questão de peso e de diploma na época, cultural, não foi porque... por mim eu faria os dois, mas assim, naquela época eu precisei fazer uma escolha. Então para mim esse peso ainda da instituição pública por ser uma federal, uma estadual, ainda isso pesa bastante na escolha dos alunos, e a questão financeira mesmo, eu acho que a questão financeira é que pesa na hora de eu fazer a escolha, porque como que eu vou pagar um curso com a minha renda, como a gente viu lá, não é uma renda... porque para ele o que ele vai ganhar a vida é o que eu ganhei muitas vezes, ele acha na cabeça dele que é aquela renda, que não pode... Então como que eu vou pagar uma particular? Estou saindo do terceiro ano, estou tendo que trabalhar, não tenho como pagar esse curso. Então a minha escolha ainda é a universidade pública, porém se a gente pensa em termos de qualidade as universidades particulares já tem também aumentado esse nível de qualidade, já não dá mais para você dizer assim: "A pública é a melhor e a particular é ruim", não porque nós temos instituições particulares extremamente equipadas com equipamentos fantásticos que muitas vezes as instituições públicas que dependem de recurso não tem, que depende de liberação de verba federal, não possui e as instituições públicas por ter investidores possuem, e aí a gente faz esse paralelo: até que ponto a pública, de fato, tem esse peso todo por ter a 
pesquisa e até que ponto a particular com toda a sua estrutura, mas com falta de pesquisa consegue fazer um bom ensino. Então são dois paralelos assim que tem que aguentar. O curso de medicina da UNIDERP tem uma estrutura fantástica e os cursos de medicina das nossas públicas será que realmente o que eu tenho numa particular enquanto estrutura, equipamentos as minhas públicas estão tendo? Porque a pública a gente sabe que depende de licitação, depende de recurso, de pesquisa, investimento e muitas vezes isso leva anos para conseguir, e se eu já tenho capital para fazer esse investimento e ter essa estrutura de uma certa maneira as práticas elas se tornam até mais efetivas na aprendizagem. Então, mas na perspectiva do estudante eu vejo que vai impactar a questão monetária e uma questão cultural de que as universidades públicas são as melhores em termos de ensino.

Pesquisadora: Ok. Vamos lá. Próximo. Só um pouquinho.

[00:25:28] 


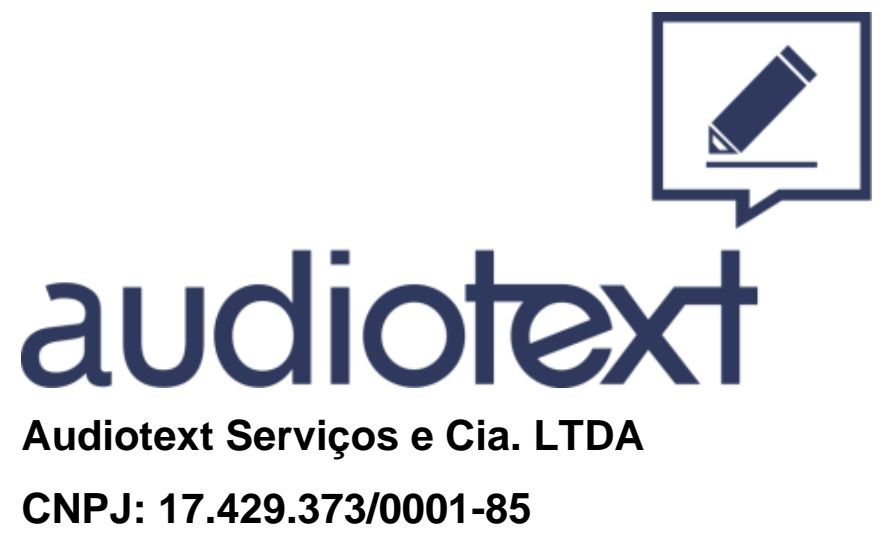

(41) 3363-3220

falecom@audiotext.com.br audiotext.com.br 
TRANSCRIÇÃO

S12917J2 - WIN_20190405_09_50_48_Pro 


\section{PARTICIPANTES}

Técnico da SED/MS 3 - P9

Pesquisadora - $\mathrm{P}$

\section{TEMPO DE GRAVAÇÃO}

25 minutos e 17 segundos

\section{MODALIDADE DE TRANSCRIÇÃO}

Padrão

\section{LEGENDA}

$\ldots \rightarrow$ pausa ou interrupção.

(inint) [hh:mm:ss] $\rightarrow$ palavra ou trecho ininteligível.

(palavra) [hh:mm:ss] $\rightarrow$ incerteza da palavra transcrita / ouvida.

A Audiotext Serviços e Cia. Ltda se reserva o direito da imprecisão dos nomes escritos, uma vez que os locutores serão identificados conforme a pronúncia de seu nome. O cliente tem o direito de fazer quaisquer alterações que julgar necessárias nas identificações aqui utilizadas. 
(INÍCIO)

[00:00:00]

Pesquisadora: Esse quadro ele mostra o quantitativo de alunos que afirmam que em algum momento da vida pensaram em ser professor, não quer dizer que realmente ele queira ser professor, ele só pensou. Então você vê que a maioria ali, olha, 63,38\% nunca pensou em ser professor e 2.891 já pensaram em ser professor. Como que você analisa essa questão?

Técnico da SED/MS 3: Olha, eu imagino que se a gente vai pensar numa prática de, vamos supor, na formação inicial desse estudante até o seu terceiro ano ele vai passar por diversas fases da vida, então a gente vê a questão desde a educação infantil, da alfabetização, aquela criança que já brinca com a outra de ensinar de casinha de ser o professor. Uma vez até esses que digam que não quiseram ser professores lá na infância tentaram ser de alguma maneira, mas que não se recordam, porque a memória tem uma tendência a ser deleta com o tempo. E eu vejo que esses que em algum momento pensaram em ser professor são aqueles estudantes que vão se identificando com os seus professores e é justamente aquilo que a gente falou anteriormente, eu consigo transcrever uma linguagem que eu entendi e esse prazer que a gente tem quando a gente contribui com o outro, quando a gente se sente útil no desenvolvimento que o outro conseguiu alcançar por meio daquilo que você promoveu eu acredito que gera essa sentido de "Ah, eu acho que eu quero ser professor". E fora que esse querer ser professor vai perpassar pelos perfis de professores que esses alunos tiveram, muitas vezes: "Eu quero ser o professor de matemática", então, por exemplo, no fundamental eu queria ser professor de matemática porque eu era bom em matemática, porém no ensino médio eu decidi que eu queria ser professor de química. Mas assim, qual o impacto nisso tudo? Foram meus professores. Então assim, essa identificação com o professor, com a metodologia do professor, com a empatia que esse professor possui e com esse desejo, porque assim, o ser professor é 
sempre um desejo, como é uma profissão de assistência ao outro, não de assistência a eles, mas de assistência ao conhecimento, a essa construção, eu vejo assim que esse desejo, quando eu tenho um perfil de empatia eu fico querendo desenvolver essa profissão, porque eu vejo a realização do outro por meio das minhas ações. Então eu acredito que esse perfil de estudante que citou é aquele estudante que se identificou em algum momento com um professor, em algum momento ele percebeu que ele conseguia fazer essa ação de ensino, de aprendizagem com o colega e nisso ele desenvolveu, por um momento, que seja o desejo de ser professor.

Pesquisadora: Aqui ele mostra nessa tabela se pensa em ser professor, seria da educação básica, do ensino superior ou de uma disciplina específica do fundamental ou do médio, então aquele não mostrado são aqueles que jamais pensaram em ser professor, então exclui-se esse dado e a gente passa a trabalhar então com aqueles que pensaram. Então de alguma disciplina específica do sexto ao nono, que é a maioria lá, ensino médio $14.37 \%$, do ensino superior $9,30 \%$, educação infantil $7,64 \%$ e de primeiro ao quinto ano $5,31 \%$, que de certa forma você viu ali que está atrelado a disciplina em específico que é o que você acabou de comentar, que em algum momento ele tem facilidade nessa aprendizagem e também pelo perfil do professor.

Técnico da SED/MS 3: Sim. Essa questão a gente vê muito mais... eu acredito também é uma identificação de fase da vida, isso para mim está muito relacionado a melhor fase em que eu vivi na minha escola, então eu tenho essa tendência a reproduzir aquilo que foi a melhor fase para mim. Então se ele é um aluno onde a professora dá educação infantil para ele foi a professora que mais destacou, eu acredito que naquele momento ele consegue fazer essa (inint) [00:05:00] diz assim: "Não, eu quero ser professor porque eu tinha uma professora na educação infantil que era assim e assim", então isso traz memórias positivas e isso pesa muito no meu campo de escolhas, a gente escolher por aquilo que nos traz bem-estar. E eu vejo que aí a fase principal são... É tanto que no nível superior eu acredito que já são... Porque quando a gente põe lá biologia, por exemplo, será que ele quer ser o professor de 
biologia ou ele quer ser o biólogo como bacharel, será que eles conseguem fazer essa distinção? Por exemplo química, eu posso fazer química para ser um químico, mas eu também posso ser um professor de química, porque é umas atribuições das 14 atribuições que um químico possui, então a quarta atribuição, por exemplo, é a licenciatura, mas só que existem inúmeras outras profissões. Então existem outras situações que também se tornam atrativas dentro da profissão que não é só a licenciatura, então é um ponto também que a gente poderia questionar: será que esse biólogo é biólogo por biologia ou só pela licenciatura em si? Apesar que todos ali caem na licenciatura. Mas aí eu vejo também que está muito relacionado a... Eu diria que assim ao meu melhor momento na escola.

Pesquisadora: Vamos lá. Aqui se pensa em ser professor do sexto ao nono ano, ensino médio, seria em qual disciplina. Veja bem, olha, educação física ranqueando de novo e aí a gente viria a matemática, história, biologia, língua portuguesa, geografia, física, inglês, artes, química, filosofia, literatura, sociologia e ciências. Deixa eu só passar aqui. Não, é isso mesmo. Como que você analisa isso? Da educação física você mencionou no quadro anterior, não é?

Técnico da SED/MS 3: Sim. Em relação me surpreende a matemática ali, sabe, me surpreende a matemática por uma questão mesmo que os dados mostram que os alunos não avançam na aprendizagem de matemática, então a gente vê que, tipo, numa análise no âmbito estadual do Brasil 7\% dos estudantes aprendem matemática. Então será de que matemática que eu estou falando? Será que eles têm noção? Por isso que eu disse, será que eles têm noção do que é um curso de matemática? Porque aí você vai fazer uma estatística das universidades nos cursos de matemática e o índice de evasão é enorme, porque na cabeça do estudante que está ali ele está enxergando a matemática só como aquelas operações básicas e a matemática ela é muito além disso, ela transcende o Teorema de Pitágoras, ela transcende uma questão de uma fórmula de Báskara. Existe toda uma contextualização que, muitas vezes, o estudante ainda não percebeu isso, então por ele ter uma facilidade 
operacional "Ah, eu quero ser professor de matemática". E eu vejo que talvez faltaria clareza de ele entender mesmo o que é, porque o dado me mostra que os estudantes não aprendem matemática e aí eu quero ser um matemático de algo que de alguma maneira eu não desenvolvi com clareza? Então eu acredito que o desejo intenso aí é mais pela facilidade operacional de achar que aquela ciência, aquele estudo é só aquela operação do que pela profissão em si de matemática, porque não é uma profissão atrativa, matemática não é uma profissão atrativa, eu acho que se não for, de alguma maneira, para aqueles que querem ser matemáticos, porque até para o mercado de trabalho não é, assim, ou é universidade ou é a pesquisa, ou você vai desenvolver outras funções paralelas juntando o seu conhecimento a partir da matemática. Me surpreendeu a matemática como uma disciplina aí com 163 alunos em vista do campo total que a gente estava olhando. Mas aí eu vejo que está relacionado a facilidade operacional, entendeu? Muito mais achar que eu consigo, e eu entendo e na realidade é uma das habilidades, porque se a gente for pegar e avaliar isso enquanto conhecimento eu tenho certeza que a estatística vai mostrar que não é bem assim. História também eu... História, biologia, língua portuguesa, geografia. A história eu já não... eu não teria tanto esse destaque assim, mas assim, o que me surpreendeu foi a matemática.

Pesquisadora: Foi a matemática, ok.

Técnico da SED/MS 3: E as outras assim, eu acredito que está muito relacionado aquilo que a gente já pontuou.

Pesquisadora: Sim, anteriormente. Então é isso, então vamos lá para o próximo. Qual a principal razão para escolher ser professor? Então os que não responderam entram naquela estatística daqueles que nunca pensaram em ser professor. Então o primeiro lá, transmitir conhecimento para as pessoas com $10 \%$, outros também é que somando dá aquela porcentagem. Gostam de trabalhar com criança, identifica se eu gosto dessa profissão, gostam de determinada disciplina do currículo, profissão digna, com boas oportunidades de emprego e estabilidade financeira, admiração pelos professores, melhorar a 
qualidade do ensino público no país, facilidade de comunicação e interação com as pessoas.

Técnico da SED/MS 3: Então se a gente pegar aí tudo aquilo que a gente já falou, a questão da transmissão do conhecimento para as pessoas, gosto de determinada disciplina do currículo, admiração pelos professores que eu tive, facilidade de comunicação e interação com as pessoas então são todas questões que eu pontuei que se a gente soma isso daria o perfil do estudante que a gente tem. Então, mas o que mais realmente saiu que a gente pontuou aí é justamente essa questão de transmitir o conhecimento para as pessoas. Então, quer dizer, em algum momento ele identificou que ele tinha essa facilidade e ele entendeu que ele podia ser professor. Então essa questão de transmitir o conhecimento é onde eu vejo que ele percebe-se com a oportunidade de ser professor, é onde ele se realiza enquanto ser humano, é onde ele consegue ver que o outro avançou, aí tanto que é um destaque. $\mathrm{E}$ essa questão disciplina também, gosta de determinada disciplina, do currículo, a identificação com o conhecimento, porque eu vejo assim, a gente só não gosta daquilo que a gente não entende, então assim, eu vou me identificar com aquilo que eu compreendo, aquilo que eu não compreendo e que eu não tenho elementos para aprender é uma tendência minha não gostar. Assim como eu me formei na área de ciências da natureza hoje eu tenho descoberto a área de ciências humanas, hoje eu tenho descoberto a área de ciências da linguagem, mas assim: será que eu nunca gostei ou será que eu não entendia? Então isso é um ponto a ser discutido, de fato, a gente não gosta de determinado conhecimento porque não sabe, não entende ou porque realmente eu não gosto? Então é uma questão a se pontuar aí mesmo. Então eu escolho aquilo, gosto de determinada disciplina por quê? Porque eu entendo a disciplina, porque eu tenho facilidade para transmitir esse conhecimento para outras pessoas, mas será que se ele desenvolvesse aquela outra habilidade ele também não gostaria, desse outro componente? Uma questão de melhoria de qualidade no ensino público eu vejo isso como... eu vejo isso até como uma das maiores razões, eu acho que pela situação, vamos dizer assim, 
socioeconômica dos estudantes, porque a gente tem um desejo nesse sentido de melhorar o país enquanto situação que eu vivo, eu vejo assim: eu quero melhorar isso de alguma maneira, não é possível que eu não consiga fazer algo para melhorar a situação não só minha, quantas pessoas passam pelo que eu estou passando. Então essa identificação com a situação socioeconômica e visualizar isso dentro da sociedade também desperta um desejo no ser humano de querer fazer algo pelo outro e de querer mudar essa realidade. Então eu acredito que melhorar a qualidade do ensino público aí é justamente nesse sentido que os estudantes estão querendo dizer, eles se identificam numa situação de vulnerabilidade social, percebe-se isso e, tipo, o que eu posso fazer para ajudar? E aí é onde entra muito a questão da filosofia, da sociologia, de toda a história mesmo dentro desse processo.

Pesquisadora: Uma coisa que eu queria te perguntar, ali quando ele destaca profissão digna com boas oportunidades de emprego e estabilidade financeira você acha que tem mudado essa questão da valorização desse professor, ele já começa a enxergar dentro da carreira do magistério, da docência uma boa oportunidade de emprego e de estabilidade financeira?

Técnico da SED/MS 3: Sim. É o que eu estou dizendo, para a realidade do nosso estado eu acredito que para esse estudante ele vê o professor como uma boa carreira, porém eu acredito que se a gente fizesse essa mesma pesquisa em outros estados e em outros municípios nós não teríamos isso como uma questão, talvez a profissão digna sim, mas não como uma oportunidade de emprego e estabilidade financeira, porque aí são questões diferentes da profissão digna e da oportunidade de emprego e estabilidade financeira. Para o Mato Grosso do Sul hoje eu acredito que pelo salário que os professores recebem e aí a gente tem uma questão estética também, como que esse professor trabalha com esse aluno, uma questão estética física, como que ele vai trabalhar, ele é um professor bem arrumado, ele é um professor que ele tem carro, os alunos observam isso, hoje os alunos são muito perceptivos nesse sentido da estética desse professor, como que esse professor trabalhar, qual é a estrutura da minha escola. Esse professor ele tem 
um notebook, esse professor ele tem uma iPhone. "Ah, professor o seu não é iPhone”. Então quer dizer, isso influencia a percepção do aluno, porque muitas vezes o aluno ele observa justamente esses detalhes, os elementos que o professor leva para a sala de aula, como que esse professor está vestido, como que esse professor chega, como que esse professor sai, o que é dignidade para ele. Um aluno que vive em vulnerabilidade social, que quer manter a sua subsistência e quer ascender dentro de um plano social ele vai observa nos fatores estéticos, externos de um outro ser. Então eu acredito que nesse ponto, quando ele fala profissão digna, tanto da profissão do professor, mas digna enquanto ser humano, de condições de vida, não de condições de subsistência. Mas assim, a gente tem um estudo aqui do estado nosso que demonstra que no Mato Grosso do Sul nós não temos situações de miséria dentro da educação de Mato Grosso do Sul já tem, inclusive fundada, apresentada uma vez pela (inint) [00:17:46], nós não tínhamos essa situação de estudante em extrema miséria vamos dizer assim, extrema pobreza. Então isso é um dado eu acredito que relevante também dentro dessa perspectiva do estudo socioeconômico e eu entendo como estabilidade financeira. E a estabilidade financeira aí eu vejo muito nela ainda hoje que ainda falta uma questão, nesse estudante, de... como que eu posso dizer? De clareza do que é estabilidade financeira. O que é estabilidade financeira para mim? Porque eu posso ganhar 10 mil e não ter estabilidade financeira, eu posso ganhar 50 mil e não ter uma estabilidade financeira, mas eu posso ganhar 7 mil e ter uma vida organizada, uma estabilidade financeira. Então eu acredito que aí essa estabilidade financeira ela vincula muito a questão "Ah, é um concurso", é tanto que se a gente puxa lá para o primeiro eu vou ter o quê, eu vou ter direito, eu vou ter medicina, então está muito vinculado a questão do ganho, mas o fato de eu ganhar não significa estável. Eu posso ter comportamentos financeiros que fazem com que isso não seja estabilidade financeira, muito pelo contrário, que seja um problema financeiro para mim. Então eu acho que essa clareza ainda ela está... que eles pontuam de estabilidade financeira está muito mais vinculada a uma questão do quantitativo do que eu ganho do que do próprio 
conceito de estabilidade financeira, então é mais do que eu ganho do que a estabilidade financeira em si.

Pesquisadora: Ótimo. Vamos lá para o próximo. Agora a principal razão para não escolher se professor, de forma alguma eles não se identificam, não tem vocação ou não gostam dessa profissão a maioria, falta de paciência para ensinar, desvalorização dessa profissão pela sociedade, principalmente pelos governantes, salário baixo, ruim, profissão muito estressante, rotina cansativa, carga horária de trabalho extensa, preferem outros cursos, alunos indisciplinados e desrespeito dos alunos com os professores e dificuldade de ensinar pessoas.

Técnico da SED/MS 3: Olha, a dificuldade de ensinar pessoas... é o que a gente viu aqui... Se a gente começando lá não se identificam, não tem vocação e não gostam dessa profissão está muito vinculado aqueles que não querem, mas assim, a falta de paciência para ensinar ela cruza justamente com aquela questão do aluno que tem a facilidade de ensinar, que são os que pontuam, a desvalorização da profissão pela sociedade, principalmente pelos governantes, eu vejo isso muito pela questão da própria mídia, a influência da mídia no aluno, e é aquilo que a gente falou, na realidade de outros estados e como que isso é posto na mídia, realmente ainda falta essa valorização dos profissionais. Tem mudado, tem mudado e claro que nós gostaríamos de ganhar muito mais, mas a gente entende que a aprendizagem ela não está vinculada somente ao ganho desse profissional e que assim o que é que eu entendo como valorização profissional. A gente ainda tem a concepção de atribuir valorização profissional somente ao salário, mas assim como eu tenho juízes que ganham milhões e não são bons juízes, médicos que não são bons médicos, professores que não bons professores, eu tenho bons e não tão bons assim, vamos dizer assim, em todas as profissões, independente ou não de quantitativos financeiros. Então, de fato, essa questão da valorização profissional hoje eu vejo que também falta clareza para essa estudante, porque o que é essa valorização profissional? É só financeiro? Então a valorização profissional ela vai passar tanto pelo desenvolvimento dele enquanto ser 
humano, da formação desse professor, das suas condições de trabalho, da sua condição financeira, do seu salário, das oportunidades que ele tem para se desenvolver ao longo da sua profissão e da vida. Então quer dizer, existem inúmeros fatores que eu considero valorização profissional e que eu ainda enxergo valorização profissional somente como um ponto salarial, como uma soma e a soma ela não pode... Eu posso triplicar o salário de um professor, mas se aquele professor não mudar a metodologia dele ele vai continuar sendo aquele professor. Então não é uma questão somente de mudar uma questão salarial, mas em mudar também a postura do professor, mudar a postura do profissional e dar condições para esse profissional trabalhar. Então quando ele põe salário baixo e ruim, então o que é baixo? O que é ruim? Então quer dizer, a gente tem no mundo pessoas vivendo com menos de 1,92 dólares por dia. Poxa, espera aí, o que é ruim? É ruim para mim, é ruim para minha realidade? Então é uma concepção muito assim abstrata ainda para se dizer. Então eu vejo isso mais como uma opinião do que eu escuto. Profissão muito estressante, rotina cansativa é aquilo que a gente pontuou, eu me vejo dentro desse processo, o professor ali dentro da escola, aquele monte de aluno 0 tempo inteiro, o professor sai de uma escola e vai para outra, "Professor, você trabalha em quantas escolas?", isso é uma pergunta muito comum dentro da... "O senhor trabalha só aqui?", "Não, eu trabalho em duas, três escolas", "Nossa, como que você consegue trabalhar os três períodos?". E essa questão de os alunos indisciplinares e desrespeitosos também que está muito relacionado com aquilo assim: eu me identifico, como que eu vou lidar com esse monte de aluno mal-educado, com esses alunos que desrespeitam o professor, que não respeitam os colegas? É uma identificação dele com ele mesmo, com a postura dele dentro da sociedade, e aí ele não se vê enquanto pessoa gerenciando um adolescente como ele. Então essa perspectiva de futuro ainda está muito distante do aluno, é tanto que dentro da... A gente teve uma palestra essa semana e o estudo da neurociência mostrava que o cérebro do adolescente ele vai se desenvolver praticamente, principalmente a região pré-frontal, que é a região da nossa razão, vai se desenvolver ali até os 23 anos, então as vezes 
eu tenho um adolescente até os 23, 24 anos, que é impulsivo, que aquela parte do seu cérebro que diz assim: "Não, não faça isso", ela ainda... Então para ela essa impulsividade, como que eu vou lidar com essa impulsividade de todos eles? Eu acredito que faz muito essa questão de a profissão ser estressante e daí...[00:25:17] 


\section{L \\ audiotext \\ Audiotext Serviços e Cia. LTDA \\ CNPJ: 17.429.373/0001-85}

(41) 3363-3220

falecom@audiotext.com.br

audiotext.com.br 
TRANSCRIÇÃO

S12917J3 - WIN_20190405_10_17_36_Pro 
PARTICIPANTES

Técnico da SED/MS 3 - P9

Pesquisadora - $P$

TEMPO DE GRAVAÇÃO

07 minutos e 26 segundos

MODALIDADE DE TRANSCRIÇÃO

Padrão

\section{LEGENDA}

$\ldots \rightarrow$ pausa ou interrupção.

(inint) [hh:mm:ss] $\rightarrow$ palavra ou trecho ininteligível.

(palavra) [hh:mm:ss] $\rightarrow$ incerteza da palavra transcrita / ouvida.

A Audiotext Serviços e Cia. Ltda se reserva o direito da imprecisão dos nomes escritos, uma vez que os locutores serão identificados conforme a pronúncia de seu nome. $O$ cliente tem o direito de fazer quaisquer alterações que julgar necessárias nas identificações aqui utilizadas. 
(INÍCIO)

[00:00:00]

Pesquisadora: Esperar começar. Próximo ali. Para traçar o perfil geral dos participantes então incluiu questões sobre sexo, idade e raça. Então a maioria dos alunos participantes da pesquisa são mulheres e depois vem o masculino, os homens, mas como que você analisa isso. É só um dado na verdade.

Técnico da SED/MS 3: Aí a gente vê que realmente se a gente fosse pensar nas profissões cruzar esse dado...

Pesquisadora: Esse dado, não é?

Técnico da SED/MS 3: ... Com aquelas profissões, por exemplo, quantos, de fato, querem ser...

Pesquisadora: Sim.

Técnico da SED/MS 3: ... Fazer direito, fazer educação física? Será que aquela questão dar uma equidade entre meninos e meninas.

Pesquisadora: E menina, não é.

Técnico da SED/MS 3: Daria para fazer...

Pesquisadora: Que seria importante isso, não é.

Técnico da SED/MS 3: Se a gente, por exemplo, ter aquele, vamos pensar assim: direito, olha, no direito quantos por cento desses são...

Pesquisadora: São mulheres.

Técnico da SED/MS 3: ... São meninas.

Pesquisadora: ... E tantos são homens.

Técnico da SED/MS 3: Então se a gente tivesse isso com mais clareza daria para fazer uma...

Pesquisadora: Daria para discutir.

Técnico da SED/MS 3: ... Uma discussão melhor nesse ponto.

Pesquisadora: Melhor. Mas esses dados são mais para conhecimento mesmo. Agora que a contagem de dados que a gente comentou lá no primeiro encontro dão entre 17 e 18 anos estão a maioria dos alunos, 62, quase 63\%, 14 a 16 
que seria na idade apropriada, vamos dizer, 18,17, entre 19 e 20 anos, dez cento mais ou menos e mais que 20 anos acima de oito por cento aqui.

Técnico da SED/MS 3: Juntando aí 19 até 20 a gente tem $28,86 \%$ de distorção, então é um dado alto se a gente for pensar em (inint) [00:01:57].

Pesquisadora: Sim, em (inint) [00:01:58].

Técnico da SED/MS 3: É um dado alto. E...

Pesquisadora: Porque na verdade, olha, entre 17 e 18 anos ele deveria concluir o ensino médio com 16 anos, entre 16 e 17.

Técnico da SED/MS 3: 16 e 17.

Pesquisadora: Então se você olhar ali 17 e 18 já ultrapassou porque...

Técnico da SED/MS 3: Já tem uma...

Pesquisadora: Você teria que somar ali $62 \%$ com esses dez por cento mais esse oito por cento, então a maioria está em distorção da idade série.

Técnico da SED/MS 3: É, por um ano ali (inint) [00:02:32] por mais.

Pesquisadora: Por mais.

Técnico da SED/MS 3: Para ver que ainda é um dado alto.

Pesquisadora: Sim, altíssimo.

Técnico da SED/MS 3: (Inint) [00:02:36], são mais de 25\% de distorção.

Pesquisadora: Sim.

Técnico da SED/MS 3: E aí o que é que acontece, porque são 638 estudantes, são 851 estudantes que não conseguiram ter sucesso, vamos dizer assim, até a idade...

Pesquisadora: Regular.

Técnico da SED/MS 3: ... Que a gente considera correta para ele concluir o seu ensino médio. Então são fatores que a gente precisaria avaliar. Como eu vejo que nosso... a nossa pesquisa aqui (inint) [00:03:11] o índice socioeconômico é muito baixo, talvez eu entenda, possa fazer uma inferência, uma hipótese que esses estudantes precisaram trabalhar e deixaram a escola ou por outros motivos de estrutura familiar ou alguma outra situação, mas eu acredito que por aquele histórico socioeconômico talvez tenham deixado a escola para poder ajudar a família ou trabalhar. Eu acredito que é nessa... 
Pesquisadora: Nessa questão.

Técnico da SED/MS 3: É uma hipótese.

Pesquisadora: Vamos lá, a autodelclaração de raça. Então a maioria são pardos ou mulatos, eles se autodeclaram, $43 \%$, depois o branco $40 \%$, negro $9,23 \%$, o amarelo/oriental $3,90 \%$ e o indígena $2,96 \%$.

Técnico da SED/MS 3: É, a gente tem uma influência muito grande da questão, vamos pôr, oriental, da questão das colônias que nós temos japoneses aqui no estado de Mato Grosso do Sul, se eu não me engano é o segundo maior do país, a gente vê que é uma questão histórica, é claro que essa questão histórica ela vai se perpetuar ainda porque a gente ainda vê a questão (inint) [00:04:34] numa questão de proporção em menores cidadãos aí, a questão indígena que também a gente tem um menor quantitativo. Então eu vejo que essa questão da declaração aí da raça em si é uma questão histórica mesmo, se a gente for analisar.

Pesquisadora: Sim, a mistura. Aqui o estado de Mato Grosso do Sul é a segunda maior comunidade indígena do país, só perde para o Amazonas. Então, mas questão é, você vê, mesmo assim é um índice baixo de alunos indígena por exemplo, quantas escolas indígenas que tem na rede, você sabe dizer?

Técnico da SED/MS 3: Não, de cabeça assim classificada não.

Pesquisadora: De cabeça assim, não?

Técnico da SED/MS 3: Mas assim, a gente tem escolas...

Pesquisadora: Sim, indígenas, não é?

Técnico da SED/MS 3: Mas eu não... de cabeça assim eu não lembro. Mas assim, hoje essa questão indígena a gente já tem os alunos também não só nas aldeias, mas também na região urbana. A Marçal de Souza aqui em Campo Grande é uma.

Pesquisadora: Sim.

Técnico da SED/MS 3: É uma escola que a gente tem indígena, agora as outras eu não tenho conhecimento não desse quantitativo de escolas teria que analisar num contexto geral. 
Pesquisadora: Geral.

Técnico da SED/MS 3: Pois é, o dado ele não vai... ele continua mostrando essa discrepância entre, além da miscigenação a questão da discrepância entre brancos, negros, e ainda tem a questão dos quilombolas, aí tem outros (inint) [00:06:08].

Pesquisadora: Essa na verdade ela foi uma questão aberta, então não tinha alternativas.

Técnico da SED/MS 3: Entendi.

Pesquisadora: Eles se autodeclaram, por isso.

Técnico da SED/MS 3: Entendi. Eles que se autodeclaram?

Pesquisadora: É, não foi sugerido uma...

Técnico da SED/MS 3: Entendi. Foi a categorização desse...

Pesquisadora: É a categorização deles que eles, "Eu acho que eu sou isso".

Técnico da SED/MS 3: Eu sou pardo, sou negro.

Pesquisadora: Sou negro, sou mulato, mas é um dado interessante também.

Técnico da SED/MS 3: Não, interessante é que não aparece os quilombolas aí.

Pesquisadora: É, então, mas ninguém se autodeclarou quilombola, por exemplo.

Técnico da SED/MS 3: Que a gente tem comunidades, por exemplo, mas aí eles entram, eu acho, que dos negros.

Pesquisadora: Sim, dos negros, eu acho que ele entende dessa forma, que ele estaria ali presente. Então está bom. Agora, esse daqui é o plano de ação que a gente tem que montar, que eu gero esse documento para entregar para a Secretaria de Educação. Então quais ações são possíveis delinear para estimular os jovens para optar pela carreira docente no estado de Mato Grosso do Sul? Então na opinião desse grupo. Esse daqui, Tom, nós vamos fazer em conjunto, que é aquela produção. Então eu vou parar a gravação por aqui por conta disso e aí eu quero conversar com esse formado de documento com você. Tudo bem?

Técnico da SED/MS 3: Tudo bem.

[00:07:26] 


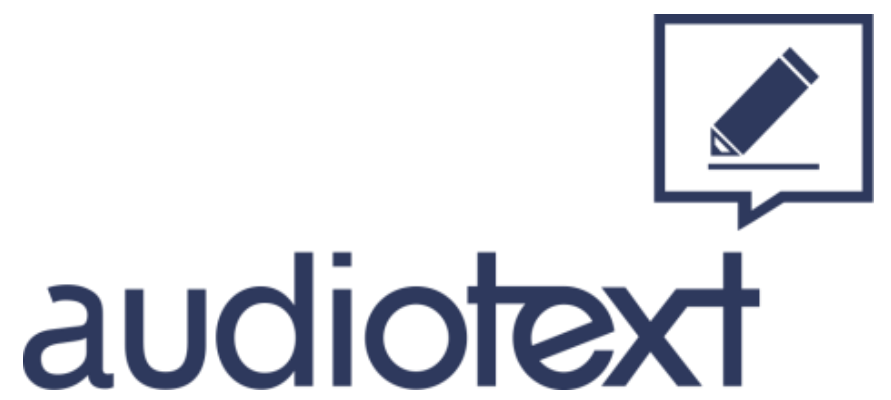

Audiotext Serviços e Cia. LTDA

CNPJ: 17.429.373/0001-85

(41) $3363-3220$

falecom@audiotext.com.br

audiotext.com.br 
TRANSCRIÇÃO

S12917J4 - WIN_20190413_09_29_18_Pro 


\section{PARTICIPANTES}

Professor do Ensino Médio - Prof.do EM 1 - P1

Professor do Ensino Médio - Prof.do EM 2 - P2

Professora do Ensino Médio - Prof ${ }^{a}$. do EM 3 - P3

Professora do Ensino Superior - Prof ${ }^{\mathrm{a}}$ do ES 1 - P4

Professora do Ensino Superior - Prof ${ }^{a}$ do ES 2 - P5

Professora do Ensino Superior - Prof ${ }^{\mathrm{a}}$ do ES 3 - P6

Técnica da Secretaria de Estado de Educação - Técnica da SED/MS 1 - P7

Técnica da Secretaria de Estado de Educação - Técnica da SED/MS 2 - P8

Técnico da Secretaria de Estado de Educação - Técnico da SED/MS 3 - P9

Pesquisadora - $\mathrm{P}$

TEMPO DE GRAVAÇÃO

23 minutos e 30 segundos

MODALIDADE DE TRANSCRIÇÃO

Padrão

\section{LEGENDA}

$\ldots \rightarrow$ pausa ou interrupção.

(inint) [hh:mm:ss] $\rightarrow$ palavra ou trecho ininteligível.

(palavra) [hh:mm:ss] $\rightarrow$ incerteza da palavra transcrita / ouvida.

A Audiotext Serviços e Cia. Ltda se reserva o direito da imprecisão dos nomes escritos, uma vez que os locutores serão identificados conforme a pronúncia de seu nome. O cliente tem o direito de fazer quaisquer alterações que julgar necessárias nas identificações aqui utilizadas. 
(INÍCIO)

[00:00:00]

P: Gente, então nós paramos, só para retomar o último encontro, nós paramos exatamente aqui ó: a quantidade de alunos que fazem cursinho, eu não sei se vocês se recordam, nós discutimos já esse assunto e agora eu vou passar para o próximo slide que é da discussão de hoje. Então aqui ele mostra a pretensão de cursos para ingressar numa instituição de ensino superior, então vocês vão ver no ranking aqui desses dez primeiros que o curso que mais eles querem fazer é o direito. Nós temos aqui um bacharel em direito, ele pode estar falando depois para a gente. Engenharia diversas áreas, medicina que a gente sempre imagina que é o primeiro que vai estar ali na lista, ele aparece em terceiro lugar, esses outros cursos são cursos que somaram $0,10 \%$ e aí a gente não contabiliza, você compacta ele. Medicina veterinária, o primeiro curso de licenciatura ou bacharelado que aparece, porque tem isso também, nem sempre o aluno opta pela licenciatura, a educação física, depois agronomia, administração, enfermagem e psicologia. Então esses dez primeiros cursos que aparecem aí, adiante a gente vai ver os outros, mas eu gostaria que vocês comentassem esses dez primeiros aqui.

Técnica da SED/MS 3: Eu tive vontade de fazer direito a pouco tempo.

Prof $^{a}$ do ES 1: Eu acho que procede, a gente tem acompanhado na época dos vestibulares aqui as cartilhas que saíam era mais ou menos real assim, a única coisa que para a gente lá seria a administração que estaria logo ali no terceiro, em quarto lugar administração, eu achei interessante ela não estar ali.

Prof ${ }^{\mathrm{a}}$ do ES 3: E a pedagogia também, os alunos falam muito da pedagogia.

Técnica da SED/MS 2: O interessante é a agronomia que é um curso, vamos dizer, é novo assim para eles.

Prof ${ }^{-a}$ do ES 1: Mas é interior, acho que é pouco.

$F$ : É, deve ser do interior. E aqui no estado não tem quase. 
Técnica da SED/MS 2: O contexto da fazenda, do campo aqui no estado acho que puxa muito...

Prof ${ }^{a}$ do ES 1: Isso, puxa.

Prof. do EM 2: ... O aluno a optar por agronomia.

P: Uma outra questão que eu gostaria que vocês comentassem é a preferência pelo curso de educação física.

Técnica da SED/MS 2: Olha, assim, vendo na questão dos meus alunos na época que eu dava aula, eu sou professora de matemática, então você escutava muito assim: "Professora, eu não vou fazer nada que envolve matemática", daí eu falei: "Direito, psicologia, educação física", que está ali naquele ramo ali, então eu escutava muito isso quando eu estava em sala de aula.

Prof. do EM 1: Hoje é a moda educação física é...

Prof ${ }^{a}$ do EM 3: É o personal trainer.

Prof. do EM 1: É personal, é aquele das lutas, como que chama aquilo lá?

Prof. do EM 2: MMA.

Técnica da SED/MS 1: UFC que eles gostam.

Técnica da SED/MS 2: Ser fit.

Prof $^{a}$ do ES 1: Moda fitness.

Técnica da SED/MS 2: O professor de educação física ele é mais querido.

Técnica da SED/MS 1: ... Vamos dizer assim, mais querido, mais molecão, mais junto com a galera, então eu acho que conquista mais o interesse do aluno.

Técnica da SED/MS 2: Não tem avaliação.

Ténica da SED/MS 1: Tem.

Prof. do EM 2: Tem avaliação, mas...

Técnica da SED/MS 1: Mas não uma avaliação, porque nós estamos falando.

Ele olha para o aluno: "Oito, sete, seis".

Prof. do EM 2: Não.

Prof $^{a}$ do EM 3: Não.

Prof. do EM 2: Hoje tem prova escrita dissertativa. 
Técnica da SED/MS 2: Hoje tem, mas...

Prof. do EM 2: De habilidades desenvolvidas no esporte $X$ ou $Y$, não é tão simples, mas na minha época de aluno era mesmo, o professor olhava e falava: "Esse aí é gordinho, não fez nada, zero".

Técnica do EM 1: Não, o contrário.

Profa do EM 3: Na minha época não, eu tinha aula teórica.

Prof. do EM 1: Isso.

Técnica da SED/MS 2: Eu aprendia tudo em sala primeiro para depois colocar na prática. Depois ir para a quadra.

Técnica da SED/MS 1: E tinha prova, tinha trabalho escrito também, mas mesmo assim eu tive vontade de ser professora de educação física, não consegui passar na UFMS, a minha segunda opção foi geografia que é o que eu estou que eu fiz na UF de Aquidauana.

$P$ : E vocês acham que o fato da educação física estar em sexto lugar tem a ver com questões de mídia?

Prof. do EM 1: Pode ser.

$P:$ Que influência? É a beleza pelo corpo perfeito?

Prof. do EM 3: Acredito que sim, sim, com certeza.

Prof. do EM 2: Está na moda, faz uns dez anos já que isso é crescente.

Técnica da SED/MS 1: E também e se na escola, por exemplo, é aquele momento que o aluno consegue sair da sala de aula...

Prof. do EM 3: Exato.

Técnica da SED/MS 1: E então eu acho que isso impacta também essa questão.

Prof. do EM 3: E agrupa todos os anos também para fazer competições, quer dizer (inint) [00:04:47].

Prof $\stackrel{a}{\text { a }}$ EM 3: Tem os intercalasses que eles fazem.

Prof. do EM 2: É o momento que eles se movimentam, gritam, falam alto, correm.

Prof. do EM 3: E as festas da escola, festa junina, festa (inint) [00:05:00].

Técnica da SED/MS 1: Tem as danças. 
Prof. do EM 3: Sempre a educação física está no pátio e eles fazem as coisas, organizam... Ensaiando.

Prof. do EM 1: ... Ensaiam, organizam, arrumam.

Técnica do EM 2: Então eu acho que talvez seja por isso.

Prof. do EM 1: Seja por isso.

P: Esses motivos aí. Então eu vou passar adiante os outros slides para a gente... Vocês viram que eu destaquei os cursos de licenciatura para a gente ter uma noção.

Técnica da SED/MS 1: O interessante é que não apareceu nada na área de informática, tecnologia lá no começo, eles gostam.

Prof. do EM 2: É, mas também é uma coisa muito nova eu acho, que a universidade mesmo de análise de sistemas no jeito moderno com aquilo de internet, web page e essas coisas assim, então...

P: Então, lá no primeiro slide apareceu, só vou retomar aqui, apareceu a engenharia, então entra também nessa área porque são diversas áreas, então engenharia da computação por exemplo, de outras áreas.

Técnica da SED/MS 1: Mecatrônica.

Profä. do ES 1: Mecatrônica entra ali na parte (inint) [00:06:02] se você vê se está em segundo lugar ranqueado ali, é bastante o apelo. E aí aqui, gente, continuando. Arquitetura e urbanismo, odontologia, que é um curso também, pelo menos na minha época muito valorizada, já hoje não está tanto, está em décimo quarto lugar.

Prof ${ }^{a}$ do ES 1: É, ele era quase pareado com medicina.

P: Com medicina antigamente. Biologia que aparece que pode ser uma outra licenciatura aqui, estética, fisioterapia, cursos técnicos, de diversas áreas, as vezes o menino também ele não quer fazer uma graduação, ele opta pelo curso técnico. Ciências contábeis, aí a nossa área de letras vai aparecer aqui em vigésimo lugar no ranking, a carreira militar, gente, que é assim que muitos querem, não está no topo que a gente pensa que poderia estar. Aí nós temos a matemática, que é a sua área, farmácia e história.

Prof ${ }^{a}$ do ES 1: E a pedagogia que está lá em cima. 
P: E a pedagogia ficou lá em cima também, isso. Aí eu queria que vocês comentassem esses cursos aí.

Técnica da SED/MS 1: Nossa, que triste que não apareceu a geografia aí. A biologia as vezes ela nem é tanto pela licenciatura, porque ela envolve muita pesquisa.

Técnica da SED/MS 2: O aluno pesquisador ele vai querer fazer a biologia para se envolver com pesquisa. Ele vai ser mais bacharel as vezes. De repente até tem um concurso militar, por exemplo, policial federal, a biologia tem um campo maior (inint) [00:07:52].

Profa do EM 3: Deu para perceber algo assim de eles já pensarem certos cursos como odonto, fisioterapia, até mesmo a medicina lá embaixo, serem cursos de elite e eles acharem que eles não vão conseguir, por isso que eles já nem pensam. Igual àquela professa que falou: "Esses alunos aqui eles não vão para a federal nunca, então para que é que eu vou mostrar isso para eles".

Prof. do EM 2: É, o curso de odontologia é um curso caro de cursar. Não é só entrar.Porque não é o... mesmo que você passe na universidade pública só de material que você tem que comprar por semestre e manter esse material.

P: A sua esposa é, não é?

Prof. do EM 2: É. É complicado.

Profa do EM 3: Eu tenho um ex-aluno lá da escola onde eu dei aula, ele passou na época pelo Prouni, ele conseguiu 100\%, ele fez, hoje ele é dentista e é de uma escola pública, ele, assim, era o sonho dele e ele conseguiu. Então ele fazia rifa e vendia lá na escola, a gente ajudava com rifas, que nem você falou não é só entrar ali na universidade pública.

Prof. do EM 2: É um curso caro.

Prof ${ }^{\text {a }}$ do EM 3: Mas manter aquilo, porque ele é bem de classe... média não, era bem humilde mesmo, só ele que é estudo em casa. Então hoje ele já formou, foi apresentar trabalhos fora, então vai isso também do aluno, de querer.

Prof. do EM 2: Eu acho que também antigamente a odontologia, o profissional da odontologia tinha campo para trabalhar, conseguia ganhar dinheiro.Hoje já 
está mais escasso. Hoje tem muita concorrência, mas muita concorrência, muita clínica popular, então isso barateia o custo para o paciente e ele não vai procurar um profissional de ponta que tem mestrado e doutorado, etc. Então fica um pouco: para que é que eu vou fazer odontologia que é um curso tão caro e eu vou demorar tanto tampo para ter retorno e se eu tiver retorno? Um plantão de médico, médico tira num plantão ganha 2.500 reais num plantão de seis horas ou de oito horas, um dentista num plantão de seis horas numa prefeitura tira 500 reais.

$P$ : A diferença é muito discrepante.

Prof. do EM 2: É muita diferença, então é muita discrepância e a classe é desunida também, é uma classe que enfraqueceu muito, então não tem mesmo 0 apelo.

P: Vou passar para o próximo então. Os cursos técnicos...

Técnica da SED/MS 1: Olha, geografia.

P: Aí aparece a geografia, vigésimo sétimo, a química que provavelmente ele não vai ser professor de química normalmente.

Técnica da SED/MS 1: É o bacharel que eles falam.

P: ... Música, e depois artes, filosofia e licenciatura outras. Eu gostaria que vocês comentassem é essa questão da escassez de alunos que optam pelos cursos de licenciatura, o que é que isso impacta no desenvolvimento econômico por exemplo do país?

Prof ${ }^{\mathrm{a}}$ do ES 1: É a falta de professores.

Técnica da SED/MS 2: E eu acredito assim que eles vendo assim nós, passamos ali pela sala de aula, eu tive muito aluno que falava assim: "Professora, Deus me livre ser professor, aguentar o que vocês aguentam", claro que eu tenho bastantes alunos que falam assim: "Professora, olha, eu fiz matemática por causa da senhora, eu fiz isso por gostar", mas assim aquela bem...

Técnica da SED/MS 1: Bem pouquinho lá mesmo, mas só que a maioria fala: "Professora, é uma classe muito desfavorecida, não tem apoio nenhum, então nesse sentido eu acho que vai cair muito mais. 
Prof ${ }^{\mathrm{a}}$ do EM 3: E atualmente nesse cenário político que a gente está vendo a classe dos professores mais ainda desvalorizada.

Técnica da SED/MS 1: E com essa questão também que eu vi esses dias, não sei se procede ainda, de o estudo em casa, então desvalorizando ainda mais ainda a nossa categoria, "Ah, o aluno não vai precisar mais ir para escola", gente, se o aluno na escola não aprende, imagine ele em casa sozinho, vamos dizer se a maioria dos pais não têm o conhecimento. Então a desvalorização é maior ainda, bem maior.

Técnica da SED/MS 2: Mas por outro lado, quando abre um concurso para professor tem muitos candidatos.

Técnica da SED/MS 1: Muitos candidatos.

Técnica da SED/MS 2: Olha, eu vou falar que eu participei de uma seleção do (inint) [00:12:40], daquela creche que tem lá no Parque dos Poderes. Gente, vocês não têm noção da quantidade de pessoas que tem mestrado, doutorado, que está desempregado e as vezes não tem qualificação nenhuma. E precisava do ensino médio para poder fazer, que é assistente administrativo, assistente de atividades educacionais, que é ajudar as professoras de pedagogia. Então assim, foi uma procura muito grande. E a gente viu, nós lá da SED, nós observamos que tem muitos profissionais que são formados em nível superior e estão desempregados, em letras, direito, assim, muita coisa.

Prof. do EM 2: Agora quanto teve a... abriu para a escola também uma série de carreiras para auxiliar alguma coisa, tem muito professor graduado. Acho que 0 salário é até bem pouco.

Técnica da SED/MS 2: É 1.200, 1.300. 40 horas.

Prof. do EM 2: Mas a coisa está tão complicada que a pessoa tem que se sujeitar porque não tem para onde correr.

Técnica da SED/MS 2: Mas por outro lado o que foi um bom aluno, se destacou ele não fica desempregado muito.

Técnica da SED/MS 1: Sim, sim.

Técnica da SED/MS 2: Tem duas, três escolas que ele está trabalhando e as pessoas ligando. 
Técnica da SED/MS 1: Isso, tem isso também.

Prof ${ }^{a}$ do ES 1: Porque lá na federal, muitas escolas ligaram: "Manda aí os dois, três melhores alunos que você tiver com o perfil assim, assim e assim", porque eles não queria só assim os melhores, assim, que tem uma família, que tem irmão pequeno, que gosta de criança, (inint) [00:14:19], muitas escolas boas da cidade eles faziam isso e os colegas eles percebiam na sala de aula, então eu chegava e fala: "Olha, tal e tal, nós temos o perfil, tal e tal, a gente vai conversar depois com quem (inint) [00:14:33], fazer uma pré-seleção". A gente vai conversar, falar como que você se apresenta, porque na maioria das vezes eles pegam as escolas particulares, nem sempre os formados mesmo, eles querem conhecer (inint) [00:14:48].

Prof ${ }^{a}$ do ES 2: Desvalorização, isso, é.

Prof $^{a}$ do ES 1: Que eles pagam menos.

Técnica da SED/MS 2: Bem menos.

Prof $^{a}$ do ES 1: "Ah, manda um aluno aí do terceiro ano".

Profa do ES 2: É, que eles barateiam o trabalho.

Prof ${ }^{a}$ do ES 1:: É interessante isso.

Técnica da SED/MS 2: Eles barateiam muito, porque eu coloquei o meu filho ano passado na escola particular, na (inint) [00:15:04], e as meninas reclamavam muito, falavam assim: "Cris...", é uma ex-aluna formada em inglês ela dá aula para o meu filho hoje, ela falou assim: "Cris, não é muito, mas já ajuda, eu já saí empregada". Aí ela dá um curso de inglês fora do horário, que já ganha um pouquinho, mas eles reclamavam muito dessa questão, não ganha tanto quanto a gente está no estado ou no município, é bem desvalorizado.

Prof. do EM 2: Que também não é muito.

Técnica da SED/MS 2: Particular sofre.

Técnica da SED/MS 1: E com relação a essa quantidade toda de pessoas que tem na hora de fazer um concurso formados na área de licenciatura, eu acredito que seja aquela segunda opção, aquela terceira opção, porque eu não consegui fazer o que eu queria, que era o direito, que é o mais difícil, que é 
jornalismo, ou que sei lá, que eu vi jornalismo, lembrei até da minha que está fazendo história licenciatura porque não conseguiu entrar no jornalismo por causa da concorrência. E aí acaba que conclui aquele curso, mas não quer... Técnica da SED/MS 2: Não exerce a profissão.

Profa do ES 1: ... Não quer exercer, só que como não consegue emprego, surgiu o concurso "Ah, vou fazer". Aí passa e vai dar aula sem gostar.

Técnica da SED/MS 1: Vou ser professor porque eu não consegui ser médico, eu não consegui ser o que eu queria, então enquanto eu não consigo chegar lá, para eu me manter, eu vou trabalhar como professor (inint) [00:16:22], que arrumar emprego está difícil, e como a Cris disse concurso é estabilidade a pessoa vai e faz.

Prof. do EM 2: E mesmo assim a concorrência nos concursos está acirradíssima.

Técnica da SED/MS 1: Eu ouvi de uma colega nossa, assim, da área de artes (inint) [00:16:39], que ela está na sede e na (inint) [00:16:42], ela agora decidiu estudar para concurso, se ela passando ela vai continuar na sede (inint) [00:16:51] e vai pedir exoneração do município devido a tanta burocracia e o segundo fator e vai... Desgaste e também o negócio da previdência que vai aumentar o tempo de... ela falou: "Eu vou ficar 40 anos?".

Prof $^{\text {a }}$ do ES 1: Eu fiquei. 40 assim, não, da situação atual. Então eu tive muita sorte.

Técnica da SED/MS 2: Muita.

Prof ${ }^{-}$do ES 1: Nossa, eu nunca tive um aluno que tivesse gritado comigo, jogado um giz, na minha vida, quase 38 anos em sala de aula.

Prof. do EM 2: Na primeira semana eu quase levei uma cadernada de um aluno.

Técnica da SED/MS 2: Não, na minha, quando eu comecei no estágio o guri pulou. Vocês conhecem o Hércules? A escola lá na vila onde eu moro é igual, que é o Valdemir, é igual ao Hercules (inint) [00:17:37], o guri pulou do primeiro andar na minha aula, eles estavam brigando, eu fechei a porta para não bater e outro pegou e pulou janela para pegar o que estava lá fora. Assim, aí você fica 
desesperada porque vocês... Isso em 2000, hoje nós estamos em 2019, agora é as drogas.

Prof. do EM 2: Sim, agora o contexto é outro.

Prof do EM 1: Bebida dentro da sala de aula.

Técnica da SED/MS 2: Aí um dia, isso foi o quê, em 2015, a menina falou assim: "Professora, olha, você sabe que dá vontade de pular dessa janela", eu: "Epa”, aí eu já tinha o Whats da escola, já foi informatizado, eu falei: "Olha, é o seguinte, vem aqui porque a menina eu acho que ela não está muito bem não", ela tinha usado droga. Já pensou se um aluno desse pula da sala de aula (inint) [00:18:21]. Então hoje em dia é, assim, eu acho que devido a tudo isso que os alunos andam vendo, esses lá de... que teve agora. E eu vi ontem, a professora estava falando, professora, que teve um episódio no Paulo Freire de um aluno.

Prof. do EM 2: Sim, saiu no jornal e tudo.

Técnica da SED/MS 2: Eu não tinha visto. Ela falou: "Gente, o que é que vai acontecer?". Então eu acho que tudo isso é onde vai caindo ali.

Prof. do EM 2: Mais um motivo.

Técnica da SED/MS 2: Sim, mais um motivo.

P: Ok. Eu vou adiante então. Agora a intenção de ingresso em instituições do ensino superior que o aluno gostaria de estar. Nós temos ali a UFMS, depois UFGD, o CDB, Unigram, UEMS, Uniderp, Federal, AMS. Eu vou passar o próximo slide porque aí a gente analisa tudo. Funed, Anhanguera, Unesp, Publica, (inint) [00:19:25], Unoeste, SENAI, Unopar, Unigram, USP e IFMS. Olha, o IFMS ali aparece no último.

Técnica da SED/MS 2: Mas eu acho que é por falta de conhecimento, poucas pessoas sabem que tem ensino superior.

Técnica da SED/MS 1: Engraçado que apareceram alguns nomes que eu não conheço.

P: Eu pesquisei e são universidades fora do estado.

Prof $^{\text {a }}$ do ES 3: Às vezes tem um polo na cidade dele e tem o curso que se interessou. 
Prof $^{\mathrm{a}}$ do ES 1: Olha, igual falar assim, o meu sobrinho hoje ele é médico, já faz o segundo ano de formado, e assim o sonho dele era ser médico e aí ele tentou, ele estudava no Bionatus, tudo, ele tentou na federal e ele saiu assim muito triste, porque no Bionatus ele teve a melhor nota de redação, porque lá eles põem até em quadro e tudo. E na federal aqui a nota dele foi lá embaixo, então ele viu muita coisa errada que falaram para ele na época, eu não sei se isso procede. Aí ele fez medicina veterinária, ele passou em medicina veterinária e ele falou assim (inint) [00:20:36], chacra e tudo, ele fez um ano, ele falou: "Pai, não é isso que eu quero, eu quero medicina". Aí ele pegou, estudou no Bionatus mais uma vez e ele falou assim: "Eu não quero na federal, eu não quero na federal aqui, eu quero na UFGD", ele estudou e ele foi para a UFGD. Ele se formou, o ano passado ele ficou o ano inteiro no SAMU lá, e para você ver a discrepância, mesmo estado, só cidades diferentes, de Dourados para cá é muito (inint) [00:21:09]. Ele falou: "Tia, lá eu consegui tirar em um mês 40 mil reais", e recebia, porque ele era o mais novo médico bombeiro do estado e ele era do SAMU e da Bravo que tem lá, então cada diária dele era assim bem...

Prof. do EM 2: Remunerado.

Prof $^{\mathrm{a}}$ do ES 1: ... Diferente do que é aqui. Aí ele queria porque queria fazer... como é fala? Cirurgião, neurocirurgião, estudando, estudando, aí ele fez, tinha uma vaga só para cá, aí ele conseguiu, está aqui, ele falou assim para minha mãe: "Vó, olha, eu conheci a pobreza", ele falou bem assim, "Eu conheci a pobreza, conheci a riqueza e agora eu estou na pobreza de novo", no sentido assim, porque a discrepância de um município para o outro da valorização do profissional, que era o que você estava falando, que o médico ele tem 2.500 no plantão e um dentista tem 500. Ele falou: "Vó, eu não vou ganhar a mesma coisa que eu ganhava lá", mas ele vai estar perto da família. Então tem tudo isso, a valorização, ele tinha o conhecimento que a UFGD era uma das melhores em medicina que ele falava e ele lutou para ir.

Prof $^{\mathrm{a}}$ do ES 3: Isso. E tem aqui também estudos que a gente viu também que muita gente de fora vem para a federal daqui, estudos que nós fizemos na 
época de escola, então você via assim, muitos, até mesmo estrangeiros, que vem para cá.

$P:$ E a questão do ENEM como que vocês percebem?

Prof $^{\text {a }}$ do ES 2: Entra pelo Prouni, pelo ENEM, eles vêm procurar, eles vêm atrás das vagas nessa questão do SISU que tem, para cá, o pessoal de fora procura mais daqui do que o próprio daqui.

Prof. do EM 2: Porque eles acham que aqui não vai ter tanta concorrência. (Inint) [00:23:24], 23 e meio já.

P: Só um pouquinho. Eu vou parar o vídeo.

[00:23:30] 


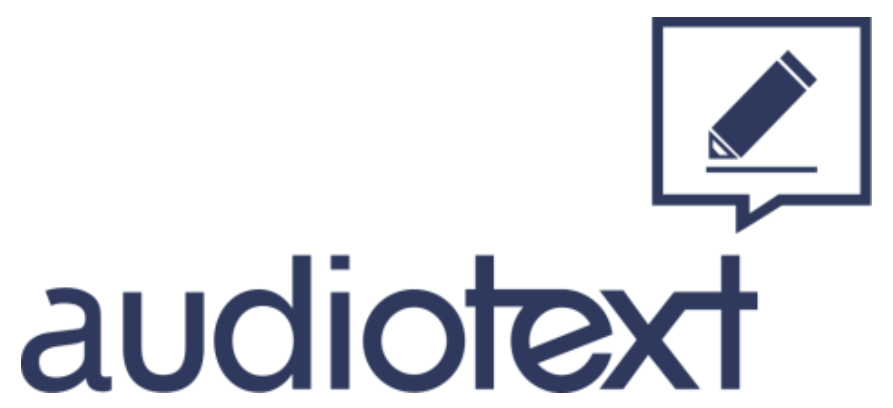

Audiotext Serviços e Cia. LTDA

CNPJ: 17.429.373/0001-85

(41) 3363-3220

falecom@audiotext.com.br

audiotext.com.br 
TRANSCRIÇÃO

-S12917J5 - WIN_20190413_09_52_56_Pro 


\section{PARTICIPANTES}

Professor do Ensino Médio - Prof.do EM 1 - P1

Professor do Ensino Médio - Prof.do EM 2 - P2

Professora do Ensino Médio - Prof ${ }^{a}$ do EM 3 - P3

Professora do Ensino Superior - Prof ${ }^{\mathrm{a}}$ do ES 1 - P4

Professora do Ensino Superior - Prof ${ }^{a}$ do ES 2 - P5

Professora do Ensino Superior - Prof ${ }^{a}$ do ES 3 - P6

Técnica da Secretaria de Estado de Educação - Técnica da SED/MS 1 - P7

Técnica da Secretaria de Estado de Educação - Técnica da SED/MS 2 - P8

Técnico da Secretaria de Estado de Educação - Técnico da SED/MS 3 - P9

Pesquisadora - $\mathrm{P}$

TEMPO DE GRAVAÇÃO

30 minutos e 19 segundos

\section{MODALIDADE DE TRANSCRIÇÃO}

Padrão

\section{LEGENDA}

$\ldots \rightarrow$ pausa ou interrupção.

(inint) [hh:mm:ss] $\rightarrow$ palavra ou trecho ininteligível.

(palavra) [hh:mm:ss] $\rightarrow$ incerteza da palavra transcrita / ouvida.

A Audiotext Serviços e Cia. Ltda se reserva o direito da imprecisão dos nomes escritos, uma vez que os locutores serão identificados conforme a pronúncia de seu nome. $O$ cliente tem o direito de fazer quaisquer alterações que julgar necessárias nas identificações aqui utilizadas. 
(INÍCIO)

[00:00:00]

Prof $^{a}$ do ES 1: Eu acho assim que (inint) [00:00:03]. Qual a porcentagem mesmo dos alunos da capital e do interior de uma forma geral qual que foi o número (inint) [00:00:13] que você pegou? 7 mil?

P: Quase 8 mil.

Técnica da SED/MS 1: Eu não sei te falar, professora, precisamente agora, eu não sei, eu tenho os dados, mas não está no slide, então eu não saberia te falar, mas a maioria que respondeu é de Campo Grande.

P: A maioria é Campo Grande, assim, foram 75 municípios, eu não sei precisar, mas Campo Grande foi a maioria que participou, porque o que é que acontece, Campo Grande concentra o maior número de escolas, então proporcionalmente é daqui mesmo.

Prof. do EM 2: É daqui mesmo.

P: Então vou seguindo aqui. Quantitativos de alunos que em algum momento pensam em ser professor, então em algum momento na vida dele ele falou...

Técnica da SED/MS 2: Ele falou: "Olha, eu acho que a professora é bonita". Aquela professora bonita. "Ah, eu queria tanto ser igual àquela professora".

P: Aqui vocês já vejam que não, $63 \%$ nunca nem pensaram em ser.

Prof. do EM 2: Nem cogitou.

P: Nunca pensou. E a grande minoria 36,62. E aí, gente?

Técnica da SED/MS 1: Eu acho que vai um pouco do estímulo do professor e dos pais em casa, porque, por exemplo, eu sou professora e eu gostaria que a minha filha fosse, porque eu acho que é uma profissão digna e não paga tão mal assim, se a gente for fazer uma comparação com outros empregos. E só que assim, é sofrido, é barra pesada, ela teria que ter pulso firme e vontade, tem que ser por amor.

Técnica da SED/MS 2: Estabilidade emocional assim muito forte.

Técnica da SED/MS 1: Tem que ser por amor porque se a pessoa está lá só pelo salário ela não dá conta. 
Técnica da SED/MS 2: Não pode ser estressada e nem ansiosa.

Técnica da SED/MS 1: E aí quando ela está lá só pelo salário ela não aquele incentivo para o aluno de que aquela profissão vale a pena. Que ela é feliz ali.

Técnica da SED/MS 2: E aí ela desestimula o aluno, "Você vai estudar para quê?", "Ah, quero ser professor", "Você é louco?".

Prof. do EM 2: É, o próprio professor fala isso. "Vai ser médico", o próprio professor fala.

Prof. do EM 1: É, o próprio professor fala.

Técnica da SED/MS2: Eu já faço o contrário, pelo menos quando eu estava em sala de aula eu incentivava os meus alunos a serem professores. Eu tive uma diretora que ela só andava no salto e ela falava assim: "Gente, vocês professores tem que andar bem arrumado, maquiada, bonita, cheirosa para mostrar para o seu aluno que vale a pena ser professor".

Técnica da SED/MS 1: Vai aquelas professoras... Não vê as fotos no face dos professores, coitadinho, tudo assim tudo. É, aí o professor chega lá de cabeça baixa, desanimado, desestimulado e o aluno não sente aquele estímulo, e aí ele vê um advogado todo de terno, todo pomposo com carrão, vê um médico ganhando bem, tem carrão, tem mansão, tem casa bonita, mora na área nobre ele vai querer ser aquilo por mais que ele nem leve jeito para aquilo ele vai querer aquilo que paga mais.

Prof. do EM 2: Ontem eu estava conversando com uns alunos do sexto ano eles falaram assim, estava calor na sala, estava reformando a escola e o ventilador estava desligado "Nossa, que calor, vamos abrir essas janelas e tal, não sei o que, deixar a porta aberta", "Porque você não vem de bermuda", eu falei: "Porque eu tenho que respeitar vocês enquanto meus alunos, que noção você vai ter de uma pessoa que quer te ensinar ou saber dele que vem de chinelo e bermuda?" "De chinelo e bermuda?" Me desculpa, isso não faz sentido, vocês têm que ter uma referência. Tem que ter essa referência, e não é porque você tem que se apresentar bem só para tentar agradar o aluno ou colocar panos quentes onde... Não, não é isso, mas tem que ter essa noção de respeito. 
Técnica da SED/MS 2: Sim.

Prof. do EM 2: Ali é o meu local de trabalho. Eu tive colegas que no inverno iam trabalhar de meia, calça de moletom e meia e chinelo numa das maiores estaduais daqui da capital.

Técnica da SED/MS 2: Crocs, era o crocs?

Prof. do EM 2: Não, era chinelo mesmo, havaiana, cortando a meia no meio.

Técnica da SED/MS 2: Jesus.

Prof. do EM 2: Sabe, um cara, assim, o físico já não ajuda, porque já tem aquela impressão de que o professor nem banho toma direito. Poxa, e aí você vai querer controlar 40 alunos para ele te ouvir o que você tem para falar.

Prof $^{a}$ do EM 3: Não vai ouvir.

Prof. do EM 2: Não, nem eu gostaria de ouvir o que ele tem para falar.

Prof $^{\mathrm{a}}$ do EM 3: Ainda vem aquele... já tem um estereótipo.

Prof. do EM 2: Muito esquisito, muito... o aluno tem que entender isso, aí eu falo: "Vocês estão aqui...", e eu brinco com eles, eles tiram o chinelo, trocam de roupa no meio da aula por causa da educação física, volta, as vezes está numa situação alarmante, mas eu falo para eles, falo: "Cinderela, vamos colocar o sapatinho, a gente não está em casa", "Mas a gente acabou de correr, estou cansado", "Tudo bem, não tem problema, descansa aí uns minutinhos, daqui a pouco eu vou cobrar de você de novo senão você vai ficar sem o sapatinho de cristal". Acho que só eu falo isso, sabe, porque os outros professores eu não vejo muito.

Técnica da SED/MS 2: Aconteceu... mas você sabe que não, aconteceu um fato até mesmo uma vez na escola, tinha uma menina que ela era assim muito terrível, e aí ela pegou, estava muito quente, ela pegou uma camisa da escola, dobrou e puxou aqui, ficou de barriga de fora, aí eu peguei e falei assim: "Filha, onde você está? Não é para fazer isso, abaixa" aí a menina virou e falou assim para mim: "A senhora está com inveja porque a senhora queria ter esse corpo que eu tenho", mas eu não pensei duas vezes, eu falei: "Olha, filha, quantos anos você tem?", "16", eu falei: "Olha, eu já tive essa idade e garanto para você 
que eu era muito mais bonita e eu não ficava mostrando nada, cada um tem a sua...", porque ela me ofendeu.

Prof. do EM 2: Lógico.

Técnica da SED/MS 2: Porque tipo assim, a senhora está querendo ser igual a mim e não pode e está brigando comigo. Menina, ela colou assim, ficou tipo um bustiê na sala, eu falei: "Não, você tem que respeitar, aqui é escola, você não vê...”, e eu sempre andei, é que nem você falou, você tem que... de uma certa forma você não vai da minissaia, de blusinha decotada. Aí eu falei assim: "Gente, que desaforo de guria", eu falei assim: "Minha filha, para começo de conversa eu não tenho inveja de você, porque eu estou aqui para ensinar", aí eu falei assim: "Gente, olha como que é a cabeça".

Prof $^{a}$ do EM 3: A formação aí de casa.

Prof. do EM 2: Agora se você também, num momento como esse, se você já não está apresentado...

Técnica da SED/MS 2: Sim, como que você vai chamar atenção?

Prof. do EM 2: ... Com essa ideia de respeito.

Técnica da SED/MS 2: Sim, sim.

Prof. do EM 2: Não é apresentável com uma roupa (inint) [00:06:43], não é ponto.

Técnica da SED/MS 2: Não. É você...

Prof. do EM 2: Mas estar com uma apresentação de respeito.

Técnica da SED/MS 2: Por exemplo, eu vou chamar atenção dela e estou lá de minissaia, blusinha lá embaixo, aí quem é você para chamar minha atenção? tem isso também.

Profa do EM 3: Então, isso é uma coisa que vem de casa, porque você chama a mãe de uma aluna que está com roupa curta na escola. A mãe vem pior que 0 aluno.

Prof. do EM 2: A mãe vem com a mesma roupa, igual.

Profa do EM 3: ... A mãe vem igual a filha ou pior.

Prof. do EM 2: É verdade. 
Prof ${ }^{\mathrm{a}}$ do EM 3: E ainda chama a atenção da diretora, não respeita a diretora, aí é onde entra, o filho vê: "A minha não respeita porque é que eu vou respeitar?" Prof. do EM 2: Também.

Prof $^{-a}$ do EM 3: Eu tenho um aluno, um ex-aluno que quando eu pensava em levar ele na coordenação o coordenador e a coordenadora falavam: "Não, isso aí é direto para a diretora, eu não converso com ele mais", ninguém queria mais receber esse aluno. Hoje ele está recebendo bolsa do CNPQ, ele entrou para o clube de ciências da escola, eu incentivei, eu fazia ele fazer seminários que ele não gostava só que eu dava os temas que ele queria fazer e aí ele fazia e foi estimulando ele. Então assim, não é forçar. É você mostrar para ele. É você adaptar o que ele quer para ele, "Ah, eu quero ser militar, eu gosto de avião, de guerra, de tanque, de isso e daquilo", "Então, isso aqui é um avião dos Estados Unidos, você vai lá falar sobre isso, isso e isso dos Estados Unidos, faz um seminário e você vai apresentar sozinho", "Beleza, professora". Hoje ele quer ser professor de biologia porque ele está fazendo pesquisa, ele está no Arandú lá na UFMS com o professor Ivo, aliás o professor Ivo já saiu, foi promovido, está outro professor agora. Então assim, o aluno que não queria nada com nada ele faz parte...

Técnica da SED/MS 1: Você incentivou ele, não é.

Prof $^{-a}$ do EM 3: Ele montou uma banda de música, que ele gosta de música, e toda feifra de ciência, toda apresentação ele vai com o projeto dele de música, ele cria música, ele faz paródia, ele junto com a banda dele. E hoje ele quer se professor e ele me agradece, ele salvou meu nome no celular dele, do WhatsApp dele como professora Sargento.

Técnica da SED/MS 1: E o aluno percebe quando o professor está preocupado com ele. Com ele e percebe também a paixão ou não que ele tem por ensinar. Prof. do EM 2: Pelo trabalho.

Técnica da SED/MS 1: Sim. Que são poucos os professores que observam isso nos alunos hoje em dia, que é aquela questão que eu estava falando para você antes, o professor desmotivado que motivação que ele vai dar para 0 aluno? 
Prof ${ }^{a}$ do ES 1: É outra geração, os professores desses alunos são bem mais jovens que esse aqui, do que ela, são bem... Assim, a nossa... a gente já foi para escola com filho, com família, com outra conscientização, esses meninos e meninos que são professores são solteiros, eles não gostam, não tem irmão pequeno, eles não gostam de brincar, eles querem... Então essa questão da proximidade da faixa etária eu acho assim muito séria.

Técnica da SED/MS 1: Olha, aconteceu um caso comigo que eu não sei se é (inint) [00:09:41], mas assim, eu fiquei muito chocada, porque eu dava aula no município em 2014, acho que foi, em 2014 teve uma transição de politicagem e aí a diretora na época colocou outra pessoa no meu lugar, colocou o namorido e menina lá na escola. Aí quando foi em maio ela me chamou: "Professora, preciso de você aqui para pegar uma sala", eu falei: "Tudo bem", pode estar a sala caindo no chão, para mim não tinha tempo ruim não, eu falei: "Não, eu vou". A sala era a pior sala do município, o aluno ele saia correndo de lá e ele vinha derrubando todas as carteiras, aí isso eu comecei com uma sala, com o sexto ano. Ela falou: "Professora, eu preciso que você, depois de julho, depois das férias, pega tal e tal sala", a carga horária da professora que estava nessa sala, beleza. Aí eu não sabia, aí eu não conhecia a professora também, aí um dia lá do planejamento ela estava lá, aí ela pegou, pelo nome que ela falou eu falei assim: "Você que é a fulana de tal?", "Sim", ela estava fazendo doutorado. Aí ela falou assim: "É você que vai pegar as minhas aulas?", olha, eu não falei merda para aquela mulher porque eu tenho educação, porque senão... e respeitei, que nem você falou, a gente tem que respeitar o lugar também. Ela falou bem assim para mim, tipo assim: "Você consegue dar aula para esse tipinho?", ele estava fazendo doutorado, eu falei: "Gente, como uma pessoa que está buscando conhecimento, está fazendo doutorado em matemática”, que nem a senhora falou, essas pessoas jovens, e falou assim: "Essa turma aí é para você mesmo", tipo assim você que está aí já muito tempo dando aula, "Essa turma é para você mesmo porque eu não tenho saco para dar aula para guri", eu falei: "Então porque está estudando? Está fazendo doutorado para que? Para ser lá só na pesquisa e estão buscando conhecimento para 
melhorar a educação em quê?". Não está buscando conhecimento para melhorar a educação. Aí eu falei assim: "Gente, é bom mesmo que um ser dessa saia da sala de aula", que é onde você falou não dá aula porque gosta. Eu falei assim: "Gente...", eu me senti mal porque eu pensei assim: "Nossa, porque só eu tenho que dar aula para eles", e pessoas humildes, crianças que as vezes vem sem comer, que vem suja.

Prof $^{\mathfrak{a}}$ do ES 1: Não tem limite em casa.

Prof. do EM 2: Mas eu acho que essa questão do desinteresse do professor, esse tipo de resposta acontece também na escola... na escola particular a gente deve trabalhar com outros professores que tem essa opinião também.

Técnica da SED/MS 1: Eu falei assim: “Gente...”, eu falei: “Como, não é?”.

Prof. do EM 2: Independente do público que você tem dentro da sala de aula.

Técnica da SED/MS 1: De onde está.

Prof. do EM 2: Eu acho que a postura do profissional que está chegando ao mercado agora talvez seja comum em vários lugares.

Técnica da SED/MS 1: Ok. A minha preocupação é quando for começar a (inint) [00:12:46] vai ter, parece que vai ter uma seleção. Vir uma pessoa de fora e conseguir, pelo título que ela tem, entrar, ir lá e escrever, ela vai escrever o quê? Se ela não conhece nada da realidade.

Prof. do EM 2: Não tem vivencia.

Técnica da SED/MS 1: Não tem vivência.

P: Pessoal, eu vou passar para o próximo slide. A professora vai ter que sair um pouco mais cedo hoje, então eu vou pegar dois slides aqui que são super importantes para a pesquisa e depois eu retomo os anteriores com vocês quatros, pode ser? Só porque senão não vai dar tempo e ela precisa ir. Então esse daqui eu vejo depois. Esses dois slides que seguem eles são os mais importantes da pesquisa aqui. Então, primeiro: qual a principal razão para escolher ser professor? Esse "não responderam" são aqueles alunos que não vão ser de modo algum, então para ele não tem razão de escola. Aqui no ranking a primeira questão: transmitir conhecimento para as pessoas, depois gostam de trabalhar com crianças, identificam-se ou gostam dessa profissão, 
gostam de determinada disciplina do currículo, profissão digna com boas oportunidades de emprego e estabilidade financeira, admiração pelos professores. Eu particularmente fiquei super feliz que tem essa.

Prof $^{a}$ do ES 1: Que tenha essa opção. Melhorar a qualidade do ensino público no país.

P: Facilidade de comunicação e interação com as pessoas. Então aqui eu gostaria, assim, que realmente vocês discutissem essas questões que são super importantes.

Técnica da SED/MS 2: Olha, eu vou falar por mim, como eu estava falando para ela, o meu sonho era ser médica, mas eu sempre fui boa na área de exatas, educação física eu queria ser também, mas a minha mãe não queria, mas eu tinha uma admiração muito grande pela minha professora de matemática, professora Jussara, que eu falo que eu fiz matemática por causa dela. Eu adorava as aulas de matemática dela, e era assim, ela levava listas e listas de exercício, enchia o quadro, eu ficava assim admirada do jeito dela explicar, o jeito que ela se... como é que fala?

Prof. do EM 2: Portava.

Técnica da SED/MS 2: A postura dela, que nem você falou, na sala de aula. Então e eu penso assim, que tudo que eu vi e que eu sou hoje e que eu fui em sala de aula praticamente eu segui assim quase igual ela fazia, que ela sempre falava assim: "Olha, se um dia vocês forem professores, vocês nunca façam chamada no último instante de aula. Vocês façam sempre no começo, no meio e no final, porque isso aqui é um documento que a gente tem, se acontecer qualquer coisa com algum estudante e vier procurar na escola no seu diário aquilo é um documento muito precioso", então isso eu carreguei comigo. Então essa admiração pelos professores ela é muito bacana e hoje em dia, que nem você falou, ainda tem e eu tive dois alunos que fizeram matemática e, assim, de informação da sede eu encontrei com uma, ela falou assim: "Essa professora foi a minha professa na época de escola", aí a pessoa: "Mas ué, professora, você é velha", eu falei: "Não, (inint) [00:16:21]". E aí outro dia eu estava em casa e aí um ex-aluno me ligou: “Oi, professora, tudo bem?”, eu 
falei: "Tudo", "Olha, eu estou precisando de uma ajuda", eu falei: "O que é que foi?", e aí ele falou para mim que ele tinha feito matemática, que ele queria a minha ajuda, se eu podia ajudar ele se ele precisasse, eu falei: "Não, pode fazer", "Eu fiz matemática, professora, por causa da senhora, porque eu admirava a senhora dar aula". Então assim, são poucos os professores que tem hoje em dia que mostram isso para os alunos, é igual a professora falou, que a gente... eu tinha esse olhar para o aluno, eu tinha, por exemplo, eu dava aula de manhã, a tarde e à noite, se eu tivesse 1.500 alunos eu sabia todos os nomes dos meus alunos, eu sabia onde ele sentava, eu sabia o problema que ele tinha, eu sabia tudo. No Conselho de Classe um dia uma colega falou assim: "Nossa, você está parecendo fifi", eu falei: "Não, não é fifi", porque chegava lá na hora e eu falava assim... Geraldo você?

Prof. do EM 2: Uhum.

Técnica da SED/MS 2: "Quem é Geraldo?", a pessoa não sabia quem era o aluno Geraldo.

Prof. do EM 2: Não conhecia a própria turma.

Técnica da SED/MS 2: O que é que ele fazia, eu falei assim: "O Geraldo é aquele menino que senta do lado da cartei do fulano, próximo da porta que faz isso, isso e isso", então eu tinha esse... eu não sei como, mas eu tinha isso.

Técnica da SED/MS 1: Memória virtual.

Técnica da SED/MS 2: Eu tinha isso e eu sabia. E você também tem mais aulas, então você fica mais tempo com eles. É. Eu sabia, então assim, as vezes aquele menino estava quieto, parado, eu dava atividade para ele "O que é que está acontecendo com você?", "Ah, professora hoje eu não dormir, eu estava ajudando o meu pai, isso e aquilo", aí o Conselho: "É porque o menino está faltando, porque isso, porque aquilo outro", então não conhece aquilo do aluno. $E$ isso vai cativando o aluno também.

Prof $^{a}$ do ES 1: Gosta de trabalhar com crianças você vê que vai para a pedagogia.

Prof ${ }^{a}$ do ES 3: Isso, pedagogia I. 
Prof. do EM 2: Que é uma coisa que não me cativa, mas o sexto ano é uma das turmas que eu mais gosto de dar aula. É muito gostoso de trabalhar.

Prof ${ }^{a}$ do ES 3: A profissão digna isso é muito bom ver que tem gente que reconhece. Ainda tem gente que pensa assim.

Prof. do EM 2: Com boas oportunidades de emprego e estabilidade.

Técnica da SED/MS 1: E estabilidade financeira.

Prof. do EM 2: É o conjunto da resposta ali foi...

Técnica da SED/MS 1: No caso ali essa estabilidade ele já disse que é um professor concursado, ele acha que todo professor é concursado o que não é verdade, tem muito professor aí que está desempregado, pega cinco aulas aqui, duas aulas ali e se vira nos 30 para conseguir.

Prof $^{a}$ do ES 1: Eu estou pensando aqui no texto, essa profissão digna com oportunidades, você tem como localizar e dar uma olhada na formação dos pais?

P: Sim, eu li todos os questionários, os quase 8 mil inteiros.

Prof $^{a}$ do ES 1: Então quando você optar em fazer alguma análise mais aprofunda que puxa para a licenciatura você pega, faz por por amostragem.

P: De modo geral, quanto maior a grau de escolaridade dos pais, eles tem melhores condições de orientar os filhos em suas escolhas profissionais. Sim, professora, então é isso que eu ia... só para complementar. Como eu li os questionários, o que é que eles colocam... quando eles colocam boas oportunidades de emprego e estabilidade financeira o pai ou a mãe é professor efetivo e aí ele tem noção de salário, de estabilidade coisas que...

Porf. do EM 2: Dos direitos.

$P$ : Dos direitos e tudo mais. Então quando tem alguém na família que é professor, ele já sabe. Ele tem uma percepção do ser professor diferente do que a mídia passa, isso daí eu vi no questionário mesmo, porque essas questões, essas... tiveram seis questões abertas e essas duas que é a razão de escolher ou não escolher ser professor foi discursiva. Então eu já li e já assinalei justamente para fazer a análise. E aí quando ele fala com "boas 
oportunidades de emprego" que ele quer dizer lá no discurso dele, no papel, que os bons professores não ficam desempregados.

Prof ${ }^{-a}$ do ES 1: Sim, que foi o que ela falou.

$P$ : Então por isso que ele vê como uma boa oportunidade, e de certa forma até mesmo aquele que não é concursado, mas ele é um ótimo professor ele também tem essa estabilidade.

Profa do ES 1: Sim, ele nunca está desempregado.

$P$ : De certa forma não é só o concurso.

Prof $^{a}$ do ES 1: Quem respondeu "melhorar a qualidade do ensino público no país" ele tem noção da perspectiva da situação atual que está acontecendo no ensino.

Técnica da SED/MS 2: A faixa etária desse aluno é um pouquinho mais maduro.

Prof $^{a}$ do ES 1: Essa questão de facilidade da comunicação e interação com as pessoas, essa pessoa, essas que responderam isso são aquelas pessoas que conversam mais, que são mais sociáveis.

Técnica da SED/MS 2: Que acha que o professor teria que ser assim.

Técnica da SED/MS 1: Não, na verdade porque tem muitos alunos que ficam só no celular, só conversam pelo WhatsApp e não gostam nem de mandar áudio, não gosta de ligar, minha filha é assim, ela não gosta de ligar, ela não gosta de mandar áudio, ela não gosta de falar, ela gosta de escrever, ela escreve, ela digita, e é rápida. Então assim, ela não quer ser professora porque ela fala que ela não leva jeito para isso por quê? Porque ela não consegue manter esse diálogo, comunicar.

Prof. do EM 2: Comunicação.

Técnica da SED/MS 1: ... Com muitas pessoas, essa comunicação. Então ali a facilidade, então assim, essa pessoa que respondeu, essas pessoas que responderam elas têm essa facilidade de comunicação que no jovem de hoje em dia já está mais difícil, eles ficam mais ali. Eles falam com Papa pelo WhatsApp.

Prof. do EM 2: É, agora face a face. 
Técnica da SED/MS 1: Só que ele não conversa com o colega do lado, as vezes manda bilhetinho. A minha está no quarto e ela manda um Whats para mim perguntando: "Mãe, o que é que vai ter de almoço?".

Técnica da SED/MS 2: Não acredito.

Técnica da SED/MS 1: E eu estou lá na cozinha. Está normal agora, na minha casa é assim. Aí eu vejo lá no celular que ela mandou a mensagem, eu nem olho a mensagem, eu falo: "O que é? O que é que você quer?", "Ai, mãe, vai me deixar no vácuo?", "Não, estou (inint) [00:22:25] você". Melhor falar no blabla mesmo. Não é? Eu estou aqui conversando, vou deixar no vácuo porque eu não respondi no celular.

Prof $^{a}$ do ES 1: Eu estou fazendo outra coisa, (inint) [00:22:35] falando. Olha, algum... eu coloquei esse tema no texto escrito (inint) [00:22:43] que eu coloquei, você verificou em alguma dessas respostas abertas aí a questão assim da... Que eu conversava no curso de letras (inint) [00:22:54] professores, a proximidade que 0 aluno tem da carreira, se isso interfere em algum lugar? Por exemplo, engenheiro você vai ter contato com a profissão na graduação, todas as outras, menos a licenciatura, não sei se eu estou equivocada, mas a licenciatura é a única profissão que você convive com ela desde sempre, tem uns que desde quando nascem eles convivem com o professor. Se isso daí vai estressando, vai dando um acumulo, vai dando assim um over.

Técnica da SED/MS 2: Mas hoje em dia, assim, na medicina você tem isso, no primeiro ano que você entra o aluno já tem o contato com os pacientes.

Profa do ES 1: Então, mas só na graduação.

Técnica da SED/MS 1: Sim, isso, na graduação, entendi.

Técnica da SED/MS 2: Tem aluno que fala assim: "A professora hoje dormiu de calça jeans".

Prof $^{a}$ do ES 1: É. Então eles comentam, eles sabem tudo, eles sabem onde a gente mora. Tudo, tudo. Eles sabem da vida desde quando... digamos assim com sete anos que vai para a escola, com seis anos, eles sabem ali da redondeza do bairro onde ele mora.

Técnica da SED/MS 1: Sim, isso é verdade. 
Prof $^{\mathrm{a}}$ do ES 1: Da professora da escola que faz carreira na escola, agora 0 professor de português (inint) [00:24:00] a vida toda, então eu sei isso, sei aquilo, sei que ela vem de carro, sei que ela vem de ônibus, quer dizer eles sabem tudo.

Técnica da SED/MS 1: Onde ela mora. O que a gente reclama, o que é que deixar de reclamar, (inint) [00:24:12]. Então é uma proximidade com a profissão muito...

Prof $^{\mathrm{a}}$ do ES 1: Sim, é verdade. É até demais, ele passa mais tempo com o professor do que com qualquer outra pessoa, será que isso? Isso já os frustram.

Técnica da SED/MS 1: ... Interfere de alguma forma? Porque é muito interessante você perceber isso, assim, a ansiedade que eles têm, uma vez dentro da sala de aula de aula, de querer passar por aquela porta, sair. E eles não querem assim, quando tem alguma coisa com muito professor é só professor de educação física, eles vão lá...

Prof $^{\mathrm{a}}$ do ES 1: E ficam agrupados em cima do professor, os outros não, termina a aula eles... um ou outro que caminha com você, na minha época carregava o material.

Prof. do EM 2: Ainda tem, são poucos, mas ainda tem.

Prof ${ }^{a}$ do EM 3: Tem.

Técnica da SED/MS 1: Tem, tem, "Deixa eu ajudar a senhora professora".

Prof ${ }^{a}$ do ES 1: Não tem mais caixinha de giz.

Técnica da SED/MS 1: Agora tem canetão.

Prof $^{\underline{a}}$ do ES 1: (Inint) [00:24:58] adoravam carregar caixinha de giz. Joguei fora essa semana a minha primeira caixinha de giz que eu ganhei no (inint) [00:25:05] escrito o meu nome e o pirografo, que era o meu pirografo que eu emprestei para a diretoria, aí no dia dos professores ela pegou (inint) [00:25:14] para todos os professores no (inint) [00:25:17]. Eu joguei fora agora.

P: Nossa, que dó.

Prof $^{a}$ do ES 1: Eu já cheguei nessa fase.

Prof. do EM 2: De desapegar. 
Prof ${ }^{a}$ do ES 1: Eu já cheguei nessa fase. Desapeguei, desapaguei. Meu filho fala assim: "Mãe, o dia que vocês morrerem no outro dia essas coisas de vocês todas serão colocadas na calçada".

Técnica da SED/MS 1: Olha lá, tem trauma de professor, olha lá, gente.

Prof. do ES 1: "Ninguém quer nada daquela casa".

Prof. do EM 2: O seu marido também é professor?

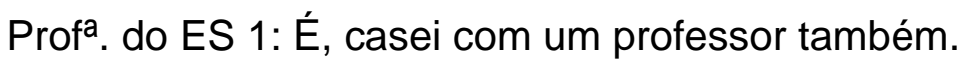

Prof. do Em 2: Então eu entendo (inint) [00:25:39].

Prof ${ }^{\mathrm{a}}$ do ES 1: Meu filho tinha seis anos, teve até um probleminha que estava... que eu ia ter uma filha, então ele se sentiu... ela seria a do meio, foi para a psicóloga tal e tal, e a gente (inint) [00:25:50] "Você tem que acompanhar, dar mais atenção para ele". Então andando no corredor, na hora do intervalo da federal ele segurou na minha mãe, até eu do lado de lá do corredor e ele do lado de cá pulando assim, chacoalhando a minha mão ele falou assim: "Eu não quero estudar aqui" e pulando.

Técnica da SED/MS 1: Já ficou traumatizado.

Profa do ES 1: Aí eu: "Por quê?", "Eu não quero estudar até (inint) [00:26:09] tamanho", que ele viu ele pequeno, seis anos, aquele monte de rapaz enorme, moça. Não é da minha faixa etária. Eu vou, eu odeio escola, que o laudo foi: "Ele não gosta da escola, de estudar, porque a escola tira vocês dele, então vocês saem de casa para ir para escola, então a escola não é lugar bom".

Técnica da SED/MS 1: Olha só, você viu.

Prof $^{\mathrm{a}}$ do ES 1: Foi uma leitura muito... E a gente percebeu realmente isso, ele não gostava, então quando a gente podia levar, quando não podia sair, (inint) [00:26:37] outras coisas agradáveis, e aqui é bom, a gente gosta de trabalhar aqui, inclusive eu nunca reclamei.

Técnica da SED/MS 1: E ele é formado em que hoje?

Prof $^{a}$ do ES 1: Ele fez administração, aí agora terminou administração, é do Banco do Brasil, e agora ele voltou para química, ele é apaixonado pelo curso de química, assim, uma coisa, ele assiste uns filmes, ele lê, (inint) [00:26:58]. E é o que está tendo segunda graduação. 
Técnica da SED/MS 1: Olha aí. Quer dizer, e ele não queria estudar. Então eu acho assim, que essa... o que passa... na cabeça.

Prof ${ }^{a}$ do ES 1: Como que isso vai acumulando neles, pois é, porque é que ele não queria? Aí a professora no final do ano falou: "Mãe...", da primeira série, "Eu queria pedir desculpa para você, a primeira vez que o Artur levantou a mão e falou na minha aula foi em agosto", uma escola super (inint) [00:27:27], top na época e eu não percebia que ele só... Ele só sentava, onde ele estivesse, ali sentado no canto observando tudo, então ela falou assim: "Olha, me desculpa, mas eu não percebi. Quando chegava na sala todo mundo vinha e ele nunca vem, eu nunca percebi, eu percebi ele em agosto", e ela é reconhecida ela, e ela veio me falar, ela me falou, então eu achei assim (inint) [00:27:50] pelo menos acordou uma hora. Muito jovem a menina, assim, vinte poucos anos. Quer dizer, então essa... é difícil essa relação.

P: Só abrindo um parênteses, professora, quando você falou que eles vão jogar tudo fora, eu tive a honra de receber de herança do marido da Carol toda a coleção de Michel Foucault. Ele deu num grupo, você lembra, que eu fui na sua casa e ele me deu toda a coleção? Ele falou: "Nela, meus filhos não se interessam, mas eu sei que você vai ler, toma de presente", ele me deu, super emocionante, eu tenho na minha biblioteca na minha casa a coleção certinha toda do Michel Foucault e já assim, leio, eu sou uma apreciadora do Michel Foucault e assim até dei uma disciplina na pós sobre ele. E está lá, e eu estou lendo e estou usando na minha tese, então assim que tiver mais coisas pode me dar. Que vocês forem jogar fora. Não joguem fora, me dá.

Prof. do EM 2: Me avisa primeiro. Antes de você morrer você manda lá para a minha casa. Você fala assim: "Olha, vou deixar no testamento, se caso algo acontecer, manda para ela. Não, mas isso é tão bonito você ter esse vínculo e o Daniel é um querido também, eu, aliás, fui para o grupo estudar Michel Foucault por conta dele que me convidou, falou: "Não, vamos lá no grupo", e assim acabei me apaixonando pelo autor. Então assim, eu sou muito grata por vocês, essa herança, eu acho que não tem herança melhor do que a do livro mesmo físico. 
Prof $^{\mathrm{a}}$ do ES 1: Sim, do ensino, da cultura.

Técnica da SED/MS 1: Do ensino, da cultura.

Prof ${ }^{a}$ do ES 1: Essa relação, como é que esses adolescentes vêm o professor?

Ou se é mãe, ou se é pai ou se é professor. Porque essa mulher fica aqui? Ela fica das sete as 11 e depois ela volta à tarde e está dando aula aqui de novo (inint) [00:29:45]. Ela não tem família? Ela não tem coisa para fazer? Como se aquilo não fosse uma produção, um trabalho.

Prof. do EM 2: Mas você sabe que esses dias assim, no começo do ano passado, esses dias, nós fomos numa confraternização na escola, o pessoal lá da SED, e foi numa sexta-feira e no sábado eu tinha... eu não lembro o que é que era para fazer, e aí eu peguei e falei assim: "Davi, vamos embora", ele não queria, o meu pequeno, ele oito anos, "Vamos embora porque a mamãe tem que trabalhar amanhã", e estava saindo eu e a Stefany e aí ele falou assim: "Que.....Pausa

[00:30:19] 


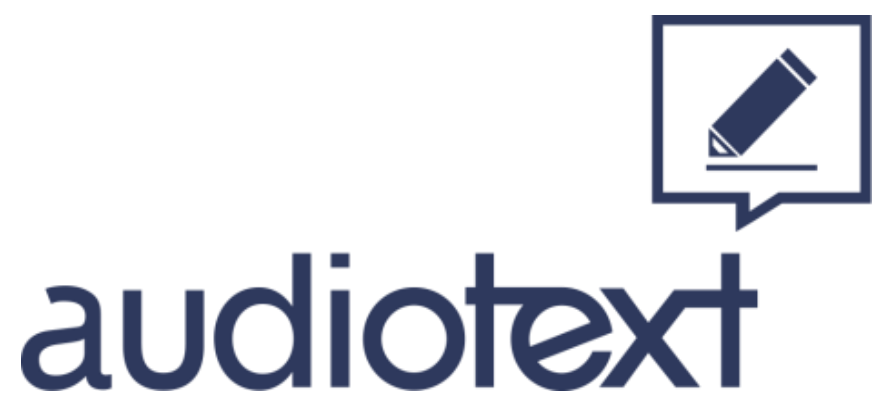

Audiotext Serviços e Cia. LTDA

CNPJ: 17.429.373/0001-85

(41) 3363-3220

falecom@audiotext.com.br

audiotext.com.br 
TRANSCRIÇÃO

-S12917J6 - WIN_20190413_10_23_21_Pro 


\section{PARTICIPANTES}

Professor do Ensino Médio - Prof.do EM 1 - P1

Professor do Ensino Médio - Prof.do EM 2 - P2

Professora do Ensino Médio - Prof ${ }^{a}$. do EM 3 - P3

Professora do Ensino Superior - Prof ${ }^{a}$ do ES 1 - P4

Professora do Ensino Superior - Prof ${ }^{a}$ do ES 2 - P5

Professora do Ensino Superior - Prof ${ }^{\mathrm{a}}$ do ES 3 - P6

Técnica da Secretaria de Estado de Educação - Técnica da SED/MS 1 - P7

Técnica da Secretaria de Estado de Educação - Técnica da SED/MS 2 - P8

Técnico da Secretaria de Estado de Educação - Técnico da SED/MS 3 - P9

Pesquisadora - $\mathrm{P}$

\section{TEMPO DE GRAVAÇÃO}

27 minutos e 05 segundos

\section{MODALIDADE DE TRANSCRIÇÃO}

Padrão

\section{LEGENDA}

$\ldots \rightarrow$ pausa ou interrupção.

(inint) [hh:mm:ss] $\rightarrow$ palavra ou trecho ininteligível.

(palavra) [hh:mm:ss] $\rightarrow$ incerteza da palavra transcrita / ouvida.

A Audiotext Serviços e Cia. Ltda se reserva o direito da imprecisão dos nomes escritos, uma vez que os locutores serão identificados conforme a pronúncia de seu nome. $O$ cliente tem o direito de fazer quaisquer alterações que julgar necessárias nas identificações aqui utilizadas. 
(INÍCIO)

[00:00:00]

Prof. do EM 2: Eu ia vim com meus dois filhos hoje, porque não tinha com quem ficasse, porque minha esposa estava em plantão.

P: É, então, eles sentem.

Prof. do EM 2: Aí acabou que chegou alguém para ficar com eles. Quando eu chego em casa, eu coloquei ele integral, aí chega em casa e ele quer ficar comigo toda hora, eles sentem falta.

Técnica da SED/MS 2: Por que você é professor?

Prof. do EM 2: É, aí vai crescer assim, mas ele fala que quer ser professor, ainda bem.

P: Gente, eu vou passar para o próximo slide porque a professora tem que ir. Vamos lá. Agora a principal razão para não escolher ser professor, novamente os que não responderam estão ali, então o primeiro item lá: não se identificam, não tem vocação ou não gostam dessa profissão, é grande, não é? Falta de paciência para ensinar, desvalorização dessa profissão pela sociedade, principalmente pelos governantes, salário baixo/ruim, profissão muito estressante, rotina cansativa, carga horária de trabalho extensa. Preferem outros cursos, alunos indisciplinados e desrespeito dos alunos com os professores e dificuldade de ensinar pessoas.

Técnica da SED/MS 2: Mas não necessariamente filho de professor, porque eu tinha alunos que falavam: "Professora, eu não quero ser professor", "Por quê?", "Como que a senhora aguenta fulano? A indisciplina dele".

Técnica da SED/MS 1: Não, eu já tive aluno que fala assim: "Como que a senhora me aguenta?", o aluno mesmo "Como que a senhora me aguenta?".

Técnica da SED/MS 2: É, então, assim, é tudo isso daí mesmo, sabe, você escutava de alunos, eles falavam: "Professora, olha, eu não quero ser", e outra, que não gostam de matemática, uma: não quero ser professor de matemática. Técnica da SED/MS 1: Eu também não, eu escolhi geografia porque eu achei que não tinha matemática, mas eu cheguei lá e tinha um monte. 
Técnica da SED/MS 2: Eles falavam assim: "Professora, eu quero fazer pedagogia que não vai ter matemática", eles falavam. Mas é isso aí mesmo que eles falam, é todo esse repertório aí desde a questão do governo, dos próprios colegas em sala de aula, eles viram e falam assim: "Professora, olha, uma coisa que eu não quero ser nunca na minha vida, porque eu acho que eu não aguentaria escutar o que a senhora escutou de fulano", eles mesmos viam isso.

Prof $^{a}$ do ES 1: É interessante ali, $25 \%$ e depois oito por cento a diferença e são... assim, a informação ali é bem forte...

Profa do ES 3: Não tem vocação. "Eu não me identifico", ele é categórico.

Prof. do EM 2: É claro para ele. Ele não quer.

Profa do ES 1: Porque não tenho vocação e eu não gosto, eu não quero, eu não... Olha, $25 \%$ e depois cai.

Prof ${ }^{a}$ do ES 3: Uma porcentagem imensa de...

Técnica do EM 1: Que não tem paciência de ensinar.

Técnica da SED/MS 1: A questão da desvalorização principalmente pelos governantes isso está muito em alta hoje em dia, os governantes eles colocam na mídia o que eles querem que pensem que professor é, que o professor ele é doutrinador. Eu estava fazendo um cursinho para concurso da PRF, eu queria virar policial, um pouco pelo salário também, que um policial rodoviário federal em janeiro desse ano começou ganhando quase 10 mil livre assim, inicial, e enquanto que um professor 40 horas, inicial não ganha nem metade disso. Então eu falei: "Eu vou procurar outra coisa, eu tenho que melhorar", eu sou muito, vamos dizer assim, ativa, eu fico um tempo num lugar, eu não quero mais ficar só naquilo, eu quero evoluir, eu quero fazer alguma coisa a mais ou mudar. Eu fiquei em sala de aula um tempo, agora eu já estou na secretaria, já vai fazer dois anos que eu estou lá e eu já quero fazer outra coisa, ou mudo de setor ou mudo de emprego. Então eu fico assim movimentando, eu não paro. E aí eu fui fazer esse cursinho, então o professor ele falou assim, uma pergunta de um aluno "Não, vocês fiquem tranquilos que quando vocês estiverem na academia vocês vão ser doutrinados", e ele é PRF. Eu olhei para ele assim, e 
ele é Bolsonaro, eu falei assim: "Ué, professor em sala de aula não pode doutrinar, mas na academia de polícia a gente pode ser doutrinado? Como assim?". Então o que os militares, o que o governo, o atual governo está colocando na mídia é tudo para jogar a população contra o professor, se o professor vai fazer um movimento de reinvindicação contra a reforma da previdência os comentários que surgem nas redes sociais falando que professor é baderneiro, que é petista.

Prof. do EM 2: Vagabundo.

Técnica da SED/MS 1: Que é petista, que é de esquerda, que é vagabundo, que não quer trabalhar, que é funcionário público é folgado.

Técnica da SED/MS 2: Eu vi num comentário, eu falei assim: "Gente, eu não vou nem discutir", eu fico só olhando assim o negócio do comentário.

Técnica da SED/MS 1: Só que quando ele se refere ao funcionário público ele está se referindo ao professor. E mais especificamente ao professor, por quê? Porque a mídia está fazendo isso e...

Técnica da SED/MS 2: Tem essa questão também da profissão professor, mas a maioria está deixando aquela sensação de que o professor ele é baderneiro, se é petista é baderneiro, é marxismo, é Paulo Freire, vamos tirar isso da... Agora vem o atual Ministro da Educação que não é da área de educação.

Técnica da SED/MS 1: Economista. Se você colocar um professor na área de lá de economia ninguém vai querer, coloca um professor na área lá de medicina, não, ninguém vai querer, o que é que o professor quer se meter aqui? Não é a área dele. Porque um economista pode ir lá na área de educação e se meter lá? É igual voluntário em escola, amigo da escola, tem amigo do médico, amigo do hospital? Não tem, não tem, porque é que na escola tem que ter um que não tem experiência, não tem formação e para ir querer ajudar na escola? No hospital não tem, como assim, vai colocar um a pessoa que não entende nada.

Prof ${ }^{a}$ do ES 1: É igual a terceirização. 
Prof $^{\mathrm{a}}$ do ES 2: Vai matar, vai tirar a vida de uma pessoa? Ué, mas E dentro da sala de aula ele vai fazer o que com o aluno? Ele vai matar aquele aluno intelectualmente, não é?

Prof $^{a}$ do ES 3: E tem aquela questão também que estava muito assim a flor da pele, eu não sei como está hoje, que no caso ali "não tenha vocação", mas, por exemplo, tem um engenheiro que ele se formou em engenharia, está desempregado e tem a terceirização, não tem, "Ah, porque você é formado em engenharia você pode dar aula de física, química, biologia e matemática", tira o lugar daquele que é formado...

Prof. do EM 2: O notório saber.

Prof. do EM 3: ... Que tem especialização, porque aquele vai cobrar quinhentão a hora e aquela lá vai cobrar 3 mil porque tem isso. Então tem tudo isso também.

Técnica da SED/MS 1: É igual o projeto da Secretaria de Educação do Estado, que ela é do Projetec, o Projetec é um professor contratado. Desvalorizou, perdeu muito o Projetec.

Prof ${ }^{a}$ do EM 3: ... Que está dentro da sala de aula para atender os professores na área de tecnologia, agora acabou.

Técnica da SED/MS 1: Mais de dez anos de projeto e ele acabou com o projeto.

Técnica da SED/MS 2: Bem mais.

Prof $^{\mathrm{a}}$ do EM 3: E o que é que ele fez? Ele abriu edital para contratar técnicos a nível médio para atender só na sala de tecnologia, só aquela parte ali da informática, ele não vai mais ajudar o professor, a parte pedagogia e tal, que era o papel, o planejamento e tal, que era o papel do Projetec. Aí o que é que vai acontecer, os próprios professores que eram Projetecs ficaram desempregados e eles vão fazer esse concurso para ganhar menos da metade do que eles ganharam com o nível médio...

Técnica da SED/MS 1: A desvalorização.

Técnica da SED/MS 2: ... Para não ficar desempregado.

Prof ${ }^{a}$ do EM 3: É muita desvalorização. 
Técnica da SED/MS 1: Que entra naquele lá "desvalorização dessa profissão". Técnica da SED/MS 2: Porque quem é técnico mesmo (inint) [00:08:08] lá, para formatar um computador é 80 reais ou mais. Ele não vai ficar 40 horas lá.

Prof. do EM 1: Ele é preso dentro.

Técnica da SED/MS 1: Sim, ele ganha muito mais ficando ali 40 horas fora. Prof ${ }^{\mathrm{a}}$ do EM 3: Fora ele ganha mais.

Técnica da SED/MS 2: Porque ele vai ter... ele vai arrumar um computador é 100 reais.

Técnica da SED/MS 1: Isso porque ele coloca tudo pirateado no seu computador.

Prof ${ }^{\mathrm{a}}$ do EM 3: Sim.

Técnica da SED/MS 1: Salário baixo e ruim, eu, bom, aqui no nosso estado pelo menos eu já não concordo tanto, é claro que se for comparar com medicina, com direito e tal, mas...

Técnica da SED/MS 2: Mas nos outros estados sim.

Técnica da SED/MS 1: ... Na maioria das outras profissões aqui no nosso estado, vamos dizer assim, eu acho que o salário do professor está bom, poderia ser mais, é claro, a gente merece maior valorização, porque eu já trabalhei de doméstica, de babá, já trabalhei de pintora de casa, que era quando eu ganhava mais, eu pintei casa por mais de dez anos e hoje eu sou professora, então o meu salário dentre as outras profissões que eu tive o meu salário agora é o que está me dando maior estabilidade. Apesar de eu estar devendo dois cartões que somando da mais de 10 mil.

Técnica da SED/MS 2: Que é o mal da gente.

Técnica da SED/MS 1: Mas eu sei que isso está acontecendo não é só comigo, todo mundo que você conversa está devendo ou está com o nome negativado ou está assim virando ao avesso para poder conseguir pagar conta, mas é o que acontece, eu tenho um carro, eu tenho uma casa.

Técnica da SED/MS 2: E os alunos observam isso.

Técnica da SED/MS 1: Sim. 
Técnica da SED/MS 2: Sim. Eu escutei esses dias um menininho, um sobrinho de uma colega minha, "Pô, professora...", e a gíria, "Pô, professora, que carrão hein", eu falei: "Pois então, você quer um carrão desse? O que é que você tem que fazer? Estudar, estudar, não usar droga, não fazer isso, não fazer aquilo. Você não quer um carrão desse?", "Eu quero", "Então o que é que você tem que fazer?", "Estudar, não é Cris? Eu vou estudar". Porque eles acham que a gente tem aquilo ali caído do céu.

Prof ${ }^{a}$ do ES 1: ... Do céu. Então eles vêm, é aquilo que... é a aparência, é o que você tem, é onde você mora, tudo eles (inint) [00:10:17]. Aluno já foi lá minha varanda e falou assim: " - Pô, professora", falou assim para mim, é uma casa normal. Mas ele falou - A sua casa linda! Mas assim, nós dois trabalhamos de professor a vida inteirinha, três períodos praticamente para poder ter o que tem hoje. Quase 15 anos três períodos, quer dizer, e assim, tudo na ponta do lápis. E eles acham assim que consegui do nada. Já quer entrar com o nosso salário. Já com aquilo tudo, é, isso. E na época que eu entrei, eu comecei a trabalhar em fevereiro no estado, o meu primeiro salário saiu, 250 reais o meu foi. Em setembro, eu recebi em três vezes, setembro, outubro e novembro, nos três últimos meses que eu recebi tudinho aqui, fevereiro, março, abril, maio, junho, julho, agosto sem receber salário, está certo, eu tinha a prefeitura, o estado eu estava começando, então eu tinha que aguentar ali para eu firmar.

Prof $^{\mathrm{a}}$ do ES 2: Nossa, quando eu comecei também a gente recebia quase quatro meses depois, nossa.

Prof $^{\mathrm{a}}$ do ES 1: Acho que foi em 80, 1980, o (inint) [00:11:21] que foi o técnico que fez a minha fichinha ali na rodoviária, a secretaria era ali na rodoviária.

Prof ${ }^{\mathrm{a}}$ do ES 2: Era o Wilson?

Prof ${ }^{\mathrm{a}}$ do ES 1: Wilson Barbosa?

Prof $^{\mathrm{a}}$ do ES 2: Entrava um e saia outro, entrava um e saia outro.

Prof $^{a}$ do ES 1: Era, eu lembro que na época de $80 \ldots$.

Prof ${ }^{\text {a }}$ do ES 2: Não mudava nada e não...

Várias vozes: (inint) [00:11:35]. 
Prof $^{\mathrm{a}}$ do ES 1: $88,89,90$, eu lembro que na época de 88 a 90 teve uma crise muito grande na educação, que os professores ficaram mais três meses de greve.

Prof ${ }^{a}$ do ES 2: No estado.

Prof $^{\mathrm{a}}$ do ES 2: Na prefeitura era um desvio eu acho, que eu estava grávida do meu filho.

Técnica da SED/MS 2: Eu não lembro quem que era, acho que era o Wilson nessa época, que eu fiz o meu ensino médio. Não teve crise.

Técnica da SED/MS 1: Eu estava no fundamental, eu parei de estudar que teve essa greve comprida por causa da greve, eu me atrasei nos estudos por causa de greve que tinha, eu ficava dois meses sem ir na escola, o que é que eu vou fazer lá de novo? Por causa da desvalorização. Você sabe, olha, eu não gosto de discutir política, mas as pessoas quando você vai falar qualquer coisa de política a pessoa fala assim: "É porque você é PT", você não pode ter um pensamento "É porque você é PT".

Prof $^{\mathrm{a}}$ do ES 1: Ou é direita ou esquerda, não tem outra.

Técnica do EM 2: Mas assim, eu penso que na época que nós fomos valorizados foi na época que o PT estava, que ele valorizou mais essa classe da gente, porque eu acho que aí que começou a aumentar, eu posso estar enganada que eu sou bem mais nova que a senhora.

Prof $^{\mathrm{a}}$ do ES 1: Mas a prefeitura sempre teve (inint) [00:12:42]. Na prefeitura ela era sempre mais do que o estado, agora parece que está sendo menos, eu ouvi uma conversa que assim, eles estão ganhando menos parece, uma coisa assim.

Prof. do EM 1: Não, o município paga melhor do que o estado.

Prof $^{a}$ do EM 3: O município ainda paga mais que o estado.

Prof $^{\mathrm{a}}$ do ES 2: Mas assim, eu lembro que eu vivenciei nessa época, eu lembro que nós não tínhamos professor de português nessa época de 88 a 90 porque tinha greve, aí começava com professor aí passava três meses tinha outro professor, aí passava mais três meses tinha outro professor, a gente não tinha quase professor por causa dessa desvalorização. Eu não sei, assim, no 
contexto que eu tenho eu penso que a educação começou a melhorar depois que eles começaram a ver, e se eu não estou enganada foi nessa época que o PT entrou, que ele olhou mais para classe, não sei se eu estou enganada, não é.

Prof $^{\text {a }}$ do ES 1: Não, quando o... a primeira vez que o Zeca entrou realmente teve uma... o estado deu uma... Deu um up na questão da educação. Deu, deu uma organizada, foi assim, fez muita diferença, depois estabilizou também.

Prof $^{a}$ do ES 2: Isso.

Prof $^{a}$ do ES 1: Mas realmente no estado... Deu uma melhora muito grande. Eles fizeram umas coisas assim, publicaram uns materiais ridículos.

Prof $^{\mathrm{a}}$ do ES 2: Isso.

Profa ${ }^{a}$ do ES 1: Fizeram muita besteira, mas fizeram...Na questão salarial eles nunca mexeram.

Profa ${ }^{a}$ do ES 2: (Inint) [00:14:01] a questão metodológica dentro da secretaria, mas assim, deu uma boa melhorada.

Prof $^{\text {a }}$ do ES 1: ... Que foi nessa época, eu penso.

Técnica do EM 1: Nó temos agora, está fazendo dez anos do FUNDEB e eles estão fazendo todo um movimento onde fala de salário baixo e ruim, porque o nosso salário é atrelado é ao FUNDEB, para que o FUNDEB continue, senão vai depender do governo federal, na situação que está...

Técnica do EM 1: Vixi Maria, nós estamos perdidos, se nem os idosos estão podendo ganhar.

Técnica do EM 2: É, porque eles estão... aos políticos, não gostaria de mencionar nomes, mas eles estão lutando aí algo...

Técnica do EM 1: Para abaixar.

Técnica do EM 2: Não, para continuar o FUNDEB.

Técnica do EM 1: Para continuar senão cai.

Técnica do EM 2: É, porque ele está tirando todos os fundos de investimentos.

Técnica do EM 1: 60\% DO FUNDEB paga os nossos salários.

Técnica do EM 2: Verdade. 
Técnica do EM 1: A questão da desvalorização de algumas disciplinas também como filosofia e sociologia que eles estão querendo extinguir, aí vem o nome ministro, é uma reportagem que é de dois anos atrás, mas surgiu à tona agora porque ele assumiu a pasta, mas o pensamento dele era de que o Nordeste não precisa estudar na faculdade de filosofia e sociologia, para quê? Eles têm que estudar agronomia.

Prof. do EM 2: Como assim?

Técnica do EM 1: Eu recebi um texto que eu achei muito lindo, o Edvaldo mandou, eu mandei ontem no grupo.

$P$ : Eu vi, lindo mesmo.

Técnica do EM 1: Eu vou mandar no grupo da (inint) [00:15:42] aí depois se você quiser ler. Fala dos autores, escritores. Se não tivesse o Jorge o Amado, se não tivesse Cecilia Meireles. Gente, a maioria, a maioria é nordeste. Gente, o que seria da nossa cultura hoje em dia?

P: Compartilha, por favor, no grupo que aí todo mundo tem acesso.

Técnica do EM 2: Muito bom.

Técnica do EM 1: Eu vou mandar.

$\mathrm{P}:$ Alguém mais quer discutir alguma questão aqui?

Prof $^{a}$ do ES 1: Aquilo lá em cima para mim foi gritante.

Prof ${ }^{a}$ do ES 2: Foi. É forte, não é?

Prof ${ }^{a}$ do EM 3: É forte (inint) [00:16:12].

$P$ : E vocês acham que o trabalho do professor, ele está atrelado a vocação?

Prof. do EM 2: Olha, eu acho que não.

Prof ${ }^{a}$ do EM 3: Mas por outro lado tem pessoas que não tem vocação e de repente começam a fazer... Eu tive uma aluna...

Prof. do EM 2: Você descobre. Se descobre, a vivência, é assim. É o que aconteceu comigo, porque ele pode falar ali que não tem vocação e ele nunca ter dado uma aula e chega lá e vê que aquilo é a vida dele. Talvez se eu tivesse participado da pesquisa no ensino médio, eu teria respondido também que eu nunca queria ser professor, aí quando eu cheguei no último ano da faculdade de direito que eu resolvi trabalhar para parar de pedir dinheiro para 0 
meu pai e para a minha mãe e falei: "A única coisa que eu tenho é um diploma de curso de inglês", e fui procurar emprego e em um mês eu estava apaixonado, dando aula o dia inteiro, dez aulas seguidas uma atrás da outra.

Prof $^{a}$ do EM 3: A vocação apaixona a pessoa.

Prof. do EM 2: Aí pensei: vou comprar a escola, vou ficar aqui. Aí que eu fui fazer letras, ainda depois de um bom tempo que eu fui fazer letras.

Profa ${ }^{\text {- }}$ do ES 1: Eu acredito assim que algum tempo atrás eu acho que não tinham tantas profissões para serem escolhidas, hoje o aluno ele tem muitas, um leque enorme de profissões, era só essa...

Profa $^{-}$do ES 2: Antigamente só as mulheres que eram professoras.

Técnica do EM 1: Só essa pesquisa que você mostrou aí quantas profissões eles têm para eles poderem escolher, não é? Eu, quando eu era criança eu queria, ou eu queria ser marinheira, porque a minha irmã era apaixonada e queria ser marinheira, eu cheguei a fazer concurso para polícia, para bombeiro, nossa, eu já fiz tanta coisa, ou eu queria ser professora, porque a minha mãe estudava a noite porque ela não queria continuar naquela vida. $E$ eu acho que o incentivo foi por causa da minha vizinha que era diretora, o marido dela era dono do bar da esquina, que era uma padaria, que era um mercadinho e ela era diretora de uma escola, e eles tinham casa bonita, eles tinham carro e tal, e eu naquela casinha de tábua pobrezinha. Eu ia ajudar a filha dela a lavar o carro só para poder chegar perto de um carro e aí eu falava assim: "Eu vou ser professora". "Se eu não for ser militar, se eu não conseguir entrar para a marinha, bombeiro, alguma coisa assim, eu vou ser professora", eram as duas coisas que eu queria, militar eu acho que por causa da época.

Técnica do EM 2: Que tinha estabilidade.

Técnica do EM 1: Militarismo era mais valorizado. Eu nasci na década de 70, ainda era ditadura, então eu acho que eu cresci com isso, hoje em dia eu já não quero tanto, se eu for vai ser mais por causa de salário. Mas a minha profissão professora eu faço porque eu gosto e porque eu sinto prazer em ver que uma criança aprendeu aquilo comigo. Quando você falou que ganhou uma coleção de livros do marido dela eu lembrei que aquele meu aluno que não 
queria nada com nada e nem o coordenador queria falar com ele mais, eu postei no grupo da escola que eu ganhei um conjunto, uma coleção completa de enciclopédias da Barsa, eu ganhei do meu sensei, que era da mulher dele que era professora, só que ela aposentou, ela não ia usar mais então ela estava doando. Quando ele me mostrou a foto o meu olho brilhou assim, porque a minha mãe tinha a Barsa, ela comprou para a gente estudar. E quando eu fui fazer faculdade eu não tinha internet e nem computador em casa, eu pesquiso tudo na Barsa, aí eu falei...

Prof $^{-a}$ do EM 3: Era a nossa internet.

Técnica do EM 1: Aí eu dava aula numa escola e eu falei assim: "Lá não tem, vou ver se a diretora quer", ela não quis, porque agora, hoje em dia não usa mais. Ultrapassado, pensou (inint) [00:19:38]. Ela falou: "Está ultrapassado, não usa mais, professora, os alunos não vão pesquisar nisso aí, porque eles acham tudo na internet", eu falei: "Está bom".

Prof $^{\mathrm{a}}$ do EM 3: Tudo as vezes (inint) [00:19:46].

Técnica da SED/MS 1: Aí eu tinha um grupo que eu estava porque era um grupo com os alunos, eu peguei e mandei naquele grupo dos alunos, eu falei: "Olha, eu estou doando", mandei a foto, falei: "Se alguém quiser é só se manifestar aqui que a gente dá um jeito de entregar", aí esse aluno meu que não queria nada com nada e que hoje quer ser professor de biologia ele foi 0 primeiro e o único que mandou assim no privado falando: "Professora, eu quero", ele foi lá em casa com o pai dele e a mãe dele de carro buscar. Eles são evangélicos e tal, e o pai dele é daqueles que o coordenador não quer conversar, porque vai lá e fala: "Meu filho não está errado, meu filho é perfeito, não tem defeito nenhum", e tem, mas ele defende o filho. Aí foram lá em casa buscar, e levou a Barsa, chegou em casa ele colocou a Barsa no quarto dele numa estantezinha, tirou foto e mandou para mim: "Olha, professora".

Prof $^{\text {a }}$ do EM 3: Olha só que bom, não é.

Técnica da SED/MS 1: Igual ela. Ele ainda não queria ser professor, mas agora ele quer e eu falei para ele: "Olha, pesquisa na Barsa antes de você ir para a 
internet, porque a internet pode ter sites que são seguros e outros que não são".

Prof. do EM 2: A gente não tem certeza da referência. E você pode até pegar num caminho errado. Tem tanto fake.

Técnica do EM 1: "... Quando você quiser comparar alguma informação da internet você procura na Barsa que com certeza você vai achar".

Prof ${ }^{-}$do ES 3: Eu acho que antigamente também quando tinha o curso de magistério já era comum, você tinha essa opção, era mais mulher que fazia magistério, eu lembro que a minha irmã mais velha fez, mas era um grupo de pessoas que já saia voltada para o mercado de trabalho para trabalhar como professor.

Profa do ES 1: Com 19 anos já começava já.

Prof. do EM 2: Hoje já não existe.

Prof $^{\mathrm{a}}$ do ES 1: $\mathrm{Na}$ época que eu entrei na escola tinha até uma siglazinha "pega marido" chamava a profissão, gente, que coisa horrível.

Prof. do EM 1: Puxa vida.

Prof $^{\mathrm{a}}$ do ES 1: Porque professora era professora de magistério.

Prof $^{a}$ do ES 3: Já tinha salário, não, chamavam assim que nós éramos a profissão pega marido porque queria ser professora, eu falei: "Não acredito", nós é que tínhamos esse rótulo, porque a gente era professora então chamava a profissão pega marido.

Técnica da SED/MS 2: Hoje em dia é o contrário. É espanta marido, porque você leva planejamento para casa, leva prova, leva um monte de coisa para corrigir, você não dá atenção para ele, você espanta marido.

Prof. do EM 2: Essa coisa que você falou de levar as coisas para casa isso é uma máxima que eu tenho comigo, eu procuro ao máximo não fazer nada em casa, porque eu fico irritado, eu preciso de concentração, eu tenho duas crianças andando para cima e para baixo, dois cachorros, vizinho tocando para brincar com as crianças e quer brincar na minha casa, que depois quer ir para outra casa e eu tenho que ficar de olho. Então ou eu faço o que eu estou fazendo bem feito ou eu não faço, então assim, de segunda a sexta e no 
sábado quando tem alguma coisa eu estou lá, agora a partir do momento que acabou eu vou para casa porque eu estou indo para a minha casa e eu demoro para desligar, eu chego em casa bravo, eu chego casa irritado, estressado, "Pai, olha isso que fiz?", eu (inint) [00:22:44]. Aí dá uns dez, quinze minutos eu começo a baixar a bola.

Técnica da SED?MS 2: Espera aí, eu vou fazer terapia. Não estressa não.

Prof. do EM 2: Às vezes eu demoro mais no caminho para casa só para dar uma desestressada mesmo. Desacelerar. Eu vou ouvindo música bem do jeito que eu gosto, cantando, pego a estrada as vezes para ir embora para dar um, sabe? Porque se eu chegar em casa, dependendo do dia... Se eu chegar em casa sexta-feira que eu fico o dia inteiro na escola integral que eu não posso nem sair para almoço, nossa, eu fico extremamente irritado, eu não tenho esse reflexo dentro da sala de aula, eu não tenho isso dentro da sala de aula com os alunos, isso é fora mesmo, é muito engraçado (inint) [00:23:23].

Técnica da SED/MS 1: É porque quando você desliga, aí desliga.

Técnica da SED/MS 2: Mas isso é histórico, a questão...

Prof. do EM 2: É porque você vai segurando, segurando, segurando durante o dia aí quando chega no final você tem que liberar e você acaba liberando na pessoa que você não pode, no caso da família, do cachorro, você xingar o cachorro, coitadinho, vem tão feliz abanando o rabo, você já briga com ele e ele vai estar lá.

Prof $^{a}$ do ES 1: É histórico, (inint) [00:23:49] quando ele conta a história da vida dos professores ele fala o que é que era antes? Porque fala hoje como sacerdócio? Porque realmente quem tinha instrução para dar aula eram os padres, eles realmente davam aula de graça. A sinhazinha, a professorinha era a filha do fazendeiro que vinha e ministrava aula de graça, porque (inint) [00:24:16]. E por muitos anos nós não tivemos horas de planejamento, então ficou, é histórico isso na nossa profissão, a gente não tem esse período de planejamento e agora com essas horas de planejamento as vezes a gente não quer fazer o planejamento na escola porque você fica lá, você senta lá no sofazinho, tem aquelas (inint) [00:24:44] tem um sofazinho, você senta...Você 
põe as perninhas para cima e fica lá. Puxa a cadeira, põe ali, aí você conversa com seu colega que é o seu momento, aquele horário de planejamento que você fica é gostoso, porque a gente não tem as vezes um irmão, uma vizinha para você conversar.

Prof ${ }^{a}$ do EM 3: Trocar ideias.

Prof ${ }^{a}$ do ES 1: Mas o seu colega está ali e isso faz bem para a gente, não é assim? Então 50 minutos de um horário que você sentou ali e conversou com o seu colega, Avon ou então olhando a Veja que estava lá em cima, comentando alguma coisa assim.

Prof $^{\mathrm{a}}$ do EM 3: Jequiti.

Prof $^{a}$ do ES 1: Olhando o Whats, é desestressante, então você não pega 30 provas para corrigir que você poderia corrigir aquelas 30 provas naquele horário, então você quer um dia livre, você quer aquele horário livre, e a mulher tem mais dificuldade de ter essa organização que vocês homens tem dentro da escola, são minoria, senta lá, ele corrige o material dele dentro da sala dos professores, as mulheres elas conversam na sala dos professores. Eles falam assim: "Nossa Senhora".

Prof. do EM 1: E atrapalha o professor que está... Não, é mentira.

Prof $^{\mathrm{a}}$ do ES 1: Ela vai até a cantina, toma o café com a merendeira, que a merendeira fica ali o dia inteiro, ela sabe de tudo, as vezes ela quer... é desestressante, pega uma xicrinha de café ou vai lá beber uma água, conversa, então faz bem para a mulher.

Prof ${ }^{a}$ do EM 3: Sim.

Prof ${ }^{-a}$ do ES1: Mas chega em casa tem que (inint) [00:26:02], a mulher não tem uma pessoa da mesma idade para conversar com os mesmos interesses e na escola tem, então isso já está dentro da gente fazer isso, então isso atrapalha muito essas horas de planejamento que a gente não consegue administrar como aula de planejamento e quando põe num dia só a pessoa fala: "Eu vou só lá para planejamento, ai, eu odeio", porque eu sempre vou chegar lá e vou fazer a mesma coisa e vou deixar para fazer o planejamento em casa. 
Técnica da SED/MS 2: É, só que tem, eu já tive experiências também de professores homens de chegar na sala de planejamento onde todo mundo está lá quietinho, planejando, corrigindo e o cara chega e começa a conversar, contar piada e dar risada e atrapalha a concentração de todo mundo.

Técnica da SED/MS 1: É, mas é mesmo. Lá era o de educação física que faz isso. A gente tinha que chegar e tinha que pedir: "Fulano, faz o favor". Prof. do EM 2: Literatura, ele tem história para contar.

[00:27:05] 


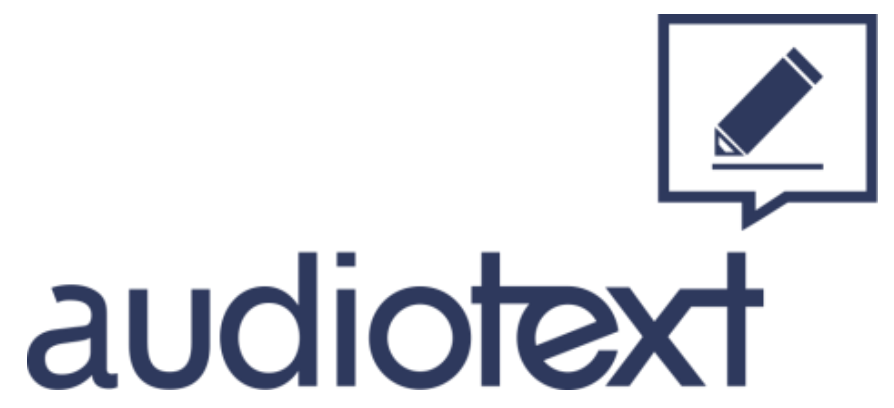

Audiotext Serviços e Cia. LTDA

CNPJ: 17.429.373/0001-85

(41) 3363-3220

falecom@audiotext.com.br audiotext.com.br 
TRANSCRIÇÃO

S12917J7 - WIN_20190413_11_06_29_Pro 


\section{PARTICIPANTES}

Professor do Ensino Médio - Prof.do EM 1 - P1

Professor do Ensino Médio - Prof.do EM 2 - P2

Professora do Ensino Médio - Prof ${ }^{a}$ do EM 3 - P3

Professora do Ensino Superior - Prof ${ }^{\mathrm{a}}$ do ES 1 - P4

Professora do Ensino Superior - Prof ${ }^{a}$ do ES 2 - P5

Professora do Ensino Superior - Prof ${ }^{\mathrm{a}}$ do ES 3 - P6

Técnica da Secretaria de Estado de Educação - Técnica da SED/MS 1 - P7

Técnica da Secretaria de Estado de Educação - Técnica da SED/MS 2 - P8

Técnico da Secretaria de Estado de Educação - Técnico da SED/MS 3 - P9

Pesquisadora - $\mathrm{P}$

TEMPO DE GRAVAÇÃO

26 minutos e 44 segundos

\section{MODALIDADE DE TRANSCRIÇÃO}

Padrão

\section{LEGENDA}

$\ldots \rightarrow$ pausa ou interrupção.

(inint) [hh:mm:ss] $\rightarrow$ palavra ou trecho ininteligível.

(palavra) [hh:mm:ss] $\rightarrow$ incerteza da palavra transcrita / ouvida.

A Audiotext Serviços e Cia. Ltda se reserva o direito da imprecisão dos nomes escritos, uma vez que os locutores serão identificados conforme a pronúncia de seu nome. $O$ cliente tem o direito de fazer quaisquer alterações que julgar necessárias nas identificações aqui utilizadas. 
(INÍCIO)

[00:00:00]

P: Gente, olha a próxima questão que a gente vai discutir, eu estou retornando.

Então se pensa em ser professor, daqueles que optaram, seria da educação básica, do ensino superior ou de uma disciplina específica do sexto ao nono ou ensino médio. Então aqueles $63 \%$ são os alunos que realmente não pensam, não querem ser professores. E a primeira com índice aqui é da disciplina específica do sexto ao nono e do ensino médio, então a maioria gostaria de ser professor da educação básica de uma disciplina, isso eu acho super importante. Depois o ensino superior ele tem menos e da educação infantil de primeiro ao quinto ano eles colaram em menores proporções, vocês vejam que tem uma discrepância no dado, no anterior eles falam que eles gostam de criança.

Técnica da SED/MS 1: ... Já cai muito.

Profáa do ES 1: De optar. Então assim, a gente não sabe se ele pensa que a criança também faz parte.

Técnica da SED/MS 1: Do sexto ao nono.

P: Do sexto ao nono, é só para dar uma pincelada nisso daí. O que é que vocês acham aí?

Técnica da SED/MS 1: É, no caso dali de alguma disciplina ele se identifica, por exemplo, educação física, por química, por biologia, por matemática, por literatura, nesse sentido eu acho que é porque é a vivência dele também, porque o ensino superior ele não conhece, então ele está... ele já passou pela educação infantil, ele está ali no médio, então ele já conhece. Se identifica por alguma disciplina.

Técnica da SED/MS 2: É, então como ele ainda não conhece o superior, não sabe como que é, então as vezes ele não sabe nem o que é que ele faria lá ou talvez: "Ah, eu não vou dar conta", então eu vou ficar por aqui que é mais fácil.

Prof. do EM 2: Talvez seja mais fácil de projetar no ensino médio ou do sexto ao nono do que no superior que ele não faz ideia de como seria.

Técnica da SED/MS 1: Eu acho, eu penso que seja bem mais simples que no ensino, eu penso, eu não sei.

Prof. do EM 2: Eu não sei, eu gostaria de descobrir logo mais. 
Técnica da SED/MS 2: É, eu acho que na verdade eu acho que seja o mesmo problema que nós temos no ensino médio quem dá aula no ensino superior deve ter o mesmo problema, porque assim, eu fiz uma outra graduação, eu fiz fisioterapia e eu tinha um problema muito sério, porque assim da minha turma eu era a única formada, os outros eram assim, era avô, era avó, era namorada, pai, era marido que pagava a faculdade, e lá, eu já trabalhava a noite, o meu pai me ajudava porque o salário não dava, para poder fazer a fisioterapia, não porquê eu não gostava de matemática, eu já era formada fazia um tempo, mas eu queria sempre estar estudando. E aí, menina, eu acabava brigando, não era brigando, discutindo com os colegas, porque eu achava o cúmulo, um dia, que nem a Carol, não é? Ela falou assim que os alunos falaram assim: "Ah, dormiu de calça jeans e não sei o que". Então tinha uma menina, eu nunca esqueço, o pai dela era dono daquele supermercado Milena que tinha aqui, e a guria ela saia assim do nada da sala de aula para fumar e a professora eu amava a aula dela, pensa numa professora assim que planejava tudo certinho no Datashow, explicava, você via que ela preparava a aula. E aí você estava bem aqui assim e a menina ali, ela fazia questão de sair daí e passar lá na frente do retroprojetor, nem falar assim: "Licença, professor", no ensino superior e eu via isso. Então um dia nós estávamos tomando café, lanchando e aí ela falou assim: "Essa professa está com falta de macho para ficar passando essas coisas, não sei o que, olha o que ela falou para mim”, aí eu peguei e fiz bem assim: "Como é que é? Você está falando o quê? Que a professora está com falta de macho. Olha, admiro muito você de estar no nível superior, isso eu escuto de aluno meu lá do ensino fundamental, do ensino médio, porque eu escutei de um aluno e eu não admito você falar isso de um professor, não admito", "Ai, Cristiane", eu falei: "Ai não", eu falei: "Porque você defende", eu falei: "Não, filha, porque acima de tudo eu também sou professora", aí ela também quis dizer assim: "Mas você é de estado, município", eu falei: "Não muda, minha filha, o nome está ali: professora. E ela também é uma professora, você não sabe a noite que ela passou estudando para preparar aquela aula".

Prof. do EM 2: Se o computador é função nossa.

Técnica da SED/MS 2: "O que ela fez para poder aplicar aquela aula. Você agiu errado, porque você nem licença pediu para ela para sair da sala de aula". Aí tinha um pessoal tudo assim, eu falei: "E outra, vocês são piores do que meus alunos do 
primeiro ano do ensino médio", aí um colega virou para mim e falou assim: "Credo, Cris", eu falei: "Credo não, vocês são piores do que os meus alunos, os meus alunos não fazem isso que vocês fazem, só porque vocês estão pagando? Não, filha, não pode", aí eu falei assim: "Gente, então...". Aí que eu falo que no ensino superior eu acho que as vezes tem coisas piores ainda do que a gente passa no ensino médio.

Prof $^{a}$ do ES 3: A melhor coisa é dar aula na pós-graduação. Que você dá a matéria e eles têm que se virar. É a melhor coisa é a pós-graduação. Eu penso que sim.

Técnica da SED/MS 2: Por experiência de ensino fundamental, de educação infantil e de ensino médio eu prefiro ficar do sexto ao nono, porque é aquela fase que eles te obedecem, tem aqueles que estão no oitava, no nono que não querem obedecer, são pirracentos mesmo, mas não são todos, e aqueles que você, eu na idade que eu já estou eu posso chegar e chamar a atenção e falar como se fosse meu filho: "Olha, eu tenho idade para ser sua mãe, sou sua professora então é isso, isso e isso, ou você concorda comigo ou você vai para coordenação ou para direção, chamar seu pai tal e tal", aí eles se aquietam. Agora vai falar isso para um aluno de ensino médio que é maior que você, que te peita. Eu te pego na saída.

Técnica da SED/MS 1: Não, ficar se maquiado, pintando a unha, passando negócio nos cílios lá na sala de aula, aquelas meninas se olhando no espelho.

Prof. do EM 2: Não, eu acho legal, mas quando isso acontece, que toda semana tem uma, falo assim: "Olha, parabéns. Para fazer o curso técnico para você abrir o seu salão e ganhar muito mais do que eu com certeza você precisa concluir o médio".

Técnica da SED/MS 1: Sim, eu também falava isso.

Prof. do EM 2: "Presta atenção na aula, passa de ano e aí depois você vai lá, faz o técnico, abre o salão. Eu vou até lá para você fazer um tratamento no meu cabelo também, vamos embora, não tem problema". E eu brinco, falo muito isso mesmo sabe.

Técnica da SED/MS 1: É cada uma. Eu também falava para caramba.

Prof. do EM: Porque é um direito deles, é uma coisa legal e é um serviço que as pessoas gastam muito para fazer, agora pelo menos sair do médio você vai ter que sair, então...

Técnica da SED/MS 1: Tem que terminar.

Prof. do EM 2: ... Vamos lá.

Técnica da SED/MS 1: Perfeito, ótimo. 
Prof $^{\mathrm{a}}$ do ES 1: Tem uma discrepância do primeiro ao quinto ou uma defasagem ali do primeiro ao quinto na parte de pedagogia, não é?

Técnica da SED/MS 1: Sim.

Prof. do EM 2: As iniciais.

Técnica da SED/MS 1: No final.

Prof $^{\mathrm{a}}$ do ES 1: Sim.

Prof. do EM 2: Eu acredito que do sexto ao nono a vontade de a criança aprender talvez seja um fator de motivar o professor a estar ali, porque a criança tem vontade de saber, ela pode não se identificar com uma matéria, ter dificuldade com outra, mas ela quer aprender, ela quer saber porque é que eu sei falar inglês e ela não sabe, o pai dela não sabe, ou porque o carro consegue se mover só com a tração da frente ou com as quatro rodas. Então por isso que eles prestam atenção, eles te perguntam, eles respondem, eles têm uma... é normal. Eles começam a descobrir. Mas eles têm um interesse que no ensino médio a gente vê que o aluno... é difícil você ter dez alunos numa sala de $30 \mathrm{com}$ interesse que os alunos do fundamental têm.

Técnica da SED/MS 1: Sim, e eu já participei de discussão...

Prof. do EM 2: 30 foi legal, 40.

Técnica da SED/MS 2: ... Da parte da educação e eu via muita coisa assim: "O que é que vocês fazem com os alunos no ensino médio e do ensino fundamental? Vocês estragam esses alunos", eu falei: "Como?", porque até quinto ano eles são ótimos alunos, eles perguntam, eles respondem, eles são curiosos, chega no sexto ao nono...

Prof $^{-}$do EM 3: Mas é a fase. Eles desaprendem tudo que eles aprenderam. Você acredita que em formação, em curso assim que eu já participei eu já escutei muito isso que nós estragamos, estragam na metade ali do sexto ao nono, quando chega no ensino médio eles já desaprendem tudo que aprendeu, que é o que a gente escuta nesses estudos que tem, nessas decaidas que tem do IDEB aí, eu falei assim: "Gente...". Mas aí é a questão do interesse do aluno, ele não está... é o que você falou, ele quer saber o inglês. O meu filho é apaixonado por inglês, ele está no terceiro ano.

Prof. do EM 2: Dar aula no sexto ano é maravilho para mim, eu saio realizado de toda aula. 
Profa ${ }^{a}$ do EM 3: Ele quer fazer inglês, ele falou: "Mãe, eu quero fazer inglês", ele escuta a música em inglês e ele fala melhor do que eu, então ele tem esse interesse. Quando chega no sexto ao nono ele vai fazendo aquela decadência, até o sexto é bom, quando passa para o sétimo.

Prof. do EM 2: Aí os interesses são outros, a família também muitas vezes larga o acompanhamento.

Técnica da SED/MS 2: Tem a questão de entreter na pré-adolescência.

Prof. do EM 2: Exato. É hormonal.

Prof ${ }^{a}$. do EM 3: E tem aquele negócio menor aprendiz não é, que o pai quer pôr o guri lá para trabalhar e ajudar em casa, a gente vê tudo isso. Eu assim um outro dado também que, por exemplo, do primeiro ao quinto ou educação infantil o professor regente ele fica mais tempo com aquele aluno em sala de aula.

Técnica da SED/MS 2: Sim.

Profa do EM 3: Então ele trabalha não só escolarização, mas também educação. Quando chega do sexto ao ensino médio tem um professor para cada disciplina. Ali também, como fala? O professor acaba trabalhando escolarização, aí vem a parte da educação que, as vezes não é trabalhada pela família, há um embate e que também tem que ter o outro lado da gestão da escola para dar um apoio ao profissional que está ali, senão não caminha. Eu estou falando isso, colocando a coordenação lá para que não deixar quando aconteça alguma coisa com o meu professor para não deixar nenhuma das partes estressadas, você chamar aquele aluno, conversar, tirar ele dá sala de aula "Você quer tomar uma água, um café? Você vai retornar, você vai pedir licença, vai dar continuidade", para que ele tenha um norte, por quê? Porque muitas vezes, esses dias na... chamando um aluno por causa da vestimenta lá, eu trabalho bastante dentro de (inint) [00:11:11], "Mas você vem $\operatorname{assim...".~}$

Técnica da SED/MS 2: Que é a melhor coisa.

Profa do EM 3: É, aí na ficha dele estava escrito assim, que eu faço a ficha, "Mãe tem, o pai: não conheço e nunca vi, não tem referência". Eu fiquei uma hora conversando com ele, não deixei assim... da vestimenta, conversei e falei: "E amanhã, você vai vir?", "Não, professora, eu sabia das regras, mas amanhã eu venho assim", eu falei assim: "Olha, está no regimento, não pode ter embate com o professor, não vai ser legal. Quando você trabalhar, você vai chegar desse jeito no 
seu emprego?", aí ele (inint) [00:11:46], ele estava com brinco, "E assim, você vai chegar com brinco?". As vezes ele não tem um norte. Uma referência, ele não tem um norte, e coisa que do primeiro ao quinto os professores da gente eles estão mais atentos, os pais também.

Várias vozes: (Inint) [00:12:04].

Técnica da SED/MS 2: Do sexto ao nono ele nem vai.

Prof. do EM 2: O acompanhamento da família, do responsável até o sexto...

Prof $^{a}$ do EM 3: No sexto ano misericórdia trazer o pai para escola. A gente vê isso nas reuniões que são convocadas na escola, do primeiro ano até o sexto ano os pais ainda vão, passou do sétimo para frente o pai não vai.

Prof. do EM 2: O oitavo ano então.

Prof $^{a}$ do EM 3: O Família na Escola que acontece no final de semana de eletivo você vê a maioria dos pais que participam do Família na Escola são dos pequenininhos e os pais que na verdade não precisam de ir.

Prof. do EM 2: Sim.

Profa do EM 3: E aqueles que os pais precisam comparecer, que a gente precisa conversar, aqueles nem vão. Eles são os pais de dezembro, ele vai só lá no final do ano. Reclamar. Saber porque é que o meu filho reprovou, porque é que é o meu filho faz exame.

P: Eu vou passar para o próximo, gente. Olha, se pensa em ser professor do sexto ao nono ano, ensino médio, então seria em qual disciplina, olha lá.

Prof. do EM 2: A educação física.

Técnica da SED/MS 2: A educação física...

Técnica da SED/MS 1: Em primeiro.

Técnica da SED/MS 2: ... No topo, no topo.

Técnica da SED/MS 1: Matemática.

Técnica da SED/MS 2: Matemática. Olha só.

Técnica da SED/MS 1: Que bom. Depois história, biologia, língua portuguesa, geografia, física, inglês, artes, química, filosofia.

Técnica da SED/MS 2: Olha! Nossa! Legal!

Profa do ES 3: Literatura, sociologia, achei ótimo.

Prof. do EM 2: Legal.

Técnica da SED/MS 1: E ciências ali. 
Técnica da SED/MS 2: Nossa, matemática eu fiquei surpresa.

Prof $^{\mathrm{a}}$ do EM 3: É, assim dado que eu (inint) [00:13:33] entrei aqui de biologia. Essa aluna que vai para os Estados Unidos, como ela já está na pesquisa já há três, quatros anos, esses dias eu perguntei ela, no dia do trote ela falou que quer ser bióloga para mexer com pesquisa, sabe? Por quê? Porque tem um professor, eu acho que não sei é por causa do clube de ciências, o apoio da família.

Técnica da SED/MS 2: Pode ser.

Profa do EM 3: E ela gostou, que aí entra naquele lá de uma disciplina. Foi o que aconteceu com esse meu aluno. Que você se interessou. Ele queria na área de militarismo e ele vai ser professor, quer ser professor de biologia. E outro dado, gente, na escola lá na coordenação o que é que eu tenho visto estagiário, tem mais estagiários da Estácio em educação física que procura a escola, tem assim, tem um de química, um de língua portuguesa, enquanto eu tenho cinco, eu acho que é um total de oito na escola assim em um tudo, dois períodos, de educação física.

Prof. do EM 2: De letras eu acho que tinha dois só.

Prof $^{\mathrm{a}}$ do EM 3: ... Não tinha na área de educação, você sabe o que é que tinha? Psicólogos, psicólogo, jornalismo, não era da área de educação que estava ali no estágio lá na escola, eram outras áreas que procuravam lá.

Prof. do EM 3: Não, a psicologia na UCDB tem bastante, eles fazem parceria, eles vão na escola.

Prof ${ }^{\mathrm{a}}$ do EM 3: Eu não sei se psicólogo.

Prof. do EM 2: Porque existe a psicologia educacional.

Prof $^{\mathrm{a}}$ do EM 3: Sim. Então esse é um ponto.

Técnica da SED/MS 2: E o jornalismo eu acho que entra por causa da parte da comunicação, a história.

Prof $^{a}$ do EM 3: Eu acho que é o jornalismo, era coisa que não tinha nada a ver com a educação e elas estavam lá, tinham duas de manhã e duas à tarde.

Técnica da SED/MS 2: Mas isso é muito comum. É, ajudam não é. Você ter outros profissionais também inseridos nesse contexto.

Prof ${ }^{a}$ do EM 3: E abriu agora porque de primeiro não tinha, desses anos para cá.

Técnica da SED/MS 2: Até para quando for escrever alguma notícia ele saber mais ou menos do que ele está falando, porque tem jornalista que escreve e que não tem 
noção do que fala. Escreve o que houve sem ter uma pesquisa prévia para saber se é realmente aquilo, se é daquele jeito mesmo que eles está postando.

$\mathrm{P}$ : Vocês querem falar mais alguma coisa?

Prof. do EM 2: Eu acho que realmente o fator da educação física é mais pela valorização da beleza e etc., está na moda. De ficar fora de sala de aula.

Prof $^{a}$ do EM 3: Ficar fora da sala de aula é o mais importante.

Prof. do EM 2: Tem a ideia de brincar não é, fazer o esporte. É, brincar, jogar futebol, na maior parte é futebol.

Prof $^{a}$ do EM 3: Eu acho que a questão da saúde também que é muito falado. Quem vai para a parte fitness.

Prof. do EM 2: É. Sim. É uma vertente já.

Prof $^{\text {a }}$ do EM 3: Que a educação física não é só como professor, pode atuar em outras áreas. É o personal, não é?

Prof. do EM 2: Em clubes, em projetos, em projetos na escola. É amplo, não é? Prof ${ }^{a}$ do EM 3: É amplo.

P: Vamos lá. Aqui já voltei na razão, então fechamos aqui, aí eu vou passar esses slides, nós já discutimos. Agora o perfil desses alunos, então a maioria é do sexo...

Prof. do EM 2: Continua sendo mulher.

P: ... Feminino, 58\%, e masculino 41,99\%. Vocês querem discutir?

Técnica da SED/MS 2: Olha, uma coisa que eu vi assim, nós participamos de uma seleção e devido tanto a parte de (inint) [00:17:03] que vem correndo ultimamente e nessa seleção que nós tivemos a responsável pelo setor lá ela falou assim: "Olha, de preferência não escolham homem". Aí eu até questionei com as meninas que eram responsáveis, eu falei: "Mas tem fulano...", que eu participei da entrevista e tudo, eu falei: "Mas fulano é uma pessoa assim...". Mas escolher professor homem? É, porque trabalhar com as crianças.

Prof. do EM 2: Professora?

Técnica da SED/MS 2: Professor.

Prof. do EM 2: Dar preferência para a professora?

Técnica da SED/MS 2: Professora. Aí nós falamos assim: "Mas por quê?", ele falou assim: "Gente, como que eu vou pôr...", aí a gente consegue assim até... mas aí não pode, que isso é um discriminação pensei eu. Aí ela falou assim: "Gente, com tanta coisa que tem, que está tendo aí, procura ao máximo evitar não selecionar homens". 
Aí eu participei do processo de seleção, então a gente fez entrevista, tudo, aí entrevistei um rapaz, ele é professor de educação física, aí eu conversei com ele, eu vi, ele ia casar de novo, tudo, gostei do jeito dele assim, de falar, do jeito que ele falou da parte da educação e tudo, aí eu cheguei na chefe que era responsável e falei assim: "Olha, é o seguinte, eu selecionei esse fulano e eu achei que ele tem o perfil para participar, outra, ele é professor de educação física, já que ele vai ser um assistente ele pode ajudar muito um professor", não vai deixar ele lá no berçário, por exemplo, lá para dar banho, fazer alguma coisa, "Mas eu acho que ele tem o perfil para poder ajudar essa professora. Eu vou...", eu falei para ela: "Eu vou selecionar ele". Aí foi assim, eu fiquei tão contente que no dia de fazer a inscrição, quer dizer, contratar, ele estava lá, eu falei: "Ah, que bom, que bom você entrou", e eu conversei com a minha chefe, eu falei: "Não...".

Prof. do EM 2: Só para saber, era professor de seleção para?

Técnica da SED/MS 2: Para uma creche, (inint) [00:19:02], é aquele que eu te falei.

Prof. do EM 2: Do município ou do estado?

Técnica da SED/MS 2: Do estado, do estado. Então assim, eu entendo o que a diretor quis dizer, mas assim, a gente tem, você tem que ver o perfil também da pessoa que você vai escolher aí, então tem essa discriminação também agora por causa disso, desses casos que estão tendo. Aí quando eu fui fazer a entrevista eu falei: "Não, mas ele é um rapaz que demonstra isso, isso e isso, e eu vou selecionar ele, ele é apto a participar". Graças a Deus ele foi chamado.

Técnica da SED/MS 1: Que hoje em dia não pode confiar nem no próprio pai. Técnica da SED/MS 2: É.

Profa do ES 3: Eu acho que é um pouco a questão cultural também, a questão de o sexo feminino estar na frente, porque desde o início a maioria do sexo feminino nessa profissão de professora, então eu acho que um pouco é cultural também.

Prof. do EM 2: Eu acho também que pela questão da remuneração.

Técnica da SED/MS 2: Sim. O homem quer ganhar mais.

Prof. do EM 2: Porque o salário...

Técnica da SED/MS 2: Quer ganhar mais que a mulher.

Prof. do EM 2: Não querer, mas a gente tem isso embutido na cabeça de que você vai ser a pessoa que deve ganhar mais.

Técnica da SED/MS 2: Ganhar melhor. 
Prof. do EM 2: A pessoa que vai levar a sua família, assim, manter e tudo mais. Técnica da SED/MS 2: O provedor.

Prof. do EM 2: O provedor, exato, isso é cultural, isso existe, tanto que se você tem um casal de amigos ou parente, ou se você está nessa situação que por um período você esposa ganha mais do que seu marido.

Técnica da SED/MS 2: Vixi, Maria.

Prof. do EM 2: Não, não é motivo de discussão, isso na minha casa já aconteceu mais de uma vez, mas a gente luta para... a gente homem a gente luta para fazer ser o contrário, porque é cultural, está embutido na nossa cabeça, eu não sou machista, não tem nada a ver com isso, mas é cultural.

Técnica da SED/MS 2: Quer ganhar mais.

Prof. do EM 2: Eu não vou falar para a minha esposa, falar assim: "Vamos sair de férias, mas então eu separei viagem para (inint) [00:20:52]", a gente pode combinar de, assim, tipo: "Eu vou pagar a viagem, mas aí quando a gente tiver lá, você vai pagar o que a gente gastar com alimentação, tudo bem?".

Técnica da SED/MS 2: Que é o mais caro.

Prof. do EM 2: Não.

Técnica da SED/MS 2: Dividir.

Prof. do EM: Mas existe isso.

Técnica da SED/MS 2: Não, eu entendi.

Prof. do EM 2: E isso é cultural mesmo, ponto, não tem jeito.

Técnica da SED/MS 2: É o ego.

Prof. do EM 2: Pode ser.

Técnica da SED/MS 2: Não, mas é. Mas é sim.

Técnica da SED/MS 1: É verdade. Eu não me sinto bem ganhando mais do que o marido, vamos dizer assim, eu já tive marido e eu ganhava mais do que ele, a vida toda eu ganhava mais do que ele, só que ele era aquele que não queria crescer. Não tinha esse ego, ele não se preocupou em procurar, ele completou o ensino médio dele porque eu insistir, ele fez um curso de normal/médio porque eu insisti e acho que um pouco era para poder ir junto comigo também porque eu fui fazer, eu tinha terminado a faculdade, eu já estava dando aula. Aí surgiu o normal/médio eu falei: "Vou fazer, que daí o meu currículo vai ficar mais amplo".

Prof. do EM 2: Completo. 
Técnica da SED/MS 1: Eu vou poder dar aula desde o ensino infantil até o ensino médio. Beleza, aí fui fazer o normal/médio, aí eu acho que para eu não ir sozinha ele pegou e foi comigo fazer.

Técnica da SED/MS 2: Entendi. Fez também por ciúmes, para não deixar você estudar a noite sozinha.

Técnica da SED/MS 1: Aí no outro ano ele foi e fez biblioteconomia, porque ele disse que para ser professor ele não ia levar jeito, ele teve uma seleção na cidade lá ele não quis ir participar da seleção, e teve alunos do normal/médio que foram contratados e que não... Eu, na minha opinião ele tinha se saído melhor do que aquele outro e aquele outro foi contratado e ele não foi, mas por quê? Porque o outro foi fazer inscrição, ele não foi porque ele não se achava preparado para cuidar de criança, para se professor, essas coisas. Ainda mais (inint) [00:22:40] achava um saco. Você é professor, você tem que saber, aí ficava enchendo ele de pergunta e ele não sabia responder, "Ah, mas você não é professor, você tem que saber", professor tem que saber de tudo. Aí fez biblioteconomia, surgiu um concurso, "Eu não vou fazer, só tem uma vaga, eu não vou passar", eu falei: "Se você continuar pensando assim você não vai passar nunca".

Técnica da SED/MS 2: É, ninguém consegue (inint) [00:23:02], é muito triste.

Técnica da SED/MS 1: Então sempre eu ganhei mais do que ele, mas eu não me sentia bem, porque a responsabilidade ficava maior para mim.

P: Gente, eu vou passar para o fator idade aqui que isso aí eu acho super importante. Vocês viram aqui que a maioria dos alunos, 62\% ele estão entre 17 e 18 anos concluindo o ensino médio, então aqui você já tem um fator de distorção idade e série e grande, muito grande. Entre 14 e 16 anos que seria o ideal para ele concluir, tem $18 \%$ só, 19 e 20 anos, veja vem, quase $11 \%$, e mais que 20 anos, mais, acima, oito por cento.

Técnica da SED/MS 2: E esse mais de 20 anos deve ser o período noturno eu acho. Técnica da SED/MS 1: Com certeza.

Prof. do Em 2: Se bobear já tem até família e tal.

Técnica da SED/MS 2: No EJA, no AJA.

$P$ : Mas vocês vejam que dado importante isso daqui.

Técnica da SED/MS 1: Olha, eu me encaixo nesse mais dos 20, que eu conclui o meu ensino médio eu já tinha 20 anos, tinha mais de 20 anos, porque lembra que eu 
falei que quando teve greve eu parei, no outro ano eu torci o tornozelo, eu não podia pôr o pé no chão, eu fiquei um mês com aquela tala no pé, eu não fui na escola mais um mês, porque eu não tinha como ir de algum meio de transporte, tinha que ir a pé, então aí eu falei: "Um mês sem ir na escola, não vou mais", parei de novo. Já comecei um ano atrasada, então terminei tarde.

P: Como Secretaria de Educação como é que vocês analisam isso? Que a secretaria tem que saber que estar tendo essa distorção, dessa entrada intermitente. Técnica da SED/MS 2: Sim, eles têm esses dados e, assim, é uma coisa muito agravante mesmo, tanto é que tem esses programas, o AJA, que é desse da distorção de idade, veio depois do EJA. E tem esse conhecimento mesmo, tem o conhecimento da evasão que é grande, aí agora tem a escola integral que vem para ajudar ou piorar, não sei.

Técnica da SED/MS 1: E os cursos técnicos também, que são concomitantes com o ensino médio.

Técnica da SED/MS 2: Tem o integrado, tem o concomitante.

Técnica da SED/MS 1: Então eu acho que veio para... eu penso que veio para ajudar nessa questão da distorção de idade, porque você pode fazer o ensino médio e fazer um técnico, ou você, depois que você terminou o ensino médio você pode fazer um técnico também. Então eu acho que isso veio para ajudar, porque assim, eles têm feito, a gente está lá há um ano, mas eles têm procurado, bate muito nessa tecla da distorção, tem esses dados que são alarmantes, sempre foi para as escolas, mesmo na época de escola quando eu estava quando nós íamos ver tinha essa distorção muito grande em sala de aula e a secretaria tem conhecimento disso $\operatorname{sim}$.

Técnica da SED/MS 2: Tem, e tem formações também...

Técnica da SED/MS 1: Tem muitas formações.

$P$ : E aquela questão do ensino médio que o aluno pode levar três dependências para o ano seguinte?

Técnica da SED/MS 1: É a RPP, começou o ano passado.

$P$ : E como é que vocês avaliam isso?

Técnica da SED/MS 2: Olha, na minha opinião e no que eu estou vendo lá no geral acontecendo, no primeiro ano surgiu um efeito de diminuição de reprovação, porém 
para o segundo ano agora já não vai ter, porque nós temos alunos que terminou o terceiro ano.

P: E vão poder fazer? E vão para a faculdade mesmo estando devendo matéria? Ela vai entrar na faculdade?

$P$ : Só um minutinho, que eu vou interromper e a gente já recomeça.

[00:26:44] 


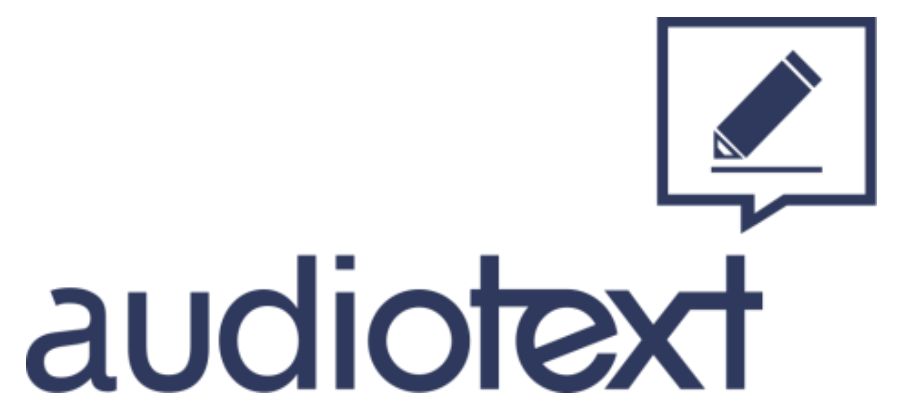

Audiotext Serviços e Cia. LTDA

CNPJ: 17.429.373/0001-85

(41) 3363-3220

falecom@audiotext.com.br audiotext.com.br 


\section{TRANSCRIÇÃO - S12917J8 - WIN_20190413_11_33_22_Pro}

\section{PARTICIPANTES}

Professor do Ensino Médio - Prof.do EM 1 - P1

Professor do Ensino Médio - Prof.do EM 2 - P2

Professora do Ensino Médio - Prof ${ }^{a}$ do EM 3 - P3

Professora do Ensino Superior - Prof ${ }^{\mathrm{a}}$ do ES 1 - P4

Professora do Ensino Superior - Prof ${ }^{a}$ do ES 2 - P5

Professora do Ensino Superior - Prof ${ }^{\mathrm{a}}$ do ES 3 - P6

Técnica da Secretaria de Estado de Educação - Técnica da SED/MS 1 - P7

Técnica da Secretaria de Estado de Educação - Técnica da SED/MS 2 - P8

Técnico da Secretaria de Estado de Educação - Técnico da SED/MS 3 - P9

Pesquisadora - $\mathrm{P}$

TEMPO DE GRAVAÇÃO

26 minutos e 17 segundos

\section{MODALIDADE DE TRANSCRIÇÃO}

Padrão

\section{LEGENDA}

$\ldots \rightarrow$ pausa ou interrupção.

(inint) [hh:mm:ss] $\rightarrow$ palavra ou trecho ininteligível.

(palavra) [hh:mm:ss] $\rightarrow$ incerteza da palavra transcrita / ouvida.

A Audiotext Serviços e Cia. Ltda se reserva o direito da imprecisão dos nomes escritos, uma vez que os locutores serão identificados conforme a pronúncia de seu nome. O cliente tem o direito de fazer quaisquer alterações que julgar necessárias nas identificações aqui utilizadas. 
(INÍCIO)

[00:00:00]

P: Deu. Pode continuar.

Técnica da SED/MS 1: Então nós temos alunos que, por exemplo, a gente tem a plataforma moodle que é onde a gente atende, nós somos tutores, nós fizemos o plano de estudo, nós elaboramos as avaliações que os alunos vão fazer e aí vai ser aplicado na escola.

Técnica da SED/MS 2: Só que esse ano já mudou.

Técnica da SED/MS 1: Mudou. Então o ano passado a gente tinha o primeiro e o segundo ano do médio, porque tem o fundamental, então, por exemplo, eu tinha o primeiro e o segundo ano, o terceiro ano não pode ficar de RPB, porém esse ano abriu uma turma no moodle que é do segundo ano especial, ou seja, terceiro ano aquele aluno que ele...

Técnica da SED/MS 2: Você vai ter alunos aqui que vai entrar depois.

Técnica da SED/MS 1: Ele ficou devendo a matéria do segundo ano e ele foi para o terceiro, ele fez aquelas provas e ele não passou, ele passou no terceiro e ficou devendo aquela matéria do segundo, tem aluno que está entrando na faculdade, entrou na faculdade e está devendo.

Técnica da SED/MS 2: Está devendo matéria do segundo e vai fazer.

Prof. do EM 2: Mas é possível isso?

$\mathrm{P}$ : E como é que vocês fazem? Mas é possível?

Técnica da SED/MS 2: Então, sim, só que assim, o que é que vai acontecer, esse aluno, por exemplo a UEMS e a federal ele vai estipular um prazo para aquele aluno. Técnica da SED/MS 1: Um prazo e um prazo mais curto.

Técnica da SED/MS 2: "Tal dia você tem que trazer o documento".

Técnica da SED/MS 1: Sim, para confirmar a matricula.

Técnica da SED/MS 2: Tanto é que esse terceiro ano especial ele vai ter mais tempo de fazer a prova, ele vai ter quatro chances de fazer essa RPB, por exemplo, mas só que é assim, é quatro chances no sentido, por exemplo, durante o ano.

Técnica da SED/MS 1: ... Falar assim: "Olha, eu quero o seu documento de conclusão definitiva do terceiro ano até julho", então ele tem duas chances para poder fazer. 
Prof. do EM 2: Certo.

Técnica da SED/MS 2: Aí se é uma instituição que não (inint) [00:01:40] tanto, que ele fala assim: "Não, até o final do curso...".

Prof. do EM: Você apresenta.

Técnica da SED/MS 2: "... Você apresentando", porque tem, tem isso daí também. Tem, tem instituição que deixa até o final do ano. Então ele tem quatro chances que seriam duas provas, durante $\mathrm{o}$ ano.

Prof. do EM 2: Até julho.

Técnica da SED/MS 2: ... Até julho e duas provas até novembro, e, assim, essas provas são todas diferentes. No normal ele só tem duas chances, por exemplo, o aluno que ficou do segundo ano no primeiro.

P: Eu pergunto assim: esse aluno passou na faculdade, começa o curso e não consegue passar nessas provas como é que faz?

Técnica da SED/MS 2: Eita.

Prof. do EM 2: Não faz.

Técnica da SED/MS 2: Aí eu já não sei.

P: Aí ele perde a vaga da universidade?

Técnica da SED/MS 1: Aí que eu também não entendi, eu falei: "Como é que aquele guri...", eu falei assim: "O ser que reprovou esse guri lá no segundo porque é que não passou ele então?" Aí vai ficar o que, o guri passou do terceiro ano e não passou do segundo, como? Como?

Técnica da SED/MS 2: Então, só que é uma minoria que foi para a faculdade, são bem poucos. É assim, não é muito não.

Prof. do EM 2: É porque acabou de começar também.

$\mathrm{P}$ : Mas então se o menino não passar na prova ele tem que sair da universidade, ele não pode cursar?

Técnica da SED/MS 2: Eu acredito que ele pode trancar a matrícula.

Técnica da SED/MS 1: É. Trancar a matrícula, aí termina essa...

Prof. do EM 2: Terminar e voltar.

$\mathrm{P}:$... E depois volta. Isso na avaliação de vocês não é uma maneira de maquiar esse índice de reprovação?

Técnica da SED/MS 2: Eu acredito que sim. Olha, a gente não pode (inint) [00:03:07]. 
Prof. do EM 2: Está gravando. É, isso.

$P:$ Não, não, mas não identifica quem fala.

Prof. do EM 2: Eu estou brincando.

$P$ : É sem identidade.

Técnica da SED/MS 2: Olha, eu não estou nem sendo filmada. Olha só, eu vou falar assim o que eu penso enquanto profissional.

$P: O$ que você pensa como professora, não como da secretaria.

Técnica da SED/MS 2: Profissional de 20 anos de escola que eu tive.

P: Sim.

Técnica da SED/MS 2: Eu acho, na verdade, que é uma enrolação. O que acontecia comigo enquanto professora de matemática, eu sabia o aluno que era bom, assim, que eu entendia que ele era bom, tanto é que eu falava assim: "Olha, fulano, você tem todas as características para fazer engenharia", "Verdade, professora?", eu falei: "Sim, porque você domina isso, isso e isso", o guri está fazendo engenharia hoje, a outra foi agrônoma. Uma mãe veio até brigar: "Professora, você está doida de falar para a minha filha fazer engenharia?", eu falei: "Não, ela tem todas as características para poder fazer", “Tem certeza, professora, porque o pai dela vai pagar?", eu falei: "Pode pôr que você não vai se arrepender", hoje ela é mestre. Então assim, eu aprendi uma coisa, quando eu entrei para dar aula eu tenho uma fala que eu nunca esqueço da minha diretora, que aquela diretora eu acho que é a melhor diretora acho que da face da Terra, porque ela enquanto profissional que sabia assim muito todas as leis, ela sabia tudo. Ela falou assim um dia numa reunião pedagógica e naquela época tinha muito pessoal de engenharia, esse pessoal de (inint) [00:04:33] que vinha fazer, dava aula lá, que não tinha tanta coisa de diploma, então qualquer um podia dar aula, que tivesse nível superior. E aí ela falou assim: "Olha, vocês não vão fazer o que professor de vocês da faculdade faziam com vocês", porque a maioria era da federal, aí ela falava assim para mim, porque matemática eu ficava louquinha, porque eu quando entrei na faculdade eu achava assim que o aluno tinha que aprender quando eu fosse dar aula, que a hora que você explicasse, a hora que você ia dar prova, o aluno, nossa, ele entendeu. Menino do céu, quando eu olhei a primeira prova, a primeira prova da minha vida eu tive um choque muito grande, eu quase chorei, a maior nota foi cinco. Aí eu falava para ela tudo que eu sentia, aí ela falou assim: "Cris, olha, e hoje sou pedagoga, eu não dependo da matemática para 
eu ser quem eu sou hoje, eu sei as quatro operações, se você pedir para eu fazer uma conta eu faço, claro que eu não domino matemática porque eu não sou matemática, mas eu penso assim, que o aluno que não quer aprender, que não quer, assim, fazer porque vai fazer uma engenharia ou matemática, ele não precisa saber a matemática de cor e salteado, esses $X$, esses $Y$ da vida, ele sabendo a matemática básica, que isso os nossos alunos não estão saindo, sabendo do ensino médio. Se ele souber multiplicar, subtrair, adicionar, saber quando que compra, quando que faz isso, está ótimo, Cris, não vai se descabelar. E assim, não vai exigir daquele aluno o que o professor seu exigia lá na faculdade porque aqui você não está numa faculdade, não vai cobrar do aluno o que o professor cobrava de você. Então você procura avaliar se ele não foi bem naquilo procura avaliar ele em outra coisa que ele faça, não só nessa avaliação, porque na escola você pode avaliar de quantas foram", aí eu falei assim: "Meu Deus do céu, o que é que eu vou fazer?", e era que (inint) [00:06:33] de notas baixas. Aí o que eu fazia para avaliar? Quando o guri entrava na porta eu já estava avaliando ele, no sentido assim de atividade, porque era o primordial, então eu sabia, o Geraldo eu explicava matéria e o Geraldo perguntava, eu via a argumentação que ele utilizava, se era coerente com aquilo que estava dizendo no conteúdo. Aí, por exemplo, a Cláudia era muito ruinzinha de matemática, aí eles faziam umas perguntas assim que não tinha nada a ver ou então quando eu dava atividade a Cláudia copiava do Geraldo.

Prof. do EM 2: Ou um ajudava o outro, a gente tem que considerar.

Técnica da SED/MS 2: Mas assim, no sentido de copiar mesmo, você via aquele que tinha a dificuldade, mas conseguia perguntar e você sabia que ele... Então eu consegui fazer isso avaliando eles dessa forma. Então aí o que é que eu fazia? Porque é que eu vou reprovar aquele guri que ele tem dificuldade em matemática e consegue dominar outra disciplina?

Prof $^{\text {a }}$ do EM 3: Eu posso falar enquanto coordenação e professora, a secretaria dá dois no ano, um é em junho, não é, e outro é dia 13 de novembro, é aula programada e os alunos de RPP, é dada aula programada para os demais alunos e alunos de RPP vem para fazer avaliação. Eu aprendi do ano passado, o ano passado eu tinha o Projetec para nos auxiliar, só que mandava, aí a secretaria pedia e o aluno não compareceu, tinha que ligar para o pai para ele contar a história. Dessa vez eu tenho toda uma listagem, quem ficou, a gente passava de sala com 
um mês de antecedência chamando o aluno, entregava o papelzinho, "Assina aqui. O seu pai tem que trazer assinado e ciente", tem toda uma parte burocrática para a ciência do pai. E aí chega no dia e ele não comparece eu tenho que ligar lá para o pai para dar uma devolutiva para a SED, aí todo aquele papel para a sede.

Técnica da SED/MS 2: (Inint) [00:08:39] não é?

Prof $^{a}$ do EM 3: Quando o aluno teve um atestado, vamos dizer que ele passou mal, que faz parte do clube de ciências, acho que é um menino hiperativo que quando fala em avaliação...

Técnica da SED/MS 2: Eles têm um bloqueio.

Profa do EM 3: ... Tem um bloqueio. Aí ele pode fazer avaliação num outro momento.

$P$ : Eu pergunto o seguinte: é entregue uma lista de conteúdo do que é que vai cair na prova?

Técnica da SED/MS 2: Sim, tem. A gente tem um plano de estudos.

P: Tudo bem, tem o plano de estudos. Aí eu pergunto o seguinte: ele tem aula daquilo ali ou ele tem que estudar sozinho?

Técnica da SED/MS 1: Olha só, ele tem que estudar pelo moodle. Na plataforma tem os tutores que somos nós lá na secretaria, cada um da sua disciplina. Eu entro de sete e meia na sede e eu ligo o computador e já coloco no site, na RPP lá no moodle, aí eu tenho lá geografia primeiro ano, segundo ano e terceiro ano. O aluno que está online eu estou vendo que ele está online, o aluno que tiver uma dúvida ele pode fazer a pergunta.

Técnica da SED/MS 2: Ele pode perguntar pelo moodle.

Técnica da SED/MS 1: Online.

P: Ele pergunta para você, então não é aula.

Técnica da SED/MS 2: Não.

P: É uma tutoria?

Técnica da SED/MS 1: É uma tutoria.

P: "Olha, eu não entendi esse conteúdo", aí ele escreve para você e você responde? Técnica da SED/MS 2: Dá a devolutiva.

$P$ : Da a devolutiva na mesma hora que ele pergunta?

Técnica da SED/MS 1: Não, as vezes não. Só se eu estiver online. Se eu tiver lá, porque por exemplo eu tem hora que eu não estou na secretaria, tem uma palestra, tem uma reunião, tem uma formação, aí eu não estou lá. 
P: Sim, sim.

Técnica da SED/MS 1: Mas fica gravado.

Prof. do EM 2: Mas aí a dúvida fica ali?

Técnica da SED/MS 1: Mas aí a pergunta dele fica lá, quando eu chego que eu ligo e eu vejo eu já respondo.

Técnica da SED/MS 2: Só que aí vezes ele não está e ele vai entrar depois, só que eles não perguntam, eles não perguntam.

Técnica da SED/MS 1: Só que nós temos um grande agravante nisso, por isso que eu falo assim, olha, é muito complicado. Nós fizemos esse plano assim com... no meu caso eu fiz tipo como eu dou em sala de aula, só que a gente não tem acesso dos alunos.

Técnica da SED/MS 2: Não, é isso que eu estou falando, porque a partir do momento que você implementa isso numa rede grande dessa você pressupõe que vai ter demandas.

Técnica da SED/MS 1: Sim, que eles vão perguntar, e a gente vai responder.

P: O que eu estou percebendo, é que não tem a demanda e aí a questão como que isso a secretaria avalia no sentido de dar continuidade nisso ou parar com isso, ou é só por uma questão de índice, tipo, eu passo o aluno para ele não reprovar, porque isso custa dinheiro.

Técnica da SED/MS 1: Esse ano mudou, viu (inint) [00:11:00], esse ano mudou, o ano passado nós que aplicamos a prova, aí os coordenadores, diretores da escola, não sei se na sua também teve, acho que foi aberto sugestões, então o responsável do RPP passou para a gente que nós preparamos as provas esse ano também, diferente das do ano passado, e assim foi enviado, colocou no moodle, tudo, só que teve escolas optaram, assim, optaram não, ficou aberto para elas em fazer a própria prova para esse aluno, porque eles questionaram o que nós preparamos de prova, o conteúdo é o mesmo, o conteúdo é aquilo lá que nós colocamos.

Técnica da SED/MS 2: Porque a gente segue a referência.

P: Sim, claro.

Técnica da SED/MS 1: Só que a prova ficou aberta para eles fazerem lá para o... Só que se, por exemplo, eu optar para fazer por história ele vai ter de fazer de toda a escola, assim, por exemplo, não vai fazer só de história, ele vai fazer as provas, não o professor ali, a escola vai fazer para todos os alunos, entendeu? Inclusive o plano 
de estudo, porque as vezes a escola ela acha que o que a gente fez não está dentro da realidade daquela escola.

Técnica da SED/MS 2: Adequado.

P: Sim. Quantos anos a SED está com esse programa?

Técnica da SED/MS 2: É o segundo ano agora.

P: É o segundo ano. Vocês avaliaram como foi o ano passado?

Técnica da SED/MS 2: Isso.

Técnica da SED/MS 1: Sim.

$P$ : Vocês têm a avaliação?

Técnica da SED/MS 2: Aí agora vai ser desse ano, que mudou, mudou.

P: E do ano passado? Qual foi a análise que vocês fizeram?

Técnica da SED/MS 2: Olha, foi bem feia, teve um alto índice de reprovação.

Técnica da SED/MS 1: Reprovação e falta.

Prof. do EM 2: E aí? Reprovação e falta, e como isso continua agora?

Técnica da SED/MS 2: Continua, é. Então, o aluno que não fez ele vai fazer de novo.

Técnica da SED/MS 1: Ele vai fazer de novo, entendeu?

$\mathrm{P}$ : Mas se ele não consegue, ele fica de novo?

Técnica da SED/MS 1: Ele não pode ficar mais que três, se ele ficar de três ele para e refaz aquilo, entendeu? É tipo uma dependência.

P: Aí vamos supor que ele ficou de três e reprova nas três um ano, dois anos e ele vai progredindo para as outras salas?

Técnica da SED/MS 2: Não, ele vai parar e vai terminar aquele lá, é igual uma dependência, pelo que eu entendi é isso.

Técnica da SED/MS 1: Até o ano passado a gente tinha orientação de que o aluno ele não concluía o terceiro ano se ele não conseguisse passar (inint) [00:13:15].

Técnica da SED/MS 2: Aí agora esse ano veio essa nova coisa para a gente.

Técnica da SED/MS 1: Só que esse ano veio uma nova orientação.

Técnica da SED/MS 2: Que o aluno concluiu o terceiro ano e ficou devendo a do segundo.

P: É grave.

Técnica da SED/MS 2: Grave, muito grave.

Técnica da SED/MS 1: É muito complicado. É triste ver essa realidade. 
Prof. do EM 2: Vai arrastado.

Técnica da SED/MS 2: É o que eu te falei. É um experimento, como em outros estados.

Técnica da SED/MS 1: E é um gasto muito grande.

Técnica da SED/MS 2: Em outros estados que já tem o RPP há mais anos, há mais tempo, o estado ele não fornece material, ele não tem aula online, esse apoio online, ele não dá nada, ele simplesmente marca a data da prova, o aluno se virar sozinho e ele vai lá no dia e faz a prova.

Técnica da SED/MS 1: Sim, tem que ter uma economia.

Técnica da SED/MS 2: Sim. Aqui o estado ele está dando o suporte com essa plataforma online com tutor para poder estar respondendo e a primeira etapa, a primeira prova... A gente também está aprendendo. A primeira prova ela foi feita num final de semana em polos, só que aí a falta dos alunos foi muito grade.

Técnica da SED/MS 1: Mudou tudo isso na estrutura esse ano.

Técnica da SED/MS 2: Porque a maioria dos alunos que reprovam são aqueles que não são dedicados.

Técnica da SED/MS 1: É os que não tem... são aqueles que são visitantes da escola.

Técnica da SED/MS 2: Problemáticos, não são dedicados e tal. Então aí e tem a questão da zona rural também que eles dependem do transporte que é em parceria com o município e aí o município não cedeu o transporte para levar final de semana, tem as escolas indígenas.

Técnica da SED/MS 1: Agora vai ser no período de aula.

Técnica da SED/MS 2: Aí a segunda prova no segundo semestre mudou, já mudou, foi no meio de semana, por isso que teve aula programada. E eles já participaram. Técnica da SED/MS 1: E aí teve uma quantidade menor de falta de alunos, a maioria esteve presente e a questão também da aprovação aumentou, porque a primeira ela teve um grande número de reprovação por causa da ausência também, foi grande. Teve aluno que perguntou para a gente depois da prova. Se eu não me engano foi $40 \%$ de ausência.

P: Então, mas aí na hora de fazer a leitura disso, a evasão é uma coisa, gente, reprovação é outra, você não pode juntar tudo como uma coisa só.

Técnica da SED/MS 2: Não, não, é errado. 
Técnica da SED/MS 1: A evasão foi muito grande.

Técnica da SED/MS 2: A evasão. O alto índice de reprovação foi devido ao...

Técnica da SED/MS 1: A evasão, não que o menino fez a prova e ele reprovou?

Técnica da SED/MS 2: Não, não, foi por causa da evasão também.

Técnica da SED/MS 1: Por exemplo, de língua portuguesa o ano passado eles tinham a prova objetiva que valia de zero a oito, de zero a sete, não lembro. De português era de zero a sete, uma redação, esse ano já não vai ter. E eles tinham uma redação que valiam os seis pontos para completar, então esse ano já não tem mais a redação que é para amenizar para o aluno. E esse ano também vai ser no período de aula dele.

Técnica da SED/MS 2: Sim, igual foi a segunda etapa do ano passado.

Prof. do EM 2: E se, por exemplo, na escola dela, se naquele período não tiver ninguém de RPP é aula normal. Não mais vai ter aquela aula? (inint) [00:16:03].

$P$ : Eu só acho assim, gente, também não sei se eu estou errada, que o aluno não deveria carregar isso para a graduação, e outra coisa, se ele fez o ENEM e passou deveria automaticamente ser anulado aquilo ali.

Técnica da SED/MS 2: Sim.

F1: Porque ele vai para uma graduação e isso causa uma desmotivação o fato ainda de você carregar disciplinas do terceiro ano do ensino médio. Então é só essa questão que eu acho incoerente na minha maneira de ler. Então se ele passou no ENEM, tem os conteúdos lá que a gente sabe que não são fáceis, então ele já foi avaliado ali, eu acho que deveria encerrar esse assunto.

Prof. do EM 2: Esse ciclo por ali e não arrastar.

Técnica da SED/MS 2: Menina, quando falou isso eu não entendi, eu falei: "Como?" Então, causa um conflito.

Técnica da SED/MS 1: A gente ficou sem entender também. Aí também tem a questão do Encceja que o aluno se ele não conseguir passa na prova ele ainda tem a chance de fazer o Encceja e eliminar a matéria que ele ficou devendo.

Técnica da SED/MS 2: Ainda tem mais, eu quero dizer assim, existem mecanismos...

Técnica da SED/MS 1: Vários mecanismos.

Técnica da SED/MS 2: E tem muitos.

Técnica da SED/MS 1: Mas as vezes o aluno ele não se interessa também. 
Prof. do EM 2: Não tem vontade.

Técnica da SED/MS 2: Não tem à vontade, porque a secretaria tem feito, é o que você está falando, tem isso, eles têm o material, tem o monitor, tem todo um suporte, então assim, a questão é, o aluno ele realmente ele não se interessa.

Prof $^{\mathrm{a}}$ do EM 3: Sim. Você sabe que nós recebíamos mensagens dos alunos depois da prova quando que ia ser a prova.

Técnica da SED/MS 1: Sim. Eu recebi mensagem de aluno de sétimo ano, porque o ano passado o professor do setor do ensino fundamental ele estava na (inint) [00:17:36] então eu fiquei responsável como tutora tanto do fundamental como do médio e tinha mais de 1.500 alunos para atender, eu fiquei desesperada quando eu fiquei sabendo que ia atender tudo isso, porém os alunos não entram na plataforma, eles entram, olham, olham, mas eles não te perguntam nada. Dava para contar nos dedos quantos alunos fizeram alguma objetiva para mim sobre o conteúdo.

$P$ : E isso daí você reporta para a gestão da secretaria no caso?

Técnica da SED/MS 2: Isso fica registado. É feito o relatório e registrado.

$P$ : E comunica as escolas, manda isso aí para as escolas?

Técnica da SED/MS 2: Isso aí fica registrado já na plataforma, porque lá fica registrado o acesso do aluno, o dia que ele entrou, que horas que ele entrou, quantos minutos ele ficou online, qual parte daquele conteúdo que eu coloquei no plano vídeo aulas, coloquei atividades, banco de atividades extras e o plano de estudo. A atividade que tem no plano de estudo eu coloquei na prova e o aluno não tirou nota. Teve aluno que entrou no sistema, eu coloquei aquele texto lá no fórum e atividades dando as boas vindas e me colocando à disposição para tirar qualquer dúvida ou ajuda-lo no conteúdo, aí ele falou assim: "Sim, eu quero o seu nudes", nudes e não sei qual que é a outra coisa que ele falou.

$P$ : Isso dá pano para a manga essa discussão.

Prof $^{\text {a }}$ do EM 3: E não foi só para mim, para as outras professoras tanto do fundamental como do médio das outras disciplinas alunos fizeram isso.

Técnica da SED/MS 2: Deixa eu só te falar. Assim, neste ano vai ter um agravante maior, assim a percepção da estrutura e aí entra a parte política também, nós não temos mais o Projetec.

Técnica da SED/MS 1: Isso. Vai ser mais lento. 
Profa do EM 3: Há duas salas (inint) [00:19:17] e os alunos me perguntam para ter acesso, eu estou na coordenação que tem que ajudar os docentes, agora eu vou deixar aluno numa sala ali tem que deixar... tem que ter alguém, porque ali tem os computadores, tem mouse, tem outros equipamentos, e isso não pensaram. $O$ ano passado eu tinha o Projetec e, graças a Deus, da minha escola eu tenho uma agenda, eu passo na sala, eu passo avisando, (inint) [00:19:46] a inscrição, comuniquei, ligo para o seu pai, então toda a informação que é mandada pela $\mathrm{Cl}$ é passado para os alunos. Você não tem noção, eu entrego para o terceiro ano, foi avisado semana passada, você tem dia 10 lá do ENEM a isenção, assina. Ele já sabe isso. Para depois falar que não foi falado. Que não foi comunicado. Eu passo dois dias, "Olha, vocês estão assinando não é por nada não, é só para eu colocar na minha agenda que vocês estão cientes da isenção".

Técnica da SED/MS 1: Mas isso que nós comentamos quando o rapaz passou para a gente, ele mesmo falou, que é o José Flávio que é o responsável, ele falou assim: "Gente, olha, a gente está preocupada porque as escolas não vão ter mais o Projetec que ajudava nessa questão", agora ficou tudo em cima do coordenador.

Técnica da SED/MS 2: Para o coordenador. Ele que vai ter que fazer tudo isso. Então quando foi feito isso nós também sentimos essa dificuldade e pensando nos colegas também de trabalho, o que é que vai fazer?

Técnica da SED/MS 1: Sabe, por exemplo, como agora vai ser num dia de aula normal, os alunos que não estão de RPP eles vão ficar em casa, aula programada, então, por exemplo, a sua escola tem cinco alunos, distribuindo então assim dez, 20 alunos, não vai ser muito, igual a primeira etapa que foi colocado em polos e outras escolas iam.

Técnica da SED/MS 2: ... Que vinham alunos de outras escolas e lotava a sala, lotou o Joaquim (inint) [00:21:07], lotou o Hercules, e aí ficava um em cada sala cuidando e aí na hora de distribuir a prova foi a maior confusão, entregaram prova errada e tal. E agora, por exemplo, ela tem 20 alunos na RPP ela vai receber a prova e ela vai receber um gabarito, ela vai corrigir e vai deixar a prova na pasta do aluno e vai mandar o gabarito corrigido de volta.

$P$ : Entendi.

Técnica da SED/MS 2: Vai ser mais tranquilo, entendeu? 
$\mathrm{P}$ : Gente, é só para finalizar aqui também, porque vai dar o horário e isso dá pano para a manda.

Técnica da SED/MS 2: Dá.

Técnica da SED/MS 1: Muito pano para a manga.

P: Então eu vou lá na secretaria para falar com o responsável, ok?

Prof. do EM 2: Cutucar.

Técnica da SED/MS 2: ... Cutucar isso daí.

Técnica da SED/MS 1: Isso aí você pode...

Técnica da SED/MS 2: É o José Flávio que você procura.

Várias vozes: (Inint) [00:21:41].

P: Isso, porque eu até preciso investigar como que são essas etapas e as estatísticas.

Técnica da SED/MS 2: A gente fez.

P: Eu vou precisar, então assim, dá muito pano para manga, eu vou parar por aqui.

Técnica da SED/MS 2: O ano passado a gente fez um gráfico da reprovação dos alunos.

Técnica da SED/MS 1: É, ele tem tudo.

P: Sim, eu quero esse gráfico e aí eu vou lá.

Prof ${ }^{-a}$ do EM 3: Eu tenho o de 2017 que eu entrei na coordenação, o ano de 2018 eu percebi o crescimento de 2017 para 2018 de quatro alunos que fizeram o Encceja e aí eles são, por exemplo, se fizeram Encceja passaram parcialmente e vão na escola assistir algumas disciplinas. De 2017 para 2018 eu tive quatro alunos e esse ano não vai ter mais.

Técnica da SED/MS 2: Mas não vai ter.

Prof $^{a}$ do EM 3: Eu entendi o que quer dizer, precisa rever essas questões.

Técnica da SED/MS 2: Rever esse conceito.

Técnica da SED/MS 1: E outra, é um investimento muito alto.

P: Isso daí gente é um feedback legal que vocês levarem para a gestão de vocês também.

Técnica da SED/MS 1: E outra, o ano passado, esse ano eu acho que não vai ter tanto assim, porque nós imprimimos as provas, muita prova e foi para fora, então teve um gasto muito grande. 
P: Então tem que avaliar, é isso que eu vou discutir com o setor esse gasto, tudo que... e qual que é o resultado disso, porque se não está dando resultado... Por que é que está fazendo?

Técnica da SED/MS 2: ... Porque é que está fazendo? É uma questão.

Técnica da SED/MS 1: Na verdade o gasto ele não é tanto agora porque a prova está sendo imprensa na escola, está aumentando a cota de impressão para aquela impressora daquela escola, então não é muito, o gasto foi quando (inint) [00:23:12] teve que imprimir tudo.

P: Tipo assim, é o tempo sabe, professora, tempo do profissional para fazer isso. Técnica da SED/MS 1: Sim.

$P:$ O que é que é investido, por exemplo, eu acredito que na hora que você foi fazer todo esse... é um tempo que você investe.

Prof ${ }^{\mathrm{a}}$ do EM 3: Nossa.

$P:$ Que é isso que eu estou chamando que é caro, você está entendendo?

Técnica da SED/MS 1: No início era assim, a gente... o técnico da disciplina ia fazer um plano de estudo...

Técnica da SED/MS 2: Sim, o plano, então.

Técnica da SED/MS 1: ... Do aluno e elaborar um plano de estudo do tutor, então a gente fez o do tutor com as respostas, com as explicações.

Técnica da SED/MS 2: Fizemos dois.

$P$ : Então isso que eu falo do tempo investido.

Técnica da SED/MS 1: Sim, você tem que parar aquilo para poder fazer outra coisa. Técnica da SED/MS 2: Para poder fazer.

$P$ : Então não estão pensando também nesse lado.

Técnica da SED/MS 2: Não, não.

Técnica da SED/MS 1: Porque a previsão era de o estado contratar um tutor. E contratar o professor para ir na escola atender o aluno pessoalmente. Aí eles disseram que a máquina não tinha mais como bancar isso financeiramente e aí colocou os técnicos para fazer esse trabalho para não ter gasto, então nós fazemos dentro do nosso período de trabalho.

P: Sim, mas aí o que é que acontece? Você trabalha dobrado, você está entendendo, é isso que eu estou falando que é o principal investimento hoje.

Técnica da SED/MS 2: Eu entendi. 
P: É o seu desgaste, é o tempo.

Técnica da SED/MS 1: Porque foi um desgaste bem maior.

Várias vozes: (inint) [00:24:29].

P: Sim, com certeza. Gente, aqui é só um panorama para a gente entender essa nossa população aí. Então a maioria dos alunos aqui, 43,54\% eles se autodeclaram pardo ou mulato, eu acho que isso é bem tranquilo de a gente entender até pela questão dos indígenas, que é a segunda maior comunidade indígena, aí tem o negro também que é muito forte. Então assim, isso daqui foi uma alta declaração, eu não coloquei como opção, ele mesmo se autodeclara. Então o branco a gente vê em segundo lugar, isso me surpreendeu um pouco, porque eu não sei, Mato Grosso do Sul é muito miscigenado.

Técnica da SED/MS 2: É, tem muito imigrante.

P: Eu achei que esse índice está altíssimo, ele não se considera, você entendeu? $\mathrm{Na}$ verdade, ele responde assim que ele se considera branco. Ele olha aqui e fala: "Eu sou branco".

Técnica da SED/MS 1: ... Precisa ver qual que é o conceito que ele tem do que é branco.

Prof $^{a}$ do EM 3: Do que é negro.

Técnica da SED/MS 2: Ou as vezes até um certo preconceito também.

$P$ : Sim, sim, as vezes ele é, tem a descendência, sabe, mas ele anuncia no discurso dele que ele é branco, ele quer ser branco. Depois a gente tem o negro, o amarelo aqui também a segunda maior comunidade oriental que a gente tem, e, por último tem o indígena que eu achei, embora tenham várias escolas participando da escola, é a maioria eu acho que das escolas indígenas estão na pesquisa, eu até destaquei, e só para finalizar.

[00:26:17] 


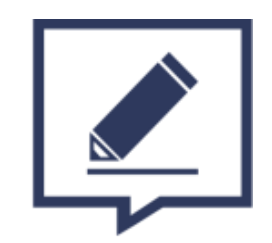

audiotext

Audiotext Serviços e Cia. LTDA

CNPJ: 17.429.373/0001-85

(41) 3363-3220

falecom@audiotext.com.br

$\underline{\text { audiotext.com.br }}$ 